NATIONAL LABORATORY

MANAGED BY UT-BATTELLE FOR THE DEPARTMENT OF ENERGY

\section{PERMEATION DISPERSAL OF TREATMENT AGENTS FOR IN SITU REMEDIATION IN LOW PERMEABILITY MEDIA: 1. FIELD STUDIES IN UNCONFINED TEST CELLS}

\author{
R. L. Siegrist \\ D. R. Smuin \\ N. E. Korte \\ D. W. Greene \\ D. A. Pickering \\ K. S. Lowe \\ J. Strong-Gunderson
}

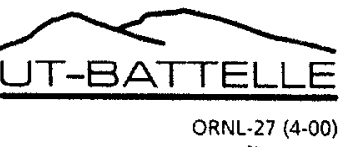


$\cdots$ 


\title{
PERMEATION DISPERSAL OF TREATMENT AGENTS FOR IN SITU REMEDIATION IN LOW PERMEABILITY MEDIA: 1. FIELD STUDIES IN UNCONFINED TEST CELLS
}

\author{
R. L. Siegrist ${ }^{1}$ \\ D. R. Smuin ${ }^{2}$ \\ N. E. Korte ${ }^{2}$ \\ D. W. Greene ${ }^{3}$ \\ D. A. Pickering ${ }^{3}$ \\ K. S. Lowe ${ }^{3}$ \\ J. Strong-Gunderson ${ }^{4}$ \\ Period of Work: 1994 to 1998 \\ Environmental Sciences Division \\ Publication No. 4761 \\ Publication Date: \\ Prepared by \\ OAK RIDGE NATIONAL LABORATORY \\ P.0. Box 2008 . \\ Oak Ridge, Tennessee 37830-6285 \\ Managed by \\ UNIVERSITY OF TENNESSEE-BATTELLE LLC \\ for the \\ U.S. DEPARTMENT OF ENERGY \\ Under Contract DE-AC05-000R22725
}

This work is funded by the Office of Science and Technology with the Department of Energy Office of Environmental Management, under the Contaminant Plume Containment Focus Area

1 Associate Professor, Colorado School of Mines, Environmental Science \& Engineering Division, Golden, Colo. Adjunct Faculty Research participant, Environmental Sciences Division, Oak Ridge National Laboratory, Oak Ridge, Tenn.

2 Research Staff member, Oak Ridge National Laboratory, Environmental Sciences Division, Grand Junction, Colo.

3 Research Staff member, Oak Ridge National Laboratory, Life Sciences Division, Grand Junction, Colo.

4 Research Staff member, Oak Ridge National Laboratory, Environmental Sciences Division, Oak Ridge, Tenn. 


\section{TABLE OF CONTENTS}

LIST OF FIGURES $\ldots \ldots \ldots \ldots \ldots \ldots \ldots \ldots \ldots \ldots \ldots \ldots \ldots, \mathrm{v}$

LIST OF TABLES $\ldots \ldots \ldots \ldots \ldots \ldots \ldots \ldots \ldots \ldots \ldots \ldots \ldots \ldots \ldots \ldots \ldots \ldots$ vii

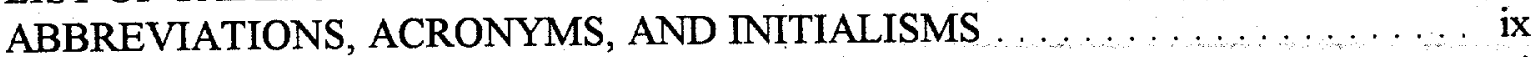

EXECUTIVE SUMMARY $\ldots \ldots \ldots \ldots \ldots \ldots \ldots \ldots \ldots \ldots \ldots \ldots \ldots \ldots \ldots$

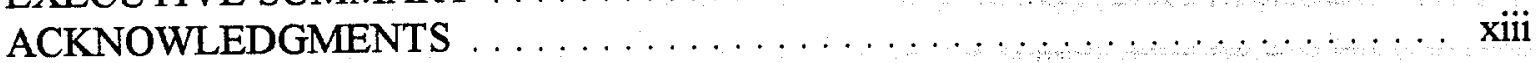

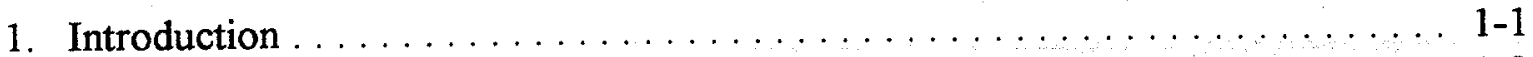

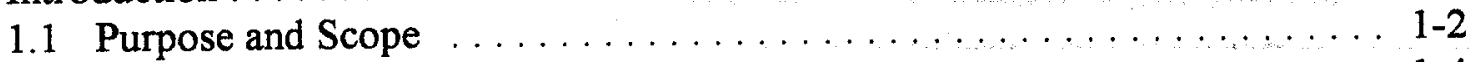

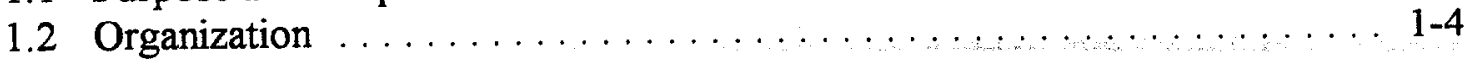

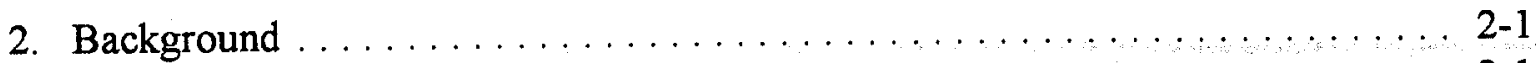

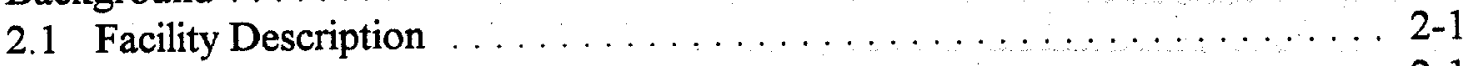

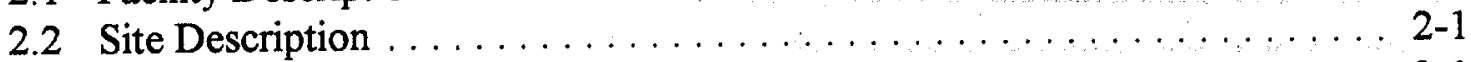

2.3 Site Geology as Defined by CTS Characterization $\ldots \ldots \ldots \ldots \ldots \ldots \ldots 2-1$

2.4 Site Geology as Defined by Pre-Treatment Characterization . . . . . . . . . . . 2-2

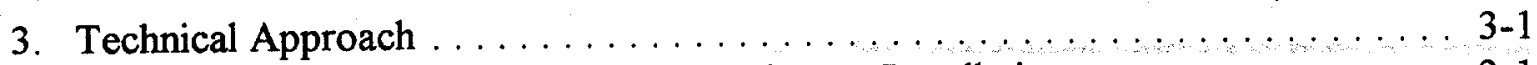

3.1 Task 1: Geoprobe Borings and Lysimeter Installation $\ldots \ldots \ldots \ldots \ldots \ldots$ 3-1

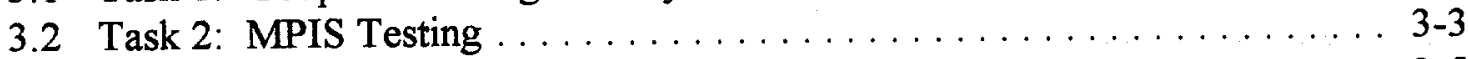

3.3 Task 3: Concurrent Monitoring ...................... 3-5

3.4 Task 4: Post-Injection Characterization and Data Collection . . . . . . . . 3-5

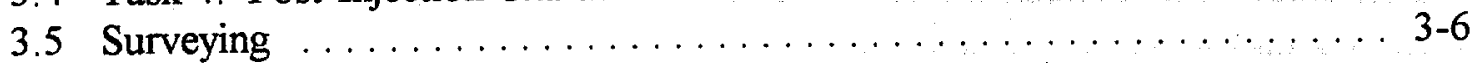

4. Specific Testing and Results $\ldots \ldots \ldots \ldots \ldots \ldots \ldots \ldots \ldots \ldots \ldots \ldots$ 4-1

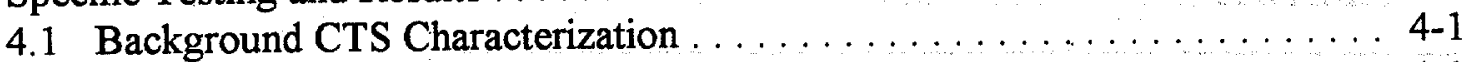

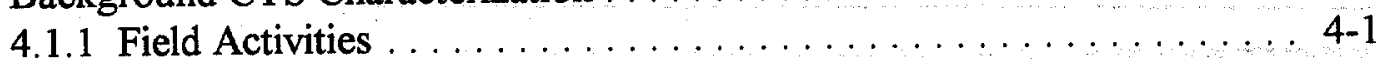

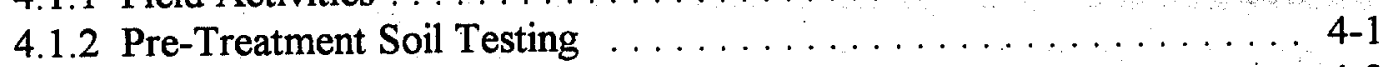

4.1.3 Background Water Testing $\ldots \ldots \ldots \ldots \ldots \ldots \ldots \ldots, 4,2$

4.2 Test Cell 1: Water Injection with Tracers $\ldots \ldots \ldots \ldots \ldots \ldots \ldots \ldots \ldots$ 4-3

4.2.1 T1 Field Activities ........................ 4-3

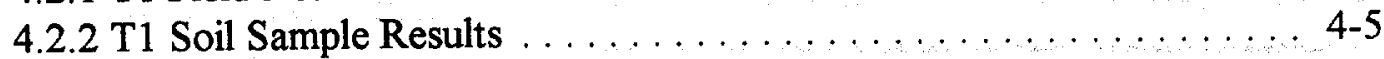

4.2.3 T1 Water Sample Results ........................ 4-6

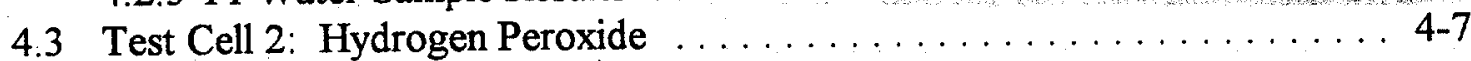

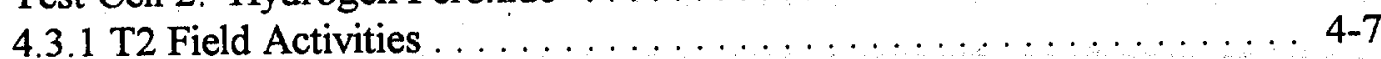

4.3.2 T2 Soil Sample Results $\ldots \ldots \ldots \ldots \ldots \ldots \ldots \ldots \ldots \ldots \ldots . \ldots . \ldots . . \ldots$

4.3.3 T2 Water Sample Results .................... 4-11

4.4 Test Cell 3: Bionutrient with Tracers $\ldots \ldots \ldots \ldots \ldots \ldots \ldots \ldots \ldots$ 4-11

4.4.1 T3 Field Activities ........................ 4-11 


\section{CONTENTS (continued)}

4.4.2 T3 Soil Sample Results . . . . . . . . . . . . . . . . . . . . . 4-13

4.4 .3 T3 Water Sample Results ... . . . . . . . . . . . . . . . . 4-14

4.5 Test Cell 4: Lime Slurry . . . . . . . . . . . . . . . . . . 4-15

4.5 .1 T4 Field Activities . . . . . . . . . . . . . . . . . . 4-15

4.5.2 T4 Soil Sample Results . . . . . . . . . . . . . . . . . . . . 4-17

4.5.3 T4 Water Sample Results ... . . . . . . . . . . . . . . . . . . 4 4-17

4.6 Test Cell 5: Potassium Permanganate $\ldots \ldots \ldots \ldots \ldots \ldots \ldots \ldots \ldots$ 4.18

4.6.1 T5 Field Activities . . . . . . . . . . . . . . . . . . . 4-18

4.6.2 T5 Soil Sample Results . . . . . . . . . . . . . . . . . . . 4 4-19

4.6.3 T5 Water Sample Results . . . . . . . . . . . . . . . . . . . 4-20

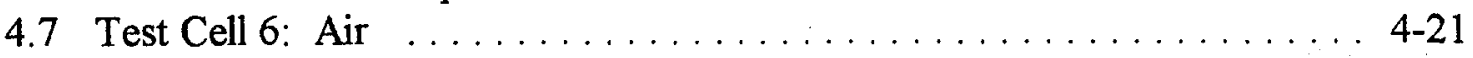

4.7.1 T6 Field Activities . . . . . . . . . . . . . . . . . . . 4-21

4.7.2 T6 Soil Sample Results . . . . . . . . . . . . . . . . . . . 4-22

4.7.3 T6 Water Sample Results . . . . . . . . . . . . . . . . . . . . . . 4-22

4.8 Test Cell 7: Micropowder Iron . . . . . . . . . . . . . . . . . 4-22

4.8.1 T7 Field Activities . . . . . . . . . . . . . . . . . . . . . 4-22

4.8.2 T7 Soil Sample Results . . . . . . . . . . . . . . . . 4 4-24

4.8.3 T7 Water Sample Results . . . . . . . . . . . . . . . 4-24

5. Equipment Operations Observations $\ldots \ldots \ldots \ldots \ldots \ldots \ldots \ldots \ldots \ldots$ 5-1

6. Summary and Conclusions $\ldots \ldots \ldots \ldots \ldots \ldots \ldots \ldots \ldots \ldots \ldots \ldots \ldots \ldots \ldots \ldots$

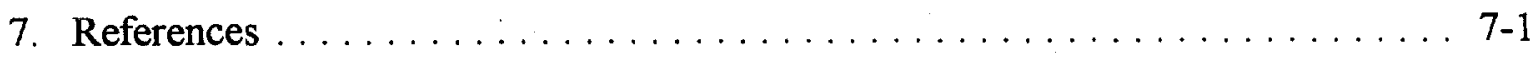

APPENDIX A - GEOTECHNICAL, BACKGROUND, AND GRAIN SIZE DISTRIBUTION RESULTS FOR THE CTS

APPENDIX B - LITHOLOGIC LOGS FOR THE TEST CELL SOIL BORINGS

APPENDIX C - DATA TREND GRAPHS FOR VARIOUS GEOCHEMICAL PARAMETERS IN SOIL AND SOIL-PORE WATER 


\section{LIST OF FIGURES}

2.1 Location of Portsmouth Gaseous Diffusion Plant . . . . . . . . . . . . . 2-4

2.2 Location of the CTS . . . . . . . . . . . . . . . . . . . 2-5

2.3 Overview of the test site with the DOE plant in the background . . . . . 2-6

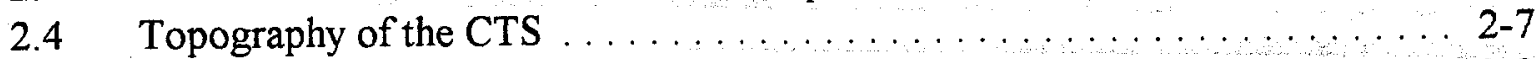

2.5 Topography and borehole locations at the CTS $\ldots \ldots \ldots \ldots \ldots \ldots \ldots \ldots$

2.6 Photographs of the CTS subsurface silty-clay media $\ldots \ldots \ldots \ldots \ldots \ldots . . \ldots 2-9$

2.7 Stratigraphic sequence of borehole number BH07 $\ldots \ldots \ldots \ldots \ldots \ldots \ldots$

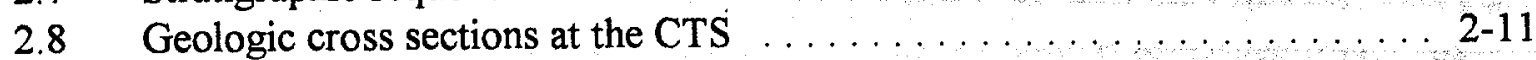

3.1 Test cells within the CTS . . . . . . . . . . . . . . . . . . $3-7$

3.2 Approximate locations for testing within a typical test cell $\ldots \ldots \ldots \ldots \ldots$ 3-8

3.3 Schematic diagram of nested lysimeters . . . . . . . . . . . . . . 3-9

3.4 Schematic diagram of piezometer . . . . . . . . . . . . . . $\ldots \ldots$

3.5 Profile view of the layout for the instrumented borings $\ldots \ldots \ldots \ldots \ldots$. . . . . .

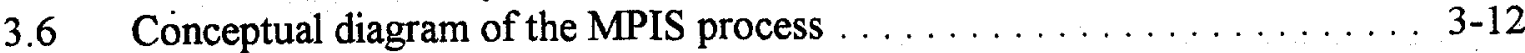

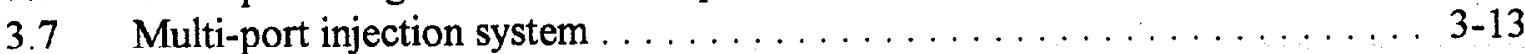

3.8 Photographs of the Hayward Baker MPIS rig and the monitoring and sampling analyses activities $\ldots \ldots \ldots \ldots \ldots \ldots \ldots \ldots$ 3-14

3.9 Photographs of intact soil cores from the permanganate (T5) and iron micropowder (T7) test cells . . . . . . . . . . . . . . . . . . . $3-15$

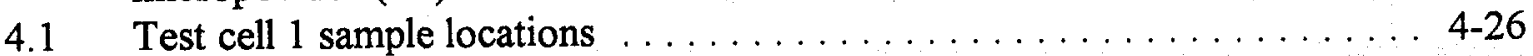

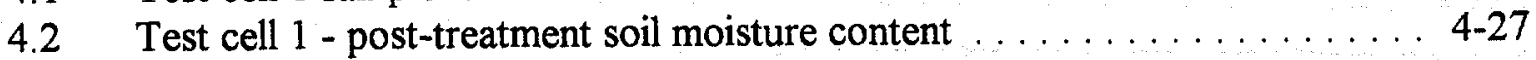

4.3 Test cell 1 - post-treatment soil bromide levels . . . . . . . . . . . . . 4-27

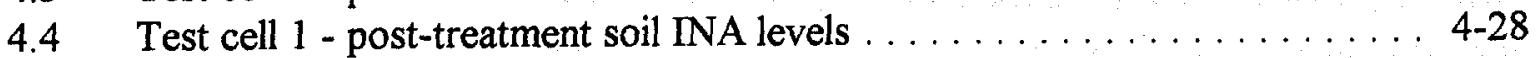

4.5 Test cell 1 - post-treatment water bromide levels $\ldots \ldots \ldots \ldots \ldots \ldots \ldots$ 4-28

4.6 Test cell 2 sample locations . . . . . . . . . . . . . . . . . . . . 4-29

4.7 Test cell 2 - post-treatment soil peroxide levels $\ldots \ldots \ldots \ldots \ldots \ldots \ldots$. $4-30$

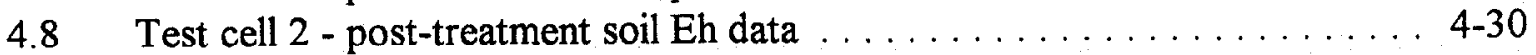

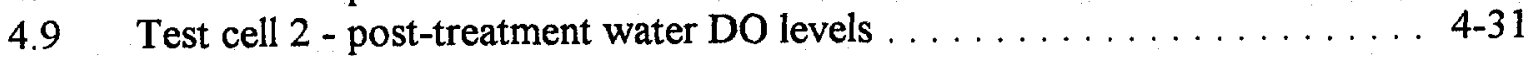

4.10 Test cell 2 - post-treatment water peroxide levels $\ldots \ldots \ldots \ldots \ldots \ldots \ldots$ 4-31

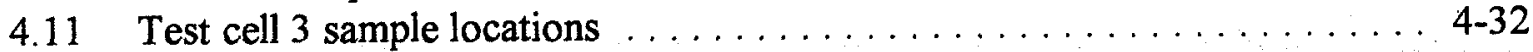

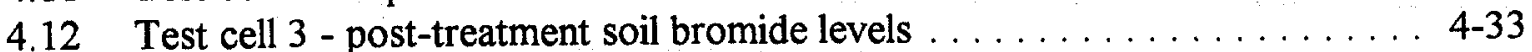

4.13 Test cell 3 - post-treatment soil INA levels . . . . . . . . . . . . . . . . 4 4-33

4.14 Test cell 3 - post-treatment water $\mathrm{pH} \ldots \ldots \ldots \ldots \ldots \ldots \ldots \ldots \ldots$ 4-34

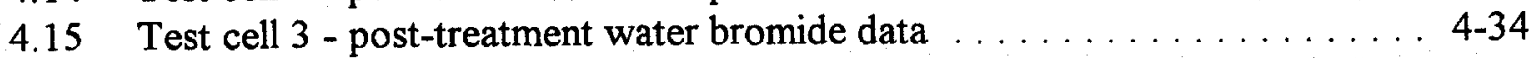

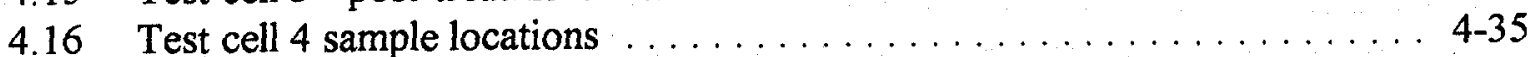

4.17 Test cell 4 - post-treatment soil $\mathrm{pH} \ldots \ldots \ldots \ldots \ldots \ldots \ldots \ldots \ldots \ldots$ 4-36

4.18 Test cell 4 - post-treatment soil calcium levels $\ldots \ldots \ldots \ldots \ldots \ldots \ldots$. . . . . . . . .

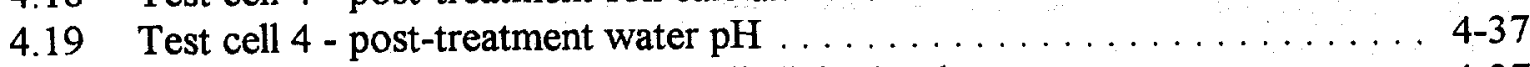

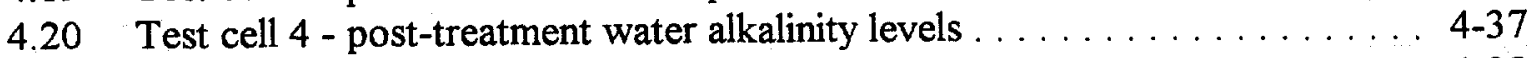

4.21 Test cell 4 - post-treatment water conductivity levels $\ldots \ldots \ldots \ldots \ldots \ldots$. . . . . . .

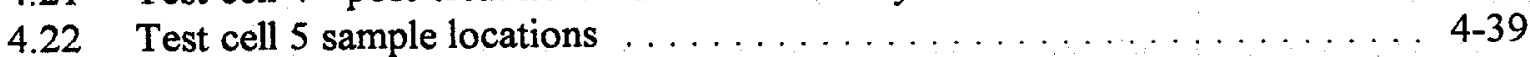




\section{FIGURES (CONTINUED)}

4.23 Test cell 5 - post-treatment soil manganese levels . . . . . . . . . . . . . . 4-40

4.24 Test cell 5 - post-treatment soil Eh levels . . . . . . . . . . . . . . . . . 4-40

4.25 Test cell 5 - post-treatment water mangansse levels . . . . . . . . . . 4-41

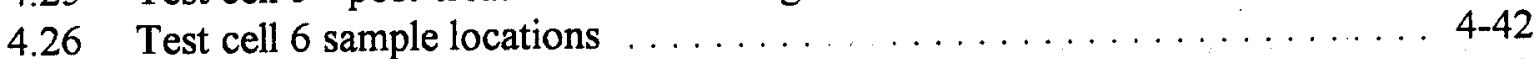

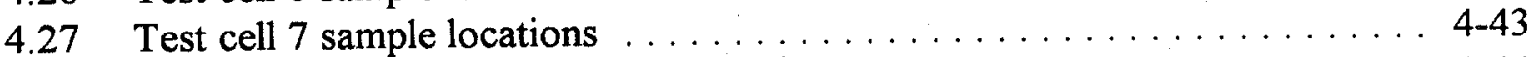

4.28 Test cell 7 - post-treatment water iron data $\ldots \ldots \ldots \ldots \ldots \ldots \ldots \ldots$. . . . . . $\ldots 4$ 


\section{LIST OF TABLES}

1.1 Field activities and analyses listed for a typical test cell for MPIS testing . . . 1-5

2.1 Ground surface and bedrock surface elevations for CTS boreholes . . . . . 2-12

2.2 Subsurface properties of the Minford Member at the CTS $\ldots \ldots \ldots \ldots .2-13$

3.1 ORNL SOPs for the MPIS demonstration $\ldots \ldots \ldots \ldots \ldots \ldots \ldots \ldots \ldots$

3.2 Activities performed in conjunction with MPIS testing $\ldots \ldots \ldots \ldots \ldots, 3-17$

3.3 Test cell design and characteristics . . . . . . . . . . . . . . . . . . 3-19

3.4 Treatment agents for MPIS testing at PORTS CTS $\ldots \ldots \ldots \ldots \ldots \ldots .3-20$

3.5 Process operating conditions for MPIS testing at the CTS $\ldots \ldots \ldots \ldots 3-21$

4.1 Summary of background soil results . . . . . . . . . . . . . . $4-45$

4.2 Water sample results from background piezometer and lysimeters $\ldots \ldots .4-46$

4.3 Tracer Test cell 1 (T1), soil sample results . . . . . . . . . . . . . . 4-48

4.4 Water sample results for the tracer test cell (T1), injection date $11 / 12 / 95 \ldots 4-49$

4.5 Hydrogen peroxide test cell (T2), soil sample results . . . . . . . . 4-51

4.6 Water sample results for the hydrogen peroxide test cell (T2), injection

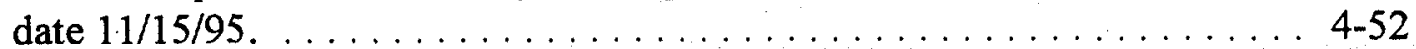

$4.7 \quad$ Bionutrient test cell (T3), soil sample results $\ldots \ldots \ldots \ldots \ldots \ldots \ldots .4-54$

4.8 Bionutrient test cell (T3) heterotrophic enumerations, cells $/ \mathrm{g} . \ldots \ldots \ldots .4-55$

4.9 Water sample results for the bionutrient test cell (T3), injection

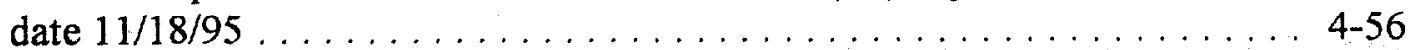

4.10 Lime slurry test cell (T4), soil sample results $\ldots \ldots \ldots \ldots \ldots \ldots \ldots \ldots 4-58$

4.11 Water sample results for the lime slurry test cell (T4), injection date 11/13/95 4-59

4.12 Potassium permanganate test cell (T5), soil sample results . . . . . . . . 4-61

4.13 Water sample results for the potassium permanganate test cell (T5), injection

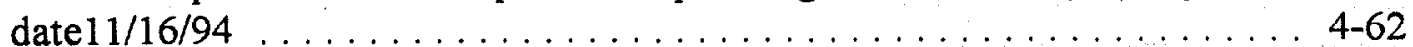

4.14 Water sample results for air test cell (T6), injection date $11 / 19 / 94 \ldots . .4464$

4.15 Iron micropowder test cell (T7), soil sample results . . . . . . . . . . 4-65

4.16 Water sample results for iron micropowder test cell (T7), injection date

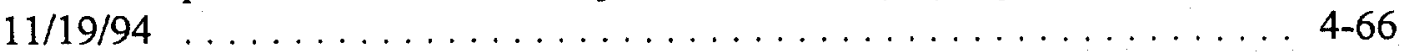

$5.1 \quad$ Task summary for MPIS testing $\ldots \ldots \ldots \ldots \ldots \ldots \ldots \ldots \ldots \ldots \ldots \ldots \ldots \ldots \ldots$ 


\section{ABBREVIATIONS, ACRONYMS, AND INITIALISMS}

\begin{tabular}{|c|c|}
\hline bgs & below ground surface \\
\hline CSM & Colorado School of Mines \\
\hline CTS & Clean Test Site \\
\hline $\mathrm{d}$ & day \\
\hline DNAPL & dense nonaqueous-phase liquids \\
\hline DO & dissolved oxygen \\
\hline DOE & U.S. Department of Energy \\
\hline ESD & Environmental Sciences Division \\
\hline $\mathrm{ft}$ & feet or foot \\
\hline $\begin{array}{l}\mathrm{g} \\
\mathrm{gal}\end{array}$ & gram \\
\hline $\begin{array}{l}\text { gal } \\
\text { GJ }\end{array}$ & gallon \\
\hline $\begin{array}{l}\text { GJ } \\
\text { ID }\end{array}$ & Grand Junction \\
\hline $\begin{array}{l}\text { ID } \\
\text { in. }\end{array}$ & inside diameter \\
\hline $\begin{array}{l}\text { in. } \\
\text { INA }\end{array}$ & inch \\
\hline $\begin{array}{l}\text { INA } \\
\mathrm{kg}\end{array}$ & ice-nucleating activity \\
\hline $\begin{array}{l}\mathrm{kg} \\
\mathrm{L}\end{array}$ & kilogram \\
\hline L & liter \\
\hline $\begin{array}{l}\text { LPM } \\
\mathrm{mg}\end{array}$ & low permeability media \\
\hline $\mathrm{mg}$ & milligram \\
\hline $\begin{array}{l}\text { LMES } \\
\text { MPIS }\end{array}$ & Lockheed Martin Energy Systems, Inc. \\
\hline MPIS & multi-port injection system \\
\hline MPN & most probable number \\
\hline $\mathrm{msl}$ & mean sea level \\
\hline $\mathrm{mV}$ & millivolt \\
\hline ORNL & Oak Ridge National Laboratory \\
\hline OST & Office of Science and Technology \\
\hline oz. & ounce \\
\hline PCE & perchloroethylene \\
\hline PE & polyethylene \\
\hline $\begin{array}{l}\text { PORTS } \\
\text { ppm }\end{array}$ & $\begin{array}{l}\text { Portsmouth Gaseous Diffusion Plant } \\
\text { parts per million }\end{array}$ \\
\hline psi & pounds per square inch \\
\hline $\mathrm{PVC}$ & polyvinyl chloride \\
\hline s & second \\
\hline SEM & scanning electron microscope \\
\hline SMT & soil moisture and temperature \\
\hline SOPs & standard operating procedures \\
\hline TBD & to be determined \\
\hline TCE & trichloroethylene \\
\hline TOC & total organic carbon \\
\hline U.S. & United States \\
\hline USEC & United States Enrichment Corporation \\
\hline
\end{tabular}


$\mathrm{x}$ 


\section{EXECUTIVE SUMMARY}

A research and demonstration project was completed to evaluate the viability of permeation dispersal as a delivery method for delivering treatment agents to enable in situ remediation of contaminated low permeability media soils. This report describes field-scale testing using unconfined test cells established at the Clean Test Site (CTS) at the DOE Portsmouth Gaseous Diffusion Plant near Piketon, Ohio. At this site a commercially available multi-port injection system (MPIS) was used to deliver contrasting agents into a silty clay deposit. A companion report describes laboratory studies completed at the Colorado School of Mines where intact soil cores collected from the CTS were injected with two chemical oxidants (hydrogen peroxide and potassium permanganate) (see Urynowicz and Siegrist, 2000).

At the CTS, seven unconfined test cells were established to enable evaluation of seven treatment agents. The treatment agents tested were selected based on their contrasting features and potential applicability to treatment of organic chemicals in the subsurface. Water amended with tracers was injected into one test cell (T1) to provide a reference for nonreactive fluid movement in the silty-clay soil. The treatment agents studied included: hydrogen peroxide (T2) and potassium permanganate (T5) as chemical oxidants capable of degradation of many toxic organics; a guar gum suspension of iron micropowder (T7) for reductive dechlorination; a lime slurry (T4) to elevate $\mathrm{pH}$ and cause alkaline destruction of organics as well as stabilize metals; a bionutrient/surfactant agent (T3) to enhance biodegradation; and compressed air (T6) to enhance permeability and aeration status and improve volatilization or biodegradation. Six of the test cells were $24 \mathrm{ft}$ by $24 \mathrm{ft}$ in surface area while one was $4 \mathrm{ft}$ by $8 \mathrm{ft}$. All cells were injected with treatment agents at an average volumetric loading of $0.27 \mathrm{gal} / \mathrm{ft}^{3}$ to a depth of $10.4 \mathrm{ft}$ below ground surface using the MPIS with four rack-mounted injectors on 2 -ft spacings. Extensive monitoring during injection and sampling and analysis before and after injection were completed to evaluate the effectiveness of MPIS delivery and the impacts of the various agents on the ambient subsurface conditions.

Field test results revealed that treatment agents can be rapidly delivered into the shallow subsurface using MPIS technology. The treatment agents injected appear to rapidly advect away from the injector bore in existing pathways such as root channels and fractures. For those agents that are persistent and react slowly in the subsurface, further dispersal can occur by slower advection in fine matrix pores as well as by diffusive transport processes. The initial dispersal of the treatment agents was similar to that of the conservative tracers. With time after the injections were completed, there were expanding effects in the subsurface within the lime, potassium permanganate and iron cells. Evaluation of injection rates, equipment and labor costs indicate that MPIS technology may be applied for $\$ 2$ to $\$ 3$ per cubic yard of soil not including the cost of reagents. 


\section{ACKNOWLEDGMENTS}

This report on the demonstration of permeation and dispersal of reactive fluids for in situ treatment in low permeability media at the U.S. Department of Energy (DOE) Portsmouth Gaseous Diffusion Plant (PORTS) is based on the combined efforts of scientific and engineering staff at Oak Ridge National Laboratory (ORNL) and Hayward Baker Environmental in collaboration with the Colorado School of Mines (CSM) and others. Project sponsorship was provided through the Subsurface Contaminant Focus Area of the DOE Office of Science \& Technology along with the DOE Office of Environmental Restoration at PORTS.

The following individuals are specifically recognized for their valuable contributions to the field demonstration:

$\begin{array}{lll}\text { Robert Barnett } & - & \text { Lockheed Martin Energy Systems (LMES) (In } \\ \text { Skip Chamberlain } & - & \text { DOmorium) } \\ \text { Tom Early } & - & \text { Subsurface Contaminant Focus Area } \\ \text { Eugene Gillespie } & - & \text { DOE Site Office, PORTS } \\ \text { Johnny Moore } & - & \text { DOE Oak Ridge Operations Office } \\ \text { Elizabeth Philips } & - & \text { Subsurface Contaminant Focus Area, Product Line } \\ \text { John Sheppard } & - & \text { Manager } \\ \text { Jim Wright } & - & \text { DOE Site Office, Paducah } \\ \text { Doug Davenport } & - & \text { Subsurface Contaminant Focus Area } \\ \text { Tom Houk } & - & \text { LMES, Technology Applications } \\ & - & \text { Bechtel Jacobs Company (BJC), Technology } \\ \text { Jim Ervin } & & \text { Applications } \\ \text { Dianne Gates } & - & \text { BJC, Construction Engineering } \\ \text { Baohua Gu } & - & \text { Lawrence Livermore National Laboratory } \\ \text { Chris Muhr } & - & \text { ORNL, Environmental Sciences Division (ESD) } \\ \text { Tony Palumbo } & - & \text { ORNL Environmental Technology Section (ETS) } \\ \text { Susan Pfiffner } & - & \text { ORNL, ESD } \\ & - & \text { Univ. Tennessee, Center for Environmental } \\ \text { Doug Pickering } & - & \text { Biotechnology } \\ \text { Kirk Roemer } & - & \text { ORNL ETS } \\ \text { Joann Sauvage } & - & \text { ORNL ETS } \\ \text { Bob Schlosser } & - & \text { ORNL ETS } \\ \text { Jim Thate } & - & \text { ORNL ETS } \\ \text { Mike Urynowicz } & - & \text { ORNL ETS Environmental Science \& Engineering } \\ \text { Olivia West } & - & \\ & - & \end{array}$




\section{Introduction}

Chlorocarbons like trichloroethylene (TCE) are common contaminants of concern at U. S. Department of Energy (DOE) facilities and industrial sites across the United States (U.S.) and abroad (Huling and Weaver 1991; U.S.EPA 1992; MacDonald and Kavanaugh 1994). These contaminants of concern are present in source areas and in soil and ground water plumes as dissolved or sorbed phase constituents as well as dense nonaqueous-phase liquids (DNAPLs). These DNAPL compounds can be released to the environment through a variety of means including leaks in storage tanks and transfer lines, spills during transportation, and land treatment of wastes. When DNAPL compounds are present in low permeability media (LPM) like silt and clay layers or deposits, there are major challenges with assessment of their behavior and implementation of effective in situ remediation technologies.

In situ remediation technology development has largely overlooked treatment of DNAPLs in LPM. Poor accessibility to the contaminants and the difficulty in delivery of treatment agents have rendered conventional bioremediation, vapor extraction, and pump-and-treat ineffective for this type of media. As a result, effective in situ treatment methods for DNAPL compounds in fine-grained deposits was recently one of the top-ranked environmental restoration needs across the DOE Complex. Similarly, within the petroleum industry, nearly $40 \%$ of the underground storage tanks in the world are located on clay soils and remediation of contaminants from leaking underground tanks in these settings has been a major challenge.

As a result of the need for solutions and the gap in the current knowledge and technology base, a project was initiated by the DOE Office of Science and Technology (OST) and the DOE Portsmouth Gaseous Diffusion Plant (PORTS) near Piketon, Ohio in collaboration with the American Petroleum Institute (API) in 1993 (API 1995, DOE 1996). In this project, in situ remediation technologies are being evaluated for both enhanced mass removal and in place destruction of DNAPL compounds in LPM, specifically chlorinated solvents [e.g., TCE, perchloroethylene (PCE)] in the vadose and saturated zones of LPM. The overall project has included a series of related tasks including: (1) preparation of 16 DNAPL focus papers and reports, (2) a field pilot test of hydraulic fracturing for dewatering, (3) a field test of enhanced air flushing for NAPL removal, (4) a field test of hydraulic fractures for hydraulic and pneumatic control and hot fluid injection, (5) a field comparison of multiple point injection and permeation dispersal of different reactants, (6) a field-scale demonstration of soil fracturing for thermally enhanced mass recovery and reactive barrier degradation, and (7) numerical and experimental analyses of the mobility of residual NAPLs versus varying degrees of remediation. The field testing activities have occurred at both clean and contaminated sites in the U.S. and Canada.

This report describes a field demonstration that was conducted at the PORTS Clean Test Site (CTS) to evaluate the feasibility of permeation and dispersal of reagents into LPM. Various reagents and tracers were injected at seven test cells primarily to evaluate the feasibility of 
delivery, but also to evaluate the effects of the injected reagents on LPM. The various reagents and tracers were injected at the PORTS CTS using a multi-port injection system (MPIS) developed and provided by Hayward Baker Environmental, Inc. The work reported here was performed by personnel from Oak Rigge National Laboratory (ORNL) in collaboration with Lockheed Martin Energy Systems [(LMES), now Bechtel Jacobs Company, LLC], Hayward Baker Environmental, Inc., and others.

Supplementary laboratory experiments at the Colorado School of Mines focused on the effects of chemical oxidants on LPM using intact cores collected from the CTS. The results of the laboratory experiments are presented in the companion report, Permeation Dispersal of Treatment Agents for In Situ Remediation in Low Permeability Media: 2. Laboratory Studies with Intact Cores (Urynowicz and Siegrist 1999). Other facets of the project have been focused on the reaction mechanisms of reagents used in this project and alternative reagent delivery methods and the results have been reported elsewhere (e.g., API 1995; DOE 1996; Pfiffner et al. 1997; Case 1997; Gates and Siegrist 1995; Gierke et al. 1995; Murdoch et al. 1997a; Murdoch et al. 1997b; Siegrist et al. 1993; Siegrist et al. 1994; Siegrist and Lowe 1995; Siegrist et al. 1995a; Siegrist et al. 1995b; Siegrist et al. 1995c; Siegrist et al. 1996; Siegrist et al. 1998; Siegrist et al. 1999; Smuin et al. 1995; Strong-Gunderson and Palumbo 1995; Walden 1993; West et al. 1995).

\subsection{Purpose and Scope}

The purpose of this project was to test an innovative approach for in situ treatment of volatile organic compounds, which are common contaminants at DOE facilities.. The PORTS CTS was chosen as an appropriate location for determining the feasibility of performing multi-point injection permeation and dispersal testing because it is representative of the low permeability soils contaminated at many DOE sites. Additionally, the CTS enabled evaluation of the feasibility of the process but did not present the complications of contaminated site operations.

The various reagents and tracers injected included water, oxidants, a bionutrient, lime, air, and zero-valence iron. Water alone was injected to provide a baseline test cell. The oxidants (hydrogen peroxide and potassium permanganate) were injected because they can catalyze and chemically oxidize chlorinated organics. The bionutrient and surfactant were injected to determine the feasibility of using the mixture to enhance the natural breakdown of chlorinated solvents by indigenous bacteria. The lime injection was tested because it could be used to adjust soil $\mathrm{pH}$ for in situ stabilization of metals. Air was injected to test the MPIS for pneumatic fracturing of LPM and zero-valence iron (iron micropowder) was injected because it has been demonstrated to act as a reducing agent for chlorinated solvents. 
The field work for this project included four tasks: (1) pre-treatment characterization of the lithology and soil conditions within seven test cells at the CTS, (2) MPIS injection and testing using various reagents and tracers at seven test cells, (3) concurrent monitoring during MPIS testing, and (4) post-treatment sampling and monitoring of the seven test cells. Several posttreatment sampling events were performed.

Samples collected during this project included soil samples for logging lithology, soil fracture characteristics and geochemical properties, and soil-pore water samples for water quality parameters and geochemical properties. Field and laboratory analysis was performed on soil samples and soil-pore water samples as indicated on Table 1.1.

The following aspects of the permeation and dispersal were evaluated during this project:

- Feasibility of using a MPIS for injection of treatment agents into the subsurface. The agents were various solutions, slurries, or emulsions of compounds that may reduce toxicity through treatment or containment, and

- Relative effectiveness of the treatment agents for in situ remediation in silty clay soils.

The general objectives of the testing and the procedures followed to achieve them are listed below.

Objective 1: To characterize fracture size and continuity in the untreated soil and determine changes in the soil after reagent injection. Pre-treatment soil samples were collected from soil borings to describe fracture morphology and determine baseline geochemical properties. Tracers were injected with the treatment agents, where compatible, in order to facilitate detection of the injected fluids and the fractures that transmitted them. Soil-pore water samples were collected from suction lysimeters to evaluate the dispersal of the injected fluids. Soil moisture probes were emplaced to monitor the increase in soil moisture due to injections. Soil samples from post-treatment borings were inspected to determine changes in fracture size and density and geochemical properties. At one location, a test pit was excavated to permit visual examination of the soil to determine if the effects of the injection technique were visible in the subsurface.

Objective 2: To determine matrix effects of the various fluids released with respect to changes in soil-pore water and soil. Suction lysimeters provided soil-pore water samples that were monitored for changes in temperature, $\mathrm{pH}$, dissolved oxygen (DO), conductivity, total organic carbon (TOC), alkalinity, $\mathrm{Fe}, \mathrm{Mn}, \mathrm{Cl}^{-}, \mathrm{No}_{3}{ }^{-}$and $\mathrm{SO}_{4}{ }^{2-}$. Soil moisture probes were monitored to determine the relative dispersal of the injected fluids. Soil samples were collected for evaluation of matrix effects and detection of injected fluids. 
Objective 3: To determine dispersal of reactive particles in LPM. An emulsion or slurry of reactive particles (e.g., iron micropowder with guar gum) was injected into the subsurface using the MPIS. The area of influence was evaluated by collecting post-treatment core samples. These cores were macroscopically inspected and chemically analyzed to determine the presence, concentration, and distribution of the reactive particles and/or tracers. Soil-pore water samples collected from suction lysimeters also provided information on dispersal of reagents.

Objective 4: To determine dispersal of oxidants in LPM. Solutions of hydrogen peroxide and potassium permanganate were injected. The area of influence was determined by collecting core samples and by collecting soil-pore water samples. These cores and water samples were analyzed to determine the effects of the reactive fluids.

Objective 5: To determine the operation and maintenance characteristics of the MPIS equipment. Observations of injection volumes, flow rates, back pressure, operational problems, etc., were documented during field tests to evaluate multi-point injection performance.

\subsection{Organization of the Report}

The remainder of this report is organized as follows:

- Section 2 describes the CTS.

- Section 3 describes the technical approach for this project.

- Section 4 discusses the testing performed in each test cell and the soil and water sampling results.

- Section 5 discusses observations made related to equipment operation.

- Section 6 is the project summary.

- Section 7 discusses application of the technique to a contaminated site. 
Table 1.1. Field activities and analyses for a typical test cell for MPIS testing

\begin{tabular}{|c|c|c|c|}
\hline Pre-treatment activities & Testing during injection & $\begin{array}{l}\text { Post-treatment No. } 1 \\
\text { activities }\end{array}$ & $\begin{array}{l}\text { Post-treatment No. } 2 \\
\text { activities }\end{array}$ \\
\hline $\begin{array}{l}\text { Soil Analyses: } \\
\text { Five soil borings per test cell:\% } \\
\text { moisture, grain size color, minera- } \\
\text { logy, SEM, X-ray, pH, Eh, TOC, Fe } \\
\text { oxides, cations, anions, bacteria }\end{array}$ & None & $\begin{array}{l}\text { Five soil borings per test cell: } \\
\% \text { moisture, grain size, color, } \\
\text { mineralogy, SEM, X-ray, pH, Eh, } \\
\text { TOC, Fe oxides, cations, anions, } \\
\text { bacteria, visual inspection }\end{array}$ & $\begin{array}{l}\text { Two soil borings per test cell: } \\
\text { \% moisture, grain size, color, } \\
\text { mineralogy, SEM, X-ray, pH, } \\
\text { Eh, TOC, Fe oxides, cations, } \\
\text { anions, bacteria }\end{array}$ \\
\hline Soil-Pore Water Analyses: & $\begin{array}{l}\text { Water injection with tracers: } \\
\text { monitored penetration rate, flow. } \\
\text { rate, pressure, and reagent } \\
\text { concentration }\end{array}$ & & \\
\hline $\begin{array}{l}\text { Three lysimeters per test cell: temp., } \\
\text { pH, } \mathrm{DO} \text {, conductivity, } \mathrm{TOC} \text {, } \\
\text { alkalinity, } \mathrm{Fe}, \mathrm{Mn}, \mathrm{Cl}, \mathrm{NO}_{3}, \mathrm{SO}_{4}{ }^{2-} \text {, } \\
\mathrm{Br}\end{array}$ & $\begin{array}{l}\text { Lysimeters: temp., } \mathrm{pH}, \mathrm{DO} \\
\text { conductivity, } \mathrm{TOC}, \text { alkalinity, } \mathrm{Fe} \text {, } \\
\mathrm{Mn}, \mathrm{Cl}^{-}, \mathrm{NO}_{3} ; \mathrm{SO}_{4}^{2-}, \mathrm{Br}^{-}\end{array}$ & $\begin{array}{l}\text { Lysimeters: temp., pH, } \mathrm{DO} \text {, } \\
\text { conductivity, TOC, alkalinity, } \mathrm{Fe} \text {, } \\
\mathrm{Mn}, \mathrm{Cl}, \mathrm{NO}_{3}^{-}, \mathrm{SO}_{4}^{2-}, \mathrm{Br}\end{array}$ & $\begin{array}{l}\text { Lysimeters: temp., pH, } \mathrm{DO} \text {, } \\
\text { conductivity, } \mathrm{TOC}, \\
\text { alkalinity, } \mathrm{Fe}, \mathrm{Mn}, \mathrm{Cl}^{-}, \mathrm{NO}_{3}{ }^{-} \\
\mathrm{SO}_{4}^{2-}, \mathrm{Br}^{-}\end{array}$ \\
\hline $\begin{array}{l}\text { One piezometer per test cell: temp., } \\
\text { pH, } \mathrm{DO} \text {, conductivity, } \mathrm{TOC} \text {, } \\
\text { alkalinity, } \mathrm{Fe}, \mathrm{Mn}, \mathrm{Cl}, \mathrm{NO}_{3}^{-}, \mathrm{SO}_{4}^{2-} \\
\mathrm{Br}^{-}\end{array}$ & Piezometer: monitored water levels & $\begin{array}{l}\text { Piezometer: temp., } \mathrm{pH}, \mathrm{DO} \\
\text { conductivity, TOC, alkalinity, } \mathrm{Fe}, \\
\mathrm{Mn}, \mathrm{Cr}, \mathrm{NO}_{3}, \mathrm{SO}_{4}{ }^{2-}, \mathrm{Br}\end{array}$ & $\begin{array}{l}\text { Piezometer: temp., } \mathrm{pH}, \mathrm{DO}, \\
\text { conductivity, } \mathrm{TOC}, \\
\text { alkalinity, } \mathrm{Fe}, \mathrm{Mn}, \mathrm{Cl}, \mathrm{NO}_{3} \text {, } \\
\mathrm{SO}_{4}^{2-}, \mathrm{Br}^{-}\end{array}$ \\
\hline
\end{tabular}

Note: Not all samples were analyzed for all constituents listed. For example, only samples from one soil boring per test cell were analyzed for \% moisture.

SEM = scanning electron microscope

$\mathrm{TOC}=$ total organic carbon 



\section{Background}

\subsection{Facility Description}

PORTS is a federal facility owned by DOE and operated under a contract with United States Enrichment Corporation (USEC). LMES (now Bechtel Jacobs Company, LLC) performs DOE-required environmental restoration, waste management, and site management functions. The 3,714-acre federal reservation lies in Pike County, Ohio, between the cities of Chillicothe and Portsmouth, approximately 70 miles south of Columbus, Ohio (Fig. 2.1).

Operating since 1954, PORTS enriches uranium for commercial nuclear reactors. The enrichment process uses molecular diffusion techniques to separate the ${ }^{235} \mathrm{U}$ isotope from the ${ }^{238} \mathrm{U}$ isotope. The plant has an extensive support complex of machine shops, laboratories, utilities, and decontamination facilities. As a result of plant operations, PORTS generates a wide variety of wastes, including low-level radioactive wastes, spent solvents, polychlorinated biphenyl-contaminated oils, electroplating wastes, paint wastes, metal sludges, acids, and caustics.

\subsection{Site Description}

The CTS is located at the south end of PORTS, north of the intersection of Hewes Street and Perimeter Road (Figs. 2.2 and 2.3). The site lies outside the plant security fence and is in an uncontaminated area. The topography of the CTS is relatively level, with a drainage area along the western boundary and a rise of higher ground along the eastern boundary of the site (Fig. 2.4). The high point of the area is located at the northeast corner, at an approximate elevation of $667 \mathrm{ft}$ above mean sea level $(\mathrm{msl})$. A storm-water retention pond is located approximately $75 \mathrm{ft}$ west of the northwest corner of the site, but is downgradient with respect to both surface and groundwater and does not appear to affect CTS conditions.

\subsection{Site Geology as Defined by CTS Characterization}

During the spring of 1994, the ORNL Grand Junction, Colorado (ORNL-GJ) characterized the geology of the CTS by installing nine boreholes to bedrock ( $\mathrm{BH} 01$ through $\mathrm{BH} 09$ ) at a depth of approximately $30 \mathrm{ft}$ below ground surface (bgs) and collecting soil samples with a hollow-stem-auger drilling rig and a GeoProbe ${ }^{\mathrm{TM}}$ rig (Fig. 2.5). The ORNL Environmental Sciences Division performed a ground-penetrating radar survey to delineate the bedrock surface. The geologic data collected from this site characterization were used to construct a bedrock surface map. 
Drilling was accomplished using an all-terrain, CME 55 drill rig. The rig used hollow-stem augers with a 3-in.-outside-diameter by 5-ft-long continuous sampler that ran a few centimeters ahead of the lead auger to obtain undisturbed soil samples for lithologic logging. An average of three soil samples per hole were collected and analyzed for moisture content, liquid limit, plastic limit, and grain size. In the summer, an additional six borings (BH10 through BH15) were drilled south of the CTS to characterize the geology in that area prior to the installation of horizontal wells. A detailed lithologic log was prepared for each hole; the continuous samples obtained from the hole were labeled and archived for future use. Lithologic logs and the results of the geotechnical analyses are provided in Appendix A. Table 2.1 summarizes the surface and bedrock elevation data for all of the borings. Table 2.2 summarizes the subsurface properties at the CTS and shows the properties determined during this study.

The soil above bedrock at the CTS is composed of unconsolidated Quaternary fluvial and lacustrine deposits of the Teays Formation. Figures 2.6 and 2.7 are examples of the soil cores and stratigraphic sequence. These deposits are characterized by 15 to $22 \mathrm{ft}$ of low permeability clays and silts known as the Minford Member overlying 2 to $6 \mathrm{ft}$ of moderately permeable sandy gravels, gravelly sands, and silty sands known as the Gallia Member. The bedrock underlying the Quaternary deposits is composed of Mississippian-age Sunbury Shale and Berea Sandstone and Shale. The Sunbury is a very low permeability shale unit underlying the saturated alluvium at the site. Figure 2.8 shows cross sections of the geology at the CTS.

The Gallia forms the principal water-bearing unit in the alluvium at the site. Water-level measurements taken during the drilling project indicate that groundwater in the Gallia, and perhaps the lower portion of the Minford, is confined by the overlying clays and silty clays. When the confining layers were penetrated by augers, the groundwater level rose an average of $13.5 \mathrm{ft}$ above the depth at which saturated sediments were first encountered during drilling (14 ft to $24.5 \mathrm{ft}$ bgs).

\subsection{Site Geology as Defined by Pre-Treatment Characterization}

Thirty-two soil borings were completed within the CTS prior to the start of injection testing. The borings were drilled to a depth of $12 \mathrm{ft}$ and were sampled continuously with a Geoprobe megabore sampler. Lithologic logs were prepared describing the soil characteristics (Appendix B). The most notable characteristics included:

- the presence of high-angle fractures in the silty clay,

- very fine laminar bedding in some sediments with multi-colored banding,

- a zone of thin-bedded gypsum (less than $1 \mathrm{~cm}$ thick) apparent across the site at depths between 6.5 to $8 \mathrm{ft}$ bgs, 
- increasing clay content with depth, and

- increasing resistance to penetration with depth.

Based on these characteristics, the upper part of the Minford appears to be primarily composed of shallow lake bed (lacustrine) sediments. There were periods during deposition when the lake dried up, thus forming the thin gypsum beds and desiccation mud cracks that were observed in the finely laminated sediments. This interpretation is consistent with the general description of the Minford given above. 


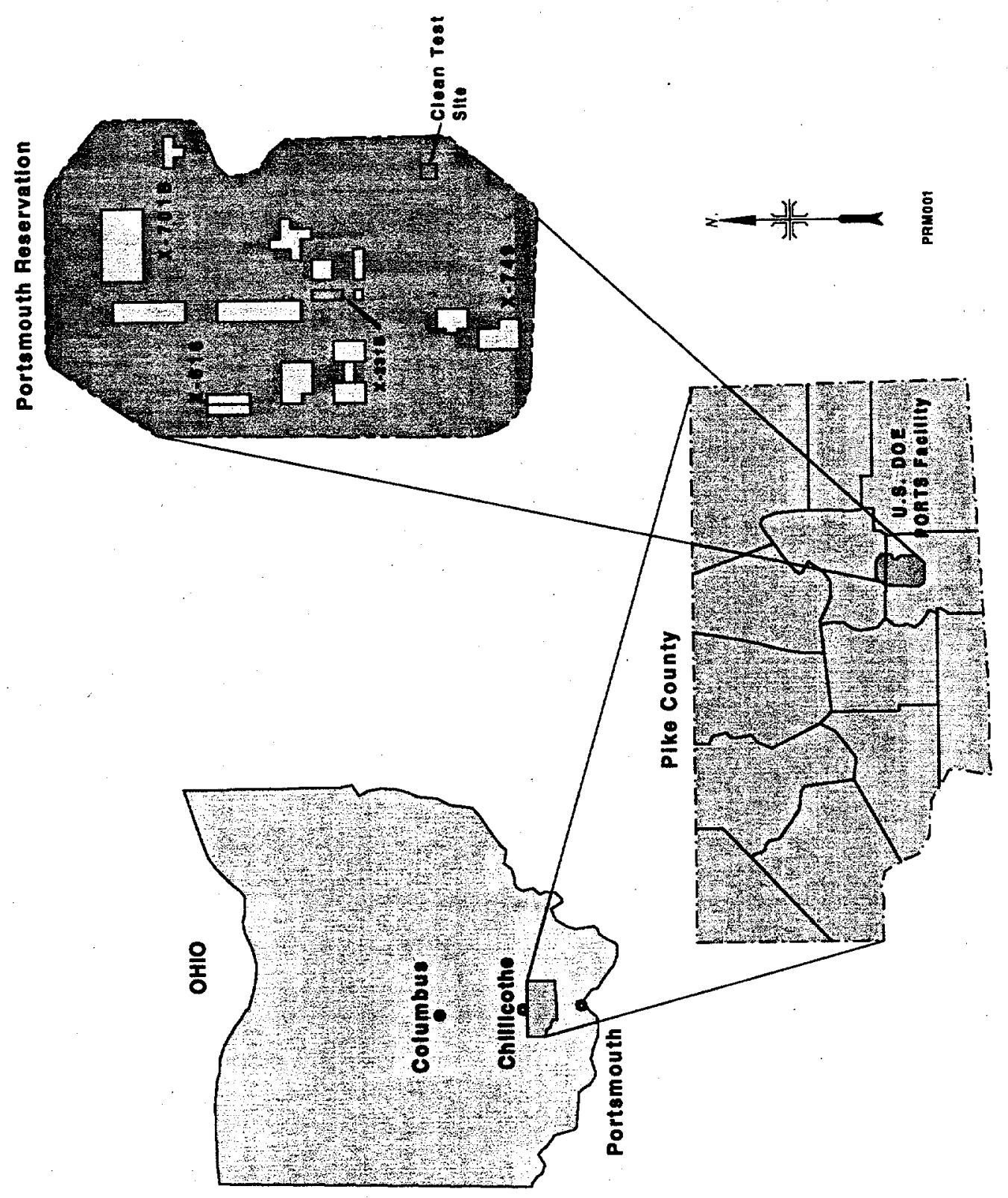

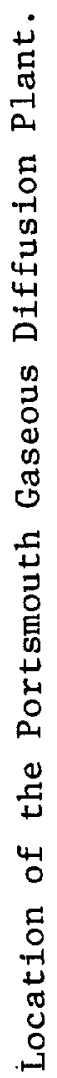

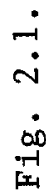



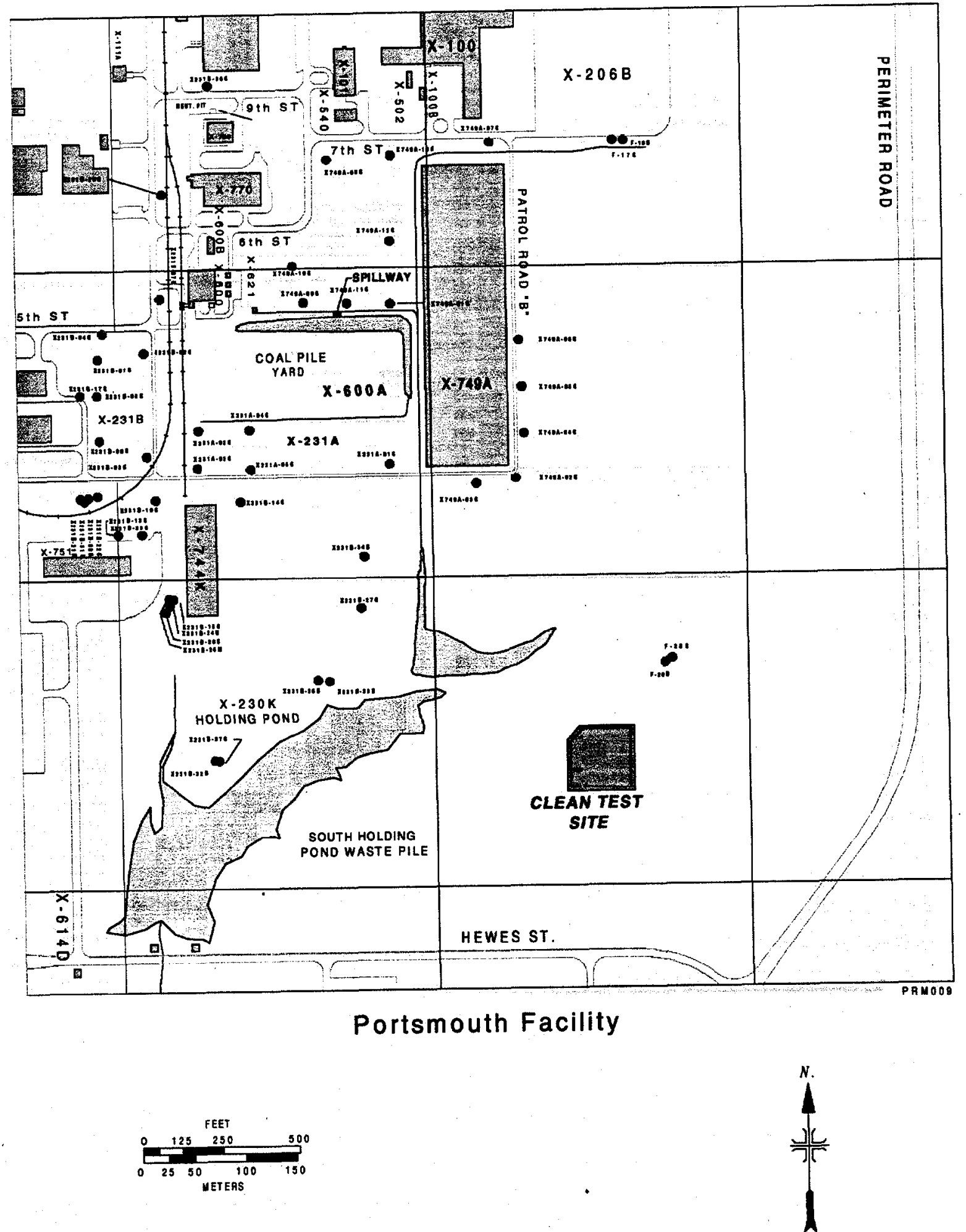

Fig. 2.2. Location of the CTS. 


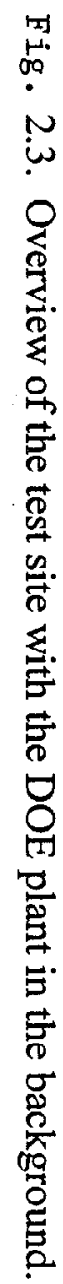



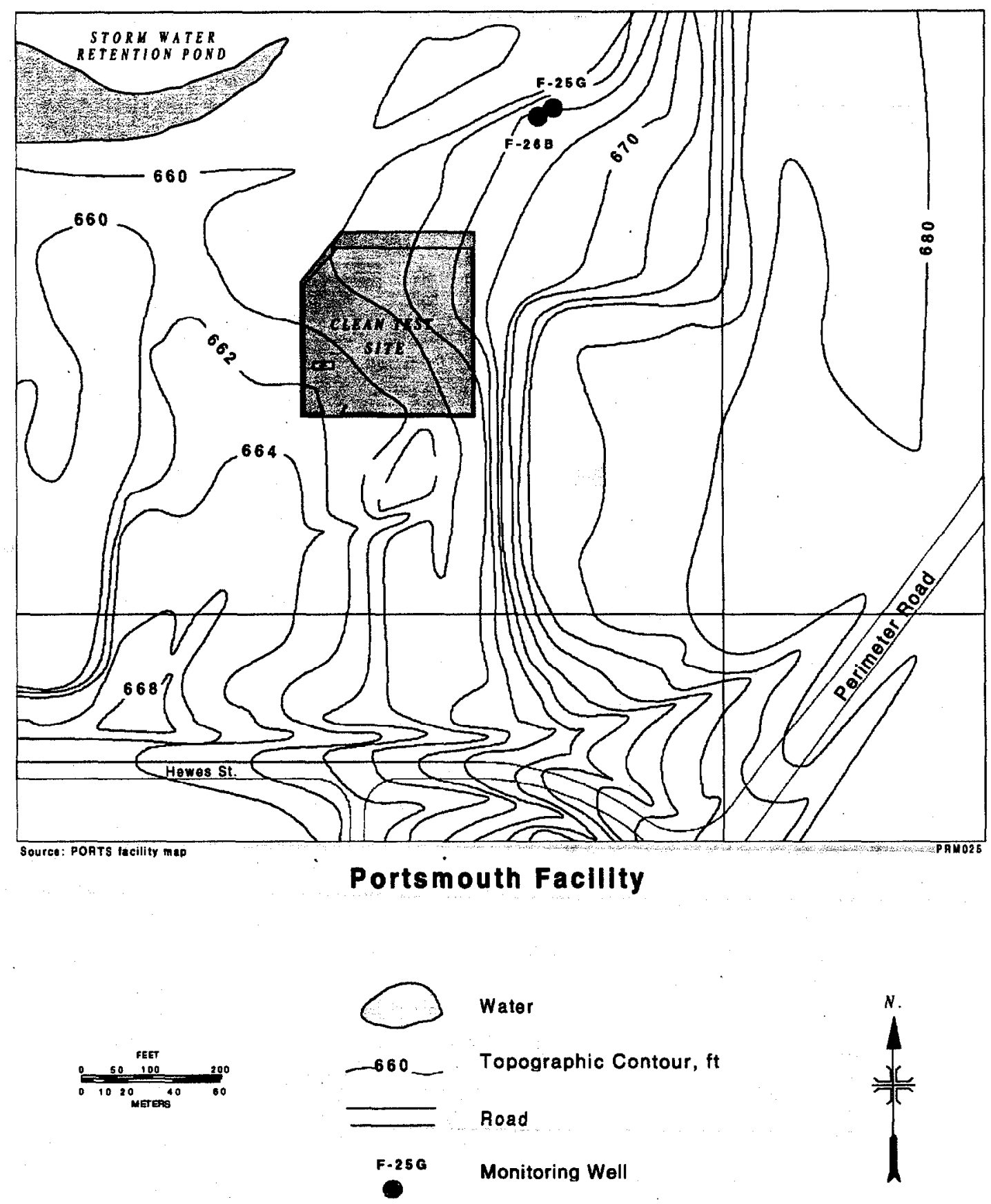

Fig. 2.4. Topography of the CTS. 


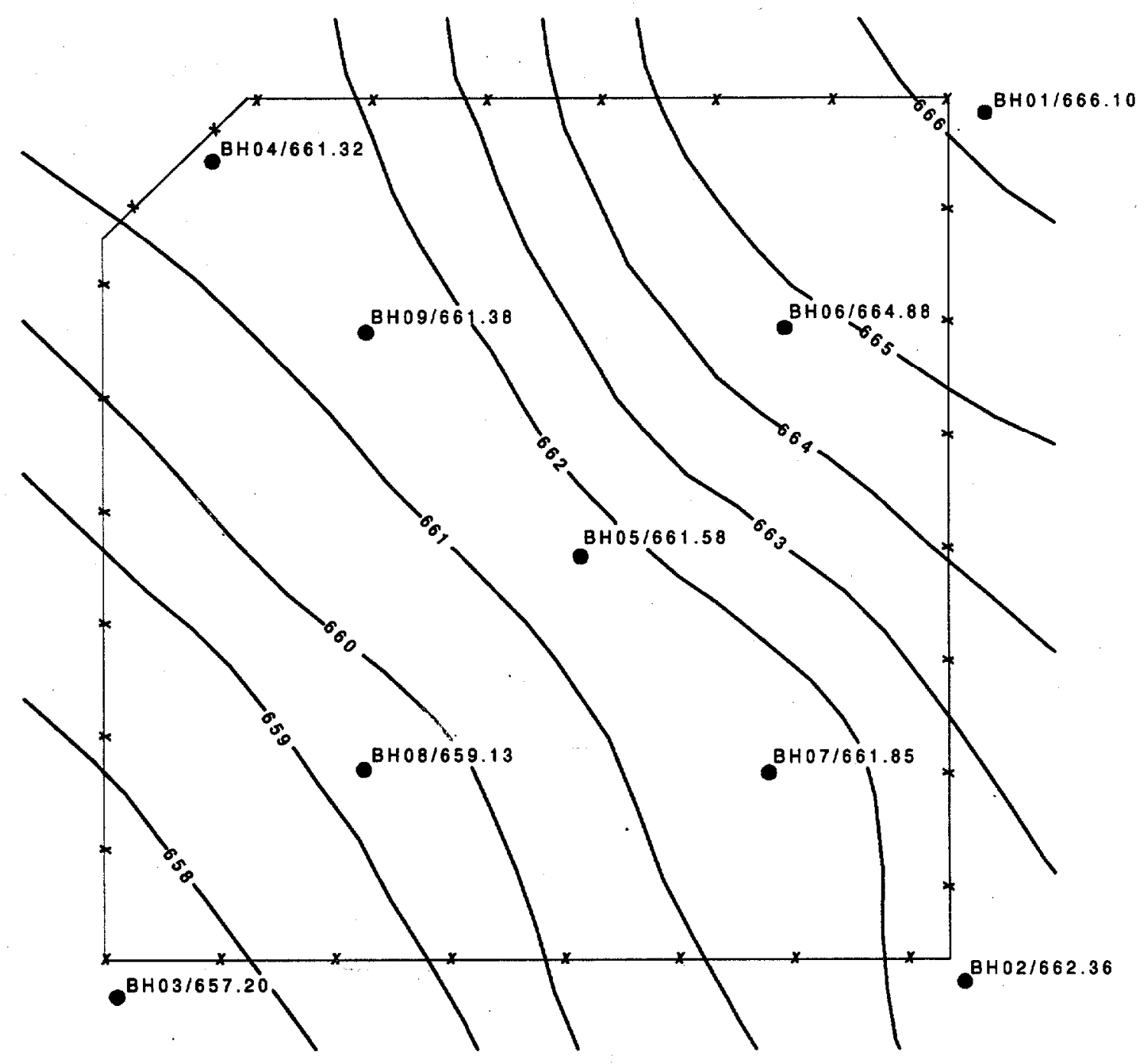

Clean Test site

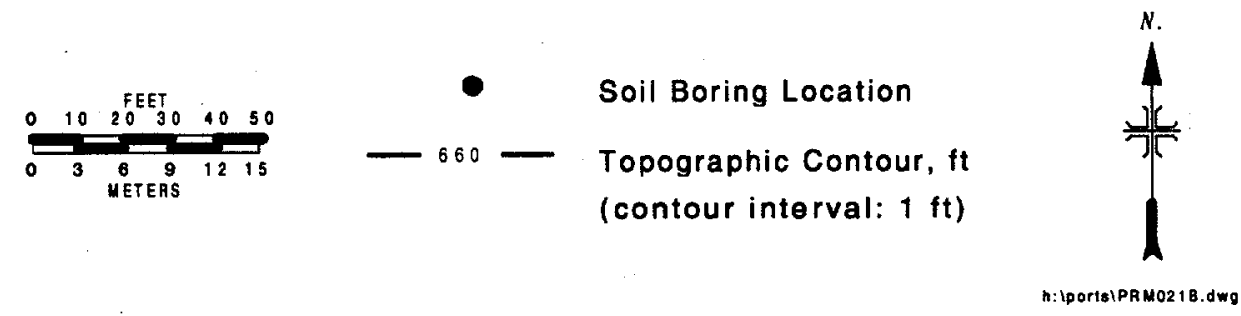

Fig. 2.5. Topography and borehole locations at the CTS. 


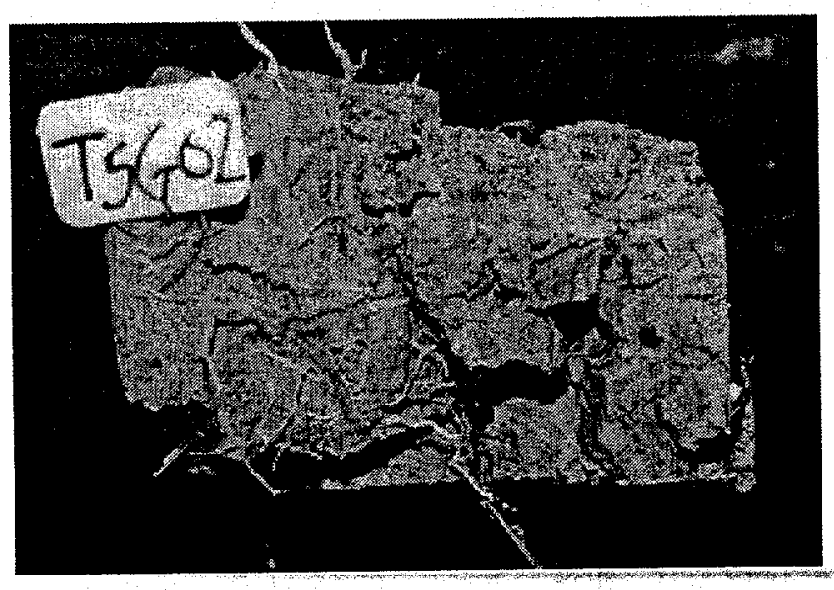

a. Soil core sample from approx. 2-ft depth.

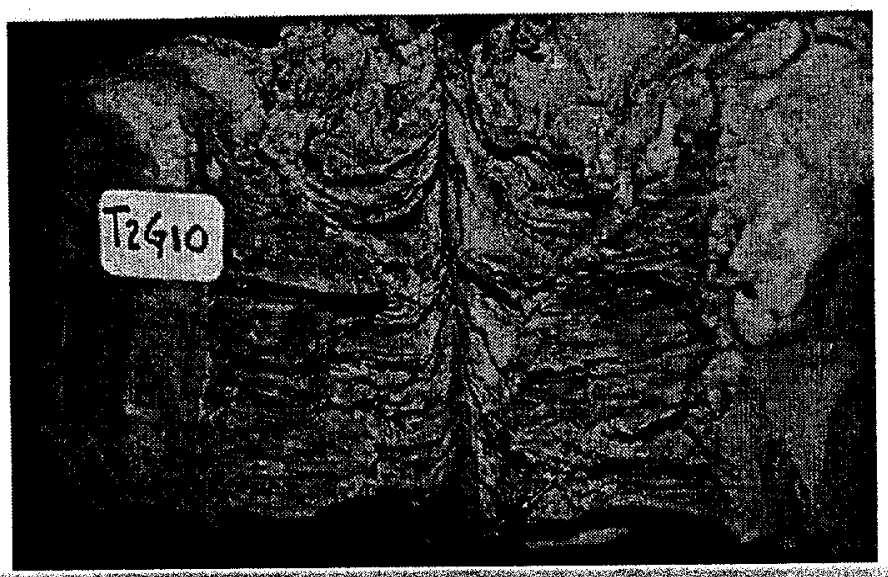

b. Soil core sample from approx. 10-ft depth.

Fig. 2.6. Photographs of the CTS subsurface silty-clay media. 
$2-10$

DEPTH (ft)

0.5

8.5

22

27

30

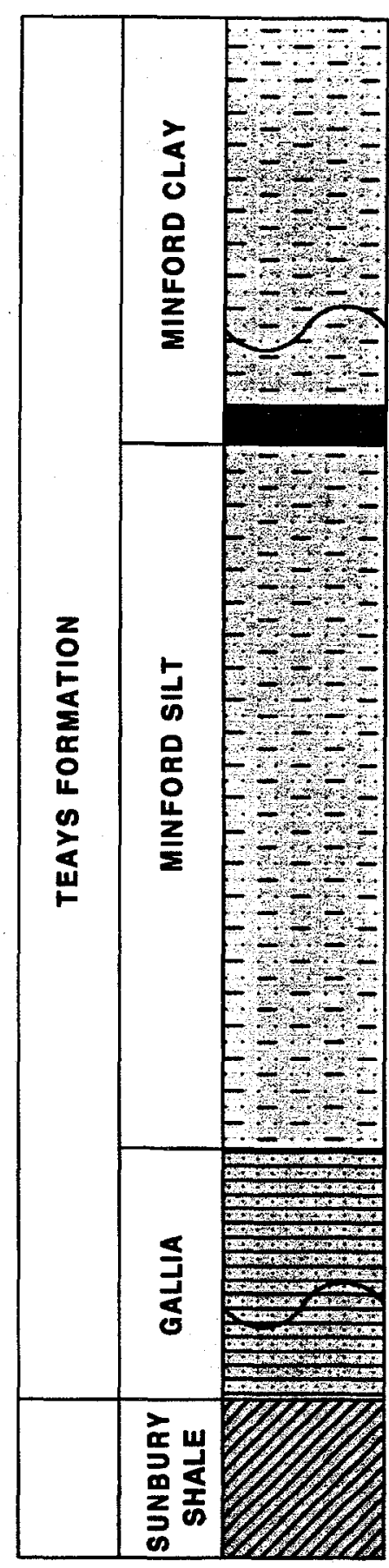

CL SILTY CLAY: yellowish brown (10YR 5/8) with gray mottling (10YR 5/1), firm, slightly moist.

scattered organic staining.

CL SILTY CLAY: yellowish brown (10YR 5/4) becoming light gray to gray $(10 Y R 7 / 1 \cdot 6 / 1)$, moist, firm.

CL CLAY: reddish brown (5YR 4/4), moist, dense, common MnO staining.

ML CLAYEY SILT: yellowish brown (10YA 6/6), moist, firm, sandy in part, angular sandstone pebble and gravels.

ML CLAYEY SILT: as above, grading to silty sand at $20 \mathrm{ft}$.

SM SILTY SAND: light olive brown $(2.5 Y 5 / 4)$ mottled with gray silt, fine grained, abundant limonite staining, moist, friable.

SM SILTY SAND: olive to olive yellow (5Y 5/4-6/6), moist, becoming wet with depth, angular pobbles.

SHALE: black carbonaceous.

PSTRAT

Fig. 2.7. Stratigraphic sequence of borehole number BH07. 

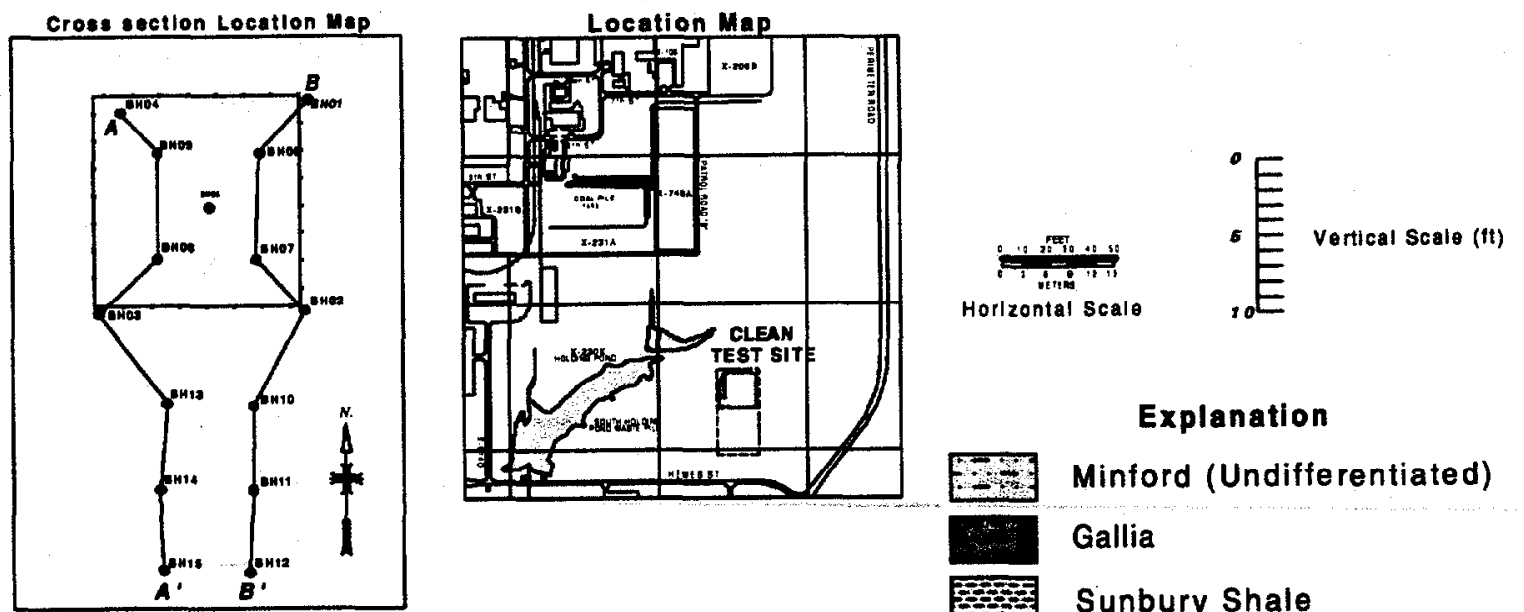

Explanation

Pro Minford (Undifferentiated)

Gallia

Sunbury Shale

A

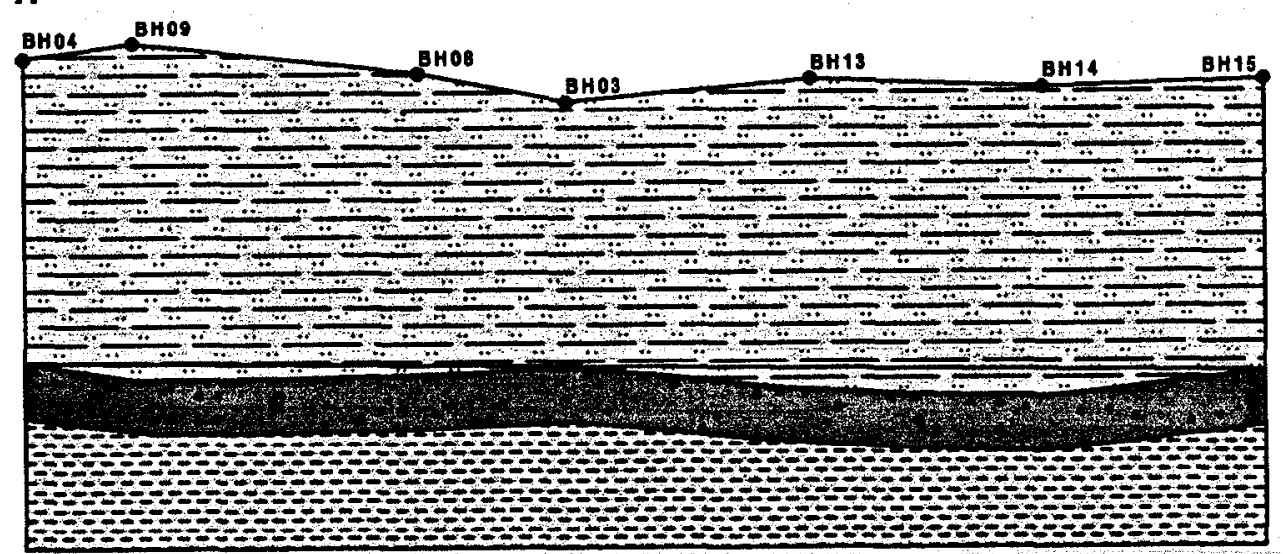

B

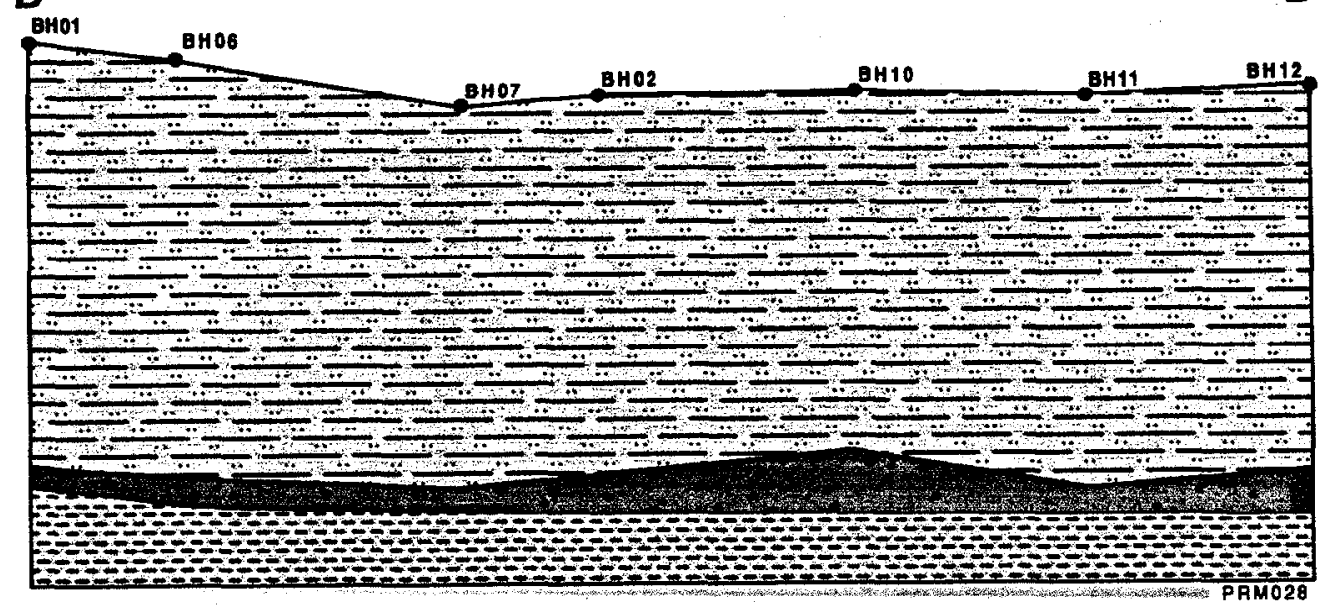

Fig. 2.8. Geologic cross sections at the CTS. 
Table 2.1. Ground surface and bedrock surface elevations for CTS boreholes

\begin{tabular}{|c|c|c|c|}
\hline Borehole number ${ }^{a}$ & $\begin{array}{c}\text { Ground elevation, } \\
\text { ft msl }\end{array}$ & $\begin{array}{c}\text { Depth to bedrock, } \\
\text { ft bgs }\end{array}$ & $\begin{array}{c}\text { Bedrock elevation, } \\
\text { ft msl }\end{array}$ \\
\hline 1 & 666.10 & 29.5 & 636.60 \\
\hline 2 & 662.36 & 28.5 & 633.86 \\
\hline 3 & 657.20 & 21.5 & 635.70 \\
\hline 4 & 661.32 & 24.5 & 636.86 \\
\hline 5 & 661.58 & 26.0 & 635.58 \\
\hline 6 & 664.88 & 29.7 & 635.18 \\
\hline 7 & 661.85 & 27.0 & 634.85 \\
\hline 8 & 659.13 & 24.0 & 635.13 \\
\hline 9 & 661.38 & 26.5 & 634.88 \\
\hline 10 & 662.70 & 28.3 & 634.40 \\
\hline 11 & 662.73 & 28.8 & 633.93 \\
\hline 12 & 663.07 & 29.1 & 633.97 \\
\hline 13 & 658.80 & 24.5 & 634.30 \\
\hline 14 & 658.12 & 24.5 & 633.62 \\
\hline 15 & 658.88 & 24.0 & 634.88 \\
\hline
\end{tabular}

${ }^{a}$ See Figs. 2.5 and 2.8 for borehole locations.

$\mathrm{msl}=$ mean sea level

bgs = below ground surface 
Table 2.2. Subsurface properties of the Minford Member at the CTS

Soil type and genesis

Silty-clay deposits of fluvio-lacustrine origin. Typically 15$\mathrm{ft}$-thick upper clay unit $(\mathrm{CH})$ transitioning to a lower $10-\mathrm{ft}$ thick silt unit (CL).

Soil particle-size distribution:

Sand size $(0.050$ to $2.000 \mathrm{~mm}) \sim 0.5$ dry weight $\%$

Silt size $(0.002$ to $0.050 \mathrm{~mm}) \sim 8.5 \mathrm{dry}$ weight $\%$

Clay size $(<0.002 \mathrm{~mm})$

Soil mineralogy $\sim 10$ dry weight $\%$ In the Minford clay unit, the sand fraction consists of mainly quartz with minor goethite. The silt fraction consists of quartz and minor feldspars, but no goethite. The clay fraction is a mixture of illite $(\sim 33 \%)$, quartz $(\sim 29 \%)$, kaolinite $(-26 \%)$, and smectite $(-12 \%)$.

Soil physical properties:

Bulk density

Water content

Liquid limit

Plastic index

Soil-pore system:

Total fractional porosity a

Water-filled saturation

Pore water saturation

Soil Chemistry:

$\mathrm{pH}$ (in water)

Eh

Organic carbon

Iron oxides

Free

Amorphous

Cation exchange capacity

Exchangeable ions:

$\mathrm{Mg}$

$\mathrm{Ca}$

Soil microbiology:

Total bacteria
$1.8 \mathrm{~g} / \mathrm{cm}^{3}$

20 weight $\%$

$\sim 60 \%$

$\sim 35 \%$

$0.40 \mathrm{v} / \mathrm{v}$

$90 \%$ pores

$10 \%$ pores

4 to 8

140 to $400 \mathrm{mV}$

500 to $7000 \mathrm{ppm}$

$23,000 \mathrm{mg} / \mathrm{kg}$

$13.50 \mathrm{mg} / \mathrm{kg}$

$17.5 \mathrm{meq} / 100 \mathrm{~g}$

$<10$ to $45 \mathrm{mg} / \mathrm{kg}$

$<1000$ to $5000 \mathrm{mg} / \mathrm{kg}$

100 to 1000 organisms/g

a estimated

Note: The information shown is based on a compilation from various sources including analyses of Minford soils from the X-231B site (ORNL 1994) and the ORNL reconnaissance boring and soil analyses completed during April and May 1994. 



\section{Technical Approach}

Work plans prepared for the project included a technical plan, a sampling and analysis plan, a quality assurance project plan, and a health and safety plan (ORNL 1994). All plans were reviewed, revised, and finalized prior to mobilization to the CTS. To ensure that representative data were collected for this project, ORNL standard operating procedures (SOPs) were used for conducting field activities (ORNL 1993). Table 3.1 lists the SOPs that were pertinent to this project. Table 3.2 summarizes the testing performed at each test cell. A readiness review for the pre-treatment site characterization was held at the PORTS facility on October 18, 1994. The readiness review for the injection testing was held on November 3,1994 , and the project was approved for start-up.

\subsection{Task 1: Geoprobe Borings and Lysimeter Installation}

The first task of this project was to characterize the soils to a depth of $12 \mathrm{ft}$ in each of seven test cells (Fig. 3.1). Each test cell was $24 \times 24 \mathrm{ft}$ in surface area except for test cell 7, which was $4 \times 8 \mathrm{ft}$. The size of test cell 7 was decreased to reduce the volume of reagent required, thereby reducing the cost for the iron micropowder. Test cell design and characteristics are summarized in Table 3.3 .

For the pre-treatment characterization, lithologic samples were collected from five bore-holes in each test cell (labeled A through E) (Fig. 3.2), except for test cell 7, which was characterized with one pre-treatment borehole. The lithologic logs and fracture descriptions were documented on borehole lithologic forms and used to describe pre-treatment soil conditions (Appendix B). Other baseline determinations included water content, grain size, color, mineralogy, scanning electron microscope (SEM) morphology, $\mathrm{pH}, \mathrm{TOC}$, iron oxides, cations, and anions. Note that all analyses were not performed on all soil samples because the parameters were not expected to vary significantly over the entire test area and to control analytical costs.

Personnel from ORNL-GJ, used a rig with Geoprobe ${ }^{\mathrm{TM}}$ tools to collect the lithologic samples. On-site technical direction was provided by an ORNL-GJ geologist. Continuous 4-ft-long cores were collected with a megabore sampler. The on-site geologist was responsible for visual classification of the soils encountered and for completing an accurate, depth-based soil boring $\log$. Microscopic examination of selected samples was also performed by the geologist; however, detailed fracture morphology was evaluated through laboratory analyses at ORNL. 
Task 1 included completion of 32 Geoprobe borings, five borings in each of test cells 1 through 6 , one boring in test cell 7 , and one in a background area. The background location was approximately $50 \mathrm{ft}$ south of the southeast corner of test cell 6 (Fig. 3.1). The boring locations were staked and surveyed shortly after completion. All pre-treatment borings were backfilled with granular bentonite or completed as piezometers or lysimeters.

Task 1 also included the installation of 24 porous ceramic cup lysimeters for sampling soil-pore water. Three lysimeters were placed in each of the seven test cells and three at a background location. The three lysimeters at each location were nested in a single borehole at depths of 4, 8, and $14 \mathrm{ft}$ bgs (Fig. 3.3). Pre-treatment borehole $\mathrm{C}$ was consistently used for the installation of these lysimeters except in test cell 7 , where borehole A was used. Lysimeters were also installed in the background soil boring. The lysimeters were 1 bar type with 15-psi bubbling pressure. The average pore diameter was $2.9 \mu \mathrm{m}$, suitable for use in soils with 0 to 1 bar of soil suction.

Installed according to manufacturers specifications, each lysimeter body was surrounded by silica slurry pack mixed from 200 mesh, $99.88 \%$ pure crystalline silica flour and distilled water at a ratio of $150 \mathrm{~mL}$ of water to $450 \mathrm{~g}$ of silica flour. A bentonite seal was placed above each lysimeter to isolate it within the borehole. Before installation, lysimeters were pre-wetted with distilled water which was evacuated after installation. A vacuum of 22 in. of $\mathrm{Hg}$ was applied to each lysimeter 12 hours before anticipated sample collection. Samples were evacuated by applying positive pressure to the lysimeter and forcing the water in the lysimeter body to the surface through the sampling tube.

A total of five 2-in.-inside-diameter (ID) piezometers were also installed, one each in four of the test cells and one at the background location (Table 3.2 and Fig. 3.4). Borehole D was used for piezometer installations. Constructed with 1-ft-long screens placed at approximately $14 \mathrm{ft}$ bgs, the piezometers were used for monitoring water levels and collecting groundwater samples. The lysimeters and piezometers were installed using solid-stem augers and standard well construction practices. All lysimeters and piezometers were sampled twice prior to the initiation of MPIS testing in order to establish baseline conditions.

Soil moisture and temperature (SMT) probes were installed approximately $2 \mathrm{ft}$ east of each set of lysimeters. A total of 24 SMT probes were installed at depths corresponding to the lysimeter depths: 4, 8, and $14 \mathrm{ft}$ bgs. The probes were seated in native soil, with wire leads routed to the ground surface inside of 1.5 -in. polyethylene $(\mathrm{PE})$ casing. The PE casing was backfilled with sand. An 18-in.-long piece of 4-in.-diameter polyvinyl chloride (PVC) casing with a slip-on cap was placed over the wire leads at the ground surface as a protective cover. Figure 3.5 provides a profile view of the layout for the instrumented borings. 


\subsection{Task 2: MPIS Testing}

Task 2 consisted of a series of multi-point injections in six of the test cells with injection done on 2-ft centers (Fig. 3.2). Test cell number 6 was injected with air and had only eight injector penetrations. The MPIS developed and provided by Hayward Baker Environmental, Inc., consisted of a tractor-mounted unit with a set of four removable injection augers mounted 2 $\mathrm{ft}$ apart on a bar across the front of the tractor. These augers have injection ports in a spiral pattern near the tip. All four of the 2-in-diameter augers were simultaneously pushed and turned into the soil to a depth of over $10 \mathrm{ft}$, stopping at 15 -in. intervals for fluid injection (Fig. 3.6). Approximately 2 gal of fluid was injected from each auger at each interval. An operator sitting on the tractor controlled the rate of penetration and injection (Fig. 3.7). The following describes the procedure used.

- The test cell was gridded on $2-\mathrm{ft}$ centers for ease of controlling the injection spacings.

- The MPIS was positioned in the northeast corner of the test cell at setup number 1 .

- The augers (4) were drilled into the soil to a depth of approximately 20 in., and 2 gal of reactive fluid were injected from each auger tip simultaneously.

- The augers were then drilled to the next position, approximately $35 \mathrm{in}$. bgs, and 2 gal were injected from each auger tip.

- This process continued at 15-in. intervals (eight injector positions) until a total depth of approximately $125 \mathrm{in}$. was attained and a total of 64 gal of fluid was injected at that setup (16 gal per injector).

- Four flow meters mounted in front of the MPIS operator were used to monitor the volume of injected fluid from each injector and the operator controlled flow to each injector separately, thus ensuring that the appropriate amount of reagent was injected from each injector at each position.

- Depth calibration marks on the mast indicated the depth of the injector points. A geologist monitored the injection process to ensure that the injections were performed uniformly across each test cell.

Few, if any, soil cuttings were generated during penetration. Upon reaching a depth of 10.4 ft (125 in.), the operator reversed the hydraulics and turned the augers up out of the soil. No fluid was injected during the upstroke. The total depth of the injections was based on the capabilities of the equipment used. Larger equipment with injection capability to $40 \mathrm{ft}$ bgs is available. 
To assess the performance of the multi-point injection equipment by means of operational checks and practice borings, process shakedown was performed in an area north of the CTS prior to initiation of the planned injection testing.

The reagents injected into each test cell, shown in Table 3.4, were delivered to the MPIS by a hose connecting the system to a pump that pulled liquid from a battery of mixing tanks stationed nearby. An air compressor provided pressurized air for the air injection test. The oxidants were injected because hydrogen peroxide and potassium permanganate can catalyze and chemically oxidize chlorinated organics to produce carbon dioxide and water. Zerovalence iron (iron micropowder) was injected because it has been demonstrated to act as a reducing agent for chlorinated solvents. Water alone was injected to provide a baseline test cell. The lime injection was tested because it could be used to adjust soil $\mathrm{pH}$ for in situ stabilization of metals. The bionutrient and surfactant were injected to determine the feasibility of using the mixture to enhance the natural breakdown of chlorinated solvents by indigenous bacteria. Air was injected to test the MPIS for pneumatic fracturing of LPM.

Tracers, including potassium bromide and Snowmax $($, were mixed into two of the solutions to provide a means of differentiating the injected fluid from the existing soil-pore water and to permit detection of soil fractures (Table 3.4). Bromide is a conservative tracer (i.e., travels at the same velocity and direction of the water it is dissolved in) used to track the extent of injected fluid penetration into the soil. Snowmax is a commercially available, ice-nucleating active bacteria product that is processed (the bacteria are killed and mixed with an inert ingredient) and sold as a nucleator for artificial snow. ORNL researchers have developed an innovative and unconventional use of Snowmax $\otimes$ and other bacteria as environmental tracers (Strong-Gunderson 1995). Snowmax $®$ concentration is expressed in ice-nucleating activity (INA) particles per mg of soil.

The injections were performed on a pattern starting with four simultaneous injections $2 \mathrm{ft}$ apart; the tractor-mounted MPIS was then moved $2 \mathrm{ft}$ backwards and another injection performed until the entire test cell had been penetrated on 2-ft centers. Table 3.5 lists the process operating conditions monitored during the MPIS testing.

Because the field work for this project was performed at an uncontaminated site, equipment cleaning procedures were minimal and were performed as necessary to maintain proper operation of the equipment and to prevent mixing of different reagents. Injectors, hoses, tanks, pumps, and mixing equipment were cleaned on site using either a fresh water rinse or a portable steam cleaner as appropriate. Fluids generated by flushing the MPIS were discharged to the ground surface away from the CTS along with other water being pumped from the site. 


\subsection{Task 3: Concurrent Monitoring}

Monitoring was performed during the MPIS injections made in each cell (Table 3.5 and Fig. 3.8). The volume of reagent injected was monitored on four separate flow gauges mounted on the MPIS unit and on a single flow meter at the pump discharge. The separate flow gauges on the MPIS unit recorded the amount of fluid injected by each of the four injectors and the flow gauge on the pump discharge recorded the total amount of fluid injected. Other observations included penetration rate, injection rate, injection pressure, surface blowout of fluid, and temperature and moisture changes in the test cell soils. Samples of the injected fluid were collected at the connection of the delivery hose to the MPIS unit periodically throughout each test cell injection to provide information on the uniformity of the batching and mixing operations.

\subsection{Task 4: Post-Injection Characterization and Data Collection}

The first phase of Task 4 for each test cell included drilling and sampling five additional soil borings in test cells 1 through 5 (boreholes $\mathrm{F}$ through $\mathrm{J}$ ) and two additional soil borings (boreholes B and C) in test cell 7 (Fig. 3.1). These borings were drilled within $24 \mathrm{~h}$ after the injections in each cell to evaluate the effective distribution of treatment agents by the system and any rapid changes occurring in the subsurface (Fig. 3.9). Soil samples were examined both macroscopically and microscopically for fracture characteristics and the presence of tracers. Morphology was evaluated in the laboratory by SEM. If bromide was injected as a tracer, soil samples were extracted and analyzed for bromide on site with an ion-selective electrode. Samples for INA analysis were sent to ORNL for analysis. Selected soil samples were also analyzed for $\mathrm{pH}, \mathrm{TOC}, \mathrm{Eh}, \mathrm{Fe}$ oxides, and $\mathrm{Mn}$.

A soil inspection trench was excavated in the shakedown area to observe the effects of lime injection on the subsurface. Because the trench did not reveal characteristics that were not observable in the soil cores, no additional soil inspection trenches were excavated.

Soil-pore water samples were collected the day after each injection and daily thereafter for several days. Water samples were collected from the lysimeters and piezometers to determine the effects of the injections on the soil-pore water chemistry. Water samples were analyzed on site for temperature, $\mathrm{pH}, \mathrm{DO}$, conductivity, alkalinity, $\mathrm{Br}, \mathrm{Fe}, \mathrm{Mn}, \mathrm{Cl}^{-}, \mathrm{NO}_{3}^{-}$, and $\mathrm{SO}_{4}{ }^{2-}$. Analyses for metals and TOC were performed at ORNL:

The first phase of post-treatment characterization was completed within 3 days after the last injection was performed (November 21, 1994). The second phase of post-treatment characterization was performed about 2 weeks later and consisted of collecting another set of water samples from the lysimeters and piezometers on December 5,1994 . The third phase of 
post-treatment characterization was performed about 1 week after the second phase and consisted of drilling two additional soil borings in test cells 1 through 5 (boreholes $\mathrm{K}$ and $\mathrm{L}$ ) and in test cell 7 (boreholes D and E) and collecting another set of water samples from the lysimeters and piezometers on December 15, 1994. A fourth phase of water sampling only was performed during the week of February 15, 1995, and a final round of groundwater samples were collected the week of May 6, 1996.

\subsection{Surveying}

The locations of all test cells, borings, lysimeters, piezometers, SMTs, and elevation bench marks were surveyed. A nearby monitoring well was used as a benchmark. The required horizontal accuracy was $\pm 0.5 \mathrm{ft}$, and the required vertical accuracy was $\pm 0.01 \mathrm{ft}$. To ensure the required accuracies, the survey was looped and closed. Surveying was performed with a theodolite equipped with electronic distance measuring and a level. Lysimeters and piezometers were identified by numbers written on the side of the protective casing. The lysimeters were numbered T1L1 and T2L1, etc., in order to identify the test cell (T1) and the lysimeter (L1). Similarly, the piezometers were marked T1P1, etc., identifying the test cell (T1) and the piezometer (P1). The soil borings were numbered in accordance with a prearranged scheme in each test cell as follows: T1-A, to indicate test cell 1 , soil boring A, T1$\mathrm{B}$ to indicate test cell 1 , soil boring $\mathrm{B}$, etc. The elevation bench marks were labeled T1S1 through T1S5 in test cell 1 and similarly in the other test cells. Elevations were checked prior to injection testing and then several times after testing to determine the amount of soil heaving caused by the injection and to determine the rate of settling. 


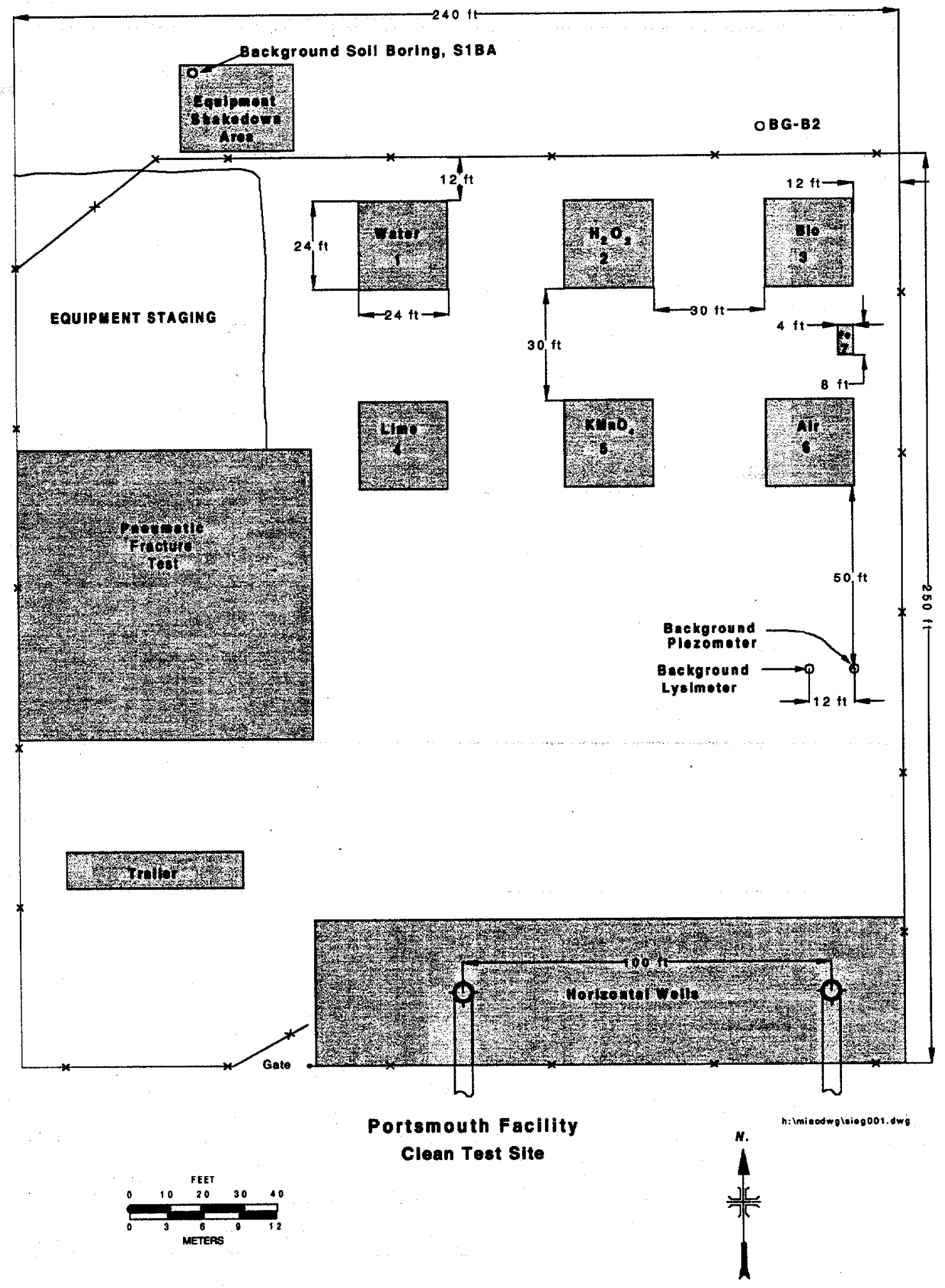

Fig. 3.1. Test cells within the CTS. 
A. PLAN
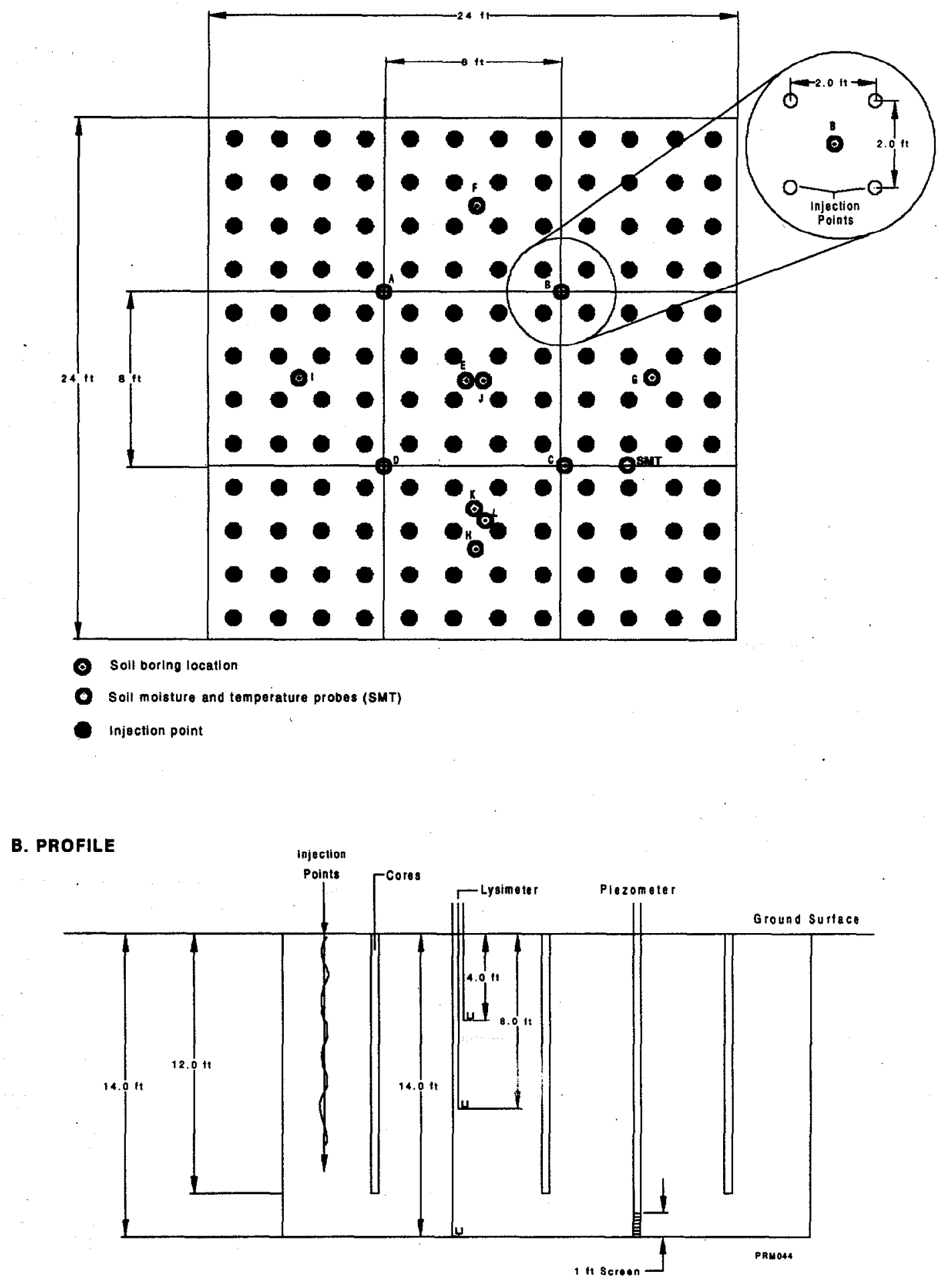

Fig. 3.2. Approximate locations for testing within a typical test cell. 


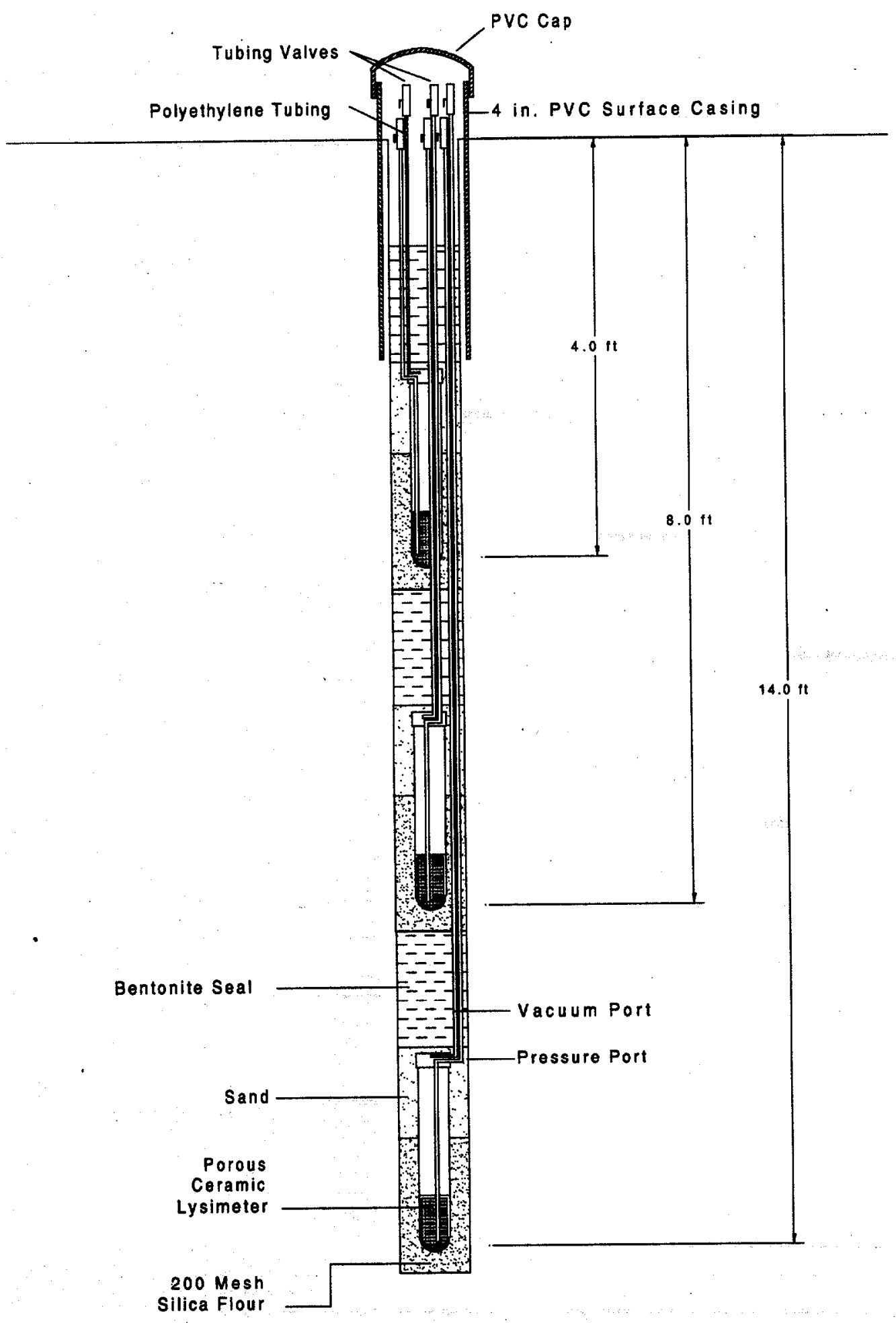

Fig. 3.3. Schematic diagram of nested 1ysimeters. 


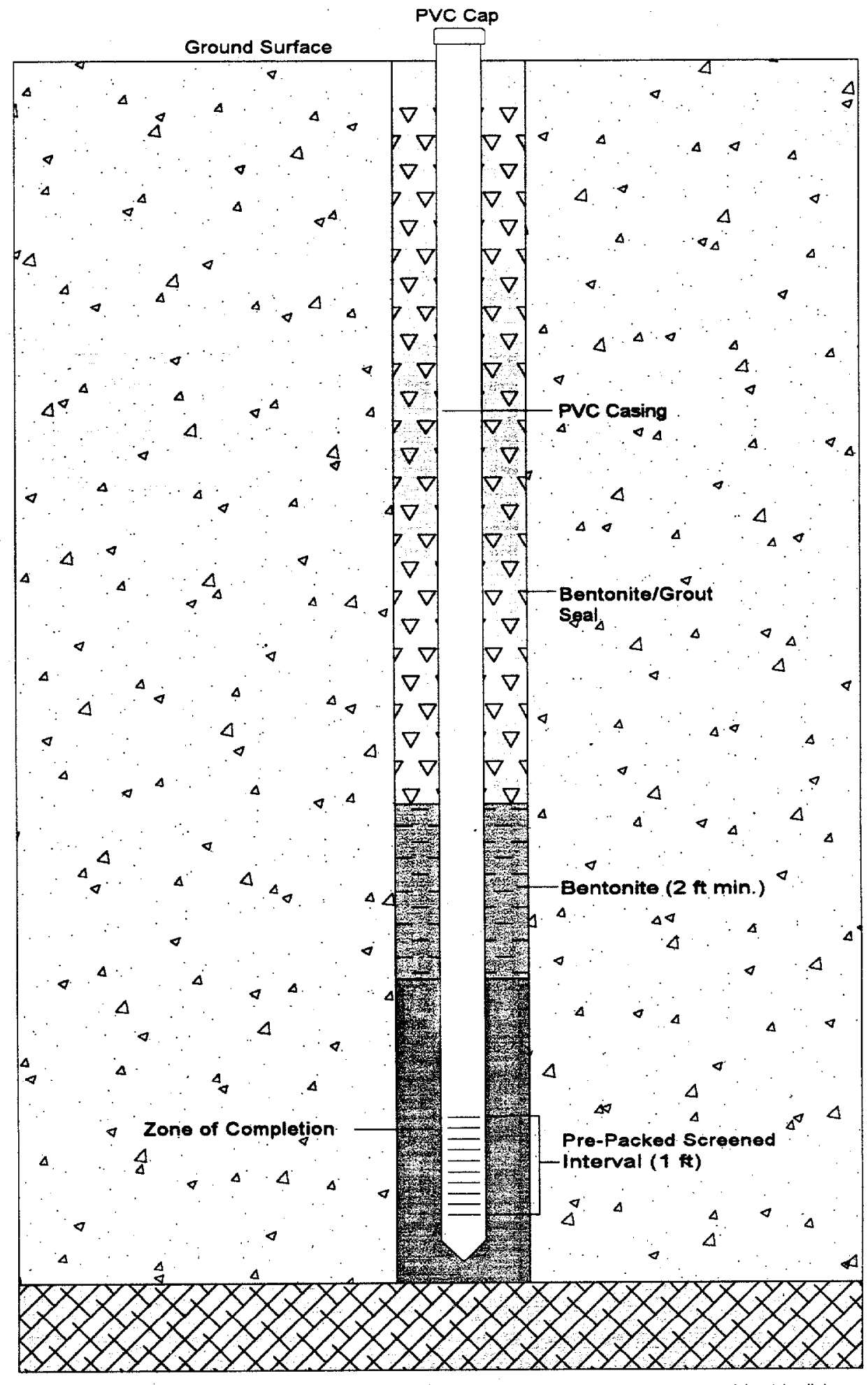

h.lportsiwell.dwg

Fig. 3.4. Schematic diagram of piezometer. 
$3-11$

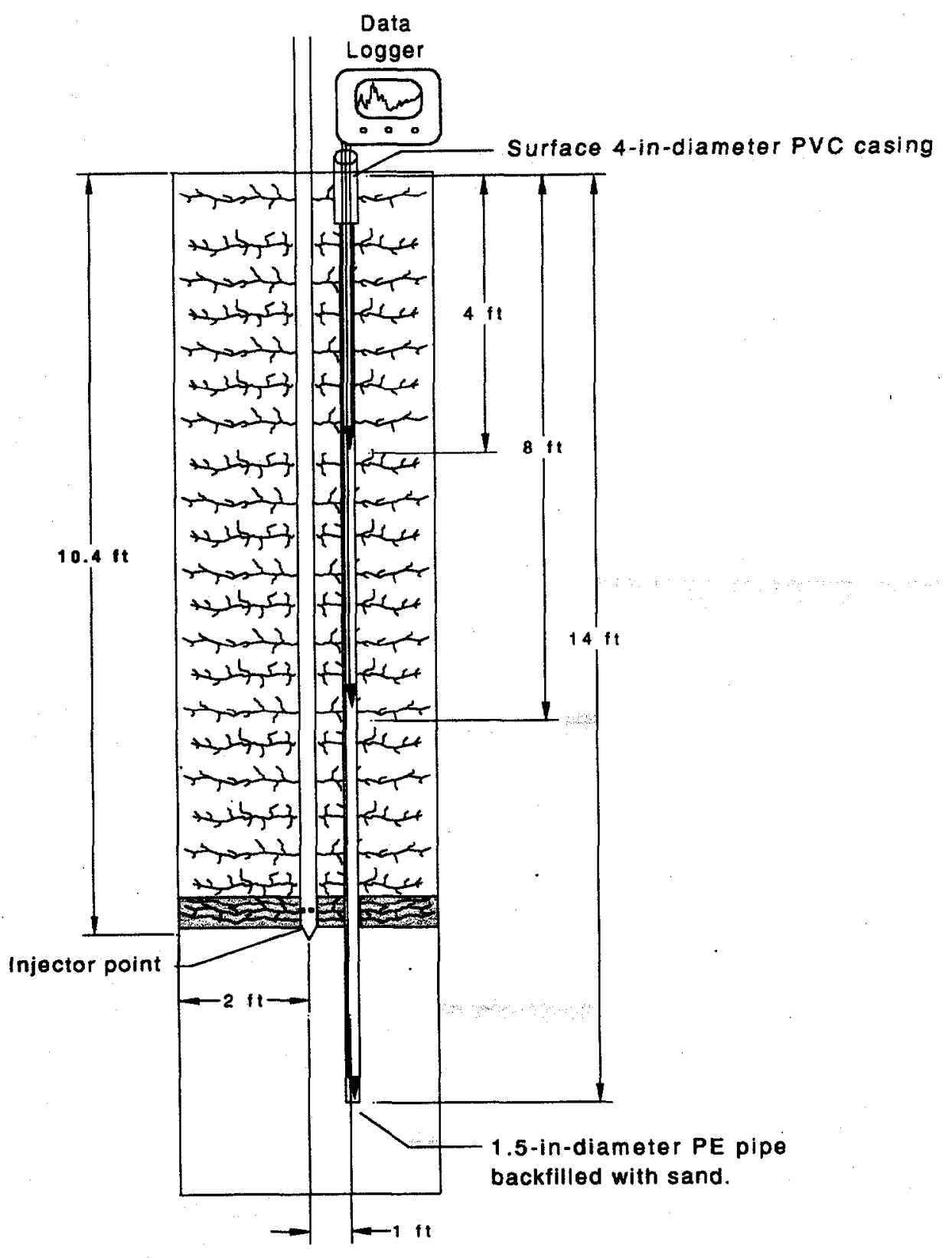

h:Imisedwgisiego05.dwg

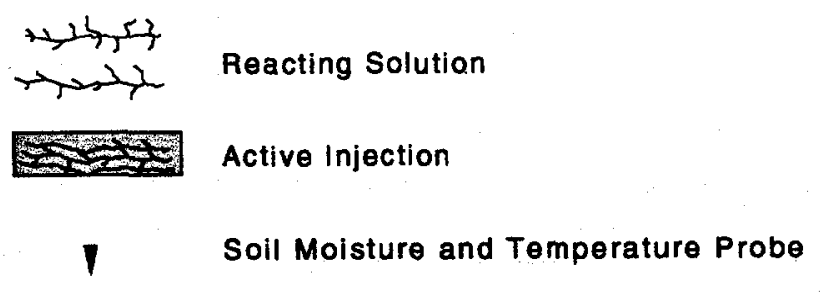

Fig. 3.5. Profile view of the layout for the instrumented borings. 


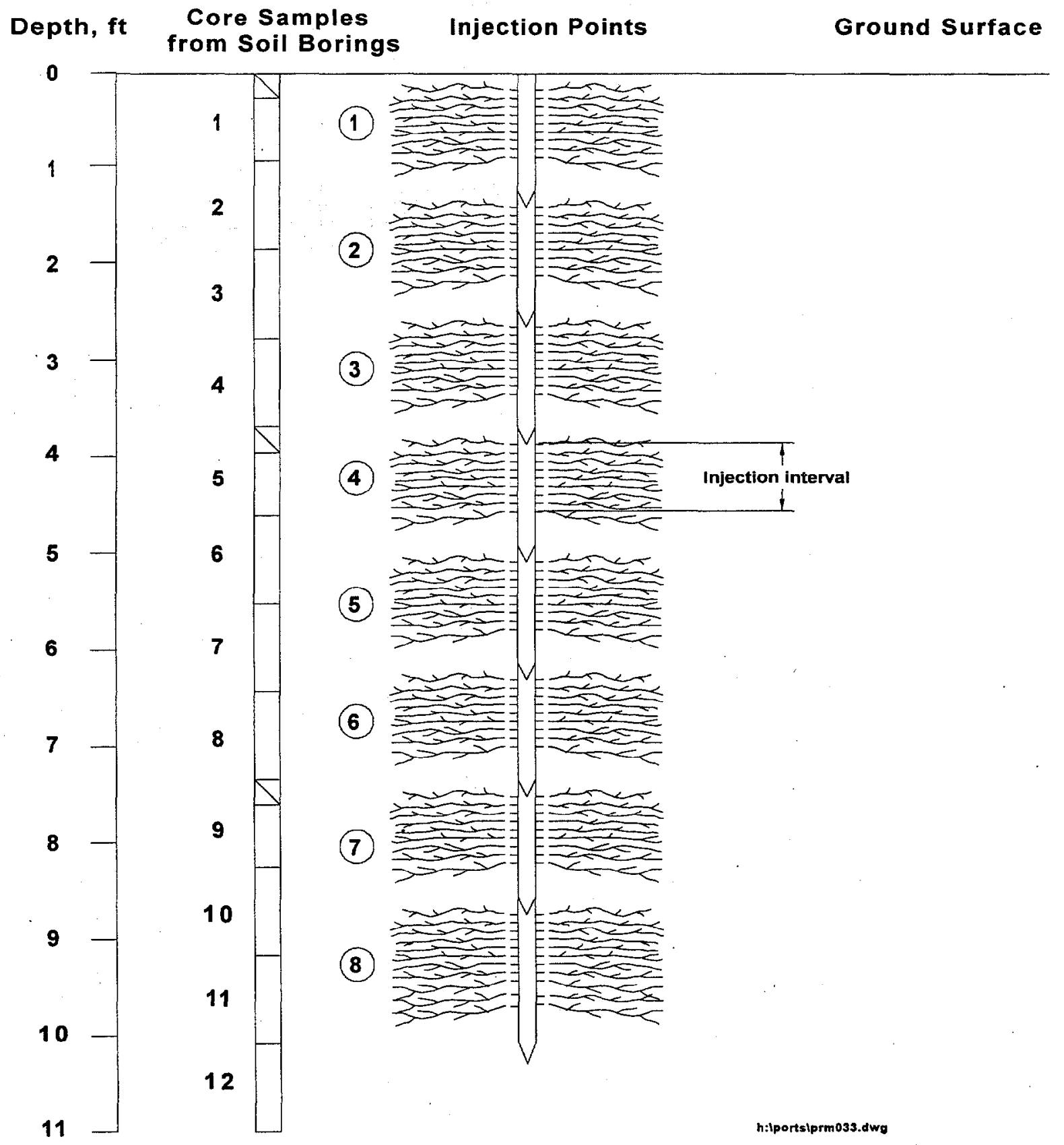

Fig. 3.6. Conceptual diagram of the MPIS process. 


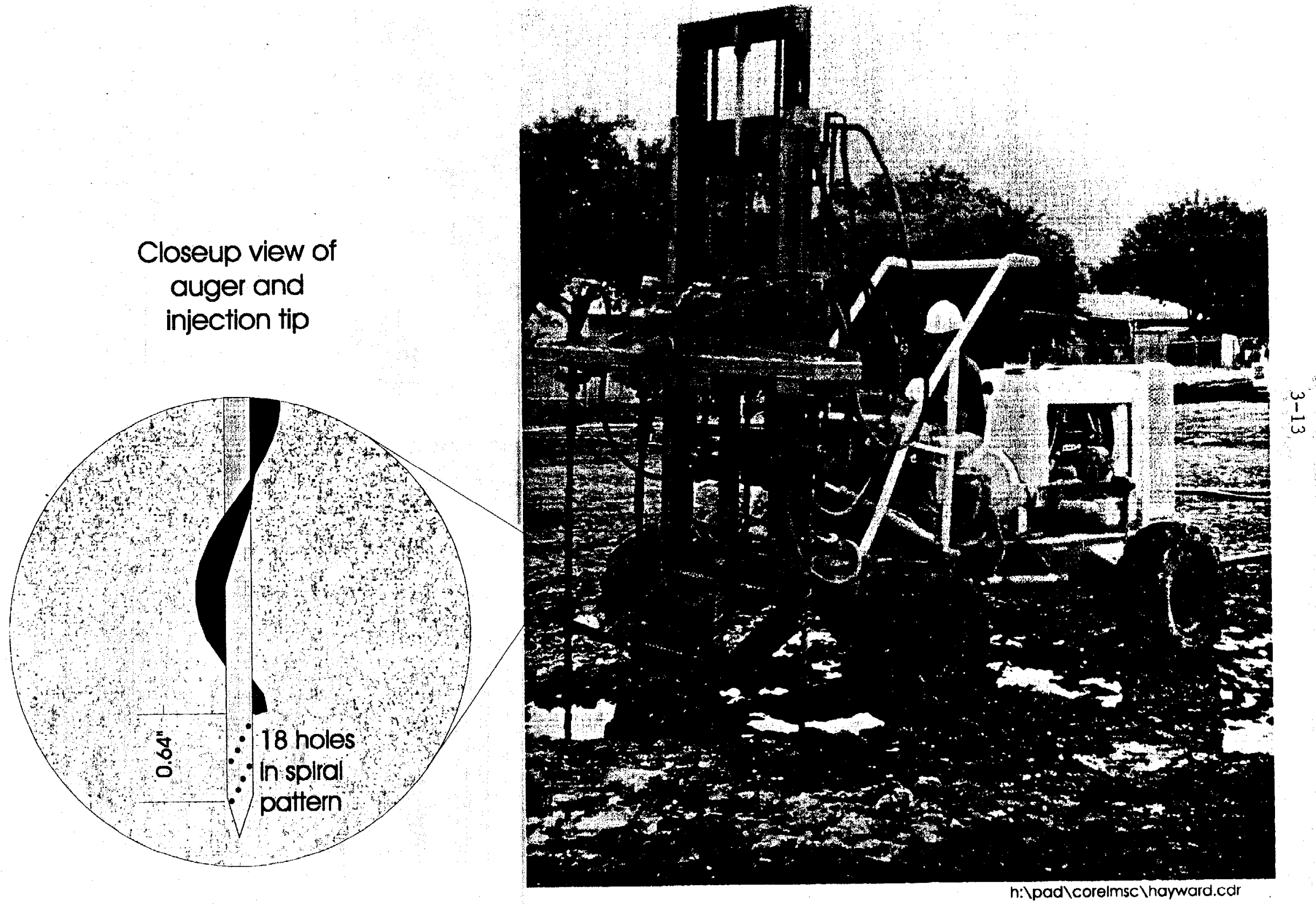

Fig. 3.7. Multi-port injection system. 


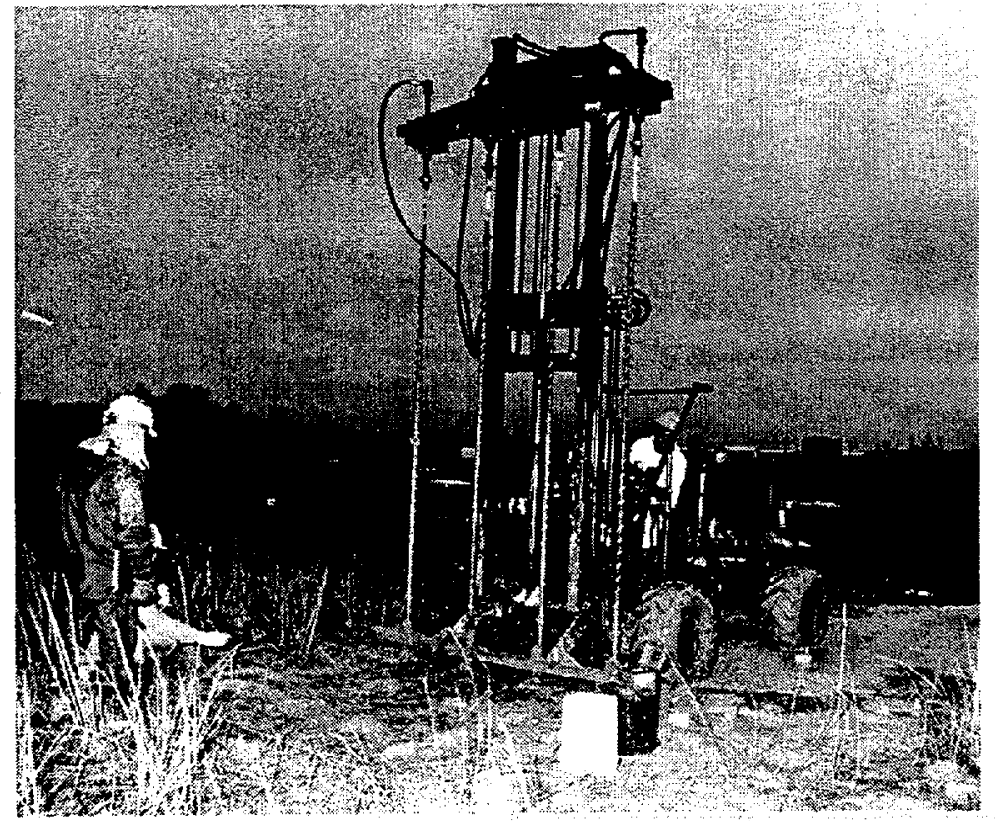

(a.) MPIS equipment performing an injection of bionutrient solution at test cell 3 .

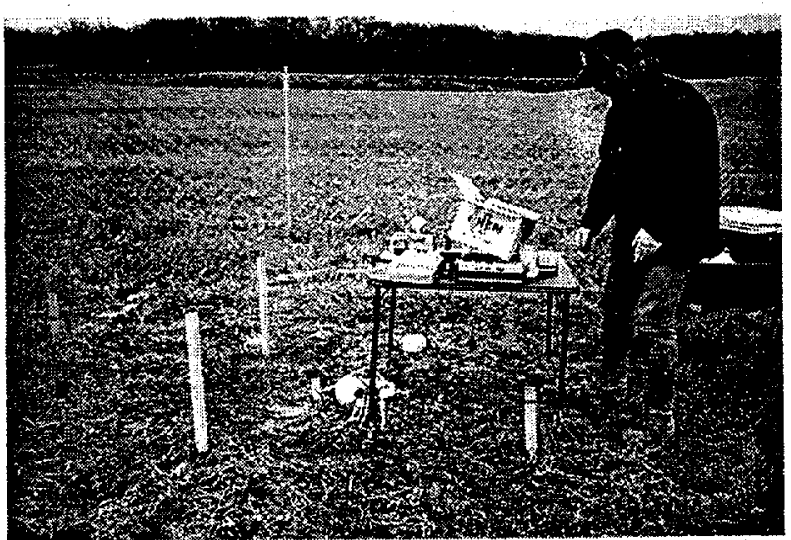

(b.) ORNL staff monitoring at test cell 7.

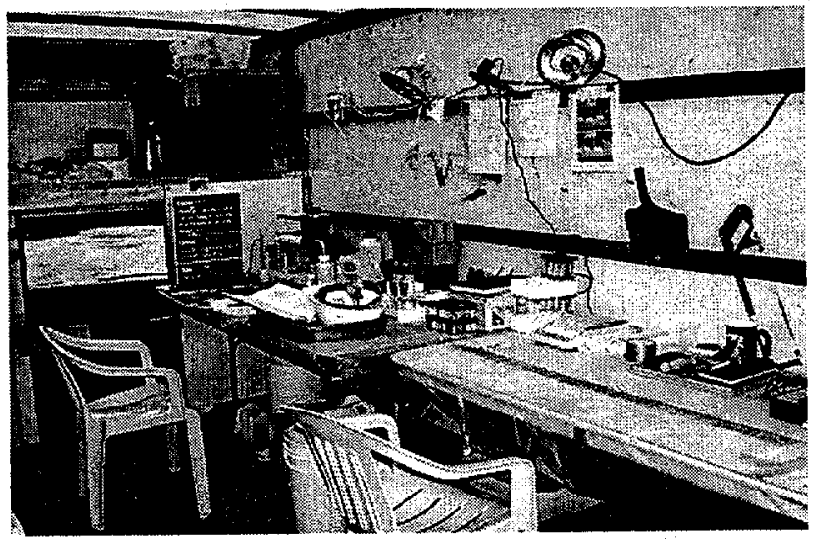

(d.) Onsite laboratory for soil core analyses.

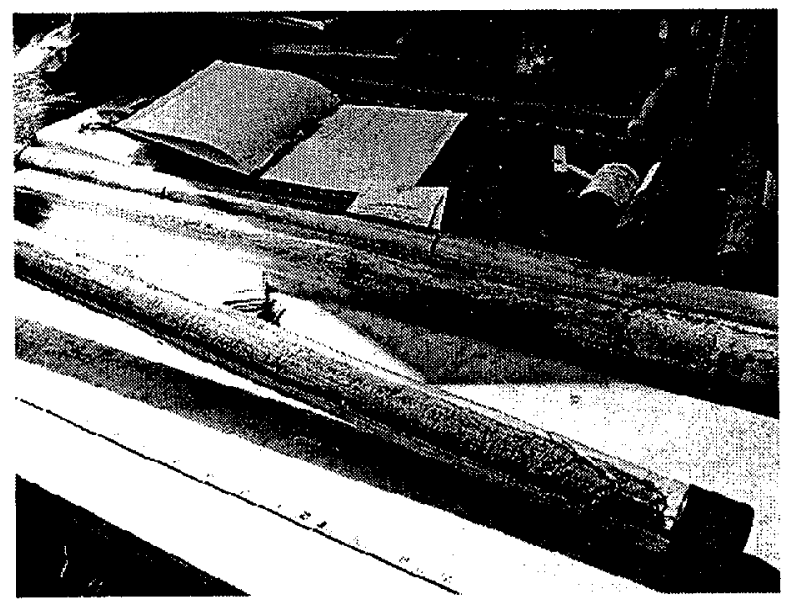

(c.) Intact soil cores used for characterization.
Fig. 3.8. Photographs of the Hayward Baker MPIS rig and the monitoring and sampling analyses activities. 
$3-15$

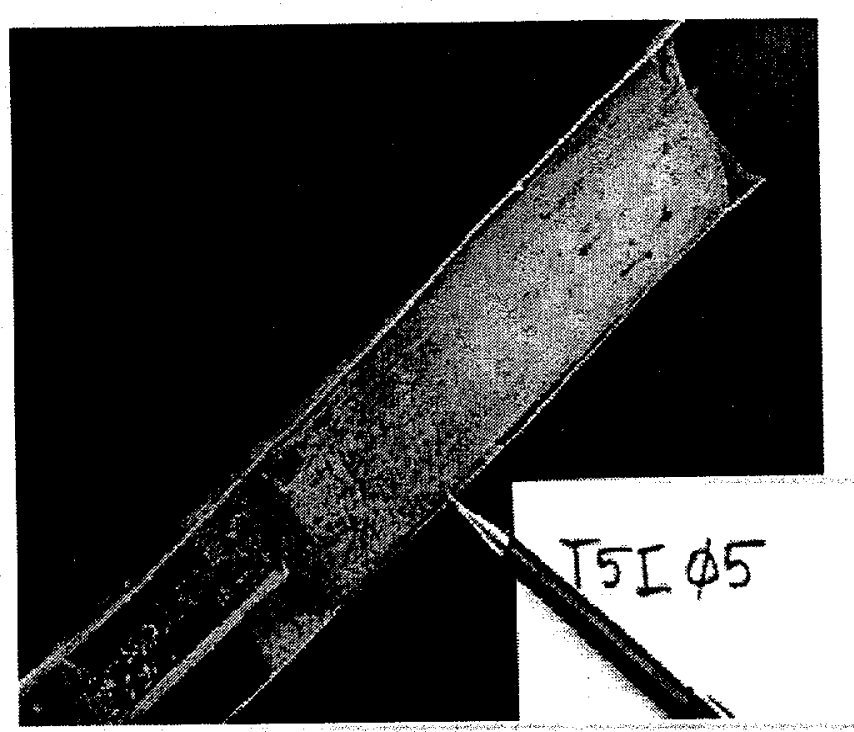

(a.) Permanganate impacted core at 5-ft. depth (the soil redox is dramatically elevated through core beyond the obvious purple staining.

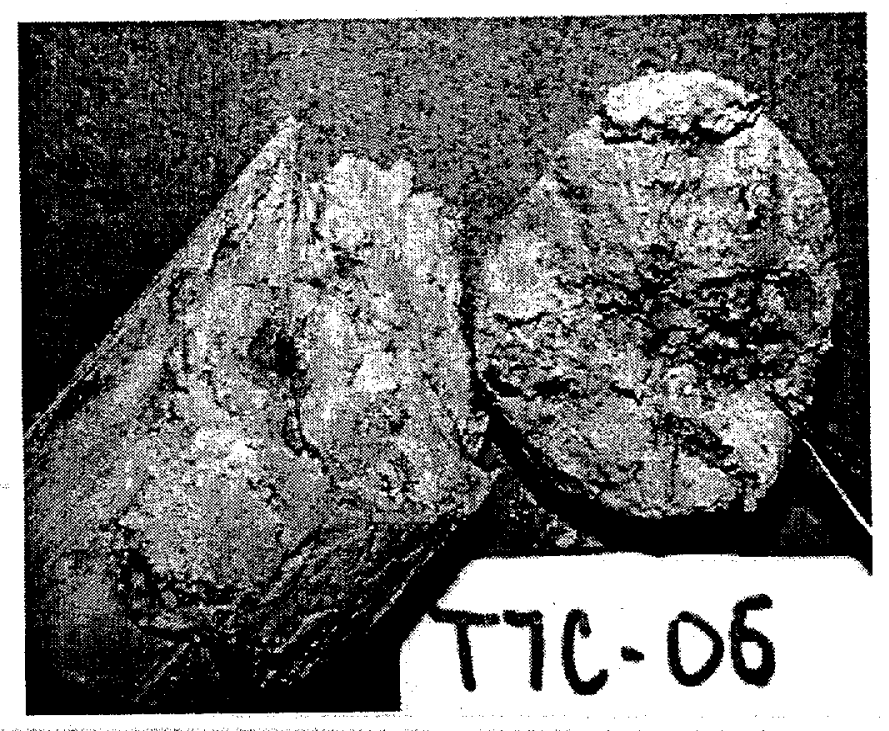

(b.) Iron micropowder deposition within silty clay soil at 6 -ft depth.

Fig. 3.9. Photographs of intact soil cores from the permanganate (T5) and iron micropowder (T7) test cells. 
Table 3.1. ORNL SOPs for the MPIS demonstration

\begin{tabular}{ll}
\hline $\begin{array}{l}\text { ORNL SOP } \\
\text { number }\end{array}$ & \\
\hline AD-050 & Quality Assurance \\
TE-061 & Measurement of pH of Water Samples \\
TE-062 & Measurement of Electrical Conductivity of Water Samples \\
TE-063 & Measurement of Dissolved Oxygen in Water Samples \\
TE-071 & Sample Documentation \\
TE-072 & Sample Packaging, Preservation, and Shipping \\
TE-073 & Equipment Decontamination \\
TE-086 & Soil Sampling for Field Screening Using the Geoprobe and U2CRT \\
TE-094 & Water-Level Measurement \\
TE-100 & Drilling Log Preparation and Well Construction Documentation \\
TE-105 & U2CRT Operation \\
TE-106 & Solid-Stem Augering Using the U2CRT \\
TE-120 & Physical Surveying \\
TE-130 & Peristaltic Pump Operation \\
TE-150 & Combustible Gas Indicator Operation \\
\hline
\end{tabular}


Table 3.2. Activities performed in conjunction with MPIS testing

\begin{tabular}{|c|c|c|c|c|}
\hline $\begin{array}{l}\text { Test cell, } \\
\text { injection treatment }\end{array}$ & $\begin{array}{l}\text { Pre-treatment } \\
\text { activities } \\
\end{array}$ & Injection testing & $\begin{array}{c}\text { Post-injection } \\
1 \text { activities }\end{array}$ & $\begin{array}{l}\text { Post-injection } \\
2 \text { activities }{ }^{\star}\end{array}$ \\
\hline No. 1, Water & $\begin{array}{l}5 \text { soil borings } \\
3 \text { lysimeters } \\
1 \text { piezometer } \\
3 \text { soil moisture probes } \\
5 \text { elevation markers }\end{array}$ & $\begin{array}{l}\text { Inject water with tracers } \\
\text { Monitor parameters }\end{array}$ & $\begin{array}{l}5 \text { soil borings } \\
\text { Sample lysimeters and piezometer } \\
\text { Monitor parameters } \\
\text { Surveyed elevation markers }\end{array}$ & $\begin{array}{l}2 \text { soil borings } \\
\text { Sample lysimeters and piezometer } \\
\text { Monitor parameters } \\
\text { Surveyed elevation markers }\end{array}$ \\
\hline No. $2, \mathrm{H}_{2} \mathrm{O}_{2}$ & $\begin{array}{l}5 \text { soil borings } \\
3 \text { lysimeters } \\
1 \text { piezometer } \\
3 \text { soil moisture probes } \\
5 \text { elevation markers } \\
\end{array}$ & $\begin{array}{l}\text { Inject reagent } \\
\text { Monitor parameters }\end{array}$ & $\begin{array}{l}5 \text { soil borings } \\
\text { Sample lysimeters and piezometer } \\
\text { Monitor parameters } \\
\text { Surveyed elevation markers }\end{array}$ & $\begin{array}{l}2 \text { soil borings } \\
\text { Sample lysimeters and piezometer } \\
\text { Monitor parameters } \\
\text { Surveyed elevation markers }\end{array}$ \\
\hline No. 3, Bionutrient & $\begin{array}{l}5 \text { soil borings } \\
3 \text { lysimeters } \\
1 \text { piezometer } \\
3 \text { soil moisture probes } \\
5 \text { elevation markers }\end{array}$ & $\begin{array}{l}\text { Inject reagent with tracers } \\
\text { Monitor parameters }\end{array}$ & $\begin{array}{l}5 \text { soil borings } \\
\text { Sample lysimeters and piezometer } \\
\text { Monitor parameters } \\
\text { Surveyed elevation markers }\end{array}$ & $\begin{array}{l}2 \text { soil borings } \\
\text { Sample lysimeters and piezometer } \\
\text { Monitor parameters } \\
\text { Surveyed elevation markers }\end{array}$ \\
\hline No. 4, Lime & $\begin{array}{l}5 \text { soil borings } \\
3 \text { lysimeters } \\
3 \text { soil moisture probes } \\
5 \text { elevation markers }\end{array}$ & $\begin{array}{l}\text { Inject reagent } \\
\text { Monitor parameters }\end{array}$ & $\begin{array}{l}5 \text { soil borings } \\
\text { Sample lysimeters } \\
\text { Monitor parameters } \\
\text { Surveyed elevation markers }\end{array}$ & $\begin{array}{l}2 \text { soil borings } \\
\text { Sample lysimeters } \\
\text { Monitor parameters } \\
\text { Surveyed elevation markers }\end{array}$ \\
\hline No. $5, \mathrm{KMnO}_{4}$ & $\begin{array}{l}5 \text { soil borings } \\
3 \text { lysimeters } \\
1 \text { piezometer } \\
3 \text { soil moisture probes } \\
5 \text { elevation markers }\end{array}$ & $\begin{array}{l}\text { Inject reagent with tracers } \\
\text { Monitor parameters }\end{array}$ & $\begin{array}{l}5 \text { soil borings } \\
\text { Sample lysimeters and piezometer } \\
\text { Monitor parameters } \\
\text { Surveyed elevation markers }\end{array}$ & $\begin{array}{l}2 \text { soil borings } \\
\text { Sample lysimeters and piezometer } \\
\text { Monitor parameters } \\
\text { Surveyed elevation markers }\end{array}$ \\
\hline
\end{tabular}


Table 3.2. (continued)

\begin{tabular}{|c|c|c|c|c|}
\hline $\begin{array}{l}\text { Test cell, } \\
\text { injection treatment }\end{array}$ & $\begin{array}{l}\text { Pre-treatment } \\
\text { activities }\end{array}$ & Injection testing ${ }^{e}$ & $\begin{array}{l}\text { Post-injection } \\
1 \text { activities }{ }^{*}\end{array}$ & $\begin{array}{l}\text { Post-injection } \\
2 \text { activities }^{2} \\
\end{array}$ \\
\hline No. 6, Air & $\begin{array}{l}5 \text { soil borings } \\
3 \text { lysimeters } \\
3 \text { soil moisture probes } \\
5 \text { elevation markers }\end{array}$ & $\begin{array}{l}\text { Inject air } \\
\text { Monitor parameters }\end{array}$ & $\begin{array}{l}\text { Sample lysimeters } \\
\text { Monitor parameters } \\
\text { Surveyed elevation markers }\end{array}$ & $\begin{array}{l}\text { Sample lysimeters } \\
\text { Monitor parameters } \\
\text { Surveyed elevation markers }\end{array}$ \\
\hline No. $7, \mathrm{Fe}$ & $\begin{array}{l}1 \text { soil boring } \\
3 \text { lysimeters } \\
3 \text { soil moisture probes } \\
1 \text { elevation marker }\end{array}$ & $\begin{array}{l}\text { Inject reagent } \\
\text { Monitor parameters }\end{array}$ & $\begin{array}{l}2 \text { soil borings } \\
\text { Sample lysimeters } \\
\text { Monitor parameters } \\
\text { Surveyed elevation marker } \\
\end{array}$ & $\begin{array}{l}2 \text { soil borings } \\
\text { Sample lysimeters } \\
\text { Monitor parameters } \\
\text { Surveyed elevation marker }\end{array}$ \\
\hline $\begin{array}{l}\text { Background } \\
\text { location }\end{array}$ & $\begin{array}{l}1 \text { soil boring } \\
1 \text { piezometer } \\
3 \text { lysimeters } \\
3 \text { soil moisture probes } \\
\end{array}$ & Monitor parameters & $\begin{array}{l}\text { Sample lysimeters and piezometer } \\
\text { Monitor parameters }\end{array}$ & $\begin{array}{l}\text { Sample lysimeters and piezometers } \\
\text { Monitor parameters }\end{array}$ \\
\hline Total & $\begin{array}{l}32 \text { soil borings } \\
24 \text { lysimeter samples } \\
5 \text { piezometer samples } \\
24 \text { soil moisture } \\
\text { probes }\end{array}$ & $\begin{array}{l}7 \text { injections } \\
\text { Multiple parameter data set }\end{array}$ & $\begin{array}{l}27 \text { soil borings } \\
\text { Multiple lysimeter samples } \\
\text { Multiple groundwater samples } \\
\text { Multiple parameter data set }\end{array}$ & $\begin{array}{l}12 \text { soil borings } \\
24 \text { lysimcter samples } \\
5 \text { groundwater samples } \\
\text { Multiple parameter data set }\end{array}$ \\
\hline
\end{tabular}

a The parameters monitored are shown in Table 1.1. 
Table 3.3. Test cell design and characteristics

\begin{tabular}{ll}
\hline Test cell geometry: & $24 \times 24 \mathrm{ft}$ \\
Ground surface area & $576 \mathrm{ft}^{2}$ \\
Soil depth & $10.4 \mathrm{ft}$ \\
Soil volume & $5,990 \mathrm{ft}^{3}$ \\
& $44,800 \mathrm{gal}$ \\
& $169,640 \mathrm{~L}$ \\
Soil weight (wet) & $305,310 \mathrm{~kg}$ \\
\hline Soil bulk density (field moist) & $1.8 \mathrm{~g}^{\mathrm{cm}} \mathrm{cm}^{3}$ \\
\hline Soil water content: & \\
Field moist basis & $20 \mathrm{weight} \%$ \\
Total water weight & $70,450 \mathrm{~kg}$ \\
\hline Soil-pore system: & \\
Total fractional porosity & $0.40 \mathrm{v} / \mathrm{v}$ \\
Total pore volume & $78,280 \mathrm{~L}$ \\
Water-filled pore volume/cell & $70,450 \mathrm{~L}$ \\
Water-filled porosity & $36 \%$ cell \\
Pore water saturation & $90 \%$ pores \\
Air-filled pore volume/cell & $7,830 \mathrm{~L}$ \\
Air-filled porosity & $4 \%$ cell \\
Pore air saturation & $10 \%$ pores \\
\hline
\end{tabular}

a estimated.

Note: See Table 2.1 also. 
Table 3.4. Treatment agents for MPIS testing at PORTS CTS

\begin{tabular}{ccclc}
\hline $\begin{array}{r}\text { Test } \\
\text { cell }\end{array}$ & $\begin{array}{c}\text { Treatment } \\
\text { type }\end{array}$ & Medium & Treatment/tracer & Concentration \\
\hline 1 & Control & Water & Water/bromide & $\mathrm{NA}$ \\
2 & Oxidant & Water & $\mathrm{H}_{2} \mathrm{O}_{2} /$ none & $10 \%$ \\
3 & Bionutrient & Water & $\begin{array}{l}\text { Surfactant, } \\
\text { nutrients/ } \\
\text { bromide and }\end{array}$ & $10 \%$ \\
& & & Snowmax & \\
& & & Lime/none & \\
4 & Stabilizer & Water & WMnO $/$ none & $5 \%$ \\
5 & Oxidant & Water & None & NA \\
6 & Fracturing & Air & Non & $20 \%$ \\
7 & Reductant & Water & $10-\mu$ Fe filings, & \\
\hline
\end{tabular}

$\mathrm{NA}=$ not applicable 
Table 3.5. Process operating conditions for MPIS testing at the CTS

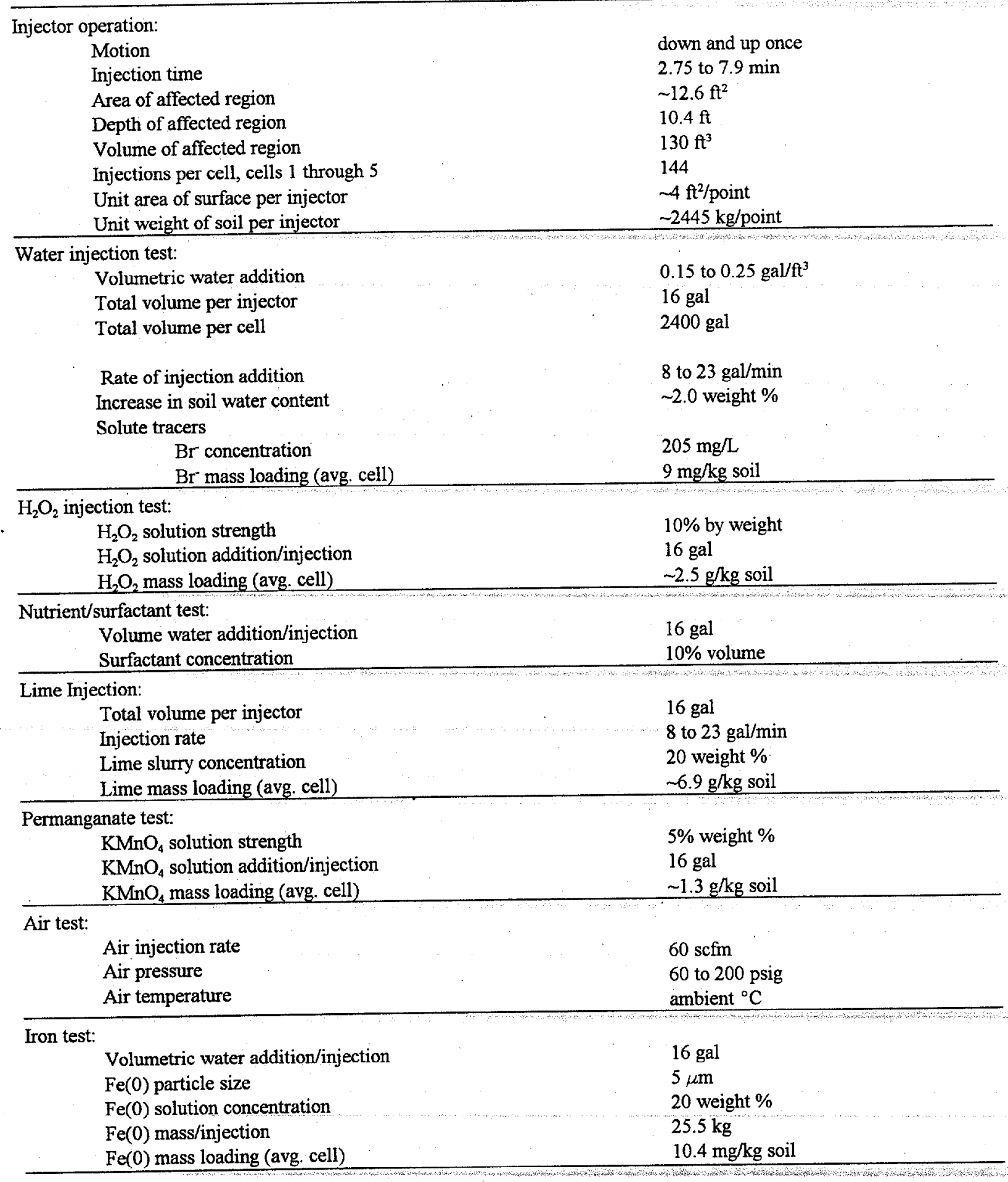


- 


\section{Specific Testing and Results}

Field activities were documented by daily entries into the project logbook and task-specific field logbooks: a geologist's logbook, health and safety logbook, water sample logbook, soil sample logbook, survey logbook, and laboratory logbook. The project logbook provides a summary record of all field activities. Information was also recorded on forms designed specifically for this project. Prior to injection, pre-treatment elevations were surveyed using control stakes placed in each test cell. These elevations are included in the ground surface

uplift graphs for each test cell that show the relative change in elevation after injection. The following is a description of the results obtained at each test cell at CTS.

\subsection{Background CTS Characterization}

\subsubsection{Field Activities}

Characterization of the geology of the CTS is described in Sect. 2.3. The site was further characterized by collecting background data specifically for this project, including drilling three additional soil borings, two in the background area (Fig. 3.1) and one in the shakedown area. Lithologic logs of these borings were prepared, and soil samples were shipped to ORNL for analysis. A piezometer was installed at boring B1-A, and three lysimeters were nested in boring B1-B. Three SMT probes were installed approximately $2 \mathrm{ft}$ east of the lysimeters. Water samples collected from the piezometer and lysimeters on November 1, 1994, were shipped to ORNL for analysis. Other water samples were collected periodically from November 12, 1994 to May 9, 1996. These samples were analyzed on-site in the field laboratory, with some ancillary testing performed at ORNL.

\subsubsection{Pre-Treatment Soil Testing}

Measurements of pre-treatment soil conditions at the CTS were made both within individual test cells (borehole $E$ in test cells 1 through 6 and borehole $A$ in test cell 7 ) and at one background location (near the equipment shakedown area). Values from these eight locations were averaged to provide a basis for experimental design and for comparison with posttreatment soil conditions. Parameters measured included soil moisture content, bulk density, temperature, $\mathrm{pH}, \mathrm{Eh}, \mathrm{TOC}$, grain size, bromide, manganese, and calcium. A summary of the pre-treatment soil conditions is presented in Table 4.1 . 
The average depth-specific soil moisture content ranged from 15 to $26 \%$ with moisture content generally increasing with depth. The moist bulk density ranged from 1.57 to 2.25 $\mathrm{g} / \mathrm{cc}$ with the an overall bulk density average of approximately $1.84 \mathrm{~g} / \mathrm{cc}$. Pre-treatment soil temperatures averaged $56^{\circ} \mathrm{F}$ at $4 \mathrm{ft}$ bgs, $58^{\circ} \mathrm{F}$ at $8 \mathrm{ft} \mathrm{bgs,}$ and $56^{\circ} \mathrm{F}$ at $14 \mathrm{ft}$ bgs. Soil pH increased with depth and ranged from 4.3 to 7.4 . Soil Eh, measured only at the background location near the shakedown area, was $400 \mathrm{mV}$ near the ground surface and decreased to 140 $\mathrm{mV}$ at $12 \mathrm{ft} \mathrm{bgs.} \mathrm{Average} \mathrm{TOC} \mathrm{ranged} \mathrm{from} 6397 \mathrm{ppm}$ near the ground surface and decreased to a minimum value of $395 \mathrm{ppm}$ at $9 \mathrm{ft}$ bgs.

During horizontal well installation at the CTS, selected samples were submitted for grain size distribution analysis. Of these samples, four samples were collected near the multi-point injection permeation and dispersal test area at depths of 4.5 to $5 \mathrm{ft}$ bgs and 13.5 to $14 \mathrm{ft}$ bgs (Appendix A). In these samples 85 to $98 \%$ of the sample passed through a \#200 mesh sieve confirming the soils as silty clays. Visual inspection of the soil cores identified the soils as silty clay with colors ranging from light yellowish brown to reddish brown with gray and green mottling.

Manganese and calcium were analyzed in soil samples from pre-treatment borings in test cells 1,2 , and 4. Most values for manganese were less than $10 \mathrm{ppm}$, except for the top one foot of soil where manganese concentrations were 20 to $45 \mathrm{ppm}$. Calcium concentrations were generally less than $1000 \mathrm{ppm}$ to depths of 6 or $7 \mathrm{ft} \mathrm{bgs}$ and then increased dramatically to generally more than $5000 \mathrm{ppm}$. These data indicated that calcium has been leached from the upper soil profile and probably redeposited at depths greater than $6 \mathrm{ft}$. This is consistent with the acidic $\mathrm{pH}$ of the upper soil, where after breakdown of $\mathrm{CaCO}_{3}$, calcium would be leached from the soil. The soil would then be enriched with calcium where soil $\mathrm{pH}$ was more neutral, thus supporting the formation of gypsum crystals observed in the 6.5 to $8 \mathrm{ft}$ bs zone.

Discussion of the bromide data and additional detail related to cation analyses are presented with the post-treatment results within the following specific test cell sections.

\subsubsection{Background Water Testing}

Parameters routinely measured in water samples from the lysimeters and piezometers included water level, $\mathrm{pH}$, conductivity, temperature, $\mathrm{DO}, \mathrm{TOC}, \mathrm{NO}_{3}^{-}, \mathrm{Br}^{-}$, alkalinity, $\mathrm{Fe}, \mathrm{Mn}, \mathrm{Cl}^{-}$, and $\mathrm{SO}_{4}{ }^{2-}$. Results from the background piezometer (B1P1) and lysimeters (B1L1, B1L2, and $\mathrm{B} 1 \mathrm{L3}$ ) are shown in Table 4.2. Water $\mathrm{pH}$ varied from 6.1 to 8.9 during the period of November 1, 1994 to February 15, 1995. The $\mathrm{pH}$ values were consistently lowest in the piezometer water samples, possibly due to contact of the water with air in the casing. DO values varied from $2 \mathrm{mg} / \mathrm{L}$ to $11.2 \mathrm{mg} / \mathrm{L}$, with no consistent trends in the data with depth or 
time. Conductivity measurements remained about the same for all sampling points over the duration of testing; however, it is interesting to note that the lowest conductivity values were measured in the shallowest sample B1L1 and the highest values were measured in the $8 \mathrm{ft}$ sample, B1L2. Alkalinity varied from 94 to $319 \mathrm{mg} / \mathrm{L}$. Alkalinity values measured in the shallow lysimeter were somewhat erratic, while values measured in the $8 \mathrm{ft}$ and $14-\mathrm{ft}$ lysimeter and the piezometer were more consistent. Bromide concentrations were less than $1 \mathrm{mg} / \mathrm{L}$ in all samples tested. Similarly, nitrate concentrations were less than $0.5 \mathrm{mg} / \mathrm{L}$ in all background samples tested. Manganese values were $1 \mathrm{mg} / \mathrm{L}$ or less and averaged approximately 0.25 $\mathrm{mg} / \mathrm{L}$. Chloride ranged from 2.5 to $23 \mathrm{mg} / \mathrm{L}$. Sulfate concentrations ranged from 425 to $1200 \mathrm{mg} / \mathrm{L}$.

\subsection{Test Cell 1: Water Injection with Tracers}

The first injection was in Test Cell 1 where water with tracers were injected. This was done to familiarize field personnel with the injection procedure and demonstrate that liquid injection was possible at this site. Thus, the test served as a practice session, while the tracers provided information on the behavior of water injected in the subsurface.

\subsubsection{T1 Field Activities}

Five pre-treatment soil borings, T1-A through T1-E, were drilled and sampled on October 23 , 1994. Lithologic logs were prepared and soil samples shipped to ORNL for analysis. One piezometer was installed at boring T1-D, and three lysimeters were nested in boring T1C (Fig. 4.1). Three SMT probes were installed approximately $2 \mathrm{ft}$ east of the lysimeters. Water samples were collected from the piezometer and the lysimeters on November 1, 1994, and were shipped to ORNL for analysis. Preparation for injection testing at test cell 1 began on November 12,1994. A set of water samples was collected from the lysimeters and piezometer, and elevation benchmarks were surveyed prior to the start of injection. Water with bromide and Snomax $\otimes$ tracers was injected on 2 - $\mathrm{ft}$ centers to a depth of $10.4 \mathrm{ft}$ starting at 2:00 p.m. The test cell injection was completed at 5:45 p.m.; thus, 225 min were required to perform 144 injections (36 MPIS set-up locations with four injector locations per setup) (Fig. 3.1). The average time for each injection setup was 6.2 min excluding $35 \mathrm{~min}$ to refill and mix three 500-gal tanks.

The objective was to inject 2 gal per injector at each 15 -in. depth interval. With four injectors per set-up location and eight positions for each injector, the target total for injection at each setup was 64 gal ( 4 injectors $\times 8$ positions $\times 2$ gal each), and the target for 36 set-up locations was 2,304 gal ( 36 setups $\times 64$ gal each) for the entire test cell. According to the flow meters, 
approximately 2400 gal of solution were delivered; the estimated amount of solution lost to seepage at the ground surface was 400 gal. Thus, the amount of solution injected into the subsurface was estimated to be 2000 gal.

Six batches of powdered $\mathrm{KBr}$ and Snomax@ solution were mixed and added to each of six 500 -gal batches of water. Two samples of each of the six batches were collected during injection to evaluate the uniformity of the injected solutions. The samples were analyzed for bromide in the on-site laboratory. Bromide concentrations varied from 190 to $235 \mathrm{mg} / \mathrm{L}$ with a mean of $205 \mathrm{mg} / \mathrm{L}$.

\begin{tabular}{lcccccc}
\hline $\begin{array}{l}\text { Test } \\
\text { Cell } \\
\text { No. }\end{array}$ & $\begin{array}{c}\text { Total } \\
\text { solution } \\
\text { injected }\end{array}$ & $\begin{array}{c}\text { Target } \\
\text { solution } \\
\text { strength }\end{array}$ & $\begin{array}{c}\text { Average } \\
\text { actual solution } \\
\text { strength }\end{array}$ & $\begin{array}{c}\text { Duration of } \\
\text { injection } \\
\text { testing }\end{array}$ & $\begin{array}{c}\text { Average } \\
\text { time per } \\
\text { setup }\end{array}$ & $\begin{array}{c}\text { Total } \\
\text { surface } \\
\text { seepage }\end{array}$ \\
\hline $\mathrm{T} 1$ & $2400 \mathrm{gal}$ & $200 \mathrm{mg} / \mathrm{L} \mathrm{Br}$ & $205 \mathrm{mg} / \mathrm{L} \mathrm{Br}$ & $225 \mathrm{~min}$ & $6.25 \mathrm{~min}$ & $400 \mathrm{gal}$ \\
\hline
\end{tabular}

Soil resistance and temperature readings were taken before, during, and after the injection. Resistance measurements showed that the soil was near saturation at $14 \mathrm{ft}$ bgs prior to injection, but was not saturated at 8 and $4 \mathrm{ft}$ bgs. However, approximately $8 \mathrm{~min}$ after injection started, the backfilled soil around the subsurface probes was saturated with injected solution, and solution began to run out the top of the protective casing onto the ground surface. Soil temperature showed an increase of $3^{\circ} \mathrm{F}$ at $4 \mathrm{ft} \mathrm{bgs}$ and no change at 8 and 14 $\mathrm{ft}$ bgs.

The first phase of post-treatment characterization began with the completion of five additional soil borings (T1-F through T1-J) to a depth of $12 \mathrm{ft}$ each. The borings were continuously sampled with 48 -in.-long megabore samplers, and the resulting 1.5 -in.-diameter soil cores were extensively subsampled. Each core was divided into 1-ft segments, and the following samples were taken from each segment: $60 \mathrm{~g}$ of soil for water content, TOC, and $\mathrm{pH} ; 10 \mathrm{~g}$ of soil for archive; $1 \mathrm{~kg}$ of soil for iron oxides, $\mathrm{x}$-ray analysis, SEM, and conductivity; $1 \mathrm{~kg}$ of soil to the field lab for $\mathrm{pH}, \mathrm{Br}, \mathrm{Cl}, \mathrm{Fe}, \mathrm{Mn}, \mathrm{SO}_{4}{ }^{2}, \mathrm{H}_{2} \mathrm{O}_{2}$, and $\mathrm{KMnO}_{4}$; and $\sim 200 \mathrm{~g}$ for INA and $\mathrm{Br}^{-}$. A few samples were wax-coated for $\mathrm{X}$-ray analysis. Not all analyses were performed on all samples. Lithologic descriptions were also prepared (Appendix B).

Post-treatment water samples were collected from the lysimeters and piezometer eight times during the 9 days following the injection and again approximately 1 and 3 months after injection. Similarly, elevation benchmarks (S1, S2, S3, S4 damaged, and S5) were surveyed six times during the nine days following the injection and again about one month after injection. During the fourth week after injection, December 12 to 14, 1994, two additional soil borings (T1-K and T1-L) were cored and sampled. The subsampling performed was not as extensive as that performed during the first phase of post-treatment soil sampling and was 
limited to performing Eh measurements as the cores were divided into 1-ft segments, preparing a lithologic log, and shipping the cores to ORNL for additional analysis.

\subsubsection{T1 Soil Sample Results}

Pre-treatment soil sample results include measurements of soil $\mathrm{pH}$, TOC, $\%$ moisture, temperature, and bulk density. Soil sample results are summarized in Table 4.3 and data trend graphs are presented in Appendix $\mathrm{C}$. Values for pre-treatment soil $\mathrm{pH}$ were measured on the core from borehole $\mathrm{E}$ and ranged from a low of 4.3 near the ground surface to a high of 7.8 at $10 \mathrm{ft}$ bgs. There was a general increase of $\mathrm{pH}$ with increasing depth. Because the injection of water with tracers was not expected to have much effect on soil $\mathrm{pH}$, no post-injection $\mathrm{pH}$ measurements were performed.

TOC was evaluated on pre-treatment core samples from borehole $\mathrm{E}$. The values ranged from a high of over $6000 \mathrm{ppm}$ near the surface to about $350 \mathrm{ppm}$ at depth. The values were highest near the ground surface due to humic material in the top soil: TOC values decreased steadily to a depth of $7 \mathrm{ft}$ bgs and then were variable but less than $1000 \mathrm{ppm}$ down to $12 \mathrm{ft}$ bgs. Because no change in TOC was expected due to the injection of water with tracers, post-treatment TOC was not measured.

Moisture content was measured in samples from one pre-treatment boring, borehole $\mathrm{E}$. Samples ranged from $15 \%$ to $27 \%$ moisture (dry wt.\%). These values are consistent with other background soil moisture measurements for the CTS. Moisture content was measured at $1 \mathrm{ft}$ intervals on five post-treatment borings (Fig. 4.2). Comparison of depth-specific moisture values showed that moisture content of the near-surface interval ( 0 to $4 \mathrm{ft} \mathrm{bgs)} \mathrm{had}$ increased from $\sim 15 \%$ to as much as $24 \%$. The intermediate-depth interval ( 4 to $8 \mathrm{ft} \mathrm{bgs)}$ was unchanged, and the deepest interval (8 to $12 \mathrm{ft} \mathrm{bgs)} \mathrm{showed} \mathrm{a} \mathrm{slight} \mathrm{increase} \mathrm{in} \mathrm{soil} \mathrm{moisture.}$ Thus, the injection of 2000 gal of water into the test cell had little effect on soil moisture content. This is consistent with predictions made which suggested an average increase of a $2.0 \mathrm{wt} . \%$ based on the volume of water added into the volume of media in the cell (Table $3.5)$.

Soil surface elevation data show that the surface of the test cell was raised about $0.1 \mathrm{ft}$ by the injection and remained near that elevation through the last measurement period (three months after injection). The volume change in a $24 \mathrm{ft} \times 24$ - $\mathrm{ft}$ area that swells $0.1 \mathrm{ft}$ is about $57 \mathrm{ft}^{3}$ or about 430 gal. Thus, 1570 gal of water are unaccounted for by swell measurements alone.

Core samples from the pre-treatment borings were carefully logged, and visible pores and fractures in the soil were noted (Appendix A). There were numerous root pores and vesicles seen from the surface down to about $5 \mathrm{ft}$ deep. Open-bed partings were noted at 7.5 to 8.5 $\mathrm{ft}$ bgs, with infillings of authigenic gypsum crystals. Clay content and soil stiffness increased 
with depth. A few high-angle fractures were noted at 5 to $6 \mathrm{ft}$ deep, but most of the fractures were between 9.5 and $11.5 \mathrm{ft}$ deep. Some of these fractures had gray-clay infillings. Posttreatment core samples were also carefully logged. There were no differences seen between the number of fractures and the appearance of fractures before and after injection.

Bromide concentrations were determined in eight pre-treatment soil samples. Concentrations ranged from 0.7 to $1.5 \mathrm{ppm}$ and averaged $0.88 \mathrm{ppm}$. Bromide concentrations were determined in post-treatment soil samples on 1-ft intervals for five borings drilled $12 \mathrm{ft}$ bgs (Fig. 4.3). For the de $\mathrm{F}$ interval of 0 to $2 \mathrm{ft}$ bgs, all measurements were above the average background bromide concentration of $0.88 \mathrm{ppm}$, mostly between 3 and $8 \mathrm{ppm}$. The interval of 2 to $5 \mathrm{ft}$ bgs showed bromide concentrations ranging from background to about $6 \mathrm{ppm}$, with an average of about $3 \mathrm{ppm}$. The interval of 5 to $7 \mathrm{ft}$ bgs showed concentrations ranging from background to $3.5 \mathrm{ppm}$, averaging about $1.5 \mathrm{ppm}$. The interval of 7 to $9 \mathrm{ft}$ bgs showed concentrations ranging from background up to $6 \mathrm{ppm}$ and averaging about $3.5 \mathrm{ppm}$. The deepest interval, 9 to $12 \mathrm{ft}$ bgs, had bromide concentrations ranging from background to 4 $\mathrm{ppm}$, averaging $1.0 \mathrm{pm}$. These data indicate that different zones in the soil were preferentially enriched with bromide tracer as a result of the injection. The estimated increase in $\mathrm{Br}$ concentration to be caused by the concentration and volume of solution injected into the cell was approximately $9 \mathrm{ppm}$ (Table 3.5). As observed, the entire cell down to $10 \mathrm{ft}$ bgs appears to have been somewhat enriched in bromide. The greatest increase in bromide was in the near surface, 0 to $2 \mathrm{ft}$, where the soils were the least compact and had the highest density of root vesicles and pores. The zone between 7 and $9 \mathrm{ft}$, where the open-bed partings were noted in pre-treatment borings, was the second most enriched zone. The least-enriched zone was below $10 \mathrm{ft}$, which correlates to the total depth of injection of about $10.4 \mathrm{ft}$.

Snomax@ tracer was evaluated by performing INA analysis on samples from five posttreatment borings (Fig. 4.4). The INA values were generally much higher in the top 4 to 5 $\mathrm{ft}$ of soil and ranged from 18 to 3500 particles $/ \mathrm{mg}$ of soil. Values dropped dramatically below $5 \mathrm{ft}$ and were generally less than 10 particles $/ \mathrm{mg}$ of soil. Some borings showed an increase in INA between 7 and $9 \mathrm{ft}$ bgs, again probably related to the visible, open-bed partings. Values in other borings dropped to near 0 from 7 to $12 \mathrm{ft} \mathrm{bgs}$.

Eh was not measured on the pre-treatment soil cores, but post-treatment Eh values ranged from 275 to $500 \mathrm{mV}$ in two boreholes, T1-L and $-\mathrm{K}$. These values are similar to those measured in the pre-treatment background boring B1A.

\subsubsection{T1 Water Sample Results}

Post-treatment water sample data are presented in Table 4.4 and data trend graphs are presented in Appendix $\mathrm{C}$. Water sample results indicate that the $\mathrm{pH}$ of the water in the 
lysimeters and piezometer varied from 6.5 to 8.7 with no apparent trends with depth of the water sample or time elapsed after the injection.

DO values in water samples from the three lysimeters were highest prior to the injection and decreased markedly in T1L2, the 8-ft-deep lysimeter, after the injection. DO values appeared to stabilize after about 3 days (November 17,1994 ) and remained relatively constant until November 21, 1994. Then, when samples were collected on December 15 and February 16, DO values were again near pre-treatment values. Piezometer DO values were more consistent throughout the analysis period.

Electrical conductivity remained about the same before and after injection except in T1L2, the 8-ft-deep lysimeter, where conductivity doubled after injection (November 14, 1994) and remained at a higher value. Data for the December 5, 1994, sampling event show low conductivity for all samples; it appears that there may have been a problem with the conductivity meter at that time.

Background bromide concentrations were around $1 \mathrm{mg} / \mathrm{L}$. Bromide was detected at 80 to $100 \mathrm{mg} / \mathrm{L}$ in T1L1 and T1L2 after the injection and then slowly decreased over the next several days (Fig. 4.5). These concentrations are about one-half the strength of the injected reagent, $205 \mathrm{mg} / \mathrm{L}$, indicating dilution by the resident soil pore water. Bromide concentrations were minimal in the deep lysimeter and piezometer, both at $14 \mathrm{ft} b g s$, indicating that the bromide tracer was not migrating rapidly downward after injection.

However, samples taken in December and February from the deep lysimeter and the piezometer showed increasing $\mathrm{Br}^{*}$ concentrations, indicating that some downward infiltration of injected solution was occurring.

Other analytes tested included alkalinity, $\mathrm{Fe}, \mathrm{Mn}, \mathrm{Cl}^{-}, \mathrm{NO}_{3}{ }_{3}$, and $\mathrm{SO}_{4}{ }^{2-}$ but since there were no noticeable changes in concentration in the first few samples, analysis for these parameters was discontinued, and no evaluation of the limited data sets was deemed necessary.

\subsection{Test Cell 2: Hydrogen Peroxide}

\subsubsection{T2 Field Activities}

Five pre-treatment soil borings, T2-A through T2-E, were drilled and sampled on October 22, 1994. Lithologic logs were prepared, and soil samples were shipped to ORNL for analysis. One piezometer was installed at boring T2-D, and three lysimeters were nested in boring T2-C (Fig. 4.6). Three SMT probes were installed approximately $2 \mathrm{ft}$ east of the lysimeters. Water samples collected from the piezometer and lysimeters on November 1 , 
1994, were shipped to ORNL for analysis. Preparation for injection testing at test cell 2 began the morning of November 15, 1994. A set of water samples was collected from the lysimeters and piezometer, and elevation benchmarks were surveyed prior to the start of injection. A $10 \%$ by wt. hydrogen peroxide solution was injected on 2 -ft centers to a depth of $10.4 \mathrm{ft}$ starting at 9:45 a.m. The first two positions were injected at a rate of $2.5 \mathrm{gal}$ per injector per position; however, there was a large amount of surface seepage, so the injection rate was reduced to 2.0 gal per injection. The test cell injection was completed at 1:10 p.m.; thus, $205 \mathrm{~min}$ were required, and the average time for each injection setup was $5.7 \mathrm{~min}$.

The objective was to inject 2 gal per injector at each 15 -in. depth interval or a total of 2,304 gal (36 setups $\times 64$ gal each) for the entire test cell. According to the flow meter at the pump, 2,352 gal were injected, and according to flow meters on the MPIS unit, 2,418 gal were injected. The estimated amount of solution lost to seepage at the ground surface.was 500 gal. Thus, the amount of solution injected into the subsurface was estimated to be 1800 gal.

The solution was delivered to the site in one batch in a 3000-gal tank with no tracer added. Six samples were collected during injection to evaluate the uniformity of the injected solution. The samples were screened for $\mathrm{H}_{2} \mathrm{O}_{2}$ in the on-site laboratory and analyzed for $\mathrm{H}_{2} \mathrm{O}_{2}$ at $\mathrm{ORNL}$.

\begin{tabular}{ccccccc}
\hline $\begin{array}{c}\text { Test Cell } \\
\text { No. }\end{array}$ & $\begin{array}{c}\text { Total } \\
\text { solution } \\
\text { injected }\end{array}$ & $\begin{array}{c}\text { Target } \\
\text { solution } \\
\text { strength }\end{array}$ & $\begin{array}{c}\text { Average } \\
\text { actual } \\
\text { solution } \\
\text { strength }\end{array}$ & $\begin{array}{c}\text { Duration } \\
\text { of } \\
\text { injection } \\
\text { testing }\end{array}$ & $\begin{array}{c}\text { Average } \\
\text { time per } \\
\text { setup }\end{array}$ & $\begin{array}{c}\text { Total } \\
\text { surface } \\
\text { seepage }\end{array}$ \\
\hline $\mathrm{T} 2$ & $2300 \mathrm{gal}$ & $10 \% \mathrm{H}_{2} \mathrm{O}_{2}$ & $10 \% \mathrm{H}_{2} \mathrm{O}_{2}$ & $205 \mathrm{~min}$ & $5.7 \mathrm{~min}$ & $500 \mathrm{gal}$ \\
\hline
\end{tabular}

Soil resistance and temperature were measured before, during, and after the injection testing. Resistance measurements showed that the soil was near saturation at 8 to $14 \mathrm{ft}$ bgs prior to injection testing, but was not saturated at $4 \mathrm{ft}$ bgs. However, soon after injection started, the backfilled soil around the subsurface probes was saturated with injected solution, and solution began to run out the top of the protective casing onto the ground surface. Soil temperature was monitored throughout the test and showed an increase of $8^{\circ} \mathrm{F}$ at $4 \mathrm{ft} \mathrm{bgs,} 2^{\circ} \mathrm{F}$ at $8 \mathrm{ft}$ bgs, and no change at $14 \mathrm{ft}$ bgs. Temperature was also monitored in one of the reacting injector holes and varied from a pre-treatment value of $56^{\circ} \mathrm{F}$ up to $80^{\circ} \mathrm{F}$ less than 1 hour after injection. Temperature decreased to $70^{\circ} \mathrm{F}$ about 3 hours after injection was completed even though gas bubbles indicated that subsurface reactions were still in progress.

Hydrogen peroxide appeared to react with the soil immediately upon injection, and gas and mud bubbled from all injector locations for several hours after injection was completed. At 
the peak of reactivity, there was brown, foaming mud up to $6 \mathrm{in}$. deep over the entire test cell. The reaction of peroxide in the soil produced gases, which rose to the surface, pushing fluid and mud out of the injection holes generating the foam as part of the reaction. In addition, there was a blowout during the injection from an injector hole in test cell 1 about $40 \mathrm{ft}$ away from the position being injected in test cell 2 . There were several areas within and near test cell 2 where the ground surface was raised to about 8 in. above the pre-treatment position, apparently due to gas buildup beneath the sod. Most of these raised areas subsided rapidly after blowouts relieved the pressure.

The first phase of post-treatment characterization began with the completion of five additional soil borings (T2-F through T2-J) to a depth of $12 \mathrm{ft}$ each. The borings were continuously sampled with 48-in.-long megabore samplers, and the resulting 1.5-in.-diameter soil cores were extensively subsampled. Each core was divided into 1 - $\mathrm{ft}$ segments, which were then subsampled. Eh was measured on the core as it was subsampled; lithologic descriptions were also prepared.

Post-treatment water samples were collected from the lysimeters and piezometer seven times during the 7 days following the injection. Similarly, elevation benchmarks (S1 - S5) were surveyed five times during the 7 days following the injection.

Another set of water samples was collected from the lysimeters and piezometer on December 5,1994 , approximately 3 weeks after the injection. During the fourth week after injection, December 12 to 14,1994 , two additional soil borings (T2-K and T2-L) were cored and sampled. The on-site subsampling performed was not as extensive as that performed during the first phase of post-treatment soil sampling and was limited to measuring Eh as the cores were divided into 1-ft segments, preparing a lithologic log, and shipping the cores to ORNL for additional analysis. An additional set of water samples was collected from the lysimeters and piezometer in December 1994, February 1995 and May 1996.

\subsubsection{T2 Soil Sample Results}

Pre-treatment soil samples collected from test cell 2 were analyzed for $\mathrm{pH}, \mathrm{Eh}, \mathrm{TOC}, \%$ moisture, manganese, and calcium. Samples were collected from borehole E. Analysis results were consistent with the background values discussed in Sect. 4.1. Post-treatment soil samples collected from the first five soil borings, T2-F through T2-J, were analyzed for $\mathrm{pH}$, peroxide, nitrate, Eh, TOC, and \% moisture. The two additional borings, T2-K and T2-L, were analyzed for Eh only. Soil sample results for test cell 2 are summarized in Table 4.5 and data trend graphs are presented in Appendix C. 
Results from $\mathrm{pH}$ measurements were similar for all boreholes, with values ranging from 4.2 to 7.5 and $\mathrm{pH}$ increasing with depth. These values are similar to the pre-treatment sample $\mathrm{pH}$ values; thus, the peroxide injection did not effect a significant $\mathrm{pH}$ change.

Peroxide was detected in four of the five post-treatment borings in the 2- to 3-ft interval (Fig. 4.7). Values ranged from approximately 4 to $100 \mathrm{mg} / \mathrm{L}$. No other peroxide was detected in the samples, excluding the 6 to $7 \mathrm{ft}$ interval in borehole $\mathrm{F}$.

Nitrate analysis was performed on soil extracts for which soil samples were extracted with water and the resulting water samples analyzed. Values ranged from 0 to $3.75 \mathrm{ppm}$; however, the results were sporadic. Values from borehole $\mathrm{H}$ were higher than those from other boreholes, however, these values are not considered to be significantly higher due to a variation in the analysis procedure. No significant trends are seen in the nitrate data.

Soil Eh measurements for all boreholes showed a general decreasing trend with depth. An average maximum of about $450 \mathrm{mV}$ was measured 2 to $3 \mathrm{ft}$ bs and an average minimum of approximately $250 \mathrm{mV}$ was observed at 7 to $12 \mathrm{ft}$ bgs (Fig. 4.8). The higher Eh values in the 2 to $3-\mathrm{ft}$ interval correspond with the depth of peroxide detection in the cell.

Post-treatment TOC measurements ranged from approximately 400 to $2900 \mathrm{ppm}$. Compared to pre-treatment measurements, there is a dramatic decrease in TOC at the 0 to $2-\mathrm{ft}$ interval. Indeed, TOC content at the 1-ft interval dropped from a pre-treatment level of $6100 \mathrm{ppm}$ to a post-treatment concentration of $2900 \mathrm{ppm}$. This effect correlates with the distribution of peroxide observed above and demonstrates the oxidizing potential of peroxide. Little change was observed at depths greater than $2 \mathrm{ft}$.

Post-treatment soil moisture readings ranged from approximately 12 to $28 \%$. Comparison to pre-treatment, depth-specific moisture values shows that moisture content in the nearsurface interval ( 0 to $4 \mathrm{ft}$ ) increased by approximately $3 \%$. The intermediate depth interval ( 4 to $8 \mathrm{ft}$ ) was unchanged, and the deepest interval ( 8 to $12 \mathrm{ft}$ ) showed a slight increase in soil moisture. These results are similar to those seen for test cell 1 (see Sect. 4.2.2).

Soil surface elevation data show that the surface of the test cell was raised approximately 0.3 $\mathrm{ft}$ by the injection and remained near that elevation through the last measurement period ( 3 months after injection). Core samples from both the pre-treatment and post-treatment borings were carefully logged, and visible pores and fractures were noted. No differences were seen between the number and appearance of fractures before and after injection. 


\subsubsection{T2 Water Sample Results}

Post-treatment results are presented in Table 4.6 and data trend graphs are presented in Appendix C. Results indicate that the $\mathrm{pH}$ of the water in the lysimeters and piezometer varied from 6.6 to 9.0 . The only trend noted was in the shallowest lysimeter, $\mathrm{T} 2 \mathrm{Ll}$, at $4 \mathrm{ft}$ bgs, where $\mathrm{pH}$ decreased steadily from the high of 9.0 to about 7.4 within 6 days after injection of peroxide. DO values were between 4 and $8 \mathrm{mg} / \mathrm{L}$ the day after injection and increased dramatically in $\mathrm{T} 2 \mathrm{~L} 1$ the second day after injection (Fig. 4.9). A significant increase (to 14 $\mathrm{mg} / \mathrm{L}$ ) was also observed in T2L2. DO in T2L 3 remained about the same for 5 days after injection (4 to $9 \mathrm{mg} / \mathrm{L}$ ) and then increased to a maximum of $11.2 \mathrm{mg} / \mathrm{L}$ approximately 2 weeks later. DO values in the piezometer were steady throughout the period measured probably due to contact of the water with air inside the casing. Conductivity varied considerably with the depth of the water sample, with the shallowest lysimeter having the lowest conductivity at about 800 to $1900 \mu$ mhos and the deepest lysimeter and the piezometer having values around $4500 \mu$ mhos. These values are not significantly different from the pre-treatment values, excluding T2L2, which had an increase of approximately 1700 $\mu$ mhos after injection.

Peroxide was detected in water samples from T2L1 and T2L 2 the day after injection, but undetected 5 days later (Fig. 4.10). Nitrate values varied between undetected and 2 ppm for all water samples for 7 days after injection except in T2L2, where nitrate increased dramatically to $12 \mathrm{ppm}$ the day after injection and then decreased to background by the fifth day after injection. It is not known if the increase in T2L2 is actual or due to a variation in the analysis procedure.

Alkalinity ranged from approximately 14 to $860 \mathrm{mg} / \mathrm{L}$, with a general trend of increase with depth. These values are not significantly different from background values, excluding T2L2, which showed a dramatic increase the fifth day after injection. This increase corresponds to the conductivity increase observed for T2L2.

Other analytes tested included $\mathrm{Fe}, \mathrm{Mn}, \mathrm{Cl}^{-}$, and $\mathrm{SO}_{4}{ }^{2}$, but since there were no noticeable changes in concentration in the first few samples, analysis for these parameters was discontinued, and no evaluation of the limited data sets was deemed necessary.

\subsection{Test Cell 3: Bionutrient with Tracers}

\subsubsection{T3 Field Activities}

Five pre-treatment soil borings, T3-A through T3-E, were drilled and sampled on October 20, 1994. Lithologic logs were prepared, and soil samples were shipped to ORNL for 
analysis. One piezometer was installed at boring T3-D, and three lysimeters were nested in boring T3-C (Fig. 4.11). Three SMT probes were installed approximately $2 \mathrm{ft}$ east of the lysimeters. Water samples collected from the piezometer and lysimeters on November 1, 1994, were shipped to ORNL for analysis. Preparation for injection testing at test cell 3 began on the morning of November 18, 1994. A set of water samples was collected from the lysimeters and piezometer, and elevation benchmarks were surveyed prior to the start of injection. A proprietary bionutrient/surfactant solution with bromide and Snomax $B$ as tracers was injected on 2-ft centers to a depth of $10.4 \mathrm{ft}$ starting at 1:35 p.m. The test cell injection was completed at 5:45 p.m.; thus, 250 min were required to perform 144 injections (36 MPIS set-up locations with four injector locations per setup). The average time for each injection setup was $6.9 \mathrm{~min}$; however, this includes stopping to mix the injection solution twice during the process (approximately $45 \mathrm{~min}$ ).

The injection solution was mixed as follows: five batches of 500 gal each ( 2500 gal total), with each batch containing $50 \mathrm{gal}$ of bionutrient/surfactant, $450 \mathrm{gal}$ of water, $421 \mathrm{~g}$ of $\mathrm{KBr}$, and $215 \mathrm{~g}$ of Snomax ${ }^{\circledR}$. The target solution strength was $10 \%$ bionutrient/surfactant, 150 $\mathrm{mg} / \mathrm{L} \mathrm{Br}$, and $114 \mathrm{mg} / \mathrm{L}$ Snomax .

The objective was to inject $2{ }^{\circ}$ gal per injector at each 15 -in. depth interval. With four injectors per set-up location and eight positions for each injector, the target total for injection at each setup was 64 gal ( 4 injectors $\times 8$ positions $\times 2$ gal each); the target for 36 set-up locations was 2,304 gal ( 36 setups $\times 64$ gal each) for the entire test cell. According to the flow meter at the pump, 2,200 gal of solution were injected, and according to flow meters on the MPIS unit, 2,160 gal were injected. The estimated amount of solution lost to the ground surface was 400 gal. Thus, the amount of solution injected into the subsurface was estimated to be 1800 gal. One sample of each of the six batches was collected during injection to evaluate the uniformity of the injected solutions.

\begin{tabular}{ccclccc}
\hline $\begin{array}{c}\text { Test } \\
\text { Cell } \\
\text { No. }\end{array}$ & $\begin{array}{c}\text { Total } \\
\text { solution } \\
\text { injected }\end{array}$ & $\begin{array}{c}\text { Target } \\
\text { solution } \\
\text { strength }\end{array}$ & $\begin{array}{c}\text { Average actual } \\
\text { solution } \\
\text { strength }\end{array}$ & $\begin{array}{c}\text { Duration of } \\
\text { injection } \\
\text { testing }\end{array}$ & $\begin{array}{c}\text { Average } \\
\text { time per } \\
\text { setup }\end{array}$ & $\begin{array}{c}\text { Total } \\
\text { surface } \\
\text { seepage }\end{array}$ \\
\hline T3 & $2200 \mathrm{gal}$ & $\begin{array}{l}10 \% \text { bionutrient } \\
\text { surfactant }\end{array}$ & $\begin{array}{l}10 \% \text { bionutrient } \\
\text { surfactant }\end{array}$ & $250 \mathrm{~min}$ & $6.9 \mathrm{~min}$ & $400 \mathrm{gal}$ \\
& & $\begin{array}{l}150 \mathrm{mg} / \mathrm{L} \mathrm{Br}- \\
114 \mathrm{mg} / \mathrm{L}\end{array}$ & $\begin{array}{l}150 \mathrm{mg} / \mathrm{L} \mathrm{Br}- \\
114 \mathrm{mg} / \mathrm{L}\end{array}$ & & & \\
& & Snowmax 8 & Snowmax 8 & & & \\
\hline
\end{tabular}

Soil resistance and temperature were measured before, during, and after the injection testing. Resistance measurements showed that the soil was near saturation at $14 \mathrm{ft}$ bgs prior to injection testing, but was not saturated at 8 and $4 \mathrm{ft}$ bgs. However, within $30 \mathrm{~min}$ after injection started, the backfilled soil around the subsurface probes was saturated with injected solution, and solution began to run out the top of the protective casing onto the ground 
surface. Soil temperature was monitored throughout the test, showing an increase of $4^{\circ} \mathrm{F}$ at $4 \mathrm{ft} \mathrm{bgs,} 1^{\circ} \mathrm{F}$ at $8 \mathrm{ft}$ bgs, and no change at $14 \mathrm{ft}$ bgs.

The bionutrient/surfactant appeared to react mildly at the surface, and a faint, musky odor was detectable. This odor persisted for several days after the test. At the peak of reactivity, brown foam up to 2 in. deep appeared at each injector location, but did not persist for more than an hour.

The first phase of post-treatment characterization began with the completion of five additional soil borings (T3-F through $\mathrm{T} 3-\mathrm{J}$ ) to a depth of $12 \mathrm{ft}$ each. The borings were continuously sampled with 48-in.-long megabore samplers, and the resulting 1.5-in.-diameter soil cores were extensively subsampled. Each core was divided into $1-\mathrm{ft}$ segments and then subsampled as described in Sect. 4.2. Eh was measured on the core as it was subsampled; lithologic descriptions were also prepared.

Post-treatment water samples were collected from the lysimeters and piezometer three times during the 3 days following the injection. Similarly, elevation benchmarks (S1 - S5) were surveyed three times during the 3 days following the injection.

Another set of water samples was collected from the lysimeters and piezometer on December 5,1994 , approximately 2 weeks after the injection. During the third week after injection, December 12 to 14,1994 , two additional soil borings (T3-K and T3-L) were cored and sampled. The on-site subsampling performed was not as extensive as that performed during the first phase of post-treatment soil sampling and was limited to measuring Eh as the cores were divided into $1-\mathrm{ft}$ segments, preparing lithologic logs, and shipping the cores to ORNL for additional analysis. An additional set of water samples was collected from the lysimeters and piezometer in December 1994, February 1995 and May 1996.

\subsubsection{T3 Soil Sample Results}

Post-treatment soil sample results are summarized in Table 4.7 and data trend graphs are presented in Appendix C. Results from pH measurements were similar for all boreholes, with values ranging from 4.7 to 7.5 and $\mathrm{pH}$ increasing with depth. These values are similar to the pre-treatment sample $\mathrm{pH}$ values; thus, the bionutrient injection did not effect a significant $\mathrm{pH}$ change.

Microbial biomass was evaluated using most probable number (MPN) techniques for aerobic and anaerobic heterotrophic populations. Both enumerations were based on turbidity being exhibited over a dilution range in 1\% PTYEG medium (Balkwill) in screw-capped test tubes (Pfiffner 1994). Aerobic enumerations were set-up in a three tube MPN series dilution scheme. Anaerobic heterotrophic enumerations utilized the same media with the additions 
of cysteine hydrochloride as the reducing agent to reach anaerobic conditions, rezaurin as Eh indicator, and nitrogen/ $\mathrm{CO}_{2}$ as the headspace gas mixture (Pfiffner 1994). Aerobic enumerations were set up in a single-series dilution scheme. The results of the microbial activity are presented in Table 4.8 .

The analysis of tracers injected with the bionutrients yielded different results. Bromide was detected in the soil profile at test cell 3 from a depth of 0 to $11 \mathrm{ft}$ bgs (Fig. 4.12), ranging from 1 to approximately $7 \mathrm{ppm}$, with the maximum concentration at $7 \mathrm{ft}$ bgs. Snomax®, measured as INA, was detected in the soil at depths from 1 to $9 \mathrm{ft}$ bgs and at $12 \mathrm{ft}$ bgs (Fig. 4.13). However, maximum concentrations were detected in the top $1 \mathrm{ft}$ of soil. Thus, it appears that the injection resulted in adequate distribution of the solution within the soil profile.

Soil Eh increased to a maximum of about $430 \mathrm{mV}$ at 2 to $4 \mathrm{ft}$ bgs and then generally decreased to around $200 \mathrm{mV}$ at $12 \mathrm{ft}$ bgs. This trend is similar to that observed for background borings.

Post-treatment soil moisture readings ranged from approximately 13 to $26 \%$. Comparison to pre-treatment, depth-specific moisture values shows that moisture content in the nearsurface interval ( 0 to $4 \mathrm{ft}$ ) increased by approximately $3 \%$. The intermediate depth interval $(4$ to $8 \mathrm{ft}$ ) and the deepest interval $(8$ to $12 \mathrm{ft}$ ) were unchanged.

Soil surface elevation data show that the surface of the test cell was raised approximately 0.5 $\mathrm{ft}$ by the injection and remained near that elevation through the last measurement period ( 3 months after injection). Core samples from both the pre-treatment and post-treatment borings were carefully logged, and visible pores and fractures were noted. No differences were seen between the number and appearance of fractures before and after injection.

\subsubsection{T3Water Sample Results}

Post-treatment water sample results are presented in Table 4.9 and data trend graphs are presented in Appendix $\mathrm{C}$. The $\mathrm{pH}$ of the water in the lysimeters steadily increased following injection of the bionutrient solution (Fig. 4.14). Maximum pH increases in T3L1 and T3L2 were observed approximately 2 weeks after injection, followed by a drop during the next 2 weeks. The $\mathrm{pH}$ of T3L 3 was initially lower than in the upper lysimeters; however, the $\mathrm{pH}$ continued to rise through the last sampling period (4 weeks after injection). This indicates a slow percolation of the reagent through the soil, as also shown by the bromide data (Fig. 4.15). A dramatic increase in bromide concentration is observed for T3L1 and T3L2 immediately following the injection period. Approximately 2 weeks after the injection, bromide was first observed in T3L3, and concentrations in the upper lysimeters began to decrease. 
DO values were slightly higher after the injection, but were inconsistent and not significantly different from background values. Conductivity remained about the same before and after injection except in T3L2, the 8-ft-deep lysimeter, where the conductivity increased dramatically after testing (November 18, 1994). Nitrate concentrations ranged from 0.1 to $1.6 \mathrm{ppm}$. Concentrations in T3L1 and T3L2 were above pre-treatment background levels, but no increases were observed in T3L3 and T3P1. The bionutrient solution probably contained a nitrate source that resulted in increases in the shallower intervals.

Alkalinity values for test cell 3 ranged from approximately 200 to $530 \mathrm{mg} / \mathrm{L}$, with a general trend of increase with depth. These values and trend are similar to those observed in the background cell.

Other analytes tested included $\mathrm{Fe}, \mathrm{Mn}, \mathrm{Cl}^{-}$, and $\mathrm{SO}_{4}{ }^{2-}$, but since there were no noticeable changes in concentration in the first few samples, analysis for these parameters was discontinued, and no evaluation of the limited data sets was deemed necessary.

\subsection{Test Cell 4: Lime Slurry}

\subsubsection{T4 Field Activities}

Five pre-treatment soil borings, T4-A through T4-E, were drilled and sampled on October 23 and 24, 1994. Lithologic logs were prepared, and soil samples were shipped to ORNL for analysis. No piezometer was installed in this test cell; however, three lysimeters were nested in boring T4-C (Fig. 4.11). Three SMT probes were installed approximately $2 \mathrm{ft}$ east of the lysimeters. Water samples were collected from the lysimeters on November 1, 1994, and were shipped to ORNL for analysis. Preparation for injection testing at test cell 4 began on November 13, 1994. A set of water samples was collected from the lysimeters, and elevation benchmarks were surveyed prior to the start of injection. A lime solution (calcium carbonate) was then injected on 2-ft centers to a depth of $10.4 \mathrm{ft}$ starting at 11:20 a.m. The test cell injection was completed at 4:05 p.m.; thus, 285 min were required to perform 144 injections (36 MPIS set-up locations with four injector locations per setup). The average time for each injection setup was $7.9 \mathrm{~min}$; however, this includes $130 \mathrm{~min}$ of lime-slurry mixing time.

The objective was to inject 2 gal per injector at each 15 -in. depth interval. With four injectors per set-up location and eight positions for each injector, the target total for injection at each setup was 64 gal ( 4 injectors $\times 8$ positions $\times 2$ gal each), and the target for 36 set-up locations was 2,304 gal ( 36 set-ups $\times 64$ gal each) for the entire test cell. According to flow meters on the MPIS unit, 2,304 gal were injected. The estimated amount of solution lost to the ground surface was 500 gal. Thus, the amount of solution injected into the subsurface was estimated to be $1800 \mathrm{gal}$. 
The solution was mixed as five batches of 500 gal of water with $400 \mathrm{lbs}$ of dry lime each with no tracer added. This mix was approximately $20 \%$ lime by weight. One sample was collected from each batch to evaluate the uniformity of the injected solution. The average injected solution was $10.7 \%$ lime by weight.

\begin{tabular}{ccccccc}
\hline $\begin{array}{c}\text { Test Cell } \\
\text { No. }\end{array}$ & $\begin{array}{c}\text { Total } \\
\text { solution } \\
\text { injected }\end{array}$ & $\begin{array}{c}\text { Target } \\
\text { solution } \\
\text { strength }\end{array}$ & $\begin{array}{c}\text { Average } \\
\text { actual } \\
\text { solution } \\
\text { strength }\end{array}$ & $\begin{array}{c}\text { Duration } \\
\text { of } \\
\text { injection } \\
\text { testing }\end{array}$ & $\begin{array}{c}\text { Average } \\
\text { time per } \\
\text { setup }\end{array}$ & $\begin{array}{c}\text { Total } \\
\text { surface } \\
\text { seepage }\end{array}$ \\
\hline T4 & $2300 \mathrm{gal}$ & $20 \%$ lime & $10.7 \%$ lime & $285 \mathrm{~min}$ & $7.9 \mathrm{~min}$ & $500 \mathrm{gal}$ \\
\hline
\end{tabular}

Soil resistance and temperature were measured before, during, and after the injection testing. Resistance measurements showed that the soil was near saturation at 8 and $14 \mathrm{ft}$ bgs prior to injection testing, but was not saturated at $4 \mathrm{ft}$ bgs. However, soon after injection started, the backfilled soil around the subsurface probes was saturated with injected solution, and solution began to run out the top of the protective casing onto the ground surface. Soil temperature was monitored throughout the test and showed an increase of $2^{\circ} \mathrm{F}$ at $4 \mathrm{ft}$ bgs and no change at 8 and $14 \mathrm{ft}$ bgs.

The first phase of post-treatment characterization began with the completion of five additional soil borings (T4-F through T4-J) to a depth of $12 \mathrm{ft}$ each. The borings were continuously sampled with 48-in.-long megabore samplers, and the resulting 1.5-in.-diameter soil cores were extensively subsampled. Each core was divided into 1 - $\mathrm{ft}$ segments and then subsampled as described above. Eh was measured on the core as it was subsampled; lithologic descriptions were also prepared.

Post-treatment water samples were collected from the lysimeters eight times during the days following the injection. Similarly, elevation benchmarks (S1 - S5) were surveyed six times during the eight days following the injection.

Another set of water samples was collected from the lysimeters on December 5, 1994, approximately three weeks after the injection. During the fourth week after injection, December 12 to 14, 1994, two additional soil borings (T4-K and T4-L) were cored and sampled. The subsampling performed was not as extensive as that performed during the first phase of post-treatment soil sampling and was limited to dividing cores into 1-ft segments, preparing a lithologic log, and shipping the cores to ORNL for analysis. An additional set of water samples was collected from the lysimeters in December 1994, February 1995 and May 1996. 


\subsubsection{T4 Soil Sample Results}

Post-treatment soil results for test cell 4 are summarized in Table 4.10 and data trend graphs are presented in Appendix C. Post-treatment $\mathrm{pH}$ values ranged from 4.5 to 12.6 (Fig. 4.17). Approximately one-half of these values are greater than the maximum value measured during pre-treatment sampling. The greatest increases over pre-treatment values occurred between 0 to $2 \mathrm{ft}$ and between 5 to $11 \mathrm{ft}$. Values for the 3 - to 5 - $\mathrm{ft}$ interval were near background levels. Generally, it appears that the MPIS was effective in distributing the lime slurry throughout the soil profile. Indeed, post-treatment soil moisture readings were higher than pre-treatment measurement for all depths, excluding the 7- to 8-ft interval.

Post-treatment calcium concentrations are shown in Fig. 4.18. Although depth-specific results are sporadic between boreholes, concentrations are generally higher than the pretreatment samples. This is particularly true for the 0- to 6-ft intervals, where dramatic increases were observed. The scattered nature of the results indicates flow of the slurry through existing preferential flow channels (e.g., fractures).

Soil surface elevation data show that the surface of the test cell was raised approximately 0.15 $\mathrm{ft}$ by the injection and remained near that elevation for approximately one month. An additional $0.10-\mathrm{ft}$ rise was observed during the last measurement period (three months after injection). Core samples from both pre-treatment and post-treatment borings were carefully logged, and visible pores and fractures were noted. Post-treatment logs indicated abundant lime in root pores and microfractures in the 0 - to 2 -ft interval. Some lime was seen in both vertical and horizontal fracture and bedding planes and in remnant root vesicles in the 4- to 8-ft interval.

\subsubsection{T4 Water Sample Results}

Post-treatment water sample results are presented in Table 4.11 and data trend graphs are presented in Appendix $\mathrm{C}$. The lime injection resulted in an immediate increase in the $\mathrm{pH}$ of the water in the two shallower lysimeters, T4L1 and T4L2 (Fig. 4.19). Increases from 7.8 to approximately 12.4 were observed, and $\mathrm{pH}$ remained fairly constant for 5 weeks, at which time values began decreasing. No increases in the $\mathrm{pH}$ of water samples from the deep lysimeter (T4L3) were observed. Alkalinity and conductivity values correlate well with the $\mathrm{pH}$ measurements, indicating that the short-term influence of the lime injection primarily

affected the 0 to 8 -ft interval. Alkalinity values in T4L1 and T4L2 increased by 700 to 1000 $\mathrm{mg} / \mathrm{L}$ following the injection and remained constant for approximately 4 weeks; however, a slight increase (approximately $200 \mathrm{mg} / \mathrm{L}$ ) was also observed in T4L3 (Fig. 4.20). A similar pattern was observed for conductivity measurements; however, the deeper lysimeter showed dramatic increases above background concentrations (Fig. 4.21). In fact, values for all three lysimeters more than doubled following the injection and remained elevated for approximately 
4 weeks. These data indicate that the calcium ions and the various carbonate species from the lime injection significantly affected the soil-pore water in test cell 4.

Post-treatment DO values ranged from approximately 2 to $12 \mathrm{mg} / \mathrm{L}$. No significant changes from background values were observed. Other analytes tested included $\mathrm{Fe}, \mathrm{Mn}, \mathrm{Cl}^{-}$, and $\mathrm{SO}_{4}{ }^{2-}$, but since there were no noticeable changes in concentration in the first few samples, analysis for these parameters was discontinued, and no evaluation of the limited data sets was deemed necessary.

\subsection{Test Cell 5: Potassium Permanganate}

\subsubsection{T5 Field Activities}

Five pre-treatment soil borings, T5-A through T5-E, were drilled and sampled on October 21 and 22, 1994. Lithologic logs were prepared, and soil samples were shipped to ORNL for analysis. One piezometer was installed at boring T5-D, and three lysimeters were nested in boring T5-C (Fig. 4.22). Three SMT probes were installed approximately $2 \mathrm{ft}$ east of the lysimeters. Water samples collected from the piezometer and lysimeters on November 1, 1994, were shipped to ORNL for analysis. Preparation for injection testing at test cell 5 began the morning of November 16, 1994. A set of water samples was collected from the lysimeters and piezometer, and elevation benchmarks were surveyed prior to the start of injection. A solution of $500 \mathrm{gal}$ of water and $100 \mathrm{~kg}$ of $\mathrm{KMnO}_{4}$ was mixed for injection $(5 \%$ $\mathrm{KMnO}_{4}$ by weight). The $\mathrm{KMnO}_{4}$ solution was injected on 2 -ft centers to a depth of $10.4 \mathrm{ft}$ starting at 1:40 p.m. The test cell injection was completed at 5:40 p.m.; thus, 240 min were required, with an average time for each injection setup of $6.7 \mathrm{~min}$. This time included stopping twice to mix more injection solution (approximately $45 \mathrm{~min}$ ).

The objective was to inject 2 gal per injector at each 15-in. depth interval or a total of 2,304 gal for the entire test cell. According to the flow meter at the pump, 2,223 gal were injected, and according to flow meters on the MPIS unit, 2,328 gal were injected. The estimated amount of solution lost to blowout at the ground surface was $400 \mathrm{gal}$. Thus, the amount of solution injected into the subsurface was estimated to be 1900 gal. One sample of each of five batches was collected during injection to evaluate the uniformity of the injected solution. The average injected solution was $4.2 \% \mathrm{KMnO}_{4}$ by weight. 


\begin{tabular}{|c|c|c|c|c|c|c|}
\hline $\begin{array}{c}\text { Test Cell } \\
\text { No. }\end{array}$ & $\begin{array}{c}\text { Total } \\
\text { solution } \\
\text { injected }\end{array}$ & $\begin{array}{l}\text { Target } \\
\text { solution } \\
\text { strength }\end{array}$ & $\begin{array}{l}\text { Average } \\
\text { actual } \\
\text { solution } \\
\text { strength }\end{array}$ & $\begin{array}{l}\text { Duration of } \\
\text { injection } \\
\text { testing }\end{array}$ & $\begin{array}{c}\text { Average } \\
\text { time per } \\
\text { setup }\end{array}$ & $\begin{array}{c}\text { Total } \\
\text { surface } \\
\text { seepage }\end{array}$ \\
\hline $\mathrm{T} 5$ & $2300 \mathrm{gal}$ & $5 \% \mathrm{KMnO}_{4}$ & $\begin{array}{c}4.2 \% \\
\mathrm{KMnO}_{4}\end{array}$ & $240 \mathrm{~min}$ & $6.7 \mathrm{~min}$ & $400 \mathrm{gal}$ \\
\hline
\end{tabular}

Soil resistance and temperature were measured before, during, and after the injection testing. Resistance measurements showed that the soil was near saturation at 8 and $14 \mathrm{ft}$ bgs prior to injection testing, but was not saturated at $4 \mathrm{ft}$ bgs. However, about $40 \mathrm{~min}$ after injection started, the backfilled soil around the subsurface probes was saturated with injected solution, and solution began to run out the top of the protective casing onto the ground surface. Soil temperature was monitored throughout the test and showed an increase of $2^{\circ} \mathrm{F}$ at $4 \mathrm{ft}$ bgs, $1^{\circ} \mathrm{F}$ at $8 \mathrm{ft} \mathrm{bgs}$, and no change at $14 \mathrm{ft}$ bgs. The $\mathrm{KMnO}_{4}$ reacted mildly upon injection, with only small amounts of gas produced; however, the fact that the soil-pore water samples were still dark purple 4 weeks later indicated that the reagent was persistent in the soil.

The first phase of post-treatment characterization began with the completion of five additional soil borings (T5-F through T5-J) to a depth of $12 \mathrm{ft}$ each. The borings were continuously sampled with 48-in.-long megabore samplers, and the resulting 1.5-in.-diameter soil cores were extensively subsampled as described in Sect. 4.2. Each core was divided into $1 \mathrm{ft}$ segments and then subsampled. Eh was measured on the core as it was subsampled; lithologic descriptions were also prepared.

Post-treatment water samples were collected from the lysimeters and piezometer 5 times during the 5 days following the injection. "Similarly, elevation benchmarks (S1, S2, S3 damaged, S4, and S5) were surveyed 4 times during the 5 days following the injection.

Another set of water samples was collected from the lysimeters and the piezometer on December 5, 1994, approximately 3 weeks after the injection. During the fourth week after injection, December 12 to 14,1994 , two additional soil borings (T5-K and T5-L) were cored and sampled. The on-site subsampling performed was not as extensive as that performed during the first phase of post-treatment soil sampling and was limited to preparing a lithologic $\log$ and segmenting the core for shipment to ORNL for analysis. An additional set of water samples was collected from the lysimeters and piezometer in December 1994, February 1995 and May 1996.

\subsubsection{T5 Soil Sample Results}

Post-treatment soil sample results are summarized in Table 4.12 and data trend graphs are presented in Appendix C. Soil sample results show a pH ranging from 4.3 to 7.8, with a trend 
of increasing $\mathrm{pH}$ values with depth. These values and trend are similar to the pre-treatment sample results; thus, no significant changes in $\mathrm{pH}$ were observed. Purple staining was noted in many of the soil extracts indicating that the $\mathrm{KMnO}_{4}$ had penetrated the soil. Core samples from the post-treatment borings showed purple staining in the upper 8 -in. of soil from surface infiltration. The deepest soil sample with purple-colored soil extract was the 8 to 9 -ft sample, and this condition was noted in three of the five borings. Purple-stained zones were observed on the soil cores at depths of 5 and $9 \mathrm{ft}$ bgs.

Compared to pre-treatment conditions, post-treatment soil moisture content increased slightly in the 0 - to 4-ft interval, decreased slightly in the 5- to 8-ft interval, and remained approximately the same in the 9- to 12-ft interval. Therefore, it appears that the bulk of the solution was injected in the top 4 to $5 \mathrm{ft}$ of the soil. This is also indicated by the posttreatment manganese concentrations measured (Fig. 4.23). Manganese concentrations at depths of 0 to $5 \mathrm{ft}$ bgs ranged from approximately 20 to $250 \mathrm{mg} / \mathrm{L}$ above background levels; however, no increases were observed in the 6- to 12-ft interval. Post-treatment Eh measurements ranged from 240 to $880 \mathrm{mV}$ (Fig. 4.24). Dramatic increases in Eh were observed throughout the soil profile, where readings were approximately double pretreatment measurements with the exception of the 0 - to $2-\mathrm{ft}$ interval. Thus, this treatment appeared to have the greatest effect on soil Eh.

Soil surface elevation data show that the surface of the test cell was raised approximately 0.1 $\mathrm{ft}$ by the injection and remained near that elevation through the last measurement period (three months after injection). Core samples from both pre-treatment and post-treatment borings were carefully logged and visible pores and fractures were noted. No differences were seen between the number and appearance of fractures before and after injection, excludirg the purple staining noted above.

\subsubsection{T5 Water Sample Results}

Post-treatment water sample results are presented in Table 4.13 and data trend graphs are presented in Appendix C. Manganese results ranged from background ( $<1 \mathrm{mg} / \mathrm{L})$ to approximately $18,000 \mathrm{mg} / \mathrm{L}$ (Fig. 4.25). The maximum concentration was detected the day after injection in the intermediate-depth lysimeter, T5L2 (8 ft bgs). Concentrations in T5L2 slowly dropped to near background levels over a 5-week period. Concentrations in the shallow lysimeter, T5L1, followed a similar trend; however, the maximum concentration was lower $(4,500 \mathrm{mg} / \mathrm{L})$. The initial field description of water collected from the lysimeters was "very purple" and "purple" respectively. A maximum concentration of $50 \mathrm{mg} / \mathrm{L}$ was detected in the deepest lysimeter, T5L3, the day after injection. The maximum concentration in the piezometer was $8 \mathrm{ppm}$. These results indicate that injection was effective in distributing the solution to the top $8 \mathrm{ft}$ of the test-cell soil. 
Post-treatment $\mathrm{pH}$ results ranged from approximately 6.0.to 8.1. Initial average values for individual lysimeters were similar to pre-treatment levels, excluding $\mathrm{T} 5 \mathrm{~L} 1$, where an average $0.5 \mathrm{pH}$ unit decrease was observed. The lowest value observed in T5L 1 occurred 5 days after injection. DO values were difficult to determine because the purple color of the water interfered with the colorimetric analysis. Due to intermittent data collection and questions regarding the validity of the measurements, no conclusions can be drawn from the DO data.

Electrical conductivity results were scattered; however, post-treatment results for $\mathrm{T} 5 \mathrm{~L} 1$ and T5L2 were generally higher than pre-treatment readings. No significant changes were observed in T5L3 or the piezometer. Post-treatment alkalinity values ranged from approximately 100 to $630 \mathrm{mg} / \mathrm{L}$. No pre-treatment alkalinity measurements were taken in test cell 5 ; thus, values were compared to samples taken from the background cell. Values for all depths at test cell 5 are approximately twice those from the background cell; however, this difference is likely a result of natural geochemical variation rather than an effect caused by the solution injection. Other analytes tested included $\mathrm{Fe}, \mathrm{Mn}, \mathrm{Cl}^{-}$, and $\mathrm{SO}_{4}{ }^{2-}$, but since there were no noticeable changes in concentration in the first few samples, analysis for these parameters was discontinued, and no evaluation of the limited data sets was deemed necessary.

\subsection{Test Cell 6: Air}

\subsubsection{T6 Field Activities}

Five pre-treatment soil borings, T6-A through T6-E, were drilled and sampled on October 21,1994 . Lithologic logs were prepared, and soil samples were shipped to ORNL for analysis. Three lysimeters were nested in boring T6-C (Fig. 4.26). Three SMT probes were installed approximately $2 \mathrm{ft}$ east of the lysimeters. Water samples collected from the lysimeters on November 1, 1994, were shipped to ORNL for analysis. Preparation for injection testing at test cell 6 began the morning of November 19, 1994. A set of water samples was collected from the lysimeters, and elevation benchmarks were surveyed prior to the start of injection. Air was injected with two injectors at four locations within the test cell to a depth of $10.4 \mathrm{ft}$ starting at $4: 10 \mathrm{p} . \mathrm{m}$. The test cell injection was completed at $4: 30 \mathrm{p} . \mathrm{m}$.; thus, $20 \mathrm{~min}$ were required, with an average time for each injection setup of $5 \mathrm{~min}$.

The objective was to inject air at each setup until air pressure reached at least 100 psi or until surface blowout was achieved. Three additional locations south of the test cell were penetrated with the injectors. However, no air was injected into these three holes since a gaseous-phase tracer study was planned at a later date to evaluate the extent of air-induced fracturing from the air injections performed within the test cell. All injector holes, including the three locations south of the test cell, were completed by placing 1/4-in.-diameter tubing in the holes and backfilling with sand and bentonite. 
The first phase of post-treatment characterization began with the collection of water samples from the lysimeters three times during the three days following the injection. Additional sets of water samples were collected from the lysimeters on December 5, 1994, approximately 3 weeks after the injection; on December 15, 1994, approximately 4 weeks after injection; on February 15, 1995, approximately 13 weeks after injection; and on May 7, 1996, approximately one and a half years after injection.

\subsubsection{T6 Soil Sample Results}

No post-treatment soil samples were collected from test cell 6 . Soil surface elevation data show no significant increases in elevation following the air injection.

\subsubsection{T6 Water Sample Results}

Post-treatment water sample results are presented in Table 4.14. Results for test cell 6 are limited due to poor sample recovery. However, little change was expected from the air injection. Because the upper lysimeter was consistently dry, only one sample was collected from T6L1. Results for $\mathrm{pH}, \mathrm{DO}$, and conductivity measurements are within the background range. Other analytes tested included $\mathrm{Fe}, \mathrm{Mn}, \mathrm{Cl}^{-}, \mathrm{NO}_{3}{ }^{-}$, and $\mathrm{SO}_{4}{ }_{4}^{2-}$, but since there were no noticeable changes in concentration in the first few samples, analysis for these parameters was discontinued, and no evaluation of the limited data sets was deemed necessary.

\subsection{Test Cell 7: Micropowder Iron}

\subsubsection{T7 Field Activities}

One pre-treatment soil boring, T7-A, was drilled and sampled on October 24, 1994. A lithologic log was prepared, and soil samples were shipped to ORNL for analysis. No piezometer was installed in this test cell; however, three lysimeters were nested in boring T7A (Fig. 4.27). Three SMT probes were installed approximately $2 \mathrm{ft}$ east of the lysimeters. Water samples collected from the lysimeters on November 1, 1994, were shipped to ORNL for analysis. Preparation for injection testing at Test Cell 7 began the morning of November 19,1994 , when a set of water samples was collected from the lysimeters. A solution of iron micropowder (approximately $20 \%$ by weight), water, and guar gum was injected on $2-\mathrm{ft}$ centers to a depth of $10.4 \mathrm{ft}$ at the $4 \mathrm{ft}$ by 8 - $\mathrm{ft}$ test cell. The injection started at $12: 40$ p.m. and was completed at 1:02 p.m.; thus, 22 min were required to perform 16 injections (four MPIS set-up locations with four injector locations per setup). The average time for each injection setup was $5.5 \mathrm{~min}$. 
The objective was to inject 2 gal per injector at each 15 -in. depth interval. With four injectors per set-up location and four positions for each injector, the target total for injection at each setup was 64 gal ( 4 injectors $\times 8$ positions $\times 2$ gal each), and the target for four set-up locations was $256 \mathrm{gal}$ ( 4 setups $\times 64$ gal each) for the entire test cell. According to the flow meter at the pump, 308 gal were injected. Because the flow meters on the MPIS unit were not working, no readings were obtained from them. The estimated amount of solution lost to the ground surface was $20 \mathrm{gal}$. Thus, the amount of solution injected into the subsurface was estimated to be 290 gal. The solution was mixed as a single batch of 500 gal of water with $400 \mathrm{lbs}$ of dry iron micropowder ( 5 um nominal particle size) and $25 \mathrm{lbs}$ of guar gum. The guar gum was added to keep the iron in suspension during injection. However, the tank required continuous stirring to prevent settling of the iron micropowder. The mixture was approximately $20 \%$ iron by weight.

\begin{tabular}{ccccccc}
\hline $\begin{array}{c}\text { Test Cell } \\
\text { No. }\end{array}$ & $\begin{array}{c}\text { Total solution } \\
\text { injected }\end{array}$ & $\begin{array}{c}\text { Target } \\
\text { solution } \\
\text { strength }\end{array}$ & $\begin{array}{c}\text { Average } \\
\text { actual } \\
\text { solution } \\
\text { strength }\end{array}$ & $\begin{array}{c}\text { Duration of } \\
\text { injection } \\
\text { testing }\end{array}$ & $\begin{array}{c}\text { Average } \\
\text { time per } \\
\text { setup }\end{array}$ & $\begin{array}{c}\text { Total surface } \\
\text { seepage }\end{array}$ \\
\hline $\mathrm{T} 7$ & $308 \mathrm{gal}$ & $20 \%$ iron & $\begin{array}{c}\text { not } \\
\text { determined }\end{array}$ & $22 \mathrm{~min}$ & $5.5 \mathrm{~min}$ & $20 \mathrm{gal}$ \\
\hline
\end{tabular}

Soil resistance and temperature were measured before, during, and after the injection testing. Resistance measurements showed that the soil was near saturation at $14 \mathrm{ft}$ bgs prior to injection testing, but was not saturated at 4 and $8 \mathrm{ft}$ bgs. However, soon after injection started, the backfilled soil around the subsurface probes was saturated with injected solution, and solution began to run out the top of the protective casing onto the ground surface. Soil temperature was monitored before and after the test and showed an increase of $2^{\circ} \mathrm{F}$ at $4 \mathrm{ft}$ bgs, $1^{\circ} \mathrm{F}$ at $8 \mathrm{ft} \mathrm{bgs,}$ and no change at $14 \mathrm{ft}$ bgs.

The first phase of post-treatment characterization began with the completion of two additional soil borings (T7-B through T7-C) to a depth of $12 \mathrm{ft}$ each. The borings were continuously sampled with 48-in.-long megabore samplers, and the resulting 1.5-in.-diameter soil cores were extensively subsampled. Each core was divided into 1 - $\mathrm{ft}$ segments and then subsampled as described in Sect 4.2. Eh was measured on the core as it was subsampled; lithologic descriptions were also prepared.

Post-treatment water samples were collected from the lysimeters twice during the 2 days following the injection. Similarly, the elevation benchmark was surveyed two times during the 2 days following the injection. Another set of water samples was collected from the lysimeters on December 5, 1994, approximately 2 weeks after the injection. During the third week after injection, December 12 to 14,1994 , two additional soil borings (T7-D and T7-E) were cored and sampled. The on-site subsampling performed was not as extensive as that 
performed during the first phase of post-treatment soil sampling and was limited to dividing cores into 1-ft segments, preparing a lithologic log, and shipping the cores to ORNL for analysis. An additional set of water samples was collected from the lysimeters in December 1994, February 1995 and May 1996.

\subsubsection{T7 Soil Sample Results}

Post-treatment soil samples are summarized in Table 4.15 and data trend graphs are presented in Appendix C. Samples were analyzed for $\mathrm{pH}$, Eh, and iron. The $\mathrm{pH}$ ranged from 5.2 to 7.1, with a trend of increasing values with depth. These values are within the background range of samples collected from the site. Post-treatment Eh values ranged from 135 to $420 \mathrm{mV}$, increasing to a maximum at 2 to $3 \mathrm{ft}$ bgs and then steadily decreasing with depth. These values and trend are consistent with sample data from the background cell.

Soil iron results showed concentrations ranging from less than $1 \mathrm{ppm}$ to over $30 \mathrm{ppm}$. No pre-treatment samples were analyzed for iron; thus, a direct comparison cannot be made. Also, analytical results cannot be compared to a regional background range of values due to differences in the analysis methods (water extraction vs acid digestion). However, based on a relative comparison of the post-treatment data collected from test cell 7 , substantial increases in iron were observed at the 1 to 3 -ft interval and the 4 to 5 - $\mathrm{ft}$ interval of borehole C. The particle size of the micropowder iron was approximately $5 \mu \mathrm{m}$ and was suspended with the guar gum.

Soil surface elevation data show that the surface of the test cell was raised approximately 0.1 $\mathrm{ft}$ by the injection, and remained near that elevation through the last measurement period ( 3 months after injection). Core samples from both pre-treatment and post-treatment borings were carefully logged, and visible pores and fractures were noted. Guar gum was observed in fractures and voids at 1 to $3 \mathrm{ft}$ bgs and at 6 to $7 \mathrm{ft} \mathrm{bgs}$.

\subsubsection{T7 Water Sample Results}

Post-treatment water sample results are presented in Table 4.16 and data trend graphs are presented in Appendix C. Post-treatment iron concentrations in test cell 7 ranged from 0.1 to over $30 \mathrm{ppm}$ (Fig. 4.28). Two samples from the test cell (December 15 samples from T7L1 and T7L2) were recorded as "over range" by the analysis method. The upper limit of detection for the analysis was approximately $30 \mathrm{ppm}$. These points are graphed as $30 \mathrm{ppm}$ on Fig. 4.28. Background concentrations of iron in water, based on analyses from other test cells, ranged from 0.1 to $1.2 \mathrm{ppm}$. Therefore, iron levels above this range are considered significant. No effects were observed in lysimeter samples collected immediately after the injection (days 1 through 3); however, dramatic increases were observed in T7L1 and T7L2 
approximately 2 weeks later. This evidence suggests that some of the injected iron was reduced to soluble $\mathrm{Fe}^{+2}$ between sampling periods. Iron levels in these lysimeters began to drop after approximately 4 weeks. Concentrations in the deep lysimeter, T7L3, steadily increased to a maximum of $1.8 \mathrm{ppm}$ at the last sampling period. This was possibly the result of percolation from the upper soil zone.

Post-treatment $\mathrm{pH}$ values from lysimeter samples ranged from 6.2 to 8.8 . There is a trend of decreasing $\mathrm{pH}$ in the upper lysimeters, T7L 1 and T7L2, following the injection period. This correlates with the reduction of iron discussed above. Hydrogen ions, produced as a result of iron reduction, would effect a decrease in $\mathrm{pH}$. Measurements in T7L3 were sporadic; however, there is no clear trend with respect to $\mathrm{pH}$.

DO values are scattered, and no significant changes are indicated when compared to background measurements. It appears that DO increased and then decreased after the injection. However, this is attributed to variation in the field measurements observed at all test cells. Conductivity values ranged from approximately 600 to $4400 \mu$ mhos. Conductivity from the deepest lysimeter, T7L3, appears to have increased over background levels; however, no significant changes were observed in T7L1 and T7L2. Other analytes tested included alkalinity, $\mathrm{Mn}, \mathrm{Cl}^{-}, \mathrm{NO}_{3}^{-}$, and $\mathrm{SO}_{4}{ }^{-}$, but since there were no noticeable changes in concentration in the first few samples, analysis for these parameters was discontinued, and no evaluation of the limited data sets was deemed necessary. 


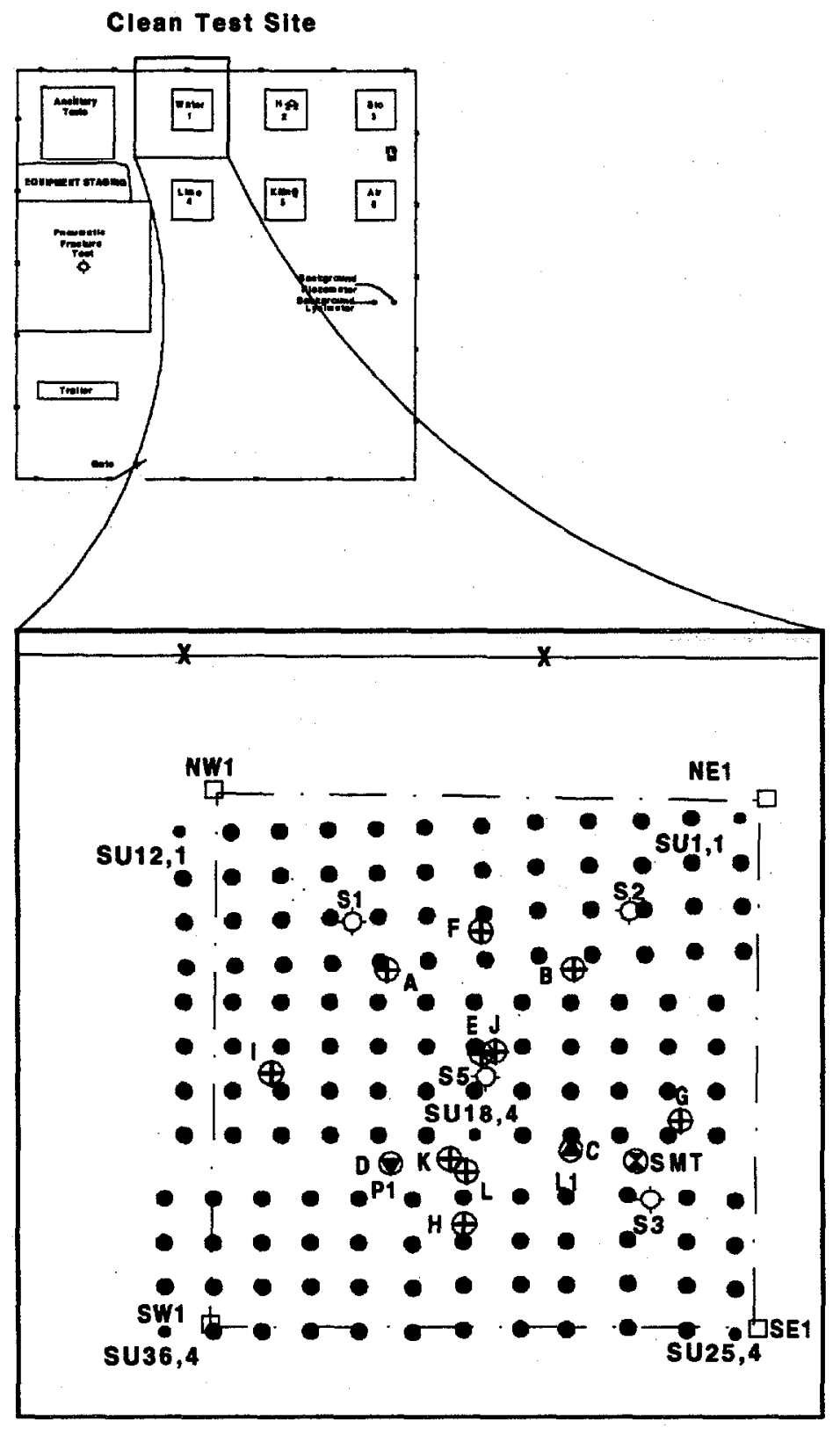

n:lportelprm os6.dwg

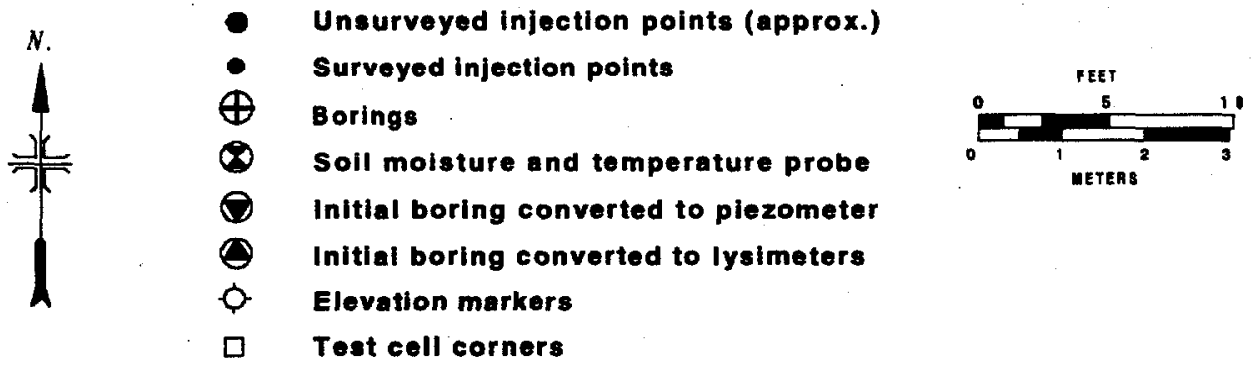

Fig. 4.1. Test cell 1 sample locations. 


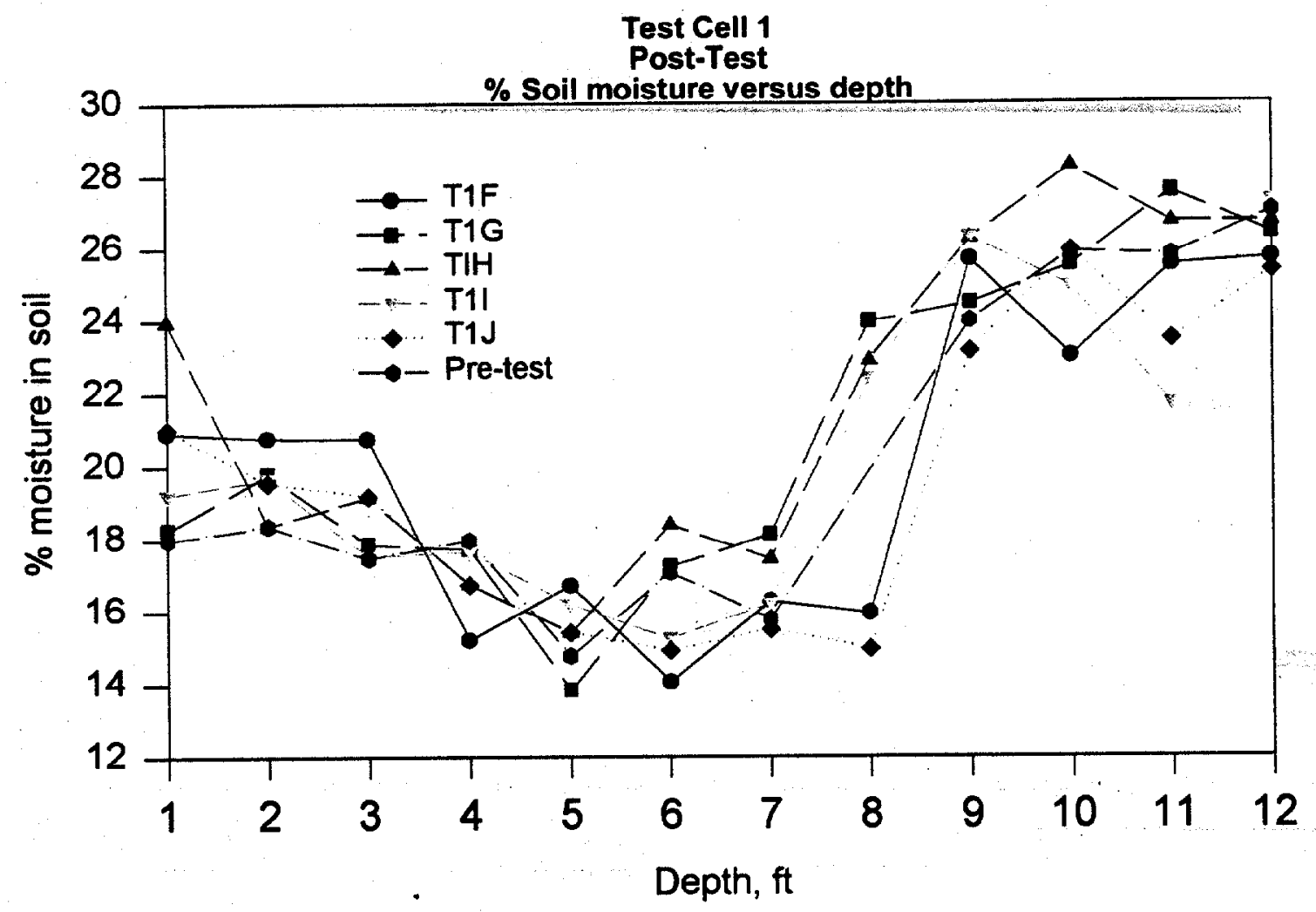

Fig. 4.2. Test cell 1 - post-treatment soil moisture content.

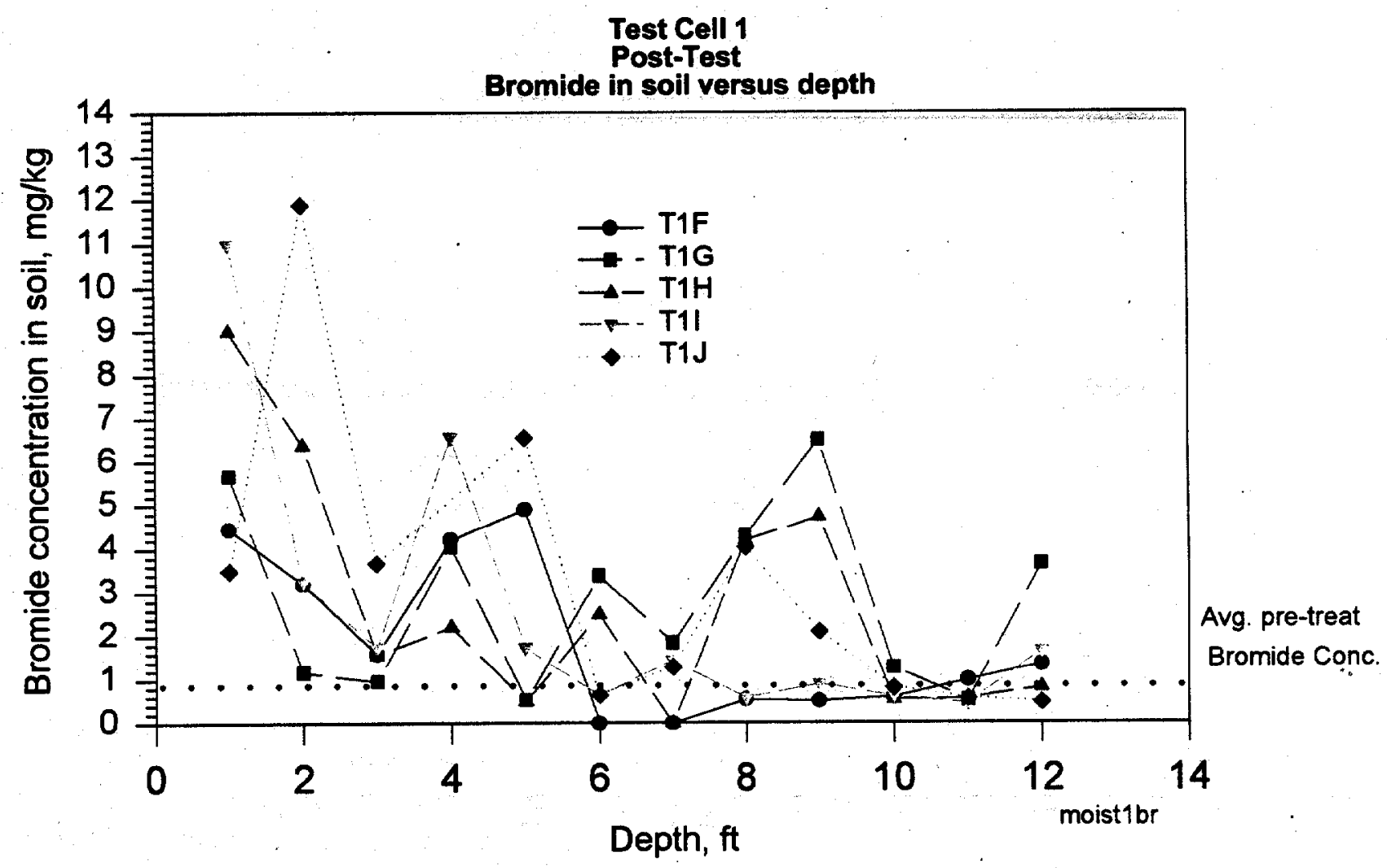

Fig. 4.3. Test cell 1 - post-treatment soil bromide levels. 


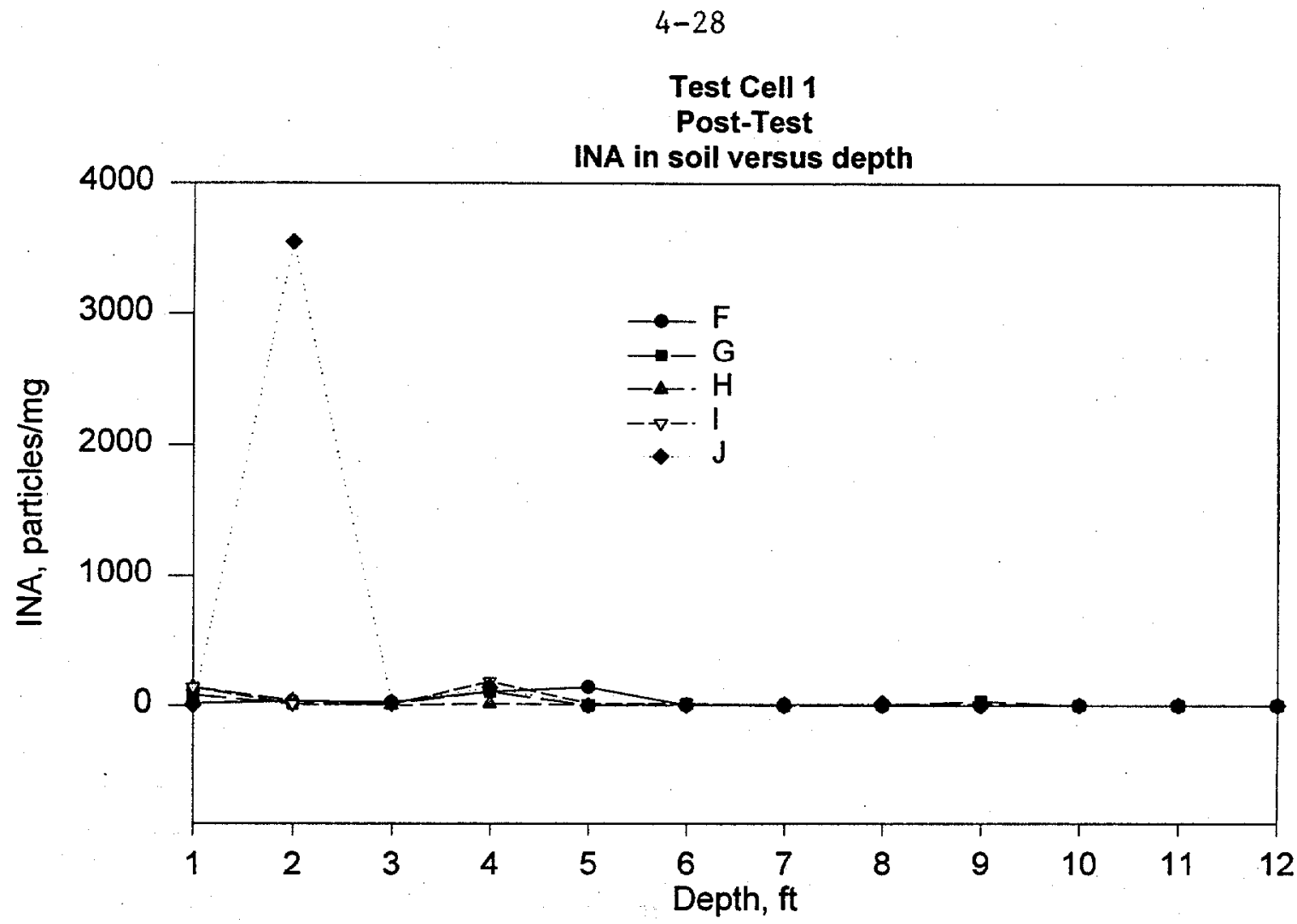

Fig. 4.4. Test cell 1 - post-treatment soil INA levels.

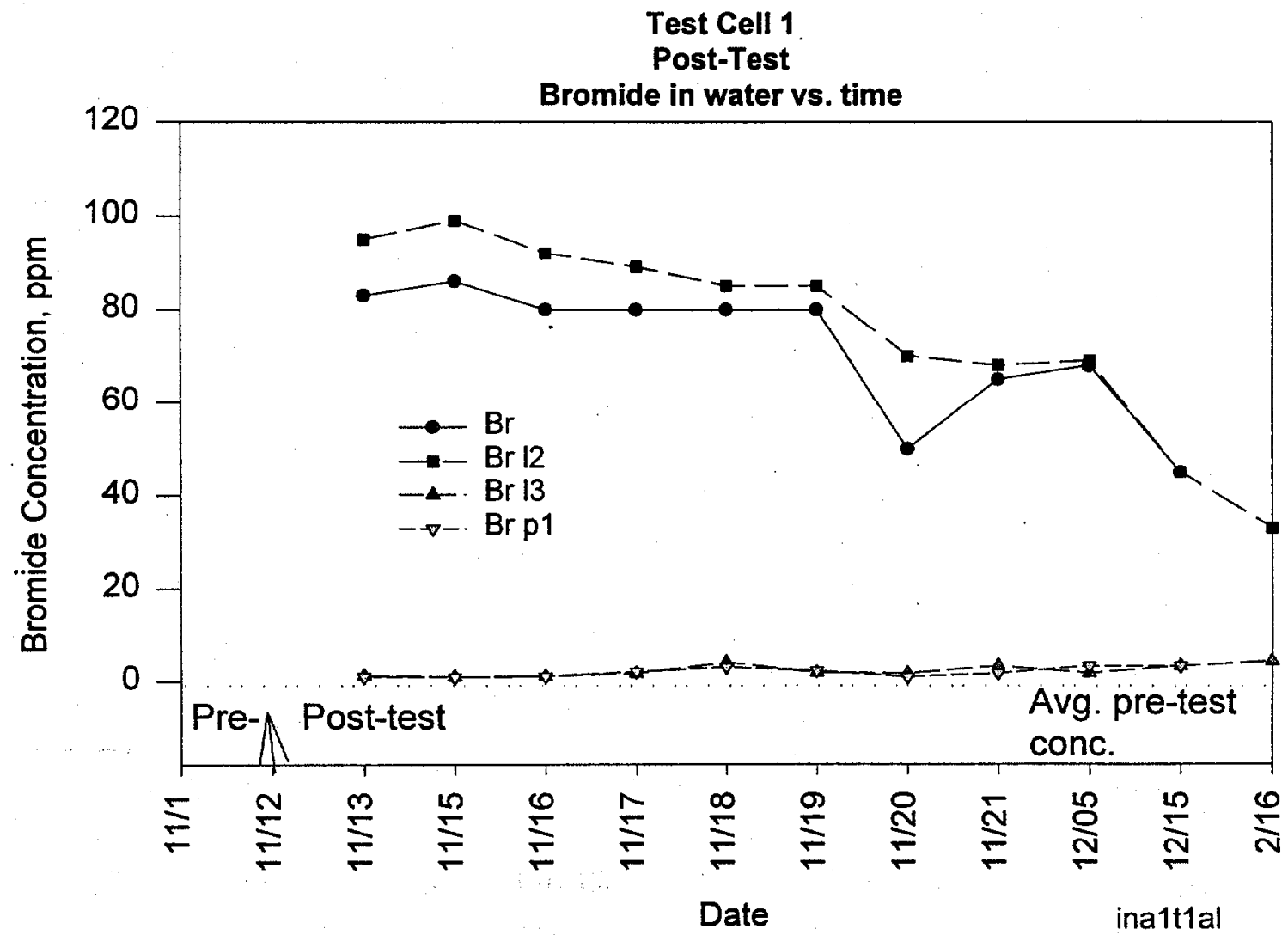

Fig. 4.5. Test cel1 1 - post-treatment water bromide levels. 

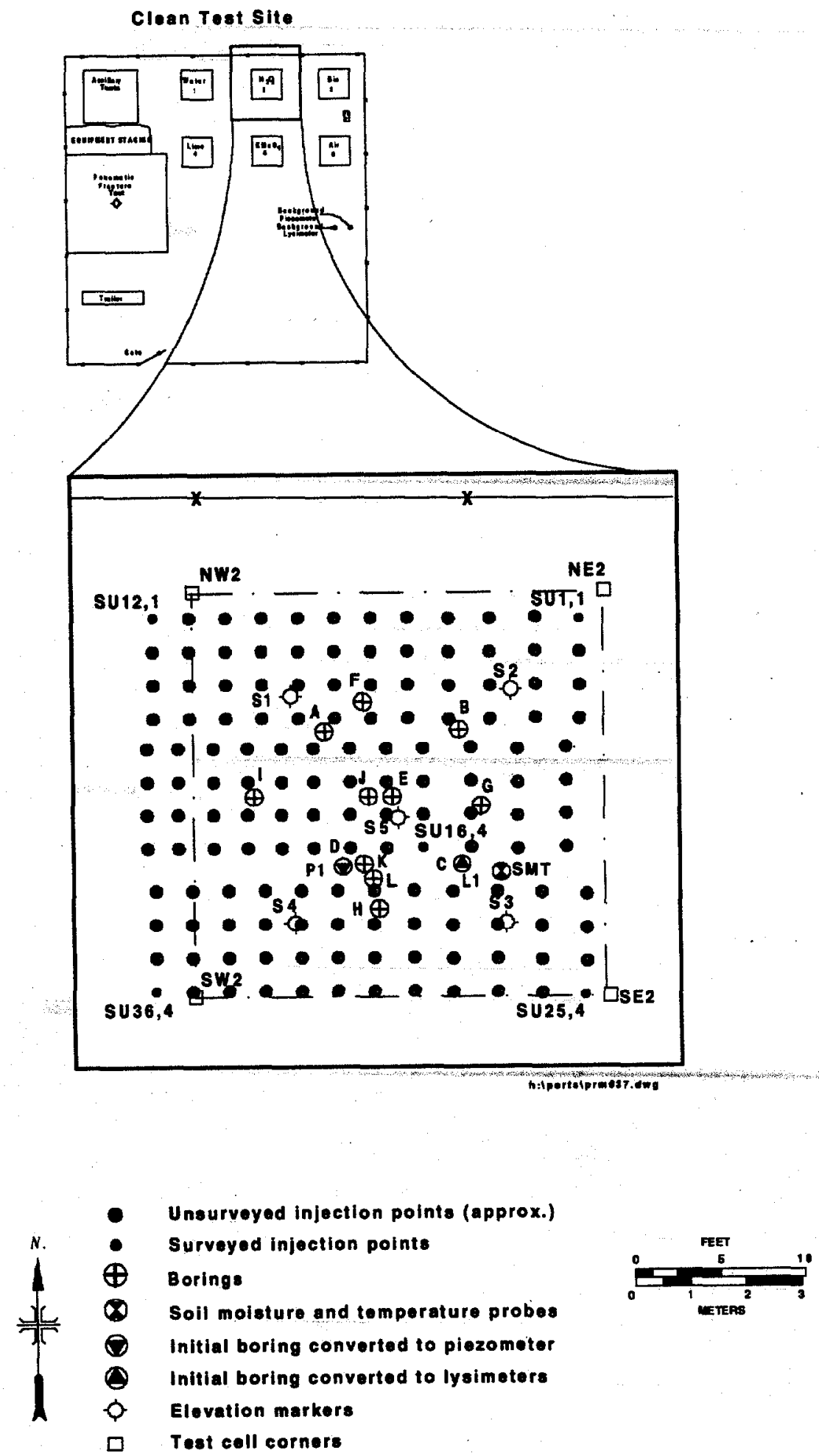

Fig. 4.6. Test cell 2 sample locations. 


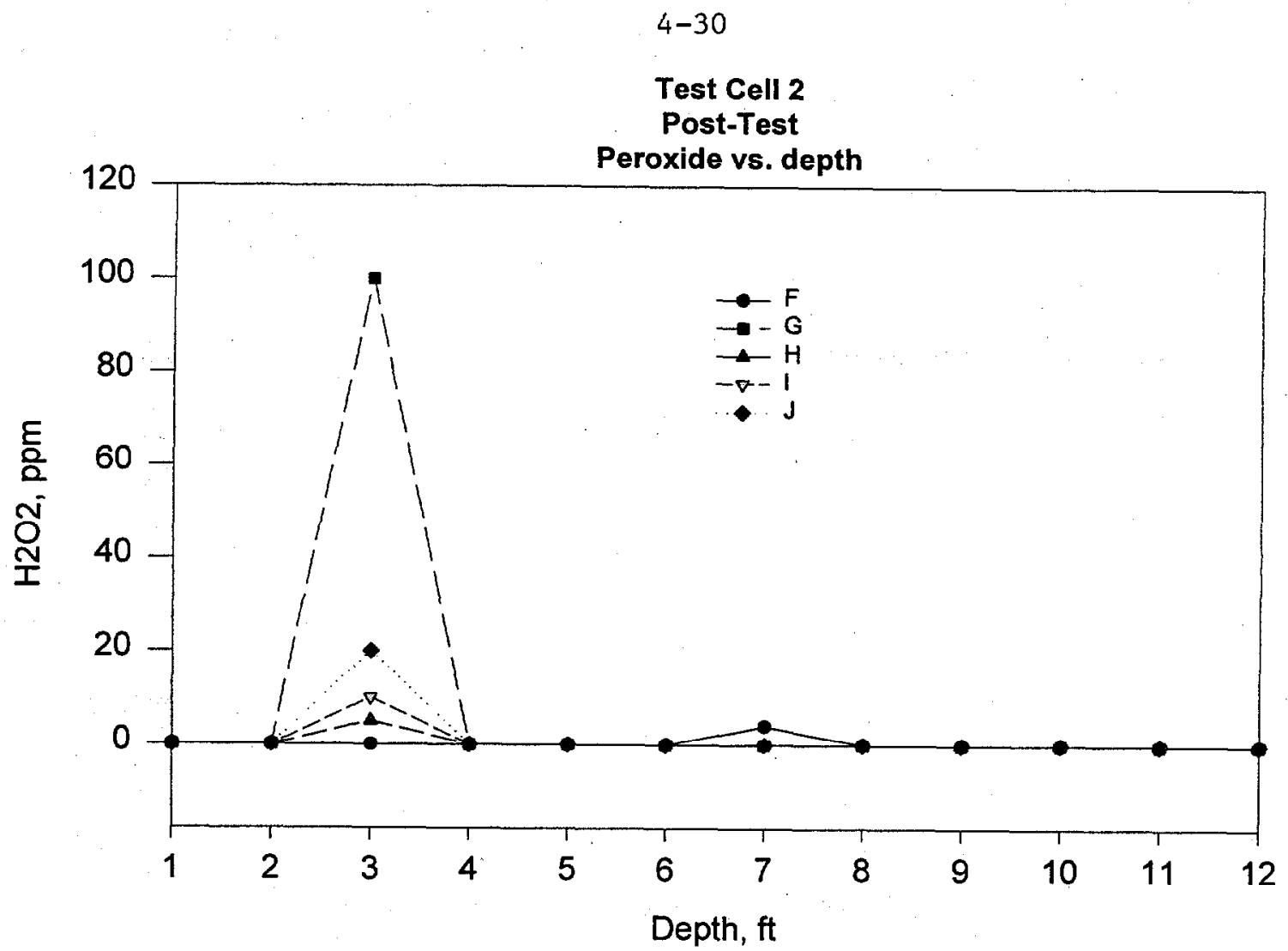

Fig. 4.7. Test cell 2 - post-treatment soil peroxide levels.

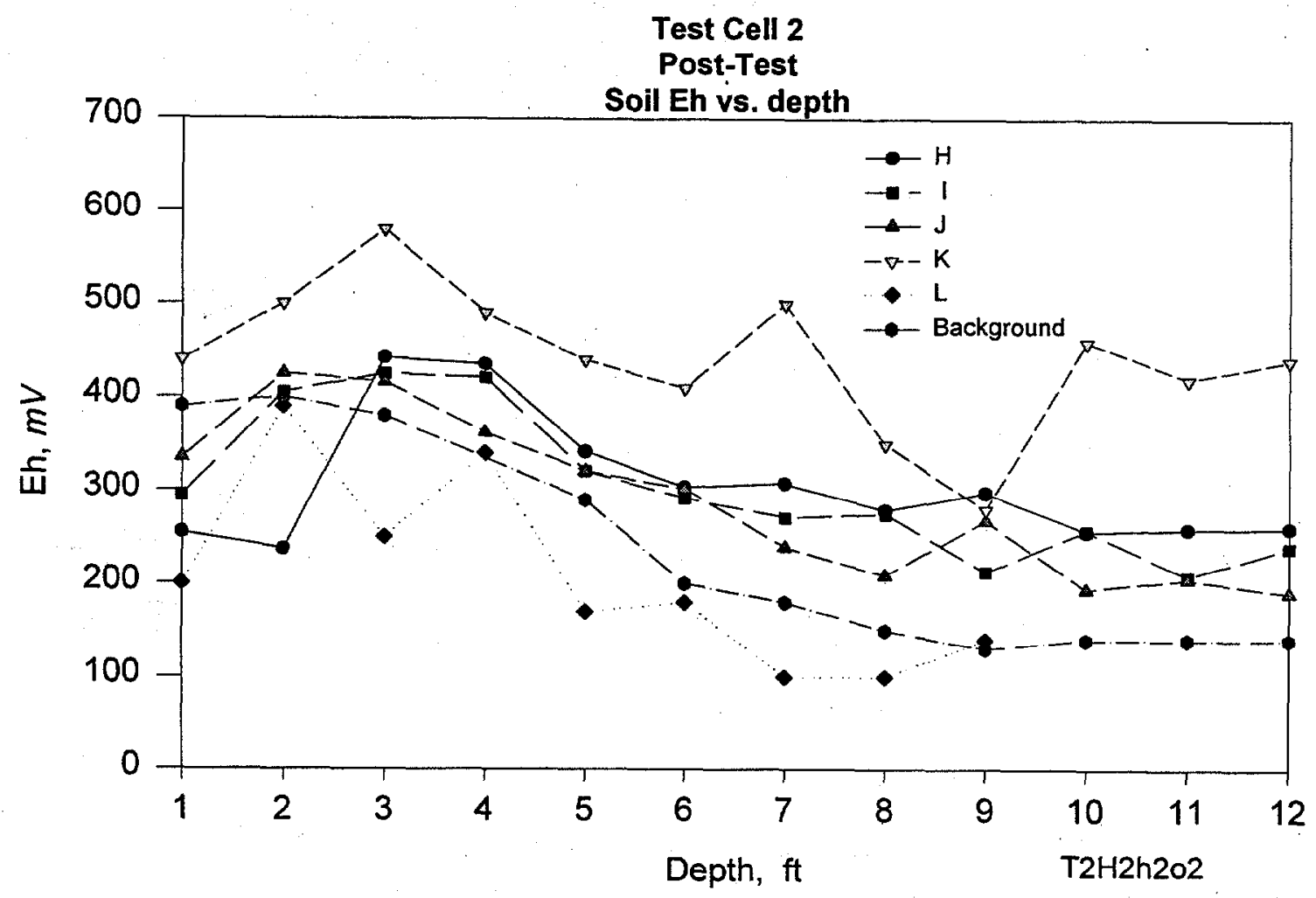

Fig. 4.8. Test cell 2 - post-treatment soil Eh data. 
Test Cell 2

Post-Test

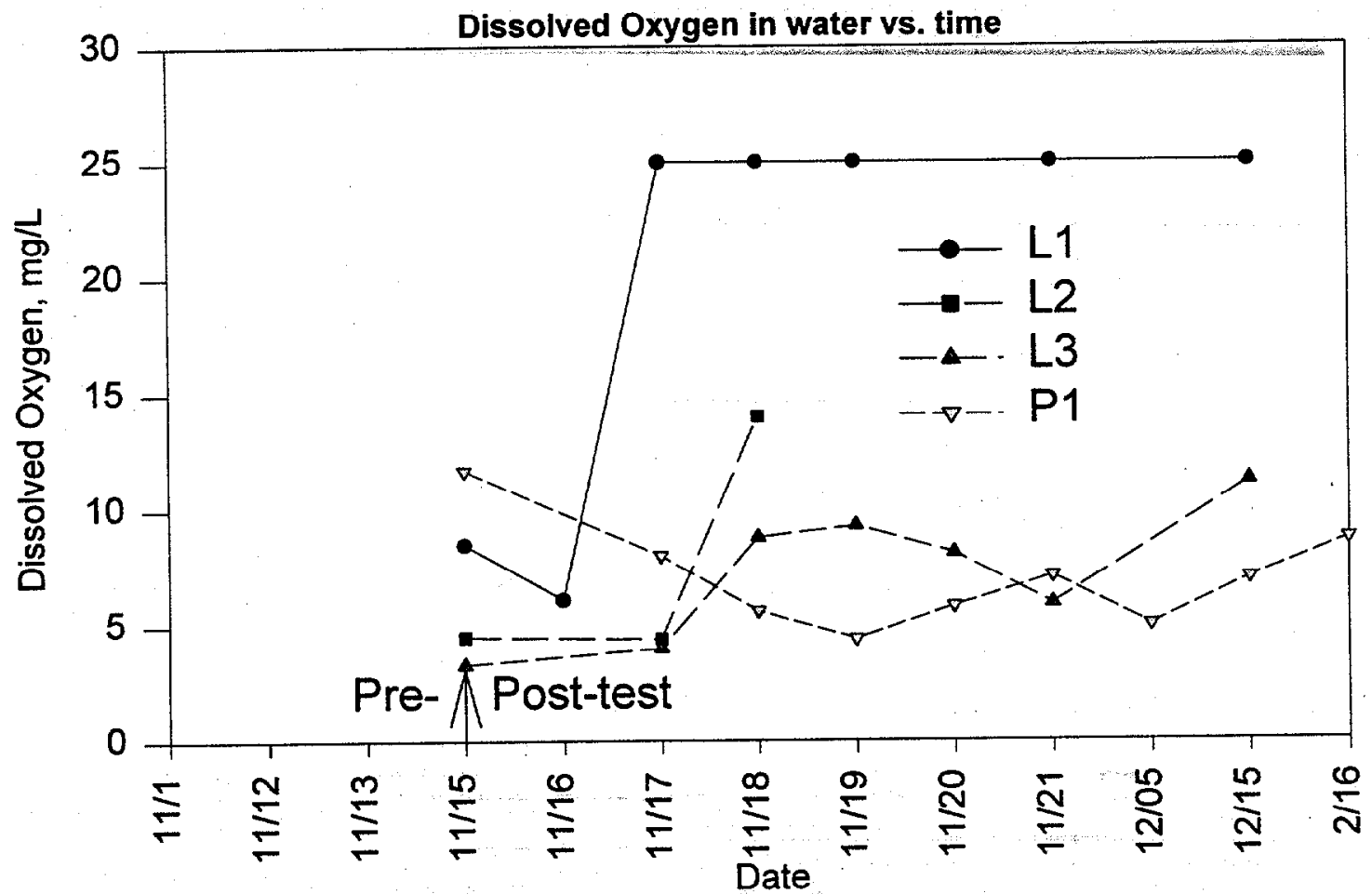

Fig. 4.9. Test cel1 2 - post-treatment water Do levels.

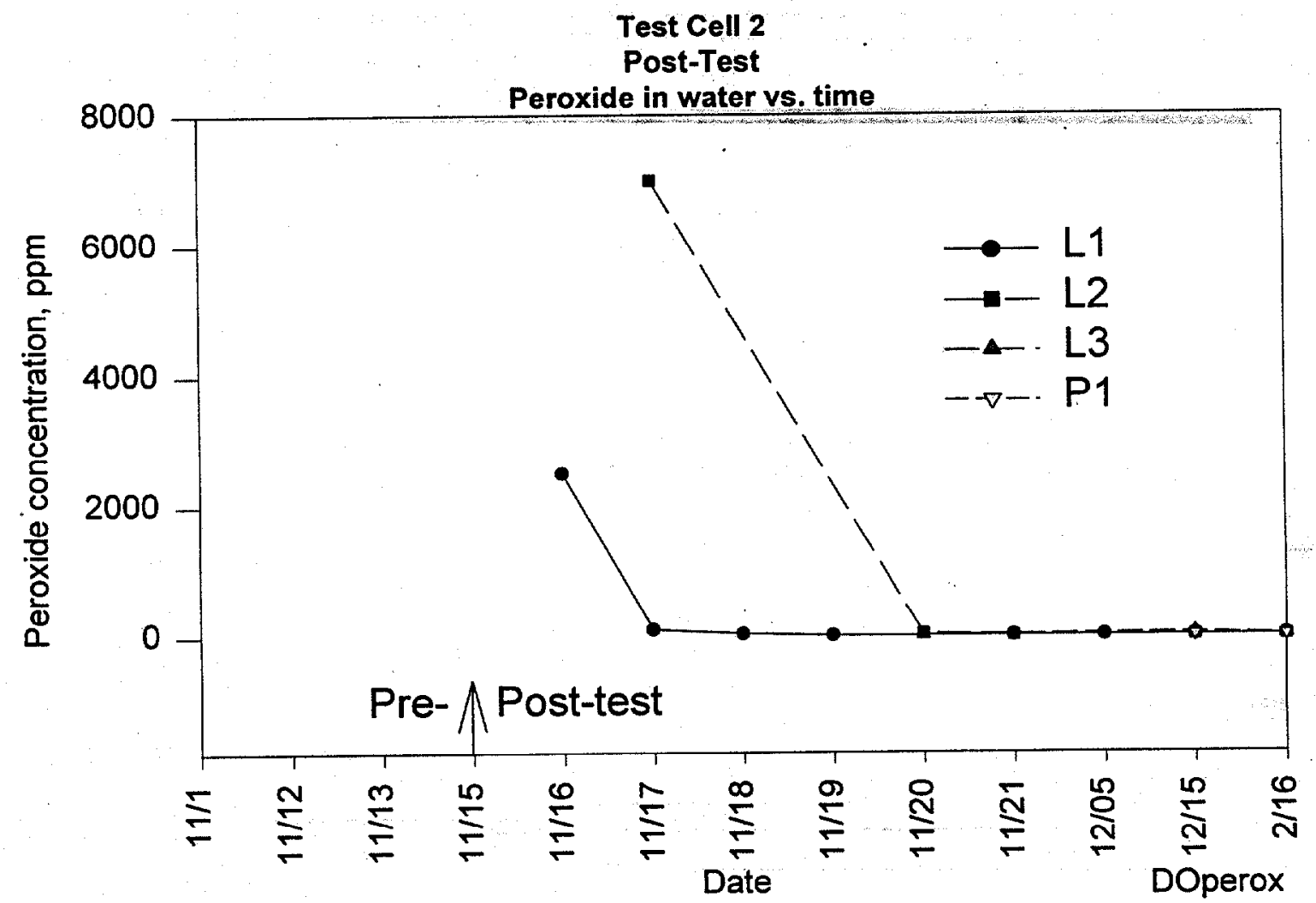

Fig. 4.10. Test cell 2 - post-treatment water peroxide levels. 

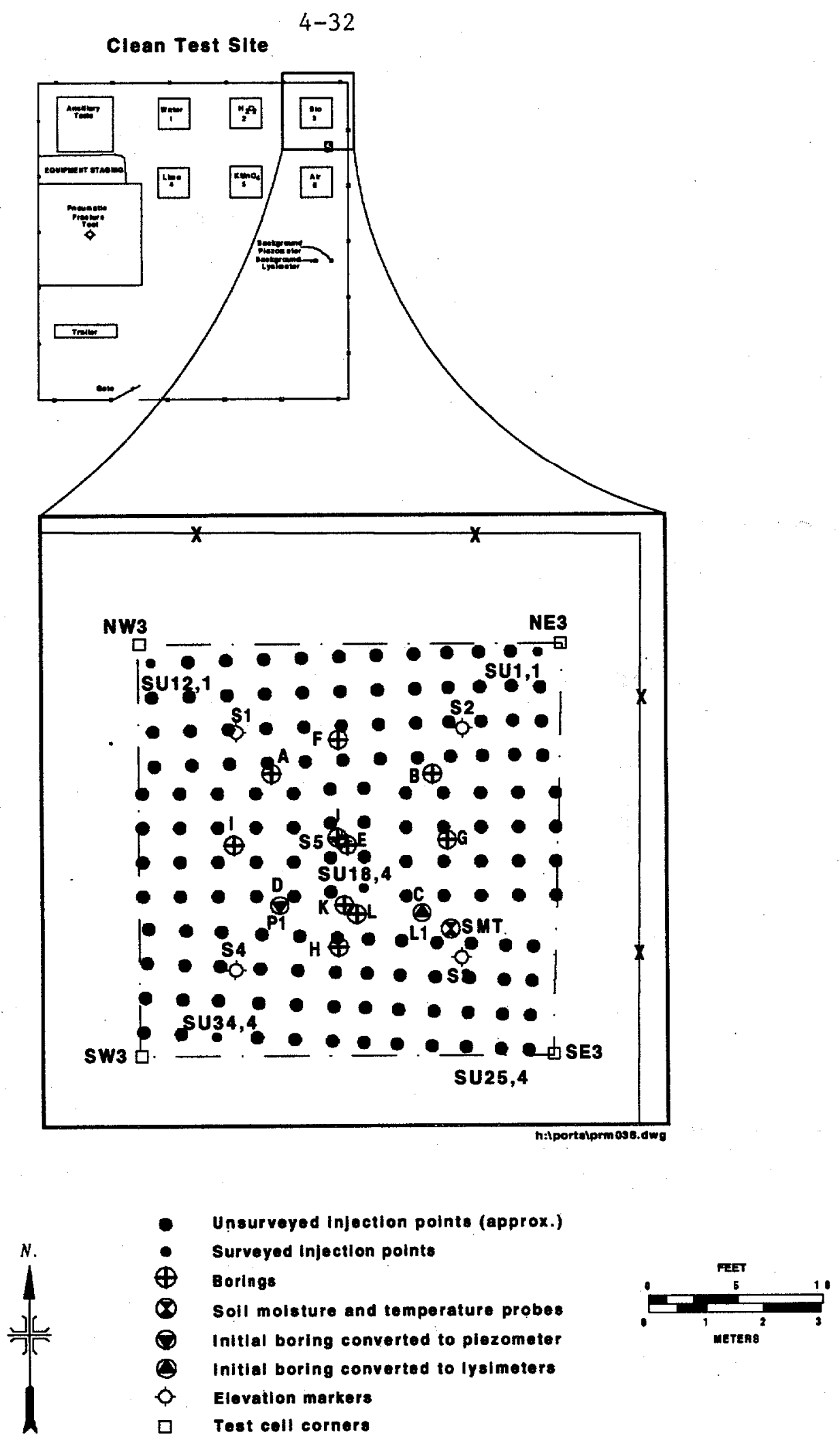

Fig. 4.11. Test cell 3 sample locations. 


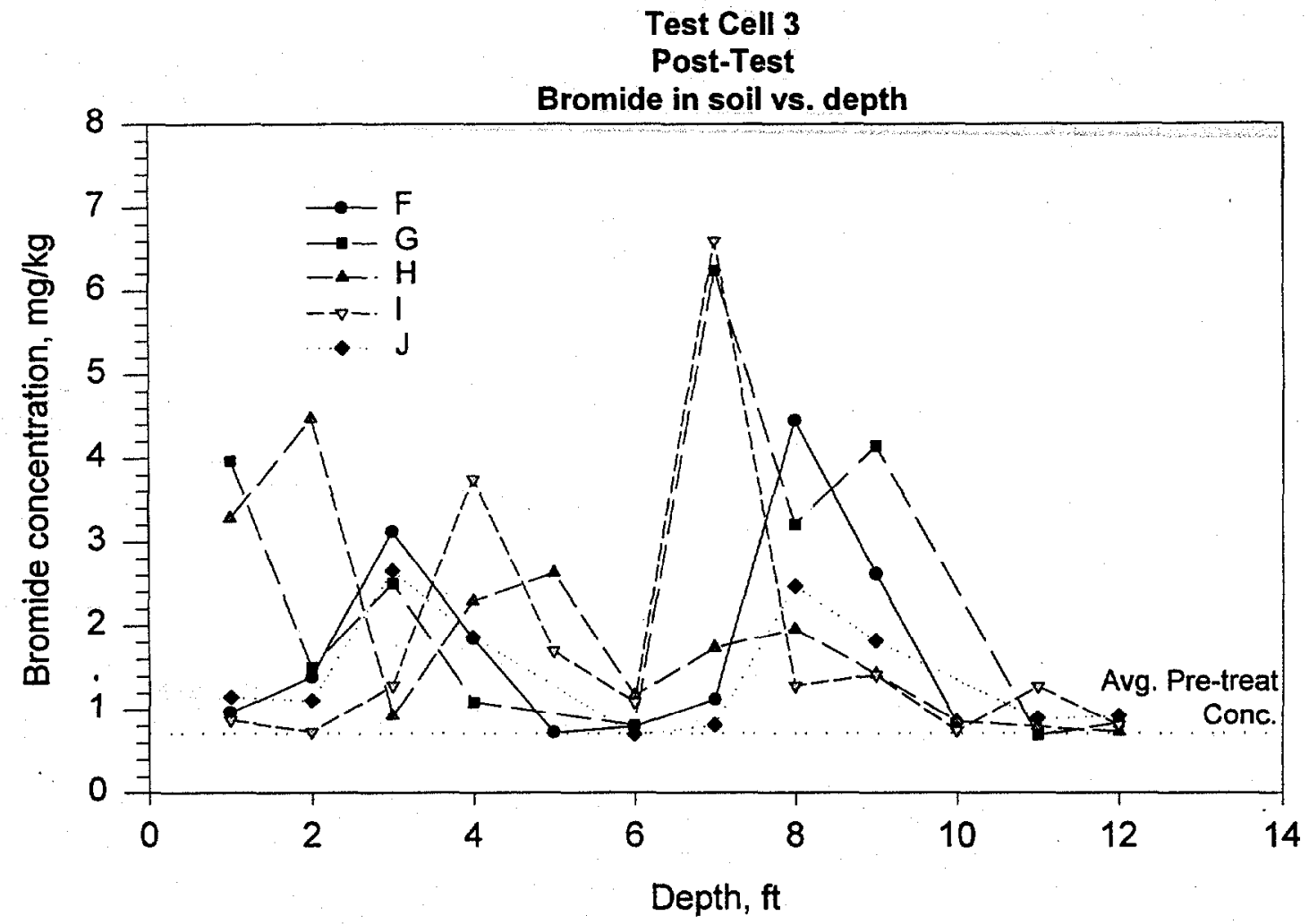

Fig. 4.12. Test cel1 3 - post-treatment soil bromide levels.

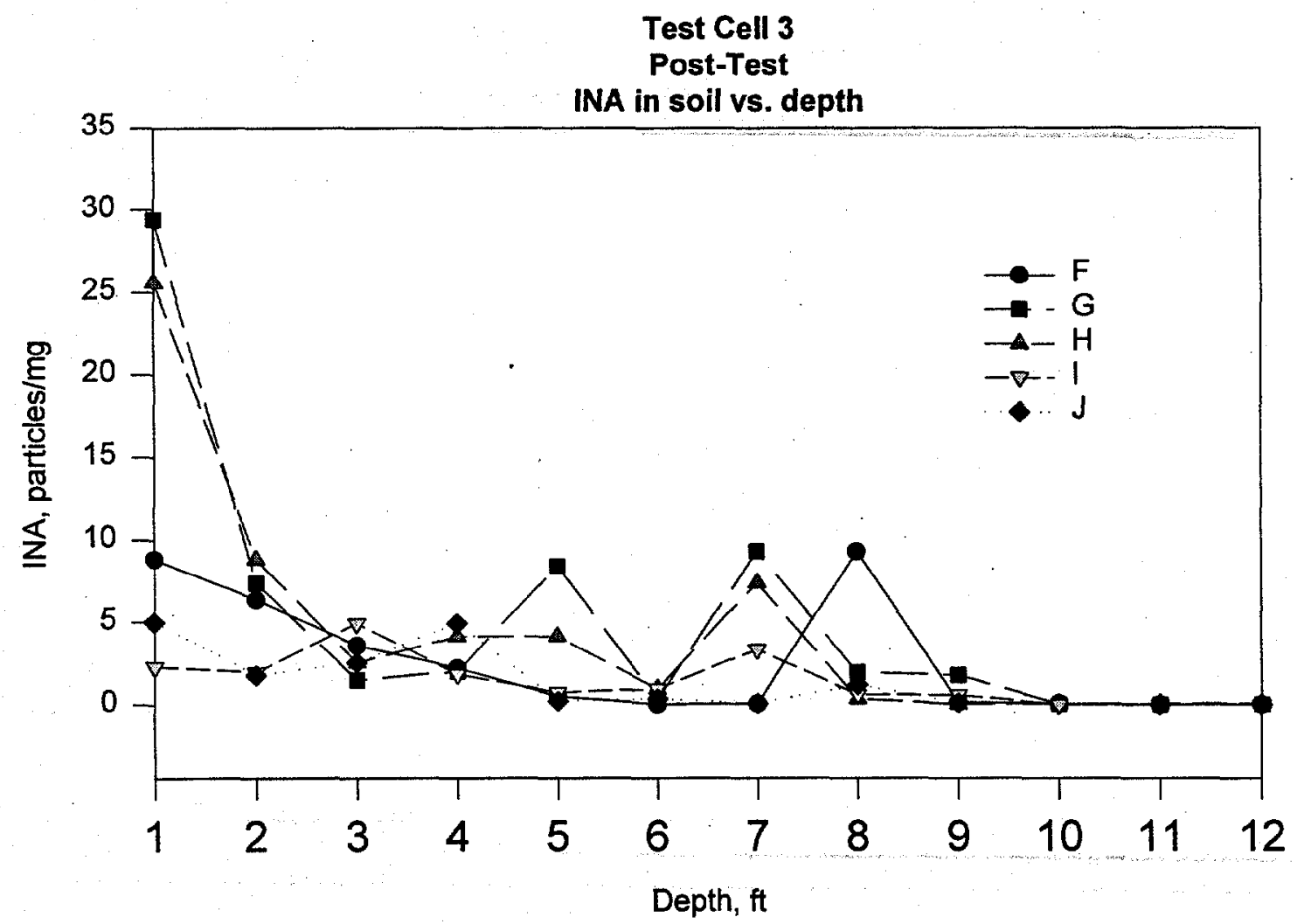

T3BRina3.SPW

Fig. 4.13. Test cell 3 -post-treatment soil INA levels. 
Test Cell 3

Post-Test

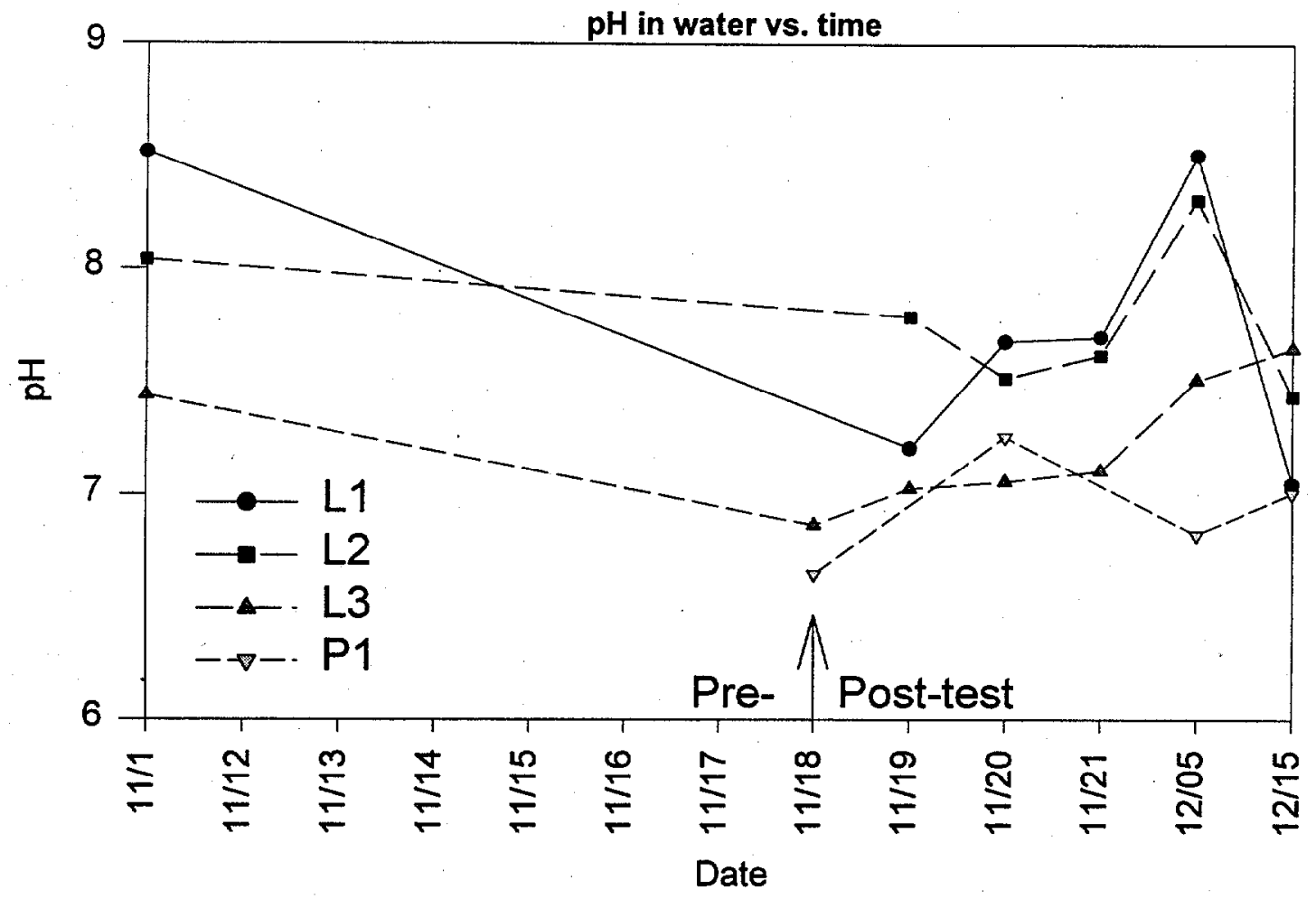

Fig. 4.14. Test cell 3 - post-treatment water pH.

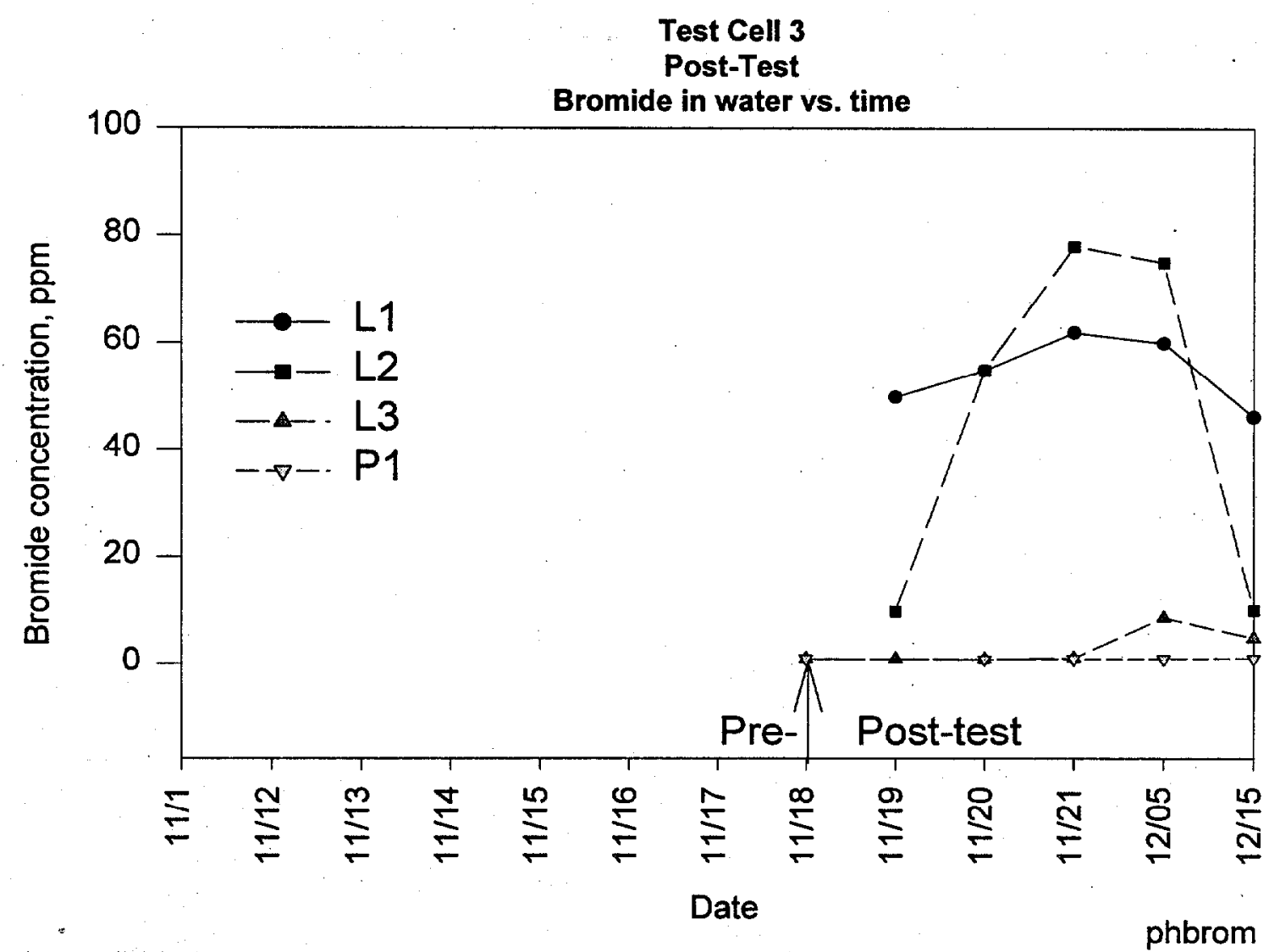

Fig. 4.15. Test cell 3 - post-treatment water bromide data. 


$$
\text { 4-35 }
$$

Clean Test SIte
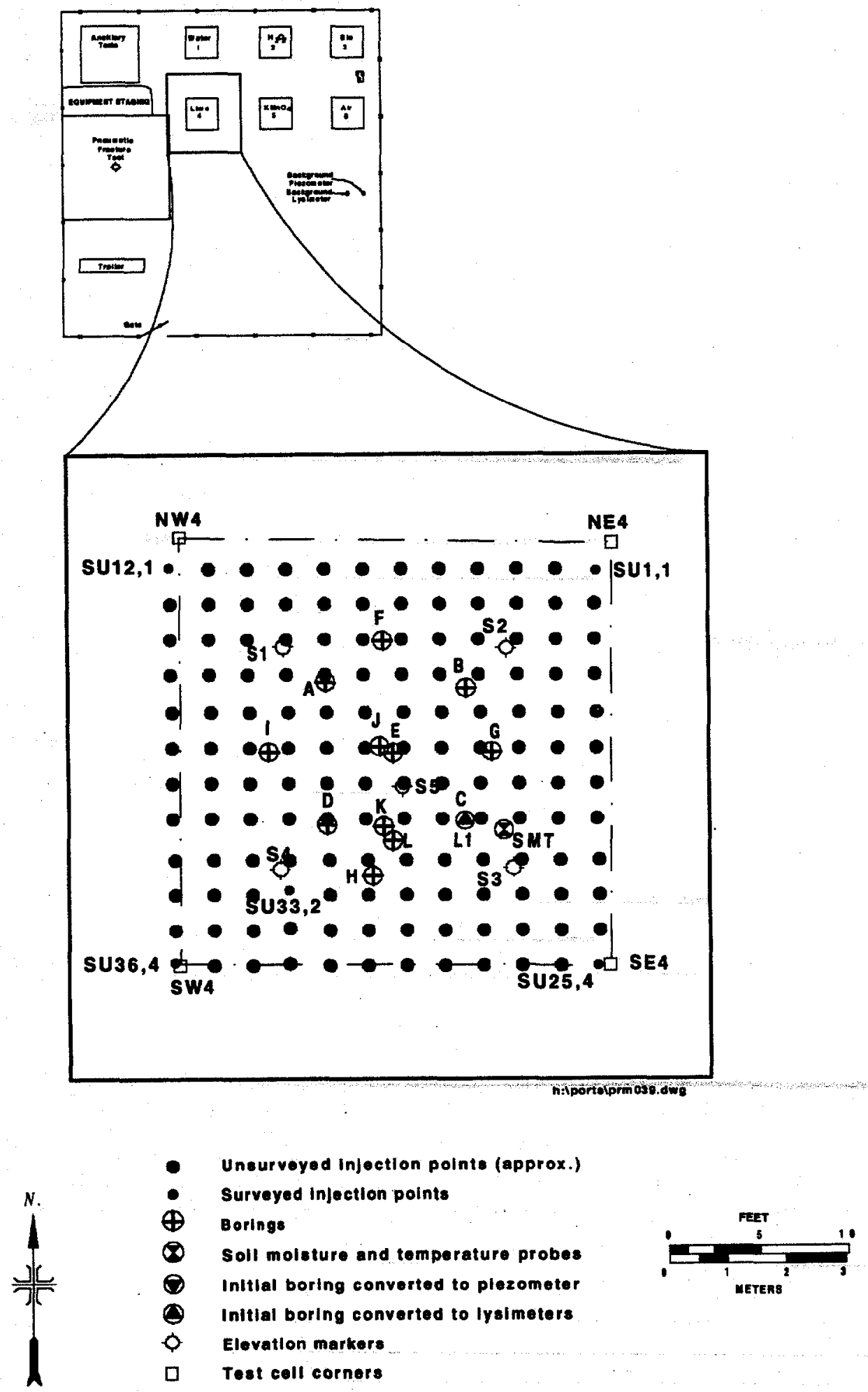

Fig. 4.16. Test cell 4 sample locations. 


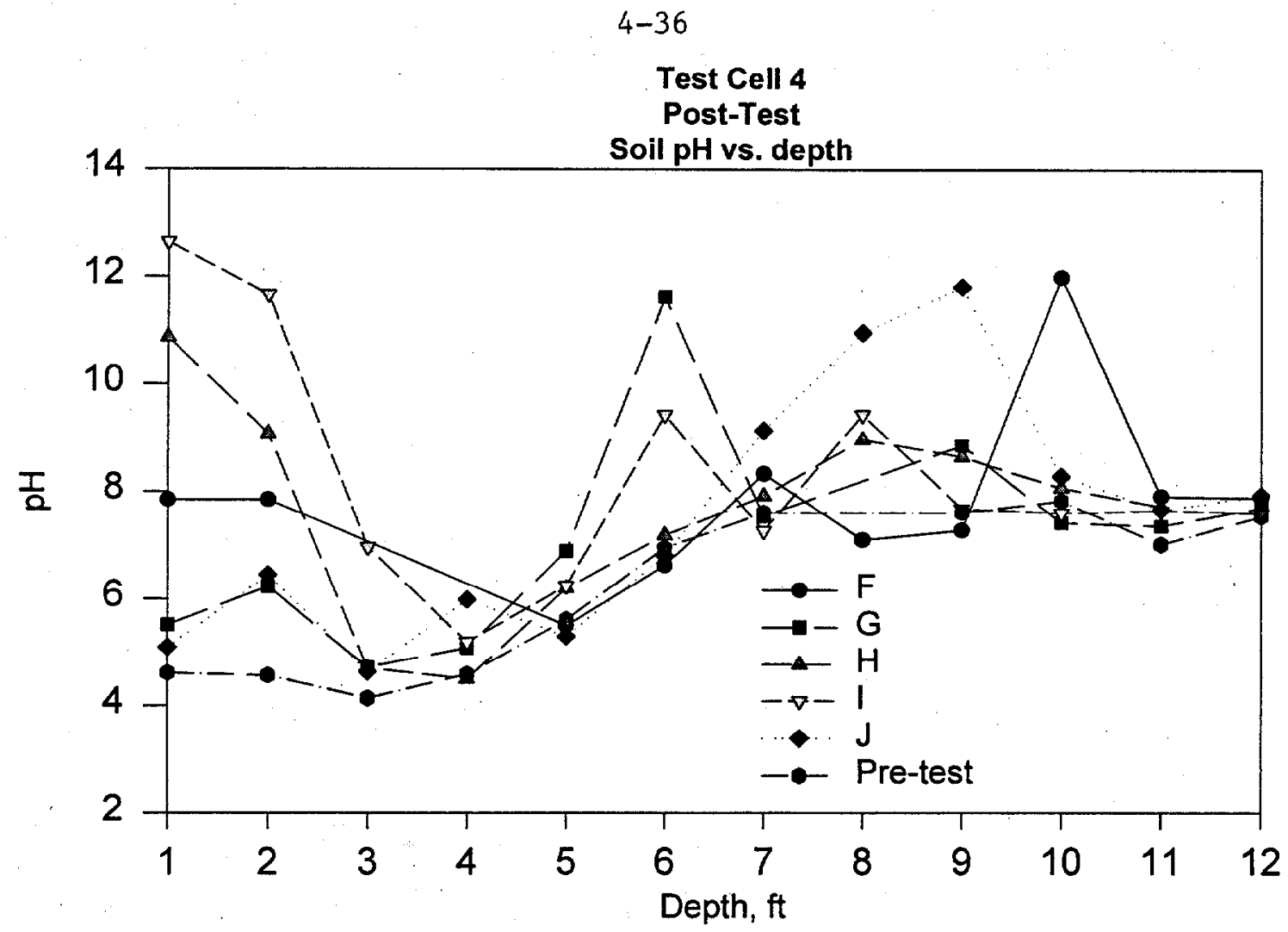

Fig. 4.17. Test cell 4 - post-treatment soil pH.

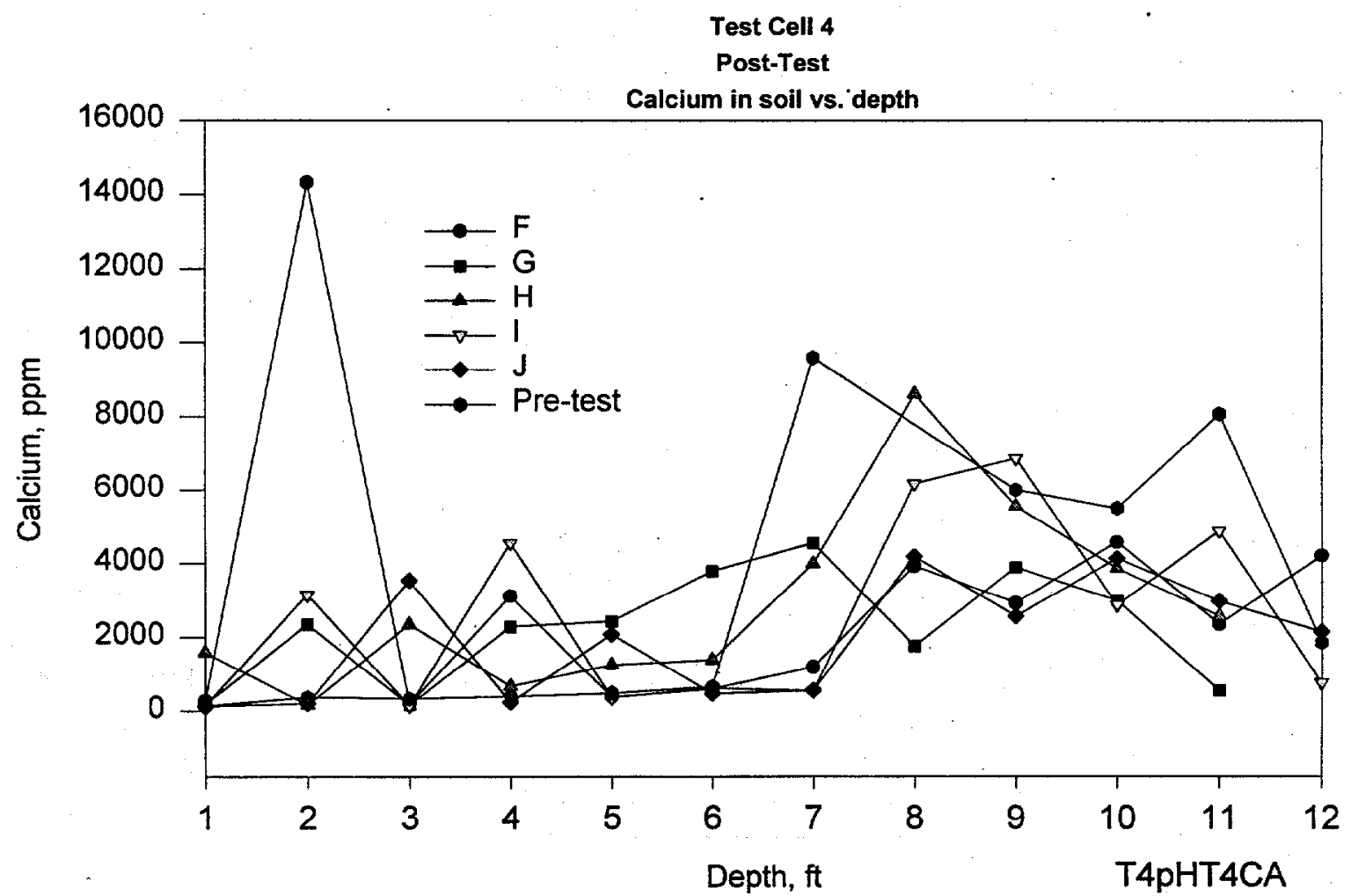

Fig. 4.18. Test cel1 4 - post-treatment soil calcium leve1s. 
Test Cell 4

Post-Test

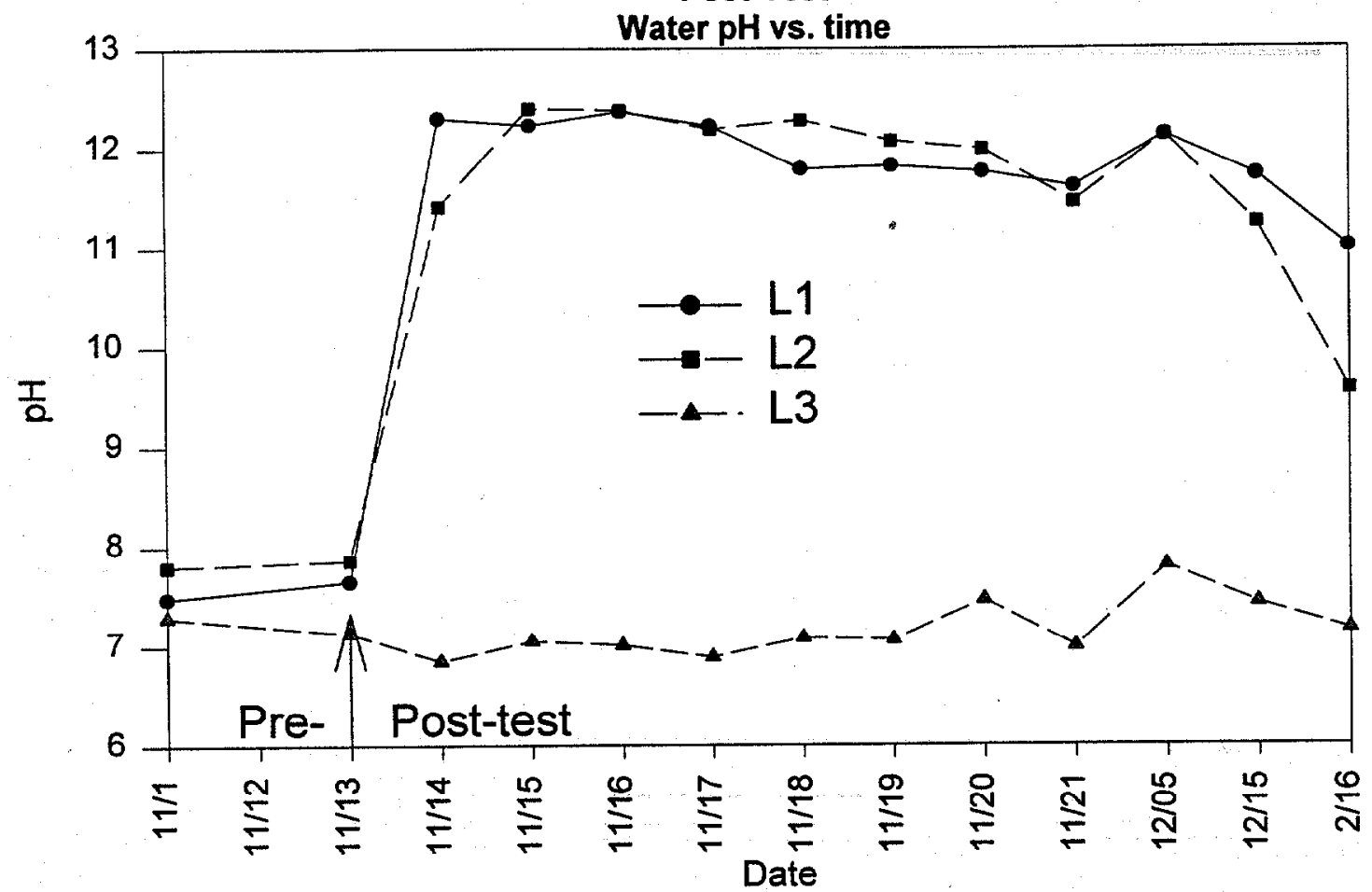

Fig. 4.19. Test cel1 4 - post-treatment water $\mathrm{pH}$.

Test Cell 4

Post-Test

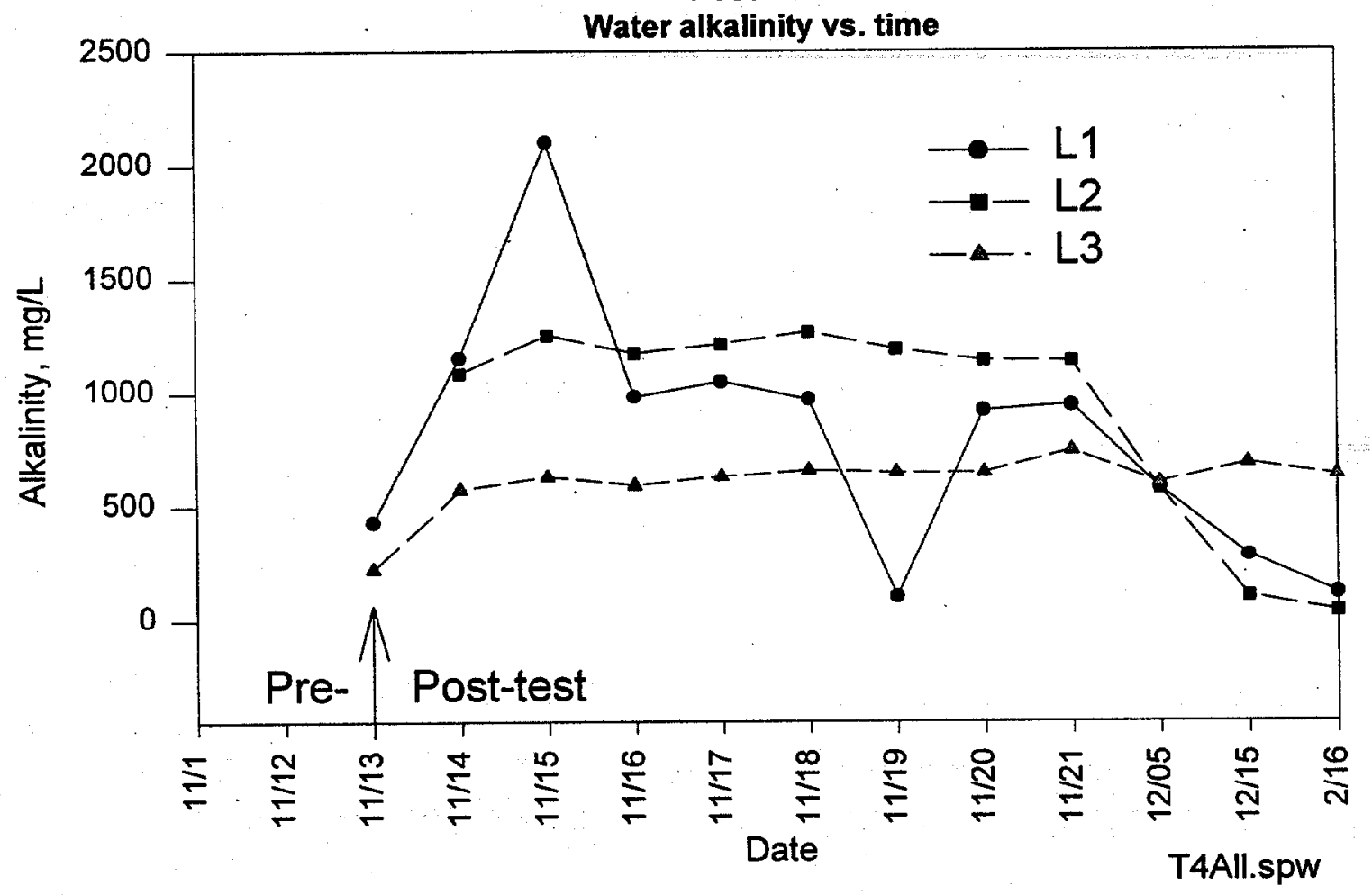

Fig. 4.20. Test ce11 4 - post-treatment water alkalinity levels. 


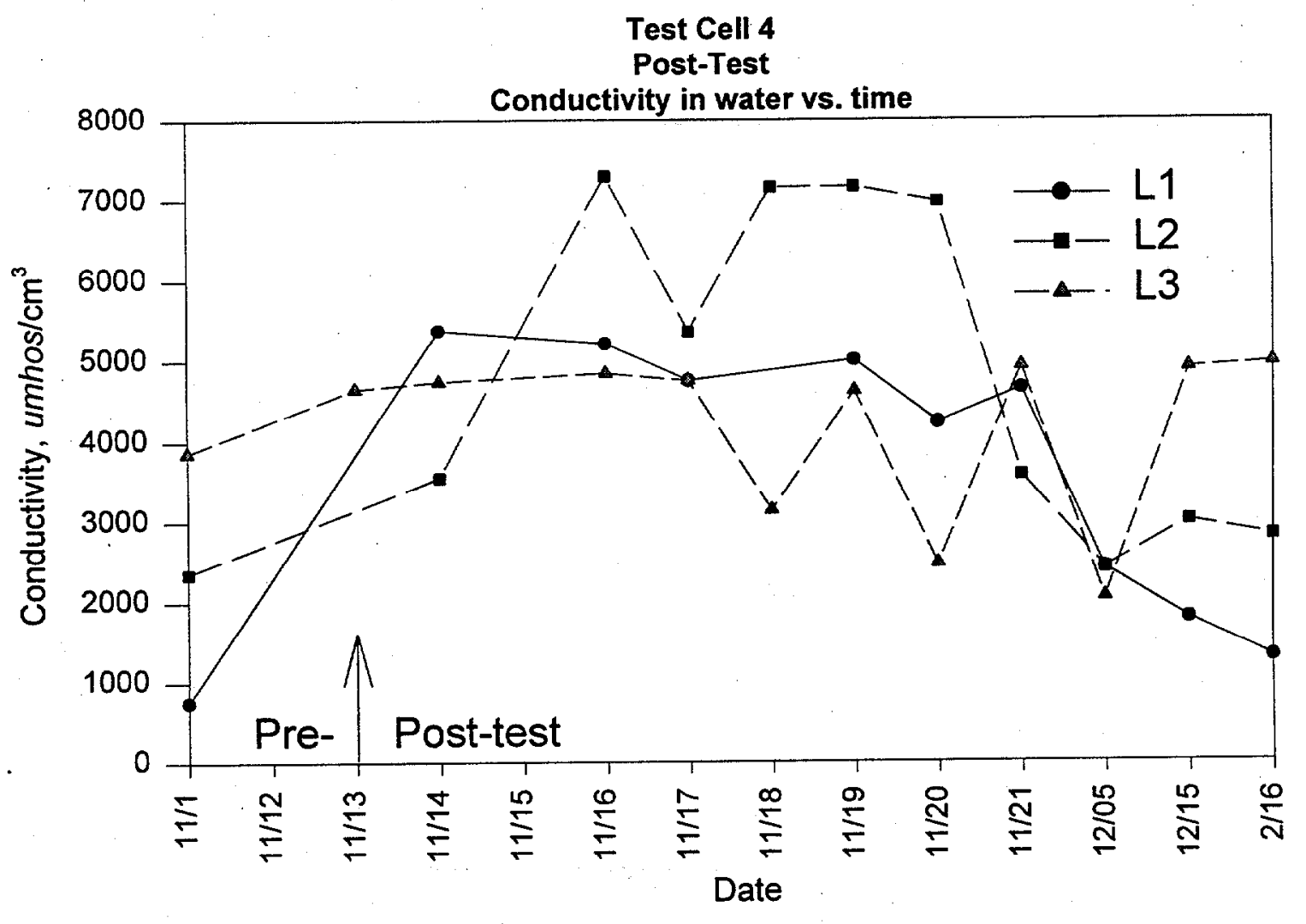

Fig. 4.21. Test cell 4 - post-treatment water conductivity levels. 


\section{Clean Teat Site}

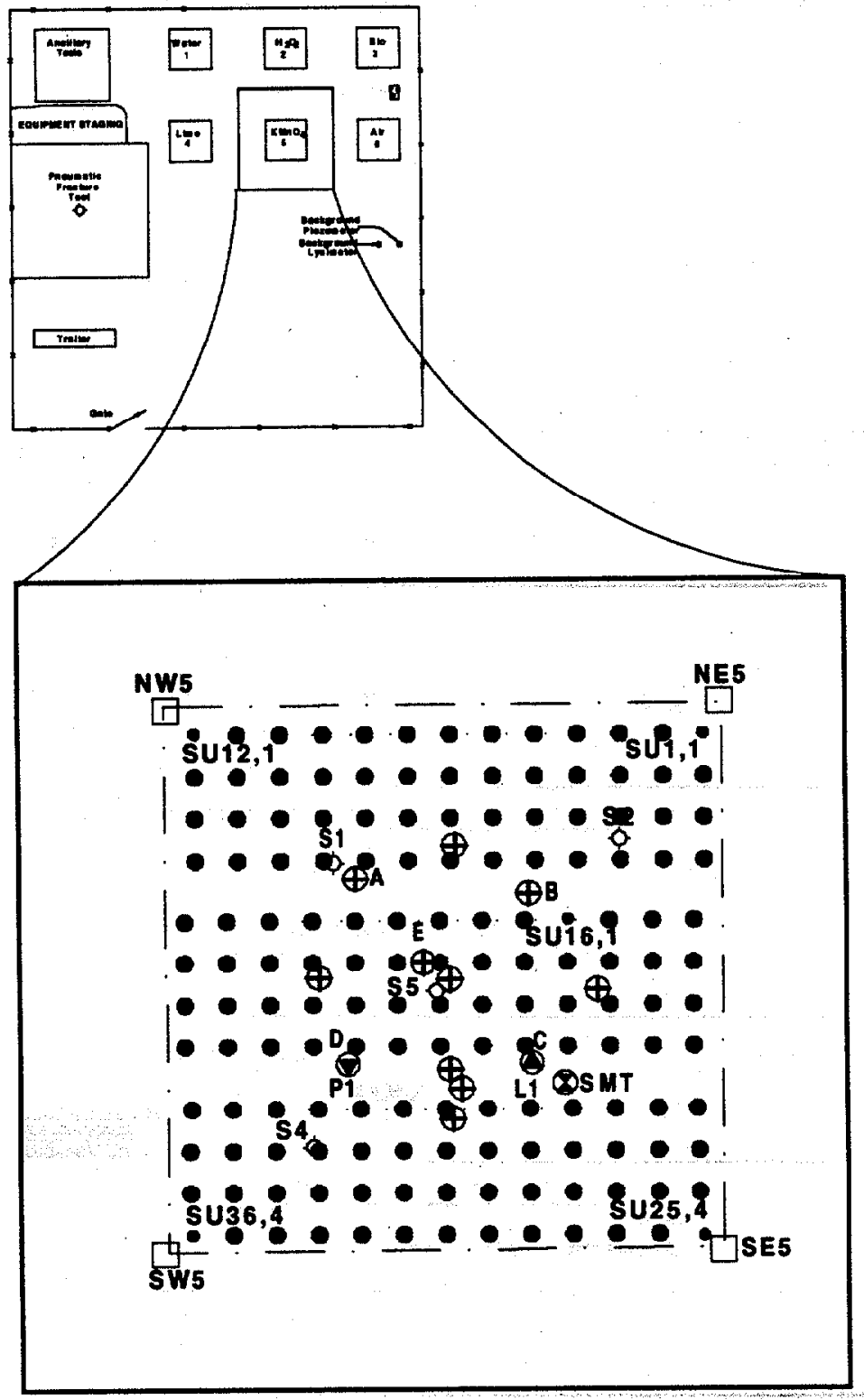

hilportelprm 040.dwo
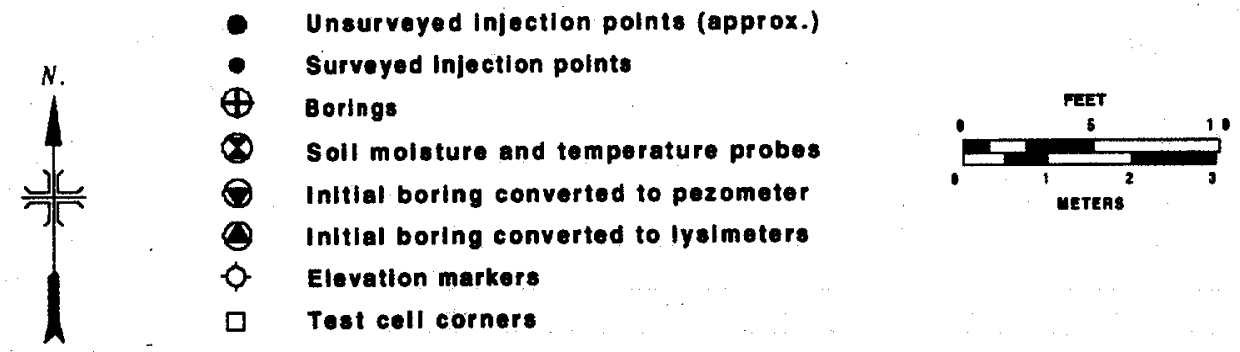

Fig. 4.22. Test cel1 5 sample locations. 


$$
\text { 4-40 }
$$

\section{Test Cell 5}

Post-Test

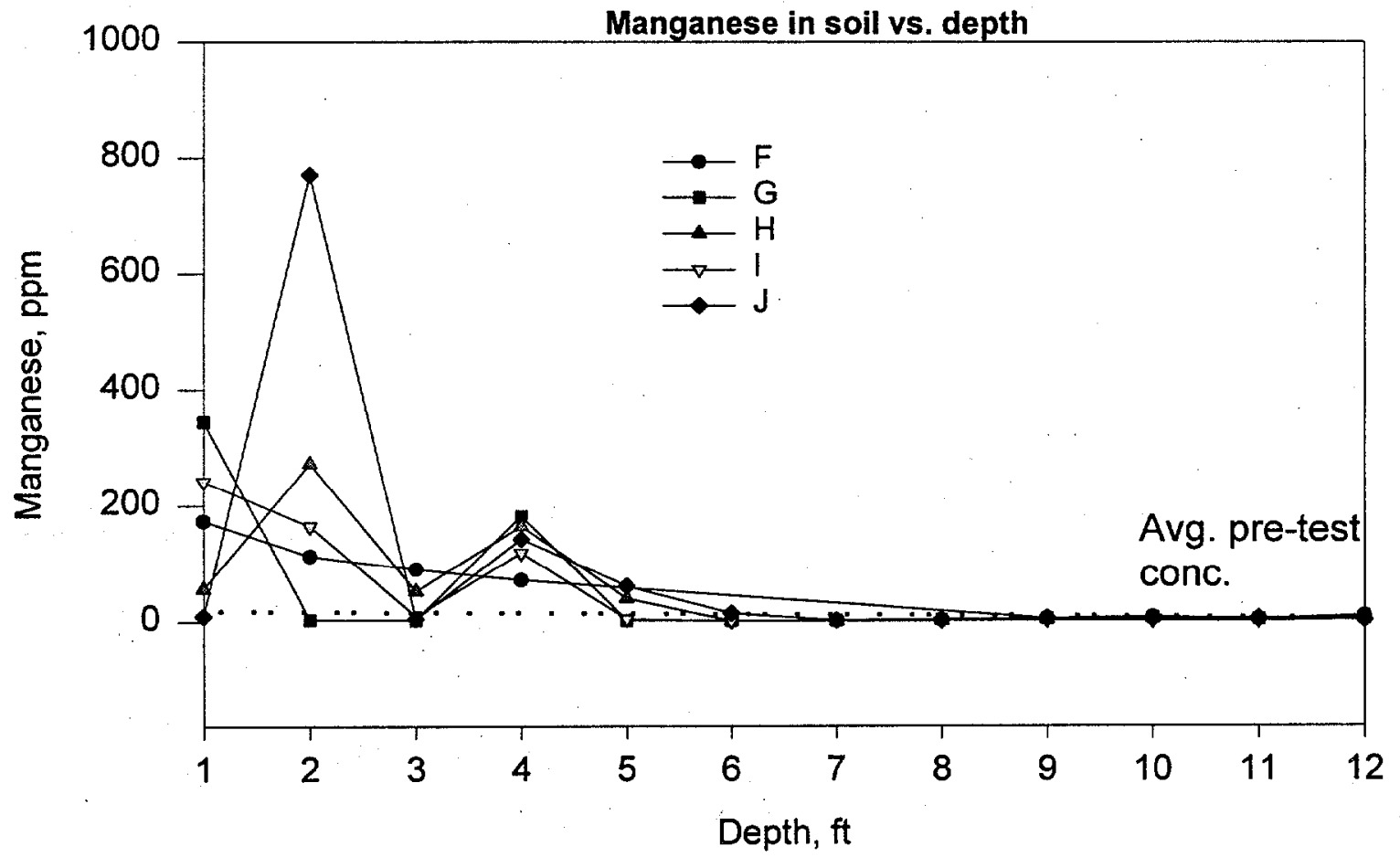

Fig. 4.23. Test cell 5 - post-treatment soil manganese levels.

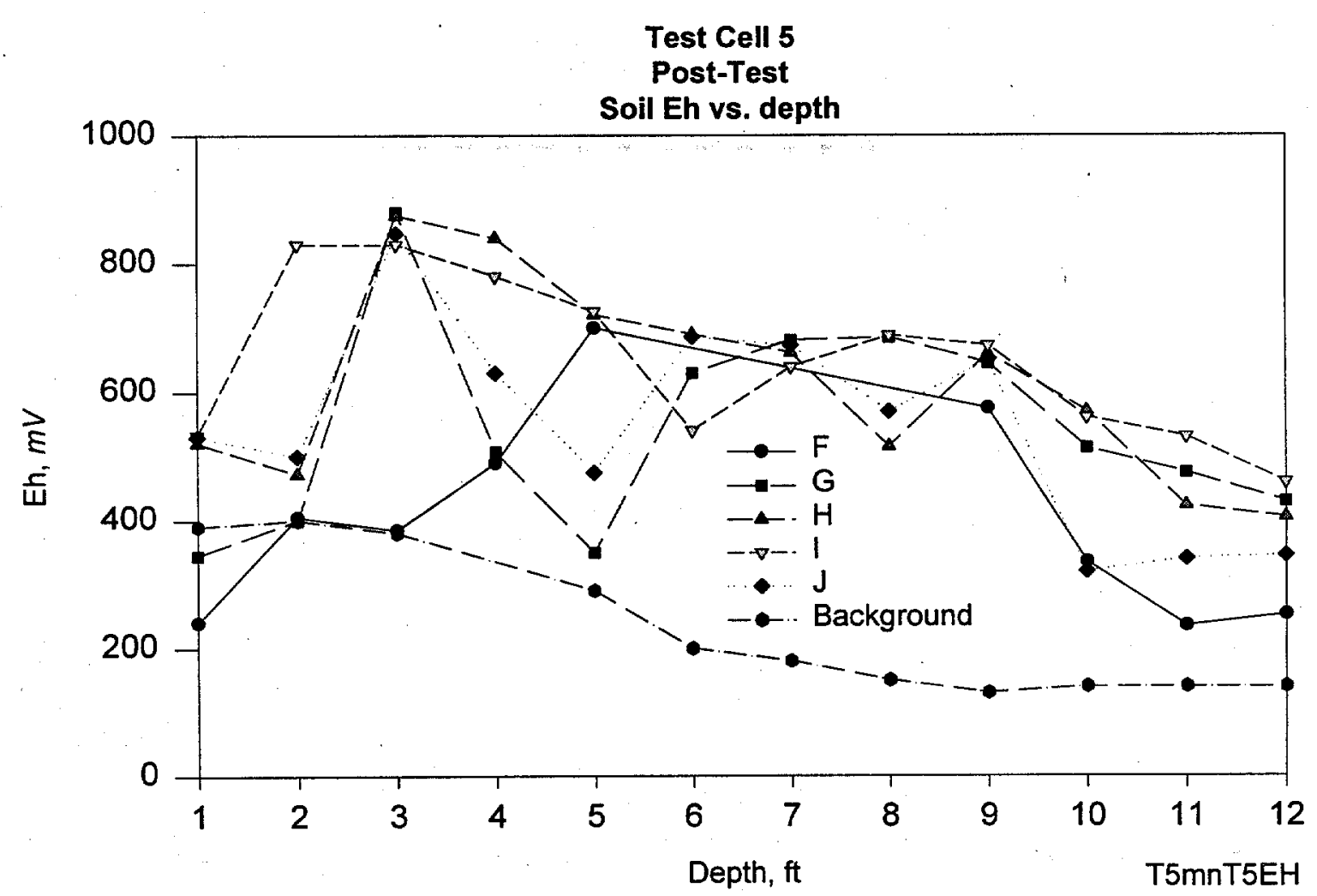

Fig. 4.24. Test ce11 5 - post-treatment soil Eh levels. 


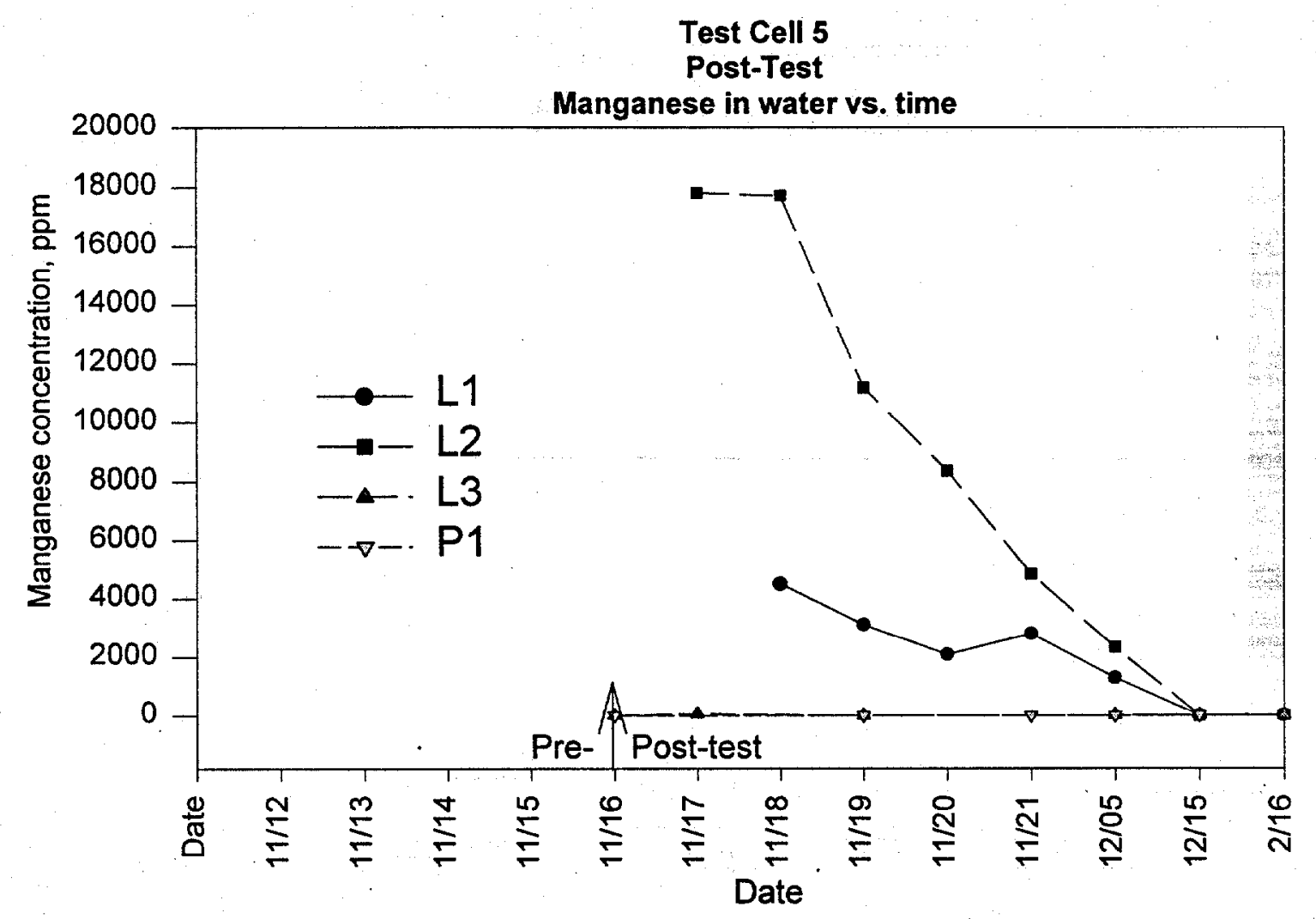

T5MANG

Fig. 4.25. Test cell 5 - post-treatment water manganese leve1s. 

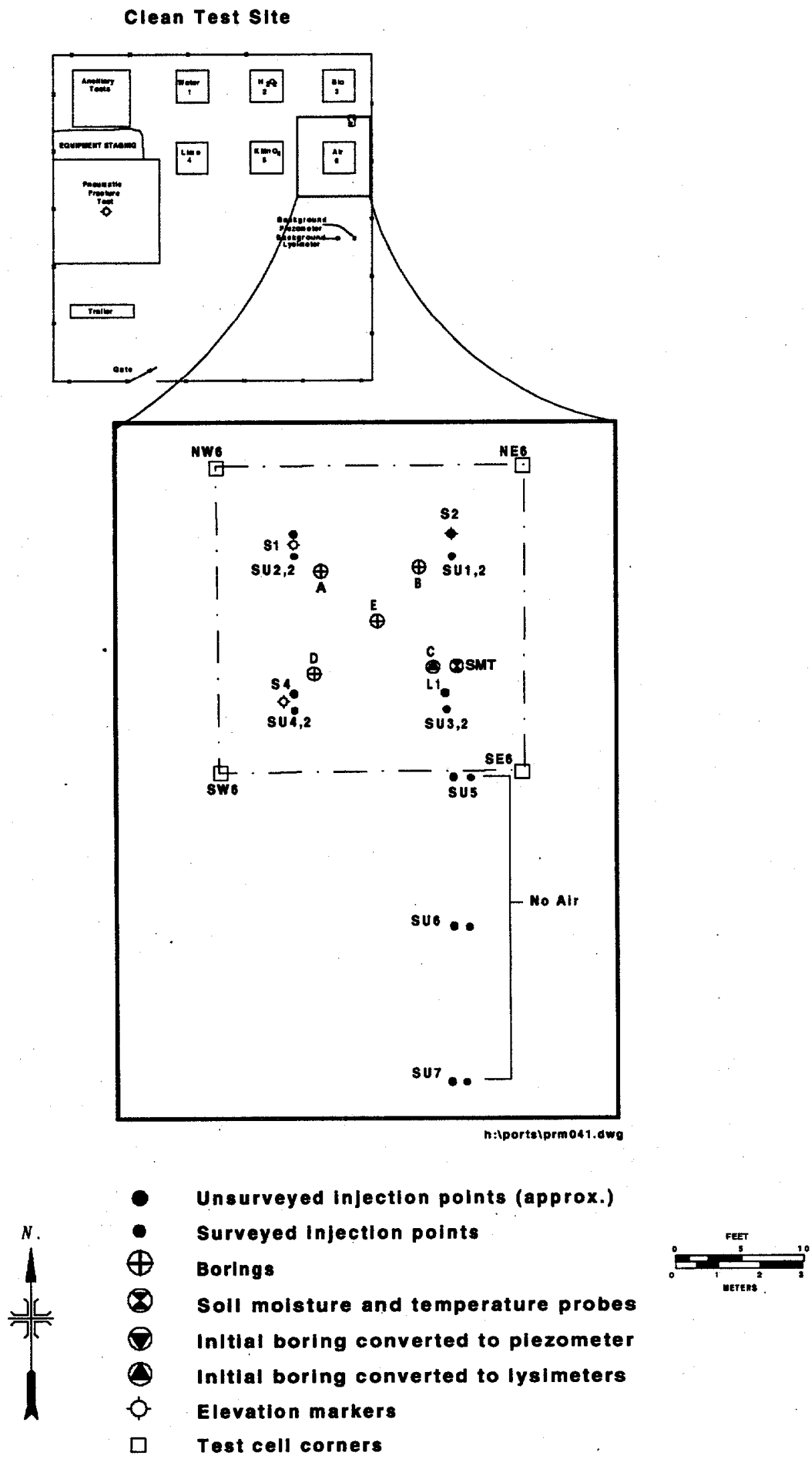

Fig. 4.26. Test cell 6 sample locations. 


$$
\text { 4-43 }
$$

\section{Clean Test Site}

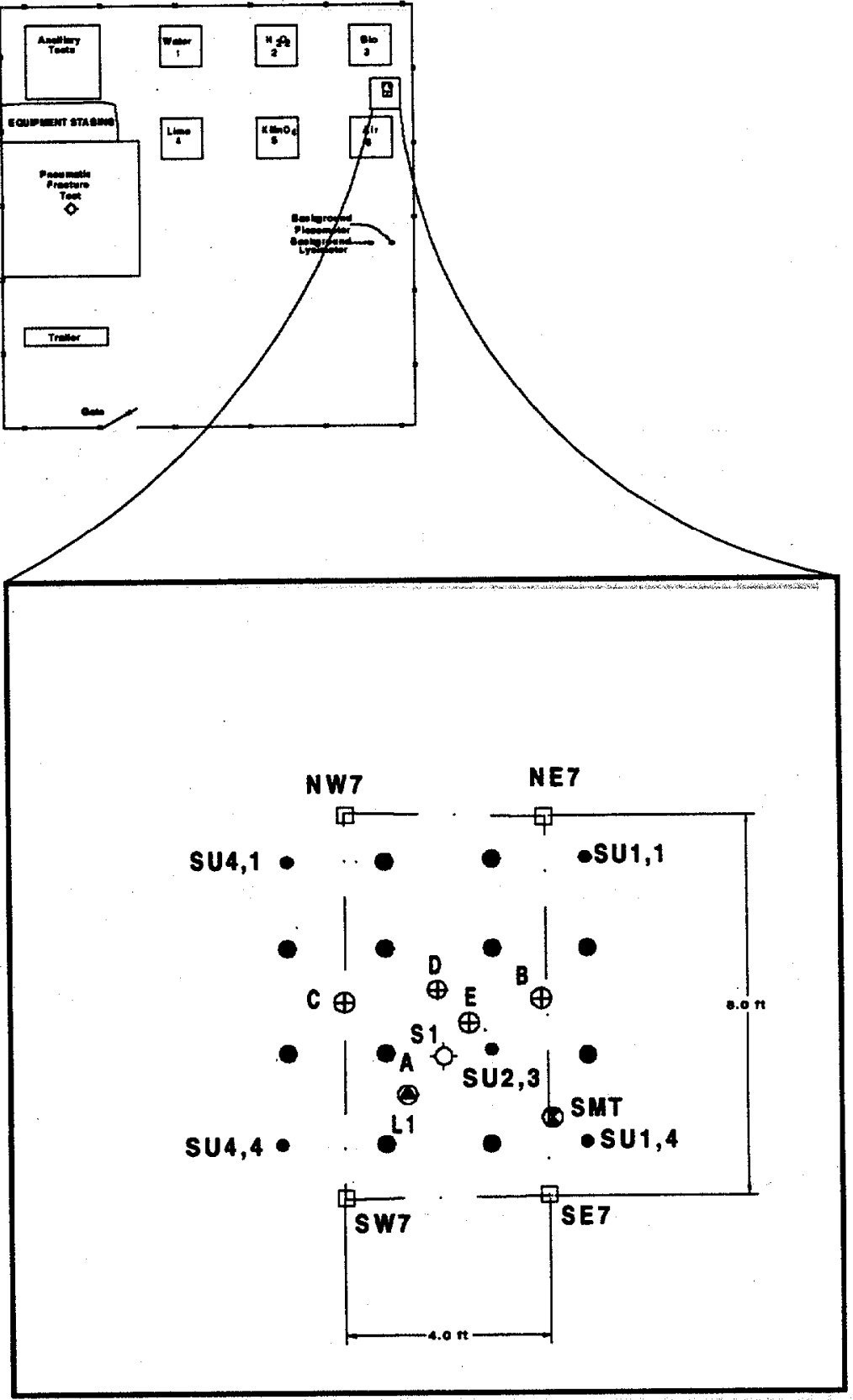

hiportelprm 0es dwo
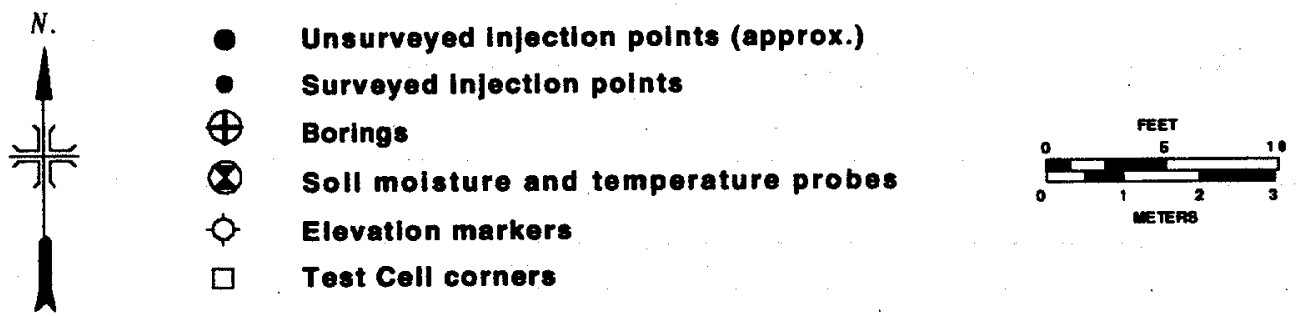

Fig. 4.27. Test cell 7 sample locations. 


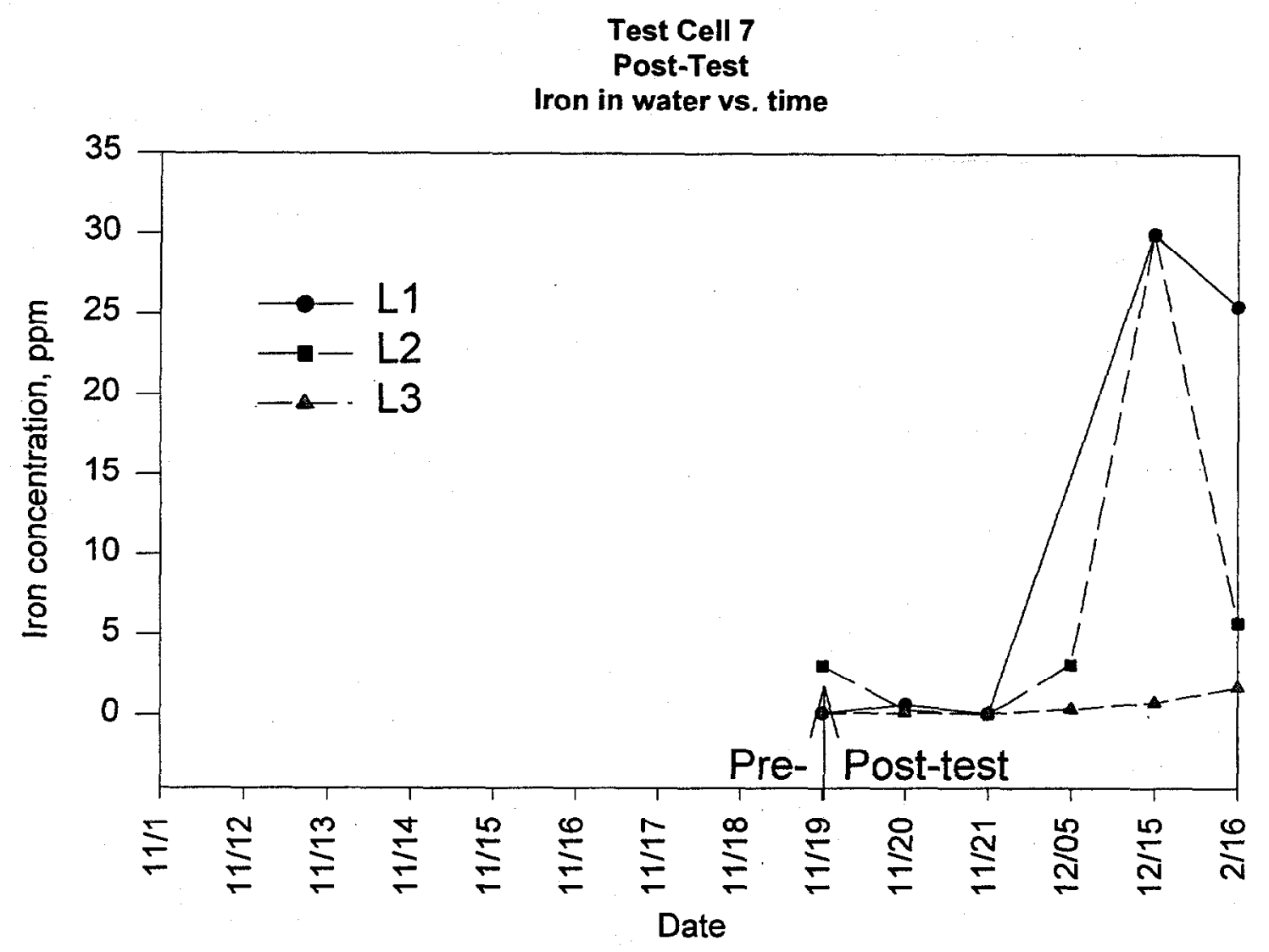

T7IRON

Fig. 4.28. Test cel1 7 - post-treatment water iron data. 
Table 4.1. Summary of background soil results

\begin{tabular}{clllll}
\hline $\begin{array}{c}\text { Depth, } \\
\mathbf{f t}\end{array}$ & $\begin{array}{l}\text { Soil } \\
\text { moisture, }\end{array}{ }^{a}$ \% & $\begin{array}{l}\text { Moist bulk } \\
\text { density, }{ }^{a} \mathbf{g} / \mathbf{c m}^{\mathbf{3}}\end{array}$ & $\mathbf{p H}^{a}$ & $\begin{array}{l}\mathbf{E h}{ }^{b} \\
\mathbf{m V}\end{array}$ & $\begin{array}{l}\text { TOC, } \\
\mathbf{p p m}\end{array}$ \\
\hline 1 & 17 & 1.93 & 4.9 & 390 & 6397 \\
2 & 18 & 1.66 & 4.5 & 400 & 1630 \\
3 & 19 & 1.79 & 4.3 & 380 & 1448 \\
4 & 15 & 1.83 & 4.7 & - & 1082 \\
5 & 15 & 1.99 & 5.7 & 290 & 1021 \\
6 & 16 & 1.96 & 6.5 & 200 & 995 \\
7 & 18 & - & 6.6 & 180 & 615 \\
8 & 21 & 2.07 & 7.0 & 150 & 558 \\
9 & 24 & 1.90 & 7.2 & 130 & 395 \\
10 & 26 & 1.81 & 7.6 & 140 & 421 \\
11 & 24 & 1.87 & 7.4 & 140 & 543 \\
12 & 24 & 1.95 & 7.4 & 140 & 526 \\
\hline
\end{tabular}

a Values averaged from borehole $\mathrm{E}$ in test cells 1 through 6 , from borehole $\mathrm{A}$ in test cell 7 and the background borehole in the shakedown area.

$b$ Values from borehole 1 in the shakedown area (S1BA)

-- $=$ No measurement taken 
Table 4.2. Water sample results from background piezometer and lysimeters

\begin{tabular}{|c|c|c|c|c|c|c|c|c|c|c|c|c|}
\hline $\begin{array}{l}\text { Sample } \\
\text { location }\end{array}$ & $\begin{array}{l}\text { Date } \\
\text { sampled }\end{array}$ & $\begin{array}{l}\text { Temperature, } \\
{ }^{\circ} \mathrm{C} \\
\end{array}$ & $\mathbf{p H}$ & $\begin{array}{l}\text { Do, } \\
\text { mg/L }\end{array}$ & $\begin{array}{l}\text { Electrical } \\
\text { conductivity, } \\
\mu \text { mhos }\end{array}$ & $\begin{array}{l}\text { Alkalinity, } \\
\mathbf{m g} / \mathbf{L}\end{array}$ & $\begin{array}{l}\mathrm{Br} \text {, } \\
\mathrm{mg} / \mathrm{L}\end{array}$ & $\begin{array}{l}\mathrm{Fe}, \\
\mathrm{mg} / \mathrm{L}\end{array}$ & $\begin{array}{l}\text { Mn, } \\
\mathrm{mg} / \mathrm{L}\end{array}$ & $\begin{array}{l}\text { Cl, } \\
\text { mg/L }\end{array}$ & $\begin{array}{l}\mathrm{NO}_{3}^{-} \\
\mathrm{mg} / \mathrm{L}\end{array}$ & $\begin{array}{l}\mathrm{SO}_{4}{ }^{2-}, \\
\mathrm{mg} / \mathrm{L}\end{array}$ \\
\hline B1LI & $\begin{array}{l}11 / 01 / 94 \\
11 / 12 / 94 \\
11 / 13 / 94 \\
11 / 14 / 94 \\
11 / 15 / 94 \\
11 / 18 / 94 \\
11 / 21 / 94 \\
12 / 05 / 94 \\
02 / 16 / 95\end{array}$ & \begin{tabular}{r|}
12.4 \\
17.4 \\
14.3 \\
12.5 \\
13.1 \\
15.6 \\
13.7 \\
\\
\end{tabular} & $\begin{array}{l}8.7 \\
8.3 \\
7.9 \\
8.0 \\
7.8 \\
7.9 \\
7.7 \\
7.9 \\
8.0\end{array}$ & $\begin{array}{l}7.3 \\
3.8 \\
4.8 \\
3.7 \\
\\
2.5\end{array}$ & $\begin{array}{l}960 \\
1112 \\
1250 \\
1390 \\
1430 \\
1440 \\
1520 \\
\\
1076\end{array}$ & $\begin{array}{r}132 \\
319 \\
157 \\
\\
216 \\
.153 \\
\\
94 \\
\end{array}$ & $\begin{array}{l}1.0 \\
\\
0.9 \\
0.9 \\
0.6 \\
\end{array}$ & $\begin{array}{l}0 \\
0 \\
0.15 \\
0 \\
0 \\
\\
\\
0.15 \\
\end{array}$ & $\begin{array}{l}0.25 \\
0.25 \\
0.25 \\
\\
0 \\
0 \\
\end{array}$ & $\begin{array}{r}23.3 \\
\\
15.0 \\
16.8 \\
9.5 \\
11.0\end{array}$ & $\begin{array}{l}0.4 \\
0 \\
0\end{array}$ & $\begin{array}{l}550 \\
525\end{array}$ \\
\hline B1L2 & $\begin{array}{l}11 / 01 / 94 \\
11 / 12 / 94 \\
11 / 13 / 94 \\
11 / 14 / 94 \\
11 / 15 / 94 \\
11 / 18 / 94 \\
11 / 21 / 94 \\
12 / 15 / 94 \\
02 / 16 / 95\end{array}$ & \begin{tabular}{r|}
12.9 \\
\\
15.4 \\
13.8 \\
14.5 \\
15.1 \\
13.7 \\
10.6 \\
4.9
\end{tabular} & $\begin{array}{l}8.9 \\
\\
7.9 \\
8.1 \\
7.2 \\
8.1 \\
7.4 \\
8.3 \\
7.7 \\
\end{array}$ & $\begin{array}{l}3.6 \\
3.3 \\
4.7 \\
8.1 \\
2.2 \\
4.5 \\
3.4 \\
\end{array}$ & $\begin{array}{l}2112 \\
2190 \\
2210 \\
1430 \\
2330 \\
1130 \\
2910 \\
\end{array}$ & $\begin{array}{l}204 \\
229 \\
\\
252 \\
248 \\
99 \\
246\end{array}$ & $\begin{array}{l}0.9 \\
\\
0.9 \\
0.8 \\
0.8 \\
0.3\end{array}$ & $\begin{array}{l}0.05 \\
0.10 \\
\\
0 \\
0.25 \\
0 \\
0 \\
\end{array}$ & $\begin{array}{l}0.25 \\
0.25 \\
\\
0.30 \\
0.17 \\
0.18 \\
0.20 \\
\end{array}$ & $\begin{array}{r}10.5 \\
9.0 \\
11.2 \\
7.8\end{array}$ & $\begin{array}{l}0.1 \\
0.2 \\
0.1\end{array}$ & $\begin{array}{l}1100 \\
1200\end{array}$ \\
\hline B1L3 & $\begin{array}{l}11 / 01 / 94 \\
11 / 12 / 94 \\
11 / 13 / 94 \\
11 / 14 / 94 \\
11 / 15 / 94 \\
11 / 18 / 94 \\
11 / 21 / 94 \\
12 / 05 / 94 \\
12 / 15 / 94 \\
02 / 16 / 95\end{array}$ & $\begin{array}{r}12.5 \\
20.6 \\
15.6 \\
14.2 \\
14.1 \\
15.3 \\
14.9 \\
12.3 \\
6.3\end{array}$ & $\begin{array}{l}7.9 \\
7.5 \\
7.4 \\
7.4 \\
6.6 \\
8.1 \\
7.1 \\
8.2 \\
8.3 \\
6.6\end{array}$ & $\begin{array}{l}2.7 \\
2.8 \\
4.9 \\
6.2 \\
4.2 \\
2.8 \\
\\
11.2 \\
2.3\end{array}$ & $\begin{array}{l}1530 \\
1652 \\
1700 \\
1760 \\
1800 \\
1790 \\
1700 \\
\\
2530 \\
1730\end{array}$ & $\begin{array}{l}212 \\
186 \\
240 \\
\\
277 \\
238 \\
213 \\
260 \\
218\end{array}$ & $\begin{array}{l}0.9 \\
0.7 \\
0.8 \\
0.8 \\
0\end{array}$ & $\begin{array}{l}0 \\
0.05 \\
0.10 \\
0 \\
0 \\
0.02 \\
0.025 \\
0.025\end{array}$ & $\begin{array}{l}0.25 \\
0.25 \\
0.25\end{array}$ & $\begin{array}{l}7.8 \\
\\
6.3 \\
6.3 \\
3.2 \\
5.2\end{array}$ & $\begin{array}{l}0.1 \\
0 \\
0.1\end{array}$ & $\begin{array}{l}750 \\
850\end{array}$ \\
\hline
\end{tabular}


Table 4.2. (continued)

\begin{tabular}{|c|c|c|c|c|c|c|c|c|c|c|c|c|}
\hline $\begin{array}{l}\text { Sample } \\
\text { location }\end{array}$ & $\begin{array}{l}\text { Date } \\
\text { sampled }\end{array}$ & $\begin{array}{l}\text { Temperature, } \\
{ }^{\circ} \mathrm{C}\end{array}$ & pH & $\begin{array}{l}\text { DO, } \\
\mathrm{mg} / \mathrm{L}\end{array}$ & $\begin{array}{l}\text { Electrical } \\
\text { conductivity, } \\
\mu \text { mhos }\end{array}$ & $\begin{array}{l}\text { Alkalinity, } \\
\mathrm{mg} / \mathrm{L}\end{array}$ & $\begin{array}{l}\text { Br, } \\
\text { mg/L }\end{array}$ & $\begin{array}{l}\text { Fe, } \\
\text { mg/L }\end{array}$ & $\begin{array}{l}\text { Mn, } \\
\text { mg/L }\end{array}$ & $\begin{array}{l}\mathrm{Cl} \text {; } \\
\mathrm{mg} / \mathrm{L}\end{array}$ & $\begin{array}{l}\mathrm{NO}_{3}, \\
\mathrm{mg} / \mathrm{L}\end{array}$ & $\begin{array}{l}\mathrm{SO}_{4}{ }^{2-}, \\
\mathrm{mg} / \mathrm{L}\end{array}$ \\
\hline B1P1 & $11 / 01 / 94$ & 12.3 & 7.2 & & 1480 & & & & & & & \\
\hline \multirow[t]{4}{*}{ duplicate } & $11 / 01 / 94$ & 12.3 & 7.2 & & 1480 & & & & & & & \\
\hline & $11 / 12 / 94$ & 17.2 & 6.6 & 1.9 & 1547 & 188 & & 0.125 & 0.25 & 5.5 & 0.1 & 750 \\
\hline & $11 / 13 / 94$ & 16.3 & 7.1 & 4.2 & 1520 & 169 & 0.9 & 0.075 & 0.25 & & & 650 \\
\hline & $11 / 14 / 94$ & 13.9 & 6.6 & 2.6 & 1600 & 174 & & 0.125 & 0.25 & 9.5 & & \\
\hline \multirow{7}{*}{ duplicate } & $11 / 14 / 94$ & & & 4.4 & & 182 & & & & 5.0 & & \\
\hline & $11 / 15 / 94$ & 14.1 & 6.6 & 2.0 & 1590 & & 0.9 & & & 5.0 & & \\
\hline & $11 / 18 / 94$ & 15.3 & 6.8 & 2.9 & 1580 & 194 & 0.9 & 0.05 & 1.00 & 2.5 & 0.1 & 425 \\
\hline & $11 / 21 / 94$ & 15.0 & 6.1 & 4.9 & 1520 & 198 & 0.8 & 0.18 & & 6.5 & 0 & 700 \\
\hline & $12 / 05 / 94$ & 15.3 & 6.9 & 3.1 & 1240 & 190 & 0.7 & 0.08 & 0.10 & & & 725 \\
\hline & $12 / 15 / 94$ & 15.0 & 7.0 & 4.3 & 1550 & 198 & 0.8 & 0.23 & 0.36 & & & \\
\hline & $02 / 16 / 95$ & 7.3 & 7.5 & NA & 1650 & 192 & 0.1 & $\mathrm{NA}$ & 0 & & 0 & \\
\hline
\end{tabular}

See Fig. 3.1 for boring locations. 
Table 4.3. Tracer test cell (T1) soil sample results

\begin{tabular}{|c|c|c|c|c|c|c|c|}
\hline \multirow{2}{*}{ Depth, ft } & \multirow{2}{*}{$\frac{\text { pH }}{\text { Pre }^{a}}$} & \multirow{2}{*}{$\begin{array}{l}\text { Eh, } \\
\text { mV } \\
\text { Post }^{b}\end{array}$} & \multirow{2}{*}{$\begin{array}{l}\text { TOC, } \\
\text { ppm } \\
\text { Pre }^{a} \\
\end{array}$} & \multicolumn{2}{|c|}{ \% Soil moisture } & \multirow{2}{*}{$\begin{array}{c}\begin{array}{c}\text { Bromide, } \\
\text { ppm }\end{array} \\
\text { Post }^{b} \\
\end{array}$} & \multirow{2}{*}{$\begin{array}{l}\text { INA, } \\
\text { particles/mg } \\
\text { Post }^{b} \\
\end{array}$} \\
\hline & & & & Pre $^{a}$ & Post $^{b}$ & & \\
\hline 1 & 4.3 & 360 to 380 & 6258 & 18.0 & 18.3 to 24.0 & 4 to 11 & 4 to 178 \\
\hline 2 & 4.4 & 350 & 1295 & 18.4 & 18.4 to 20.8 & 1 to 12 & 12 to 3543 \\
\hline 3 & 4.6 & 390 to 460 & 2130 & 17.5 & 17.6 to 20.8 & 1 to 4 & 4 to 26 \\
\hline 4 & 4.6 & 390 to 430 & 1471 & 18.0 & 15.7 to 17.8 & 2 to 7 & 18 to 181 \\
\hline 5 & 4.8 & 395 to 490 & 1226 & 14.8 & 13.9 to 18.7 & 1 to 7 & 2 to 138 \\
\hline 6 & 6.0 & 370 to 390 & 1216 & 17.1 & 14.1 to 18.4 & 1 to 3 & 3 to 16 \\
\hline 7 & .7 .0 & 280 to 350 & 685 & 15.8 & 15.5 to 18.2 & 1 to 2 & 1 to 9 \\
\hline 8 & -- & 305 to 325 & -- & -- & 15.0 to 24.0 & 1 to 4 & 0 to 20 \\
\hline 9 & 7.1 & 320 to 340 & 354 & 24.0 & 23.2 to 26.3 & 1 to 7 & 0 to 34 \\
\hline 10 & 7.8 & 295 to 305 & 333 & 25.9 & 23.0 to 28.3 & 1 to 2 & 0 to 1 \\
\hline 11 & 7.6 & 305 to 330 & 653 & 25.8 & 21.7 to 27.5 & 1 & 0 \\
\hline 12 & 7.4 & 275 to 330 & 555 & 27.0 & 25.4 to 27.3 & 1 to 4 & 0 \\
\hline
\end{tabular}

${ }^{a}$ Pre-treatment results

${ }^{b}$ Ranges of values are from five post-treatment soil borings.

- No sample taken 
Table 4.4. Water sample results for the tracer test cell (T1), injection date 11/12/95

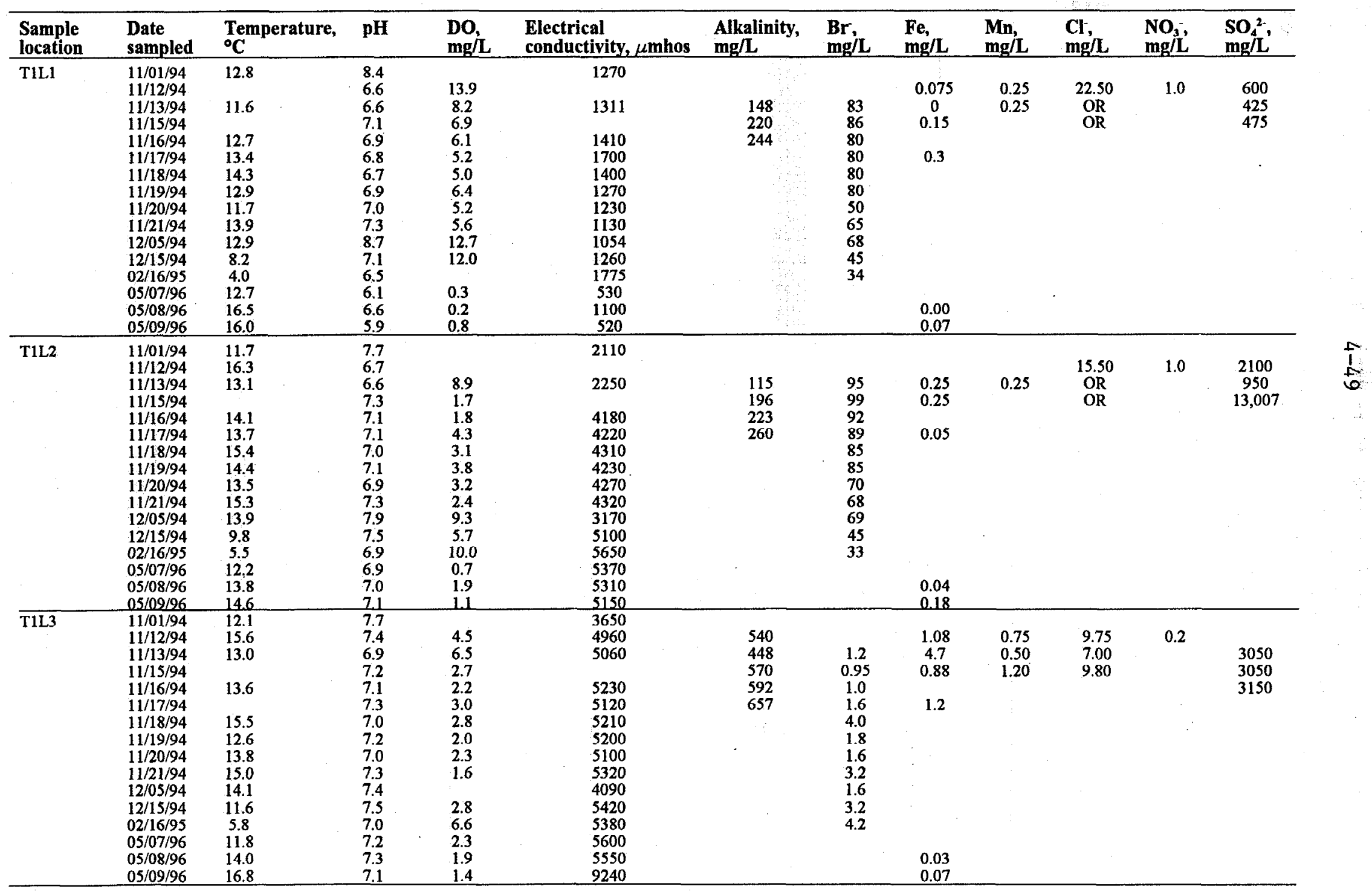


Table 4.4. (continued)

\begin{tabular}{|c|c|c|c|c|c|c|c|c|c|c|c|c|}
\hline $\begin{array}{l}\text { Sample } \\
\text { location }\end{array}$ & $\begin{array}{l}\text { Date } \\
\text { sampled }\end{array}$ & $\begin{array}{l}\text { Temperature, } \\
{ }^{\circ} \mathrm{C}\end{array}$ & $\mathbf{p H}$ & $\begin{array}{l}\mathrm{DO}, \\
\mathrm{mg} / \mathrm{L}\end{array}$ & $\begin{array}{l}\text { Electrical } \\
\text { conductivity, } \\
\mu \text { mhos }\end{array}$ & $\begin{array}{l}\text { Alkalinity, } \\
\mathrm{mg} / \mathrm{L}\end{array}$ & $\begin{array}{l}\mathrm{Br} \\
\mathrm{mg} / \mathrm{L}\end{array}$ & $\begin{array}{l}\text { Fe, } \\
\mathrm{mg} / \mathrm{L}\end{array}$ & $\begin{array}{l}\text { Mn, } \\
\text { mg/L }\end{array}$ & $\begin{array}{l}\mathrm{Cl}^{-} \\
\mathrm{mg} / \mathrm{L}\end{array}$ & $\begin{array}{l}\mathrm{NO}_{3} ; \\
\mathrm{mg} / \mathrm{L}\end{array}$ & $\begin{array}{l}\mathrm{SO}_{4}{ }^{22} \\
\mathrm{mg} / \mathrm{L}\end{array}$ \\
\hline T1P1 & $\begin{array}{l}11 / 01 / 94 \\
11 / 12 / 94 \\
11 / 13 / 94 \\
11 / 15 / 94 \\
11 / 16 / 94 \\
11 / 17 / 94 \\
11 / 18 / 94 \\
11 / 19 / 94 \\
11 / 20 / 94 \\
11 / 21 / 94 \\
12 / 05 / 94 \\
12 / 15 / 94 \\
02 / 16 / 95 \\
05 / 07 / 96\end{array}$ & $\begin{array}{l}11.4 \\
16.0 \\
14.3 \\
13.9 \\
14.6 \\
14.9 \\
13.5 \\
13.4 \\
15.0 \\
14.5 \\
12.0 \\
5.8\end{array}$ & $\begin{array}{l}7.2 \\
6.8 \\
7.0 \\
6.8 \\
6.8 \\
6.8 \\
6.8 \\
6.8 \\
6.9 \\
7.0 \\
7.1 \\
7.0 \\
7.1\end{array}$ & $\begin{array}{l}5.4 \\
6.4 \\
\\
5.3 \\
4.3 \\
4.6 \\
5.6 \\
2.3 \\
5.4 \\
4.6\end{array}$ & $\begin{array}{l}5060 \\
5150 \\
5340 \\
\\
5250 \\
5140 \\
5200 \\
5260 \\
4980 \\
5170 \\
4050 \\
5300 \\
5060\end{array}$ & $\begin{array}{l}560 \\
601 \\
564 \\
602 \\
\\
\\
\end{array}$ & $\begin{array}{l}1.0 \\
0.9 \\
1.0 \\
2.0 \\
3.0 \\
2.2 \\
0.9 \\
1.6 \\
3.2 \\
3.2\end{array}$ & $\begin{array}{l}0 \\
0.125 \\
0.1 \\
\\
0.02\end{array}$ & $\begin{array}{l}0 \\
0.50\end{array}$ & $\begin{array}{c}10.50 \\
7.25 \\
10.30\end{array}$ & 0.6 & $\begin{array}{l}3250 \\
3450 \\
3250\end{array}$ \\
\hline & $\begin{array}{r}05 / 08 / 96 \\
05 / 09 / 96 \\
\end{array}$ & $\begin{array}{l}16.5 \\
19.0 \\
\end{array}$ & $\begin{array}{l}7.2 \\
7.0 \\
\end{array}$ & $\begin{array}{l}5.8 \\
3.9 \\
\end{array}$ & $\begin{array}{l}4850 \\
8470 \\
\end{array}$ & & . & $\begin{array}{l}0.02 \\
0.11 \\
\end{array}$ & & & & $\because$ \\
\hline B1P1 & $5 / 09 / 96$ & 19.2 & 6.9 & 11.8 & 1700 & & & 0.42 & & & & \\
\hline B1L1 & $5 / 09 / 96$ & 20.0 & 8.1 & 2.4 & 450 & & & 0.05 & & & & \\
\hline B1L2 & $5 / 09 / 96$ & 14.8 & 7.7 & 0.7 & 3550 & & & 0.06 & & & & \\
\hline B1L3 & $5 / 09 / 96$ & 19.2 & 8.2 & 2.5 & 1020 & & & 0.05 & & & & \\
\hline
\end{tabular}

$\mathrm{OR}=$ over range 
Table 4.5. Hydrogen peroxide test cell (T2), soil sample results

\begin{tabular}{|c|c|c|c|c|c|c|c|c|c|}
\hline \multirow[t]{2}{*}{ Depth, ft } & \multicolumn{2}{|r|}{ pH } & \multirow{2}{*}{$\begin{array}{l}\text { Eh, } \\
\text { mV }\end{array}$} & \multicolumn{2}{|c|}{$\begin{array}{l}\text { TOC, } \\
\text { ppm }\end{array}$} & \multicolumn{2}{|c|}{ \% Soil moisture } & \multirow{2}{*}{$\begin{array}{c}\begin{array}{c}\text { Nitrate, } \\
\text { ppm }\end{array} \\
\text { Post }^{b} \\
\end{array}$} & \multirow{2}{*}{$\begin{array}{c}\begin{array}{c}\text { Peroxide, } \\
\text { mg/L }\end{array} \\
\text { Post }^{b} \\
\end{array}$} \\
\hline & Pre $^{a}$ & Post $^{b}$ & & Pre $^{a}$ & Post $^{b}$ & Pre $^{a}$ & Post $^{b}$ & & \\
\hline 1 & 4.6 & 4.7 to 5.4 & 200 to 440 & 6107 & 2495 to 2896 & 17.6 & 19.5 to 23.1 & 0 to 3.75 & 0 \\
\hline 2 & 4.3 & 4.2 to 4.7 & 237 to 500 & 1576 & 1747 to 1525 & 19.5 & 19.4 to 21.2 & 0 to 1.25 & 0 \\
\hline 3 & 4.1 & 4.5 to 4.6 & 250 to 580 & 1083 & 1437 to 1770 & 17.8 & 16.9 to 20.5 & 0 to 3.75 & 5 to 100 \\
\hline 4 & 4.6 & 4.8 to 4.9 & 340 to 490 & 993 & 1048 to 1163 & 15.7 & 15.2 to 15.4 & 0 to 1.20 & 0 \\
\hline 5 & 5.9 & 6.1 to 6.9 & 170 to 440 & 1353 & 958 to 1006 & 16.0 & 12.1 to 14.7 & 0 to 1.25 & 0 \\
\hline 6 & 6.9 & 6.5 to 7.0 & 180 to 410 & 890 & 976 to 1329 & 17.2 & 15.6 to 17.9 & 0 to 1.25 & 0 \\
\hline 7 & 7.0 & 6.2 to 7.3 & 100 to 500 & 431 & 653 to 782 & 17.3 & 18.1 to 19.6 & -- & 0 to 4 \\
\hline 8 & -- & 6.7 to 7.2 & 100 to 350 & -- & 401 to 2079 & -- & 15.9 to 22.0 & 0 to 1.25 & 0 \\
\hline 9 & 7.8 & 7.2 to 7.5 & 140 to 298 & 288 & 427 to 545 & 24.6 & 22.1 to 26.5 & 0 to 2.50 & 0 \\
\hline 10 & 7.7 & 5.5 to 7.5 & 194 to 460 & 436 & 543 to 630 & 25.0 & 23.0 to 27.6 & -- & 0 \\
\hline 11 & 7.8 & 7.1 to 7.5 & 205 to 420 & 425 & 608 to 771 & 25.8 & 22.1 to 27.6 & 0 to 2.50 & 0 \\
\hline 12 & 7.7 & 7.2 to 7.4 & 190 to 440 & 640 & 648 to 784 & 21.8 & 20.7 to 27.0 & 0 to 1.25 & 0 \\
\hline
\end{tabular}

${ }^{a}$ Pre-treatment results

${ }^{b}$ Ranges of values are from five post-treatment soil borings.

-- No sample taken 
Table 4.6. Water sample results for the hydrogen peroxide test cell (T2), injection date 11/15/95

\begin{tabular}{|c|c|c|c|c|c|c|c|c|c|c|c|c|}
\hline $\begin{array}{l}\text { Sample } \\
\text { location }\end{array}$ & $\begin{array}{l}\text { Date } \\
\text { sampled }\end{array}$ & $\begin{array}{l}\text { Temperature, } \\
{ }^{\circ} \mathrm{C}\end{array}$ & pH & $\begin{array}{l}\text { DO, } \\
\text { mg/L }\end{array}$ & $\begin{array}{l}\text { Electrical } \\
\text { conductivity, } \\
\mu \text { mhos }\end{array}$ & $\begin{array}{l}\text { Alkalinity, } \\
\mathrm{mg} / \mathbf{L}\end{array}$ & $\begin{array}{l}\mathrm{H}_{2} \mathbf{O}_{2} \\
\mathbf{m g} / \mathbf{L}\end{array}$ & $\begin{array}{l}\mathrm{Fe}, \\
. \mathrm{mg} / \mathrm{L}\end{array}$ & $\begin{array}{l}\mathrm{Mn}, \\
\mathbf{m g} / \mathrm{L}\end{array}$ & $\begin{array}{l}\mathrm{Cl} \\
\mathrm{mg} / \mathrm{L}\end{array}$ & $\begin{array}{l}\mathrm{NO}_{3}^{-} \\
\mathrm{mg} / \mathrm{L}\end{array}$ & $\begin{array}{l}\mathrm{SO}_{4}{ }^{2-}, \\
\mathrm{mg} / \mathrm{L}\end{array}$ \\
\hline $\mathrm{T} 2 \mathrm{~L} 1$ & $\begin{array}{l}11 / 01 / 94 \\
11 / 15 / 94 \\
11 / 16 / 94 \\
11 / 17 / 94 \\
11 / 18 / 94 \\
11 / 19 / 94 \\
11 / 20 / 94 \\
11 / 21 / 94 \\
12 / 05 / 94 \\
12 / 15 / 94 \\
02 / 16 / 95 \\
05 / 07 / 96 \\
05 / 08 / 96 \\
05 / 09 / 96 \\
\end{array}$ & $\begin{array}{l}12.7 \\
14.0 \\
13.9 \\
16.3 \\
16.2 \\
14.5 \\
15.4 \\
13.7 \\
10.0 \\
4.5 \\
13.9 \\
14.0 \\
16.5\end{array}$ & $\begin{array}{l}9.0 \\
8.5 \\
8.1 \\
8.2 \\
7.7 \\
7.3 \\
7.4 \\
8.7 \\
7.4 \\
7.0 \\
6.6 \\
6.7 \\
6.5 \\
\end{array}$ & $\begin{array}{c}8.5 \\
6.1 \\
25.0 \\
25.0 \\
25.0 \\
\\
25.0 \\
\\
25.0 \\
\text { OR } \\
11.0 \\
11.0 \\
8.6 \\
\end{array}$ & $\begin{array}{l}1380 \\
1420 \\
1750 \\
1920 \\
1820 \\
1920 \\
2130 \\
\end{array}$ & $\begin{array}{c}102 \\
146 \\
\\
108 \\
95 \\
\\
114 \\
204 \\
180 \\
194\end{array}$ & $\begin{array}{l}2500 \\
100 \\
30 \\
1 \\
\\
0 \\
0 \\
0 \\
0\end{array}$ & $\begin{array}{l} \\
0.00 \\
0.07 \\
\end{array}$ & 0 & $\begin{array}{l}22.8 \\
16.5\end{array}$ & $\begin{array}{l}0 \\
1.3 \\
1.6 \\
1.8 \\
2.3 \\
2.1 \\
\\
1.3\end{array}$ & $\begin{array}{l}40 \\
550\end{array}$ \\
\hline $\mathrm{T} 2 \mathrm{~L} 2$ & $\begin{array}{l}11 / 01 / 94 \\
11 / 14 / 94 \\
11 / 15 / 94 \\
11 / 16 / 94 \\
11 / 17 / 94 \\
11 / 18 / 94 \\
11 / 19 / 94 \\
11 / 20 / 94 \\
11 / 21 / 94 \\
12 / 05 / 94 \\
12 / 15 / 94 \\
02 / 16 / 95 \\
05 / 07 / 96 \\
05 / 08 / 96 \\
05 / 09 / 96 \\
\end{array}$ & $\begin{array}{r}14.4 \\
14.6 \\
11.5 \\
17.1 \\
14.6 \\
16.4 \\
\\
14.5 \\
11.5 \\
4.3\end{array}$ & $\begin{array}{l}8.2 \\
7.1 \\
7.3 \\
6.9 \\
7.6 \\
7.4 \\
7.2 \\
7.4 \\
\\
8.9 \\
7.6 \\
7.1\end{array}$ & $\begin{array}{c}4.5 \\
4.4 \\
14.0 \\
\end{array}$ & $\begin{array}{l}2010 \\
\\
3680 \\
3580 \\
3550 \\
3710 \\
3880 \\
\\
3700 \\
4930 \\
5460\end{array}$ & $\begin{array}{c}265 \\
\\
14 \\
221 \\
375 \\
254 \\
\\
614 \\
860 \\
402\end{array}$ & $\begin{array}{l}7000 \\
\\
30 \\
1 \\
\\
3 \\
0 \\
0\end{array}$ & 0.05 & & $\begin{array}{l}8.0 \\
6.0\end{array}$ & $\begin{array}{l}0 \\
12.0 \\
8.5 \\
4.0 \\
2.4 \\
1.8\end{array}$ & $\begin{array}{l}2250 \\
2200\end{array}$ \\
\hline $\mathrm{T} 2 \mathrm{~L} 3$ & $\begin{array}{l}11 / 01 / 94 \\
11 / 14 / 94 \\
11 / 15 / 94 \\
11 / 16 / 94 \\
11 / 17 / 94 \\
11 / 18 / 94 \\
11 / 19 / 94 \\
11 / 20 / 94 \\
11 / 21 / 94 \\
12 / 05 / 94 \\
12 / 15 / 94 \\
02 / 16 / 95 \\
05 / 07 / 96 \\
05 / 08 / 96 \\
05 / 09 / 96\end{array}$ & $\begin{array}{r}12.6 \\
14.4 \\
\\
12.1 \\
15.5 \\
15.5 \\
13.8 \\
14.8 \\
15.2 \\
14.5 \\
12.3 \\
4.8 \\
13.4 \\
14.7 \\
15.4\end{array}$ & $\begin{array}{l}7.5 \\
7.0 \\
7.4 \\
7.0 \\
7.0 \\
7.4 \\
7.5 \\
7.0 \\
6.6 \\
8.3 \\
7.1 \\
6.8 \\
6.9 \\
7.0 \\
6.9 \\
\end{array}$ & $\begin{array}{c}3.3 \\
4.0 \\
8.8 \\
9.3 \\
8.1 \\
5.9 \\
\\
11.2\end{array}$ & $\begin{array}{l}4250 \\
4580 \\
\\
4570 \\
4500 \\
4500 \\
4320 \\
4520 \\
2390 \\
3890 \\
4610 \\
4840 \\
4390 \\
4490 \\
4540 \\
\end{array}$ & $\begin{array}{l}685 \\
551 \\
576 \\
613 \\
625 \\
595 \\
604 \\
732 \\
615 \\
620\end{array}$ & $\begin{array}{l}0 \\
30 \\
0 \\
0\end{array}$ & $\begin{array}{r} \\
\\
\\
0.15 \\
0.85 \\
\end{array}$ & 0.25 & $\begin{array}{l}4.0 \\
4.0\end{array}$ & $\begin{array}{l}0 \\
0 \\
0 \\
0.1 \\
0\end{array}$ & $\begin{array}{l}2750 \\
2600\end{array}$ \\
\hline
\end{tabular}


Table 4.6. (continued)

\begin{tabular}{|c|c|c|c|c|c|c|c|c|c|c|c|c|}
\hline $\begin{array}{l}\text { Sample } \\
\text { location }\end{array}$ & $\begin{array}{l}\text { Date } \\
\text { sampled }\end{array}$ & $\begin{array}{c}\text { Temperature, } \\
{ }^{\circ} \mathrm{C}\end{array}$ & $\mathbf{p H}$ & $\begin{array}{l}\text { Do, } \\
\text { mg/L }\end{array}$ & $\begin{array}{c}\text { Electrical } \\
\text { conductivity, } \\
\mu \mathrm{mhos}\end{array}$ & $\begin{array}{c}\text { Alkalinity, } \\
\mathrm{mg} / \mathrm{L}\end{array}$ & $\begin{array}{c}\mathrm{H}_{2} \mathbf{O}_{2}, \\
\mathrm{mg} / \mathrm{L}\end{array}$ & $\begin{array}{c}\text { Fe, } \\
\mathrm{mg} / \mathrm{L}\end{array}$ & $\begin{array}{l}\text { Mn, } \\
\mathbf{m g} / \mathbf{L}\end{array}$ & $\begin{array}{c}\mathrm{Cl}, \\
\mathrm{mg} / \mathrm{L}\end{array}$ & $\begin{array}{l}\mathrm{NO}_{3} \\
\mathrm{mg} / \mathrm{L}\end{array}$ & $\begin{array}{l}\mathrm{SO}_{4}{ }^{2-} \\
\mathrm{mg} / \mathrm{L}\end{array}$ \\
\hline duplicate & $\begin{array}{l}11 / 01 / 94 \\
11 / 14 / 94 \\
11 / 15 / 94 \\
11 / 16 / 94 \\
11 / 17 / 94 \\
11 / 18 / 94 \\
11 / 19 / 94 \\
11 / 20 / 94 \\
11 / 20 / 94 \\
11 / 21 / 94 \\
12 / 05 / 94 \\
12 / 15 / 94 \\
02 / 16 / 95 \\
05 / 07 / 96 \\
05 / 08 / 96 \\
05 / 09 / 96\end{array}$ & $\begin{array}{c}11.6 \\
14.4 \\
\\
12.7 \\
16.0 \\
15.6 \\
14.3 \\
14.4 \\
14.4 \\
15.0 \\
14.7 \\
11.6 \\
7.3\end{array}$ & $\begin{array}{l}7.4 \\
6.6 \\
6.9 \\
6.8 \\
6.9 \\
6.8 \\
7.0 \\
7.2 \\
7.0 \\
6.7 \\
7.0 \\
7.0 \\
7.4 \\
\\
7.3 \\
7.1\end{array}$ & $\begin{array}{l}11.7 \\
8.0 \\
5.6 \\
4.4 \\
5.8 \\
7.1 \\
7.1 \\
5.0 \\
7.0 \\
8.7 \\
4.8 \\
5.3 \\
5.6\end{array}$ & $\begin{array}{l}4410 \\
4850 \\
\\
4720 \\
4700 \\
4380 \\
4530 \\
4370 \\
4370 \\
2500 \\
3700 \\
4071 \\
4610\end{array}$ & $\begin{array}{l}570 / 587 \\
549 \\
662 \\
561 \\
560 \\
556 \\
556 \\
604 \\
569 \\
597 \\
560\end{array}$ & $\begin{array}{l}0 \\
0 \\
0\end{array}$ & $\begin{array}{l}0.6 \\
0.13\end{array}$ & 0.25 & $\begin{array}{l}4.0 \\
3.8 \\
\end{array}$ & $\begin{array}{l}0.8 \\
0.4 \\
1.2 \\
0.6 \\
0.6 \\
0.8 \\
0 \\
\\
\\
0.5\end{array}$ & $\begin{array}{l}3500 \\
2750\end{array}$ \\
\hline
\end{tabular}


Table 4.7. Bionutrient test cell (T3), soil sample results

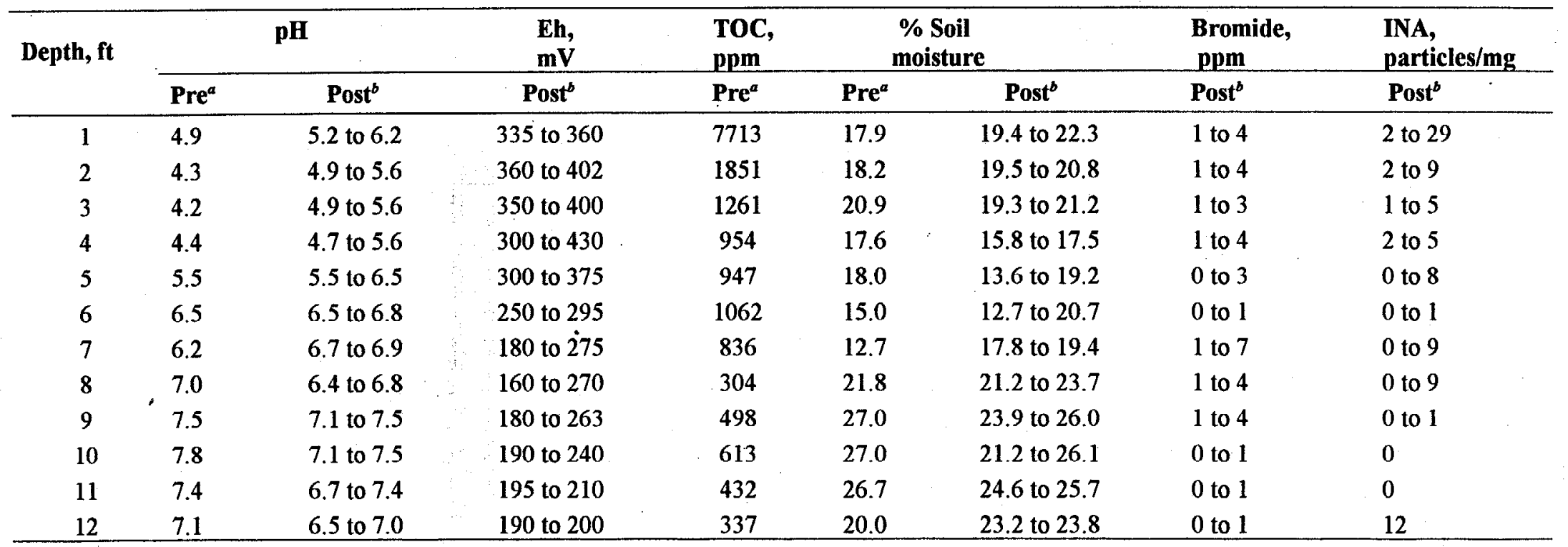

a Pre-treatment results

${ }_{b}$ Ranges of values are from five post-treatment soil borings. 
Table 4.8. Bionutrient test cell (T3) heterotrophic enumerations, cells/g

\begin{tabular}{|c|c|c|c|c|}
\hline \multirow[b]{2}{*}{ Location/Time } & \multicolumn{2}{|c|}{ Aerobic } & \multicolumn{2}{|c|}{ Anaerobic } \\
\hline & $4 \mathrm{ft}$ depth & $10 \mathrm{ft}$ depth & $4 \mathrm{ft}$ depth & $10 \mathrm{ft}$ depth \\
\hline T1/Pretest & $>1,100,000$ & 2400 & 100 & 10 \\
\hline T2/Pretest & $>1,100,000$ & 3900 & 10 & 10 \\
\hline T3/Pretest & $>1,100,000$ & 2400 & 1000 & 10 \\
\hline T3-G/3 days after injection & $\begin{array}{c}15,000 \\
\text { (2800 fungal) }\end{array}$ & 240 & 10 & 1 \\
\hline $\mathrm{T} 1-\mathrm{J} / 3$ days after injection & $\quad 3000$ & $\mathrm{ng}^{b}$ & 10 & ng \\
\hline T3-J /3 days after injection & $\begin{array}{c}46,000 \\
\text { (750 fungal) }\end{array}$ & 240 & 1 & ng \\
\hline $\mathrm{T} 1-\mathrm{K} / 30$ days after injection & 230 & 230 & ng & 100 \\
\hline T1-L/30 days after injection & 230 & 23 & 10 & 10 \\
\hline $\mathrm{T} 3-\mathrm{K} / 30$ days after injection & 23,000 & 23 & ng & 10 \\
\hline T3-L/30 days after injection & 230 & 23 & ng & ng \\
\hline
\end{tabular}

a fungal growth observed in serial dilutions in addition to bacterial growth.

${ }^{b} \mathrm{ng}=$ no growth observed.

Note: sample results shown are two week observations, while the "ng" results are four week observations.

Source: Pfiffner 1994. 
Table 4.9. Water sample results for the bionutrient test cell (T3), injection date 11/18/95

\begin{tabular}{|c|c|c|c|c|c|c|c|c|c|c|c|c|}
\hline $\begin{array}{l}\text { Sample } \\
\text { location }\end{array}$ & $\begin{array}{l}\text { Date } \\
\text { sampled }\end{array}$ & $\begin{array}{l}\text { Temperature, } \\
{ }^{\circ} \mathrm{C}\end{array}$ & pH & $\begin{array}{l}\text { Do, } \\
\text { mg/L }\end{array}$ & $\begin{array}{l}\text { Electrical } \\
\text { conductivity, } \\
\mu \mathrm{mhos}\end{array}$ & $\begin{array}{l}\text { Alkalinity, } \\
\text { mg/L }\end{array}$ & $\begin{array}{l}\text { Br, } \\
\text { mg/L }\end{array}$ & $\begin{array}{l}\mathrm{Fe}, \\
\mathrm{mg} / \mathrm{L}\end{array}$ & $\begin{array}{l}\text { Mn, } \\
\text { mg/L }\end{array}$ & $\begin{array}{l}\mathrm{Cl}^{-} \\
\mathrm{mg} / \mathrm{L}\end{array}$ & $\begin{array}{l}\mathrm{NO}_{3} \\
\mathrm{mg} / \mathrm{L}\end{array}$ & $\begin{array}{l}\mathrm{SO}_{4}{ }^{2-}, \\
\mathrm{mg} / \mathrm{L}\end{array}$ \\
\hline T3L1 & $\begin{array}{l}11 / 01 / 94 \\
11 / 19 / 94 \\
11 / 20 / 94 \\
11 / 21 / 94 \\
12 / 05 / 94 \\
12 / 15 / 94 \\
02 / 16 / 95 \\
05 / 07 / 96 \\
05 / 08 / 96 \\
05 / 09 / 96 \\
\end{array}$ & $\begin{array}{r}13.2 \\
14.8 \\
12.6 \\
14.3 \\
13.4 \\
9.7 \\
5.1 \\
13.0 \\
\\
16.1 \\
\end{array}$ & $\begin{array}{l}8.5 \\
7.2 \\
7.7 \\
7.7 \\
8.5 \\
7.1 \\
6.6 \\
6.4\end{array}$ & $\begin{array}{r}3.7 \\
4.9 \\
\\
12.0 \\
2.1 \\
0.8 \\
2.8 \\
0.8 \\
\end{array}$ & $\begin{array}{l}800 \\
1550 \\
1490 \\
1490 \\
1066 \\
1290 \\
1040 \\
990 \\
\\
1380 \\
\end{array}$ & $\begin{array}{l}323 \\
298 \\
228 \\
240 \\
188 \\
202\end{array}$ & $\begin{array}{l}50 \\
55 \\
62 \\
60 \\
46.3 \\
23.1\end{array}$ & $\begin{array}{l} \\
0.59 \\
\text { OR } \\
\end{array}$ & $\begin{array}{l}0.86 \\
0.50\end{array}$ & $\begin{array}{l}55.0 \\
60.0\end{array}$ & $\begin{array}{l}1.4 \\
1.2 \\
0.7 \\
. \\
0.3\end{array}$ & $\begin{array}{l}250 \\
450\end{array}$ \\
\hline T3L2 & $\begin{array}{l}11 / 01 / 94 \\
11 / 19 / 94 \\
11 / 20 / 94 \\
11 / 21 / 94 \\
12 / 05 / 94 \\
12 / 15 / 94 \\
02 / 16 / 95 \\
05 / 07 / 96 \\
05 / 08 / 96 \\
05 / 09 / 96 \\
\end{array}$ & $\begin{array}{r}13.5 \\
14.7 \\
13.6 \\
15.2 \\
14.6 \\
11.9 \\
5.8\end{array}$ & $\begin{array}{l}8.0 \\
7.8 \\
7.5 \\
7.6 \\
8.3 \\
7.4 \\
7.0 \\
.\end{array}$ & $\begin{array}{l}3.7 \\
7.0 \\
\\
3.3 \\
2.2 \\
1.7 \\
\\
3.2 \\
\end{array}$ & $\begin{array}{l}1650 \\
1790 \\
3500 \\
3910 \\
3310 \\
4750 \\
4280\end{array}$ & $\begin{array}{l}196 \\
194 \\
211 \\
218 \\
270 \\
316\end{array}$ & $\begin{array}{c}9.7 \\
55 \\
78 \\
75 \\
9.9 \\
20.4\end{array}$ & $\begin{array}{l}0.20 \\
0.15 \\
\\
0.37\end{array}$ & 0 & $\begin{array}{l}36.2 \\
54.0\end{array}$ & $\begin{array}{r}1.3 \\
1.6 \\
1.6 \\
\\
0.3\end{array}$ & $\begin{array}{l}2375 \\
2125\end{array}$ \\
\hline T3L3 & $\begin{array}{l}11 / 01 / 94 \\
11 / 18 / 94 \\
11 / 19 / 94 \\
11 / 20 / 94 \\
11 / 21 / 94 \\
12 / 05 / 94 \\
12 / 15 / 94 \\
02 / 16 / 95 \\
05 / 07 / 96 \\
05 / 08 / 96 \\
05 / 09 / 96\end{array}$ & $\begin{array}{c}12 \\
14.1 \\
9.3 \\
13.7 \\
15 \\
14.3 \\
12.9 \\
6.6 \\
14.4 \\
\\
16.4\end{array}$ & $\begin{array}{l}7.4 \\
6.9 \\
7.0 \\
7.1 \\
7.1 \\
7.5 \\
7.7 \\
6.9 \\
6.8\end{array}$ & $\begin{array}{r}1.6 \\
6.4 \\
3.0 \\
4.2 \\
5.3 \\
10.9 \\
0.6 \\
0.5\end{array}$ & $\begin{array}{l}3110 \\
4190 \\
4630 \\
4390 \\
4470 \\
3260 \\
4550 \\
4060 \\
4790\end{array}$ & $\begin{array}{l}517 \\
530 \\
518 \\
513 \\
480 \\
520 \\
486\end{array}$ & $\begin{array}{l}0.9 \\
0.9 \\
0.8 \\
1 \\
8.5 \\
4.7 \\
5.1\end{array}$ & $\begin{array}{l}0.12 \\
0.25 \\
0.28\end{array}$ & $\begin{array}{l}8.80 \\
1.15\end{array}$ & $\begin{array}{l}3.2 \\
3.0 \\
3.0\end{array}$ & $\begin{array}{l}0.1 \\
0.1 \\
0.1 \\
0.1 \\
\\
0.1\end{array}$ & $\begin{array}{l}2625 \\
2375 \\
2750\end{array}$ \\
\hline
\end{tabular}


Table 4.9. (continued)

\begin{tabular}{|c|c|c|c|c|c|c|c|c|c|c|c|c|}
\hline $\begin{array}{l}\text { Sample } \\
\text { location }\end{array}$ & $\begin{array}{l}\text { Date } \\
\text { sampled }\end{array}$ & $\begin{array}{l}\text { Temperature, } \\
{ }^{\circ} \mathrm{C}\end{array}$ & pH & $\begin{array}{l}\text { DO, } \\
\text { mg/L }\end{array}$ & $\begin{array}{l}\text { Electrical } \\
\text { conductivity, } \\
\mu \text { mhos }\end{array}$ & $\begin{array}{l}\text { Alkalinity, } \\
\text { mg/L }\end{array}$ & $\begin{array}{l}\text { Br, } \\
\text { mg/L }\end{array}$ & $\begin{array}{l}\text { Fe, } \\
\mathrm{mg} / \mathrm{L}\end{array}$ & $\begin{array}{l}\text { Mn, } \\
\text { mg/L }\end{array}$ & $\begin{array}{l}\mathrm{Cl}, \\
\mathrm{mg} / \mathrm{L}\end{array}$ & $\begin{array}{l}\mathrm{NO}_{3} \\
\mathrm{mg} / \mathrm{L}\end{array}$ & $\begin{array}{l}\mathrm{SO}_{4}^{2-} \\
\mathrm{mg} / \mathrm{L}\end{array}$ \\
\hline \multirow[t]{8}{*}{ T3P1 } & $11 / 18 / 94$ & 14.6 & 6.7 & 5.0 & 3240 & 410 & 0.9 & 0.20 & 2.00 & 5.2 & 0.3 & 1375 \\
\hline & $\begin{array}{l}11 / 19 / 94 \\
11 / 20 / 94\end{array}$ & 11.9 & 7.3 & 5.4 & 3710 & 395 & 0.8 & 0.33 & & & 0.1 & 2000 \\
\hline & $11 / 21 / 94$ & 15.3 & & & 3540 & 388 & 0.9 & & & & 0.1 & \\
\hline & $12 / 05 / 94$ & 14.7 & 6.9 & 2.5 & 3050 & 387 & 0.9 & & & & & \\
\hline & $12 / 15 / 94$ & 14.1 & 7.0 & & 3960 & 420 & 0.96 & & & & & \\
\hline & $02 / 16 / 95$ & 7.8 & 7.0 & & 4180 & 430 & 1.3 & & & & 0.1 & \\
\hline & $05 / 07 / 96$ & 16.1 & 6.7 & 3.0 & 3800 & & & & & & & \\
\hline & $05 / 08 / 96$ & 17.8 & 6.9 & 2.9 & 3930 & & & 2.95 & & & & \\
\hline
\end{tabular}

OR - over range 
Table 4.10. Lime slurry test cell (T4), soil sample results

\begin{tabular}{|c|c|c|c|c|c|c|c|c|}
\hline \multirow[t]{2}{*}{ Depth, ft } & \multicolumn{2}{|c|}{$\mathbf{p H}$} & \multirow{2}{*}{$\begin{array}{c}\mathbf{E h}, \\
\mathbf{m V}\end{array}$} & \multicolumn{2}{|c|}{$\begin{array}{c}\text { Ca, } \\
\text { ppm }\end{array}$} & \multirow{2}{*}{$\begin{array}{c}\text { TOC, } \\
\text { ppm }\end{array}$} & \multicolumn{2}{|c|}{$\%$ Soil moisture } \\
\hline & Pre $^{a}$ & Post $^{b}$ & & Pre $^{a}$ & Post $^{b}$ & & Pre $^{a}$ & Post $^{b}$ \\
\hline 1 & 4.6 & 5.1 to 12.6 & 360 to 380 & 128 & 121 to 1584 & 6933 & 16.0 & 18.6 to 20.4 \\
\hline 2 & 4.6 & 6.2 to 11.7 & 350 & 365 & 159 to 14,322 & 1707 & 17.8 & 17.8 to 20.1 \\
\hline 3 & 4.1 & 4.6 to 7.0 & 390 to 460 & 322 & 136 to 3533 & 1724 & 21.1 & 20.1 to 22.4 \\
\hline 4 & 4.6 & 4.5 to 6.0 & 390 to 430 & 378 & 225 to 4545 & 977 & 16.8 & 17.4 to 20.6 \\
\hline 5 & 5.6 & 5.3 to 6.9 & 395 to 490 & 475 & 355 to 2410 & 889 & 14.6 & 15.0 to 20.1 \\
\hline 6 & 7.0 & 6.6 to 11.6 & 370 to 390 & 645 & 464 to 3787 & 1187 & 15.3 & 17.3 to 21.5 \\
\hline 7 & 7.6 & 7.3 to 9.1 & 280 to 350 & 9575 & 526 to 4545 & 420 & 23.8 & 20.2 to 22.9 \\
\hline 8 & -- & 7.1 to 11.0 & 305 to 325 & -- & 3925 to 8607 & -- & - & 23.0 to 25.6 \\
\hline 9 & 7.6 & 7.3 to 11.8 & 320 to 340 & 6000 & 1750 to 6859 & 412,430 & 24.0 & 22.3 to 27.1 \\
\hline 10 & 7.8 & 7.4 to 12.0 & 295 to 305 & 3500 & 2852 to 4573 & 305,412 & 26.9 & 22.9 to 26.9 \\
\hline 11 & 7.0 & 7.3 to 7.9 & 305 to 330 & 8075 & 2341 to 4885 & 305 & 23.2 & 23.4 to 47.6 \\
\hline 12 & 7.5 & .7 .6 to 7.9 & 275 to 330 & 1838 & 549 to 4200 & 821 & 25.3 & 22.7 to 26.2 \\
\hline
\end{tabular}

a Pre-treatment results

b Ranges of values are from five post-treatment soil borings.

-- No sample taken 
Table 4.11. Water sample results for the lime slurry test cell (T4), injection date 11/13/95

\begin{tabular}{|c|c|c|c|c|c|c|c|c|c|c|}
\hline $\begin{array}{l}\text { Sample } \\
\text { location }\end{array}$ & $\begin{array}{l}\text { Date } \\
\text { sampled }\end{array}$ & $\begin{array}{l}\text { Temperature, } \\
{ }^{\circ} \mathrm{C} \\
\end{array}$ & pH & $\begin{array}{l}\text { DO, } \\
\text { mg/L }\end{array}$ & $\begin{array}{l}\text { Electrical } \\
\text { conductivity, } \\
\mu \text { mhos }\end{array}$ & $\begin{array}{l}\text { Alkalinity, } \\
\mathrm{mg} / \mathrm{L}\end{array}$ & $\begin{array}{l}\mathrm{Fe}, \\
\mathrm{mg} / \mathrm{L}\end{array}$ & $\begin{array}{l}\mathrm{Mn}, \\
\mathrm{mg} / \mathrm{L}\end{array}$ & $\begin{array}{l}\mathrm{Cl}, \\
\mathrm{mg} / \mathrm{L}\end{array}$ & $\begin{array}{l}\mathrm{SO}_{4}^{2-} \\
\mathrm{mg} / \mathrm{L}\end{array}$ \\
\hline $\mathrm{T} 4 \mathrm{~L} 1$ & $\begin{array}{l}11 / 01 / 94 \\
11 / 13 / 94 \\
11 / 14 / 94 \\
11 / 15 / 94 \\
11 / 16 / 94 \\
11 / 17 / 94 \\
11 / 18 / 94 \\
11 / 19 / 94 \\
11 / 20 / 94 \\
11 / 21 / 94 \\
12 / 05 / 94 \\
12 / 15 / 94 \\
02 / 16 / 95 \\
05 / 07 / 96 \\
05 / 08 / 96 \\
05 / 09 / 96 \\
\end{array}$ & $\begin{array}{l}13.2 \\
11.6 \\
12.3 \\
13.4 \\
14.4 \\
12.9 \\
13.5 \\
15.0 \\
13.2 \\
10.6 \\
13.8 \\
14.2 \\
15.3 \\
17.5 \\
\end{array}$ & $\begin{array}{r}7.5 \\
7.7 \\
12.3 \\
12.2 \\
12.4 \\
12.2 \\
11.8 \\
11.8 \\
11.8 \\
11.6 \\
12.1 \\
11.7 \\
11.0 \\
7.7 \\
9.2 \\
8.2 \\
\end{array}$ & $\begin{array}{r}6.5 \\
7.4 \\
5.1 \\
3.1 \\
\\
3.1 \\
3.4 \\
1.8 \\
11.7 \\
3.5 \\
3.1 \\
1.4 \\
0.3 \\
1.0 \\
\end{array}$ & $\begin{array}{r}750 \\
5380 \\
5210 \\
4750 \\
5000 \\
4230 \\
4650 \\
2420 \\
1790 \\
1305 \\
1980 \\
2100 \\
2450 \\
\end{array}$ & $\begin{array}{r}430 \\
1150 \\
2100 \\
980 \\
1047 \\
968 \\
100 \\
918 \\
942 \\
574 \\
280 \\
113 \\
\vdots \\
\\
\end{array}$ & $\begin{array}{l}0.15 \\
\\
\\
\\
0.21 \\
0.41 \\
\end{array}$ & 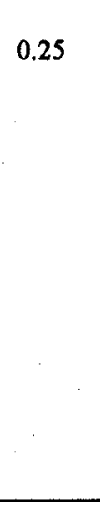 & $\begin{array}{l}23.3 \\
29.8\end{array}$ & $\begin{array}{l}425 \\
180 \\
175\end{array}$ \\
\hline T4L2 & $\begin{array}{l}11 / 01 / 94 \\
11 / 13 / 94 \\
11 / 14 / 94 \\
11 / 15 / 94 \\
11 / 16 / 94 \\
11 / 17 / 94 \\
11 / 18 / 94 \\
11 / 19 / 94 \\
11 / 20 / 94 \\
11 / 21 / 94 \\
12 / 05 / 94 \\
12 / 15 / 94 \\
02 / 16 / 95 \\
05 / 07 / 96 \\
05 / 08 / 96 \\
05 / 09 / 96\end{array}$ & \begin{tabular}{|l|}
14.4 \\
12.8 \\
14.4 \\
\\
14.8 \\
15.1 \\
16.2 \\
14.1 \\
14.4 \\
15.8 \\
13.2 \\
12.6 \\
4.7 \\
13.9 \\
13.5
\end{tabular} & $\begin{array}{r}7.8 \\
7.9 \\
11.4 \\
12.4 \\
12.4 \\
12.2 \\
12.3 \\
12.1 \\
12.0 \\
11.5 \\
12.1 \\
11.3 \\
9.6 \\
6.9 \\
9.0\end{array}$ & $\begin{array}{r}12.0 \\
5.0 \\
6.3 \\
2.7 \\
2.6 \\
3.1 \\
\\
2.9 \\
11.7 \\
7.9 \\
3.2 \\
2.1 \\
3.0 \\
7.4 \\
\end{array}$ & $\begin{array}{l}2350 \\
3550 \\
\\
7300 \\
5360 \\
7160 \\
7170 \\
6980 \\
3580 \\
2420 \\
3010 \\
2820 \\
4660 \\
3910\end{array}$ & $\begin{array}{r}1084 \\
1250 \\
1170 \\
1210 \\
1262 \\
1187 \\
1138 \\
1136 \\
574 \\
100 \\
33\end{array}$ & 0.23 & 0.75 & $\begin{array}{l}20.0 \\
17.8 \\
22.5\end{array}$ & $\begin{array}{l}1500 \\
1600 \\
2125 \\
1500\end{array}$ \\
\hline
\end{tabular}


Table 4.11. (continued)

\begin{tabular}{|c|c|c|c|c|c|c|c|c|c|c|}
\hline $\begin{array}{l}\text { Sample } \\
\text { location }\end{array}$ & $\begin{array}{l}\text { Date } \\
\text { sampled }\end{array}$ & $\begin{array}{l}\text { Temperature, } \\
{ }^{\circ} \mathrm{C} \\
\end{array}$ & pH & $\begin{array}{l}\mathrm{DO}, \\
\mathrm{mg} / \mathrm{L}\end{array}$ & $\begin{array}{l}\text { Electrical } \\
\text { conductivity, } \\
\mu \text { mhos }\end{array}$ & $\begin{array}{l}\text { Alkalinity, } \\
\text { mg/L }\end{array}$ & $\begin{array}{l}\text { Fe, } \\
\text { mg/L }\end{array}$ & $\begin{array}{l}\text { Mn, } \\
\mathbf{m g} / \mathbf{L}\end{array}$ & $\begin{array}{l}\mathrm{Cl} \text {, } \\
\mathrm{mg} / \mathrm{L}\end{array}$ & $\begin{array}{l}\mathrm{SO}_{4}^{2-}, \\
\mathrm{mg} / \mathrm{L}\end{array}$ \\
\hline \multirow[t]{15}{*}{ T4L3 } & $11 / 01 / 94$ & 12.8 & 7.3 & 2.0 & 3860 & & & & & \\
\hline & $11 / 13 / 94$ & 14.1 & 7.1 & 3.1 & 4650 & - 220 & 0.08 & 0.25 & 6.0 & 2600 \\
\hline & $11 / 14 / 94$ & 10.3 & 6.9 & 5.2 & 4740 & 570 & 0.13 & 0.25 & 7.0 & 2700 \\
\hline & $11 / 15 / 94$ & & 7.1 & 1.9 & & 626 & 0.05 & . & 6.8 & 3250 \\
\hline & $11 / 16 / 94$ & 14.1 & 7.0 & 1.9 & 4840 & 588 & & & & 2900 \\
\hline & $11 / 17 / 94$ & 14.9 & 6.9 & 3.3 & 4750 & 627 & & & & \\
\hline & $11 / 18 / 94$ & 15.5 & 7.1 & 4.1 & 3140 & 655 & & & & \\
\hline & $11 / 19 / 94$ & 13.7 & 7.1 & 9.2 & 4620 & 646 & & & & \\
\hline & $11 / 20 / 94$ & 14.4 & 7.5 & 2.2 & 2470 & 645 & & & & \\
\hline & $11 / 21 / 94$ & 15.4 & 7.0 & 12.5 & 4920 & 741 & & & & \\
\hline & $12 / 05 / 94$ & 14.0 & 7.8 & 4.6 & 2050 & 598 & & & & \\
\hline & $12 / 15 / 94$ & 12.5 & 7.4 & 1.4 & 4900 & 685 & & & & \\
\hline & $02 / 16 / 95$ & 6.6 & 7.2 & & 4960 & 631 & & & & \\
\hline & $05 / 08 / 96$ & 14.7 & 7.1 & 1.4 & 4740 & & 0.01 & & & \\
\hline & $05 / 09 / 96$ & 16.3 & 6.8 & 1.5 & 4830 & & 0.07 & & & \\
\hline
\end{tabular}


Table 4.12. Potassium permanganate test cell (T5), soil sample results

\begin{tabular}{|c|c|c|c|c|c|c|c|}
\hline \multirow[t]{2}{*}{ Depth, it } & \multicolumn{2}{|c|}{ pH } & \multirow{2}{*}{$\begin{array}{l}\text { Eh, } \\
\text { mV } \\
\text { Post }^{b}\end{array}$} & \multirow{2}{*}{$\begin{array}{l}\text { TOC, } \\
\text { ppm } \\
\text { Pre }^{a}\end{array}$} & \multicolumn{2}{|c|}{$\begin{array}{c}\text { \% Soil } \\
\text { moisture }\end{array}$} & \multirow{2}{*}{$\begin{array}{c}\begin{array}{c}\text { Manganese, } \\
\text { ppm }\end{array} \\
\text { Post }^{b}\end{array}$} \\
\hline & Pre ${ }^{a}$ & Post $^{b}$ & & & Pre $^{a}$ & Post $^{b}$ & \\
\hline 1 & 4.7 & 4.7 to 5.3 & 240 to 533 & 3483 & 15.7 & 17.4 to 20.8 & 9 to 344 \\
\hline 2 & 4.7 & 4.4 to 4.8 & 400 to 830 & 1295 & 19.0 & 19.3 to 20.8 & 4 to 770 \\
\hline 3 & 4.3 & 4.4 to 4.9 & 385 to 880 & 1103 & 16.9 & 14.8 to 21.4 & 3 to 89 \\
\hline 4 & 4.7 & 4.4 to 5.0 & 490 to 840 & 1108 & 12.3 & 14.1 to 17.4 & 71 to 181 \\
\hline 5 & 6.7 & 6.0 to 7.1 & 350 to 725 & 989 & 18.4 & 12.7 to 17.0 & 0 to 60 \\
\hline 6 & 7.1 & 6.8 to 7.0 & 540 to 690 & 405 & 19.8 & 17.1 to 19.2 & 0 to 14 \\
\hline 7 & 6.2 & 6.7 to 7.2 & 639 to 680 & 286 & 21.5 & 18.6 to 19.7 & 0 to 1 \\
\hline 8 & 7.8 & 7.4 to 7.6 & 515 to 688 & 367 & 24.4 & 21.6 to 24.2 & 0 to 3 \\
\hline 9 & 7.5 & 6.8 to 7.7 & 575 to 672 & 381 & 25.3 & 25.1 to 25.9 & 1 to 5 \\
\hline 10 & 7.7 & 6.9 to 7.6 & 320 to 570 & 396 & 26.3 & 26.1 to 27.4 & 1 to 7 \\
\hline 11 & 7.6 & 7.3 to 7.6 & 235 to 530 & 492 & 27.8 & 19.9 to 27.1 & 1 to 6 \\
\hline 12 & 6.9 & 7.4 to 8.0 & 252 to 460 & 630 & 22.5 & 22.7 to 26.9 & 2 to 10 \\
\hline
\end{tabular}

a Pre-treatment results

${ }^{b}$ Ranges of values are from five post-treatment soil borings. 
Table 4.13. Water sample results for the potassium permanganate test cell (T5), injection date 11/16/94

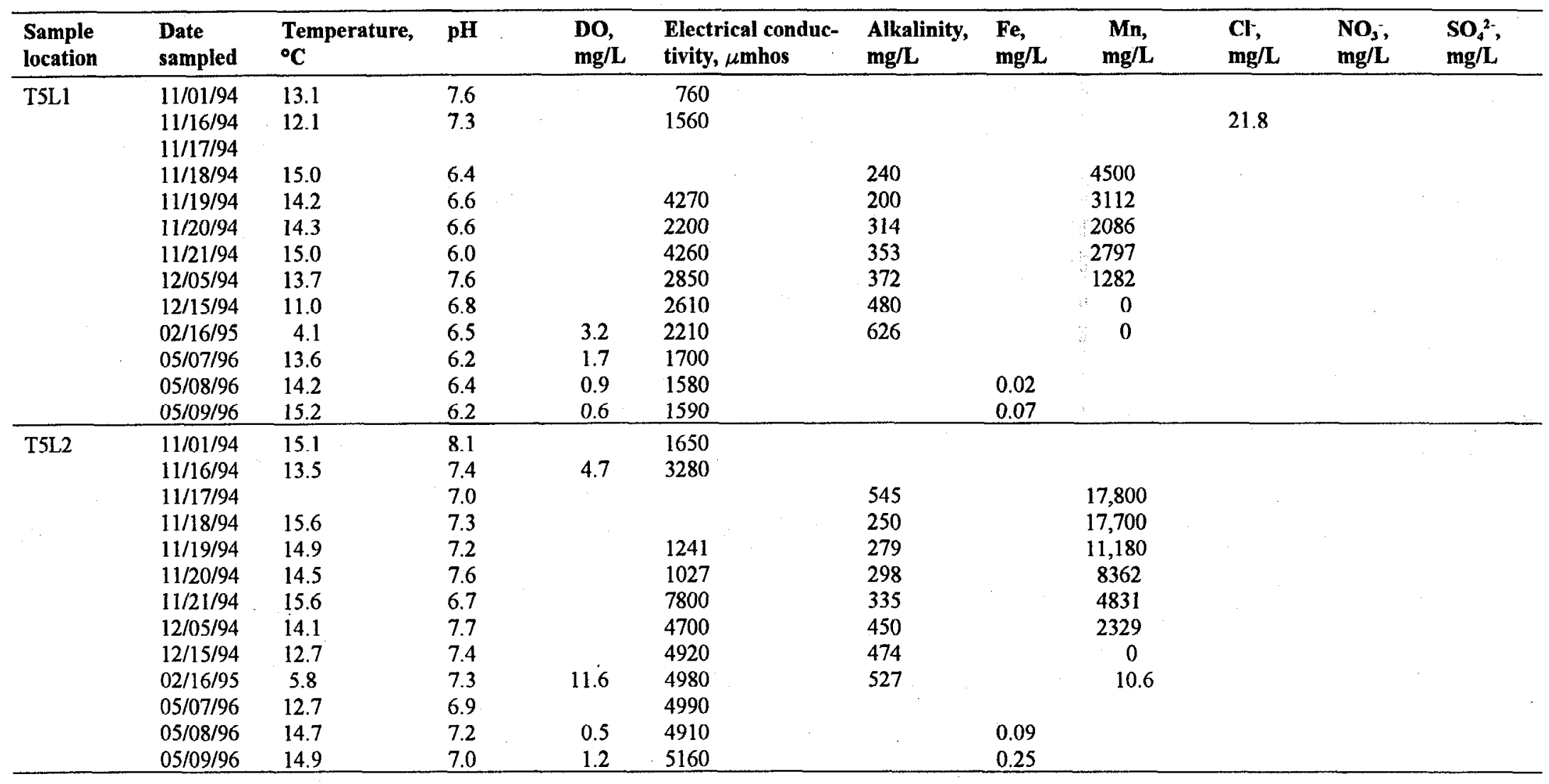


Table 4.13. (continued)

\begin{tabular}{|c|c|c|c|c|c|c|c|c|c|c|c|}
\hline $\begin{array}{l}\text { Sample } \\
\text { location }\end{array}$ & $\begin{array}{l}\text { Date } \\
\text { sampled }\end{array}$ & $\begin{array}{l}\text { Temperature, } \\
{ }^{\circ} \mathrm{C}\end{array}$ & pH & $\begin{array}{l}\mathrm{DO}, \\
\mathrm{mg} / \mathrm{L}\end{array}$ & $\begin{array}{l}\text { Electrical conduc- } \\
\text { tivity, } \mu \text { mhos }\end{array}$ & $\begin{array}{l}\text { Alkalinity, } \\
\text { mg/L }\end{array}$ & $\begin{array}{l}\text { Fe, } \\
\mathrm{mg} / \mathrm{L}\end{array}$ & $\begin{array}{l}\text { Mn, } \\
\text { mg/L }\end{array}$ & $\begin{array}{l}\mathrm{Cl} \text {; } \\
\mathrm{mg} / \mathrm{L}\end{array}$ & $\begin{array}{l}\mathrm{NO}_{3} \\
\mathrm{mg} / \mathrm{L}\end{array}$ & $\begin{array}{l}\mathrm{SO}_{4}{ }^{2-} \\
\mathrm{mg} / \mathrm{L}\end{array}$ \\
\hline \multirow[t]{2}{*}{ T5L3 } & $11 / 01 / 94$ & 12.9 & 7.4 & & 3010 & & & & & & \\
\hline & $11 / 16 / 94$ & 13.5 & 7.1 & 6.0 & 4320 & 530 & 0 & 0.6 & 7.8 & 0.1 & 2050 \\
\hline \multirow[t]{11}{*}{ duplicate } & $11 / 16 / 94$ & & 7.2 & & & & & & 6.5 & & \\
\hline & $11 / 17 / 94$ & & 7.0 & & & 523 & & 50.4 & 8.0 & & 2750 \\
\hline & $11 / 18 / 94$ & 15.0 & 6.9 & & & 568 & & & & & \\
\hline & $11 / 19 / 94$ & 15.0 & 7.4 & 3.5 & 4420 & 294 & & 1.75 & & & \\
\hline & $11 / 20 / 94$ & 14.6 & 7.2 & 2.3 & 4660 & 578 & & & & & \\
\hline & $12 / 05 / 94$ & 14.2 & 7.3 & 6.4 & 3810 & 603 & & 6.6 & & & \\
\hline & $12 / 15 / 94$ & 130 & 7.0 & 2.5 & 4830 & 588 & & 4.89 & & & \\
\hline & $02 / 16 / 95$ & 6.7 & 6.8 & 4.3 & 4710 & 570 & & 0 & & & \\
\hline & $05 / 07 / 96$ & 12.9 & 6.9 & 1.4 & 4420 & & & & & & \\
\hline & $05 / 08 / 96$ & 15.0 & 7.0 & 4.2 & 4330 & & 0.07 & & & & \\
\hline & $05 / 09 / 96$ & 17.4 & & 1.5 & 4520 & & 0.14 & & & & \\
\hline \multirow[t]{11}{*}{$\mathrm{T} 5 \mathrm{P} 1$} & $11 / 01 / 94$ & 11.6 & 7.1 & & 4370 & & & & & & \\
\hline & $11 / 16 / 94$ & 13.7 & 6.7 & 5.7 & 4860 & 570 & 0.1 & 0 & 4.0 & 0.2 & \\
\hline & $11 / 19 / 94$ & 15.3 & 6.8 & & 2500 & 249 & & 0.4 & & & \\
\hline & $11 / 20 / 94$ & 14.6 & 7.0 & 6.1 & 4270 & 525 & & & & & \\
\hline & $11 / 21 / 94$ & 15.5 & 6.7 & 12.8 & 960 & 98 & & 0.34 & & & \\
\hline & $12 / 05 / 94$ & 14.5 & 6.8 & 4.7 & 3760 & 562 & & 0 & & & \\
\hline & $12 / 15 / 94$ & 12.9 & 7.0 & & 5040 & 587 & & 8.14 & & & \\
\hline & $02 / 16 / 94$ & 7.0 & 7.4 & & 4780 & 565 & & & & & \\
\hline & $05 / 07 / 96$ & & & 8.3 & & & & & & & \\
\hline & $05 / 08 / 96$ & 17.0 & 7.1 & 4.6 & 4350 & & 0.00 & & & & \\
\hline & $05 / 09 / 96$ & 19.8 & 6.8 & 3.2 & 4690 & & 0.25 & & & & \\
\hline
\end{tabular}


Table 4.14. Water sample results for air test cell (T6), injection date 11/19/94

\begin{tabular}{|c|c|c|c|c|c|c|c|c|c|c|c|}
\hline $\begin{array}{l}\text { Sample } \\
\text { location }\end{array}$ & $\begin{array}{l}\text { Date } \\
\text { sampled }\end{array}$ & $\begin{array}{c}\text { Temperature, } \\
{ }^{\circ} \mathrm{C} \\
\end{array}$ & pH & $\begin{array}{l}\text { DO, } \\
\text { mg/L }\end{array}$ & $\begin{array}{l}\text { Electrical } \\
\text { conductivity, } \\
\mu \text { mhos }\end{array}$ & $\begin{array}{l}\text { Alkalinity, } \\
\mathrm{mg} / \mathrm{L}\end{array}$ & $\begin{array}{l}\text { Fe, } \\
\mathrm{mg} / \mathrm{L}\end{array}$ & $\begin{array}{l}\mathrm{Mn}, \\
\mathrm{mg} / \mathrm{L}\end{array}$ & $\begin{array}{l}\mathrm{Cl}^{-}, \\
\mathrm{mg} / \mathrm{L}\end{array}$ & $\begin{array}{l}\mathrm{NO}_{3}^{-} \\
\mathrm{mg} / \mathrm{L}\end{array}$ & $\begin{array}{l}\mathrm{SO}_{4}^{2-} \\
\mathrm{mg} / \mathrm{L}\end{array}$ \\
\hline T6L1 & $\begin{array}{l}11 / 01 / 94 \\
11 / 19 / 94 \\
11 / 20 / 94 \\
11 / 21 / 94 \\
12 / 05 / 94 \\
12 / 15 / 94 \\
02 / 16 / 95 \\
05 / 07 / 96 \\
05 / 08 / 96 \\
05 / 09 / 96 \\
\end{array}$ & $\begin{array}{l}\text { dry } \\
\text { dry } \\
\text { dry } \\
\text { dry } \\
\text { dry } \\
13.0 \\
\text { dry } \\
15.3 \\
15.5 \\
15.8 \\
\end{array}$ & $\begin{array}{l}8.3 \\
6.3 \\
6.4 \\
6.1 \\
\end{array}$ & $\begin{array}{l}4.7 \\
1.8 \\
2.6 \\
\end{array}$ & $\begin{array}{l}430 \\
430 \\
450 \\
\end{array}$ & & $\begin{array}{l}0.13 \\
0.24 \\
\end{array}$ & & . & & \\
\hline T6L2 & $\begin{array}{l}11 / 01 / 94 \\
11 / 19 / 94 \\
11 / 20 / 94 \\
11 / 21 / 94 \\
12 / 05 / 94 \\
12 / 15 / 94 \\
02 / 16 / 95 \\
05 / 07 / 96 \\
05 / 08 / 96 \\
05 / 09 / 96 \\
\end{array}$ & $\begin{array}{c}\text { dry } \\
11.5 \\
\text { dry } \\
15.5 \\
\text { dry } \\
13.0 \\
7.5 \\
\\
14.3 \\
15.0 \\
\end{array}$ & $\begin{array}{l}7.4 \\
7.2 \\
8.0 \\
7.3 \\
7.3 \\
\end{array}$ & $\begin{array}{l}6.1 \\
4.0 \\
8.7 \\
2.7 \\
2.9 \\
\end{array}$ & $\begin{array}{r}1380 \\
1350 \\
2230 \\
2190 \\
1310 \\
1600 \\
\end{array}$ & . & $\begin{array}{l}0.37 \\
0.30 \\
\end{array}$ & 0.4 & 13.5 & 0.2 & 500 \\
\hline T6L3 & $\begin{array}{l}11 / 01 / 94 \\
11 / 19 / 94 \\
11 / 20 / 94 \\
11 / 21 / 94 \\
12 / 05 / 94 \\
12 / 15 / 94 \\
02 / 16 / 95 \\
05 / 07 / 96 \\
05 / 08 / 96 \\
05 / 09 / 96\end{array}$ & $\begin{array}{r}12.9 \\
13.0 \\
13.6 \\
15.1 \\
14.2 \\
13.0 \\
6.4 \\
14.4 \\
17.1 \\
17.6 \\
\end{array}$ & $\begin{array}{l}7.8 \\
7.4 \\
7.3 \\
6.7 \\
7.3 \\
7.3 \\
7.0 \\
7.3 \\
7.1 \\
\end{array}$ & $\begin{array}{l}2.9 \\
3.8 \\
\\
1.7 \\
4.0 \\
3.4 \\
2.8 \\
4.5 \\
3.4 \\
\end{array}$ & $\begin{array}{l}1720 \\
1300 \\
1170 \\
1070 \\
884 \\
2230 \\
1938 \\
520 \\
460 \\
520 \\
\end{array}$ & $\begin{array}{l}258 \\
271\end{array}$ & $\begin{array}{l} \\
0.01 \\
0.04 \\
\end{array}$ & $\begin{array}{l}0.7 \\
1.55\end{array}$ & $\begin{array}{l}5.8 \\
3.8 \\
\end{array}$ & $\begin{array}{l}0 \\
0.1\end{array}$ & $\begin{array}{l}875 \\
975\end{array}$ \\
\hline
\end{tabular}


Table 4.15. Iron micropowder test cell (T7), soil sample results

\begin{tabular}{clllll}
\hline Depth, ft & & pH & $\begin{array}{l}\text { Eh, } \\
\mathbf{m V}\end{array}$ & $\begin{array}{l}\text { TOC, } \\
\text { ppm }\end{array}$ & $\begin{array}{l}\text { Iron, } \\
\text { ppm }\end{array}$ \\
\cline { 2 - 6 } & Pre $^{a}$ & Post $^{b}$ & Post $^{b}$ & Pre & Post $^{b}$ \\
\hline 1 & 6.5 & 5.4 to 5.5 & 330 to 380 & 6893 & 3.0 to 3.5 \\
2 & 4.6 & 5.7 to 6.4 & 380 to 390 & 1903 & 13.1 to OR \\
3 & 4.7 & 5.2 to 5.4 & 410 to 420 & 1110 & 0.9 to 29.5 \\
4 & 4.9 & 5.5 to 5.6 & 370 to 380 & 1277 & 0.5 to 1.2 \\
5 & 6.4 & 5.5 to 6.3 & 270 to 280 & 866 & 2.3 to 32.8 \\
6 & 6.7 & 6.4 to 6.4 & 210 to 240 & 1631 & 1.0 to 1.0 \\
7 & 6.5 & 6.4 to 6.5 & 200 to 230 & 531 & 2.4 to 3.5 \\
8 & 7.4 & 6.4 to 6.6 & 150 to 200 & 385 & 0.9 to 1.2 \\
9 & 7.0 & 6.8 to 7.1 & 150 to 180 & 383 & 0.2 to 1.2 \\
10 & 6.9 & 6.5 to 6.7 & 135 to 165 & 394 & 1.2 to 1.7 \\
11 & 6.9 & 6.6 to 6.8 & 140 to 165 & 033 & 1.3 to 1.8 \\
12 & 7.7 & 6.1 & 170 & 393 & 1.4 to 3.2 \\
\hline
\end{tabular}

${ }^{a}$ Pre-treatment results

${ }^{b}$ Ranges of values are from five post-treatment soil borings.

$\mathrm{OR}=$ over range 
Table 4.16. Water sample results for iron micropowder test cell (T7), injection date 11/19/94

\begin{tabular}{|c|c|c|c|c|c|c|c|c|c|c|c|c|}
\hline $\begin{array}{l}\text { Sample } \\
\text { location }\end{array}$ & $\begin{array}{l}\text { Date } \\
\text { sampled }\end{array}$ & $\begin{array}{l}\text { Temperature, } \\
{ }^{\circ} \mathrm{C}\end{array}$ & pH & $\begin{array}{l}\mathrm{DO}, \\
\mathrm{mg} / \mathrm{L}\end{array}$ & $\begin{array}{l}\text { Electrical } \\
\text { conductivity, } \\
\mu \mathrm{mhos} \\
\end{array}$ & $\begin{array}{l}\text { Alkalinity, } \\
\text { mg/L }\end{array}$ & $\begin{array}{l}\mathrm{Br}, \\
\mathrm{mg} / \mathbf{L}\end{array}$ & $\begin{array}{l}\text { Fe, } \\
\mathrm{mg} / \mathrm{L}\end{array}$ & $\begin{array}{l}\mathrm{Mn}, \\
\mathrm{mg} / \mathrm{L}\end{array}$ & $\begin{array}{l}\mathrm{Cl}^{-}, \\
\mathrm{mg} / \mathrm{L}\end{array}$ & $\begin{array}{l}\mathrm{NO}_{3}^{-} \\
\mathrm{mg} / \mathrm{L}\end{array}$ & $\begin{array}{l}\mathrm{SO}_{4}^{2-}, \\
\mathrm{mg} / \mathrm{L}\end{array}$ \\
\hline \multirow[t]{10}{*}{ T7L1 } & $11 / 01 / 94$ & 12.7 & 8.8 & & 460 & & & & & & & \\
\hline & $11 / 19 / 94$ & 9.2 & 7.6 & & 860 & 200 & & 0.1 & 0.4 & 34.0 & 1.1 & 150 \\
\hline & $11 / 20 / 94$ & 12.0 & 7.9 & & 790 & 163 & 0.9 & 0.7 & & 3.7 & 1.1 & 188 \\
\hline & $11 / 21 / 94$ & 15.4 & 7.2 & 6.5 & 590 & & & 0.1 & & & & 188 \\
\hline & $12 / 05 / 94$ & & & & & & & & & & & \\
\hline & $12 / 15 / 94$ & 11.6 & 6.6 & 10.4 & 795 & & & OR & 2.0 & & & \\
\hline & $02 / 16 / 95$ & 4.0 & 6.2 & 11.0 & 833 & & & 25.5 & 2.7 & & & \\
\hline & $05 / 07 / 96$ & 14.7 & 6.1 & 1.8 & 430 & & & & & & & \\
\hline & $05 / 08 / 96$ & 15.8 & 5.9 & 1.2 & 280 & & & 2.98 & & & & \\
\hline & $05 / 09 / 96$ & 15.9 & 5.9 & 1.0 & 490 & & & OR & & & & \\
\hline \multirow[t]{9}{*}{ T7L2 } & $11 / 01 / 94$ & 14.7 & 9.0 & & 1030 & & & & & & & \\
\hline & $11 / 19 / 94$ & 9.1 & 8.0 & & 820 & 188 & & 3.1 & 0.4 & 10.5 & 0.6 & 330 \\
\hline & $11 / 20 / 94$ & 13.0 & 8.0 & 5.2 & 1000 & 173 & 0.7 & 0.3 & 0.2 & 11.2 & 0.2 & 900 \\
\hline & $12 / 05 / 94$ & 14.8 & 7.3 & 11.5 & 1381 & & & 3.2 & 0.5 & & & 850 \\
\hline & $12 / 15 / 94$ & 12.7 & 6.9 & 3.0 & 2580 & & & OR & & & & \\
\hline & $02 / 16 / 95$ & 4.8 & 7.3 & 5.6 & 1913 & & & 5.8 & & & & \\
\hline & $05 / 07 / 96$ & 13.7 . & 7.2 & 0.9 & 2140 & & & & & & & \\
\hline & $05 / 08 / 96$ & 13.7 & 7.2 & 1.2 & 2120 & & & OR & & & & \\
\hline & $05 / 09 / 96$ & 16.4 & 7.2 & 2.4 & 2000 & & & OR & & & & \\
\hline
\end{tabular}


Table 4.16. (continued)

\begin{tabular}{|c|c|c|c|c|c|c|c|c|c|c|c|c|}
\hline $\begin{array}{l}\text { Sample } \\
\text { location }\end{array}$ & $\begin{array}{l}\text { Date } \\
\text { sampled }\end{array}$ & $\begin{array}{l}\text { Temperature, } \\
{ }^{\circ} \mathrm{C} \\
\end{array}$ & pH & $\begin{array}{l}\text { DO, } \\
\mathrm{mg} / \mathrm{L}\end{array}$ & $\begin{array}{l}\text { Electrical } \\
\text { conductivity, } \\
\mu \text { mhos }\end{array}$ & $\begin{array}{l}\text { Alkalinity, } \\
\mathrm{mg} / \mathrm{L}\end{array}$ & $\begin{array}{l}\mathrm{Br} \\
\mathrm{mg} / \mathrm{L}\end{array}$ & $\begin{array}{l}\text { Fe, } \\
\mathrm{mg} / \mathrm{L}\end{array}$ & $\begin{array}{l}\mathrm{Mn}, \\
\mathrm{mg} / \mathrm{L}\end{array}$ & $\begin{array}{l}\mathrm{Cl} \text {, } \\
\mathrm{mg} / \mathrm{L}\end{array}$ & $\begin{array}{l}\mathrm{NO}_{3} \\
\mathrm{mg} / \mathrm{L}\end{array}$ & $\begin{array}{l}\mathrm{SO}_{4}^{2-}, \\
\mathrm{mg} / \mathrm{L}\end{array}$ \\
\hline \multirow[t]{10}{*}{ T7L3 } & $11 / 01 / 94$ & 13.0 & 7.6 & & 2780 & & & & & & & $\cdot$ \\
\hline & $11 / 19 / 94$ & 13.0 & 7.3 & 1.6 & 3520 & 380 & & 0.1 & 1.6 & 4.0 & 0.1 & 900 \\
\hline & $11 / 20 / 94$ & 13.3 & 7.3 & 3.1 & 2090 & 451 & 0.7 & 0.2 & 2.2 & 3.2 & 0.6 & 2432 \\
\hline & $11 / 21 / 94$ & 15.1 & 6.8 & 9.4 & 3620 & & & 0.1 & 2.0 & & & 2375 \\
\hline & $12 / 05 / 94$ & 14.8 & 8.5 & & & & & 0.4 & 1.5 & & & \\
\hline & $12 / 15 / 94$ & 13.2 & 7.2 & 4.9 & 4390 & & & 0.8 & 3.3 & & & \\
\hline & $02 / 16 / 95$ & 5.8 & 7.0 & 1.7 & 4350 & & & 1.8 & 1.3 & & & \\
\hline & $05 / 07 / 96$ & 14.1 & 6.9 & 1.0 & 3840 & & & & & & & \\
\hline & $05 / 08 / 96$ & 14.8 & 7.1 & 3.5 & 3740 & & & 0.06 & & & & \\
\hline & $05 / 09 / 96$ & 17.1 & 6.9 & 2.3 & 3920 & & & 0.16 & & & & \\
\hline
\end{tabular}

$\mathrm{OR}=$ over range

Blanks indicate insufficient sample volume for analyses 



\section{Equipment Operations Observations}

One of the objectives of this field test was to determine the operational characteristics of the MPIS process. This objective was accomplished by observation and documentation during the field tests. Observations included injection volumes, flow rates, back pressure, general equipment operations, and operational and maintenance problems.

The average volume of fluid injected into the soil at the CTS was about $0.27 \mathrm{gal} / \mathrm{ft}^{3}$, calculated in the following way:

$7,030 \mathrm{ft}^{3}=$ cell volume (effective treated cell size of $26 \mathrm{ft} \times 26 \mathrm{ft} \times 10.4 \mathrm{ft}$ ),

$1900 \mathrm{gal}=$ average volume injected ( $2300 \mathrm{gal}$ per test cell minus $400 \mathrm{gal}$ lost to surface seepage)

$0.27 \mathrm{gal} / \mathrm{ft}^{3}=1900 \mathrm{gal} / 7,098 \mathrm{ft}^{3}$.

The approximate volume of the air-filled pores within each test cell prior to injection was estimated at about 2,000 gal or $270 \mathrm{ft}^{3}$. This was in part, the basis for the target injection volume. If the injected fluid, which equaled approximately 1900 gal, entered the air filled pores, then the soil within each test cell should have been $100 \%$ saturated after injection. Post-treatment soil sample data indicate that the soil was not uniformly $100 \%$ saturated; thus, some of the injected fluid must have moved outside of the test cell boundaries along fractures and other preferred flow paths.

Although the average injection pressure was about $100 \mathrm{psi}$, it fluctuated between 60 and 200 psi depending on the resistance of the soil to injection. This injection pressure range is similar to that used during a previous conventional soil fracturing test conducted at the CTS and may have had similar effects (i.e., creating fractures in the fine-grained media). During fluid injection, the flow rates varied from 15 to $40 \mathrm{gal} / \mathrm{min}$, again depending on the resistance of the soil to injection. Activities performed, production rates, and total time for each major activity are shown on Table 5.1.

Based on the work conducted, it appears that the system is capable of delivering approximately 2 gal of reagent per injector per 15 -in. interval to a depth of $10.4 \mathrm{ft}$ in about 5 to $6 \mathrm{~min}$ per injection location. The cost per day for subcontractor equipment and labor was approximately $\$ 1300$ (1994 cost). The equipment is capable of delivering reagent to between 10,500 and $16,000 \mathrm{ft}^{3}$ of soil in an 8-h work day. Thus, the cost per cubic foot of soil at the CTS was between $\$ 0.12 / \mathrm{ft}^{3}$ and $\$ 0.08 / \mathrm{ft}^{3}$ ( $\$ 3.24$ to $\$ 2.16 /$ cubic yard). The cost for reagents varied considerably, depending on the particular chemical, the purity, and the desired concentration of the injected solution. Extrapolation of these costs to a contaminated site would require a multiplier to account for additional operating requirements such as waste management, a higher level of worker protection, and other issues. 
During the injections, several operational requirements were noted. The machine operates by performing an injection and then backing up $2 \mathrm{ft}$ to start the next injection. Because the solution delivery hose connects to the back of the machine, the hose must be moved manually so the machine does not run over it. Much time can be spent in mixing reagent solutions and the injection progresses much more rapidly if enough solution is mixed to inject the entire area to be treated prior to starting the injection. This could require mixing almost 5,000 gal of solution for a full day of injection activities. The individual injector ports can clog with soil very easily when stop-and-go injection is performed. It is prudent to check the injector ports aboveground occasionally to see if all injectors are open. If there are clogged ports, they can be easily cleared with a piece of wire. If work is being conducted in a contaminated area, some means of containing any seepage to the ground surface should be in place prior to the start of injection to prevent spreading contamination in runoff from the injected site. This could be accomplished with a shallow trench, filter booms, and/or silt fencing. Work can be conducted in relatively restricted surroundings as the equipment is highly maneuverable and is capable of angled injections.

Generally speaking, the MPIS provides a rapid means of injecting reagent into the subsurface to a depth of $10.4 \mathrm{ft}$. There are other units available capable of injecting to $30 \mathrm{or} 40 \mathrm{ft}$, but these are not as maneuverable and their cost is considerably more than the system tested for this demonstration. The system tested is largely nondisruptive to subsurface supports such as footers or pipe beds, and injections can be performed close to buildings and other cultural features. The system is also capable of being using an angles up to $45^{\circ}$ from vertical. 
Table 5.1. Task summary for MPIS testing

\begin{tabular}{|c|c|c|}
\hline Activity & Production rate & Total time \\
\hline $\begin{array}{l}\text { Pre-treatment } \\
\text { characterization }\end{array}$ & $\begin{array}{l}\text { Pre-treatment borings, } \\
6 \text { to } 7 / \mathrm{d} \\
\text { Lysimeters, } 12 / \mathrm{d} \\
\text { Piezometers, } 5 / \mathrm{d} \\
\text { SMT probes, } 24 / \mathrm{d} \\
\text { Water samples, } 30 / \mathrm{d}\end{array}$ & $\begin{array}{l}5 \mathrm{~d} / 32 \text { borings } \\
2 \mathrm{~d} / 24 \text { lysimeters } \\
1 \mathrm{~d} / 5 \text { piezometers } \\
1 \mathrm{~d} / 24 \text { SMT probes } \\
1 \mathrm{~d} / 30 \text { samples }\end{array}$ \\
\hline $\begin{array}{l}\text { Mobilization and } \\
\text { shakedown }\end{array}$ & $\begin{array}{l}\text { Mobilization, } 2 \mathrm{~d} \\
\text { Shakedown, } 2 \mathrm{~d}\end{array}$ & $4 \mathrm{~d}$ \\
\hline Reagent mixing & 0.5 to $1 \mathrm{~h} / 1000 \mathrm{gal}$ batch & $10 \mathrm{~h} / 13,000 \mathrm{gal}$ \\
\hline Test cell 1 injection & $5.3 \mathrm{~min} / \mathrm{setup}$ & $190 \min$ for 36 setups \\
\hline Test cell 2 injection & $5.7 \mathrm{~min} / \mathrm{setup}$ & $205 \min$ for 36 setups \\
\hline Test cell 3 injection & $5.7 \mathrm{~min} / \mathrm{setup}$ & 205 min for 36 setups \\
\hline Test cell 4 injection & $4.3 \mathrm{~min} / \mathrm{setup}$ & $155 \min$ for 36 setups \\
\hline Test cell 5 injection & $5.4 \mathrm{~min} / \mathrm{setup}$ & 195 min for 36 setups \\
\hline Test cell 6 injection & $5 \mathrm{~min} / \mathrm{setup}$ & $20 \mathrm{~min}$ for four setups \\
\hline Test cell 7 injection & $5.5 \mathrm{~min} / \mathrm{setup}$ & $22 \mathrm{~min}$ for four setups \\
\hline $\begin{array}{l}\text { Post-treatment } \\
\text { characterization }\end{array}$ & $\begin{array}{l}\text { Soil borings, } 5 \text { to } 6 / \mathrm{d} \\
\text { Water samples, } 12 \text { to } 30 / \mathrm{d}\end{array}$ & $\begin{array}{l}7 \mathrm{~d} / 37 \text { borings } \\
11 \mathrm{~d} / 200 \text { samples }\end{array}$ \\
\hline
\end{tabular}





\section{Summary and Conclusions}

The purpose of the permeation and dispersal of reactive fluids project at the PORTS CTS was to evaluate:

- the feasibility of using the MPIS for injection of treatment agents into the subsurface, and

- the relative effectiveness of injecting contrasting treatment agents for in situ remediation of low permeability soils.

The stated objectives of this project were to:

- characterize pore fracture size and continuity in the untreated soil and then determine changes in fracture size and continuity as affected by reagent or air injection,

- determine matrix effects of the various fluids released with respect to changes in soil $\mathrm{pH}$, TOC, conductivity, etc.,

- determine dispersal of reactive particles in LPM,

- determine dispersal of oxidants in LPM, and

- determine the operation and maintenance characteristics of the injection tool.

Performance testing of the MPIS at the PORTS CTS has demonstrated that it is feasible to use the MPIS for injection of various reagents into relatively shallow depths of low permeability soil. However, observations suggest that the treatment agents injected advect along pre-existing preferential flow paths and only in cases of persistent agents, do they diffuse into matrix blocks. Observations of the various injections also indicate that the initial effect generally occurred in the upper more structured zone of the subsurface at the test site. Percolation of the injected media from the saturated upper soils over time resulted in subsequent, and less dramatic, changes to the deeper portions of the cells.

The relative success of injecting the various treatments appears to be similar. Post-treatment soil sampling results and boring logs indicate that the distribution patterns for the treatment agents were comparable. Thus, the slurry mixtures (i.e., lime, iron micropowder/guar gum) flowed through the injector system and penetrated the subsurface equally as well as other media (e.g., peroxide solution). From an operational standpoint, no problems occurred with the MPIS during injection of any of the treatments; however, the tank containing the iron micropowder required continuous stirring to prevent settling of the metal particles.

Pre-treatment and post-treatment soil boring logs were prepared for each test cell to assess macroscopic changes in pore fracture size and continuity. No significant changes were observed, excluding the filling of the existing fractures and macropores with the injected 
media. Sample cores from each test cell were also collected for X-ray and SEM analysis to assess pre- and post-treatment fracture morphology. X-ray data were inconclusive, and SEM analyses were not completed.

Varying matrix effects were observed for the various treatment injections. No notable effects were observed for test cell 1 (water with tracers) and test cell 6 (air). The most significant effect observed in test cell 2 (hydrogen peroxide) was a significant decrease in TOC at a depth of up to $2 \mathrm{ft}$ bgs; however, little change was observed at greater depths. The peroxide injection also effected a significant increase in DO in the lysimeter (water) samples. Results from test cell 2 also indicate that the peroxide reacts rapidly in the fine-grained soil and degrades in a relatively short time (a few days). No significant matrix effects were observed in test cell 3 (bionutrients with tracers) soils. However, increased nitrate levels were measured in lysimeter samples as a result of the nutrient ingredients.

Significant matrix effects were observed in test cell 4 (lime slurry). The lime injection resulted in dramatic $\mathrm{pH}$ increases in both soil and lysimeter samples. Alkalinity and conductivity measurements also increased substantially in the water samples. These effects appear to be fairly long lasting (at least 4 weeks). Post-treatment results from test cell 5 (potassium permanganate) indicated dramatic increases in soil Eh throughout the soil profile and a slight decrease in $\mathrm{pH}$ in the water samples. Post-treatment manganese concentrations in lysimeter samples remain elevated for. approximately 5 weeks. Thus, of the oxidants injected, the potassium permanganate appears to react mildly but will persist longer than the peroxide. No significant matrix effects were observed for test cell 7 (iron micropowder) soils, excluding an increase in the iron concentration. However, a decrease in $\mathrm{pH}$ was observed in the water samples in conjunction with an increase in the soluble iron concentration.

The dispersal of the various treatment agents in low permeability soils was generally related to the success of the injection. Thus, there was a similar pattern of initial dispersal in each test cell as discussed previously. However, additional dispersal in the subsurface over time was observed for those treatments (i.e., lime, potassium permanganate, and iron) that were soluble and more persistent. This appeared to occur as affected water percolated downward through the soil.

Based on the results of the testing at the PORTS CTS, the MPIS shows promise for treatment of contaminants in shallow, low permeability soils. The injected treatment agents follow preexisting preferential flow paths in low permeability soils (e.g., fractures) but do not appear to create new fractures. The system could be used to deliver a treatment medium into the preferential flow paths, thereby preventing further migration of contaminants, at least until the agent was exhausted or flushed out by surface recharge. Additional treatment could occur by subsequent percolation of affected water through the contaminated soil layer. The MPIS would probably be very effective at delivering solutions into unconsolidated sandy sediments or loose tailings. 


\section{$6-3$}

Based on their inherent reactive characteristics, three of the treatments tested at the CTS have potential application for in situ remediation of VOCs in low permeability soils. These include hydrogen peroxide, potassium permanganate, and iron micropowder. Further testing of these treatments in conjunction with the MPIS is recommended for a contaminated site. The other treatments tested at the CTS are generally not effective for chlorinated solvents; however, they could be delivered with the MPIS for in situ treatment at other contaminated sites. 



\section{References}

American Petroleum Institute. 1995. Petroleum Contaminated Low Permeability Soil: Hydrocarbon Distribution Processes, Exposure Pathways and In Situ Remediation Technologies. Health and Environmental Sciences Dept. Publication No. 4631, September.

Case, T. 1997. Reactive permanganate grouts for horizontal permeable barriers and in situ treatment of ground water. M.S. thesis, Environmental Science \& Engineering Division, Colorado School of Mines, Golden, Colorado.

Davenport, D.T., D.J. Georgopoulos, R.L. Siegrist, M.I. Morris, and O.R. West. 1994. Technology Demonstration, Assessment, and Application for a RCRA Closure: Observations and Lessons Learned in the Process. Proc. Spectrum '94, Atlanta, August, 1994.

Gates, D.D. and R.L. Siegrist. 1995. In Situ Chemical Oxidation of Trichloroethylene Using Hydrogen Peroxide. ASCE Journal of Environmental Engineering, 121(9):639-644.

Gierke, J.S., C. Wang, O.R. West, and R.L. Siegrist. 1995. "In Situ Mixed Region Vapor Stripping of Low Permeability Media: 3. Modeling of Field Tests". Environ. Science \& Technology, 29(9):2208-2216.

Huling, S.G. and J.W. Weaver. 1991. Dense Nonaqueous Phase Liquids. Ground Water Issue Paper, EPA/540/4-91-002. Office of Research and Development, Washington, D.C. 20460.

Johnson, R., D. Grady, T. Walden, and H. Hopkins. 1995. Remediation of Gasoline Contaminated Low Permeability Media as Evaluated at a Controlled Release Test Site. Invited presentation at the Second International Conference on Challenges and Innovations in the Management of Hazardous Wastes. Air and Waste Management Conference, May, 1995, Washington, D.C.

Johnson, R.L., and D. Grady. 1995. Remediation of Tight Soils Using Air Flushing: Summary of 1994 Field Experiments at Sarnia Ontario. Prepared for the American Petroleum Institute by Oregon Graduate Institute Center for Groundwater Research, Beaverton, Oregon.

MacDonald, J. A. and M. Kavanaugh. 1994. Restoring Contaminated Groundwater: An Achievable Goal? 1994. Environmental Science \& Technology, 28(8):362A-368A.

Murdoch, L., B. Slack, B. Siegrist, S. Vesper, and T. Meiggs. 1997a. Hydraulic Fracturing Advances. Civil Engineering, May, pp. 10A-12A. 
Murdoch, L., W. Slack, R. Siegrist, S. Vesper, and T. Meiggs. 1997b. Advanced Hydraulic Fracturing Methods to Create In Situ Reactive Barriers. Proc. International Containment Technology Conference and Exhibition. February 9-12, 1997, St. Petersburg, FL. In press.

ORNL. 1994. Final Work Plan for Multi-port Injector System Testing in Low-Permeability Soils at the Clean Test Site. Oak Ridge National Laboratory, Grand Junction, Colorado.

ORNL. 1993. Environmental Technology Section (formerly Pollutant Assessments Group) Procedures Manual. ORNL-6645/R2. Oak Ridge National Laboratory, Grand Junction, Colorado.

Pfiffner, S.M., R.L. Siegrist, K.S. Lowe, D.B. Ringleberg, and A.V. Palumbo. 1997. Sarnia: Bioremediation Processes Demonstrated at a Controlled Release Site. Symposium on In Situ and On-Site Bioremediation. April 1997. New Orleans.

Pfiffner, S. 1994. Written communication with R. L. Siegrist, ORNL from Susan Pfiffner, University of Tennessee Center for Environmental Biotechnology, Microbial Enumerations and Activities.

Siegrist, R. L., K. S. Lowe, L. C. Murdoch, D. A. Pickering, and T. L. Case. 1999. In Situ Oxidation by Fracture Emplaced Reactive Solids. J. Environmental Engineering. 125(5):429-440.

Siegrist, R. L., K. S. Lowe, L. C. Murdoch, W. W. Slack, and T. C. Houk. 1998. $X-231 A$ Demonstration of In Situ Remediation of DNAPL Compounds in Low Permeability Media by Soil Fracturing with Thermally Enhanced Mass Recovery or Reactive Barrier Destruction. ORNL/TM-13534. Oak Ridge National Laboratory, Oak Ridge, Tennessee.

Siegrist, R.L., N.E. Korte, D. Smuin, O.R. West, D.D. Gates, and J.S. Gunderson. 1996. In Situ Treatment of Contaminants in Low Permeability Soils: Biogeochemical Enhancement by Subsurface Manipulation. Invited presentation at First International Conference on Contaminants in the Soil Environment in the Australasia-Pacific Region. February 1996, Adelaide, South Australia.

Siegrist, R.L. and K.S. Lowe (ed.). 1995. In Situ Remediation of DNAPL Compounds in Low Permeability Media - Interim Report. Interim project report prepared by Oak Ridge National Laboratory with contributions from an ad hoc team of scientists and engineers from DOE national laboratories, academia, and industry. 
Siegrist, R.L., O.R. West, M. I. Morris, D. A. Pickering, D. W. Greene, C. A. Muhr, D. D. Davenport and J .S. Gierke.. 1995a. In Situ Mixed Region Vapor Stripping of Low Permeability Media. 2. Full Scale Field Experiments. Environ. Science \& Technology. 29(9):2198-2207.

Siegrist, R.L., N. E. Korte, M.T. Muck, D.R. Smuin, A.D. Laase, O.R. West, D.T. Davenport, and J. Walker. 1995b. Field Evaluation of Subsurface Manipulation by Fracturing, Multipoint Injection/Dispersal, and Directional Drilling Using Unconfined Test Cells. Invited presentation at the Second International Conference on Challenges and Innovations in the Management of Hazardous Wastes. Air and Waste Management Conference, May, 1995, Washington, D.C.

Siegrist R.L., N.E. Korte, M.T. Muck, D.R. Smuin, A.D. Laase, O.R. West, D.T. Davenport, and J. Walker. 1995c. Field Evaluation of Subsurface Manipulation by Fracturing, Permeation Dispersal, and Horizontal Well Recirculation Using Unconfined Test Cells. Invited presentation at the National Ground Water Association Annual Educational Conference, October, 1995, Indianapolis, IN.

Siegrist, R. L., M. I. Morris, O. R. West, D. A. Pickering, C. A. Muhr, D. W. Greene, D. D. Gates, T. J. Mitchell, R. A. Jenkins, and T. McKnight. 1994a. X-231B Technology Demonstration for In Situ Treatment of Contaminated Soil: Field Evaluation of Mixed Region Vapor Stripping, Chemical Oxidation, and Solidification Processes. ORNL/TM12261. Oak Ridge National Laboratory, Oak Ridge, Tennessee.

Siegrist, R. L., M. I. Morris, O. R. West, D. D. Gates, D. A. Pickering, R. A. Jenkins, T. J. Mitchell, D. W. Greene, C. A. Muhr, S. E. Herbes, T. M. Gilliam, H. L. Jennings, A. J. Lucero, J. Zutman, T. McKnight, and J. S. Watson. 1995. The X-231B Technology Demonstration for In Situ Treatment of Contaminated Soil: Field Demonstration and Testing of Vapor Stripping, Peroxidation, and Solidification. ORNL/TM-12261. Oak Ridge National Laboratory, Oak Ridge, Tennessee.

Siegrist, R.L., O. R. West, D. D. Gates, S. E. Herbes, M. I. Morris, T. M. Gilliam, H. L. Jennings, A. J. Lucero, J. S. Watson, D. A. Pickering, D. W. Greene, C. A. Muhr, J. Zutman, R. A. Jenkins, T. J. Mitchell, T. McKnight, D. T. Davenport. 1993. In: Post, R. G. Full-scale Field Demonstration and Testing of Physicochemical Processes for In Situ Treatment of Contaminated Soil. Proc. Waste Management '93. Feb. 28 - Mar. 41993. Tucson, AZ. American Nuclear Society, pp. 849 - 854. 
Smuin, D.R., R.L. Siegrist, N.E. Korte, O.R. West, J. Strong-Gunderson, and P.M. Kearl. 1995. Bromide Tracer Evaluation of a Multipoint Injection System for Soil Treatment. Presentation at American Geophysical Union, Fall, 1995 meeting.

Strong-Gunderson. J. M., and A. V. Palumbo. 1995. Laboratory Studies Demonstrate an Innovative Colloid Traccr: Real Time, Sensitive, and Non-Persistent.

Urynowicz, M. A. and R. L. Siegrist. 2000. Permeation Dispersal of Treatment Agents for In Situ Remediation in Low Permeability Media: 2. Laboratory Studies with Intact Cores. ORNL/TM-13597. Oak Ridge National Laboratory, Oak Ridge, Tennessee.

U.S. DOE. 1996. In Situ Remediation of DNAPL Compounds in Low Permeability Media Fate/Transport, In Situ Constol Technologies, and Risk Reduction. ORNL/TM13305. Oak Ridge National Laboratory, Oak Ridge, Tennessee.

U.S. EPA. 1992. Dense Nonaqueous Phase Liquids -- A workshop Summary. EPA/600/R-92/030. Office of Research and Development, Washington, D.C. 20460.

Walden, T. 1993. Remediation of Low Permeability Soils: An API Research Program. Proc. 1993 Petroleum Hydrocarbons and Organic Chemicals in Groundwater: Prevention, Detection, and Restoration. Houston, TX. National Water Well Assn. pp. 623-629.

West, Or. R., R. L. Siegrist, J. S. Gierke, S. W. Schmunk, A. J. Lucero, and H. L. Jennings. 1995. In Situ Mixed Region Vapor Stripping of Low Permeability Media. 1. Process Features and Laboratory Experiments. Environmental Science \& Technology. 29(9):2191 - 2197. 
APPENDIX A

GEOTECHNICAL, BACKGROUND, AND GRAIN SIZE DISTRIBUTION RESULTS FOR THE CTS 
A-1

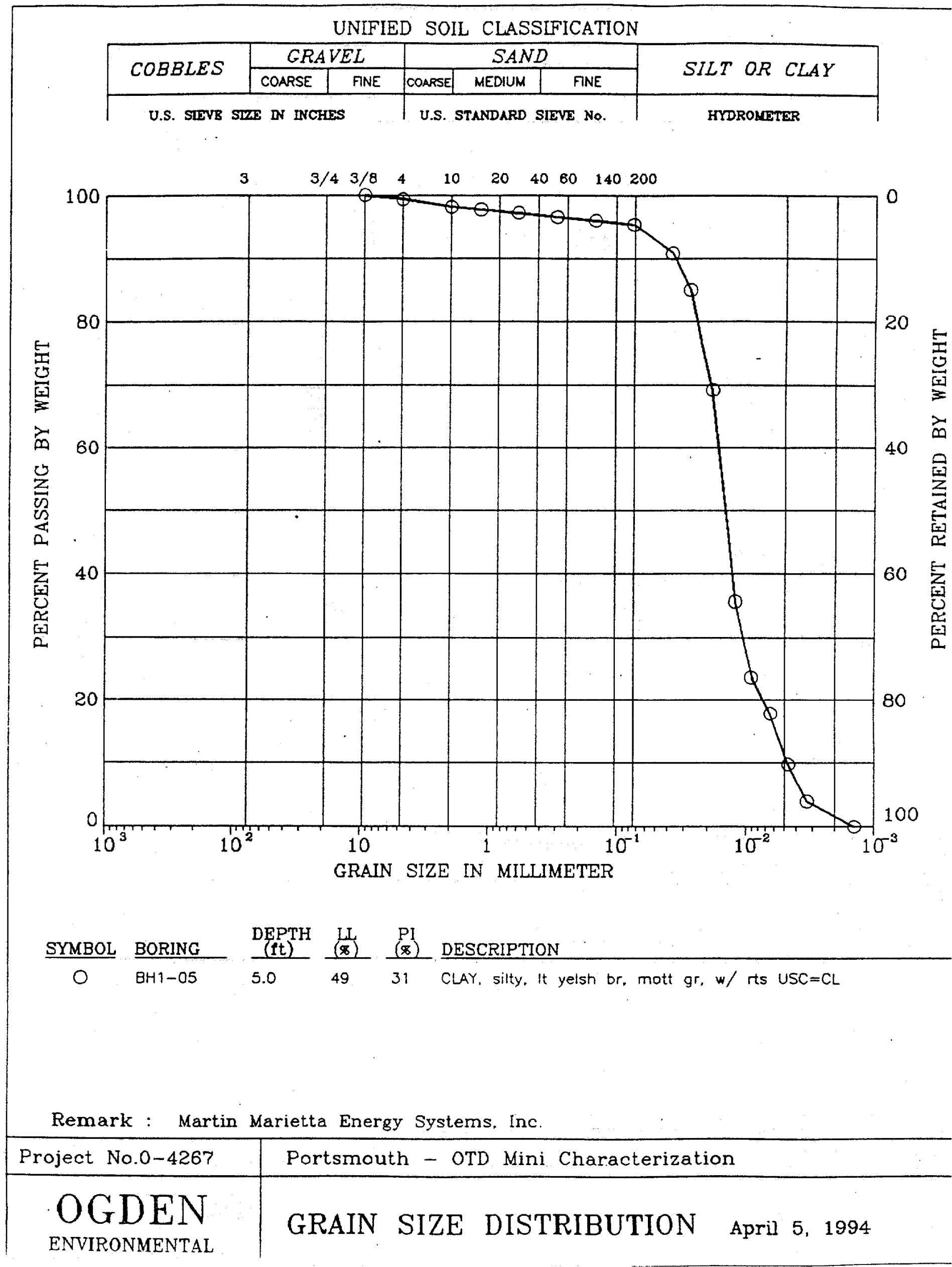


$A-2$

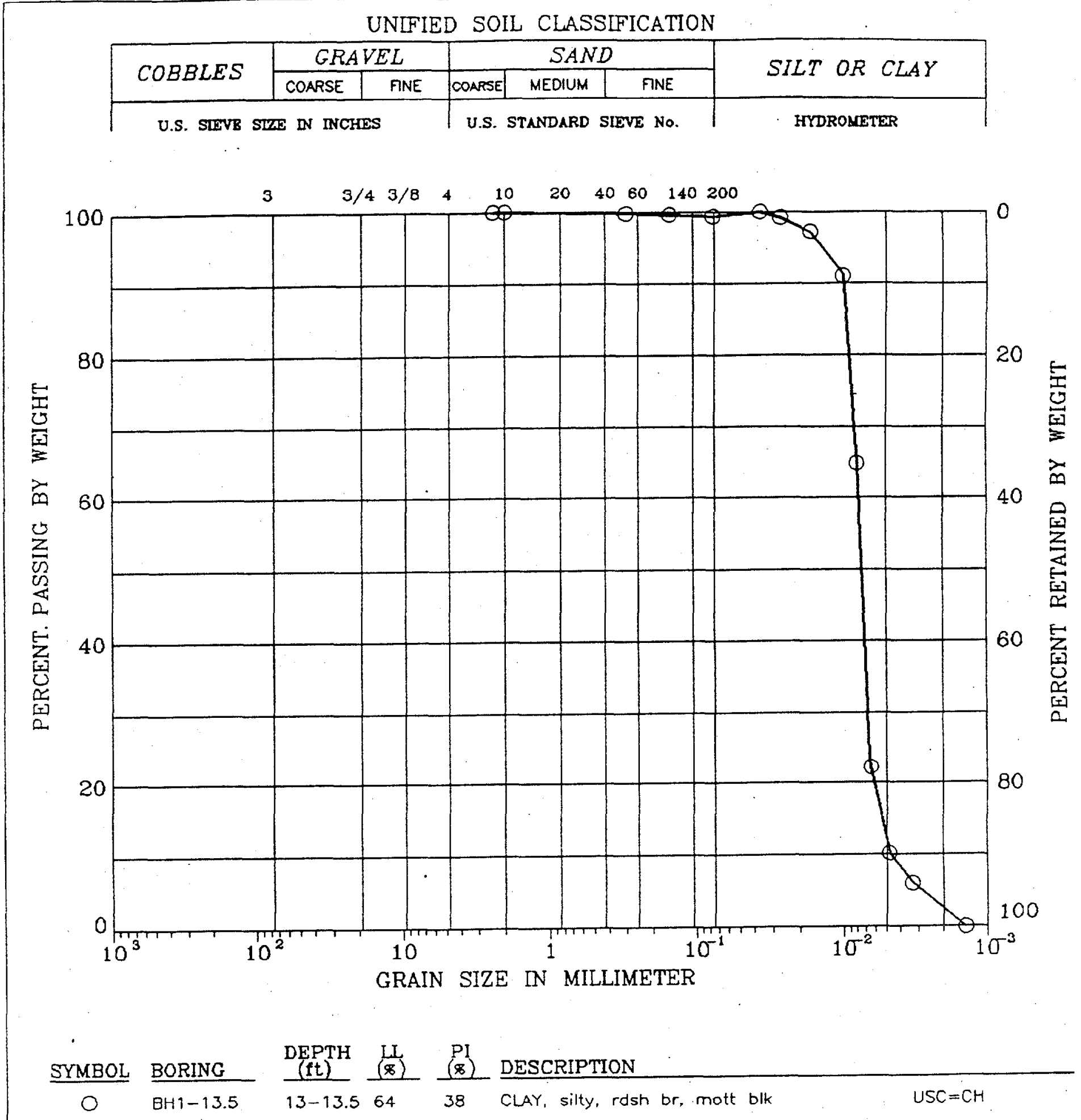

Remark : Martin Marietta Energy Systems, Inc.

\begin{tabular}{|l|l}
\hline Project No.0-4267 & Portsmouth - OTD Mini Characterization
\end{tabular}

\section{OGDEN GRAIN SIZE DISTRIBUTION April 5. 1994}


A-3

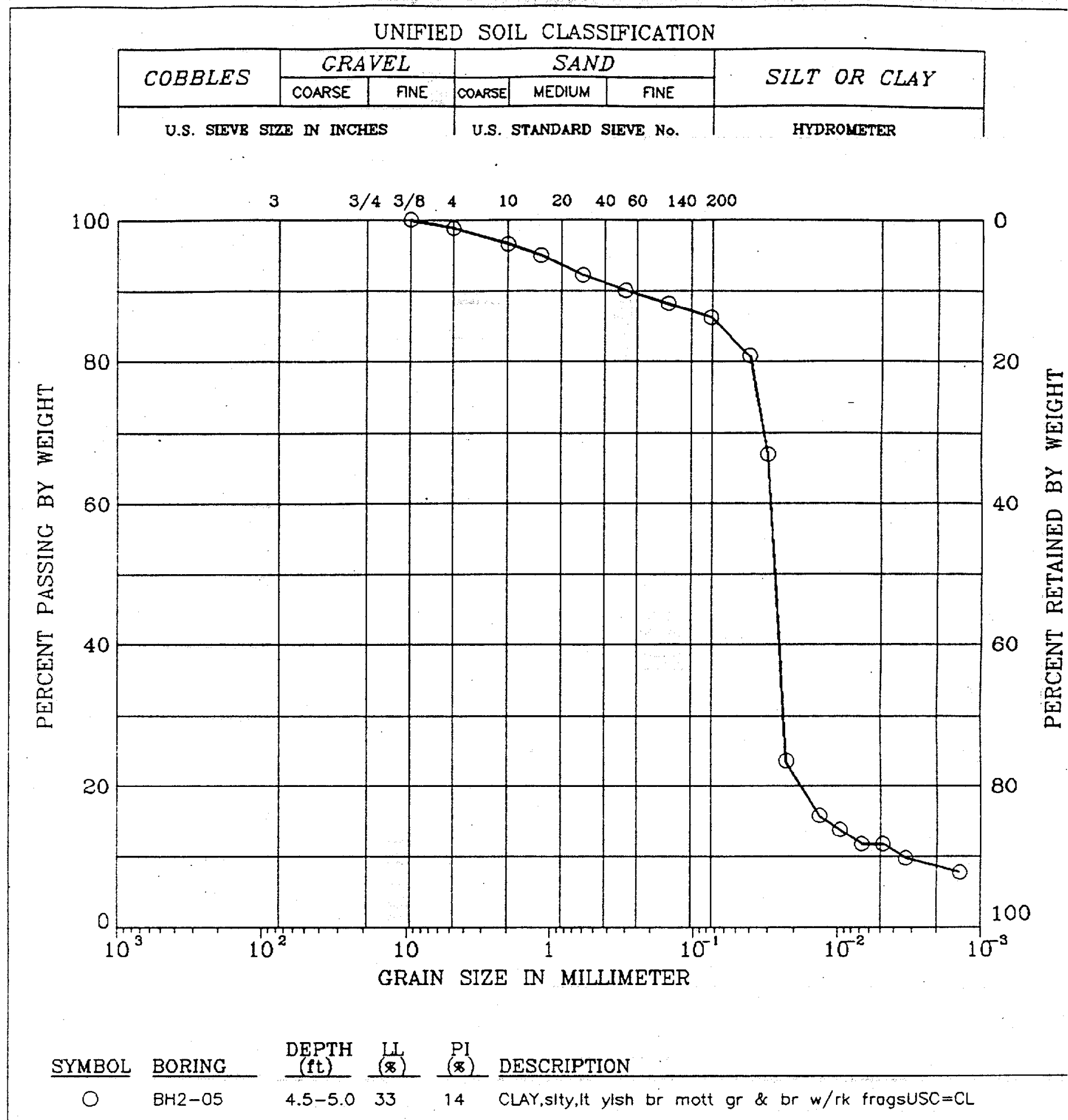

Remark : Martin Marietta Energy Systems, Inc. 
$-4$

UNIFIED SOIL CLASSIFICATION

\begin{tabular}{|c|c|c|c|c|c|c|}
\hline \multirow{2}{*}{ COBBLES } & \multicolumn{2}{|c|}{ GRAVEL } & \multicolumn{3}{|c|}{ SAND } & \multirow{2}{*}{ SILT OR CLAY } \\
\hline & COARSE & FINE & COARSE & MEDIUM & FINE & \\
\hline
\end{tabular}

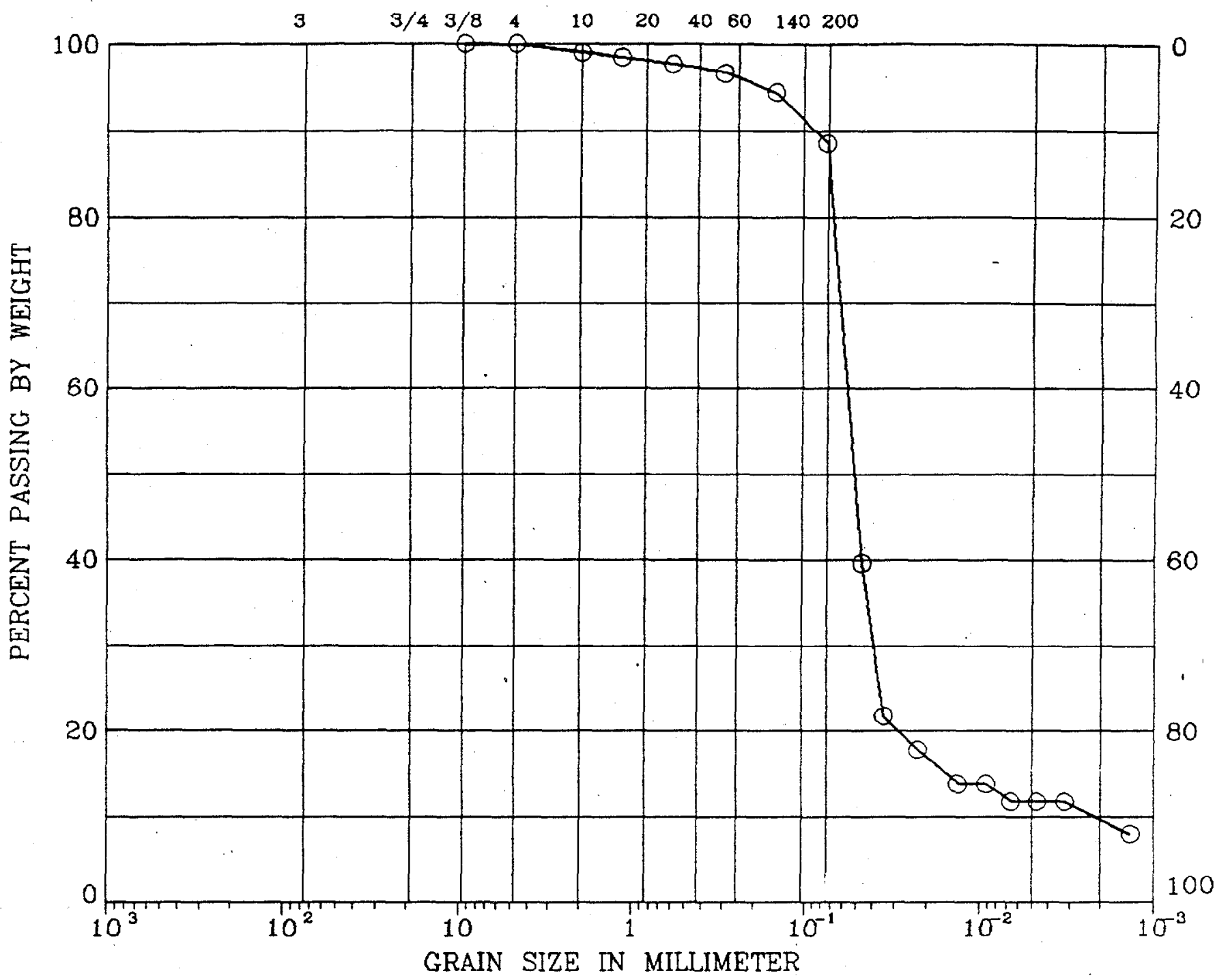

焉

SYMBOL BORING

O $\mathrm{BH} 2-14$

DEPTH

IL $(\mathrm{ft})(\mathrm{s})$ $13.5-1426$

( $\mathrm{PI}$ DESCRIPTION

12 ClaY, silty. yellowish brown

$\mathrm{USC}=\mathrm{CL}$

Remark : Martin Marietta Energy Systems, Inc.

\begin{tabular}{|l|l} 
Project No.0-4267 & Portsmouth - OTD Mini Characterization
\end{tabular}




\section{SUMMARY OF LABORATORY TEST RESULTS}

\begin{tabular}{|c|c|c|c|c|c|c|c|c|c|c|c|c|}
\hline & & & & & $\begin{array}{r}\text { UN } \\
\text { WEIC } \\
\text { (PC }\end{array}$ & & $\begin{array}{l}\text { SPECIFIC } \\
\text { GRAVITY }\end{array}$ & ATT & $\begin{array}{l}\text { BERG } \\
\text { ITS }\end{array}$ & & & $\begin{array}{l}\text { Project: Portsmouth ODT Mini Characterization } \\
\text { Project Number: } 0-4267-0088 \\
\text { Date: May 20, } 1994\end{array}$ \\
\hline $\begin{array}{l}\text { Hole } \\
\text { No. }\end{array}$ & $\begin{array}{l}\text { Sample } \\
\text { No. }\end{array}$ & $\begin{array}{l}\text { Sample } \\
\text { Type* }\end{array}$ & $\begin{array}{l}\text { Depth } \\
\text { (ft) }\end{array}$ & $\begin{array}{c}\text { Natural } \\
\text { Moisture } \\
(\%)\end{array}$ & Wet & Dry & $G_{*}$ & $\begin{array}{l}\text { Liquild } \\
\text { Limit } \\
(\%)\end{array}$ & $\begin{array}{l}\text { Plasticity } \\
\text { Index } \\
(\%) \\
\end{array}$ & $\begin{array}{c}\text { Unified } \\
\text { Soil } \\
\text { Classification }\end{array}$ & $\begin{array}{l}\text { Other } \\
\text { Test } \\
\text { "*" }\end{array}$ & Soll Description \\
\hline BH-1.05 & & ss & 5.0 & 23.4 & & & 2.66 & 49 & 31 & $\mathrm{CL}$ & & $\begin{array}{l}\text { CLAY, silty, light yellowish brown mottled gray } \\
\text { with roots }\end{array}$ \\
\hline BH-1.13.5 & & ss & $13.0 \cdot 13.5$ & 32.4 & & & 2.63 & 64 & 38 & $\mathrm{CH}$ & & CLAY, silty, reddish-brown mottled black \\
\hline$B H \cdot 1-22$ & & ss & $21.5 \cdot 22.0$ & 21.2 & & & 2.67 & 27 & 15 & $\mathrm{CL}$ & & $\begin{array}{l}\text { CLAY, silty, llght yellowish brown mottled brown } \\
\text { with weathered shalo fragments }\end{array}$ \\
\hline BH-2-05 & & ss & $4.5 \cdot 5.0$ & 22.6 & & & 2.60 & 33 & 14 & $\mathrm{CL}$ & & $\begin{array}{l}\text { CLAY, silty, llght yellowish brown mottled gray } \\
\text { and brown with rock fragments }\end{array}$ \\
\hline BH-2-14 & & ss & $13.5 \cdot 14.0$ & 22.6 & & & $\dot{2.69}$ & 26 & 12 & $\mathrm{Cl}$ & & CLAY, silty, slightly sandy, tan \\
\hline $\mathrm{BH} \cdot 2-28$ & & ss & $27.5 \cdot 28.0$ & 19.1 & & & 2.75 & 31 & 13 & $\mathrm{CL}$ & & $\begin{array}{l}\text { CLAY, silty, dark yellowish brown whth rock } \\
\text { fragments }\end{array}$ \\
\hline $\mathrm{BH}-3.09$ & & ss & $8.5 \cdot 9.0$ & 24.5 & & & 2.66 & 50 & 28 & $\mathrm{CL}$ & & CLAY, slty, tan mottled light gray \\
\hline $\mathrm{BH} \cdot 3.12$ & & ss & $11.5 \cdot 12.0$ & 35.5 & & & 2.73 & 72 & 49 & $\mathrm{CH}$ & & CLAY, silty, light brown mottled gray \\
\hline $\mathrm{BH} \cdot 3 \cdot 19$ & & ss & $18.5 \cdot 19.0$ & 17.7 & & & 2.68 & 23 & 11 & $\mathrm{CL}$ & & $\begin{array}{l}\text { CLAY, silty, derk greenish brown with rock } \\
\text { fragments }\end{array}$ \\
\hline $\mathrm{BH}-4.07$ & & ss & $6.5 \cdot 7.0$ & 26.7 & & & 2.69 & 60 & 35 & $\mathrm{CH}$ & & $\begin{array}{l}\text { CLAY, silty, light brown mottled gray and } \\
\text { yellowish-brown }\end{array}$ \\
\hline BH-4-15 & & ss & $14.5-15.0$ & 31.0 & & & 2.69 & 69 & 43 & $\mathrm{CH}$ & & CLAY, sllty, light brown mattled gray \\
\hline
\end{tabular}

- ST-SHELBY TUBE SAMPLE, SS-SPLIT SPOON SAMPLE, B-BAG SAMPLE " "TEST RESULTS REPORTED ON OTHER SHEETS: 


\section{SUMMARY OF LABORATORY TEST RESULTS}

\begin{tabular}{|c|c|c|c|c|c|c|c|c|c|c|c|c|}
\hline & & & & & $\begin{array}{r}\text { UN } \\
\text { WEI } \\
\text { (PC }\end{array}$ & & $\begin{array}{l}\text { SPECIFIC } \\
\text { GRAVITY }\end{array}$ & ATTE & $\begin{array}{l}\text { BERG } \\
\text { ITS }\end{array}$ & & & $\begin{array}{l}\text { Prolect: Portsmouth OOT Mini Characterization } \\
\text { Project Number: } 0-4267-0088 \\
\text { Date: May 20, } 1994\end{array}$ \\
\hline $\begin{array}{l}\text { Hole } \\
\text { No. }\end{array}$ & $\begin{array}{l}\text { Sample } \\
\text { No. }\end{array}$ & $\begin{array}{l}\text { Sample } \\
\text { Type* }\end{array}$ & $\begin{array}{l}\text { Depth } \\
\text { (it) }\end{array}$ & $\begin{array}{c}\text { Natural } \\
\text { Moisture } \\
(\%)\end{array}$ & Wot & Dry & G. & $\begin{array}{l}\text { Liquid } \\
\text { Limit } \\
(\%)\end{array}$ & $\begin{array}{l}\text { Plastlcity } \\
\text { Index } \\
(\%) \\
\end{array}$ & $\begin{array}{c}\text { Unified } \\
\text { Soll } \\
\text { Classification } \\
\end{array}$ & $\begin{array}{l}\text { Other } \\
\text { Test } \\
\text { ** }\end{array}$ & Soll Description \\
\hline BH-4-21 & & ss & $20.5-21.0$ & 36.7 & & & 2.72 & 48 & 26 & $\mathrm{CL}$ & & $\begin{array}{l}\text { CLAY, silty, brown mottled gray and reddish- } \\
\text { brown }\end{array}$ \\
\hline BH.5.08 & & ss & $7.5 \cdot 8.0$ & 32.3 & & & 2.69 & 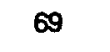 & 44 & $\mathrm{CH}$ & & CLAY, sllty, light brown mottled gray \\
\hline $8 \mathrm{H}-5-13$ & & ss & $12.5 \cdot 13.0$ & 39.9 & & & 2.70 & 46 & 25 & $\mathrm{CL}$ & & $\begin{array}{l}\text { CLAY, silty, light brown mottled gray yellowish- } \\
\text { brown and reddish-brown }\end{array}$ \\
\hline BH-5-19 & & ss & $18.5 \cdot 19.0$ & 20.7 & & & 2.66 & 26 & 11 & $\mathrm{CL}$ & & $\begin{array}{l}\text { CLAY, silty, yellowish-brown mottled light gray } \\
\text { with rock fragments }\end{array}$ \\
\hline BH-5-23 & & ss & $22.5 \cdot 23.0$ & 30.9 & & & 2.70 & 28 & 15 & $\mathrm{Cl}$ & & CLAY, silty slightly sandy light yellowish-brown \\
\hline $\mathrm{BH}-6-02$ & & ss & $1.5-2.0$ & 25.9 & & & 2.62 & 41 & 25 & $\mathrm{CL}$ & & CLAY, sity, light yellowish-brown \\
\hline$B H-6 \cdot 18$ & & ss & $17.5 \cdot 18.0$ & 21.7 & & & 2.65 & 26 & 13 & $\mathrm{CL}$ & & CLAY, silty, light yellowish-brown \\
\hline BH-6.29 & & ss & $28.5 \cdot 29.0$ & 14.3 & & & 2.69 & & & & & CLAY, slty, dark brown with rock fragments \\
\hline $\mathrm{BH}-7.12$ & & ss & $11.5 \cdot 12.0$ & 20.7 & & & 2.70 & 28 & 14 & $\mathrm{CL}$ & & CLAY, silty, slightly sandy, light yellowish-brown \\
\hline $\mathrm{BH}-7-20$ & & ss & $19.5 \cdot 20.0$ & 19.3 & & & 2.65 & 30 & 14 & $\mathrm{CL}$ & & CLAY, sitty, slightly sandy, yellowish-brown \\
\hline BH-7-26 & & ss & $25.5 \cdot 26.0$ & 17.3 & & & 2.65 & 29 & 12 & $\mathrm{CL}$ & & CLAY, silty, dar brown \\
\hline
\end{tabular}

- ST-SHELBY TUBE SAMPLE, SS-SPLIT SPOON SAMPLE, B-BAG SAMPLE * "TEST RESULTS REPORTED ON OTHER SHEETS:

C.CONSOLIDATION

P.PROCTOR TEST

S-SIEVE OR GHAIN SIZE ANALYSIS

D-DIRECT SHEAR TEST

U.UNCONFINED COMPRESSION TEST

T.TRIAXIAL TEST

GA Technical Services 


\section{SUMMARY OF LABORA TORY TEST RESULTS}

\begin{tabular}{|c|c|c|c|c|c|c|c|c|c|c|c|c|}
\hline & & & & & $\begin{aligned} \text { UI } \\
\text { WEI } \\
(P\end{aligned}$ & & $\begin{array}{l}\text { SPECIFIC } \\
\text { GRAVITY }\end{array}$ & & $\begin{array}{l}\text { BERG } \\
\text { ITS }\end{array}$ & & & $\begin{array}{l}\text { Project: Portsmouth ODT Minl Characterization } \\
\text { Project Number: } \underline{0-4267-0088}\end{array}$ \\
\hline $\begin{array}{l}\text { Hole } \\
\text { No. }\end{array}$ & $\begin{array}{c}\text { Sample } \\
\text { No. }\end{array}$ & $\begin{array}{l}\text { Sample } \\
\text { Type** }\end{array}$ & $\begin{array}{l}\text { Depth } \\
\text { (t) }\end{array}$ & $\begin{array}{l}\text { Natural } \\
\text { Molsture } \\
(\%)\end{array}$ & Wet & Dn & G, & $\begin{array}{l}\text { Liquild } \\
\text { Limit } \\
(\%)\end{array}$ & $\begin{array}{l}\text { Plasticity } \\
\text { Index } \\
(\%)\end{array}$ & $\begin{array}{l}\text { Unified } \\
\text { Soil } \\
\text { Clessification }\end{array}$ & $\begin{array}{l}\text { Other } \\
\text { Test } \\
*\end{array}$ & Soll Description \\
\hline BH.B.13 & & ss & $12.5 \cdot 13.0$ & 33.5 & & & 2.68 & 61 & 41 & $\mathrm{CH}$ & & CLAY, silty, reddish-brown \\
\hline $8 \mathrm{H}-8-22$ & & ss & $21.5-22.0$ & 28.5 & & & 2.72 & 26 & 12 & $\mathrm{CL}$ & & $\begin{array}{l}\text { CLAY, silty, dark brown mottled dark gray with } \\
\text { rock tragments }\end{array}$ \\
\hline BH-9-09 & & ss & $8.5 \cdot 9.0$ & 33.6 & & & 2.70 & 71 & 48 & $\mathrm{CH}$ & & $\begin{array}{l}\text { CLAY, sllty, light reddish-brown mottled gray and } \\
\text { yellowish-brown }\end{array}$ \\
\hline$B H-9-21$ & & ss & $20.9 \cdot 21.0$ & 36.4 & & & 2.73 & 53 & 28 & $\mathrm{CH}$ & & CLAY, silty, gray mottled reddlsh-brown \\
\hline $8 H-9.21 .5$ & & ss & $21.0 \cdot 21.5$ & 29.9 & & & 2.75 & 51 & 26 & $\mathrm{CH}$ & & CLAY, silty, gray mottled greenish-brown \\
\hline & & & & & & & & & & & & \\
\hline & & & & & & & & & & & & \\
\hline & & & & & & & & & & & & \\
\hline & & & & & & & & & & & & \\
\hline & & & & & & & & & & & & \\
\hline & & & & & & & & & & & & \\
\hline
\end{tabular}

*ST-SHELBY TUBE SAMPLE, SS-SPLIT SPOON SAMPLE. B-BAG SAMPLE " TEST RESULTS REPORTED ON OTHER SHEETS:

C.CONSOLIDATION

S.SIEVE OR GRAIN SIZE ANALYSIS

U.UNCONFINED COMPRESSION TEST
P.PROCTOR TEST

D.DIRECT SHEAR TEST

T.TRIAXIAL TEST
GA Technical Services 
MPIS Baseline Soil Characteristics: Moisture Content, Bulk Density, Porosity, pH, TOC

\begin{tabular}{|c|c|c|c|c|c|c|c|c|c|c|c|c|c|c|c|c|}
\hline Pan ID & Sample Name & Depth & $\begin{array}{c}\% \text { Moisture } \\
\text { based on dry } \\
\text { wt }\end{array}$ & $\mid \begin{array}{c}\% \text { Moisture } \\
\text { based on wet } \\
\text { wt }\end{array}$ & $\begin{array}{c}\text { Wt bulk } \\
\text { Density, } \\
\text { g/cc }\end{array}$ & $\begin{array}{c}\text { Dry bulk } \\
\text { Density, } \\
\text { g/cc }\end{array}$ & \begin{tabular}{|c|} 
Dry wt \\
$\%$ \\
moisture
\end{tabular} & $\begin{array}{c}\% \text { volume } \\
\text { porosity }\end{array}$ & $\begin{array}{c}\% \text { volume } \\
\text { water-filled } \\
\text { porosity }\end{array}$ & $\begin{array}{l}\% \text { volume } \\
\text { air-filled } \\
\text { porosity }\end{array}$ & pH & $\begin{array}{l}\text { TOC, } \\
\text { ppm }\end{array}$ & \begin{tabular}{|c|} 
Avg. \% \\
suil moisture \\
(wet wt)
\end{tabular} & \begin{tabular}{|l|} 
Avg. pH \\
\end{tabular} & $\begin{array}{c}\text { Avg. bulk } \\
\text { density } \\
\text { (moist), } \\
\text { g/cc }\end{array}$ & $\begin{array}{c}\text { Avg. TOC } \\
\text { ppm }\end{array}$ \\
\hline 1 & T1-BE-00-01 & 1 & 21.95 & 18 & & & & & & & 4.26 & 6253 & 16.73 & 4.89 & & 6396.63 \\
\hline 14 & T2-BE-00-01 & 1 & $\begin{array}{c}\ldots 21.4 \\
-\quad \\
\end{array}$ & 17.63 & & $\begin{array}{l}\text { median moist } \\
\text { density }\end{array}$ & t bulk & & & & 4.61 & 6107 & & & & \\
\hline 27 & T3-BE-00-01 & 1 & 21.82 & 17.91 & & 1.83 & & & & & 4.87 & 7713 & & & & \\
\hline 40 & T4-BE-00-01 & 1 & 19.03 & 15.99 & & & & & & & 4.62 & 6933 & & & & \\
\hline 53 & T5-BE-00-01 & 1 & 18.66 & 15.72 & & & & & & & 4.67 & 3483 & & & & \\
\hline 66 & T6-BE-00-01 & 1 & 21.76 & 17.87 & & & & & & & 4.93 & 6893 & & & & \\
\hline 79 & T7-BA-00-01 & $T$ & 18.21 & 15.41 & & & & & & & 6.5 & 6662 & & & & \\
\hline 92 & S1-BA-00-01 & 1 & 18.09 & 15.32 & & & & & & & 4.68 & 7129 & & & & \\
\hline 2 & T1-BE-01-02 & 2 & 22.52 & 18.38 & & & & & & & 4.42 & 1295 & 18.39 & 4.49 & & 1629.50 \\
\hline 15 & T2-BE-01-02 & 2 & 24.4 & 19.61 & & & & & & & 4.3 & 1576 & & & & \\
\hline 28 & T3-BE-01-02 & 2 & 22.26 & 18.21 & & & & & & & 4.34 & 1851 & & & & \\
\hline 41 & T4-BE-01-02 & 2 & 21.75 & 17.86 & & & & & & & 4.57 & 1707 & & & & \\
\hline 54 & T5-BE-01-02 & 2 & 23.5 & 19.03 & & & & & & & 4.74 & 1296 & & & & \\
\hline 67 & T6-BE-01-02 & 2 & 24.6 & 19.74 & & & & & & & 4.51 & 1903 & & & & \\
\hline 80 & T7-BA-01-02 & 2 & 22.41 & 18.3 & & & & & & & 4.6 & 1693 & & & & \\
\hline 93 & S1-BA-01-02 & 2 & 19.03 & 15.99 & & & & & & & 4.43 & 1716 & & & & \\
\hline 3 & T1-BE-02-03 & 3 & 21.31 & 17.57 & & & & & & & 4.6 & 2130 & 18.69 & 4.33 & 1.67 & 1447.75 \\
\hline 16 & T2-BE-02-03 & 3 & 21.82 & 17.91 & & & & & & & 4.13 & 1083 & & & & \\
\hline 29 & T3-BE-02-03 & 3 & 26.13 & 20.72 & & & & & & & 4.23 & 1261 & & & & \\
\hline 42 & T4-BE-02-03 & 3 & 26.78 & 21.12 & & & & & & & 4.14 & 1724 & & & & \\
\hline 55 & T5-BE-02-03 & 3 & 19.97 & 16.64 & 1.67 & 1.4 & 19.22 & 49.2 & 26.85 & 22.35 & 4.33 & 1103 & & & & \\
\hline 68 & T6-BE-02-03 & 3 & 21.96 & 18.01 & & & & & & & 4.47 & 1110 & & & & \\
\hline 81 & T7-BA-02-03 & 3 & 22.34 & 18.26 & & & & & & & 4.66 & 2016 & & & & \\
\hline 94 & S1-BA-02-03 & 3 & 23.89 & 19.29 & & & & & & & 4.1 & 1155 & & & & \\
\hline $4^{*}$ & T1-BE-03-04 & 4 & 22 & 18.03 & & & & & & & 4.65 & 1471 & 15.46 & 4.67 & & 1082.38 \\
\hline 17 & T2-BE-03-04 & 4 & 18.7 & 15.76 & & . & & & & & 4.62 & 993 & & & & \\
\hline 30 & T3-BE-03-04 & 4 & 21.34 & 17.59 & & & & & & & 4.36 & 954 & & & & \\
\hline 43 & T4-BE-03-04 & 4 & 19.85 & 16.56 & & & & & & & 4.59 & 977 & & & & \\
\hline 56 & T5-BE-03-04 & 4 & 13.77 & 12.1 & & & & & & & 4.73 & 1108 & & & & \\
\hline 69 & T6-BE-03-04 & 4 & 16.17 & 13.92 & & & & & & & 4.99 & 1277 & & & & \\
\hline 82 & T7-BA-03-04 & 4 & 16.69 & 14.3 & & $\cdot$ & & & & & 4.92 & 1014 & & & & \\
\hline 95 & S1-BA-03-04 & 4 & 18.19 & 15.39 & & & & & & & 4.48 & 865 & & & & \\
\hline 5 & T1-BE-04-05 & 5 & 17.27 & 14.73 & 2.25 & 1.96 & 15.12 & 28.79 & 29.61 & -0.82 & 4.81 & 1220 & 15.33 & 5.73 & 1.88 & 1021.13 \\
\hline 18 & T2-BE-04-05 & 5 & 19.1 & 16.04 & 1.57 & 1.32 & 19.42 & 52.09 & 25.59 & 26.51 & 5.94 & 1353 & & & & \\
\hline 31 & T3-BE-04-05 & 5 & 22 & 18.03 & 1.71 & 1.37 & 24.3 & 50.03 & 33.39 & 16.65 & 5.48 & 947 & & & & \\
\hline 44 & T4-BE-04-05 & 5 & 14.99 & 13.03 & 1.88 & 1.59 & 18.18 & 42.05 & 28.90 & 13.09 & 5.62 & 889 & & & & \\
\hline 57 & T5-BE-04-05 & 5 & 22.44 & 18.32 & 2.03 & 1.65 & 23.23 & 40.11 & 38.27 & & 6.66 & 989 & & & & \\
\hline
\end{tabular}


MPIS Baseline Soil Characteristics: Moisture Content, Bulk Density, Porosity, pH, TOC

\begin{tabular}{|c|c|c|c|c|c|c|c|c|c|c|c|c|c|c|c|c|}
\hline Pan ID & Sample Name & Depth & \begin{tabular}{|c|}
$\%$ Moisture \\
based on dry \\
wt
\end{tabular} & $\begin{array}{c}\% \text { Moisture } \\
\text { based on wet } \\
\text { wt }\end{array}$ & $\begin{array}{c}\text { Wt bulk } \\
\text { Density, } \\
\text { g/cc }\end{array}$ & $\begin{array}{l}\text { Dry bulk } \\
\text { Density, } \\
\text { g/cc }\end{array}$ & $\begin{array}{c}\text { Dry wt } \\
\% \\
\text { moisture }\end{array}$ & $\begin{array}{c}\% \text { volume } \\
\text { porosity }\end{array}$ & $\begin{array}{c}\% \text { volume } \\
\text { water-filled } \\
\text { porosity }\end{array}$ & $\begin{array}{c}\% \text { volume } \\
\text { air-filled } \\
\text { porosity }\end{array}$ & pH & $\begin{array}{l}\text { TOC, } \\
\text { ppm }\end{array}$ & \begin{tabular}{|c|} 
Avg. \% \\
soil moisture \\
(wet wt)
\end{tabular} & Avg. pH & $\begin{array}{c}\text { Avg. bulk } \\
\text { density } \\
\text { (moist), } \\
\text { g/cc }\end{array}$ & $\begin{array}{c}\text { Avg. TOC } \\
\text { ppm } \\
\end{array}$ \\
\hline 70 & T6-BE-04-05 & 5 & 14.38 & 12.57 & 1.89 & 1.66 & 14.03 & 39.77 & 23.23 & 16.54 & 6.18 & 866 & & & & \\
\hline 83 & T7-BA-04-05 & 5 & 16.52 & 14.18 & 1.85 & 1.57 & 18.1 & 42.94 & 28.4 & 14.54 & 6.37 & 1081 & & & & \\
\hline 96 & S1-BA-04-05 & 5 & 18.67 & 15.73 & 1.82 & 1.54 & 17.58 & 43.82 & 27.16 & 16.66 & 4.79 & 818 & & & & \\
\hline 7 & T1-BE-05-06 & 6 & 20.66 & 17.12 & & & & & & & 6.04 & 1217 & 16.08 & 6.47 & & 994.88 \\
\hline 20 & T2-BE-05-06 & 6 & 20.91 & 17.3 & & & & & & & 6.89 & 890 & & & & \\
\hline 33 & T3-BE-05-06 & 6 & 17.64 & 14.99 & & & & & & & 6.46 & 1062 & & & & \\
\hline 46 & T4-BE-05-06 & 6 & 18.04 & 15.28 & & & & & & & 6.95 & 1187 & & & & \\
\hline 59 & T5-BE-05-06 & 6 & 24.59 & 19.74 & & & & & & & 7.07 & 405 & & & & \\
\hline 72 & T6-BE-05-06 & 6 & 20.6 & 17.08 & & & & & & & 6.08 & 1631 & & & & \\
\hline 85 & T7-BA-05-06 & 6 & 15.5 & 13.42 & & & & & & & 6.74 & 1065 & & & & \\
\hline 98 & S1-BA-05-06 & 6 & 15.87 & 13.7 & & & & & & & 5.5 & 502 & & & & \\
\hline 8 & T1-BE-06-07 & 7 & 18.61 & 15.69 & & & & & & & 7 & 685 & 17.79 & 6.57 & 1.72 & 615.00 \\
\hline 21 & T2-BE-06-07 & 7 & 21.18 & 17.48 & & & & & & & 6.99 & 431 & & & & \\
\hline 34 & T3-BE-06-07 & 7 & 14.35 & 12.55 & & & & & & & 6.22 & 836 & & & & \\
\hline 47 & T4-BE-06-07 & 7 & 31.15 & 23.75 & & & & & & & 7.61 & 420 & & & & \\
\hline 60 & T5-BE-06-07 & 7 & 27.29 & 21.44 & 1.72 & 1.36 & 26.17 & 50.42 & 35.68 & 14.74 & 6.23 & 286 & & & & \\
\hline 73 & T6-BE-06-07 & 7 & 23.09 & 18.76 & & & & & & & 6.67 & 531 & & & & \\
\hline 86 & T7-BA-06-07 & 7 & 20.81 & 17.23 & & & & & & & 6.47 & 894 & & & & \\
\hline 99 & S1-BA-06-07 & 7 & 18.27 & 15.45 & & & & & & & 5.38 & 837 & & & & \\
\hline 9 & T1-BE-07-OS & 8 & no core & & & & & & & & & & 20.77 & 7.03 & & 558.20 \\
\hline 22 & T2-BE-07-08 & 8 & no core & & & & & & & & & & & & & \\
\hline 35 & T3-BE-07-08 & 8 & 27.91 & 21.82 & & & & & & & 6.95 & 305 & & & & \\
\hline 48 & T4-BE-07-OB & 8 & no core & & & & & & & & & & & & & \\
\hline 61 & T5-BE-07-08 & 8 & 31.67 & 24.05 & & & & & & & 7.75 & 367 & & & & \\
\hline 74 & T6-BE-07-08 & 8 & 28.27 & 22.04 & & & & & & & 6.74 & 385 & & & & \\
\hline 87 & 77-BA-07-08 & 8 & 24.72 & 19.82 & & & & & & & 7.44 & 567 & & & & \\
\hline 100 & S1-BA-07-08 & 8 & 19.2 & 16.11 & & & & & & & 6.27 & 1167 & & & & \\
\hline 10 & T1-BE-08-09 & 9 & 31.65 & 24.04 & & & & & & & 7.08 & 354 & 24.13 & 7.21 & 1.98 & 395.00 \\
\hline 23 & T2-BE-08-09 & 9 & 32.52 & 24.54 & & & & & & & 7.75 & 288 & & & & \\
\hline 36 & T3-BE-08-09 & 9 & 36.93 & 26.97 & & & & & & & 7.48 & 498 & & & & \\
\hline 49 & T4-BE-08-09 & 9 & 31.65 & 24.04 & & & & & & & 7.61 & 420 & & & & \\
\hline 62 & T5-BE-08-09 & 9 & 34.05 & 25.4 & 1.98 & 1.5 & 31.77 & 45.33 & 47.77 & -2.43 & 7.51 & 381 & & & & \\
\hline 75 & T6-BE-08-09 & 9 & 21.99 & 18.03 & & & & & & & 6.99 & 383 & & & & \\
\hline 88 & T7-BA-08-09 & 9 & 32.49 & 24.52 & & & & & & & 7 & 403 & & & & \\
\hline 101 & S1-BA-08-09 & 9 & 34.17 & 25.47 & & & & & & & 6.29 & 433 & & & & \\
\hline 11 & T1-BE-09-10 & 10 & 35.01 & 25.93 & & & & & & & 7.78 & 333 & 26.27 & 7.55 & & 421.00 \\
\hline 24 & T2-BE-09-10 & 10 & 33.22 & 24.93 & & & & & & & 7.68 & 436 & & & & \\
\hline 37 & T3-BE-09-10 & 10 & 36.88 & 26.94 & & & & & & & 7.82 & 613 & & & & \\
\hline
\end{tabular}


MPIS Baseline Soil Characteristics: Moisture Content, Bulk Density, Porosity, pH, TOC

\begin{tabular}{|c|c|c|c|c|c|c|c|c|c|c|c|c|c|c|c|c|}
\hline Pan ID & Sample Name & Depth & $\left|\begin{array}{c}\text { \% Moisture } \\
\text { based on dry } \\
\text { wt }\end{array}\right|$ b & $\begin{array}{c}\text { \% Moisture } \\
\text { based on wet } \\
\text { wt }\end{array}$ & $\begin{array}{c}\text { Wt bulk } \\
\text { Density, } \\
\text { g/cc }\end{array}$ & $\begin{array}{l}\text { Dry bulk } \\
\text { Density, } \\
\text { g/cc }\end{array}$ & \begin{tabular}{|c|} 
Dry $w t$ \\
$\%$ \\
moisture
\end{tabular} & $\begin{array}{c}\text { \% volume } \\
\text { porosity }\end{array}$ & $\begin{array}{c}\% \text { volume } \\
\text { water-filled } \\
\text { porosity }\end{array}$ & $\begin{array}{c}\% \text { volume } \\
\text { air-filled } \\
\text { porosity }\end{array}$ & $\mathrm{pH}$ & $\begin{array}{l}\text { TOS, } \\
\text { ppm }\end{array}$ & \begin{tabular}{|c|} 
Avg. \% \\
soil moisture \\
(wet wt)
\end{tabular} & Avg. pH & $\begin{array}{c}\text { Avg. bulk } \\
\text { density } \\
\text { (moist), } \\
\text { g/cc }\end{array}$ & $\begin{array}{c}\text { Avg. TOC, } \\
\text { ppm }\end{array}$ \\
\hline 50 & T4-BE-09-10 & 10 & 36.72 & 26.86 & & & & & & & 7.83 & 412 & & & & \\
\hline 63 & T5-BE-09-10 & 10 & 35.8 & 26.36 & & & & & & & 7.74 & 396 & & & & \\
\hline 76 & T6-BE-09-10 & 10 & 39.39 & 28.26 & & & & & & & 7.37 & 394 & & & & \\
\hline 89 & T7-BA-09-10 & 10 & 33.36 & 25.01 & & & & & & & 6.93 & 334 & & & & \\
\hline 102 & S1-BA-09-10 & 10 & 34.89 & 25.87 & & & & & & & 7.34 & 450 & & & & \\
\hline 12 & T1-BE-10-11 & 11 & 34.56 & 25.69 & 1.8 & 1.34 & 34.47 & 51.2 & 46.25 & 4.95 & 7.56 & 653 & 23.98 & 7.43 & 1.82 & 543.38 \\
\hline 25 & T2-BE-10-11 & 11 & 34.75 & 25.79 & 1.76 & 1.29 & 37 & 53.16 & 47.66 & 5.5 & 7.75 & 425 & & & & \\
\hline 38 & T3-BE-10-11 & 11 & 35.96 & 26.45 & 1.74 & 1.29 & 34.67 & 53.13 & 44.68 & 8.45 & 7.36 & 432 & & & & \\
\hline 51 & T4-BE-10-11 & 11 & 30.36 & 23.29 & 1.92 & 1.53 & 25.5 & 44.43 & 38.97 & 5.46 & 7.02 & 305 & & & & \\
\hline 64 & T5-BE-10-11 & 11 & 38.2 & 27.64 & 1.75 & 1.26 & 38.54 & 54.19 & 48.55 & 5.64 & 7.55 & 492 & & & & \\
\hline 77 & T6-BE-10-11 & 11 & 28.93 & 22.44 & 1.92 & 1.5 & 27.89 & 45.43 & 41.86 & 3.57 & 7.76 & 933 & & & & \\
\hline 90 & T7-BA-10-11 & 11 & 24.76 & 19.85 & 1.83 & 1.48 & 23.38 & 46.03 & 34.71 & 11.33 & 6.92 & 493 & & & & \\
\hline 103 & S1-BA-10-11 & 11 & 26.06 & 20.67 & 1.84 & 1.46 & 26.6 & 47.07 & 38.72 & 8.35 & 7.52 & 614 & & & & \\
\hline 13 & T1-BE-11-12 & 12 & 37.03 & 27.03 & & & & & & & 7.41 & 555 & 23.57 & 7.39 & & 525.88 \\
\hline 26 & T2-BE-11-12 & 12 & 27.76 & 21.73 & & & & & & & 7.74 & 640 & & & & \\
\hline 39 & T3-BE-11-12 & 12 & 24.74 & 19.83 & & & & & & & 7.13 & '337 & & & & \\
\hline 52 & T4-BE-11-12 & 12 & 33.62 & 25.16 & & & & & & & 7.54 & 821 & & & & \\
\hline 65 & T5-BE-11-12 & 12 & 28.69 & 22.29 & & & & & & & 6.9 & 630 & & & & \\
\hline 78 & T6-BE-11-12 & 12 & 28.24 & 22.02 & & & & & & & 6.87 & 393 & & & & \\
\hline 91 & T7-BA-11-12 & 12 & 34.29 & 25.53 & & & & & & & 7.73 & 510 & & & & \\
\hline 104 & S1-BA-11-12 & 12 & 33.26 & 24.96 & & & & & & & 7.81 & 321 & & & & \\
\hline
\end{tabular}




\section{APPENDIX B}

\section{LITHOLOGIC LOGS FOR TEST CELL SOIL BORINGS}





\section{B-1}

Borehole Summary Information

OrI 1 OAK RIDGE NATIONAL LABORATORY

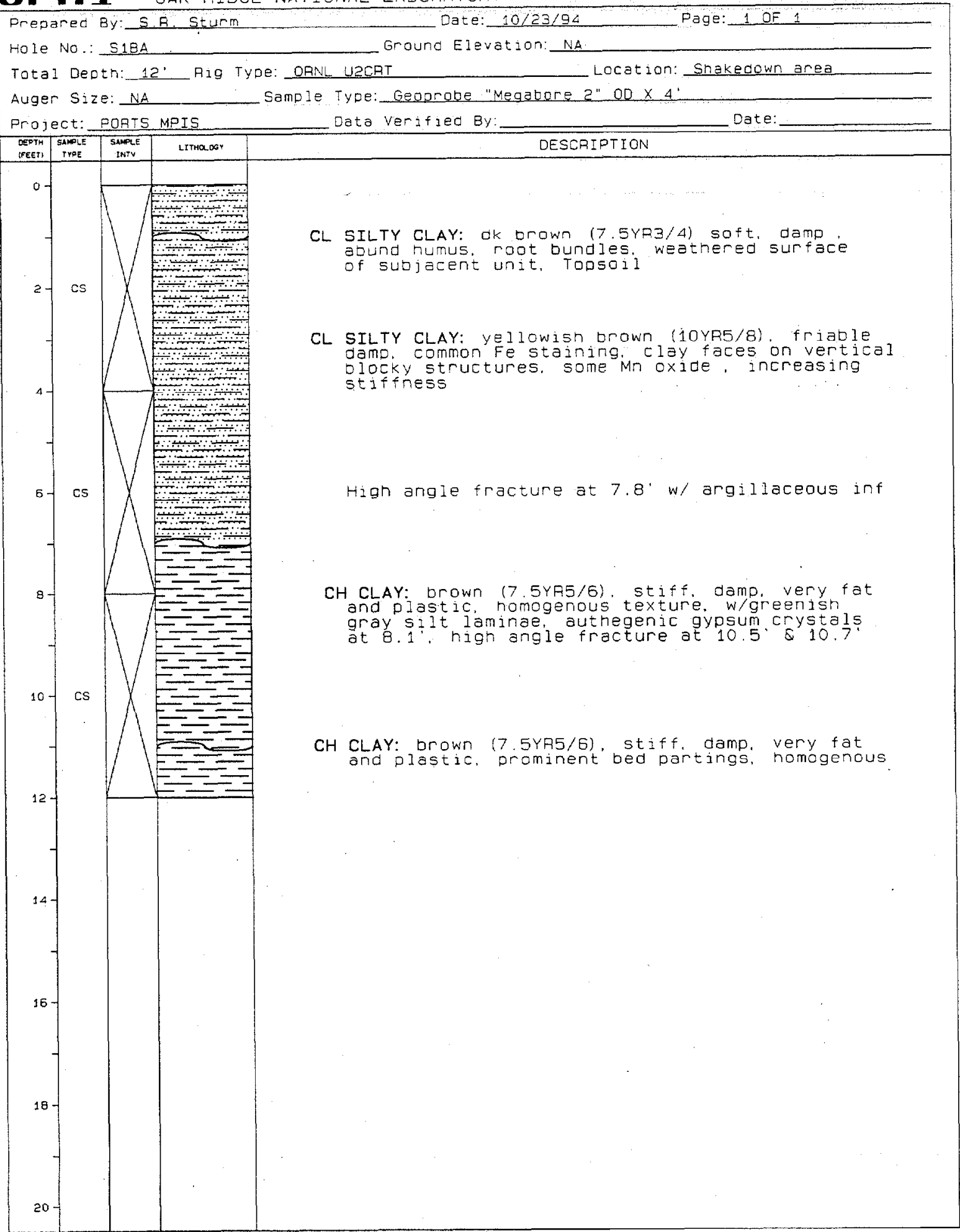




\section{B-2}

orn 1

Borehole Summary Information

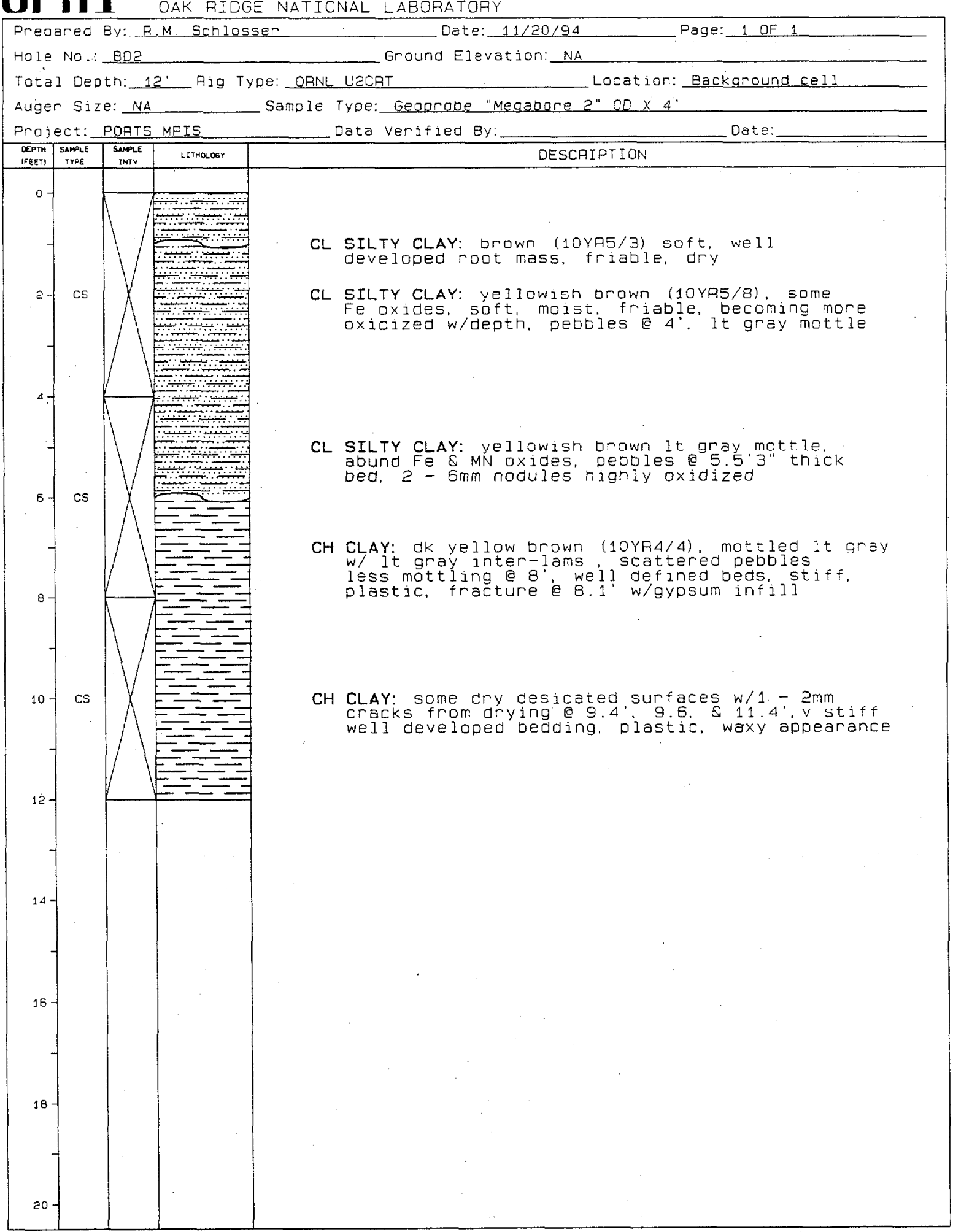




\section{B-3}

orn 1 oak ridge national Laboratory

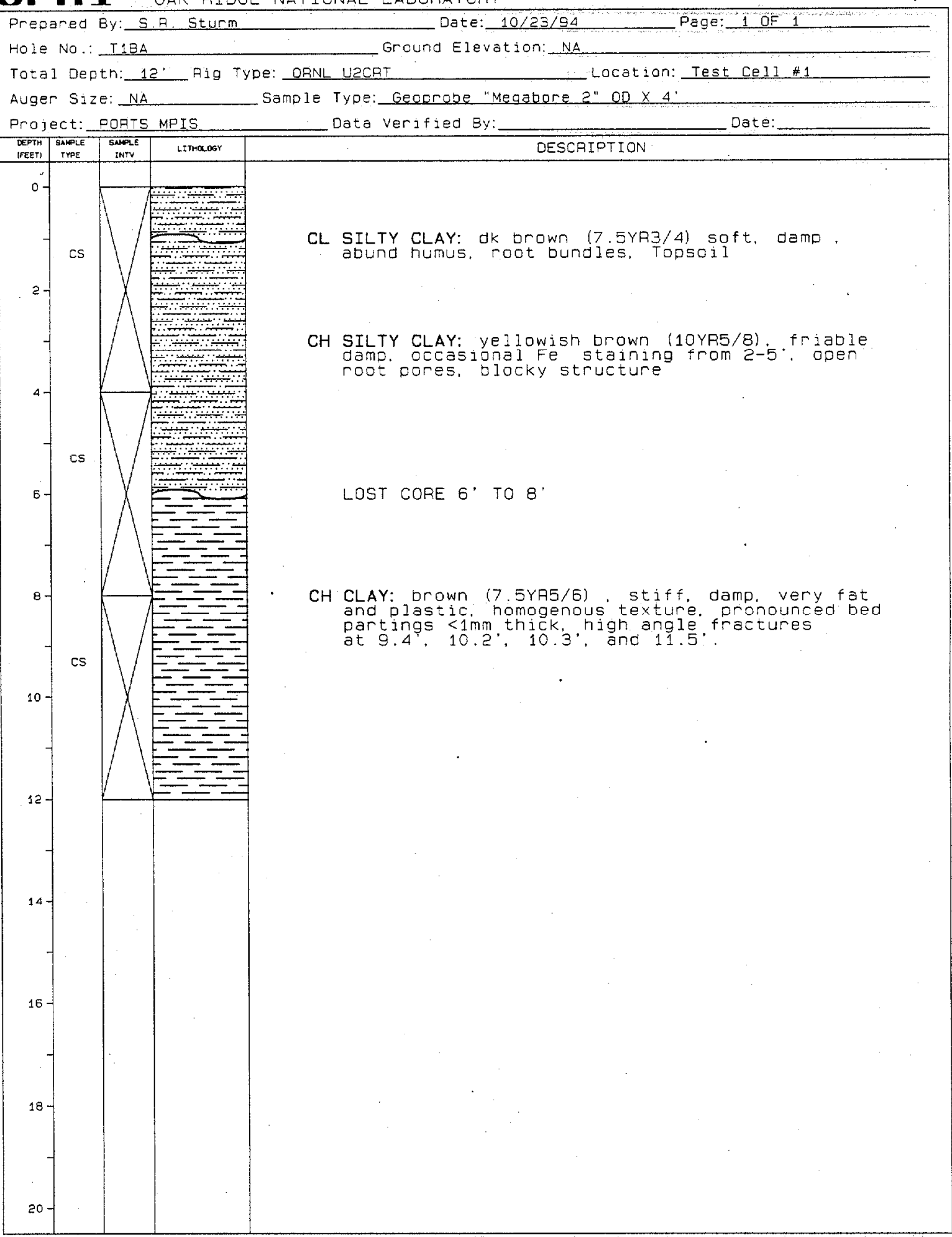




\section{B-4}

OTI OAK Rioge national Laboratory

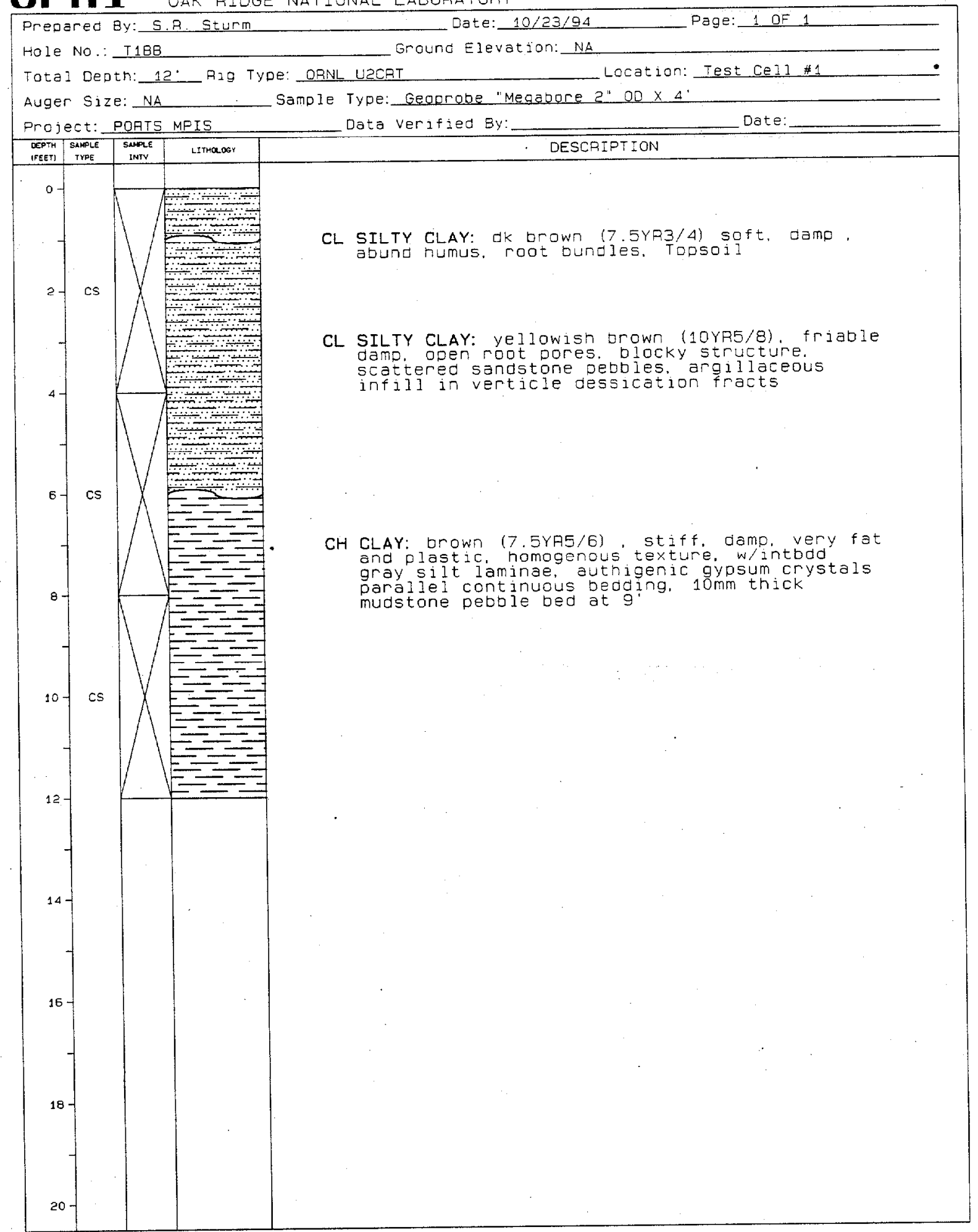




\section{B-5}

OrI OAK RIDGE NATIONAL LABORATORY 1 Borehole Summary Information

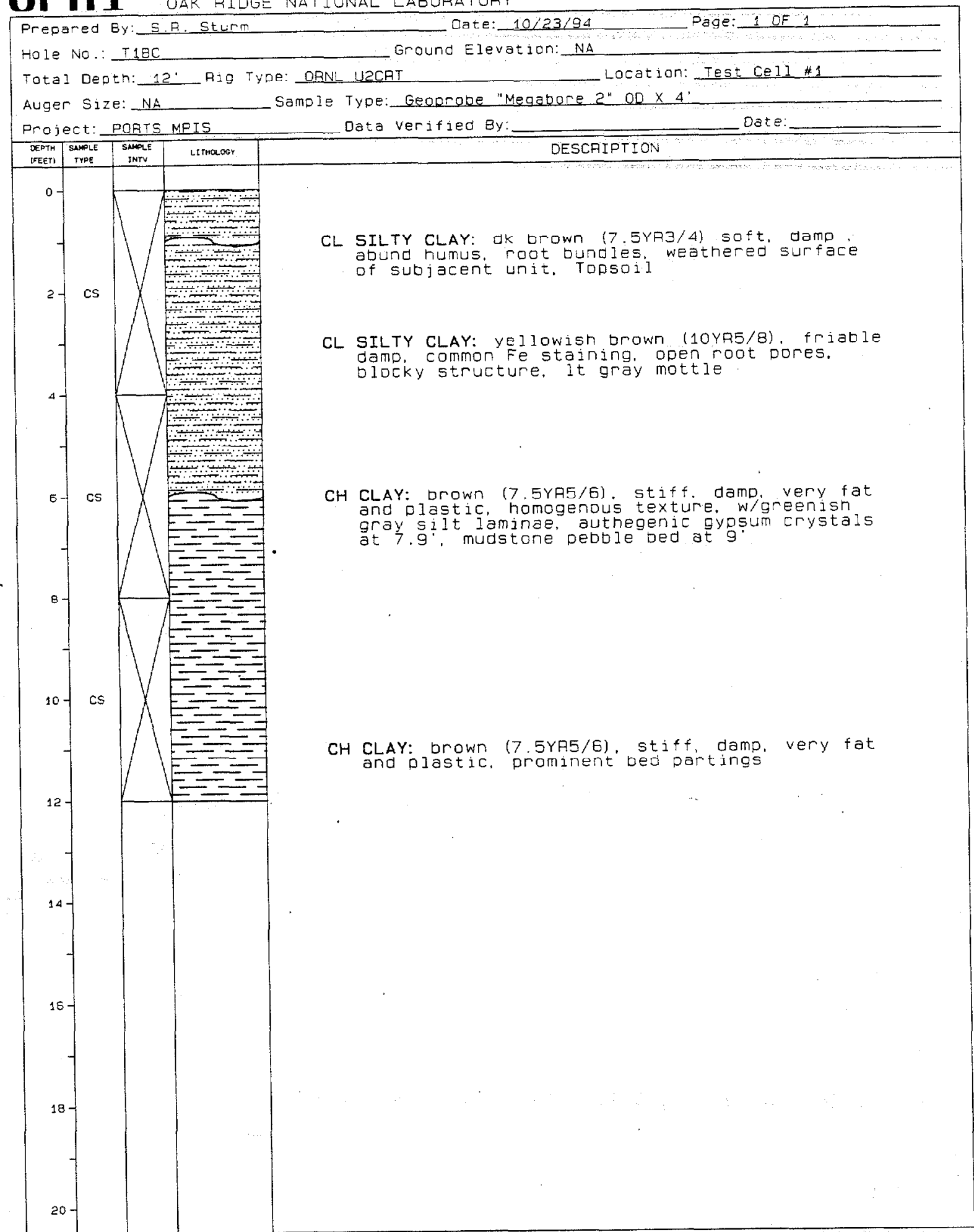


B-6

Borehole Summary Information

OAK RIDGE NATIONAL LABORATORY

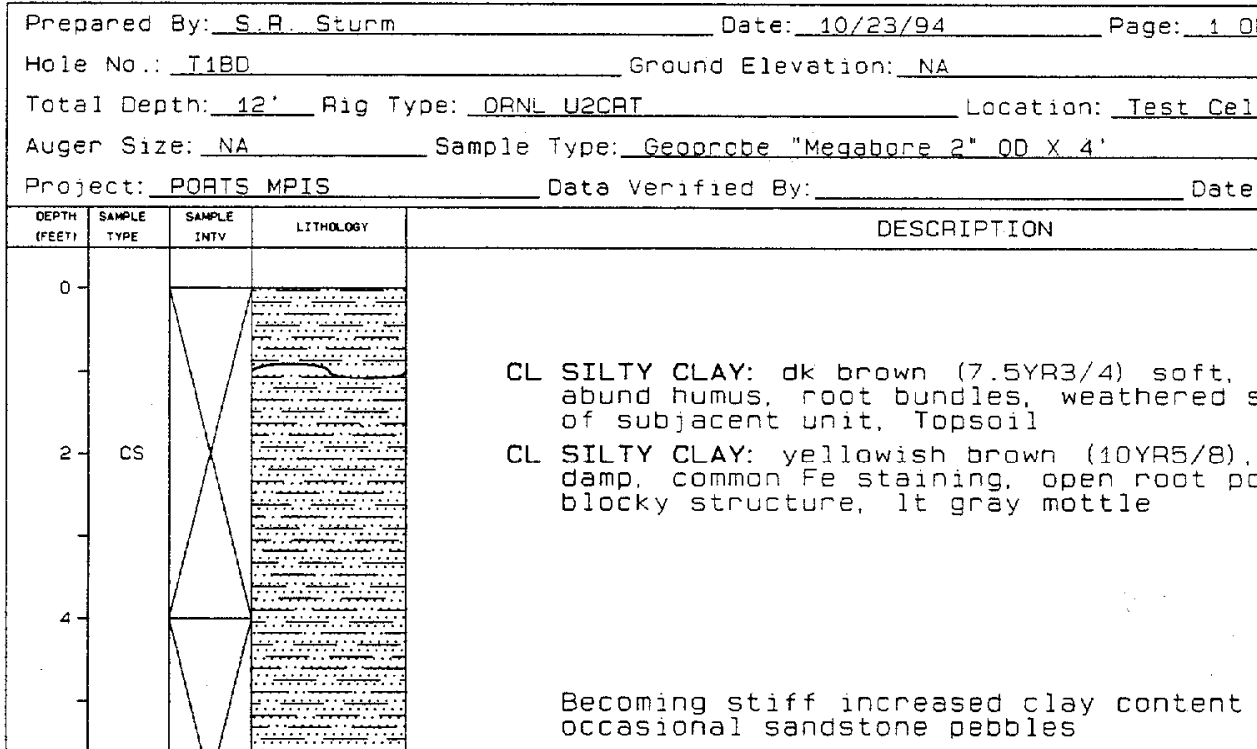

Becoming stiff increased clay content
occasional sandstone pebbles

cs

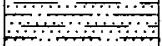

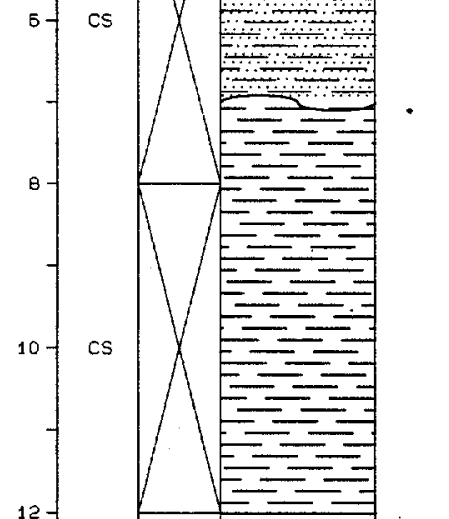

CH CLAY: brown (7.5YP5/6), stiff, damp, very fat ond plastic. with intrbdd greenish gray silt laminae, flecks of $M n$ oxide, parallel continuous bedding, becoming very homogenous 
Borehole Summary Information.

OIII oak ridge national Laboratory

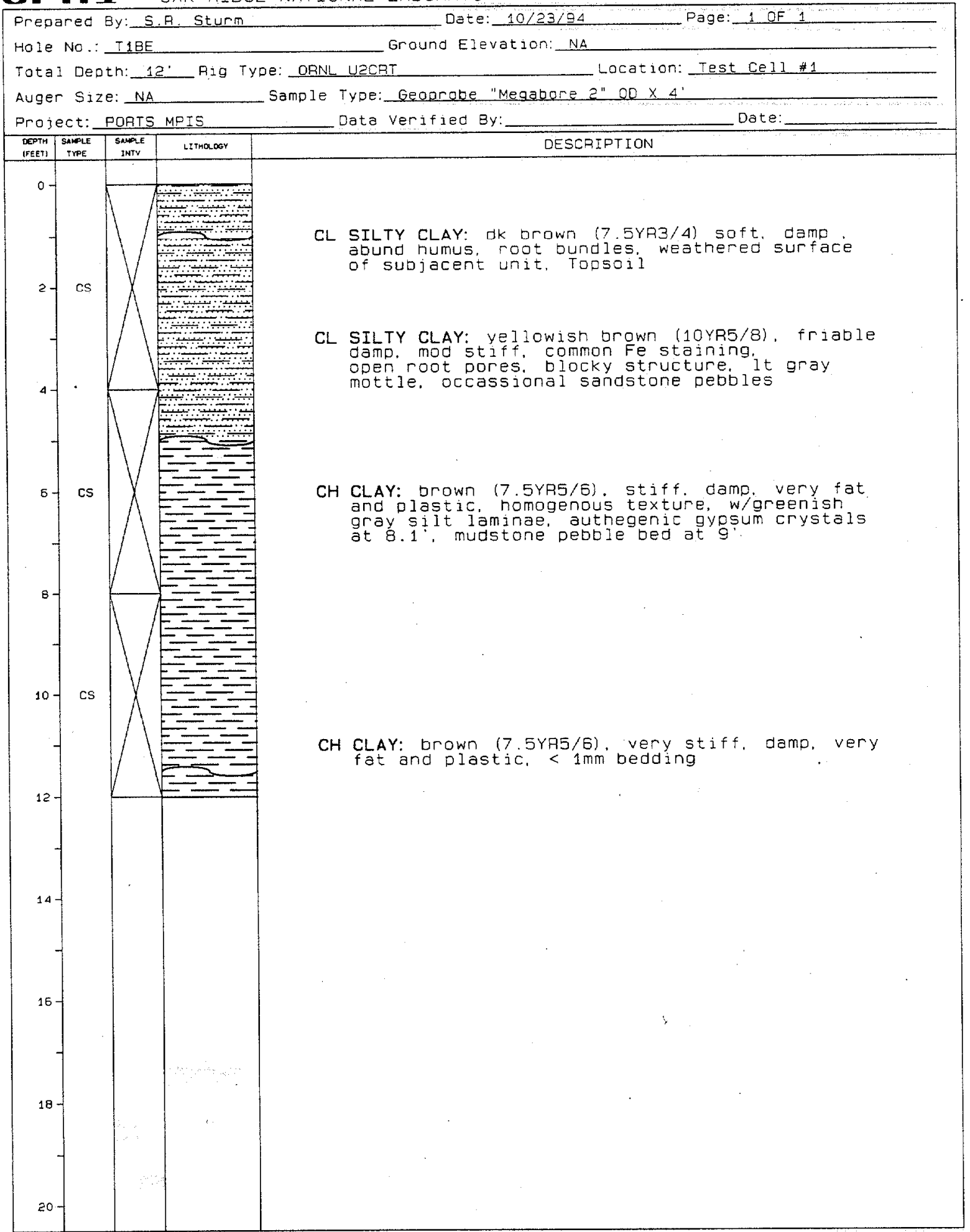




\section{B-8}

OII 11 aak ridge national Laboratory

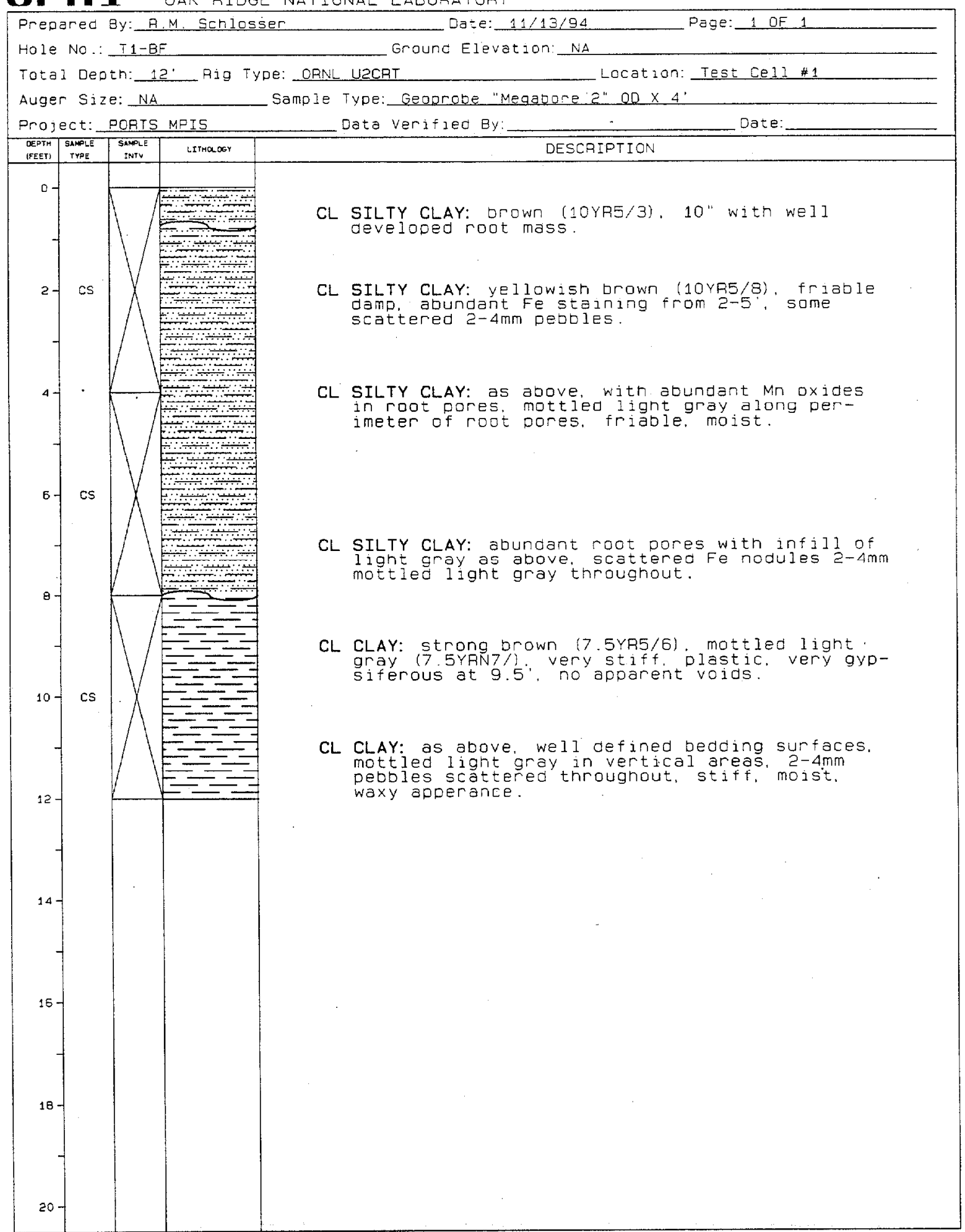




\section{B-9}

Borehole Summary Information

QIn 1 oak ridge national Laboratory

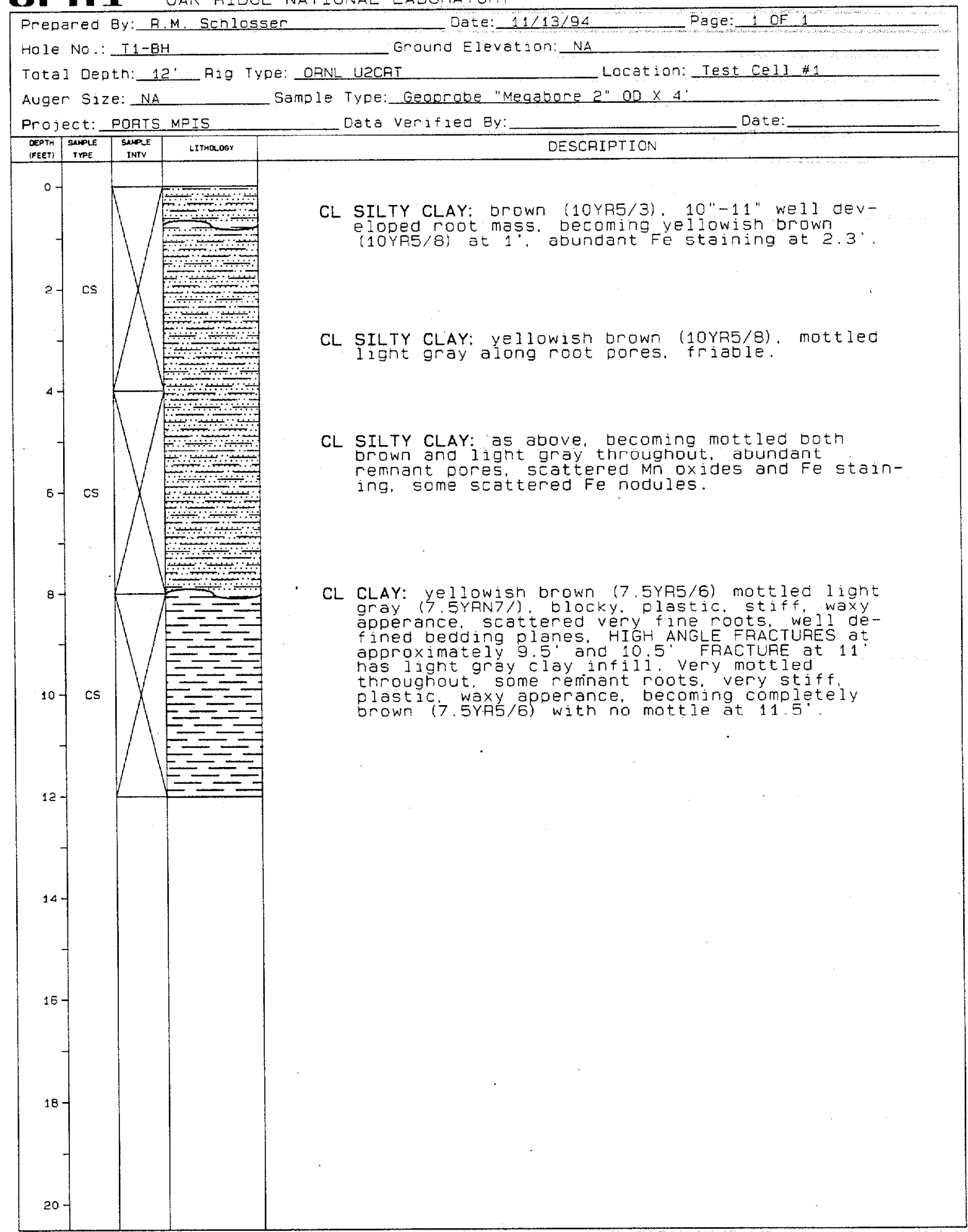




\section{B-10}

orn 1 oak ridge national laboratory

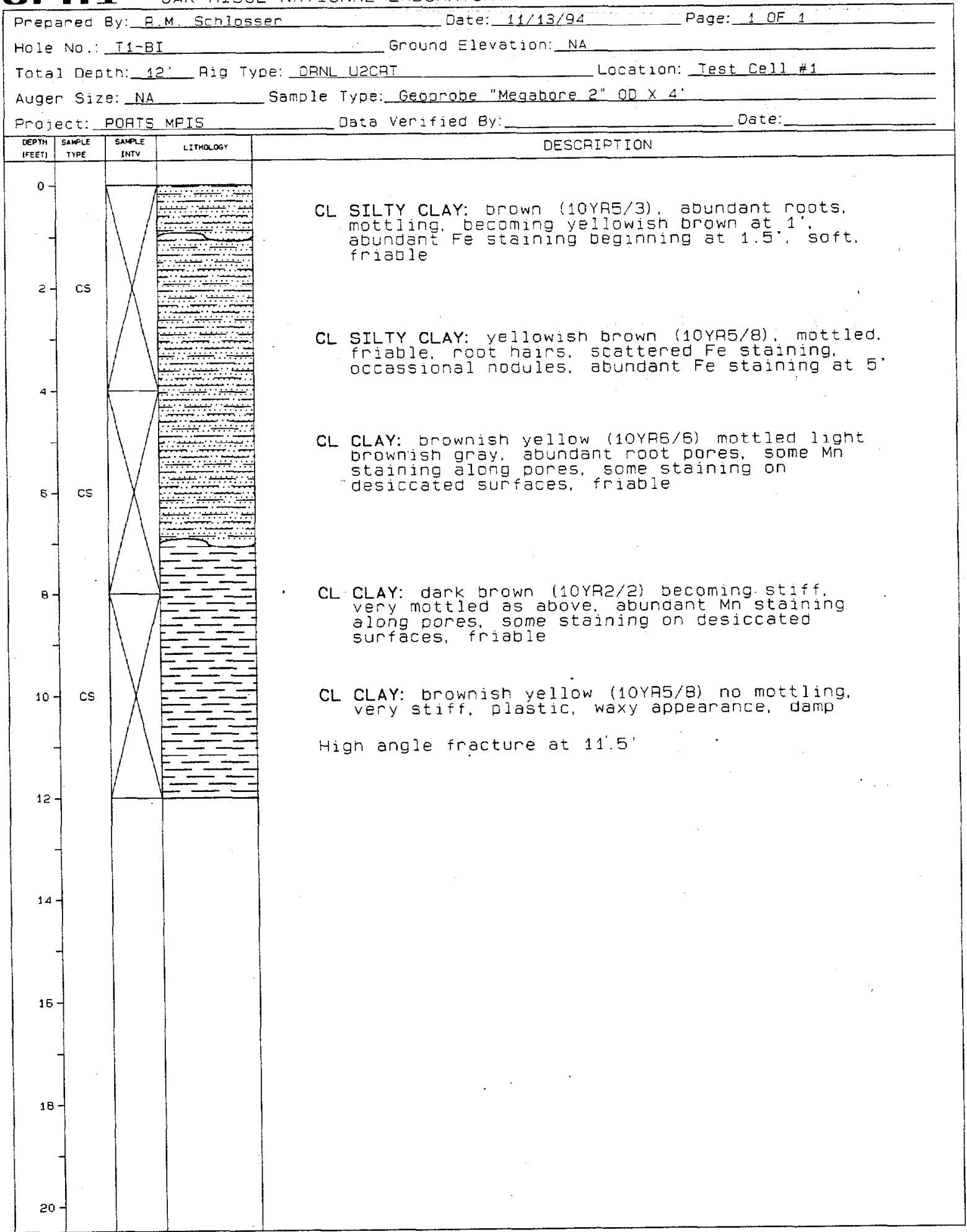




\section{B-11}

OrI oak ridge national laboratory

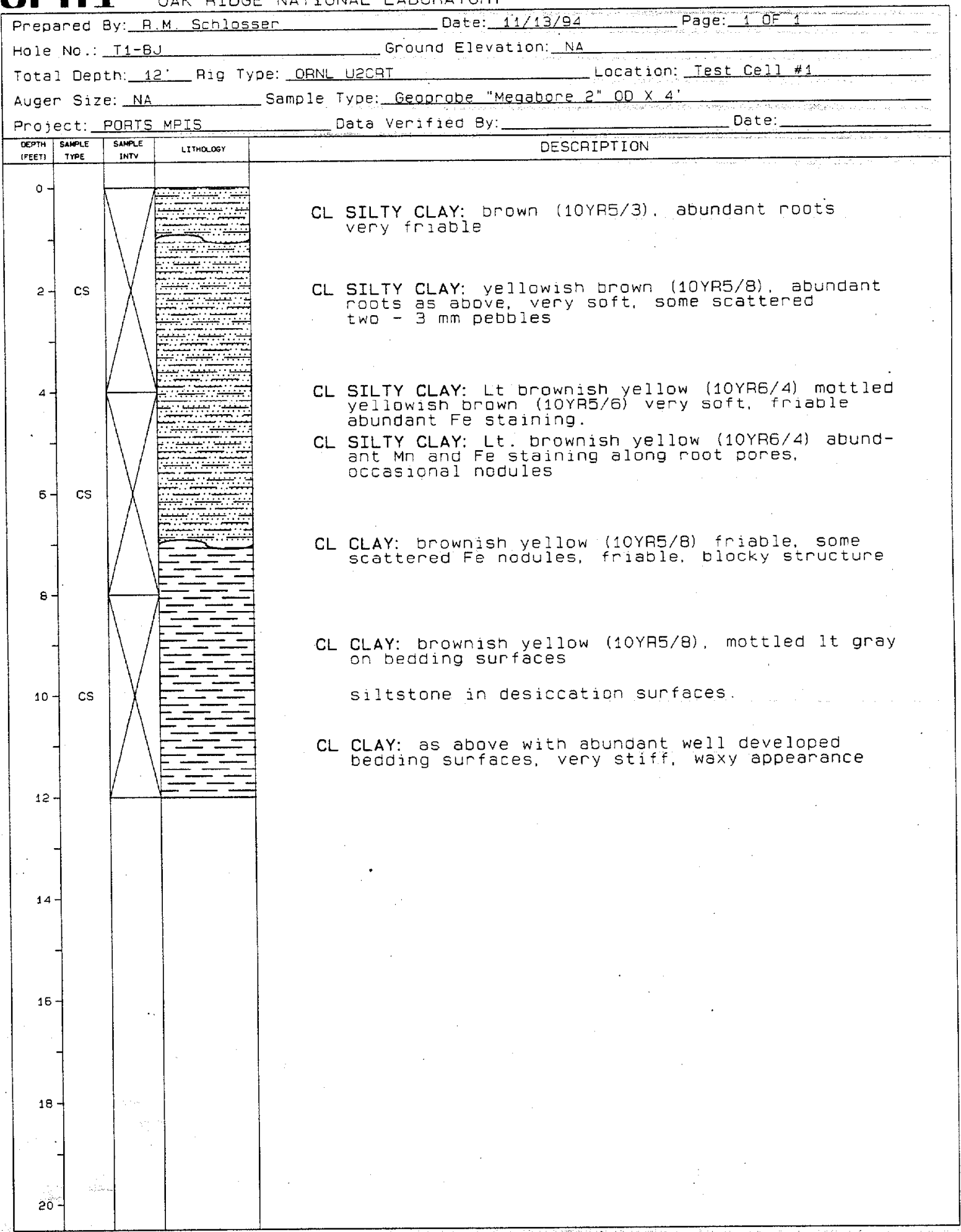




\section{B-12}

\section{orn 1}

\section{Borehole Summary Information}

OAK RIDGE NATIONAL LABORATORY

Hole No.: T1Bk Ground Elevation: NA

Total Deptr: 12: Rig Type: ORNL UZCAT

Datc: $12 / 13 / 94$

Pagc: 1 OF 1

Location: Test Cell \#1

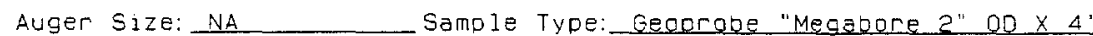

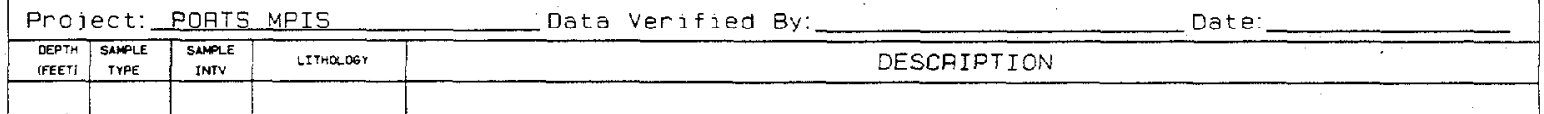

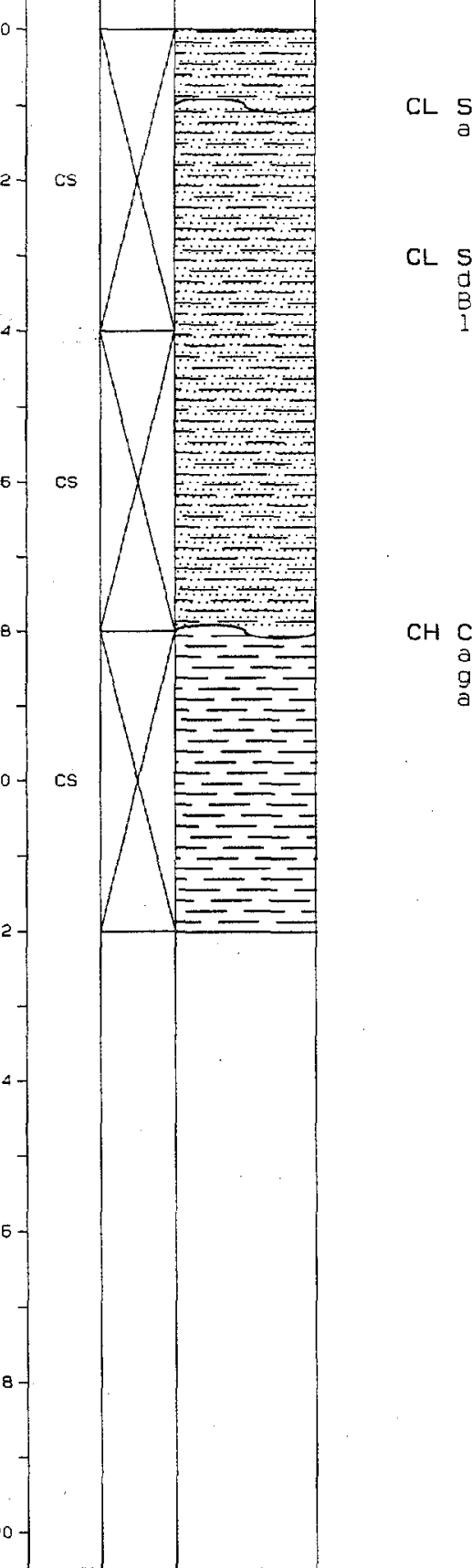
SILTY CLAY: dK brown (7.5YR3/4) soft, damp.
abund numus, root bundies. Topsoil

SILTY CLAY: yellowisn. DFOWH (10YRE/E), friadIe damp. open root pores. blocky structure.

Becoming $v$ stiff. increasing silt content.

imonite staining. abund $\mathrm{Fe}$ nods 5 to 7 .

CH CLAY: brown (7.5YA5/6) stiff, damp. very fat and plastic, homogenous texture. w/intbdd gray silt Iaminae, no visible fractures or alterations 


\section{B-13}

OII oak ridoge national Laboratory

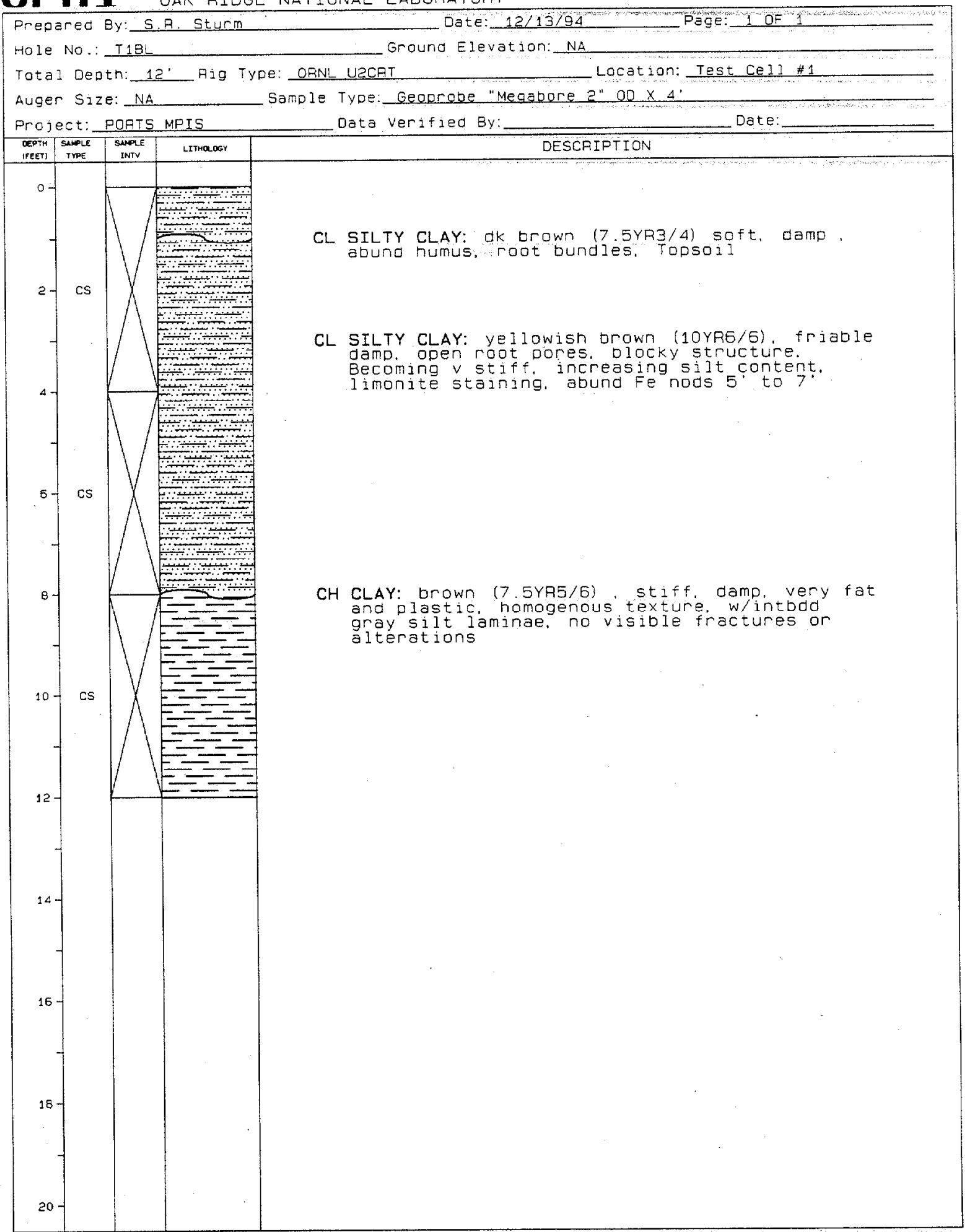




\section{B-14}

\section{Borehole Summary Information}

OIII OAK ridge national Laboratory

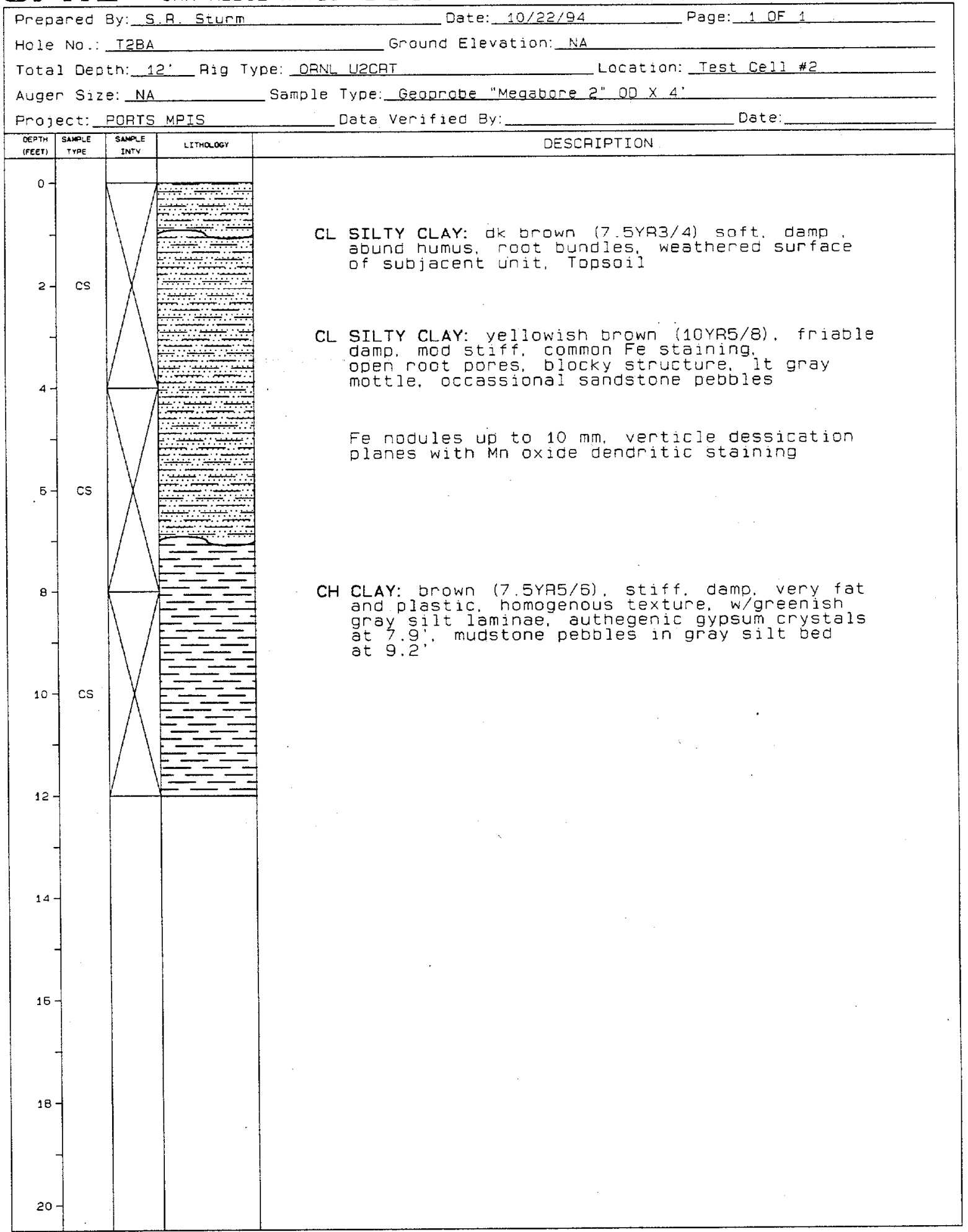




\section{B-15}

QIn 1 oak ridge national LaBORatory

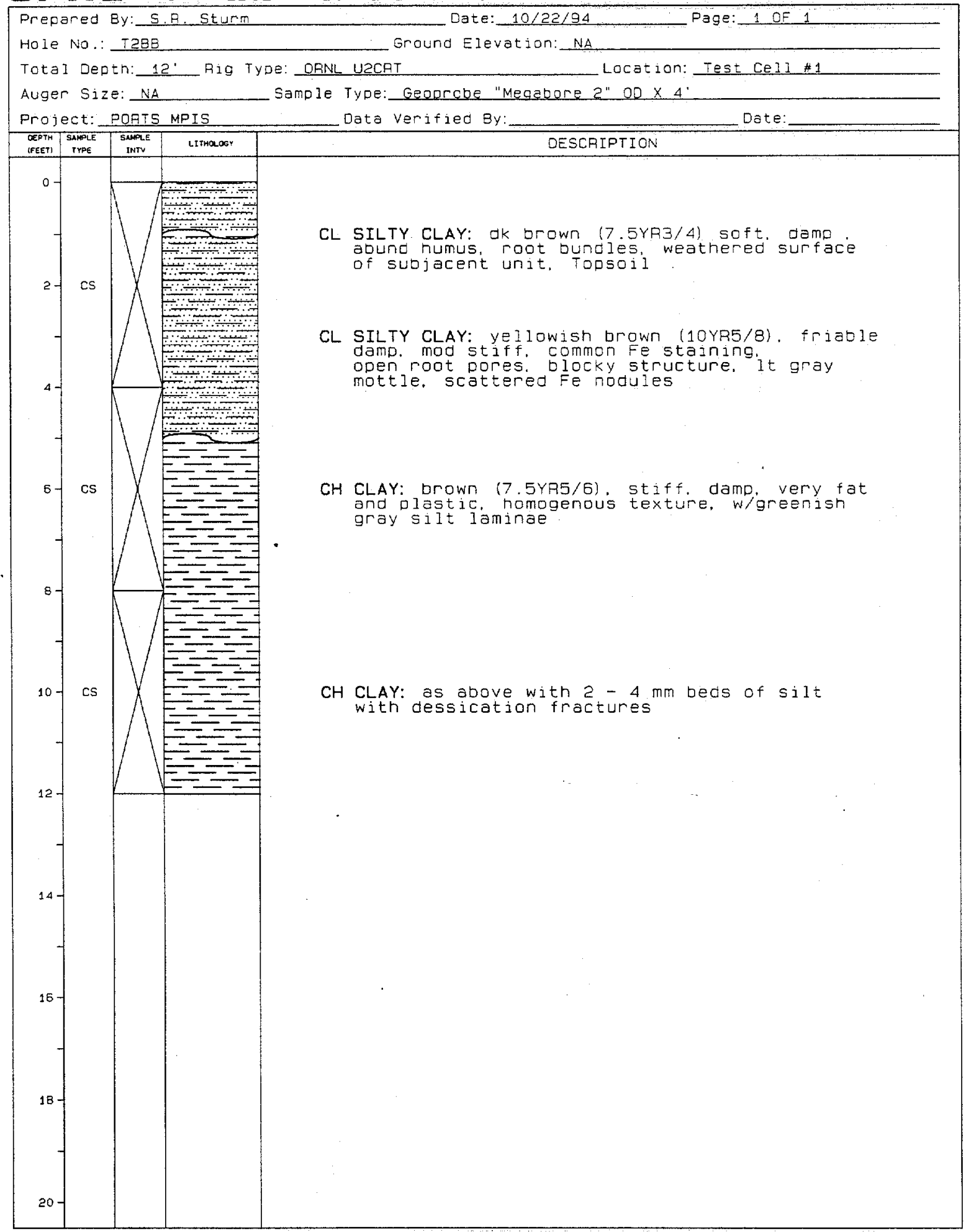




\section{B-16}

QIm 1 oak Ridge national Laboratory

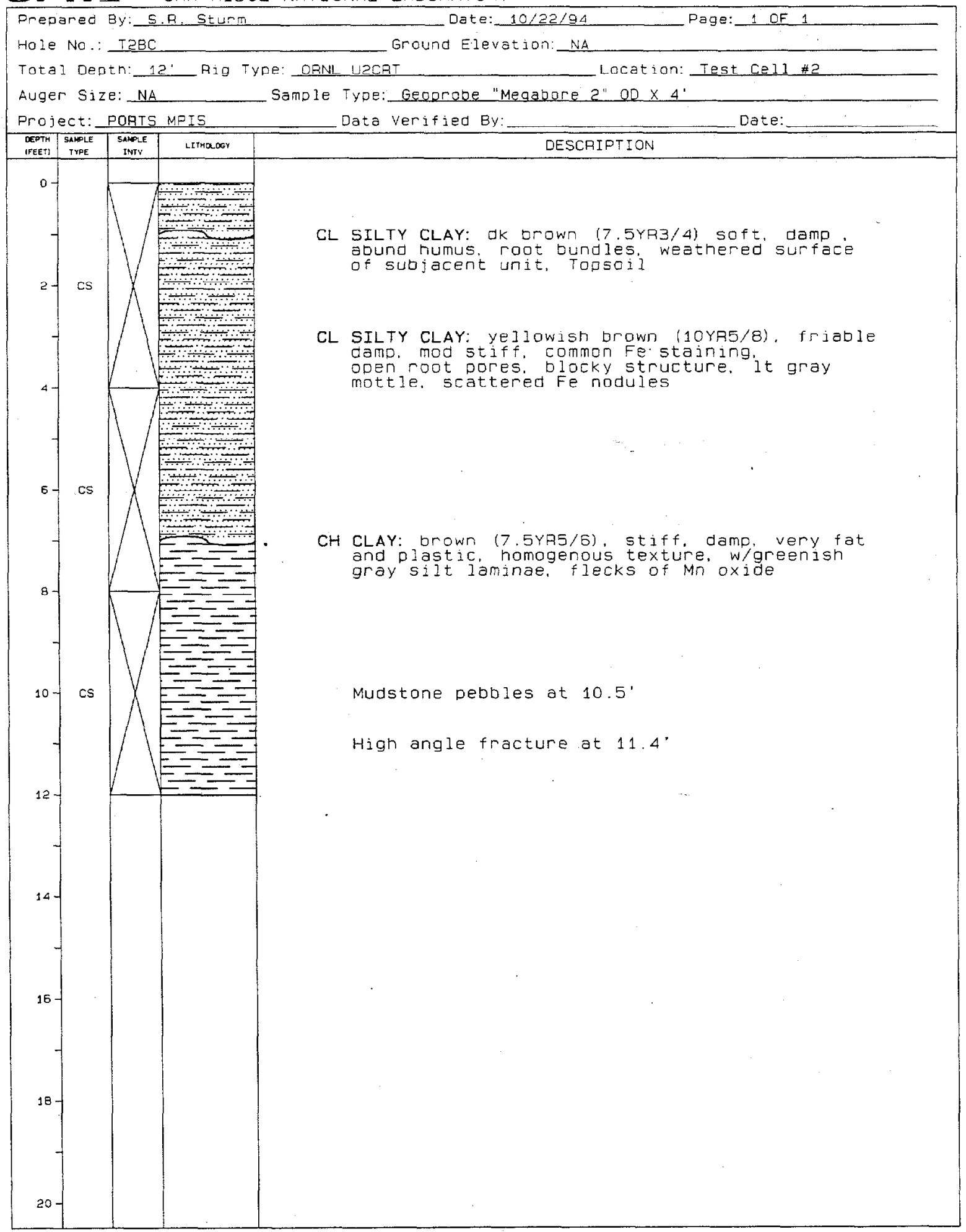




\section{B-17}

Borehole Summary Information

Qrn] oak Ridge national Laboratory

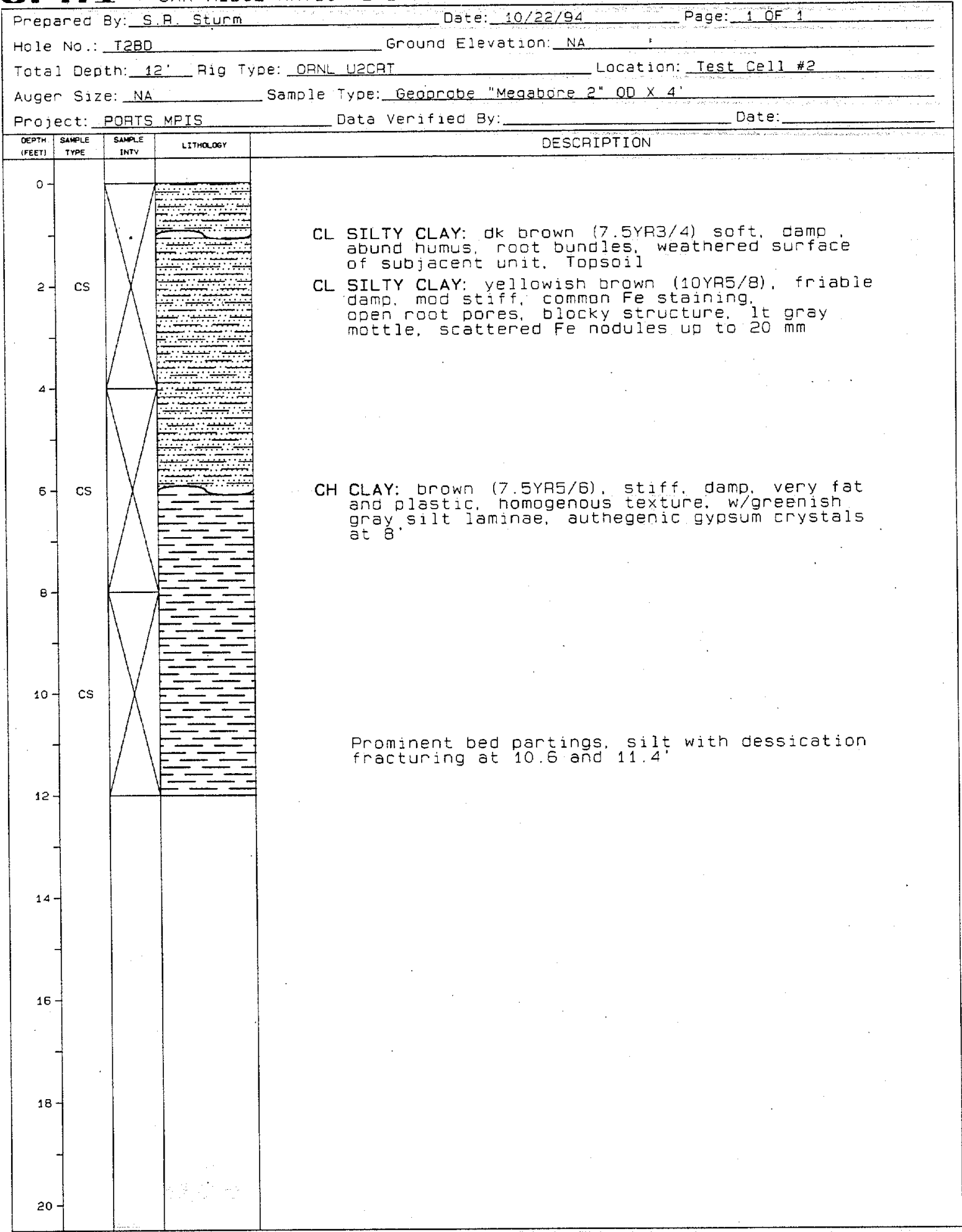




\section{B-18}

Borehole Summary Information

QI 1 oak ridge national laboratory

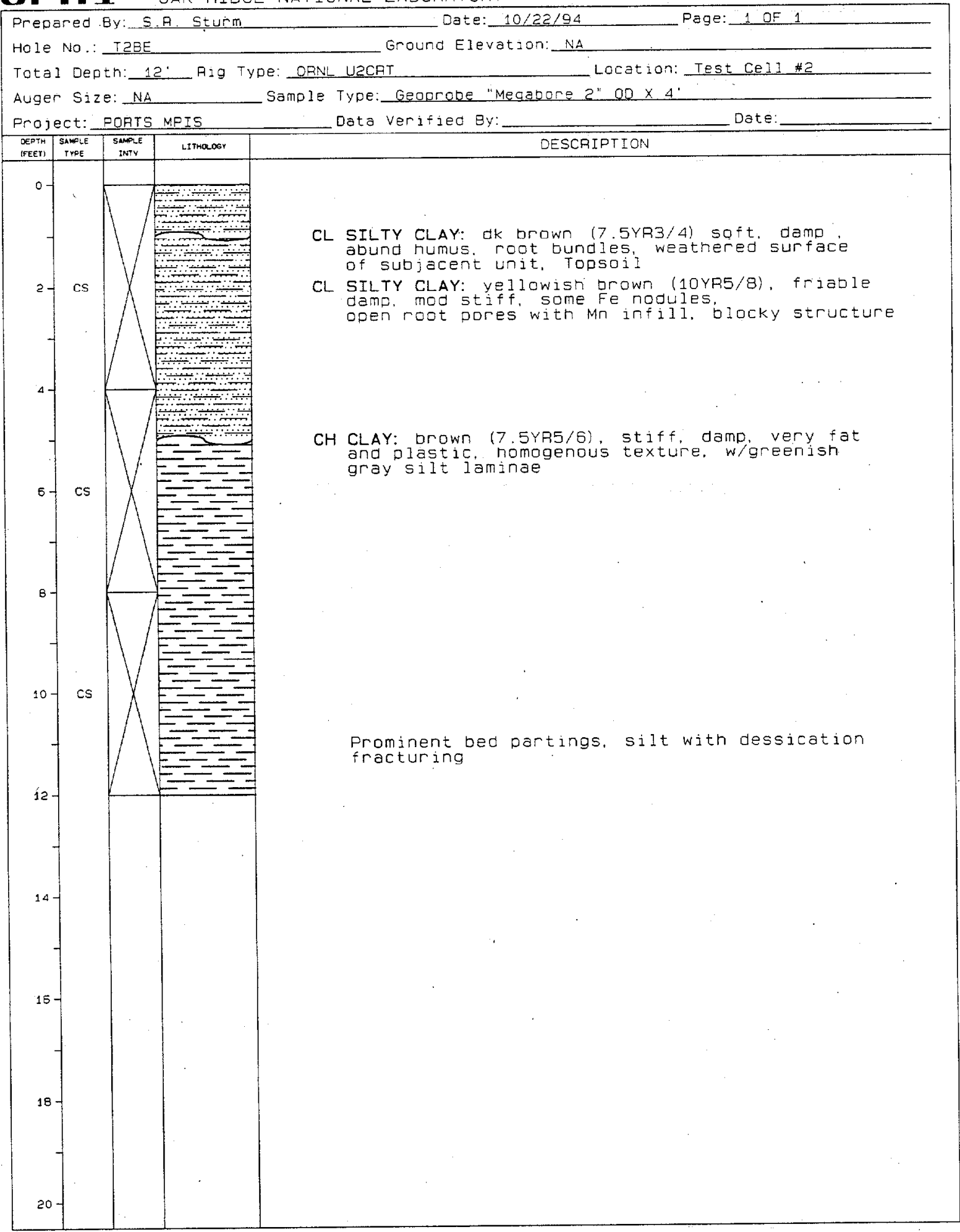




\section{B-19}

QrI oak fidge national labohatofy

\section{Borehole Summary Information}

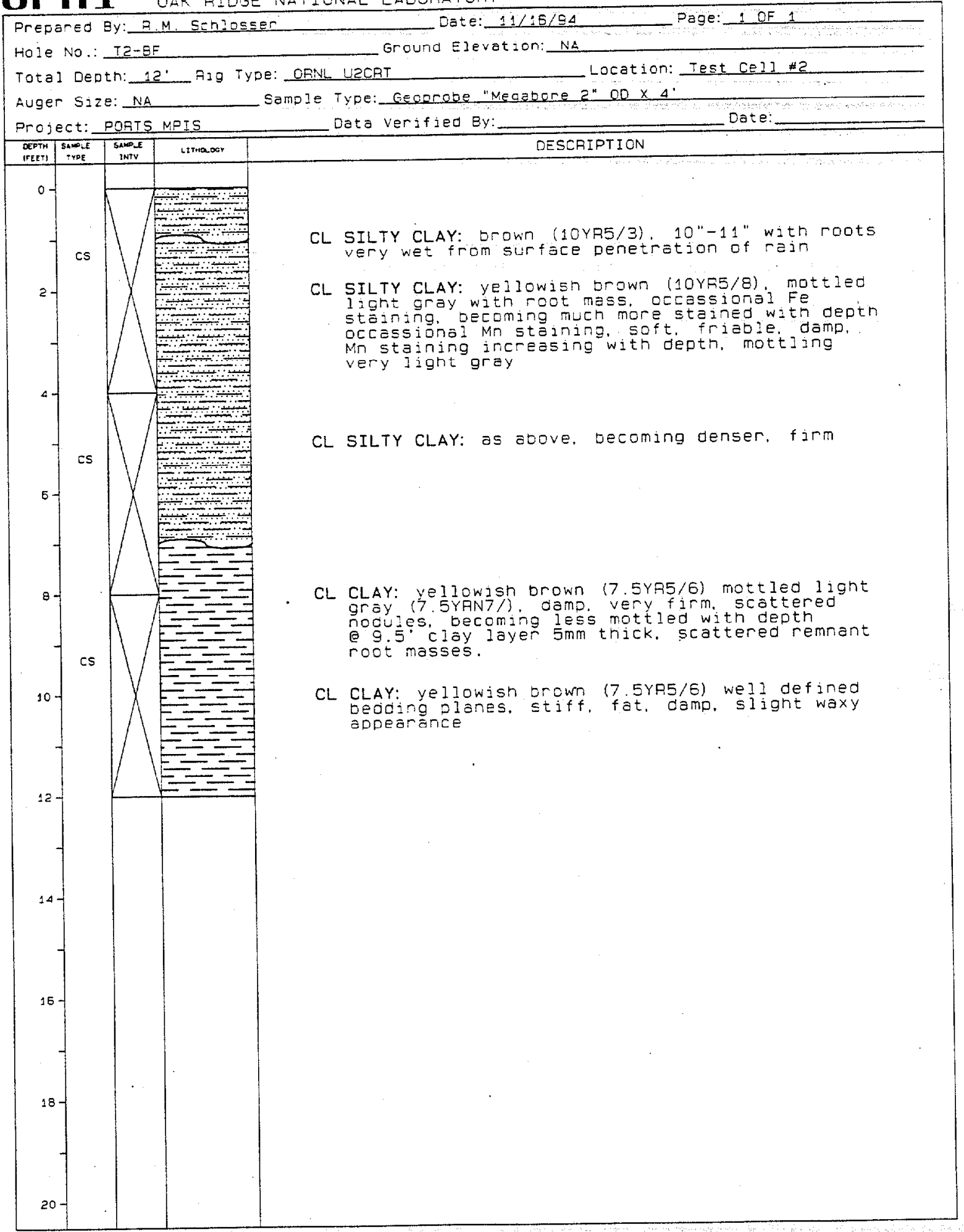




\section{B-20}

DrI oak ridge national laboratory

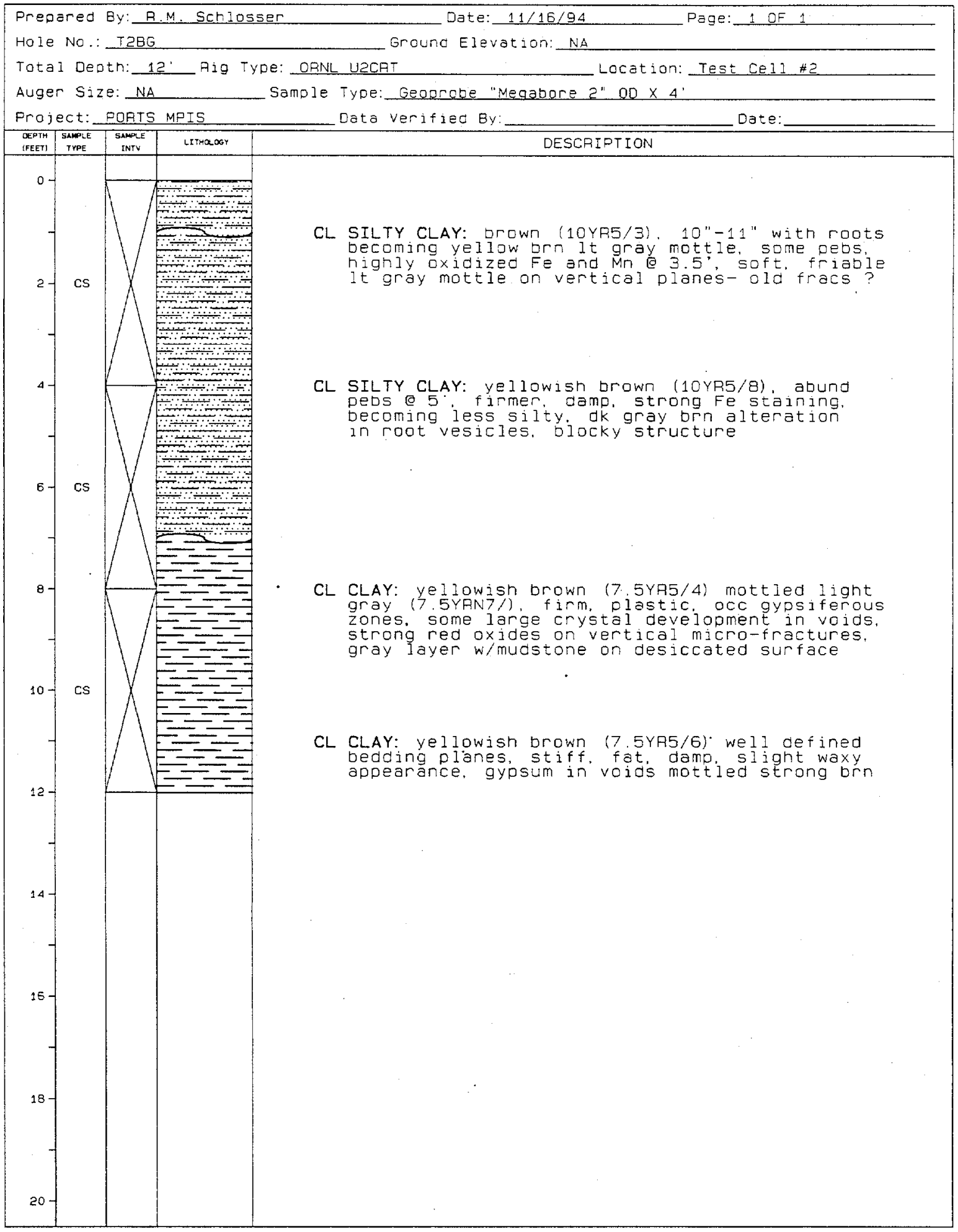




\section{B-21}

Borehole Summary Information

OrII OAK RIDGE nATIONAL LABORATORY

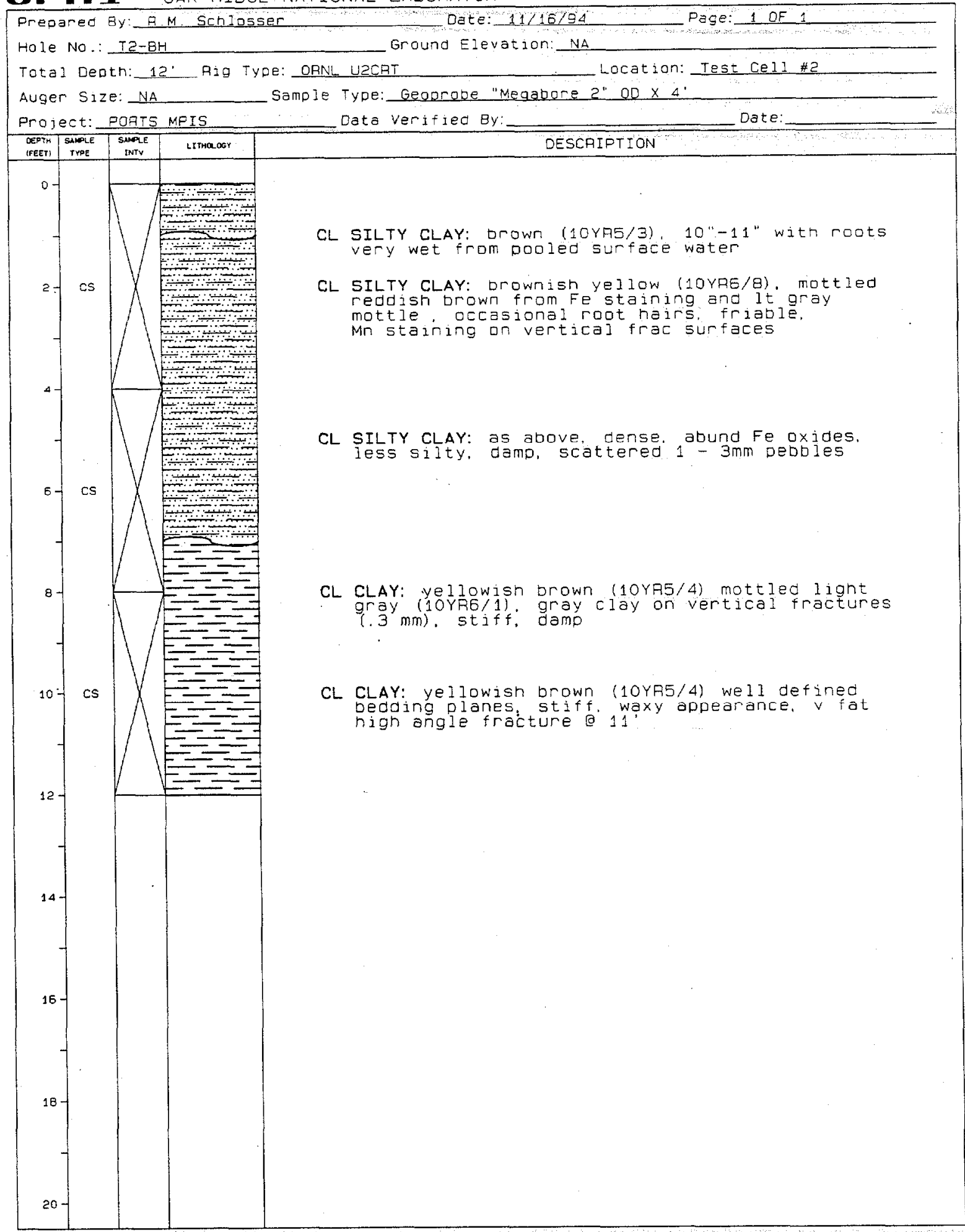




\section{B-22}

DIII Dak Ridge national Lagopatogy

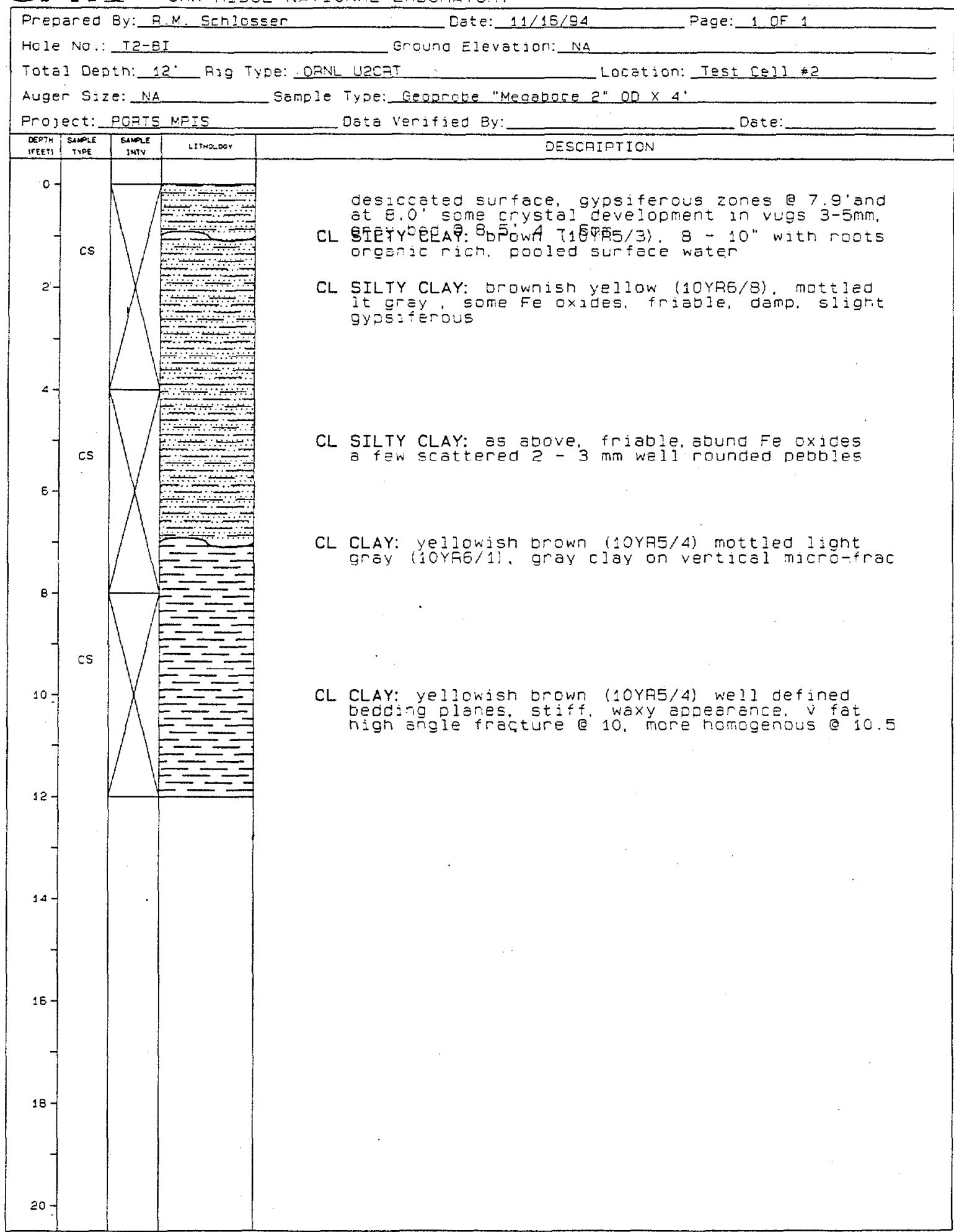




\section{B-23}

orI 1 oak RIDGe national Laboratory

Borehole Summary Information

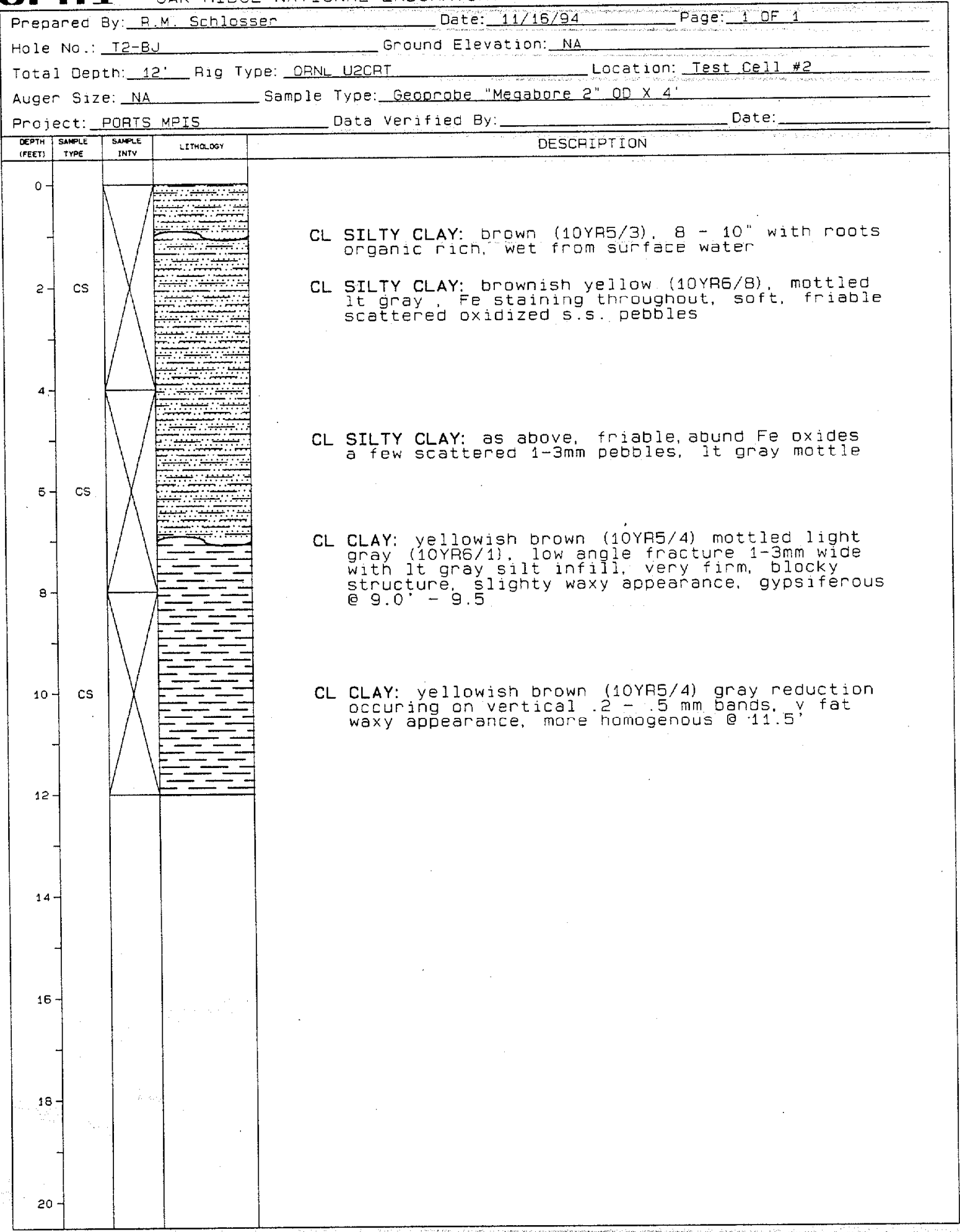


OTI oak ridge national laboratory

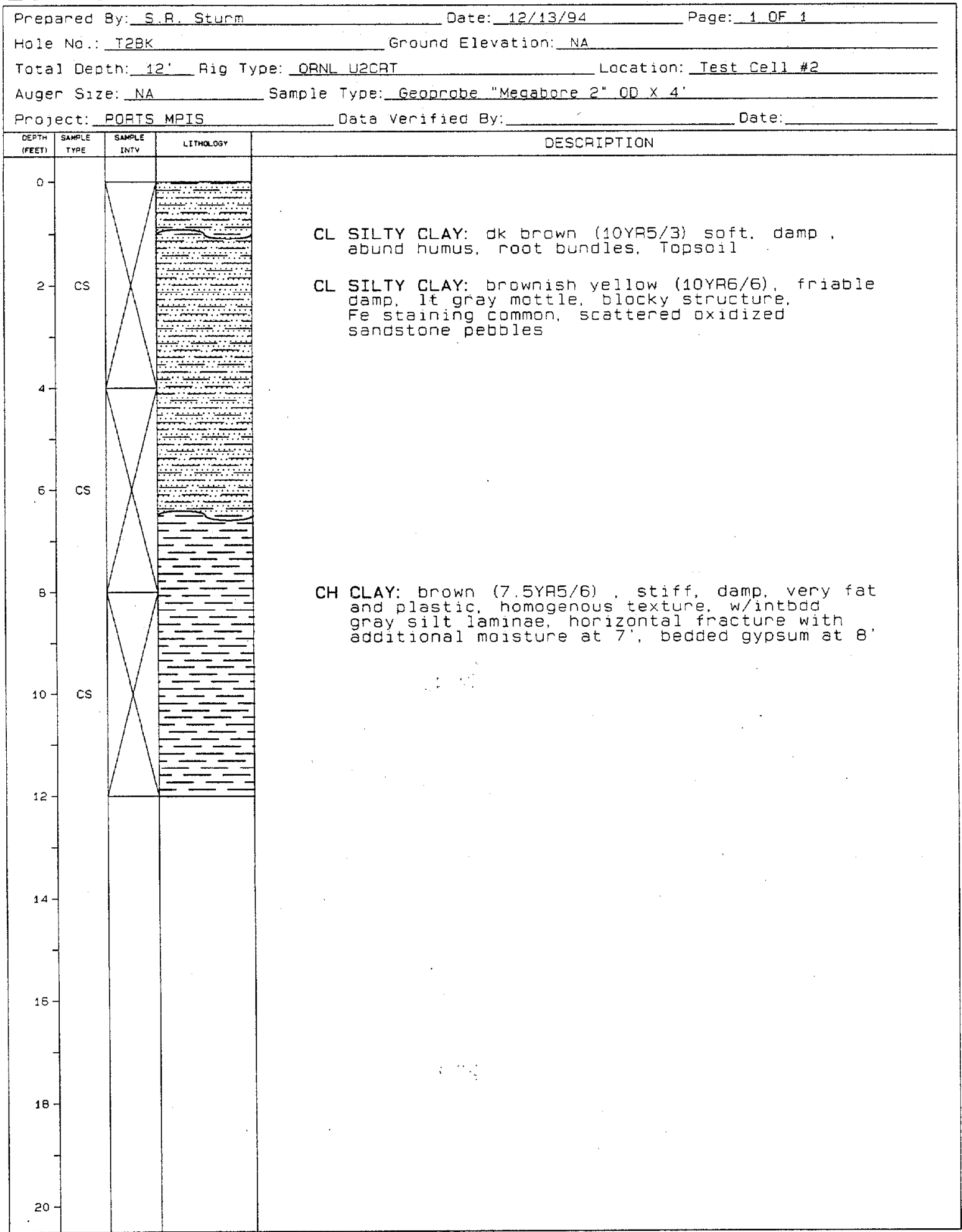


Borehole Summary Information

QII OaK ridge national LabORatory

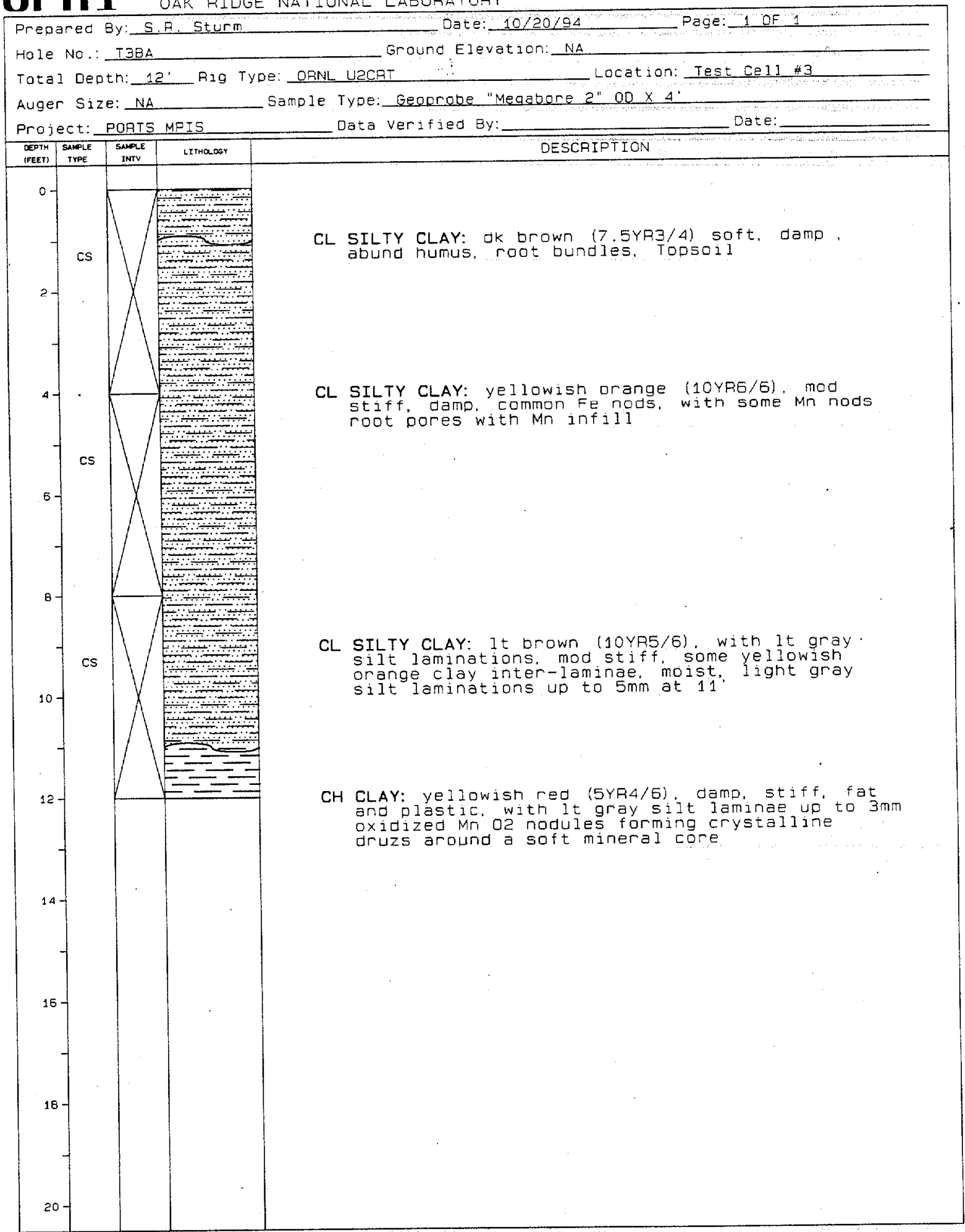




\section{B-26}

QTI oak ridge national Laboratory

\section{Borehole Summary Information}

Prepared By:S.A.Sturm Date:10/20/94_Page:1. DF 1

Hole No.: T3BB Ground Elevation: $\mathrm{NA}$

Total Deptn: 12. Aig Type: DRNL UaCRT Location: Test Cel1 \#3

Auger Size: NA Sample Type: Gegorcbe "Megabore 2 " $00 \times 4^{\text {" }}$

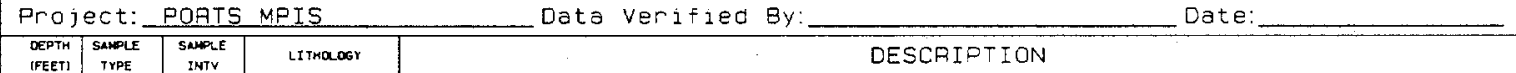

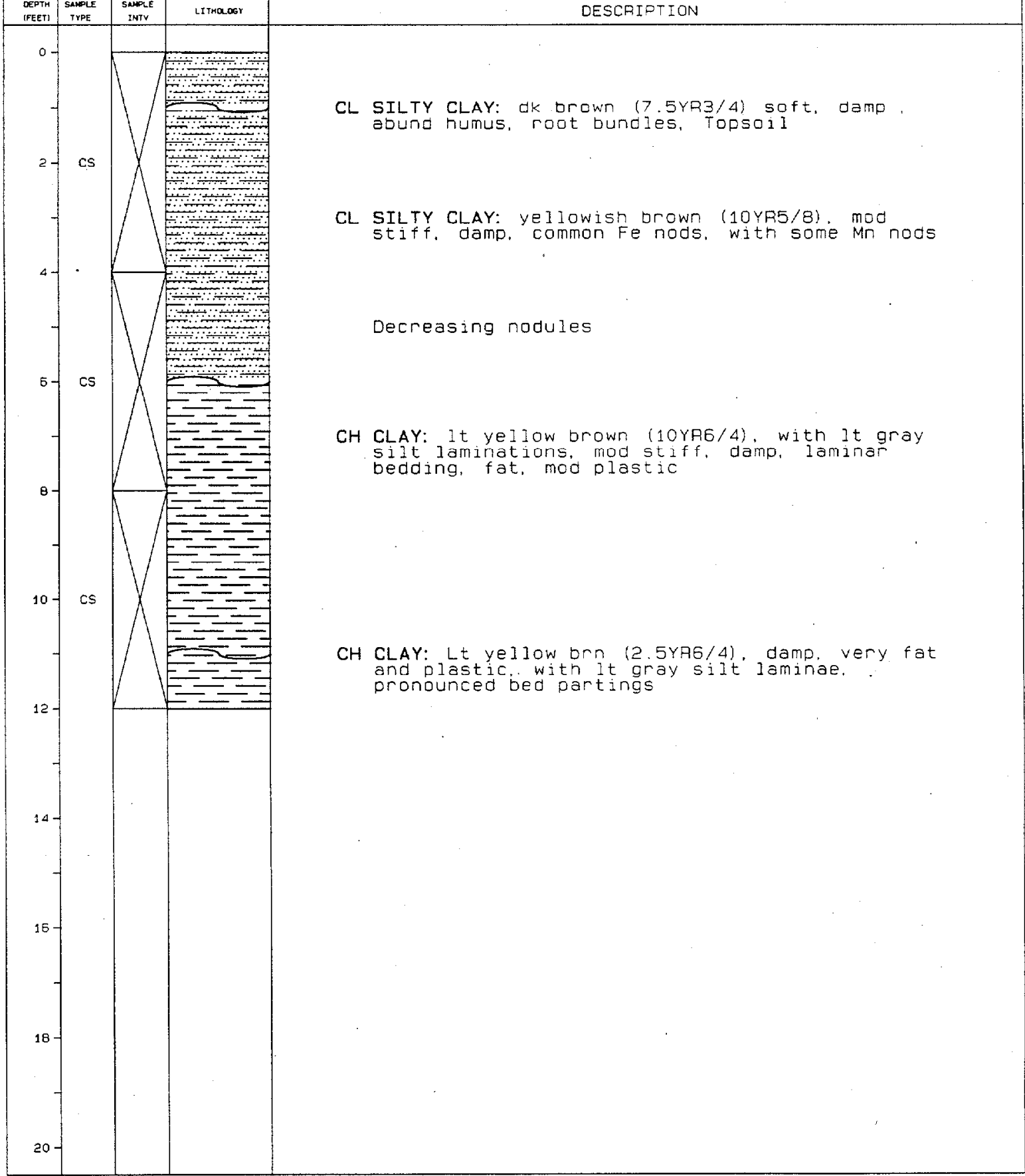




\section{B-27}

Borehole Summary Information

OMI OAK ridge national Laboratory

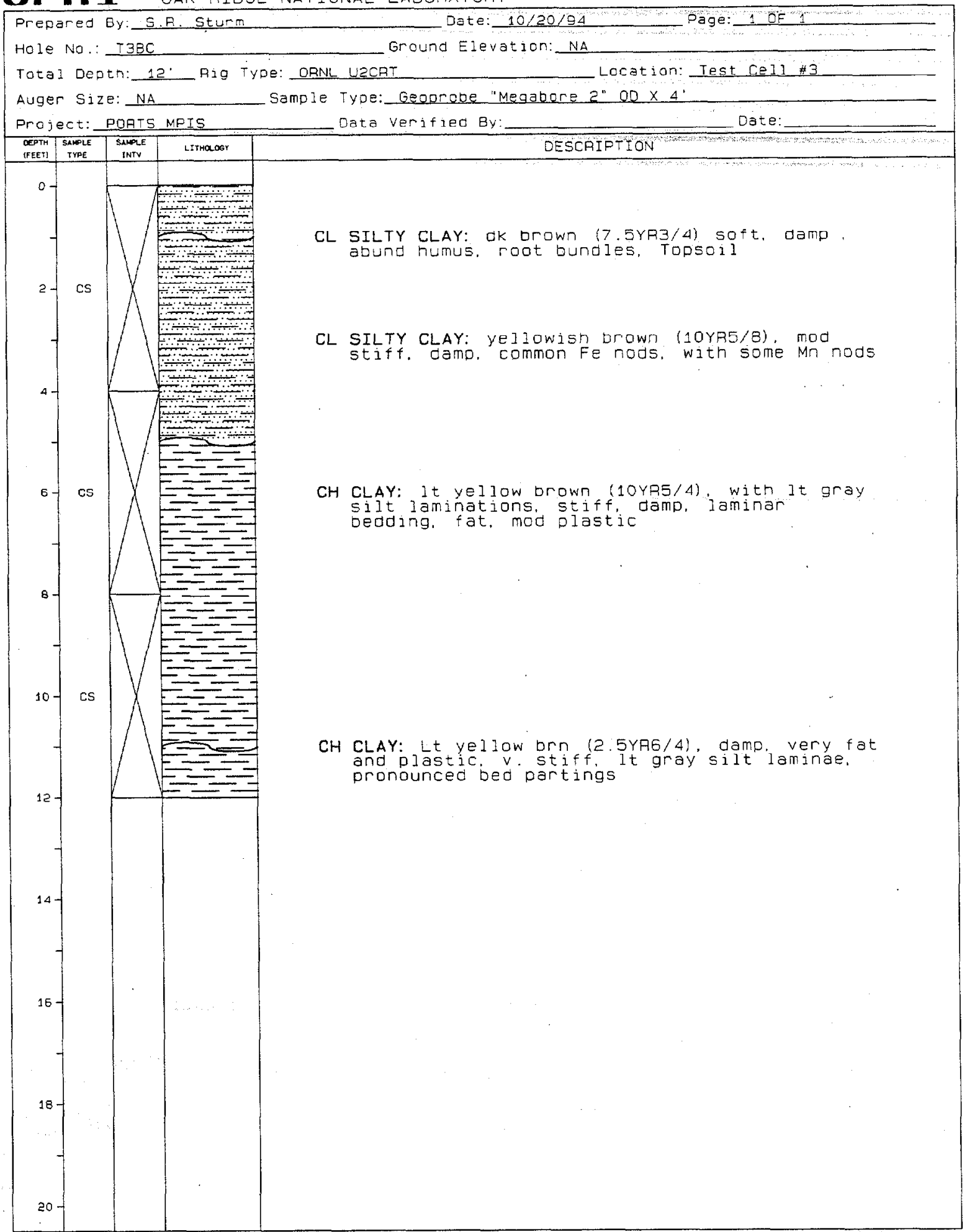




\section{B-28}

0 II oak rigge national Laboratory

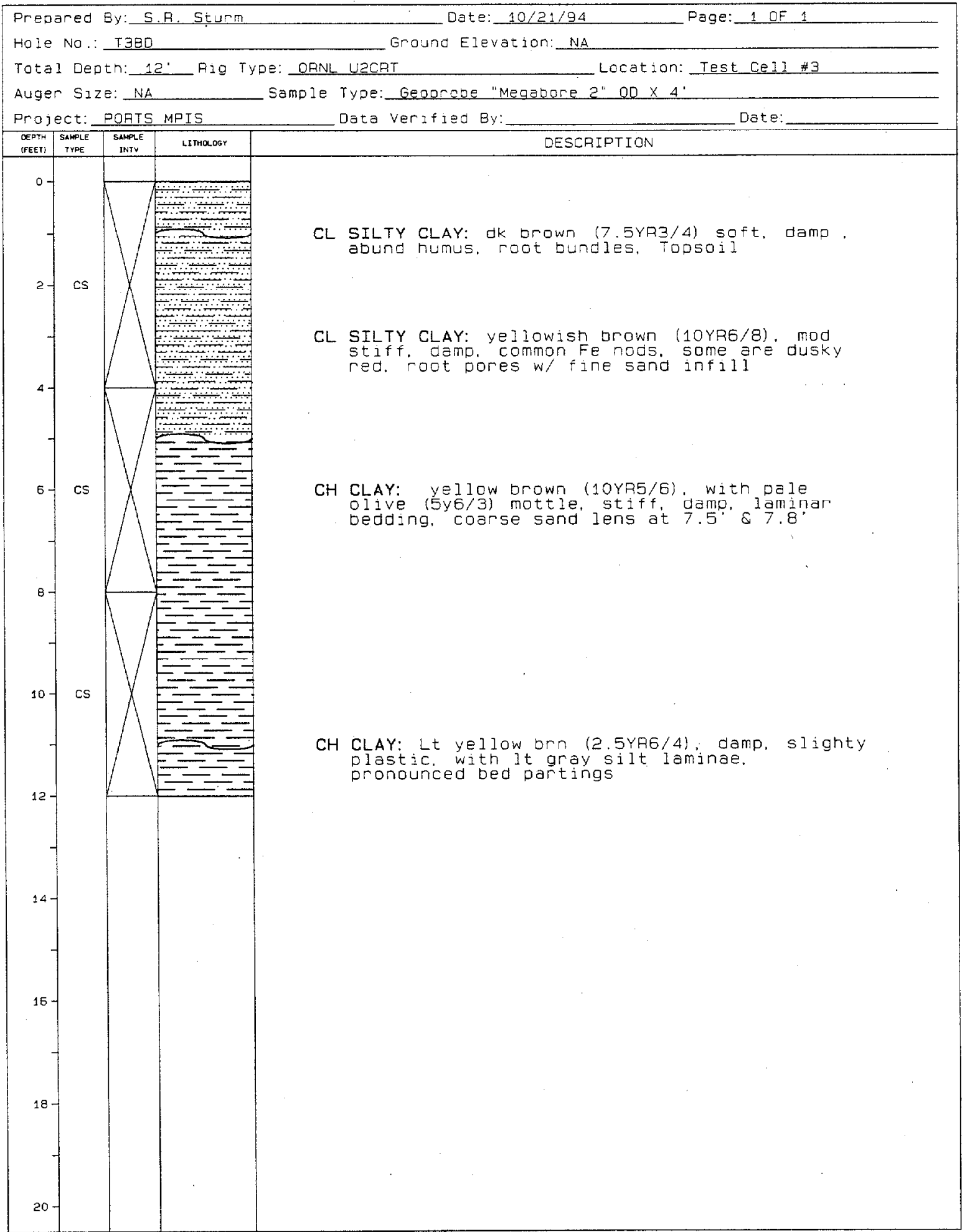




\section{B-29}

Borehole Summary Information

OTI 1 OAK RIDGe national LABORATORY

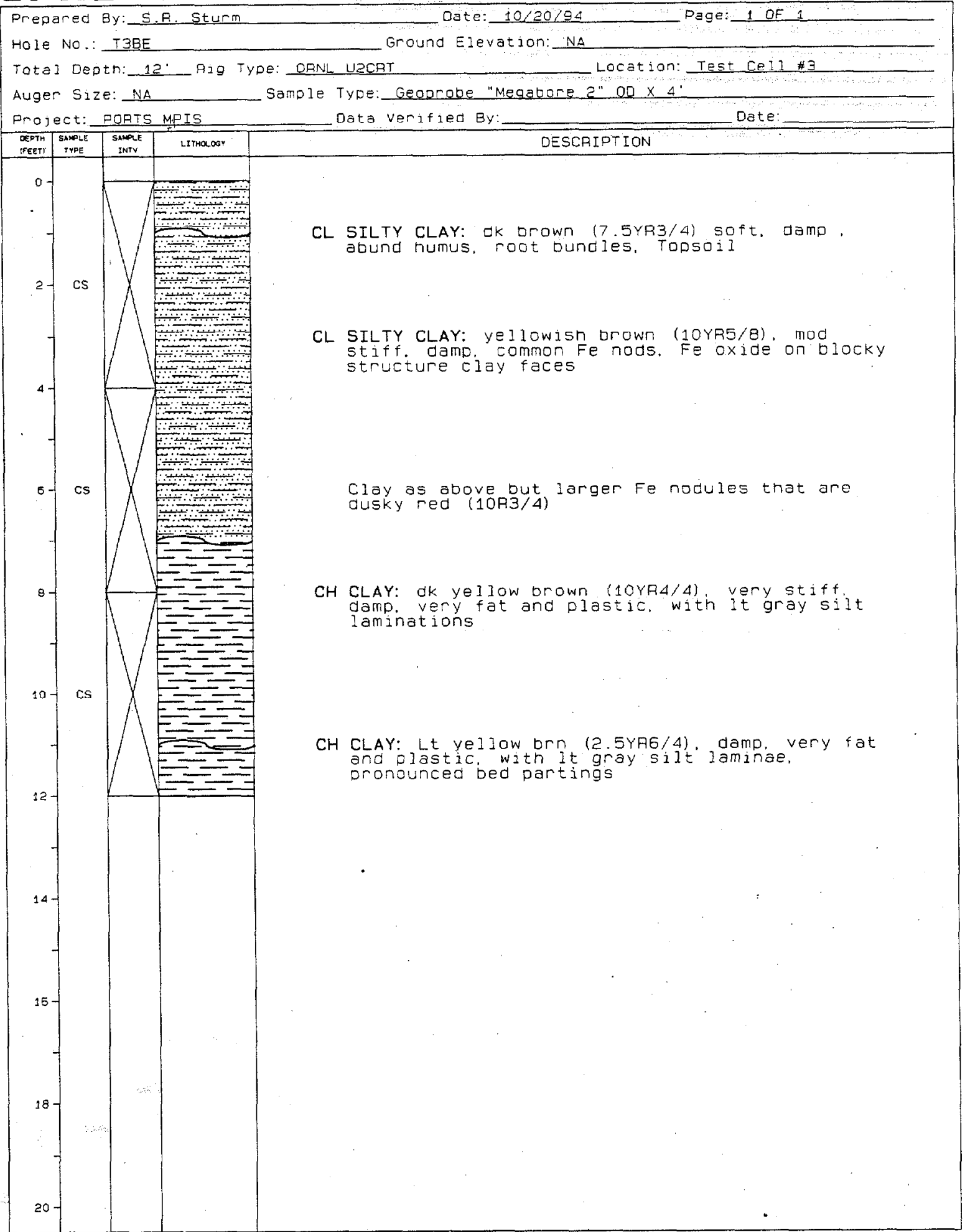




\section{B-30}

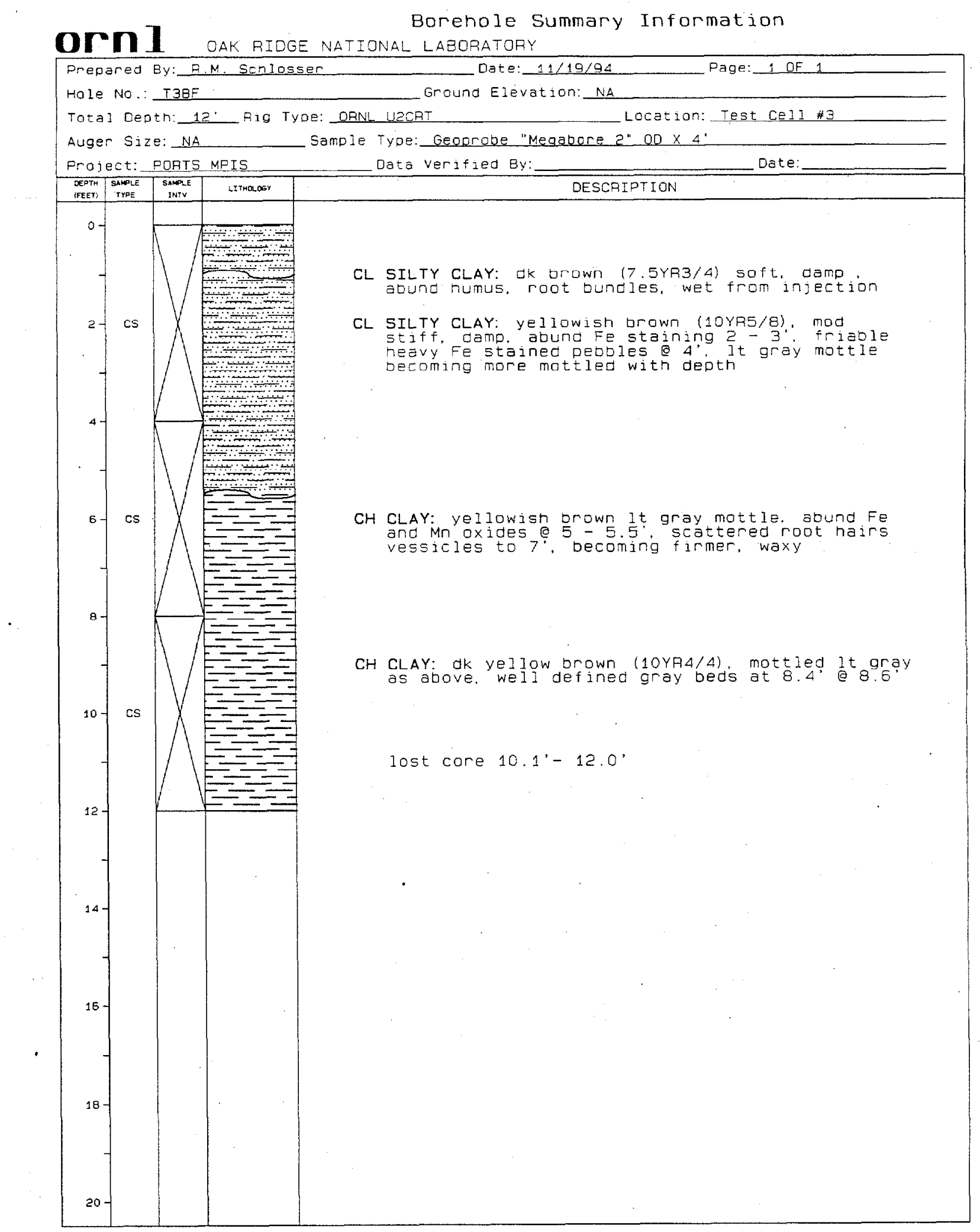




\section{B-31}

OrI 1 oak ridge national Laboratory

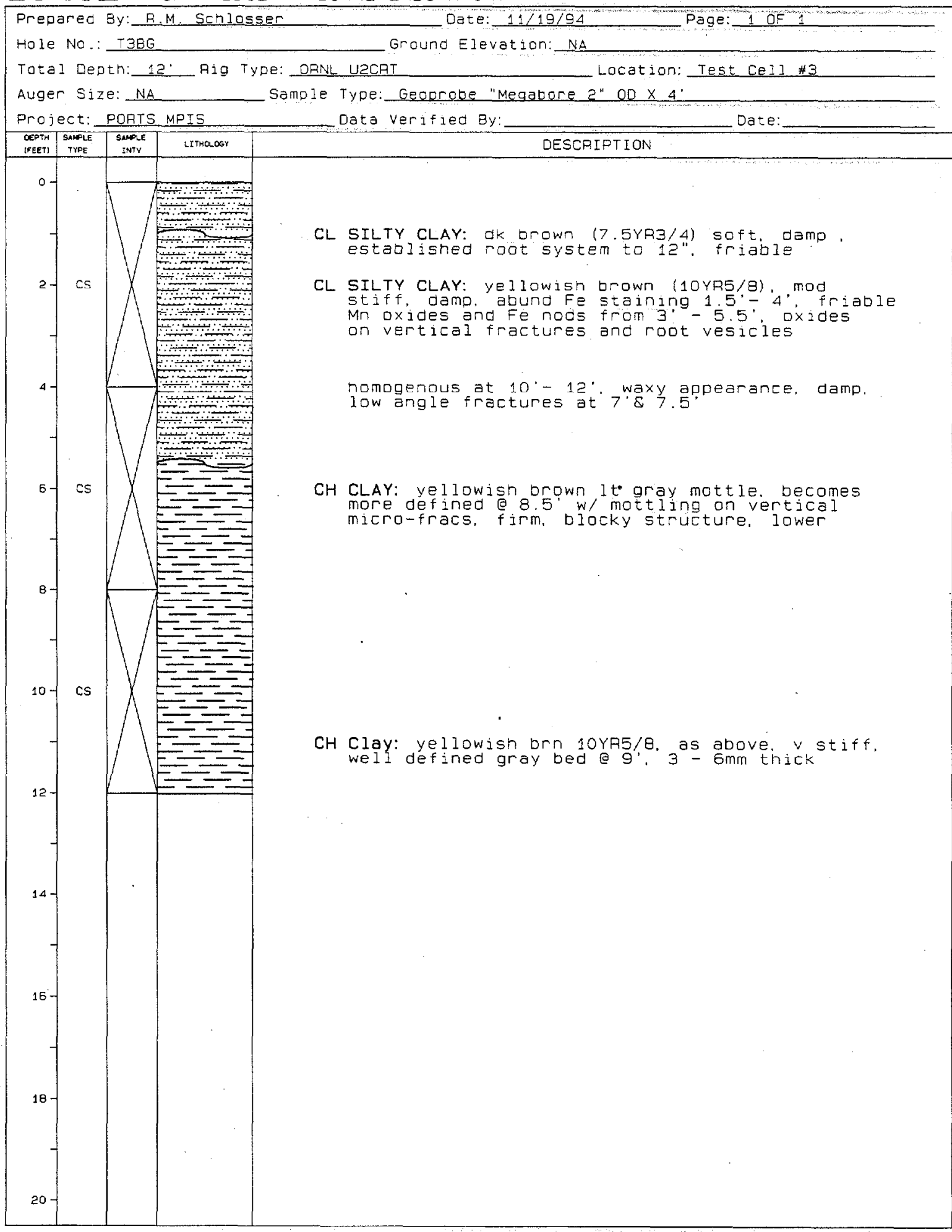




\section{B-32}

Orn 1 Borehole Summary Information

OI I OAK RIDGE NATIONAL LABORATORY

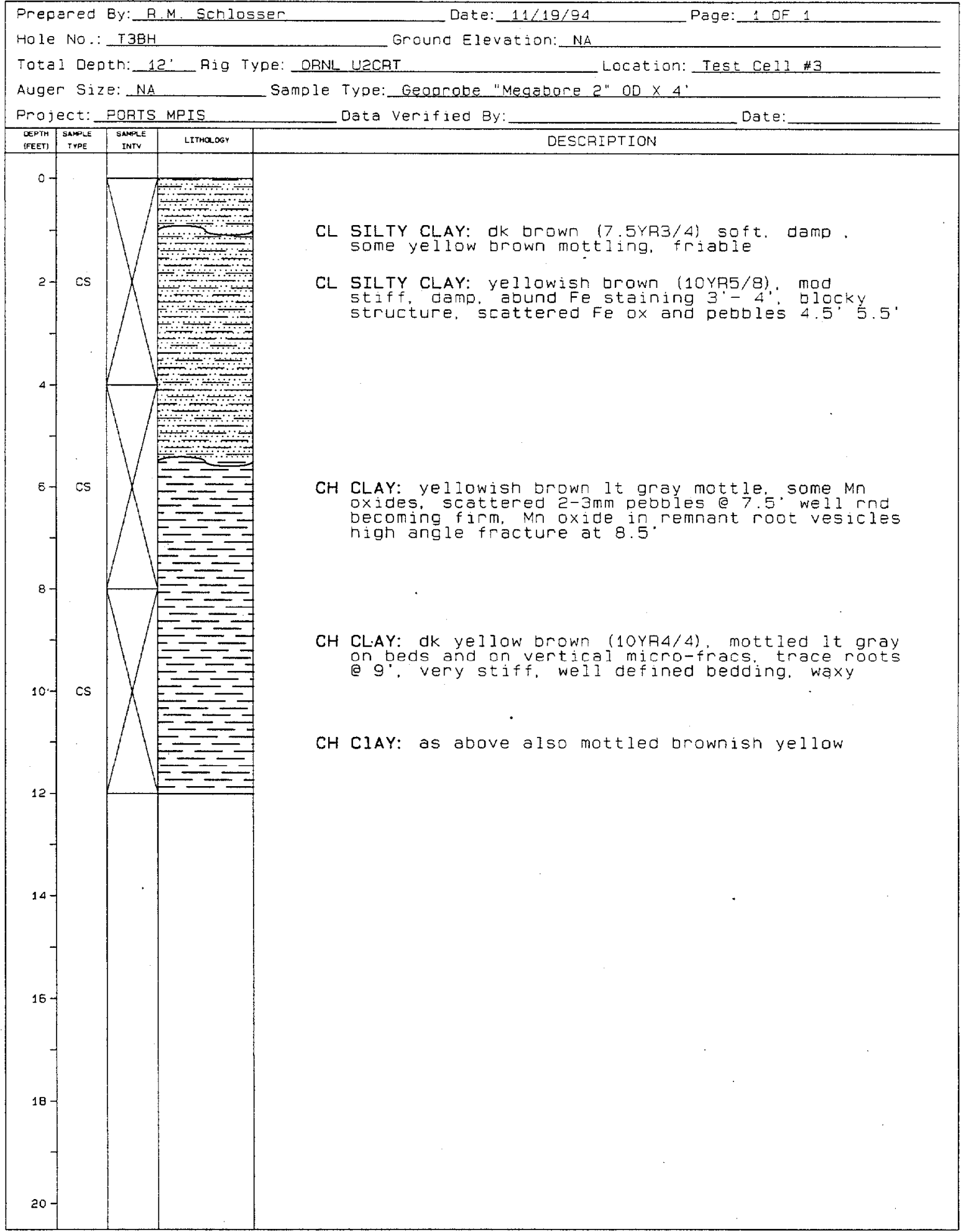




\section{B-33}

Orn 1 oak fioge national Lagohatory

\section{Borehole Summary Information}

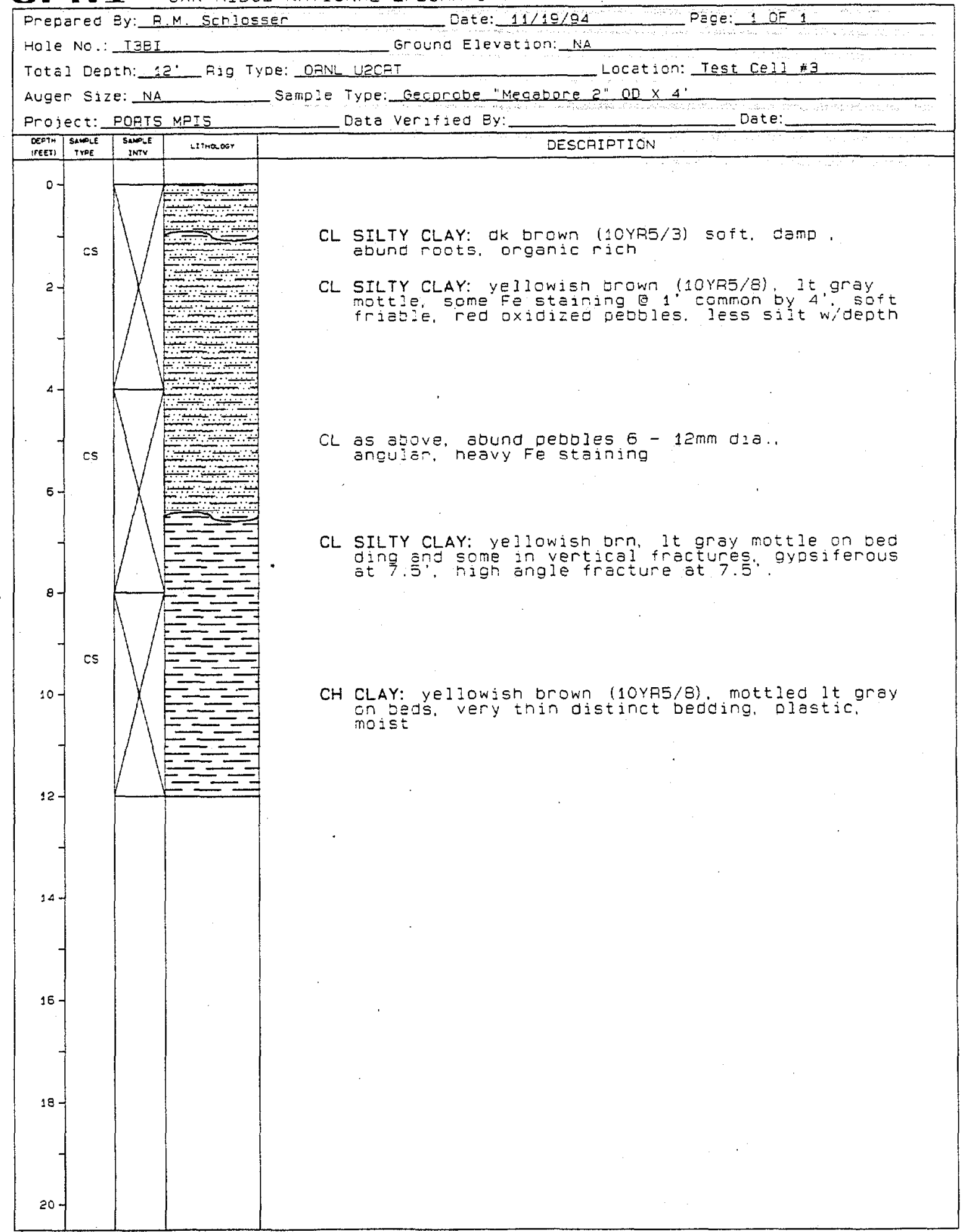




\section{B-34}

$\operatorname{arn} 1$

Borehole Summary Information

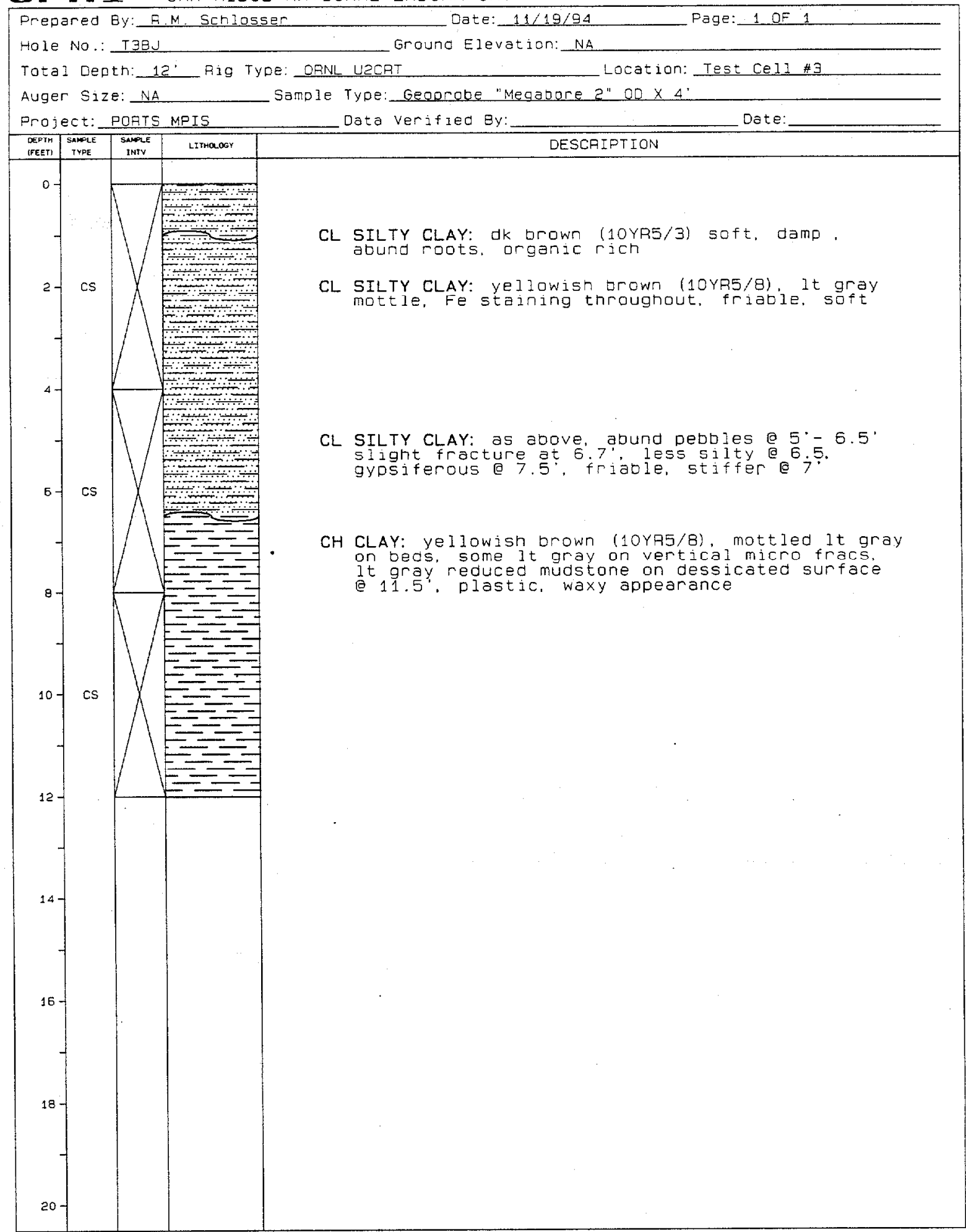




\section{B-35}

QTI oak ridge national Laboratory

\section{Borehole Summary Information}

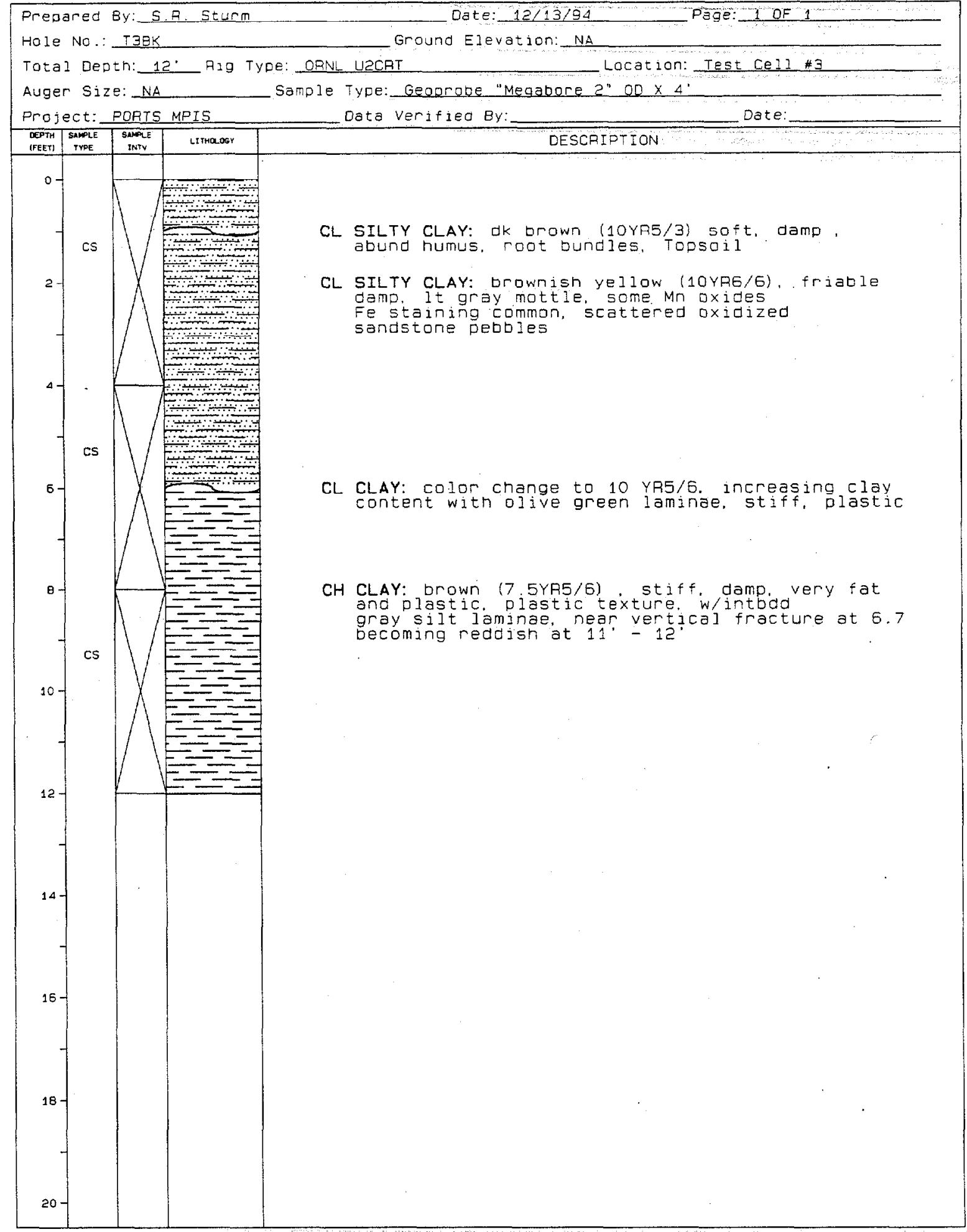




\section{B-36}

OTI oak ridge national Laboratory

Borehole Summary Information

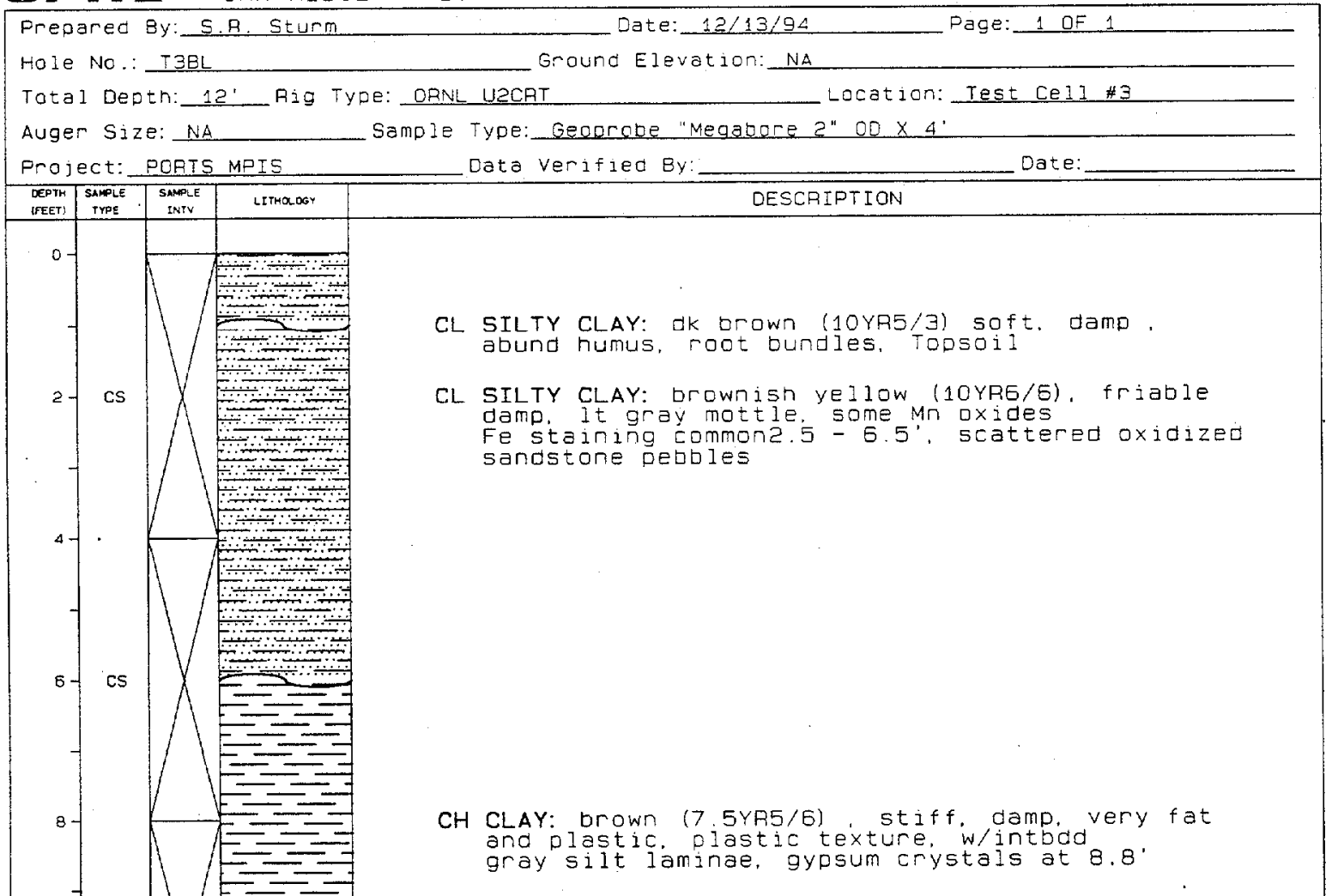

CH CLAY: becoming red brown 


\section{B-37}

QII oak ridge national Laboratory

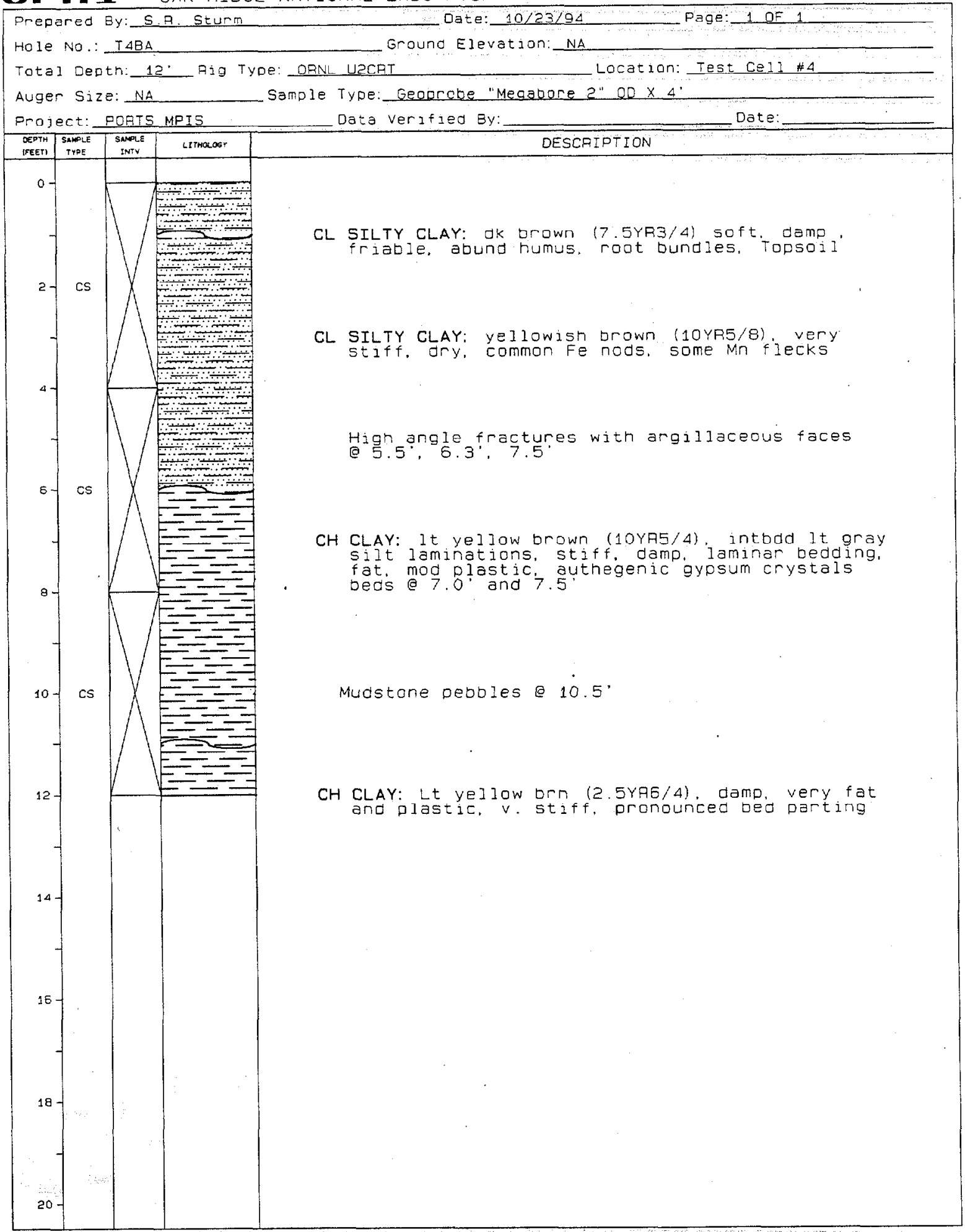




\section{B-38}

OTI OAK ridge national Laboratory

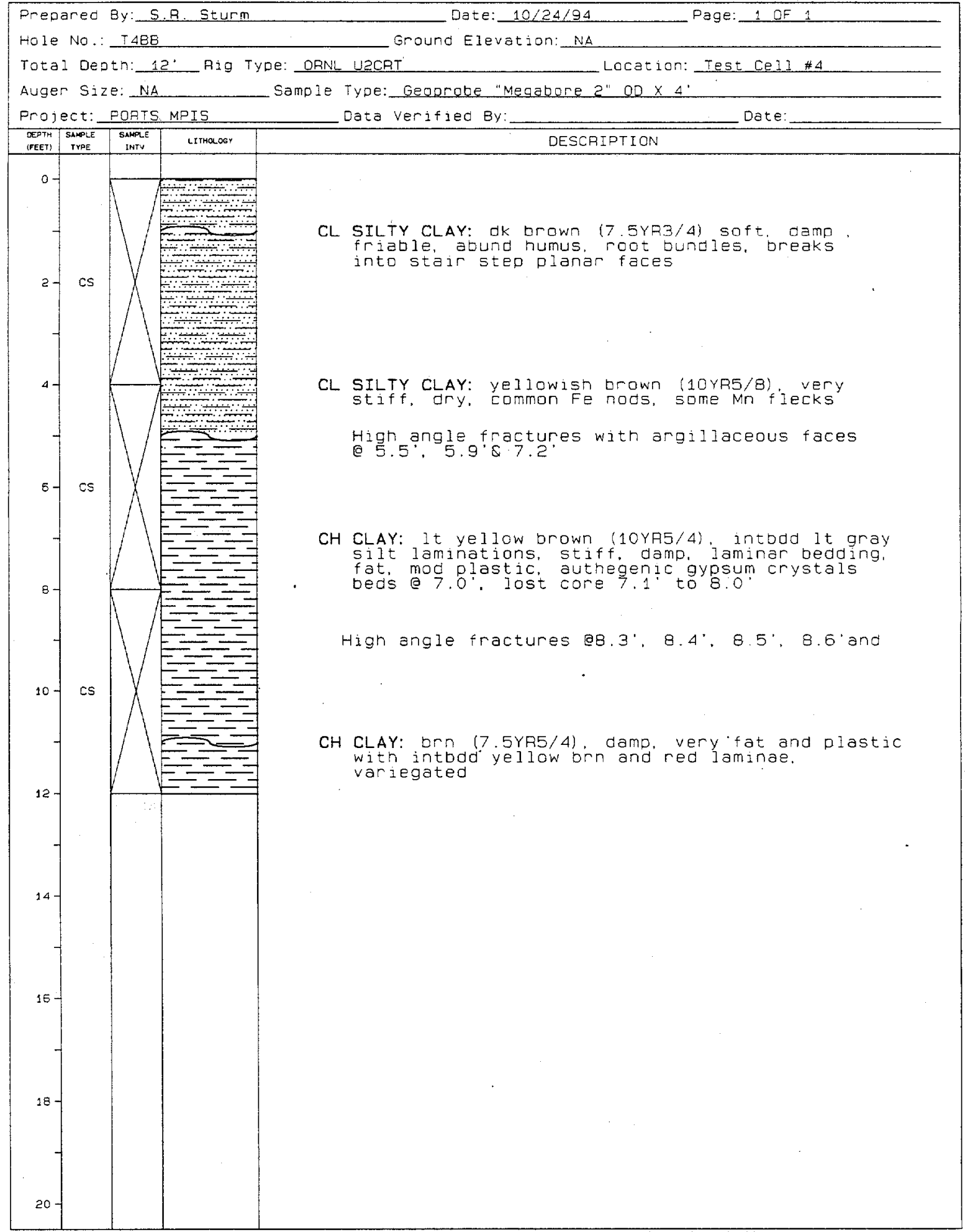




\section{B-39}

0II oak ridge national laboratory

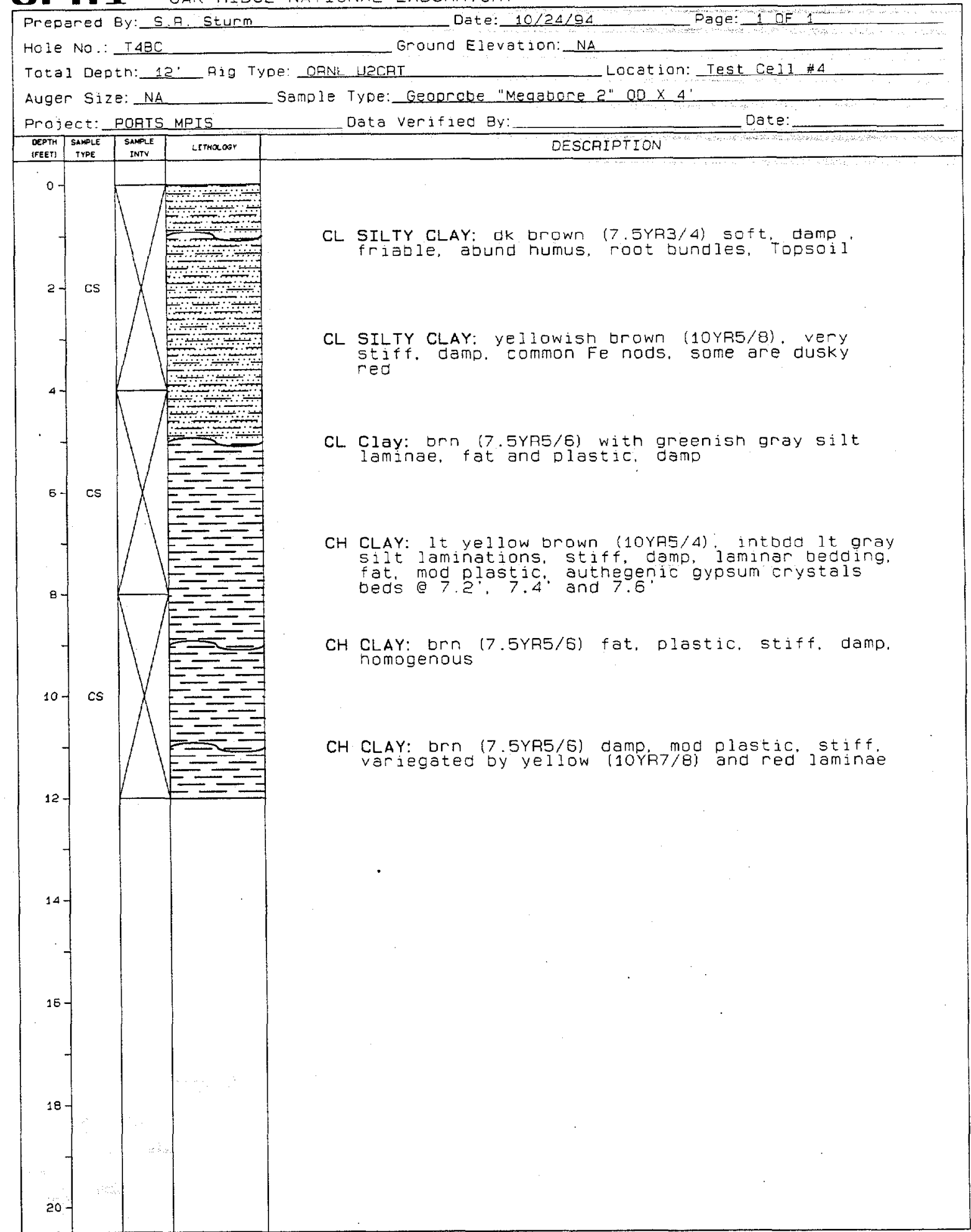




\section{B-40}

DIn 1 oak rigge national laboratory

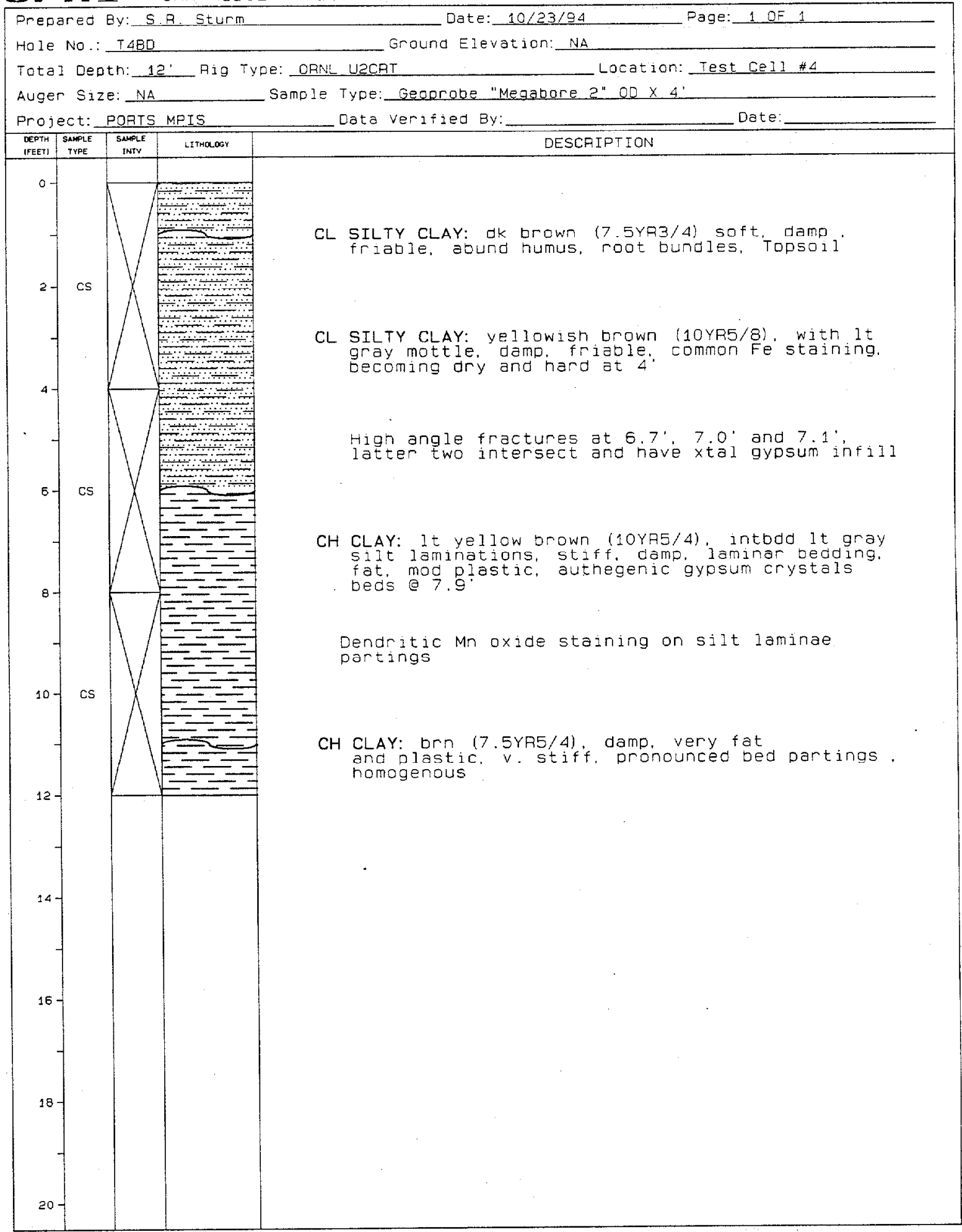




\section{B-41}

QIII oak rigge national Laboratory

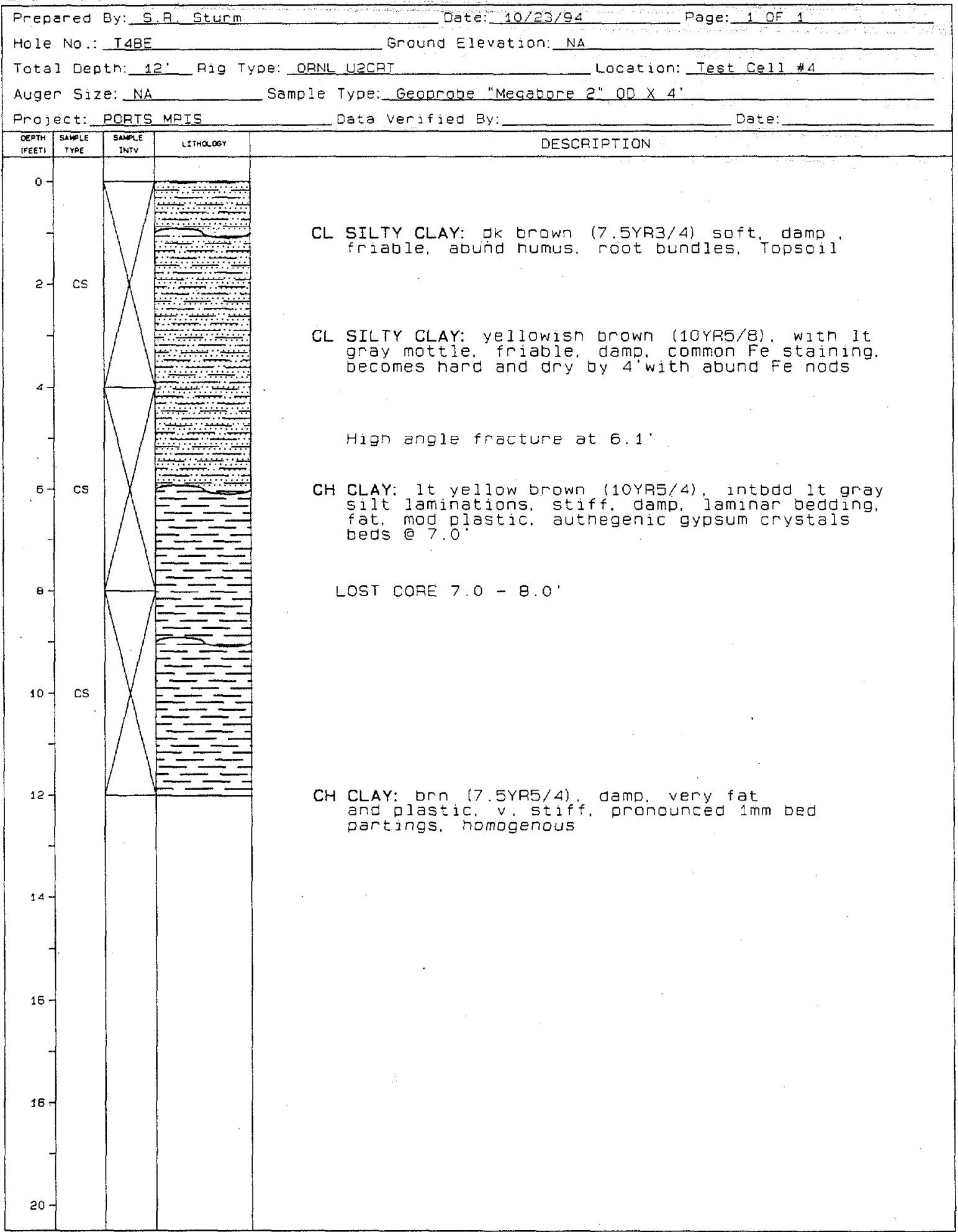




\section{B-42}

OII oak ridge national Laboratory

Borehole Summary Information

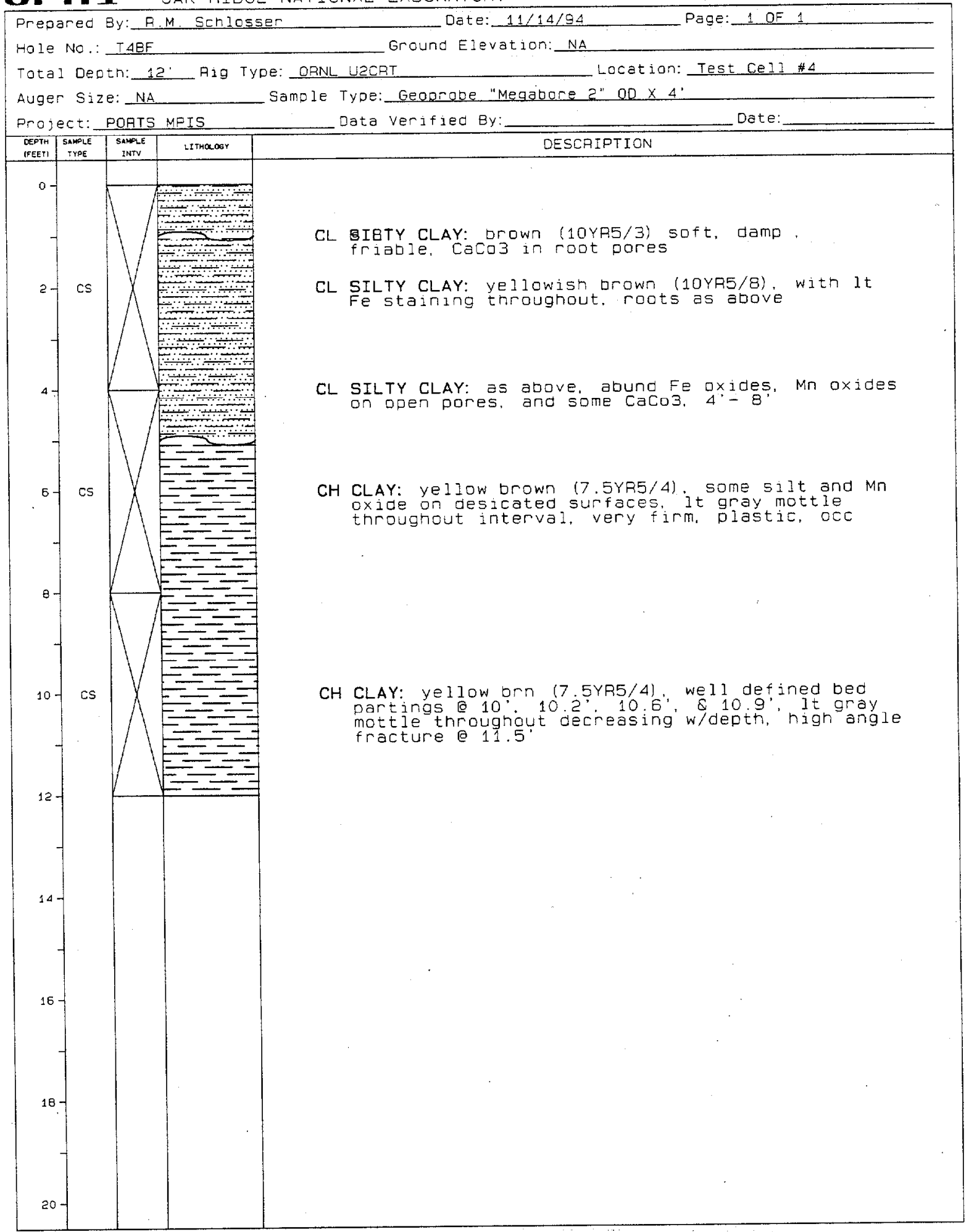




\section{B-43}

OrI OAK RIDGE National LABORATORY

\section{Borehole Summary Information}

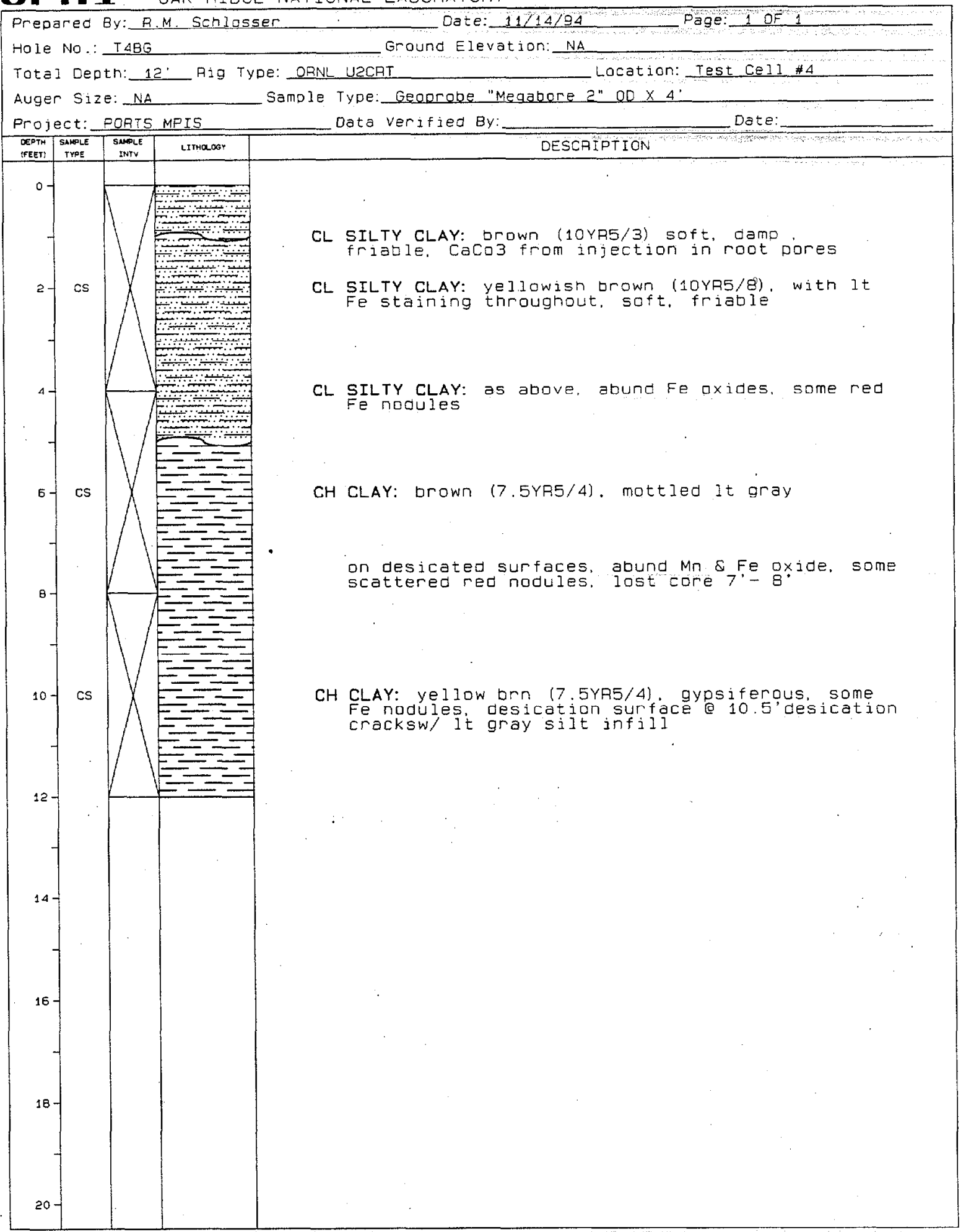




\section{B-44}

OrI oak ridge national laboratory

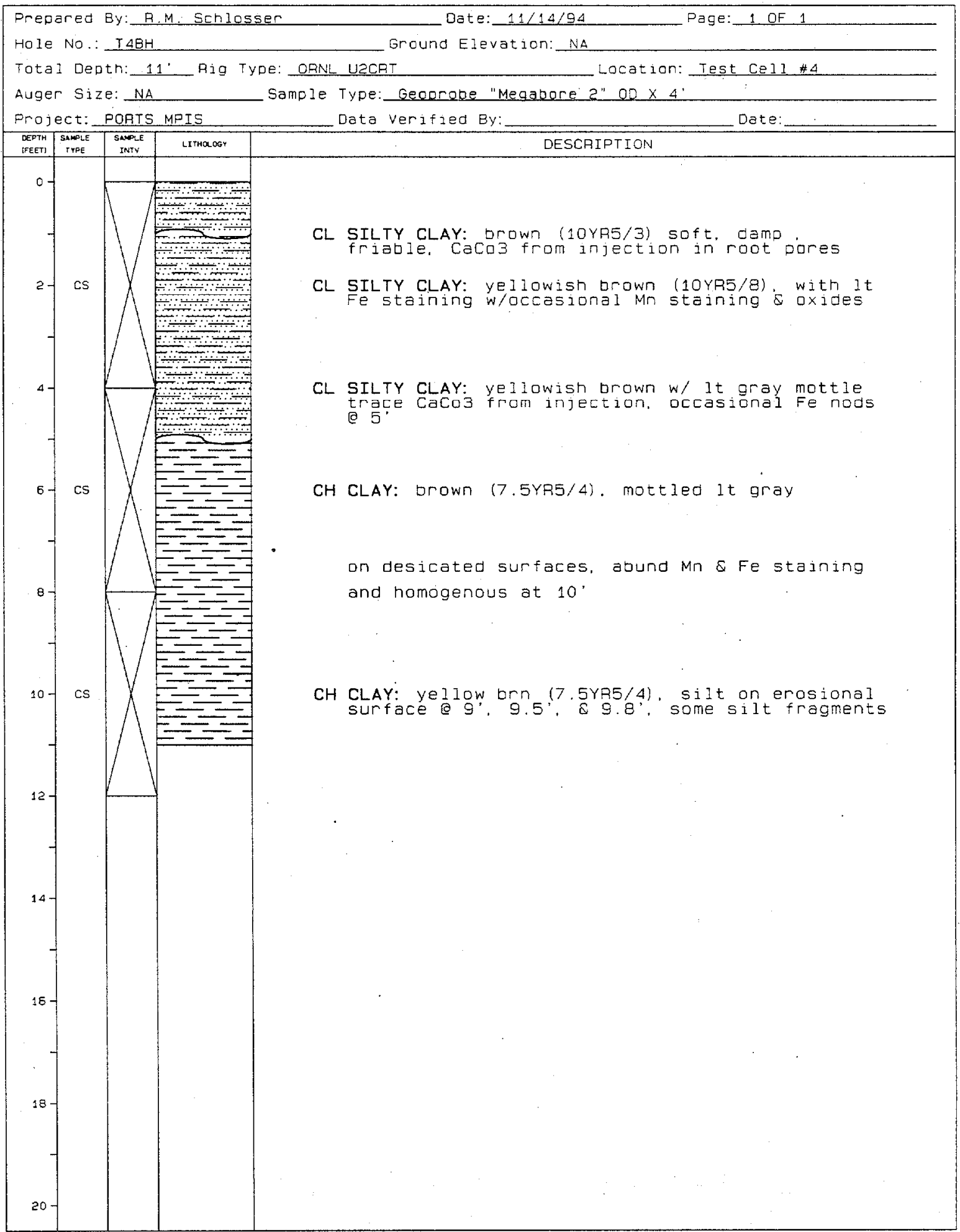




\section{B-45}

QII oak ridge national laboratory

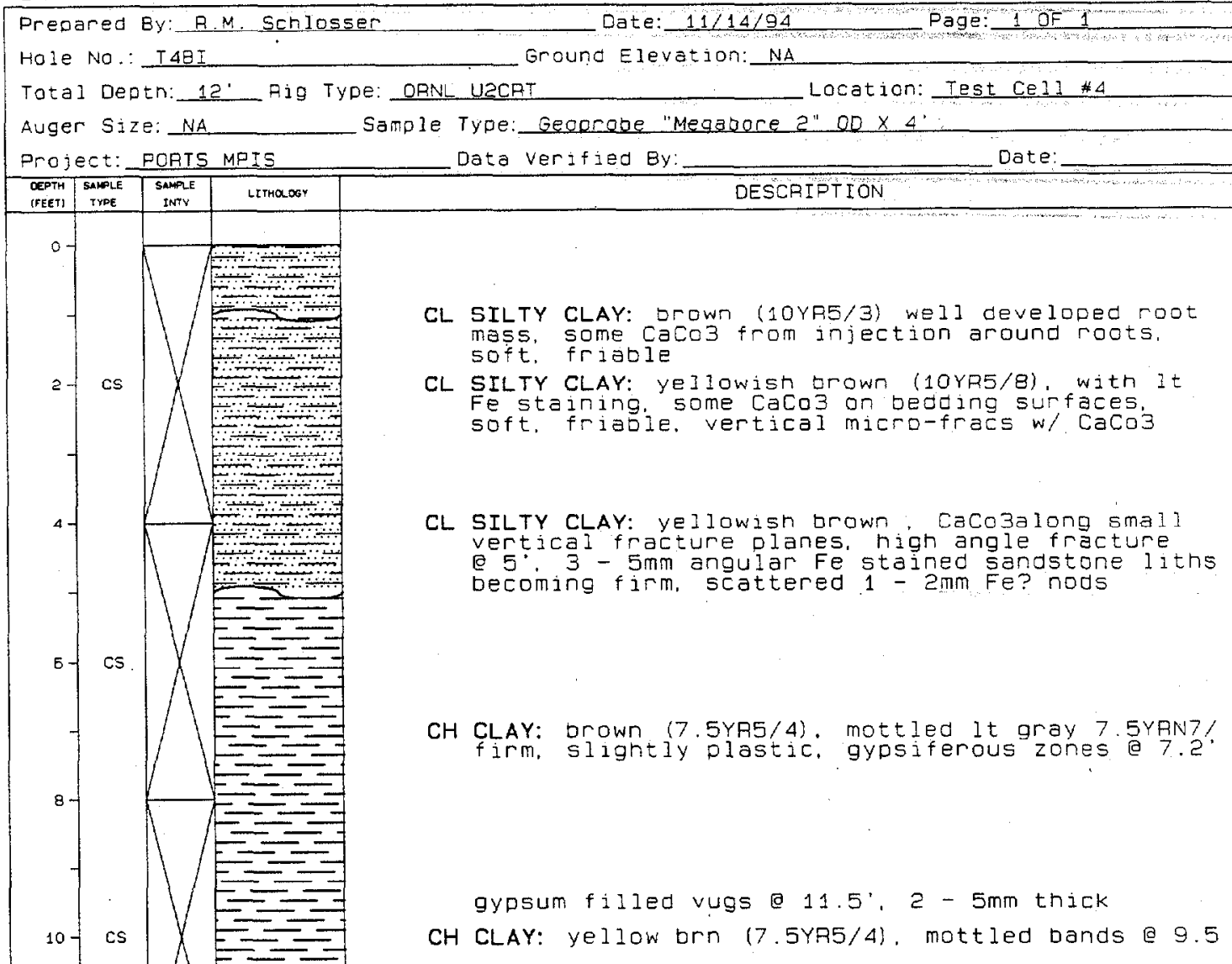

CH CLAY: yellow brown, very firm, fat $\&$ plastic. waxy appearance. 


\section{B-46}

OII oak ridge national laboratory

\section{Borehole Summary Information}

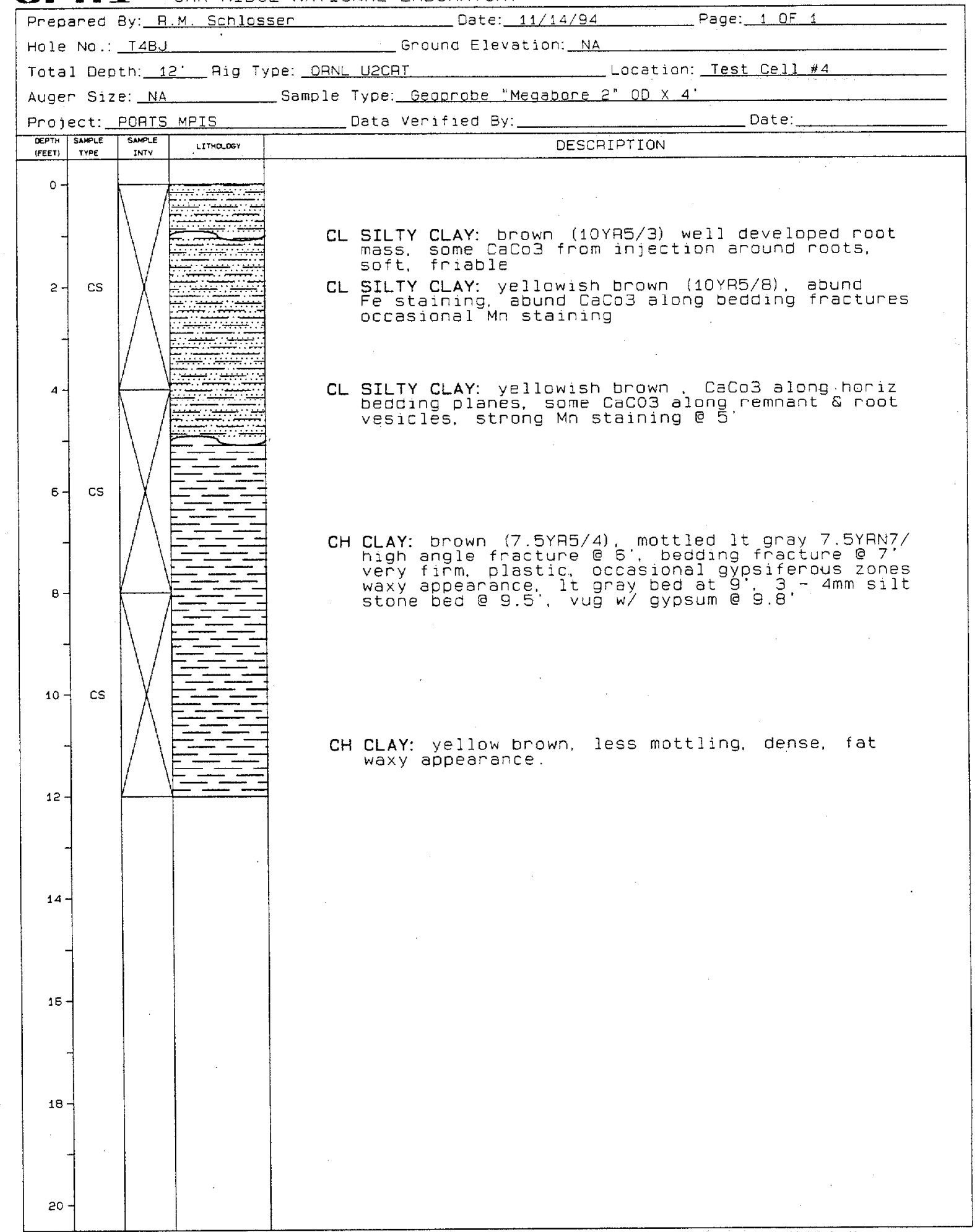




\section{B-47}

QII 1 oAK ridge national Laboratory

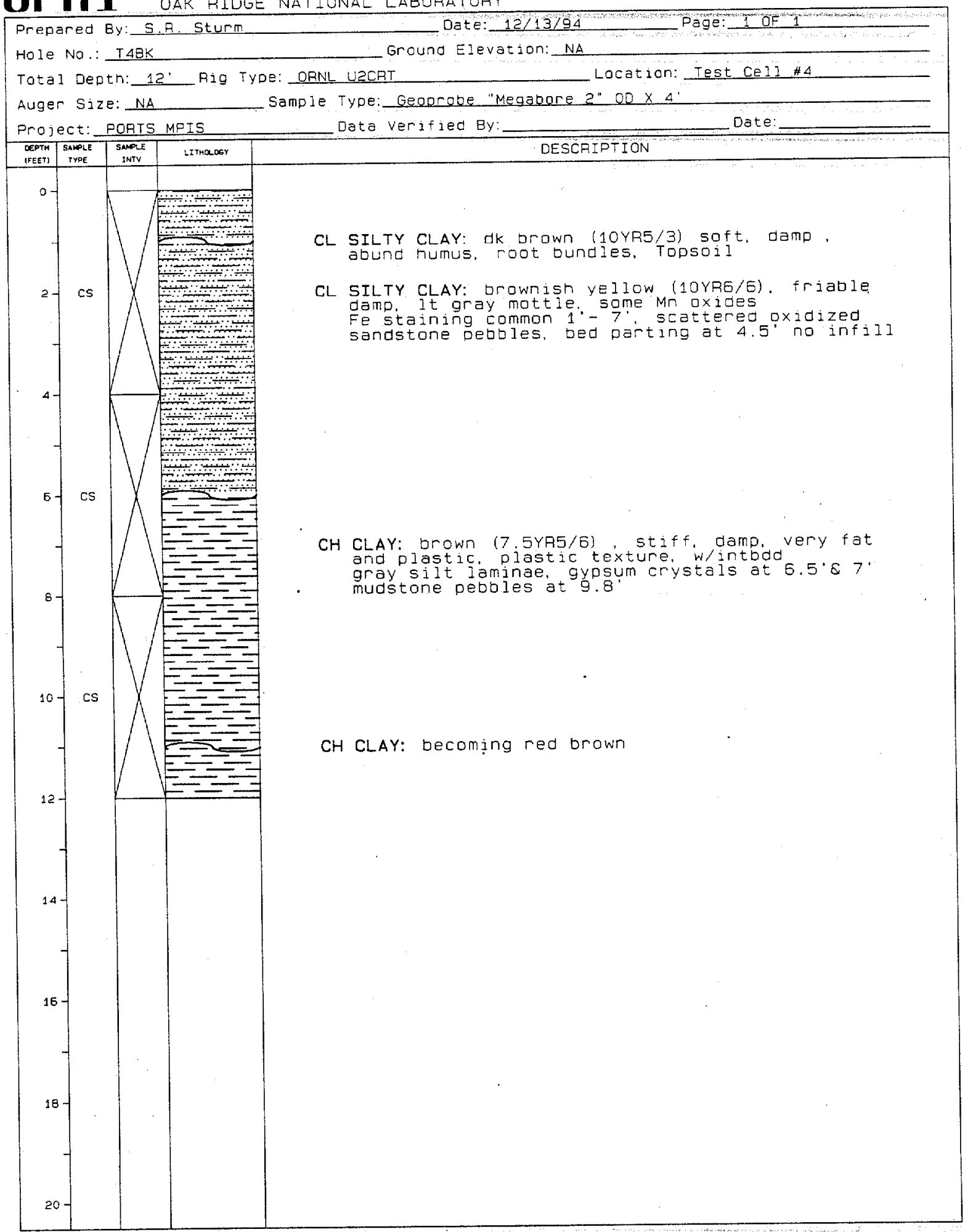




\section{B-48}

QII oak ridge national laboratory

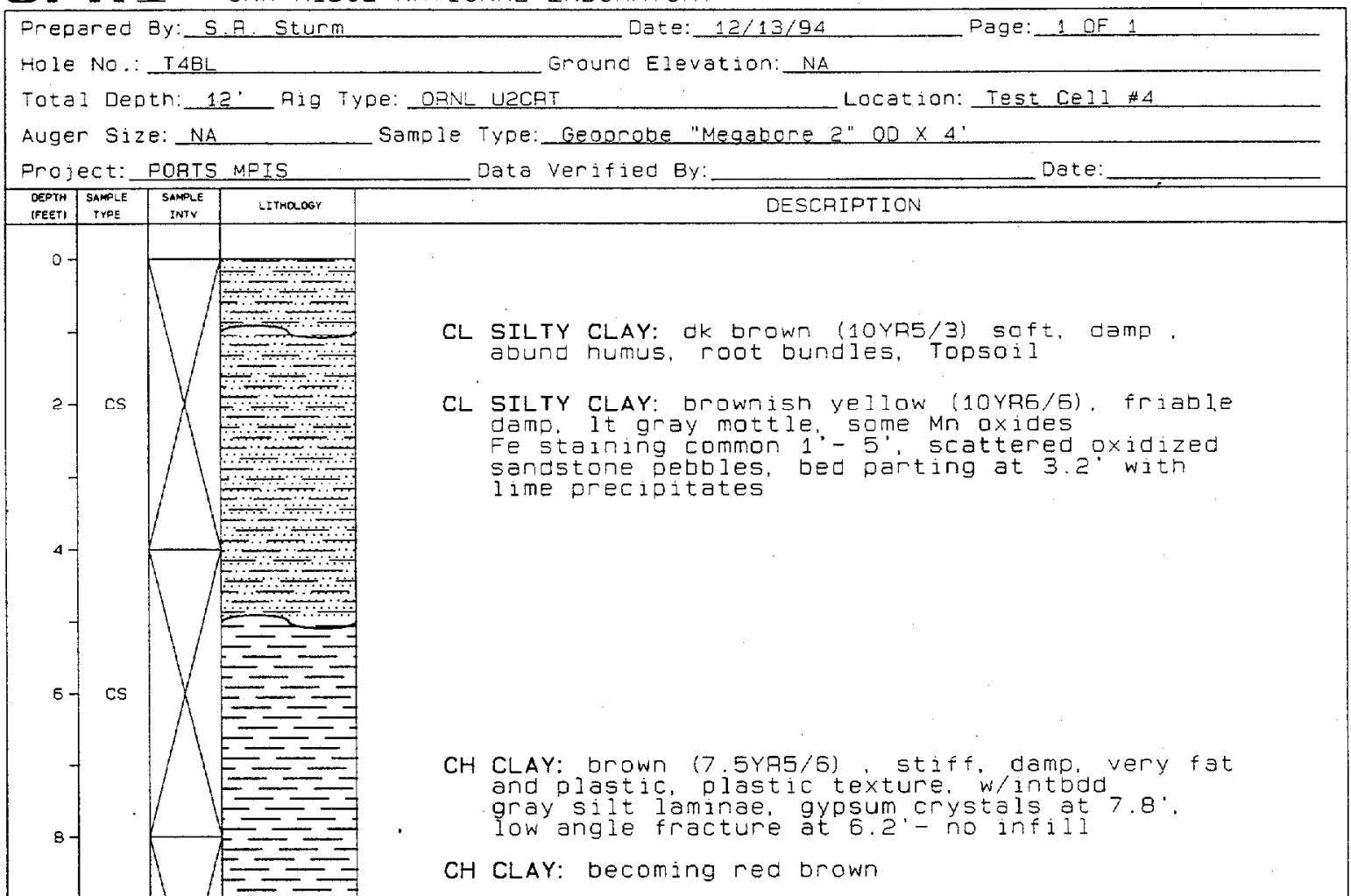

cs

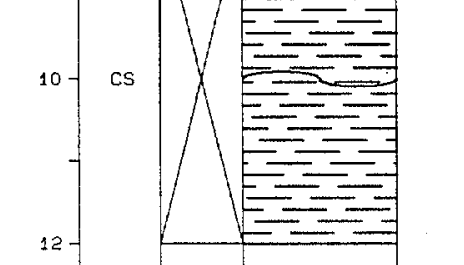




\section{B-49}

QIII OAK figge national laboratory

Borehole Summary. Information

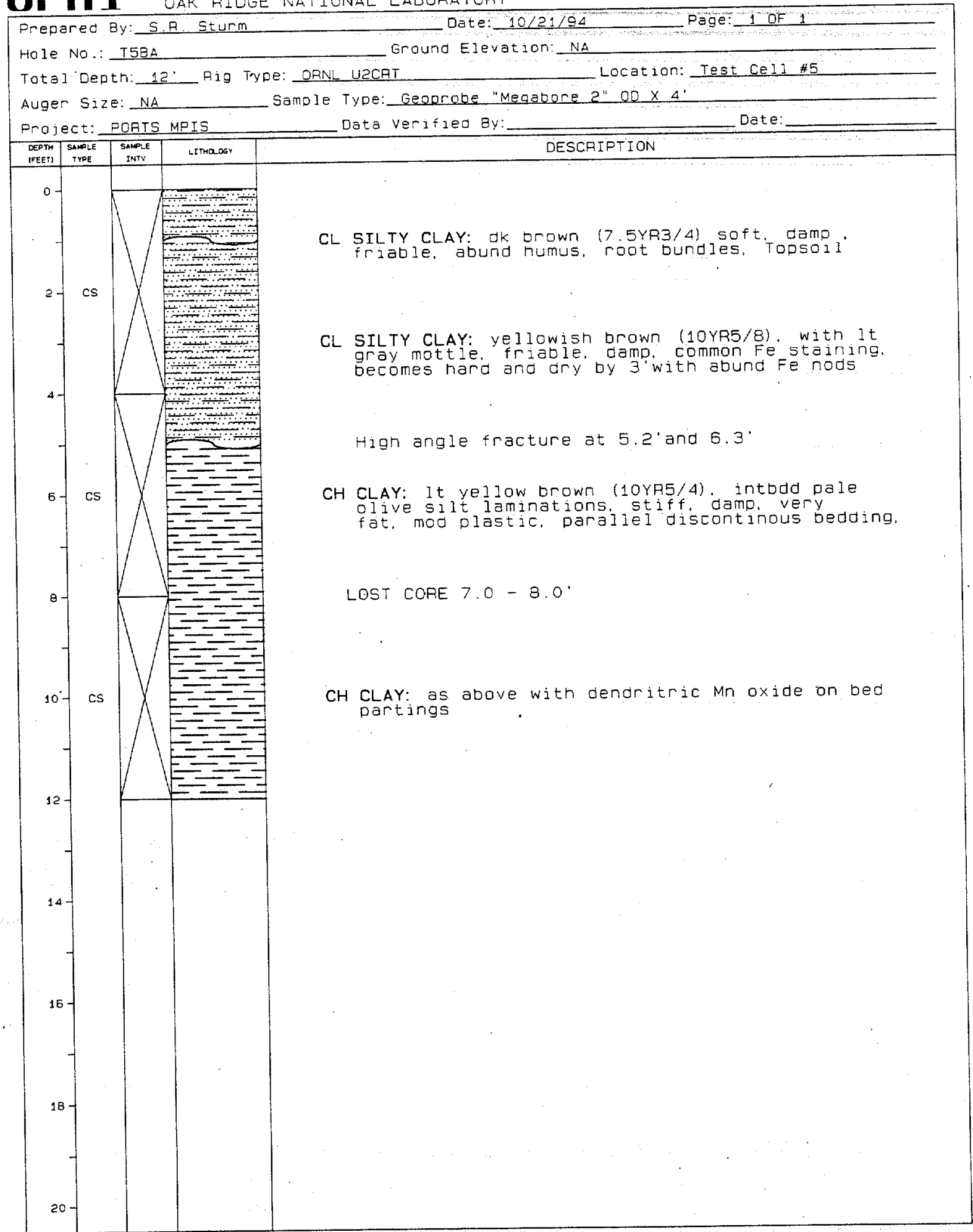




\section{B-50}

\section{Or] Borehole Summary Information}

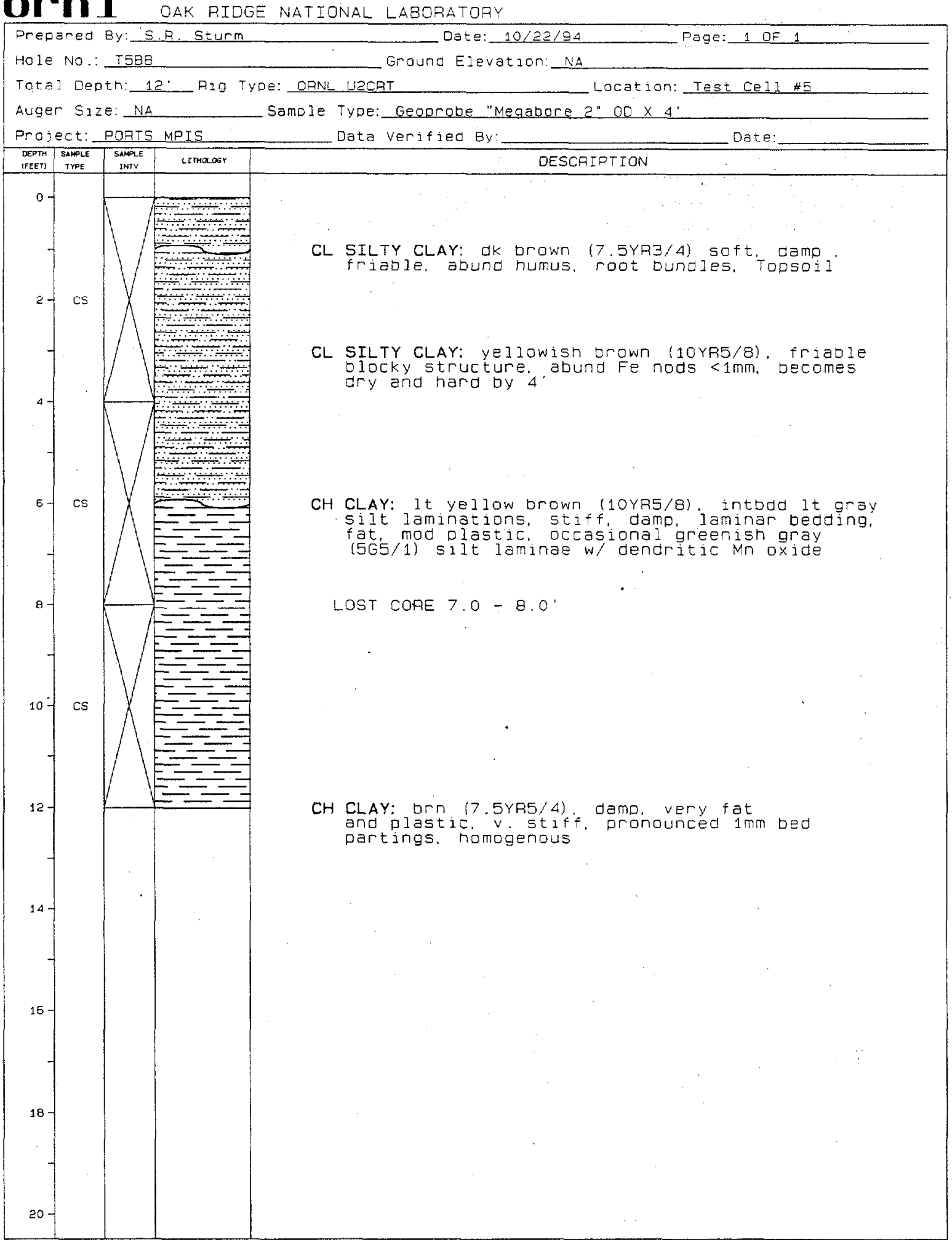




\section{B-51}

QTI oak ridge national laboratory

Borehole Summary Information

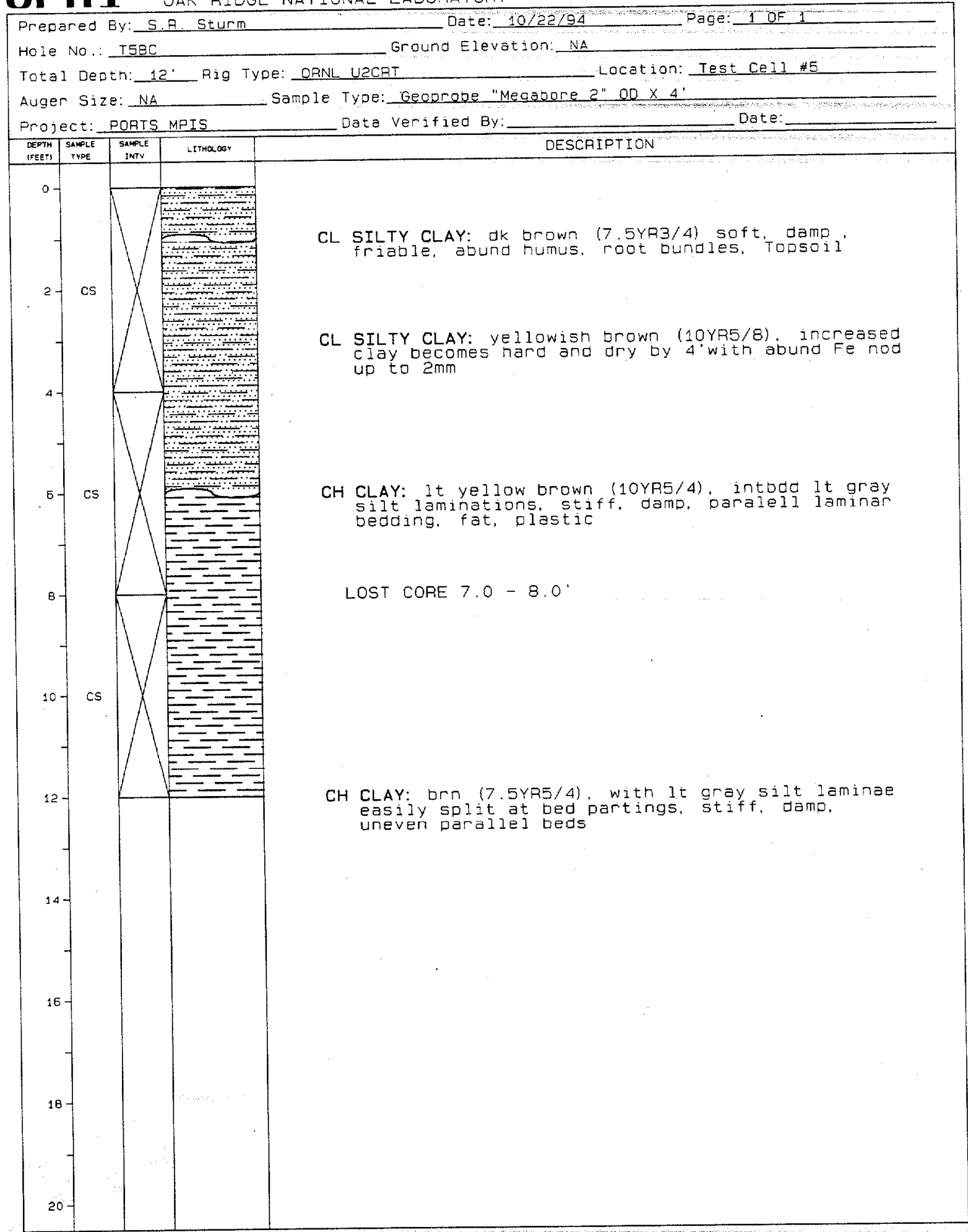




\section{B-52}

OrI Oak ridge national Laboratory

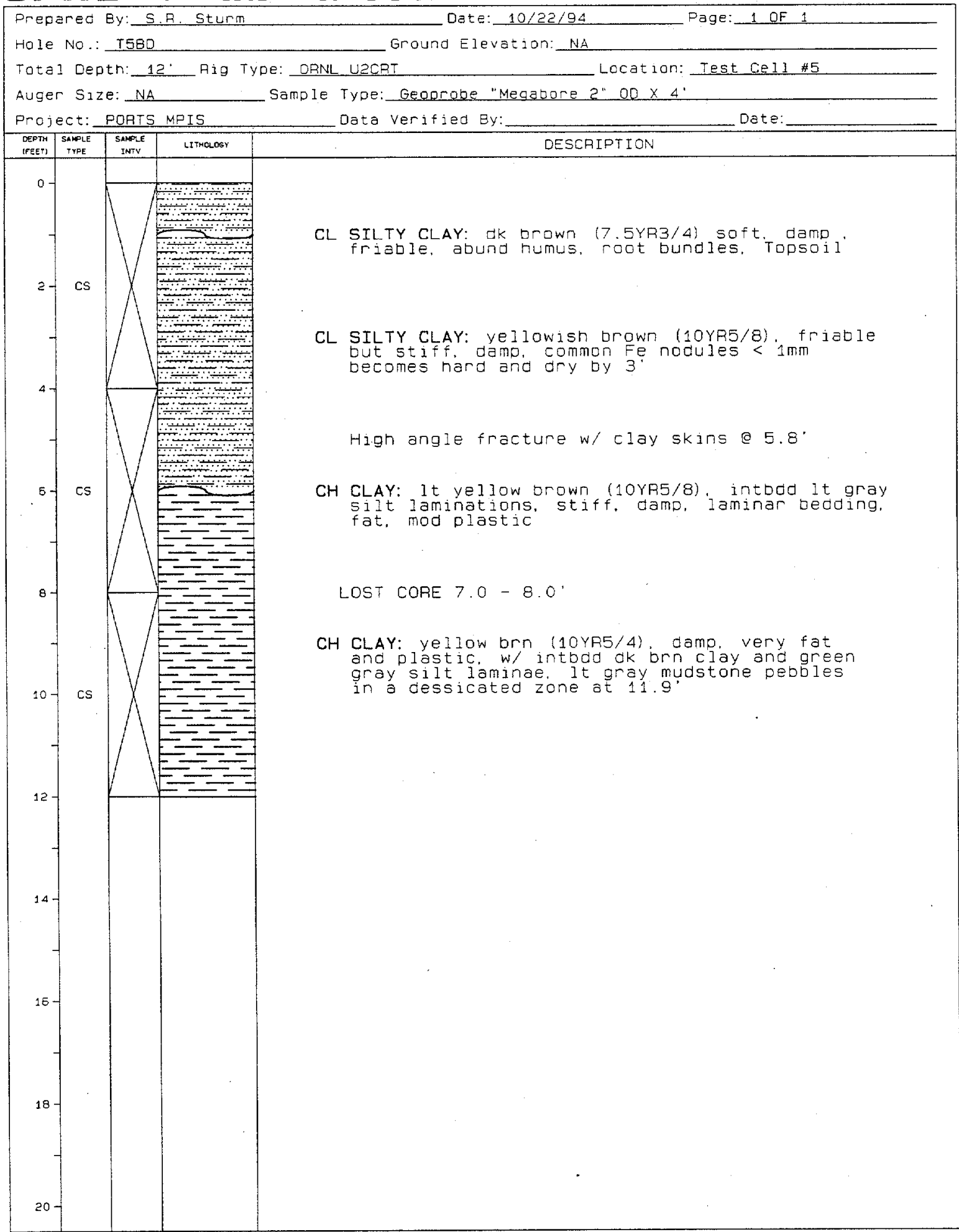




\section{B-53}

\section{Borehole Summary Information}

0【I oak fidge national laboratory

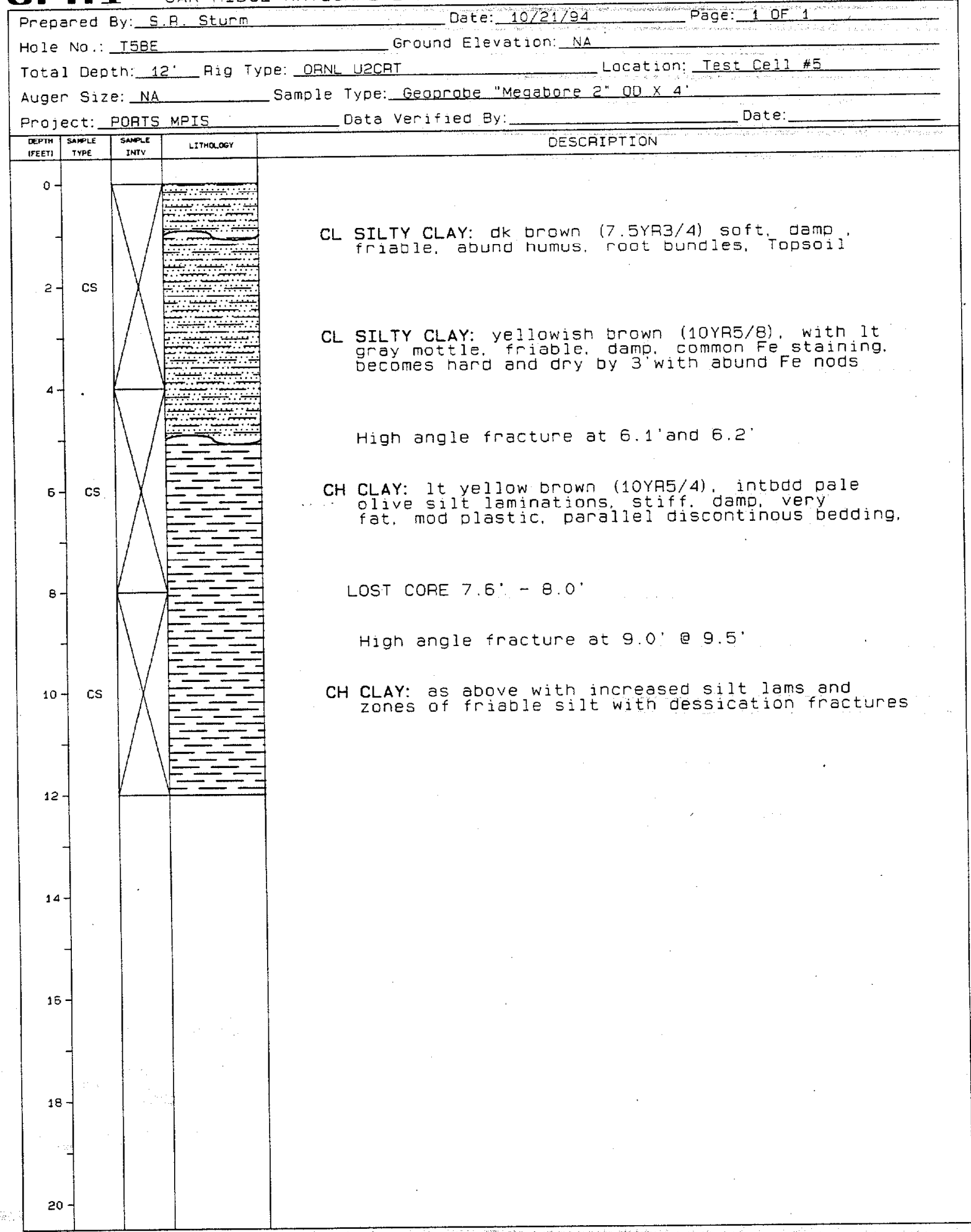




\section{B-54}

OIn oak rioge national Laboratopy

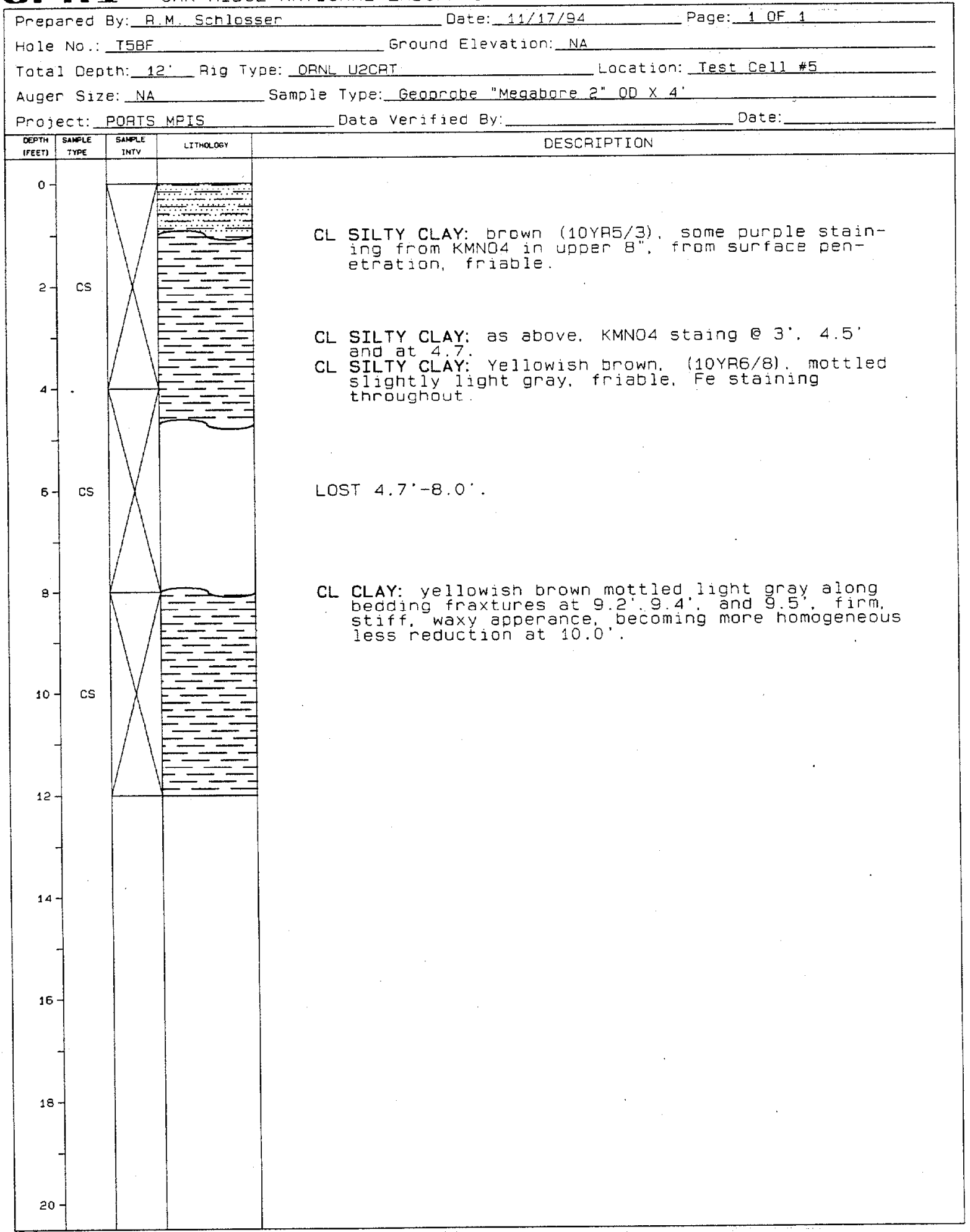




\section{B-55}

QII oak ridge national Laboratory

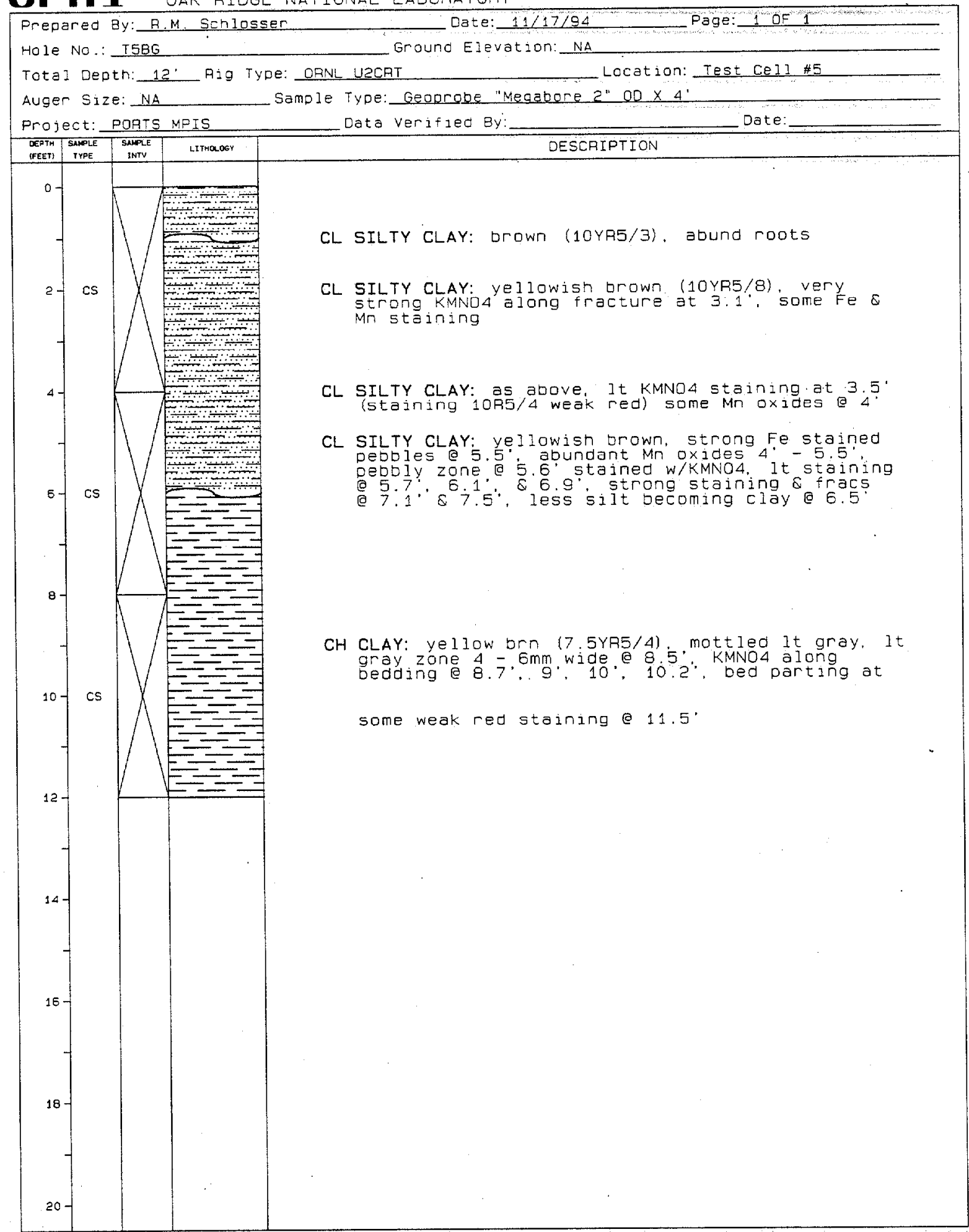




\section{B-56}

OIII oak ridge national Laboratory

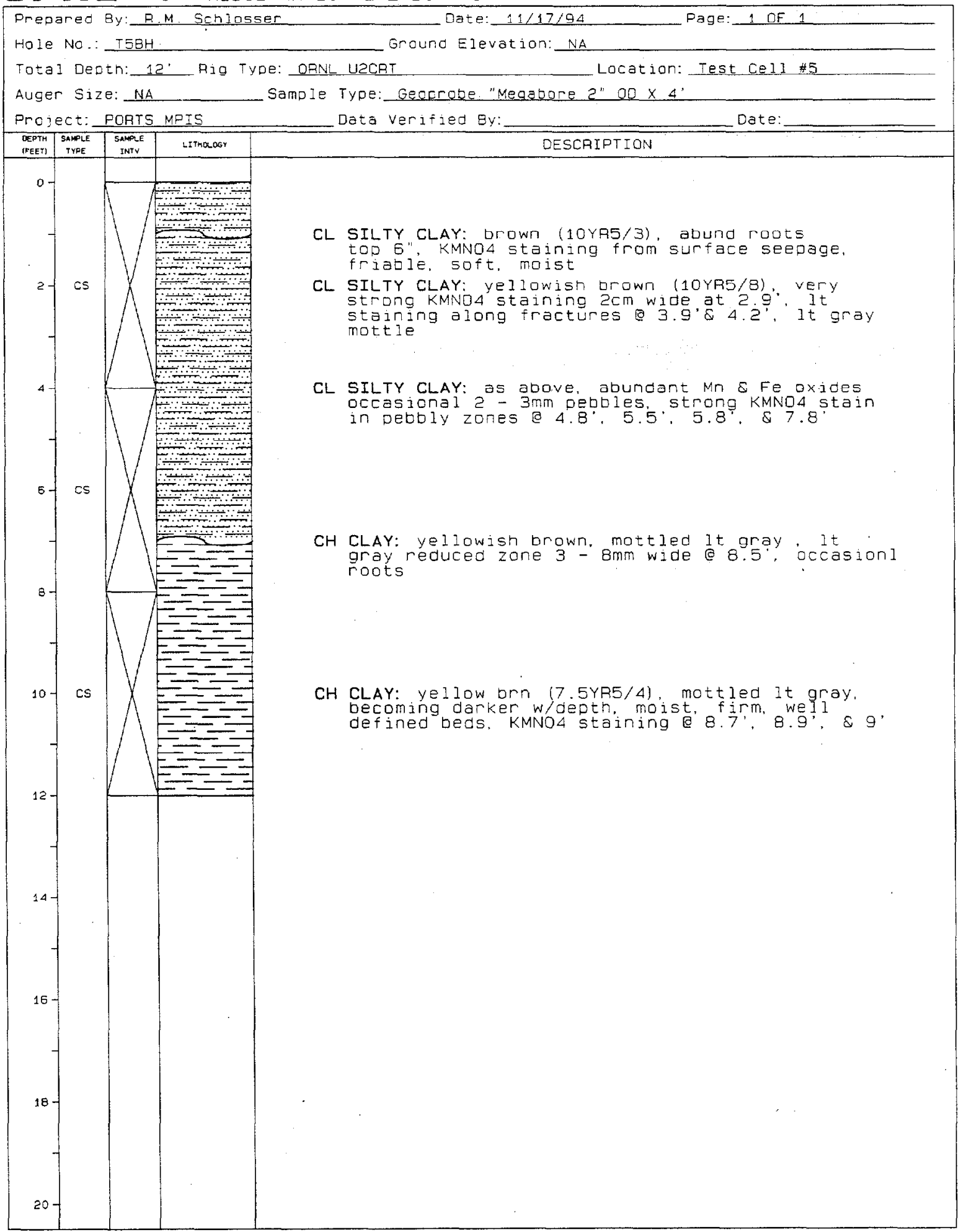




\section{B-57}

QII oak ridge national Laboratory

\section{Borehole Summary Information}

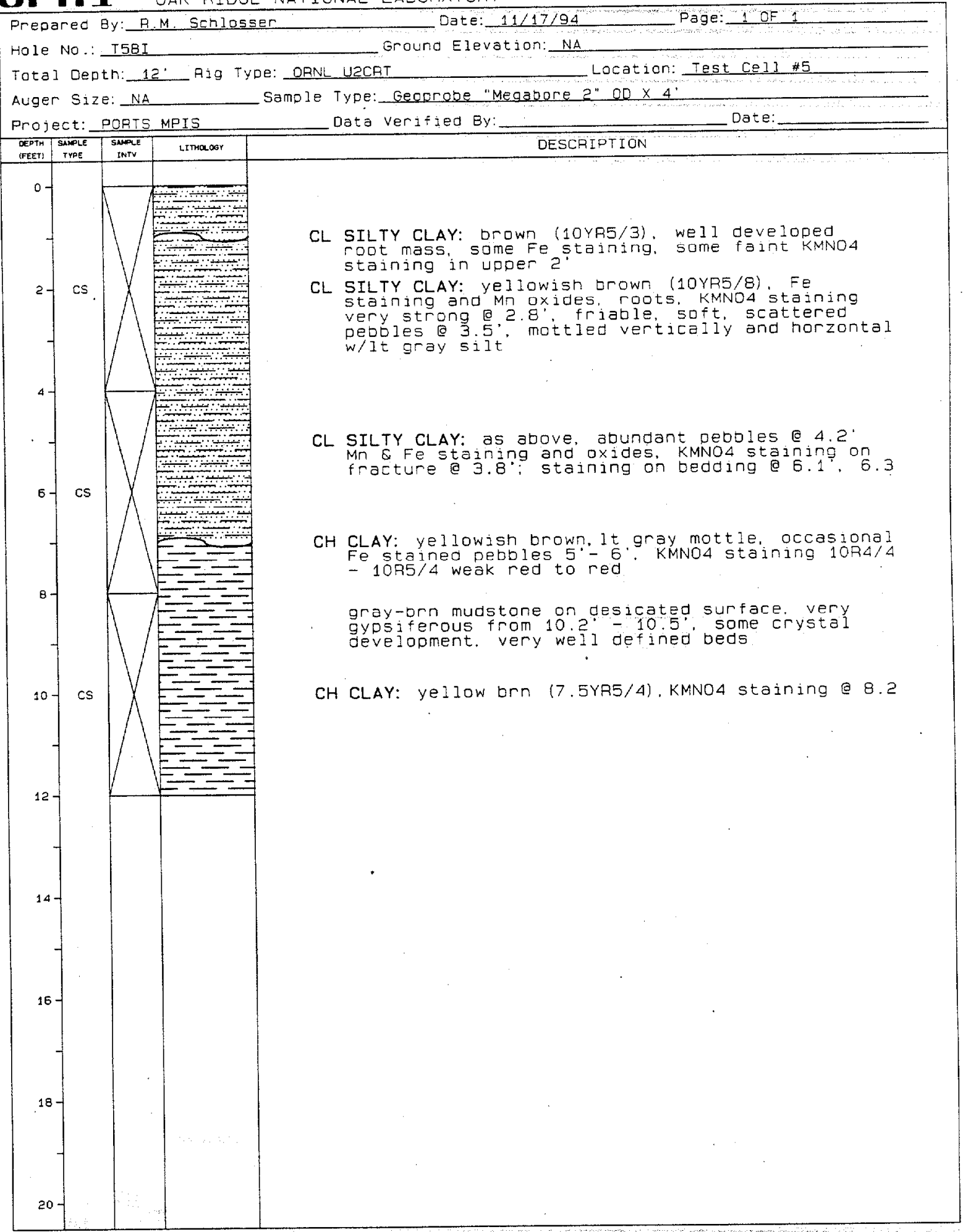




\section{B-58}

OII oak ridge national laboratory

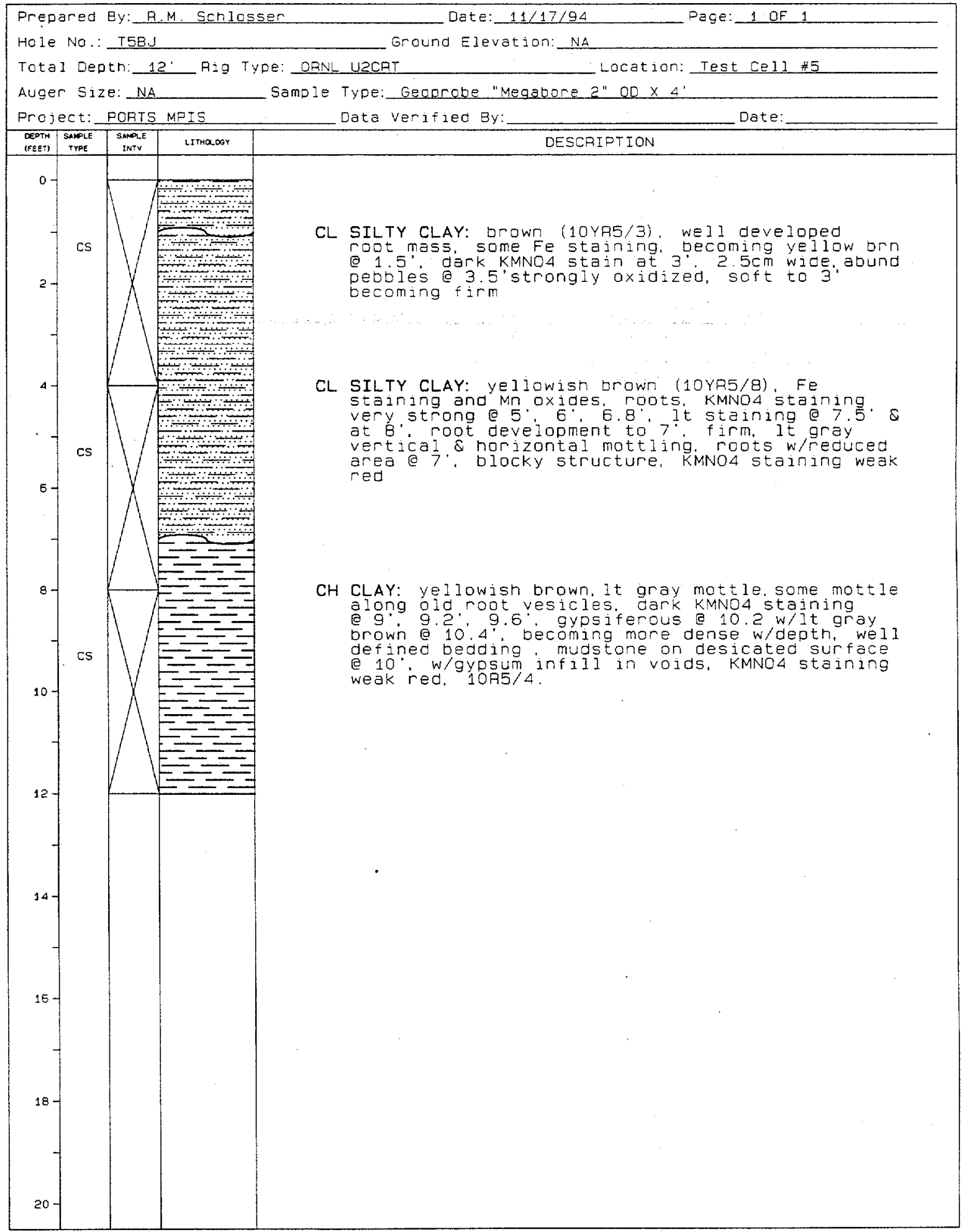




\section{B-59}

Orn 1 OAK RIDGE NATIONAL LABORATORY

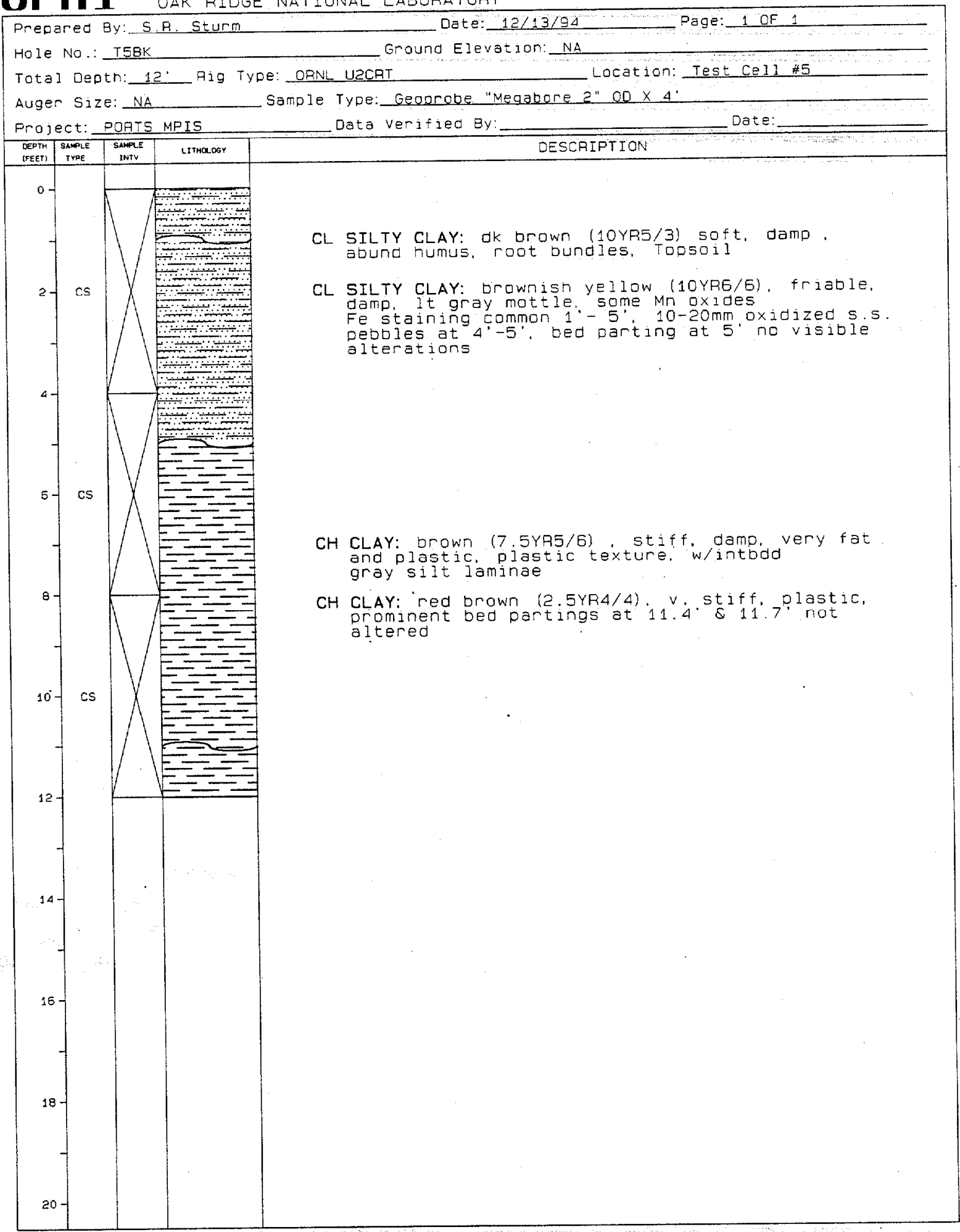




\section{B-60}

DT Borehole Summary Information

QIII OAK PIDGE national LaBORATORY

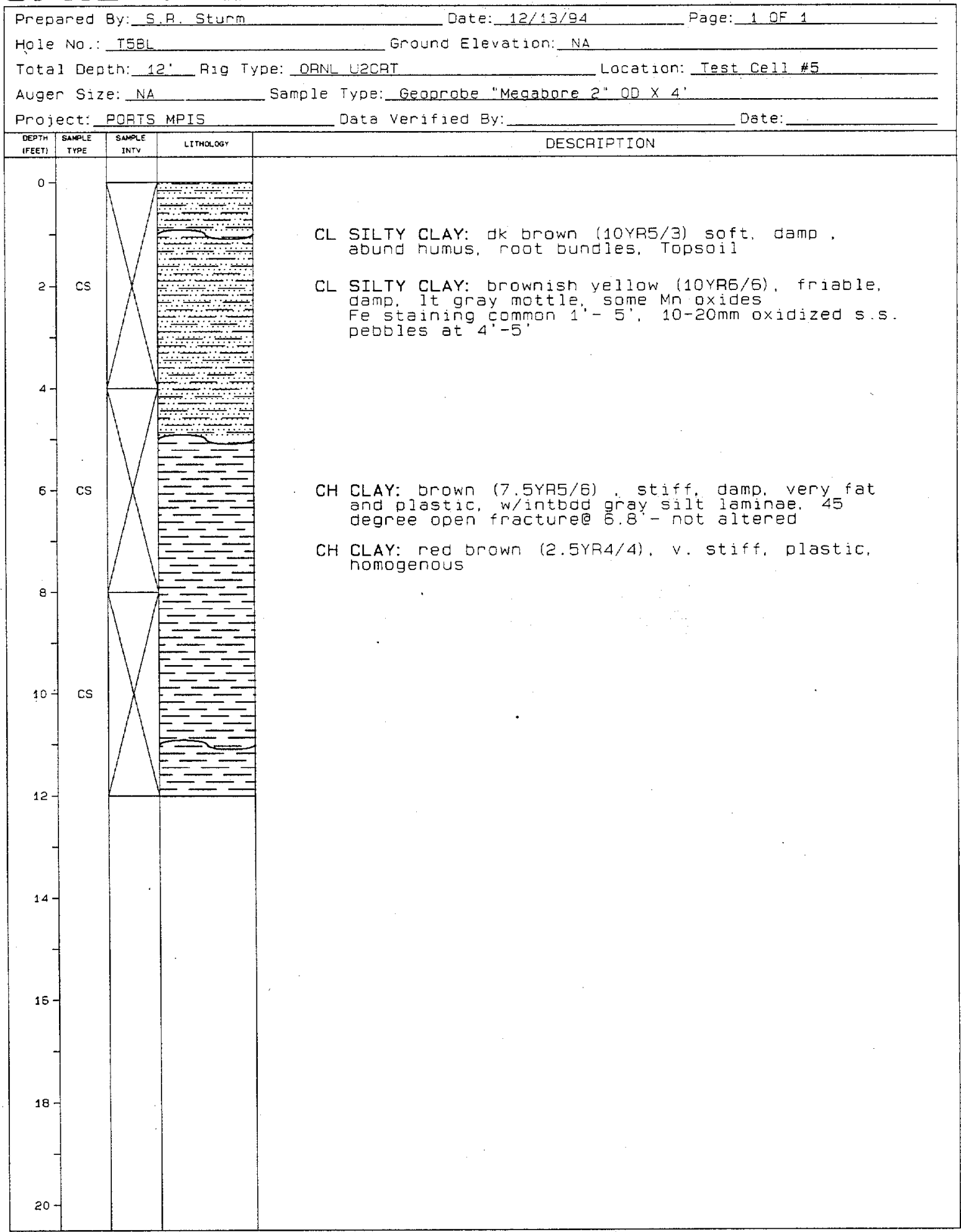




\section{B-61}

orn 1 oak ridge national Laboratory

\section{Borehole Summory Information}

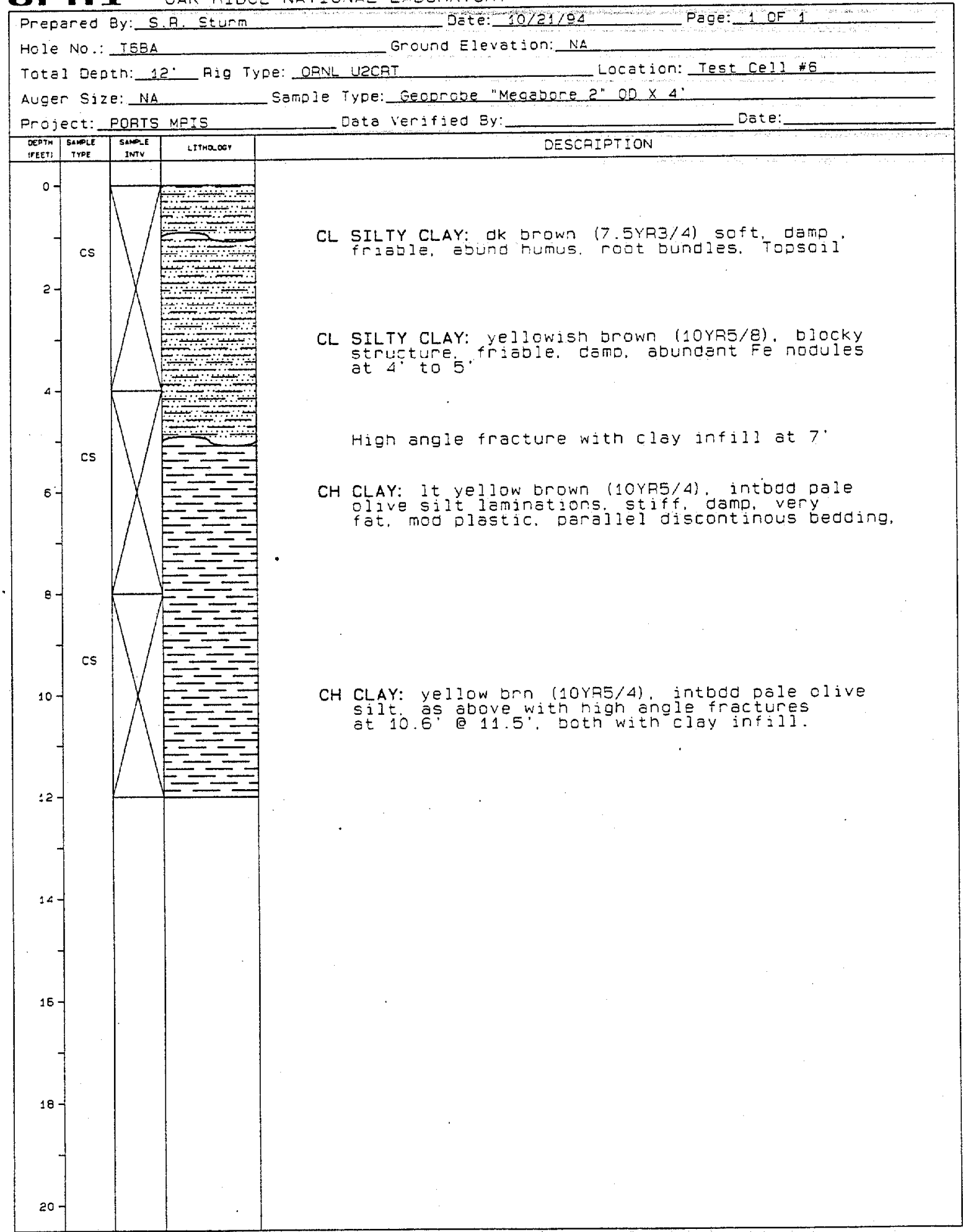




\section{B-62}

OII OAK ridge national Laboratory

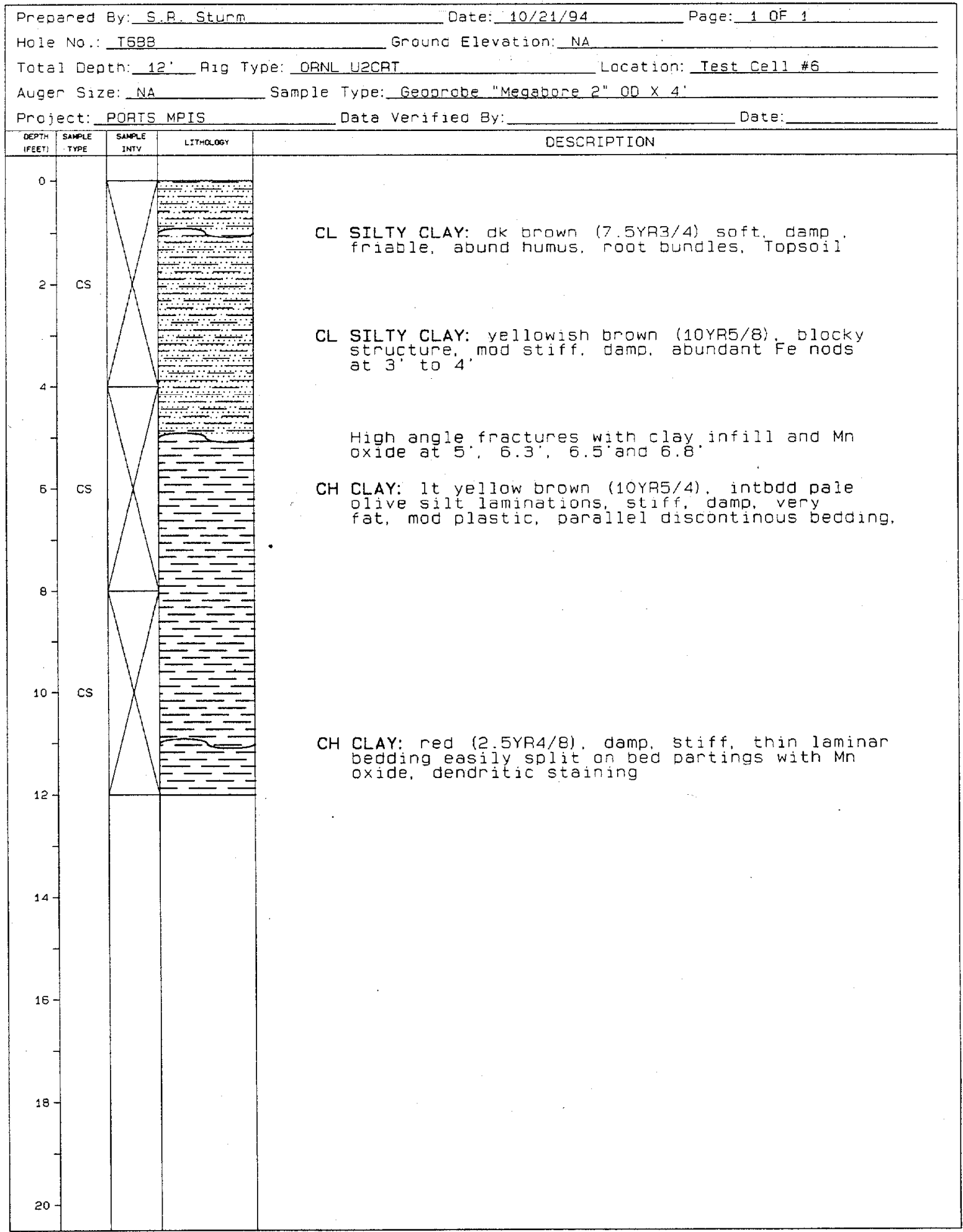




\section{B-63}

QII OAK RIDGe national Laboratory

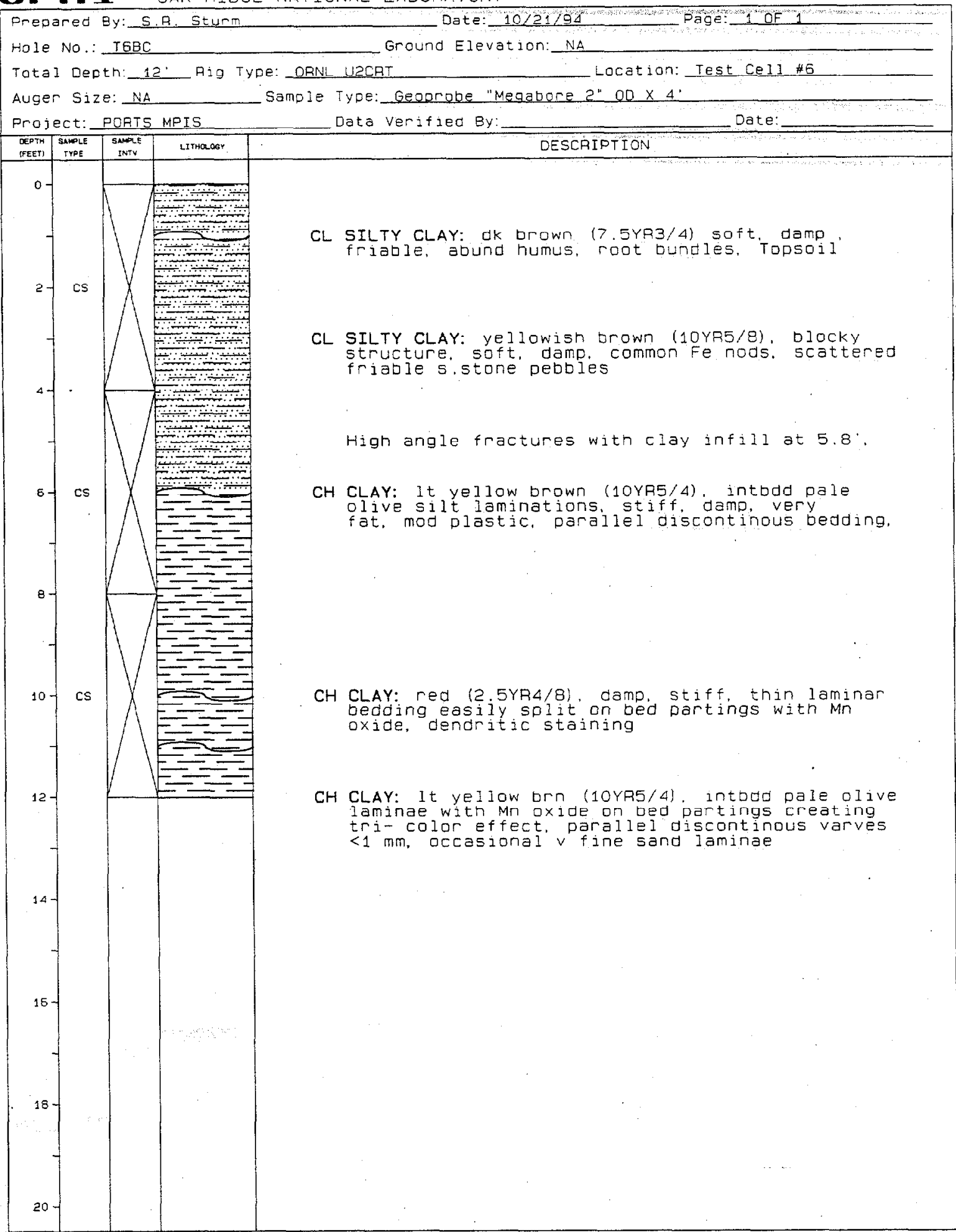




\section{B-64}

OrI OAK RIDGe national Laboratory

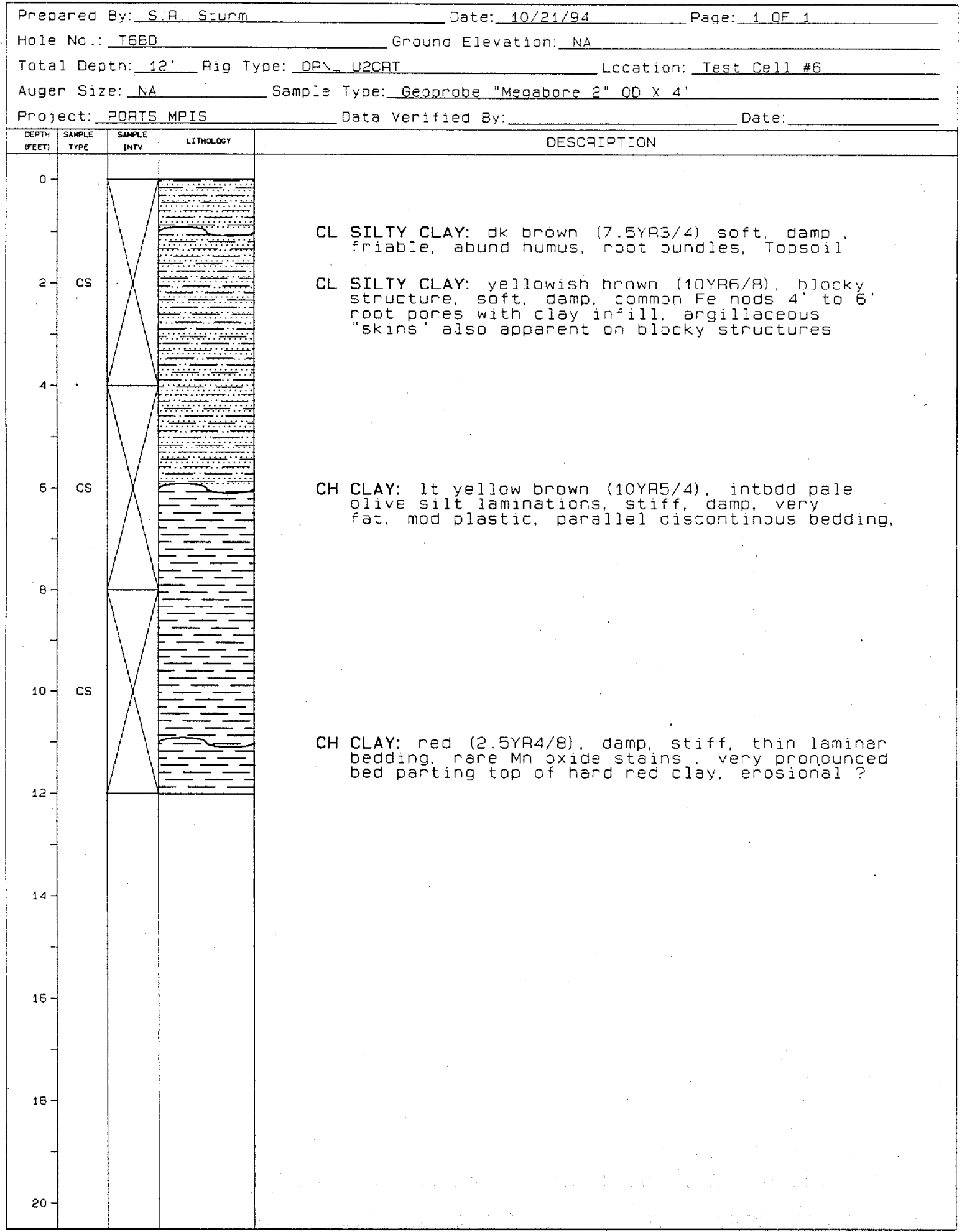


QIn 1 aak ridge national laboratory

Borehole Summary Information

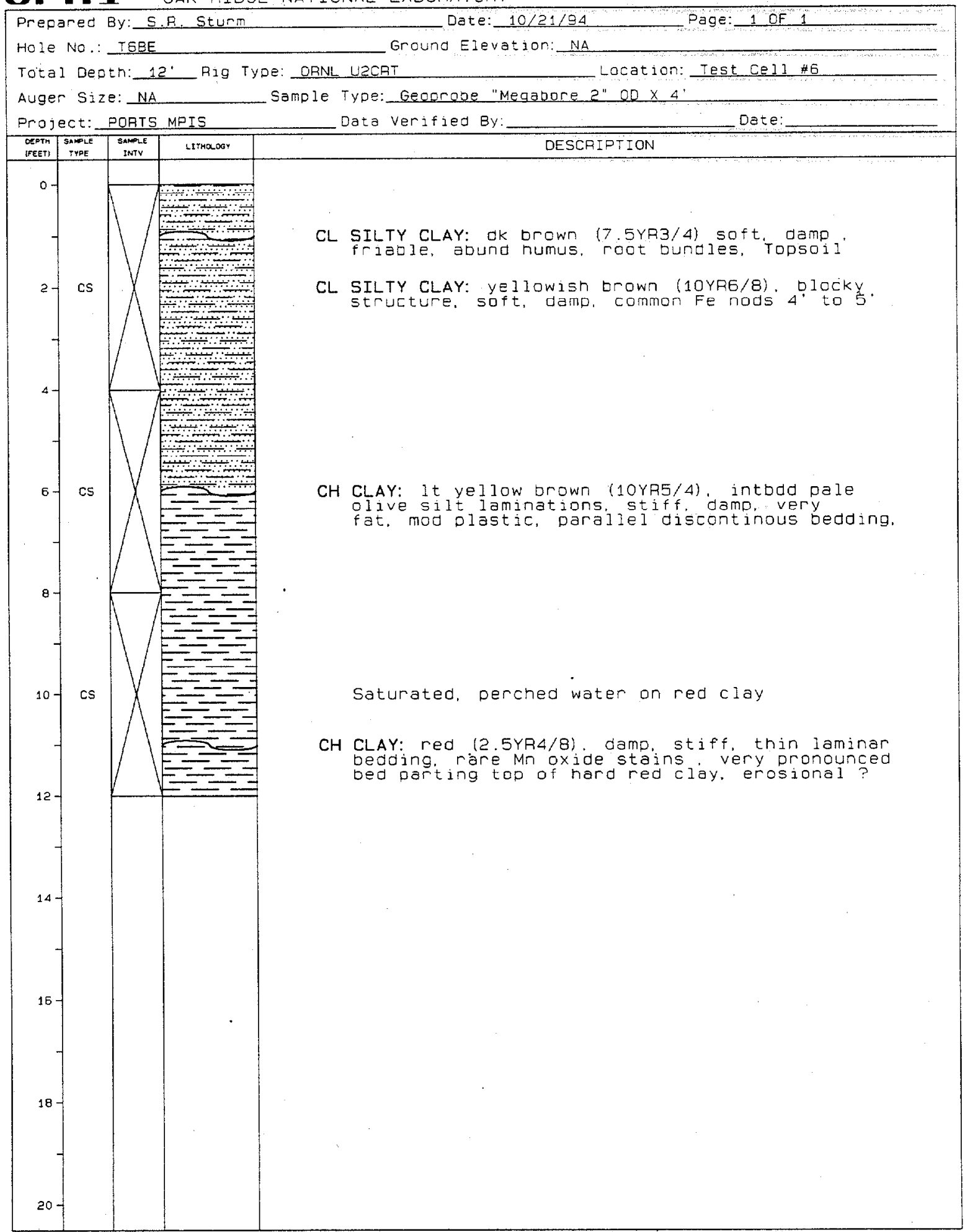




\section{B-66}

OII oak ridge national laboratory

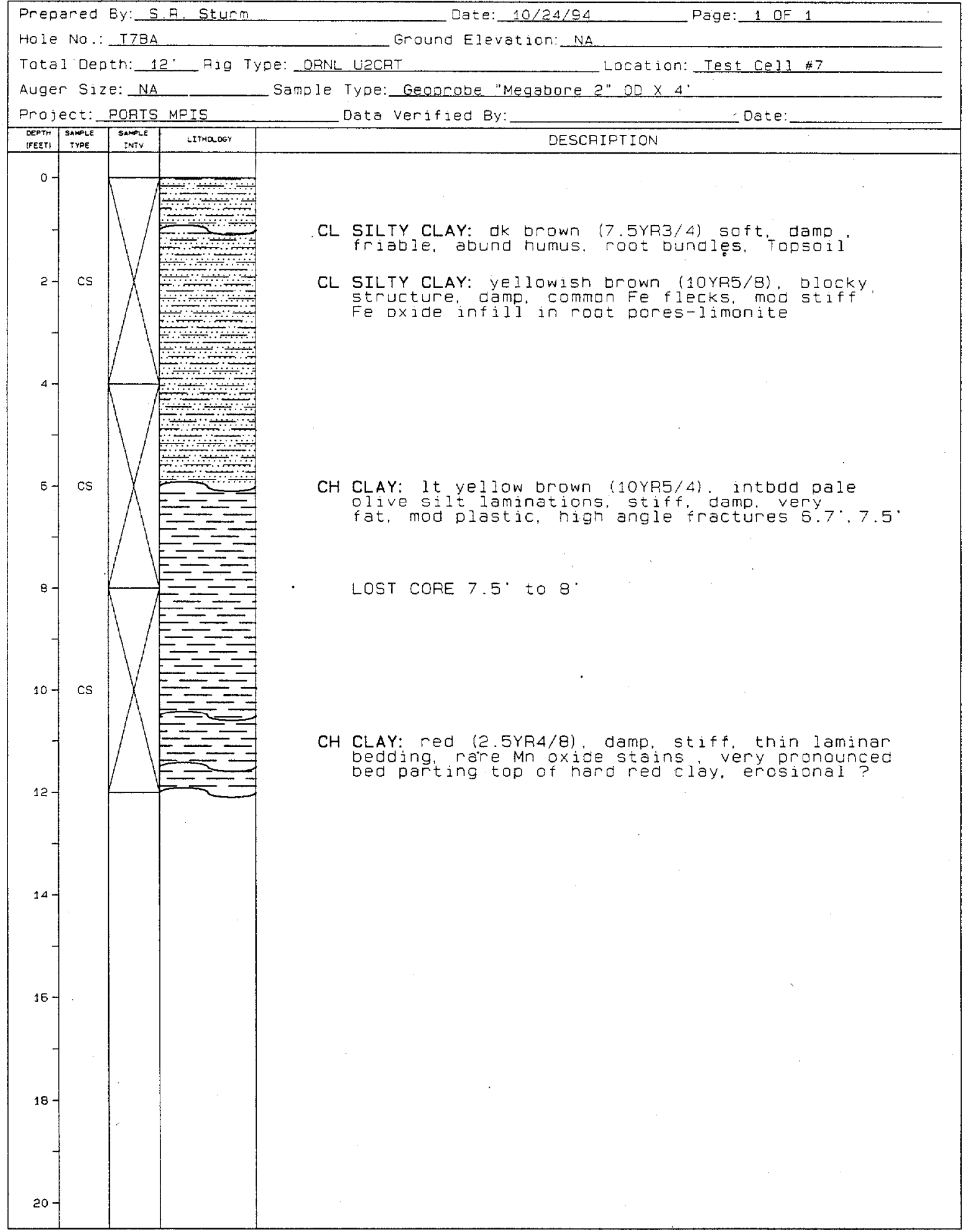


orn 1

Borehole Summary Information

O OAK RIDGE NATIONAL LABORATORY

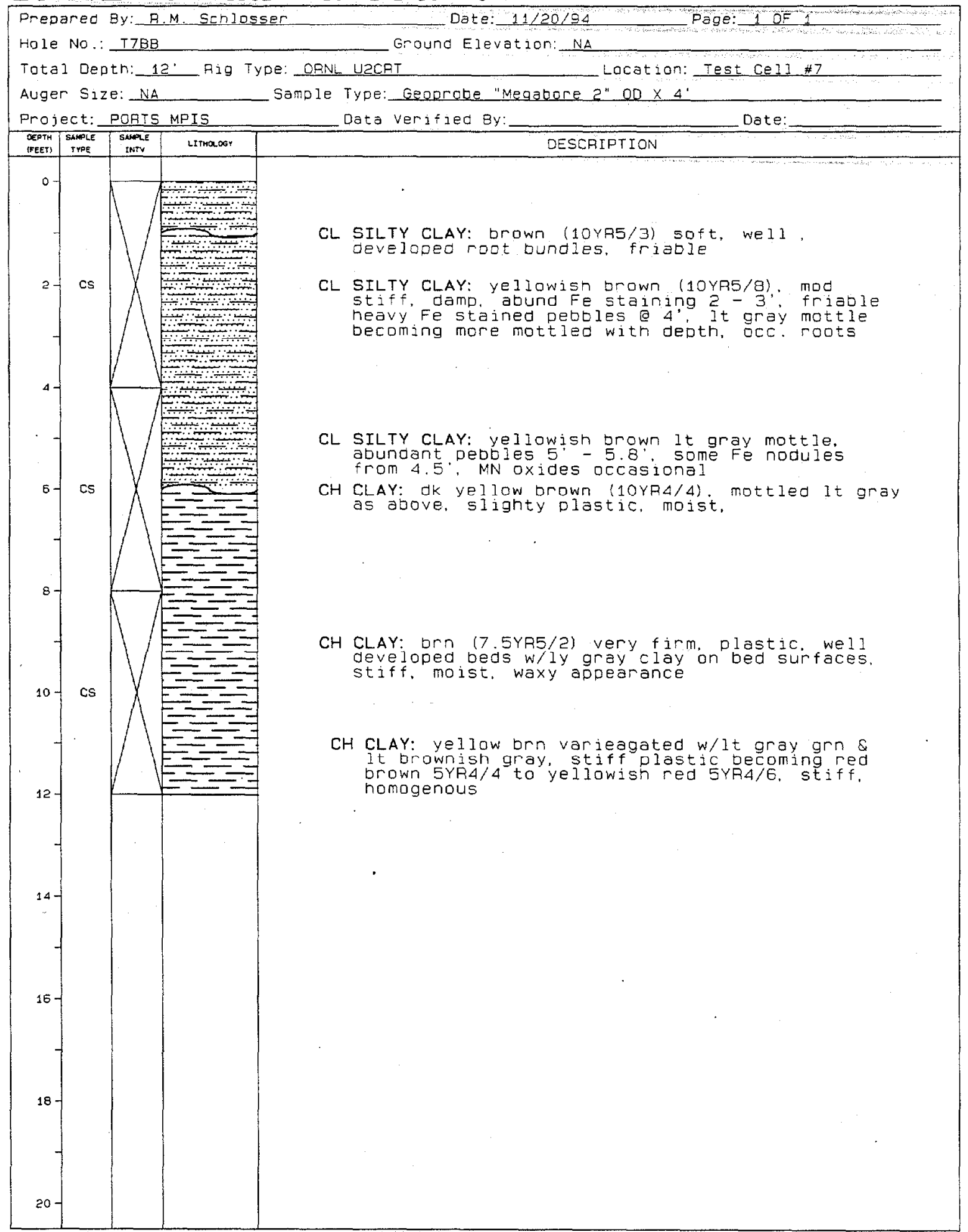




\section{B-68}

\section{OrI oak ridge national Laboratory}

\section{Borehole Summary Information}

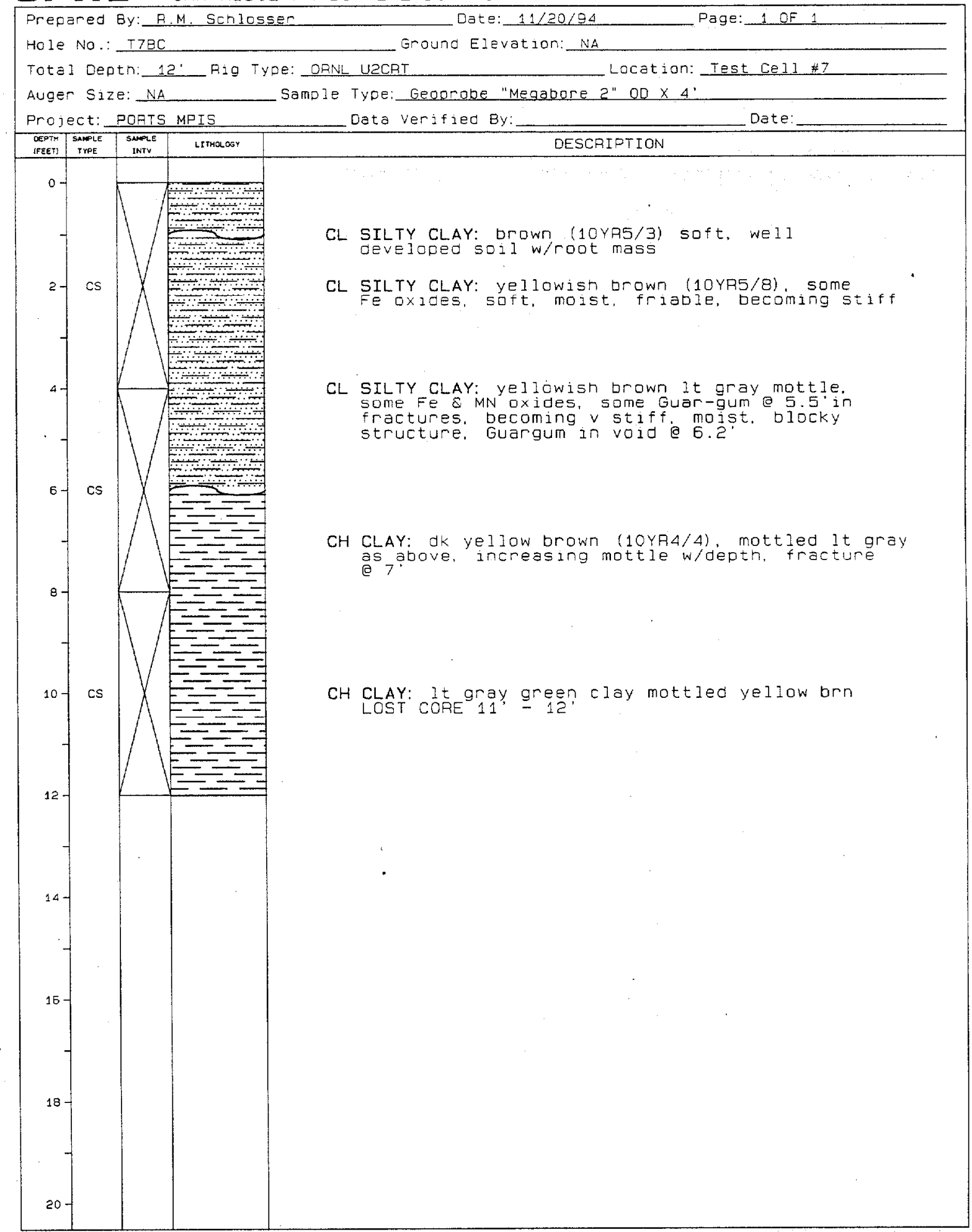




\section{B-69}

OTI oak ridge national laboratory

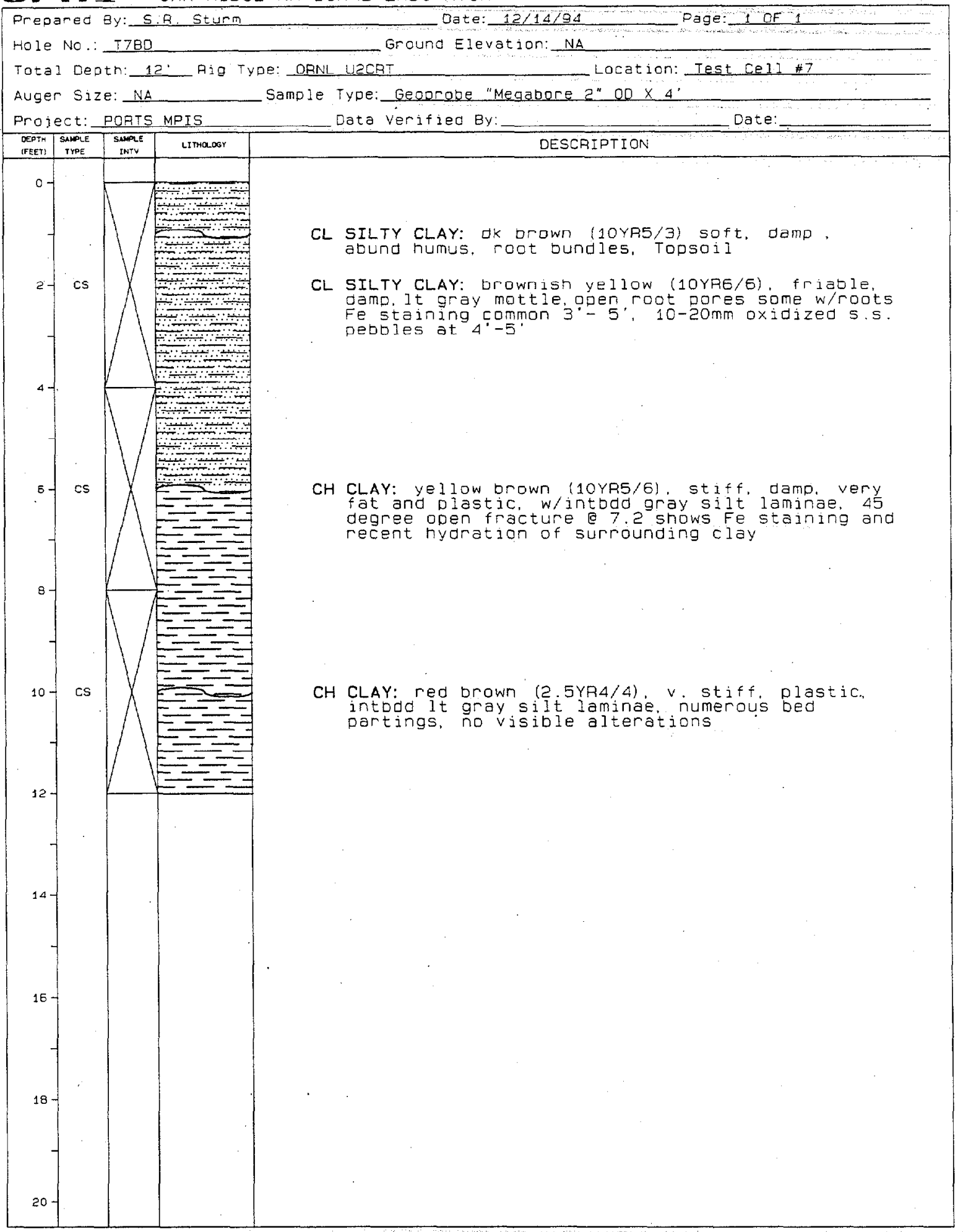


QTI I OAK aidge natzonaL Borehole Summary Information

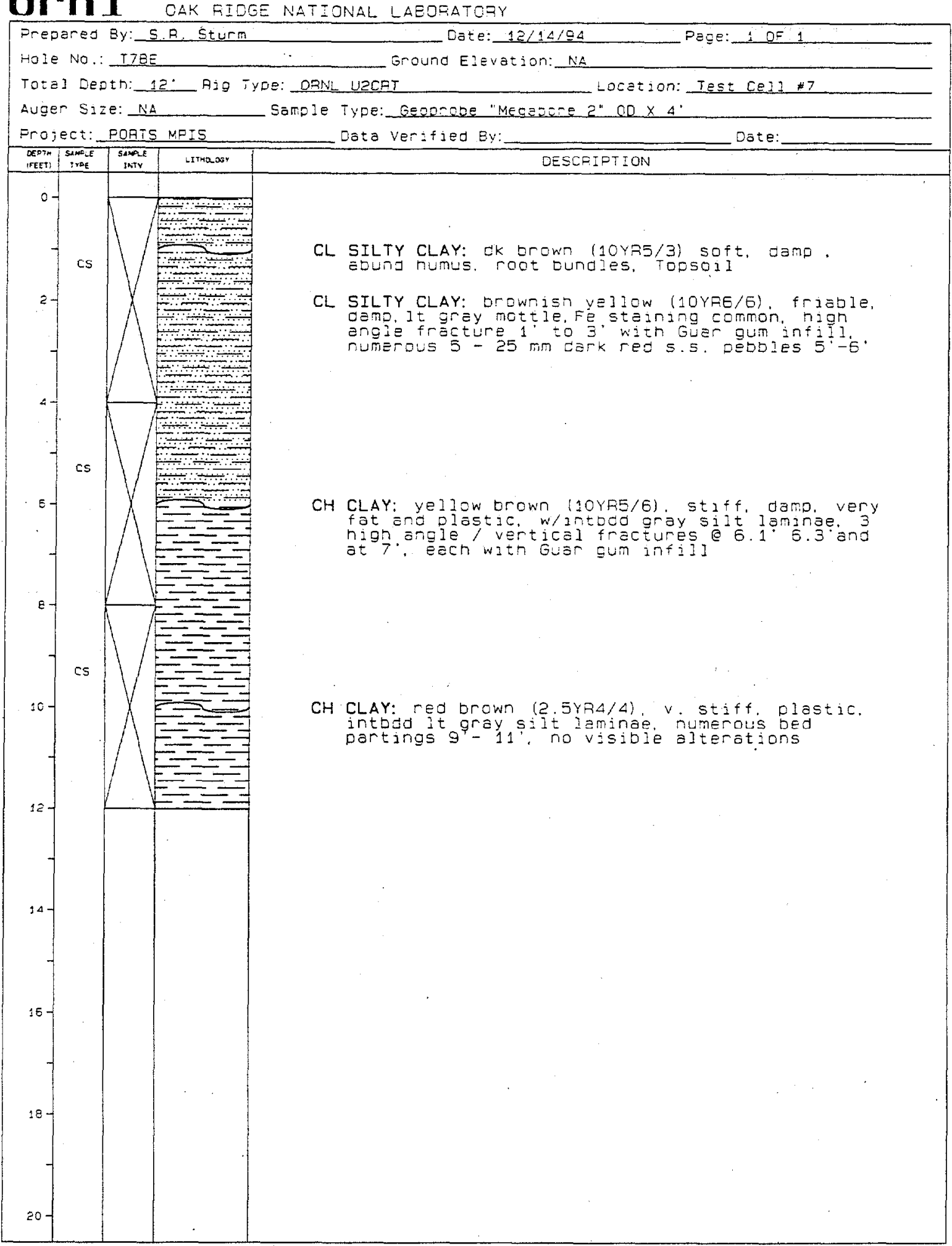




\section{APPENDIX C}

DATA TREND GRAPHS FOR VARIOUS GEOCHEMICAL PARAMETERS IN SOIL AND SOLLPORE WATER 


\begin{abstract}
.
\end{abstract}$$
\text { . }
$$ 


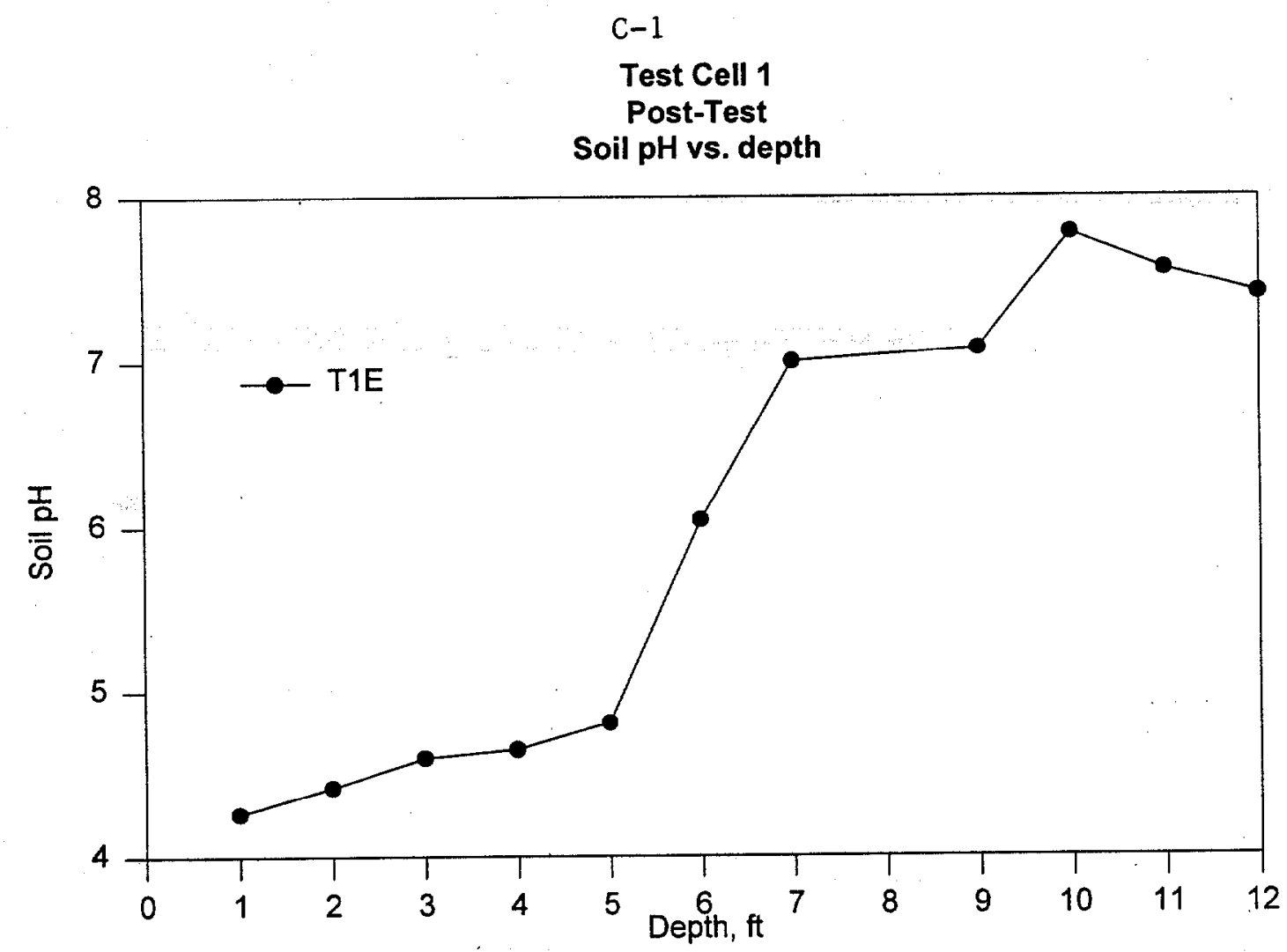

Fig. C.1. Test cell 1 - post-treatment soil pH.

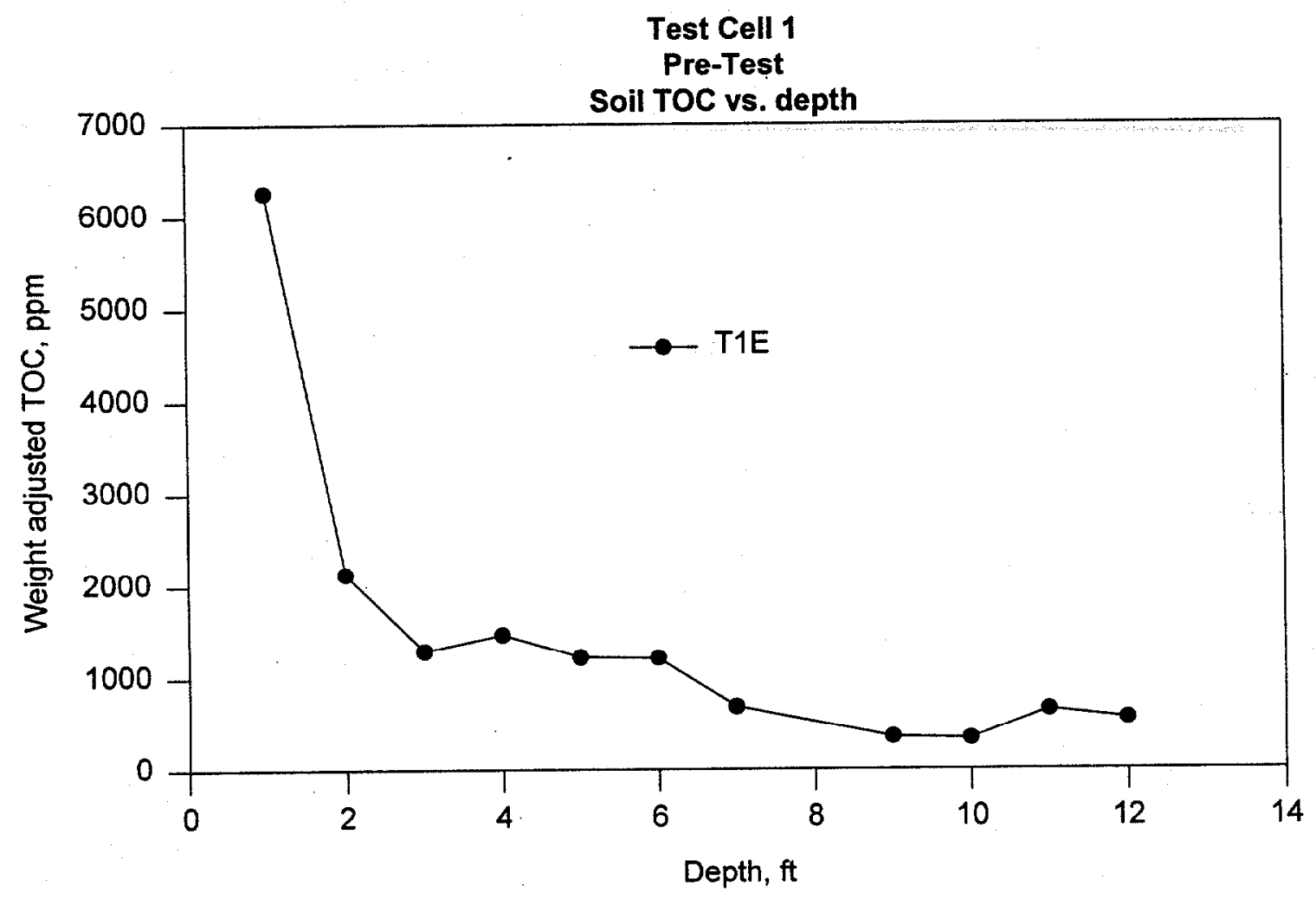

t1phtoc

Fig. C.2. Test cell 1 - pre-treatment soil TOC content. 
$\mathrm{C}-2$

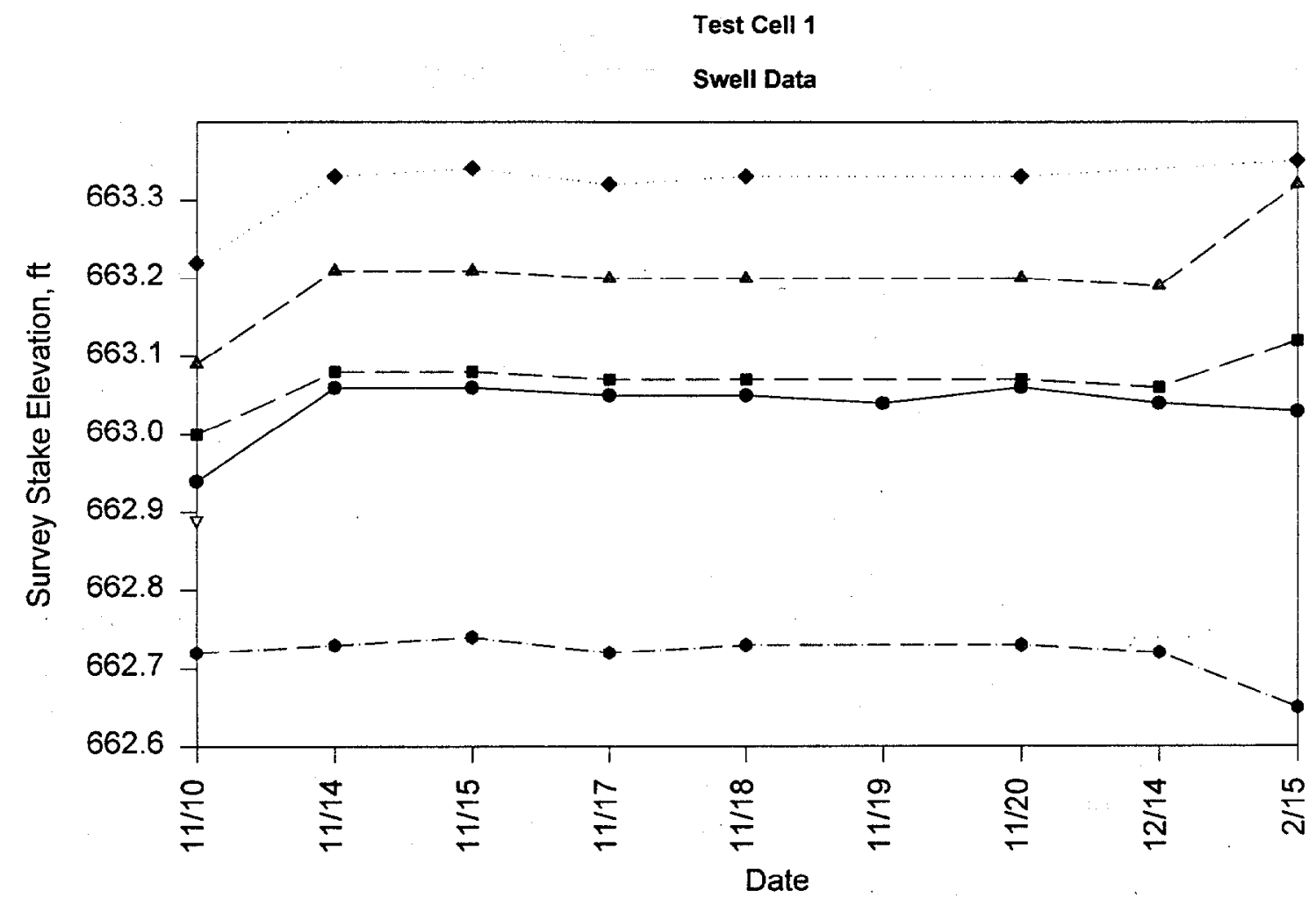

Fig. C.3. Test cell 1 - post-treatment soil swell data. Post-Test

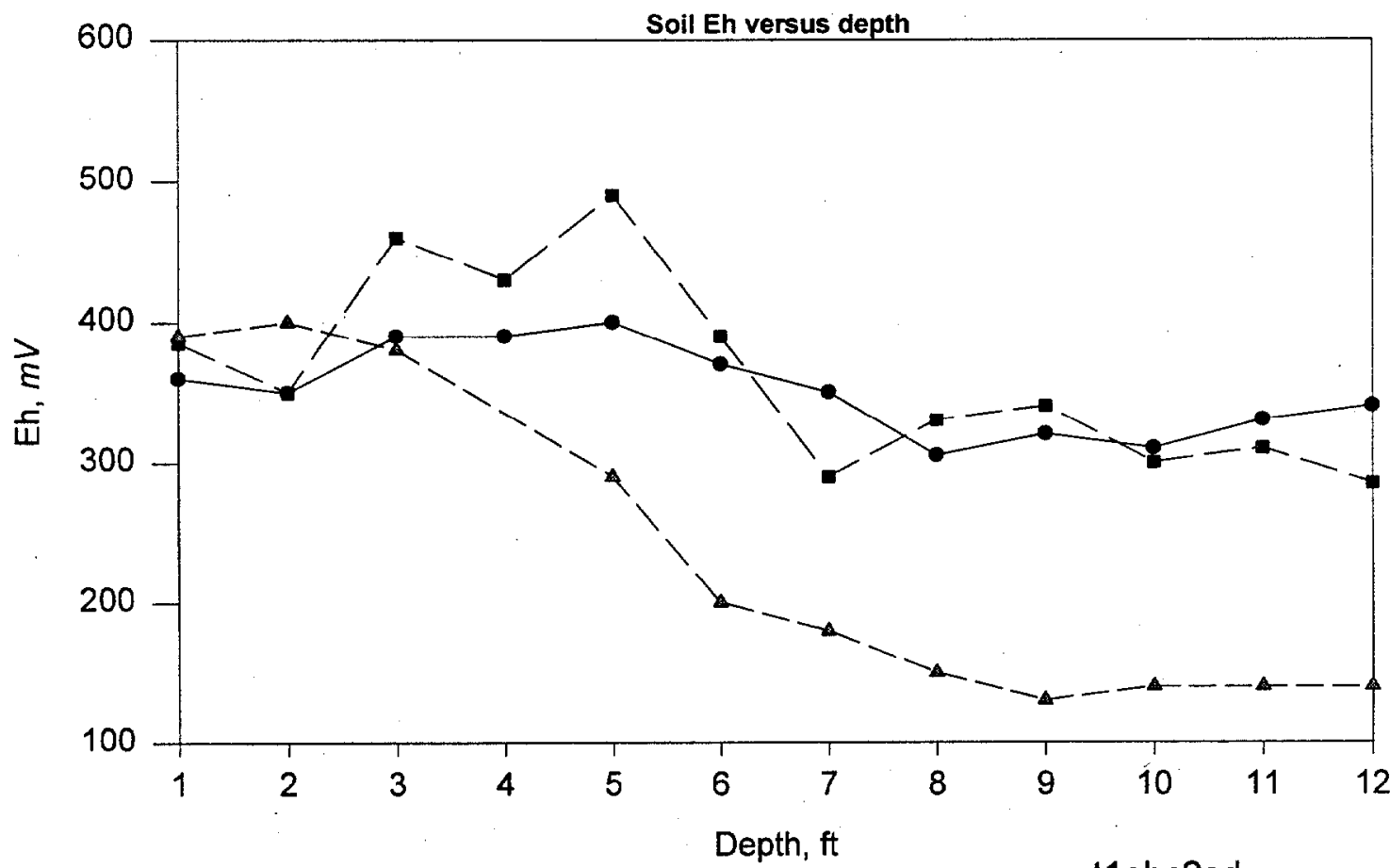

t1ehc2sd

Fig. C.4. Test cel1 1 - post-treatment soil Eh. 


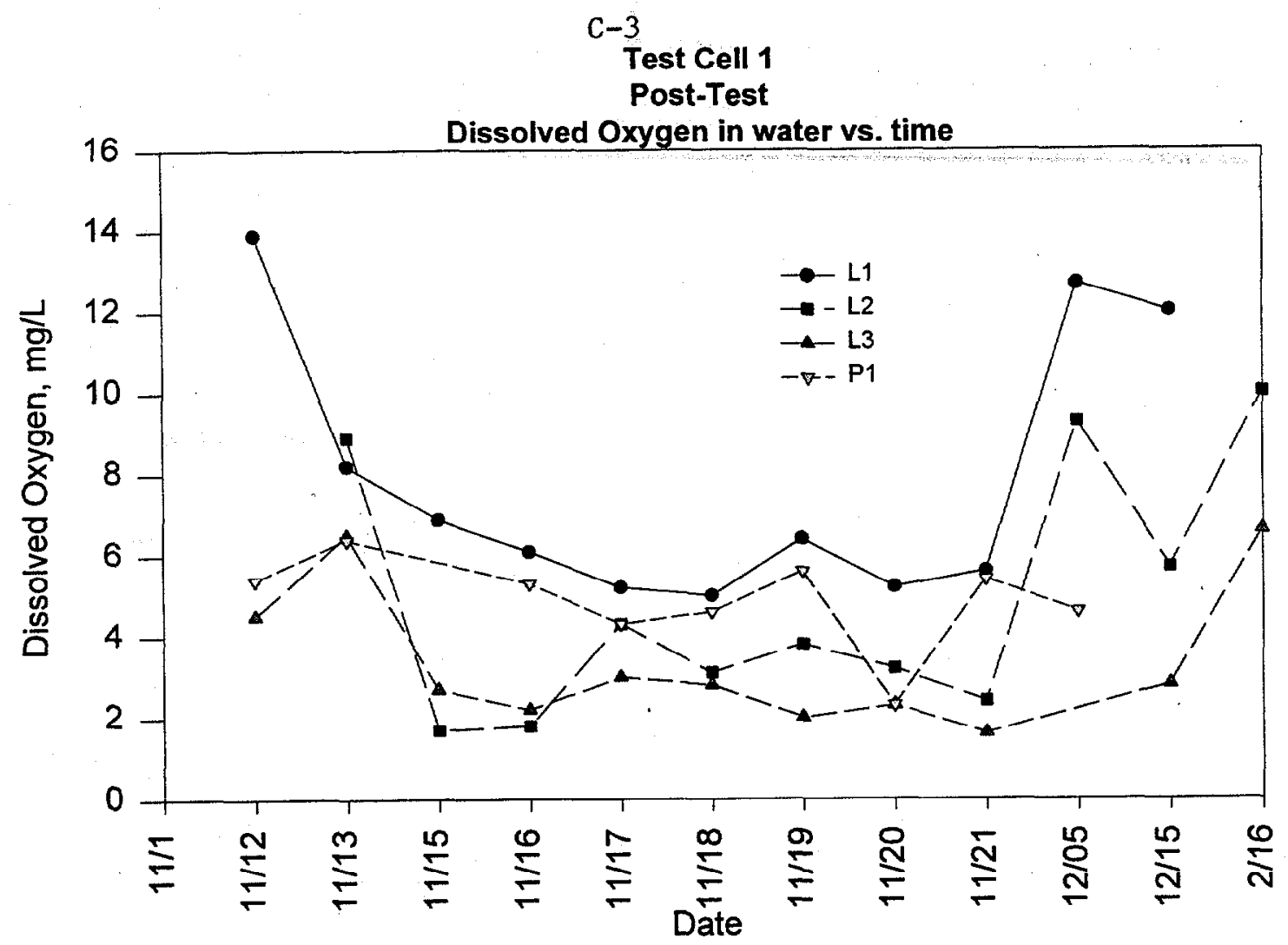

Fig. C.5. Test cell 1 - post-treatment water DO levels.

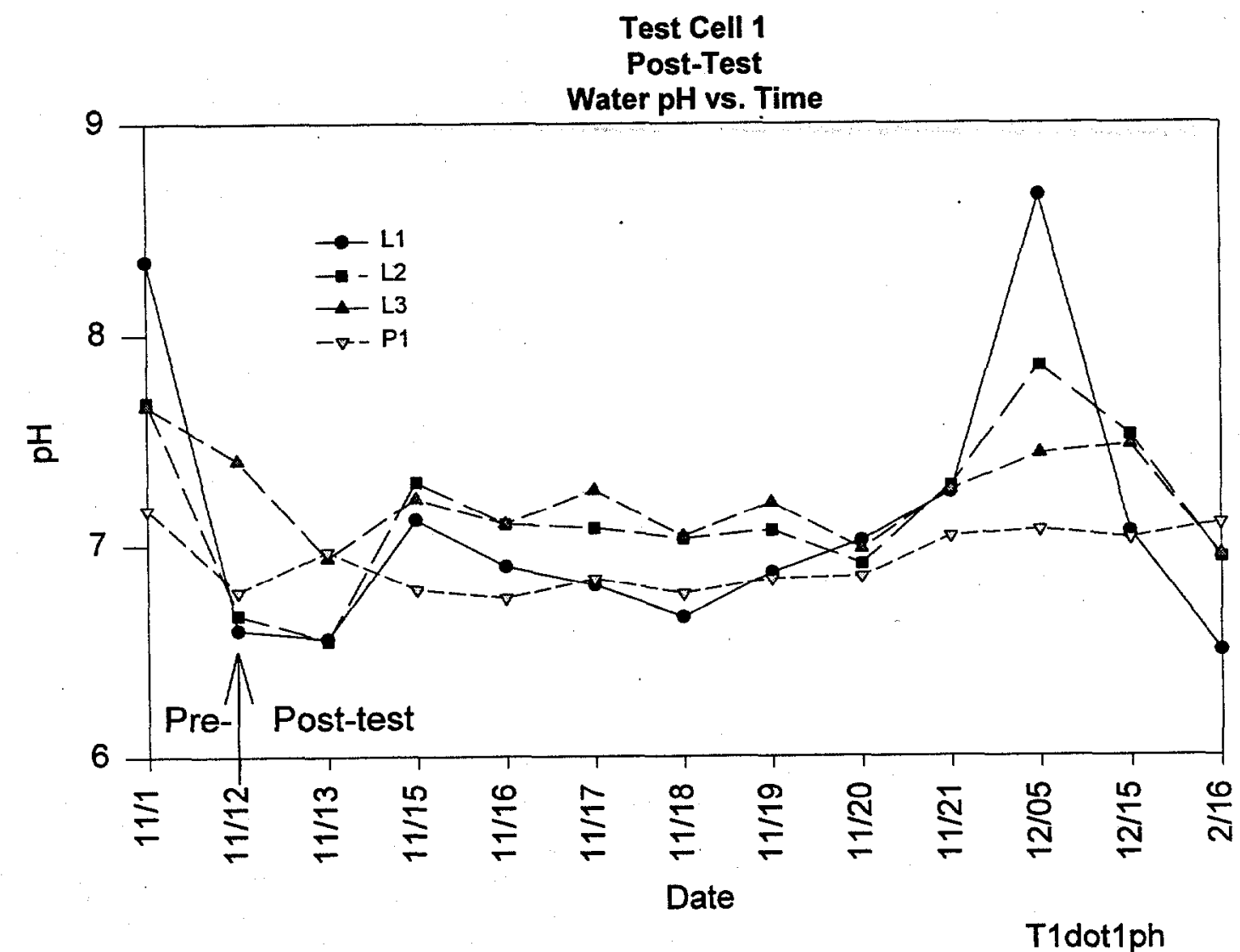

Fig. C.6. Test cel1 1 - post-treatment water $\mathrm{pH}$. 


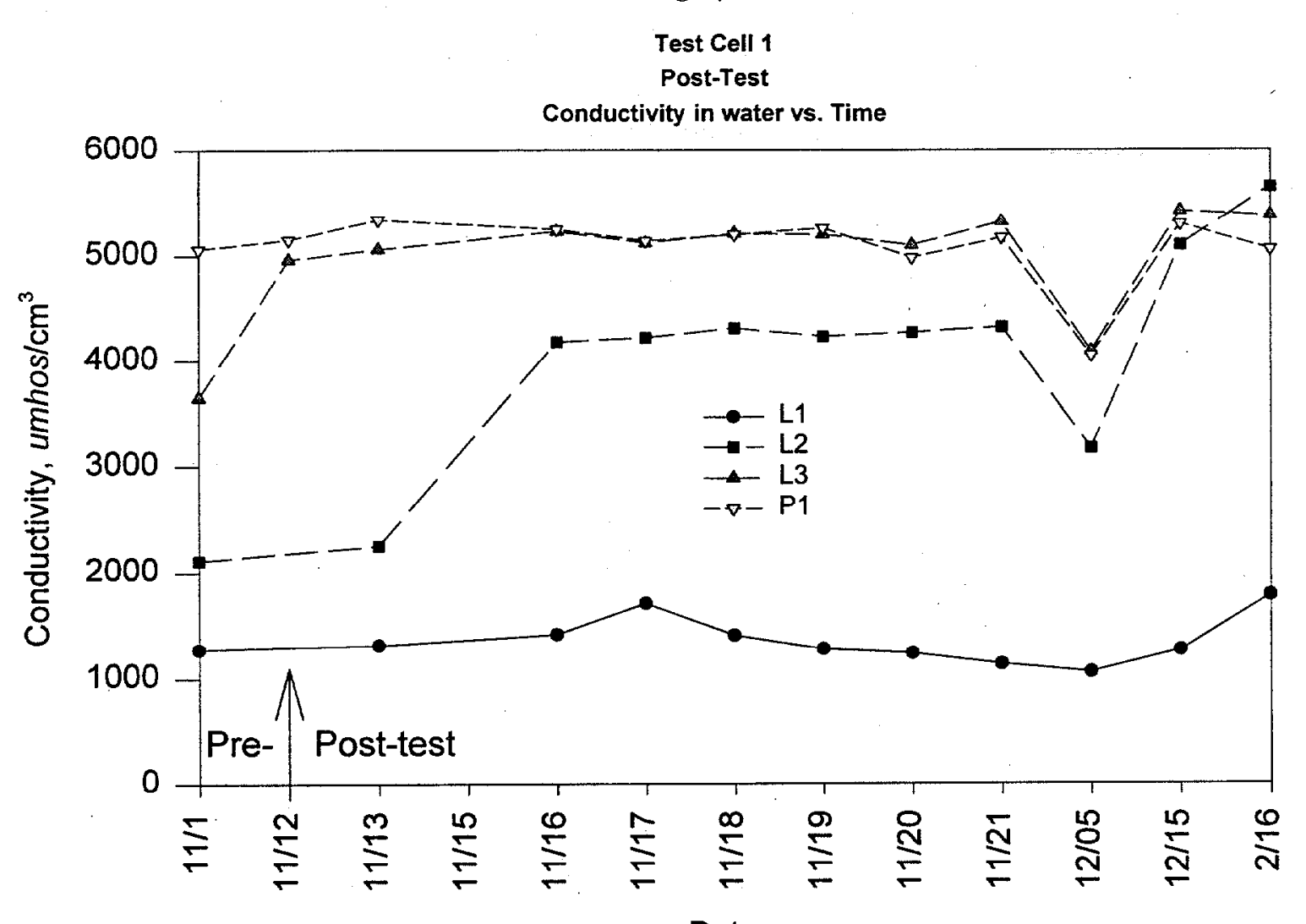

Date

Fig. C.7. Test cell 1 - post-treatment water conductivity levels.

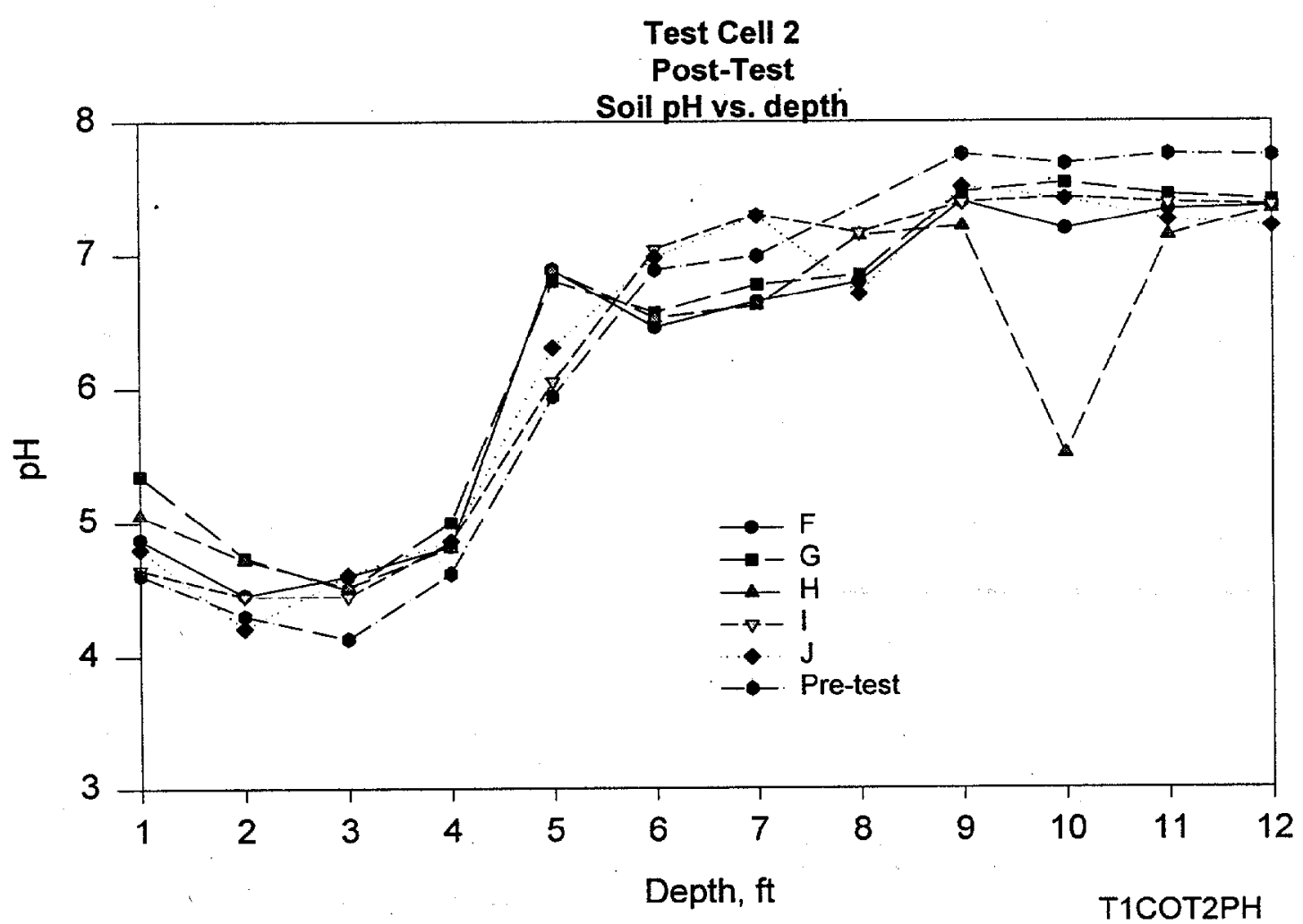

Fig. C.8. Test cell 2 - post-treatment soil pH. 


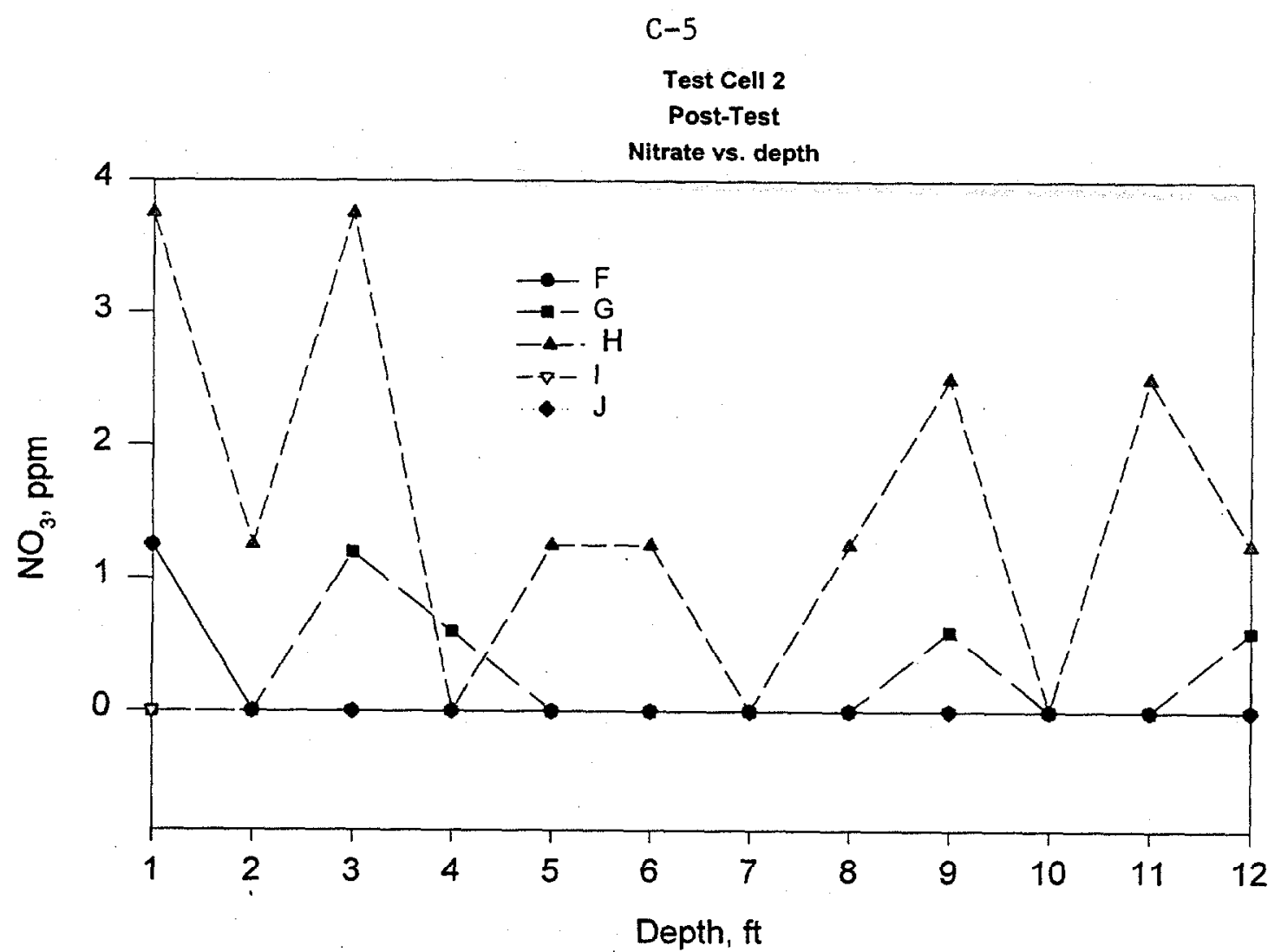

Fig. C.9. Test cell 2 - post-treatment soil nitrate levels.

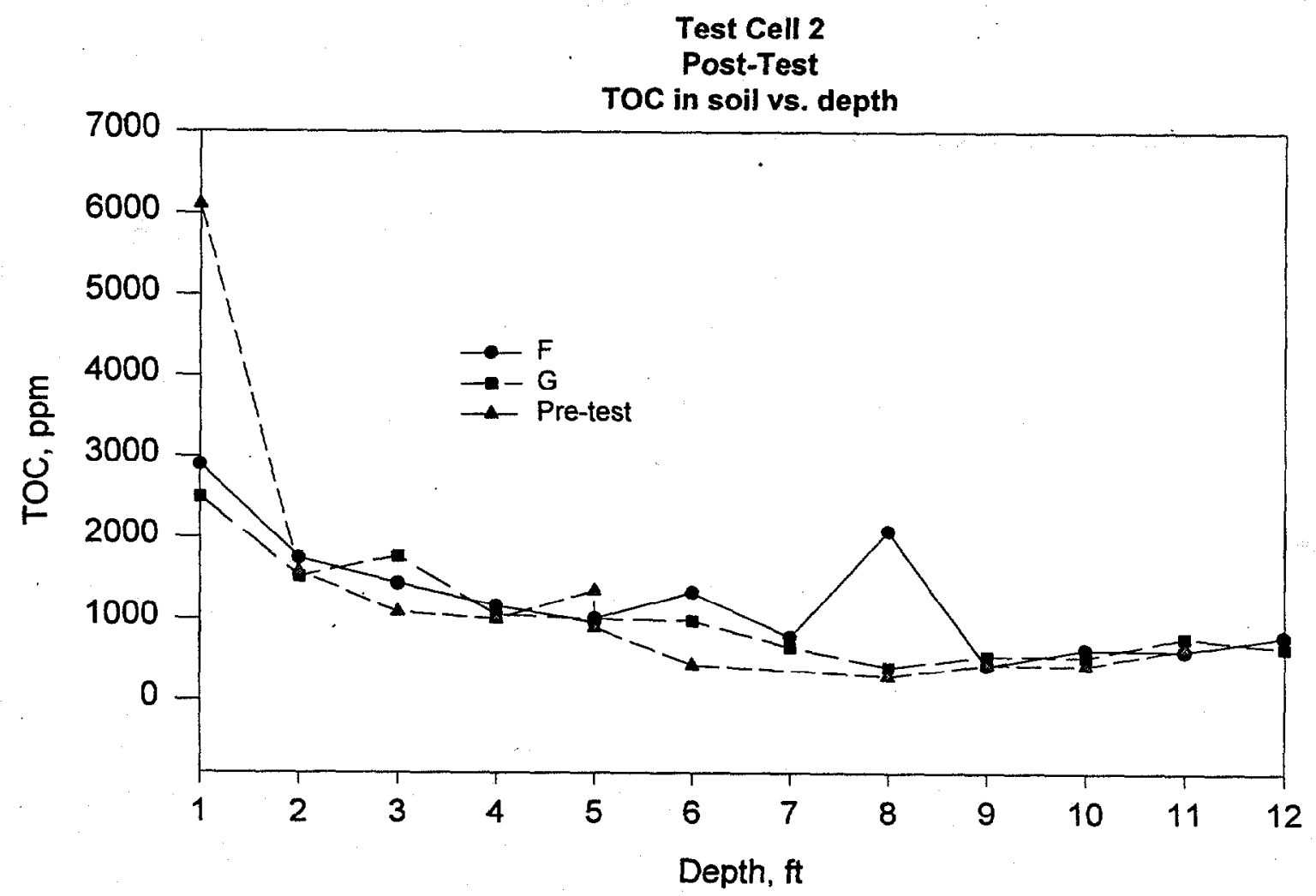

Fig. C.10. Test cel1 2 - post-treatment soil TOC content. 


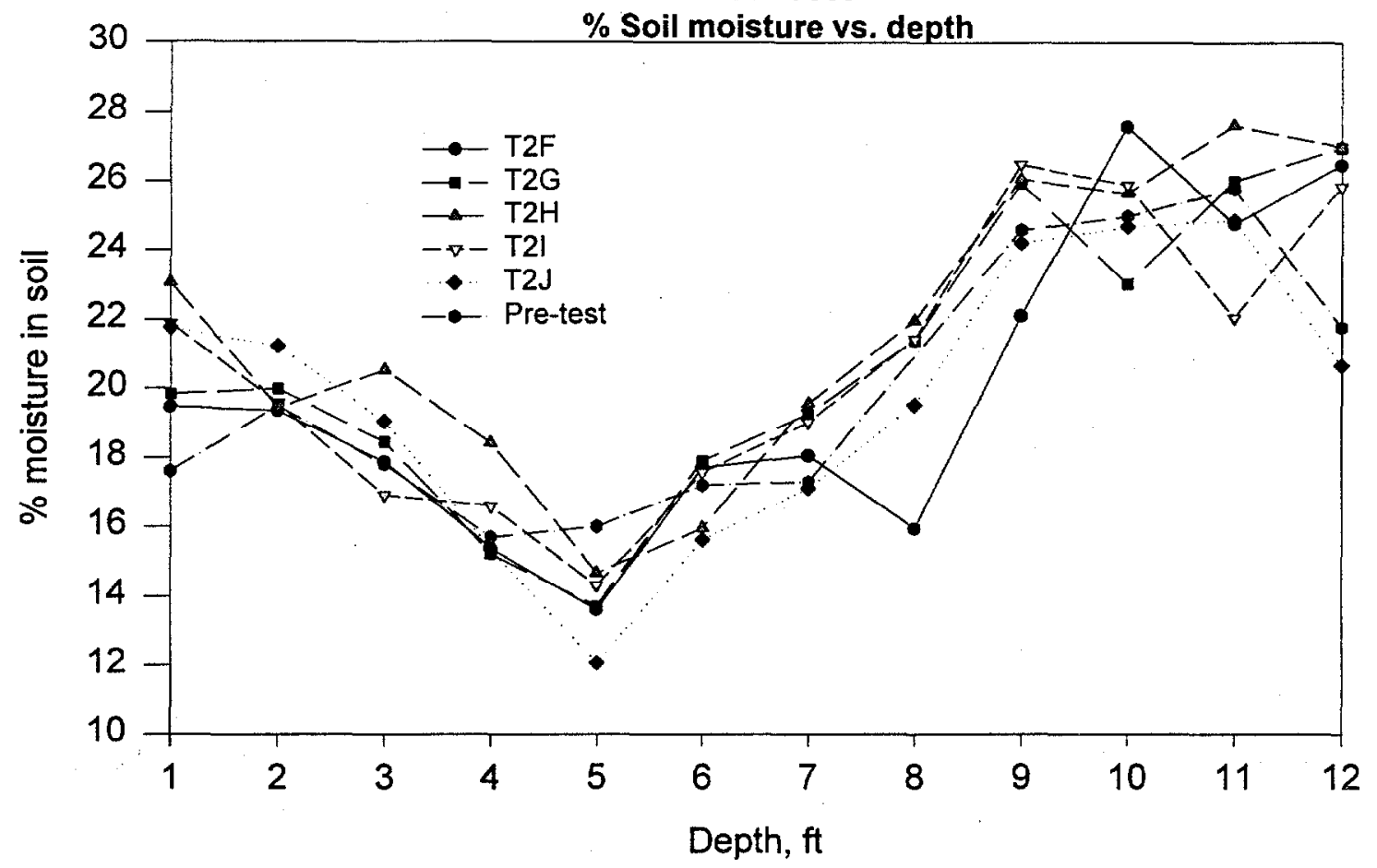

Fig. C.11. Test cell 2 - post-treatment soil moisture content.

Test Cell 2

Swell Data

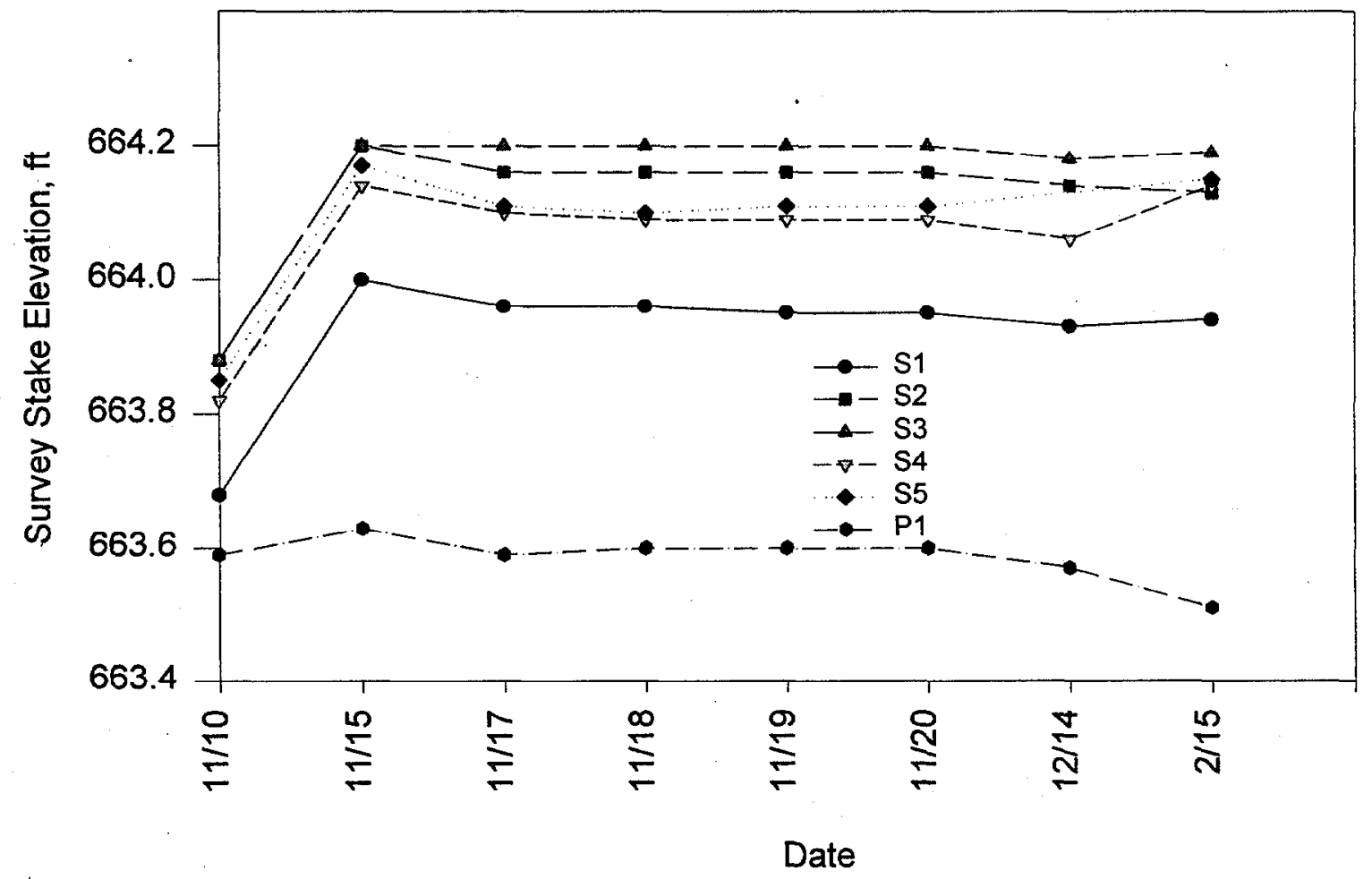

Ł2mot2sd

Fig. C.12. Test cell 2 - post-treatment soil swell data. 


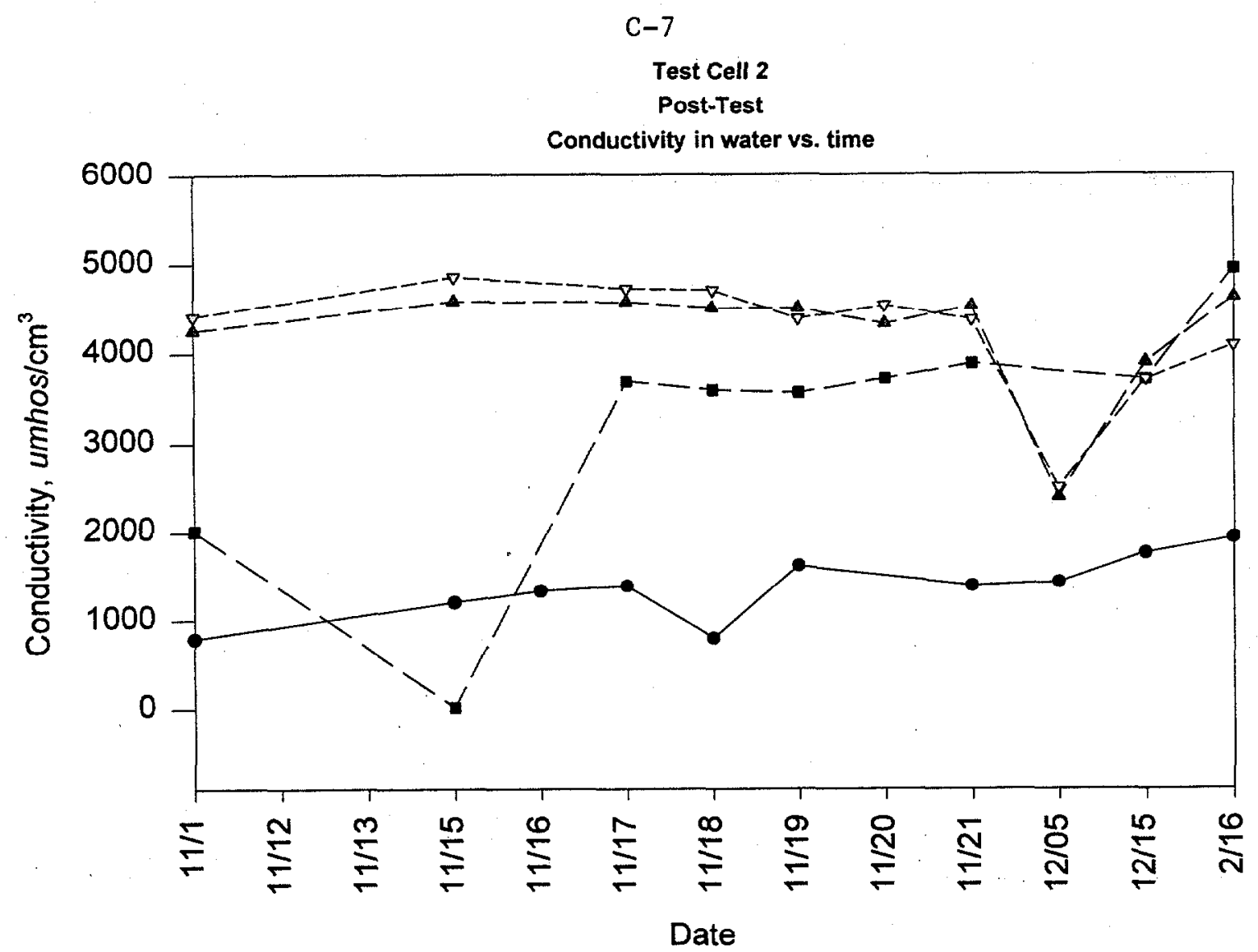

Fig. C.13. Test cel1 2 - post-treatment water conductitivity leve1s.

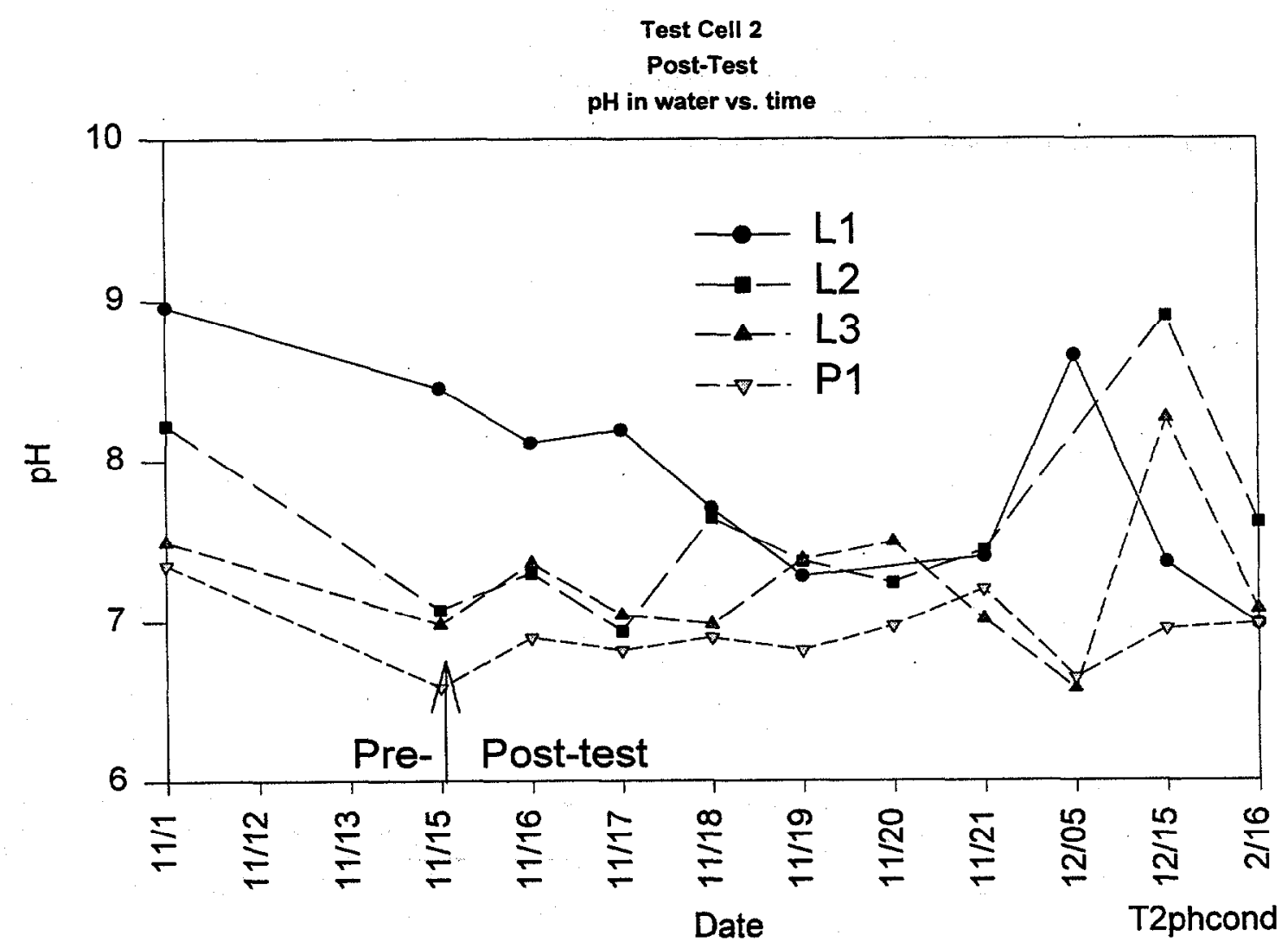

Fig. C.14. Test cel1 2 - post-treatment water $\mathrm{pH}$. 


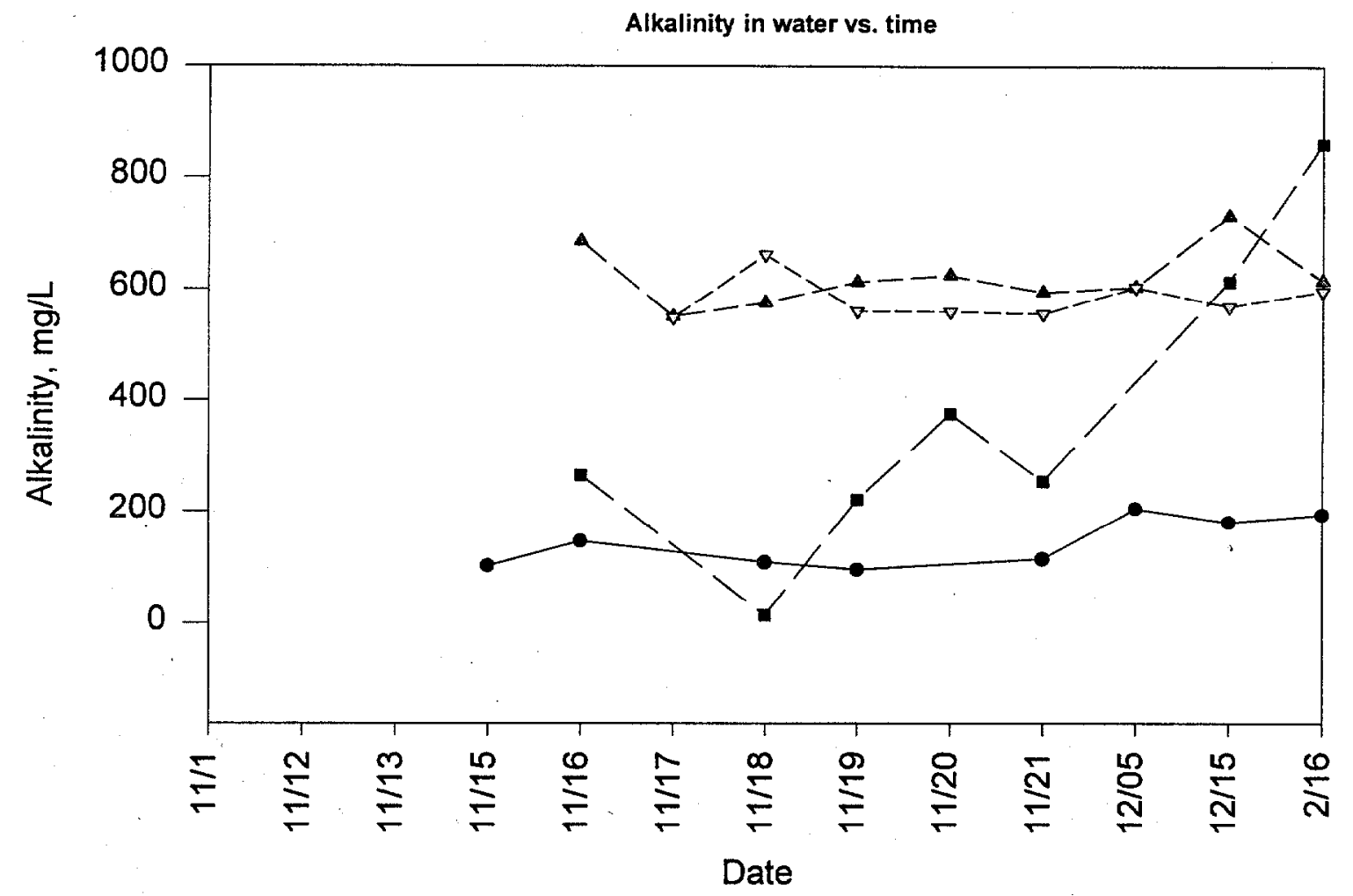

Fig. C.15. Test ce11 2 - post-treatment water alkalinity levels.

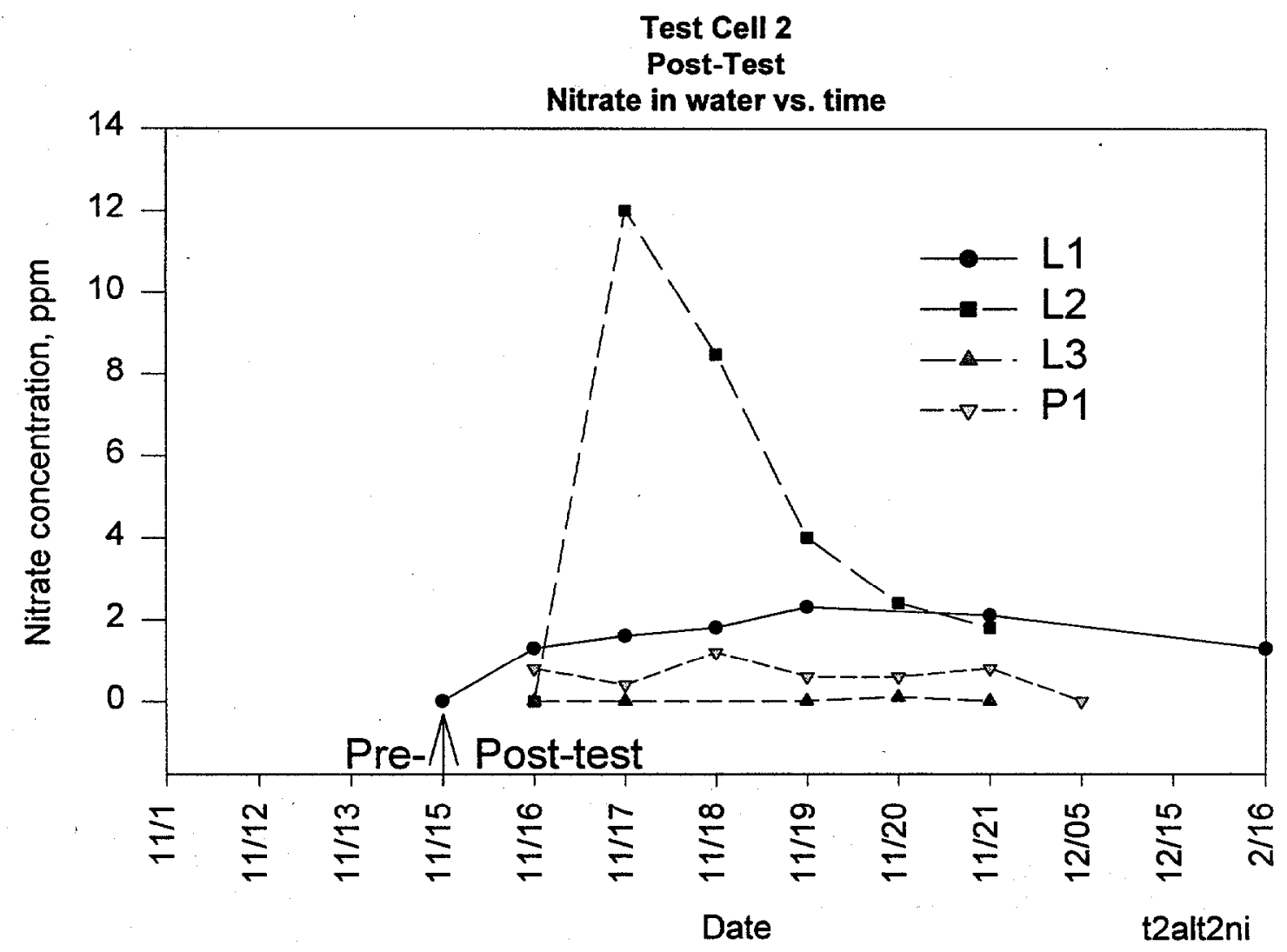

Fig. C.16. Test ce11 2 - post-treatment water nitrate levels. 
Test Cell 3

Post-Test

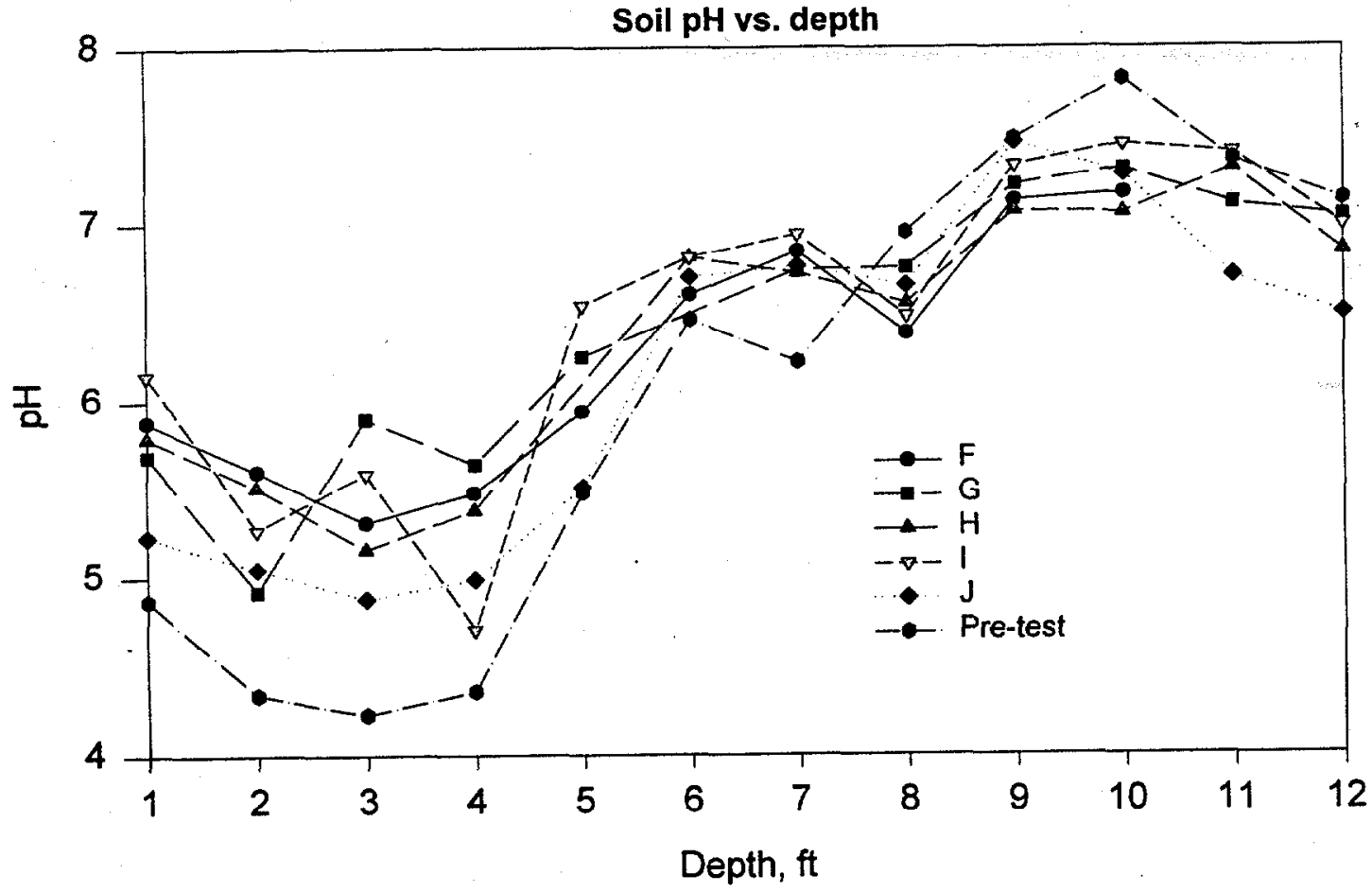

Fig. C.17. Test cell 3 - post-treatment soil pH.

Test Cell 3

Post-Test

Soil moisture vs. depth

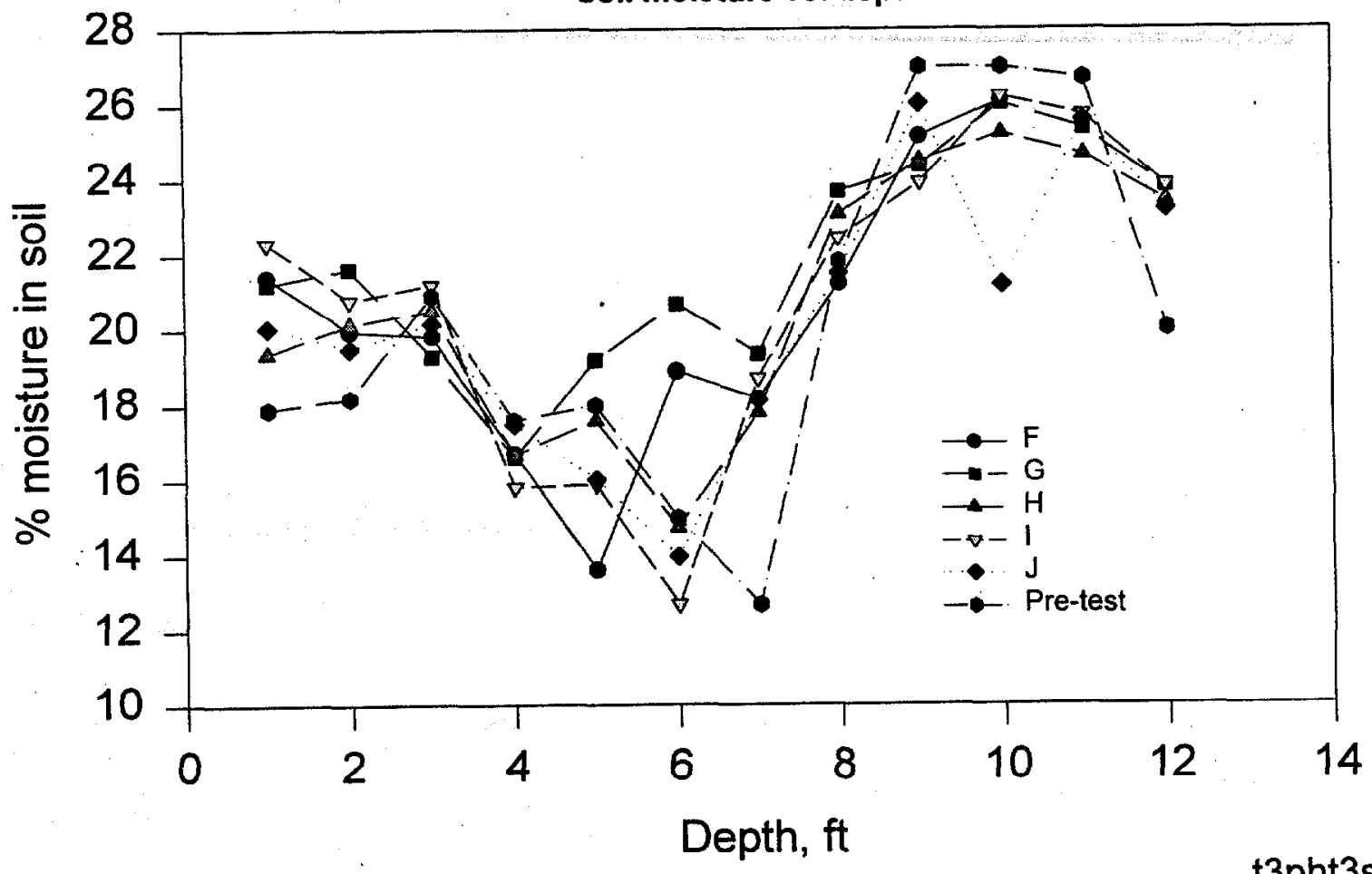

t3pht3sm

Fig. C.18. Test cell 3 - post-treatment soil moisture levels. 


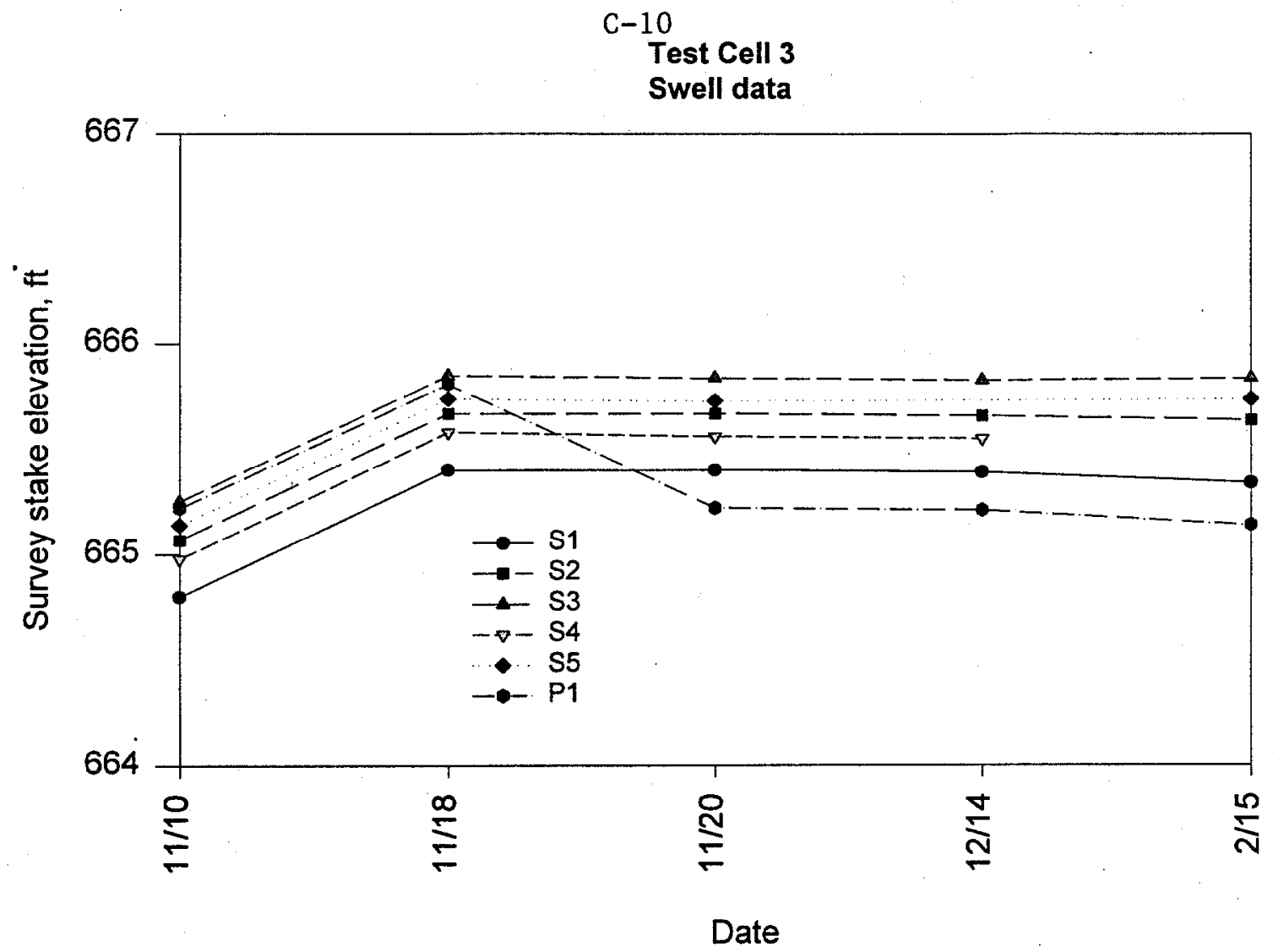

Fig. C.19. Test cell 3 - post-treatment soil swell data.

Test Cell 3

Post-Test

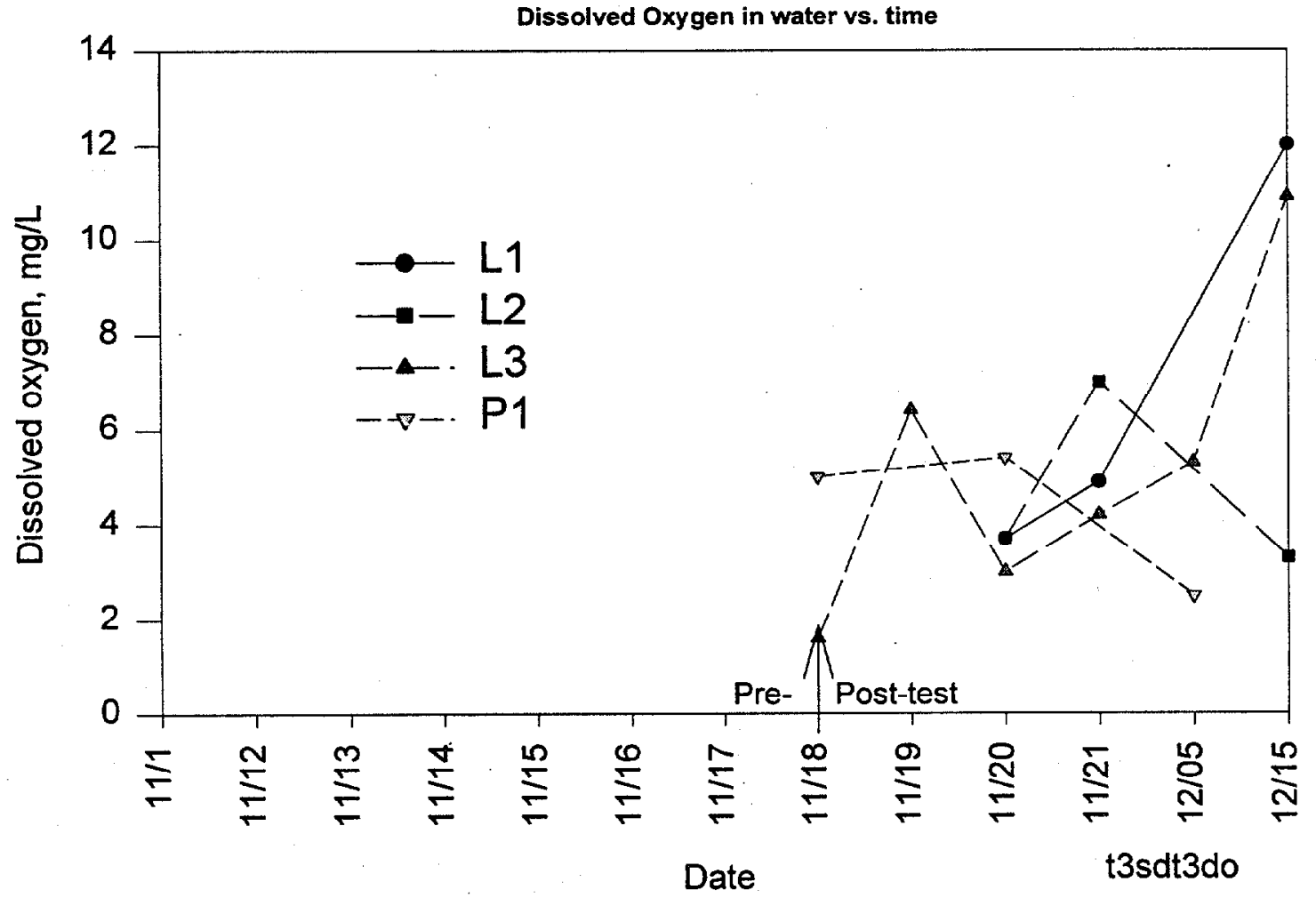

Fig. C.20. Test cell 3 - post-treatment water DO levels. 


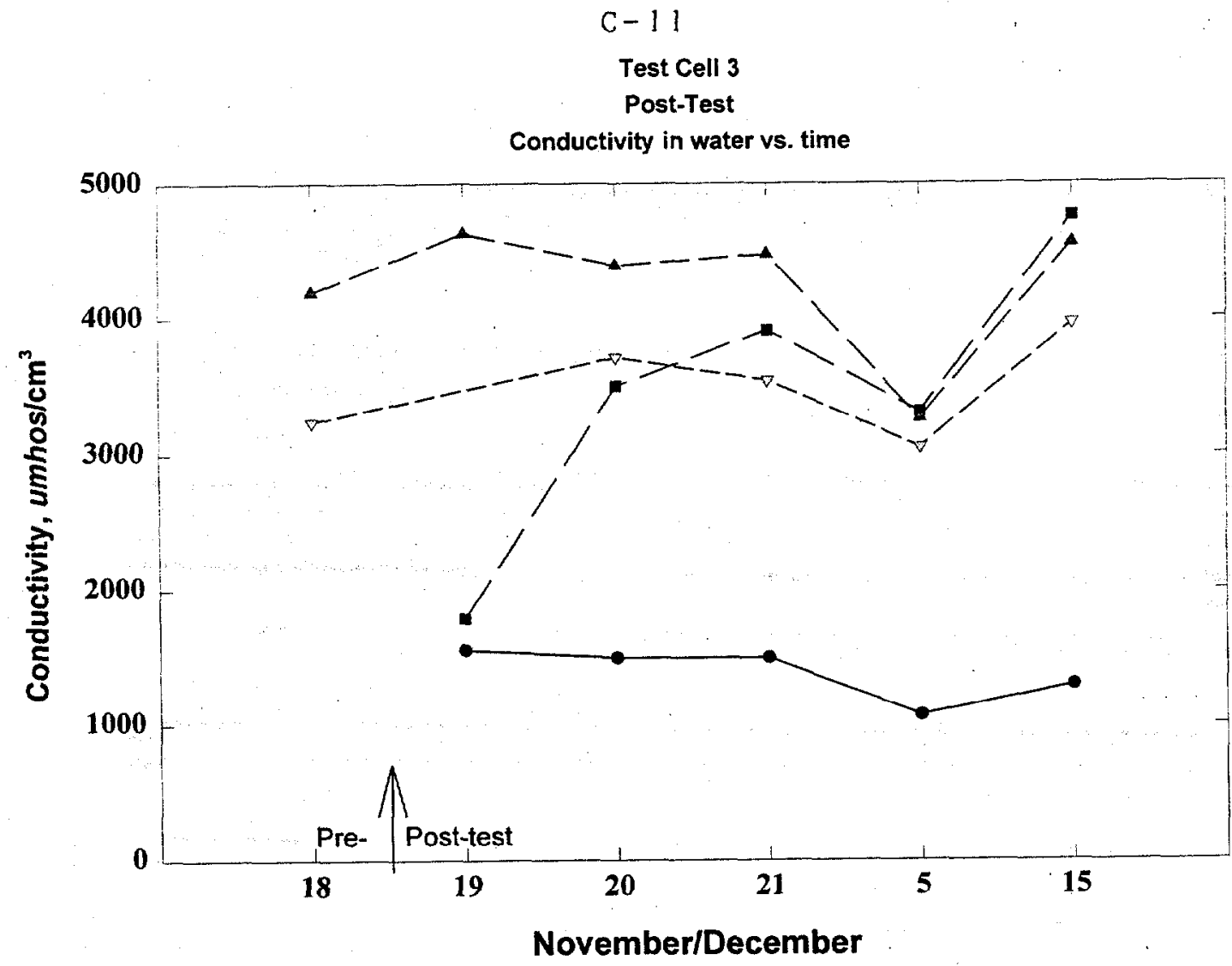

Fig. C.21. Test cell 3 - post-treatment water conductivity levels. Test Cell 3

Post-Test.

Nitrate in water vs. time

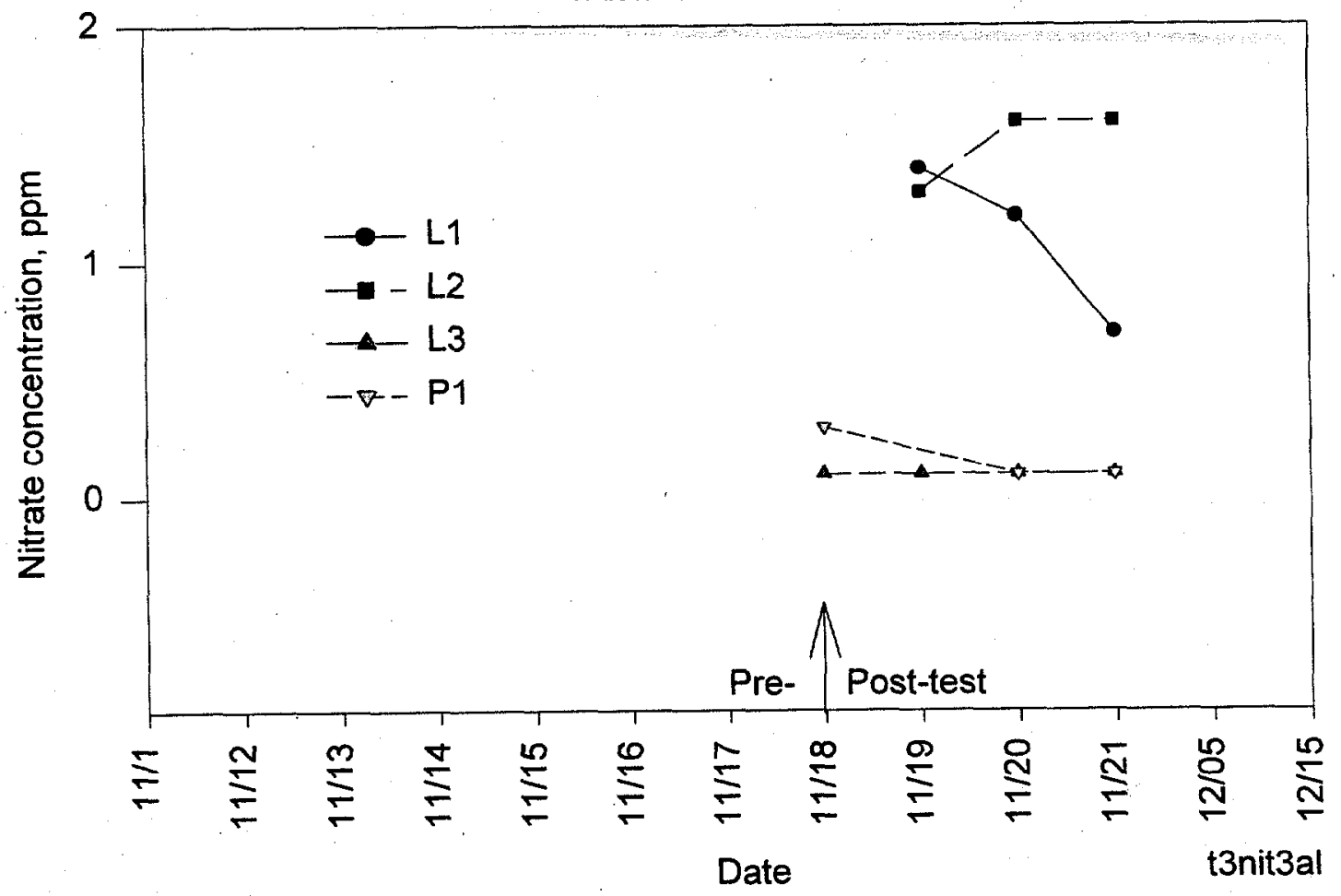

Fig. C.22. Test cel1 3 - post-treatment water nitrate levels. 


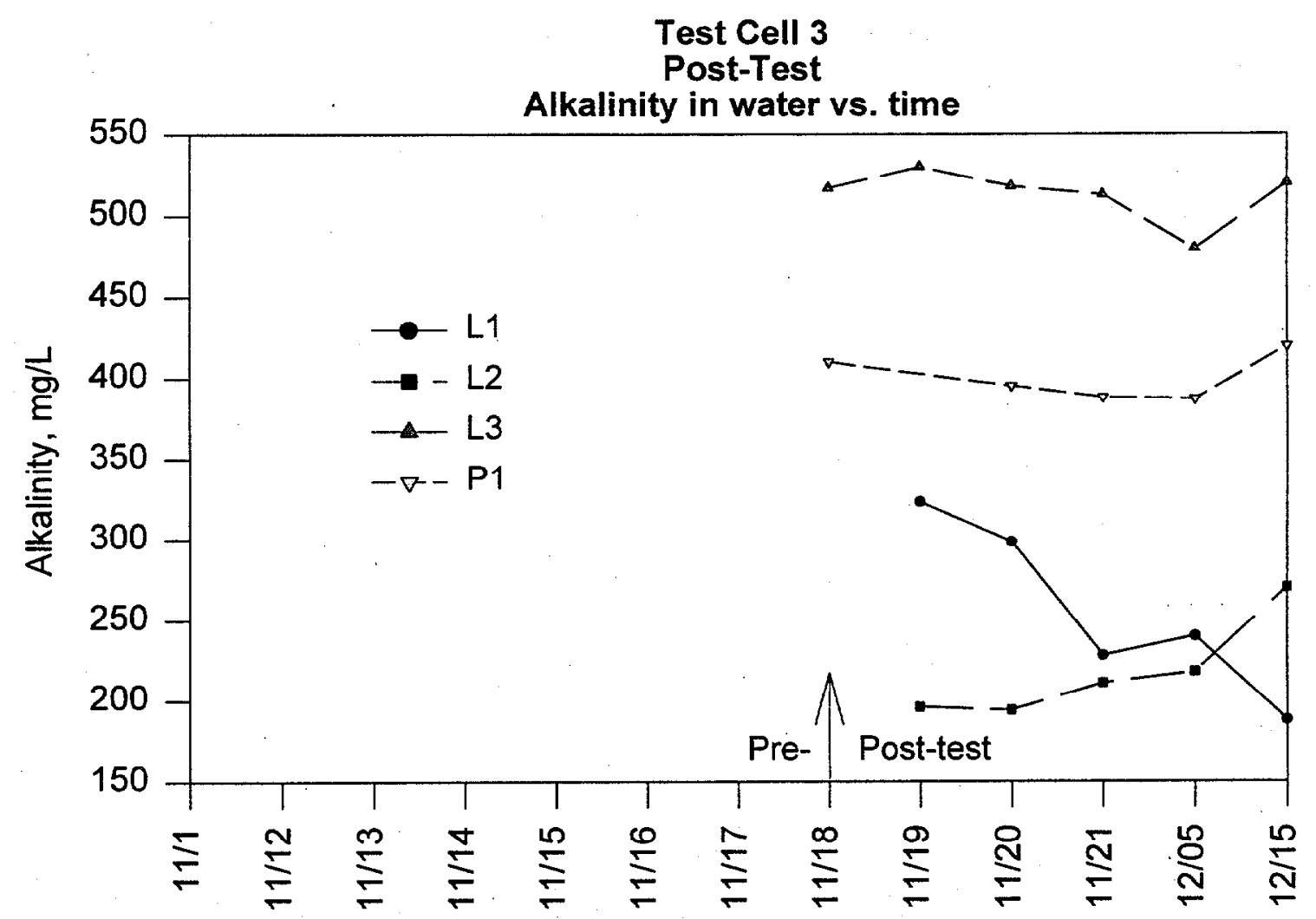

Fig. C.23. Test cell 3 - post-treatment water alkalinity levels.

\section{Test Cell 4}

Post-Test

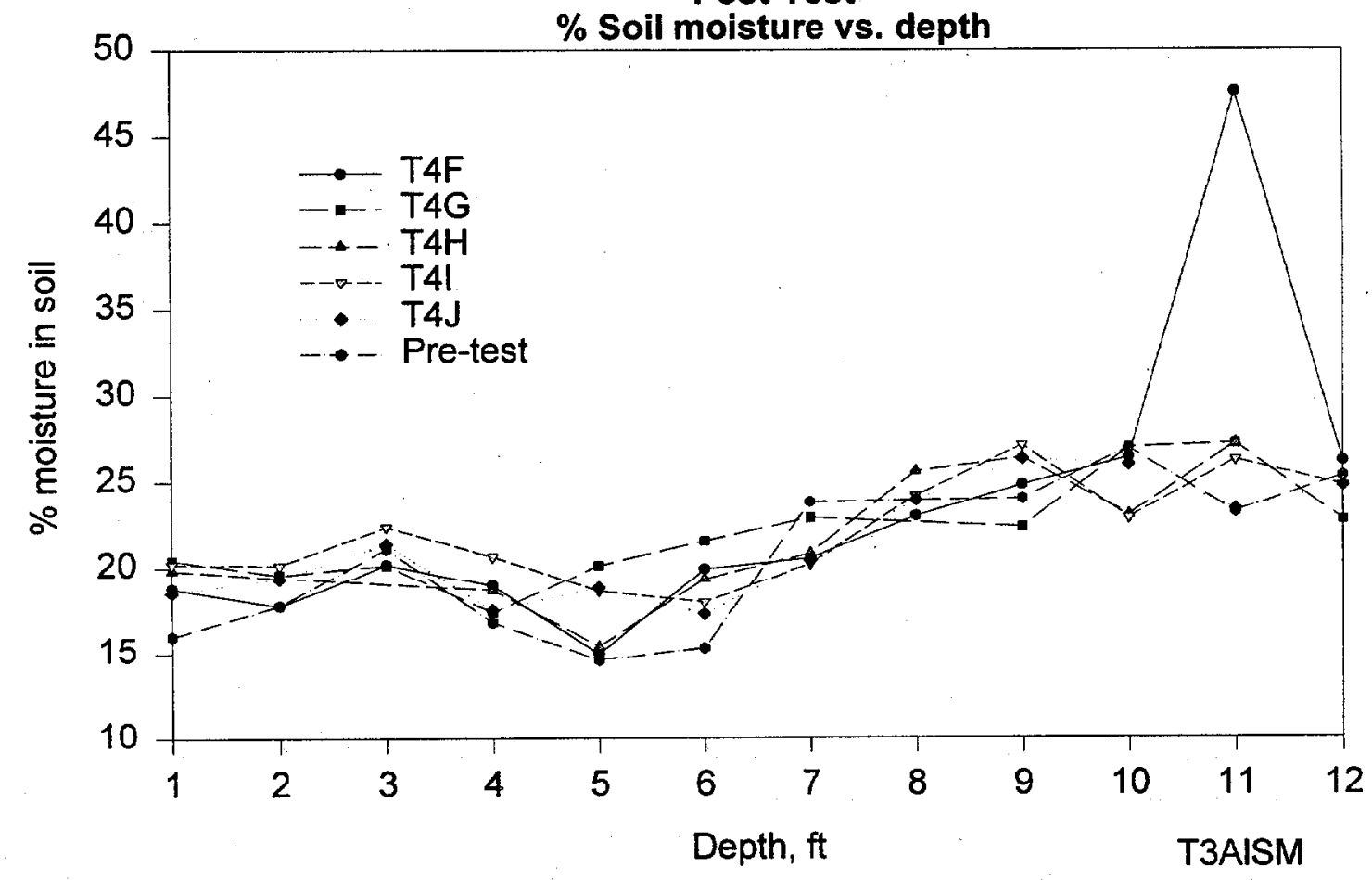

Fig. C.24. Test cell 4 - post-treațment soil moisture levels. 
Test Cell 4

Swell data

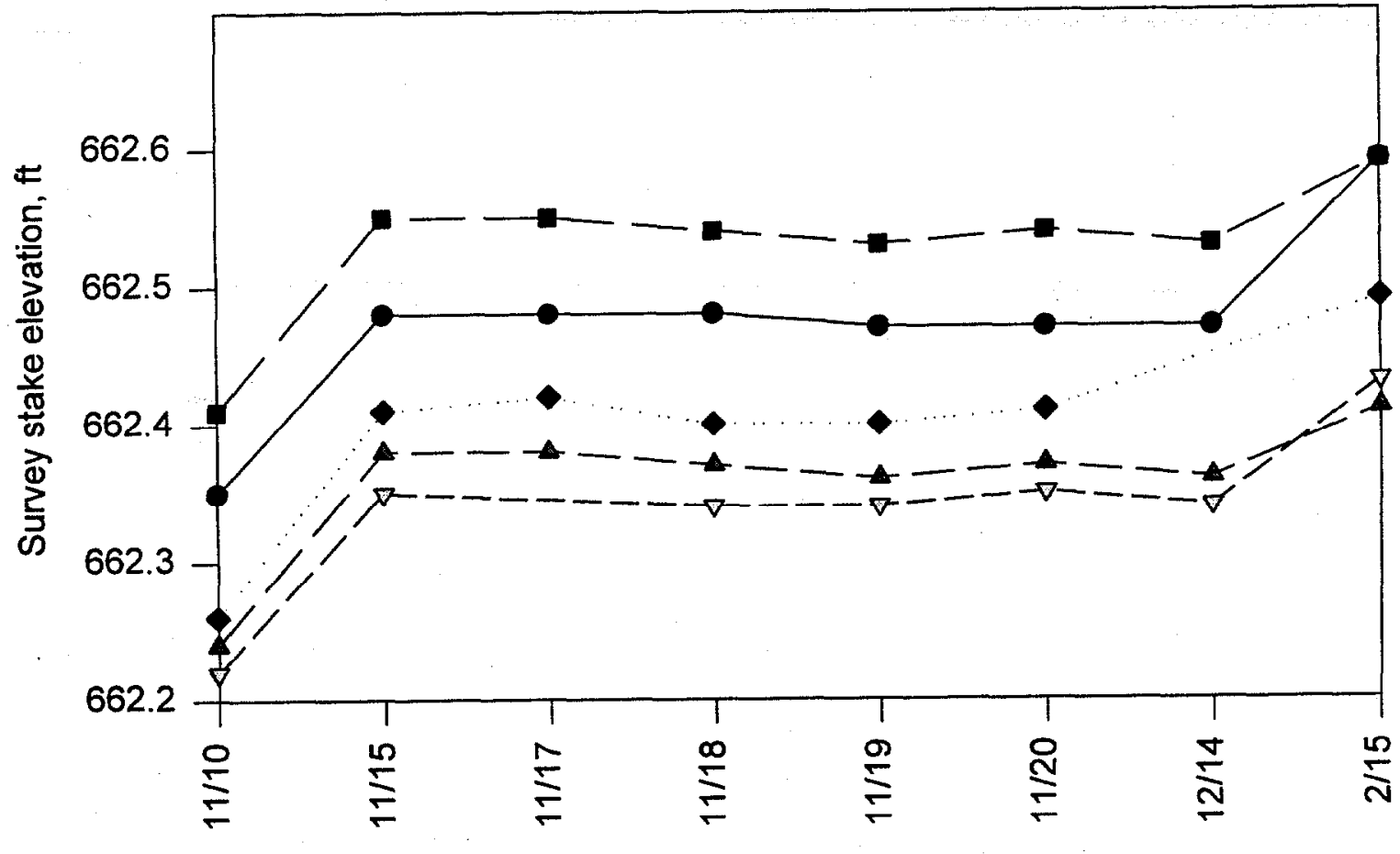

Fig. C.25. Test cell 4 - post-treatment soil swell data.

Test Cell 4

Post-Test

Dissolved oxygen in water vs. time

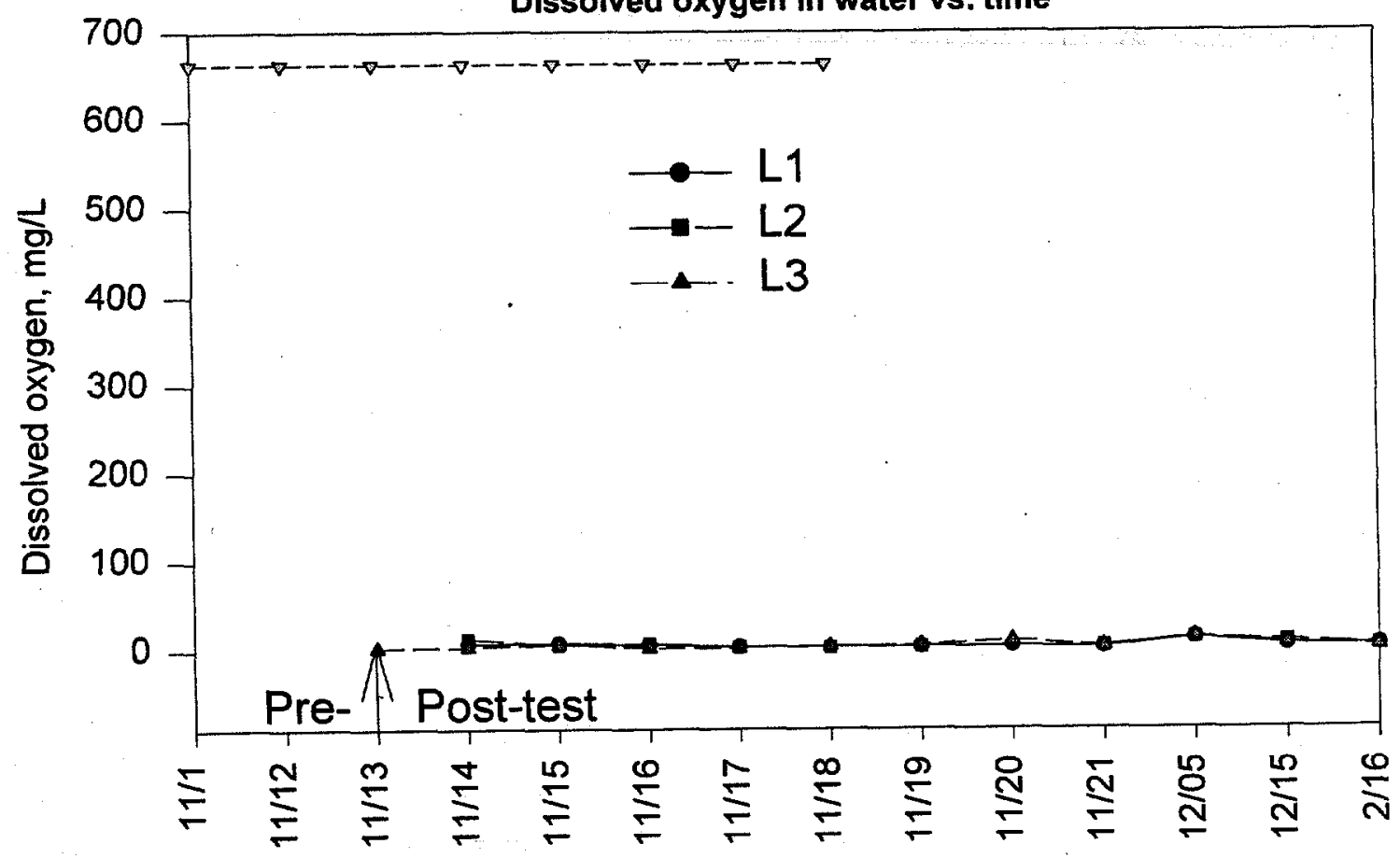

Date

T4dosd

Fig. C.26. Test cel1 4 - post-treatment water Do leviels. 
C- 14

Test Cell 5

Post-Test

Soil pH vs. depth

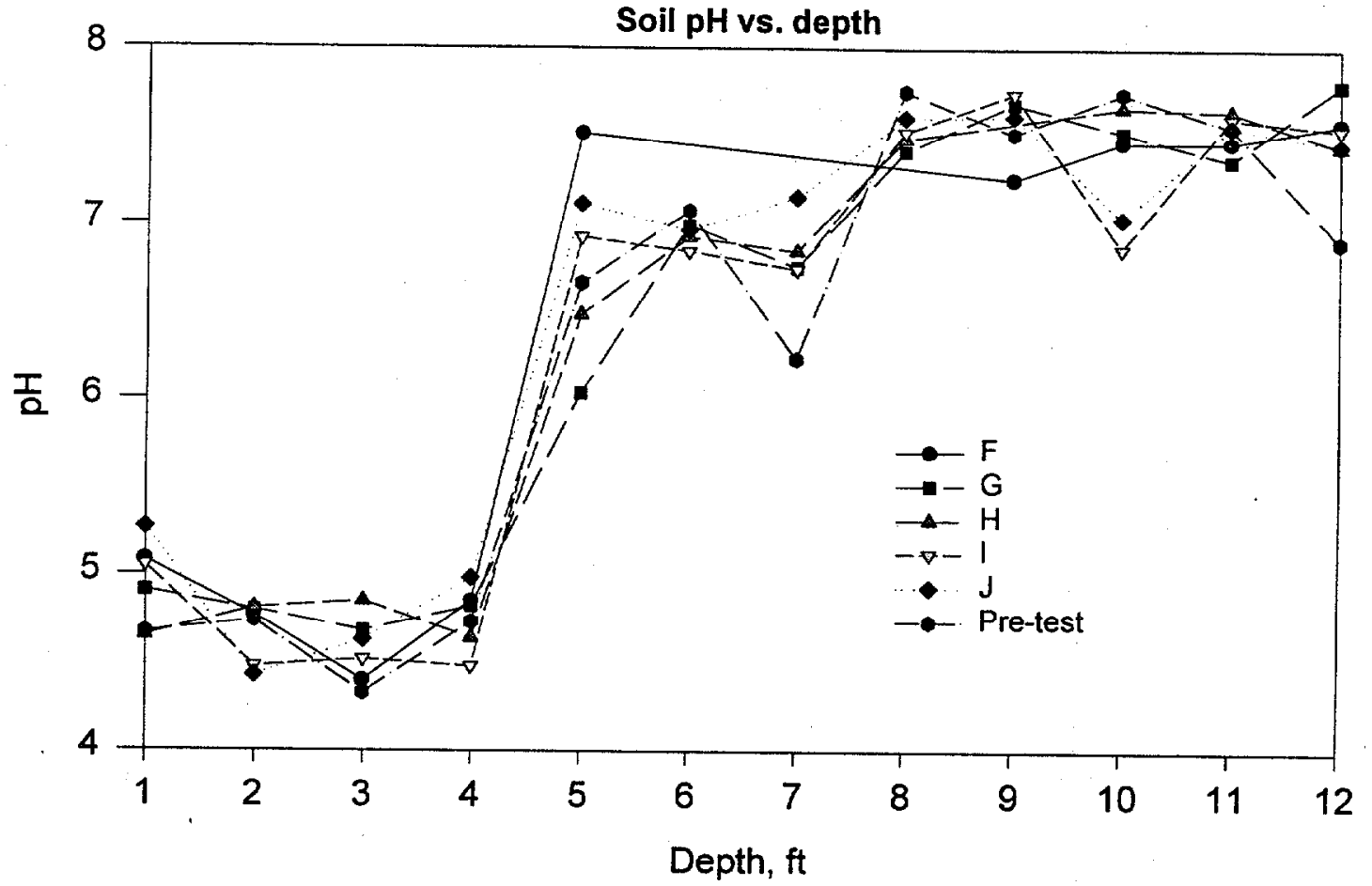

Fig. C.27. Test cell 5 - post-treatment soil $\mathrm{pH}$.

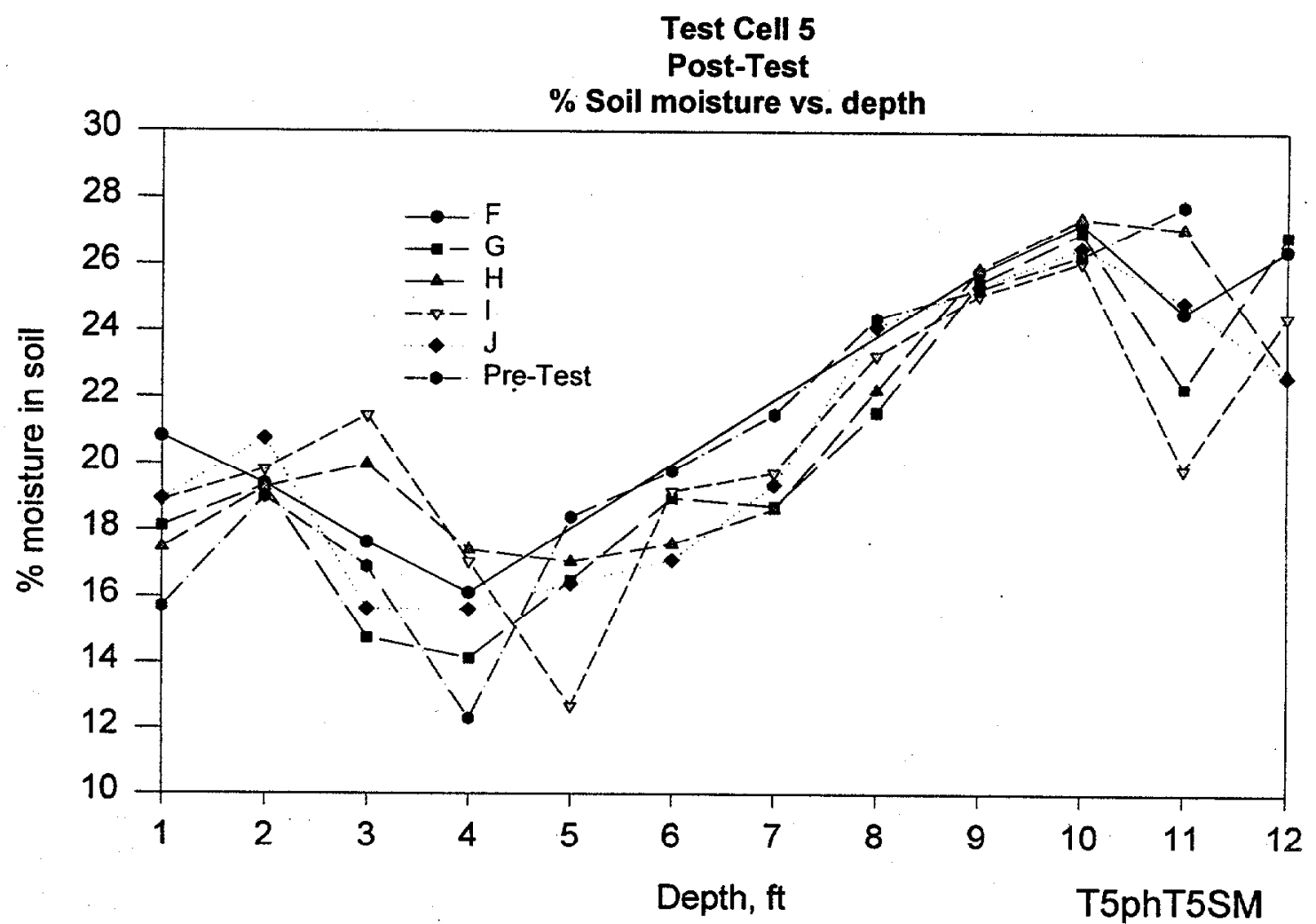

Fig. C.28. Test cell 5 - post-treatment soil moisture levels. 


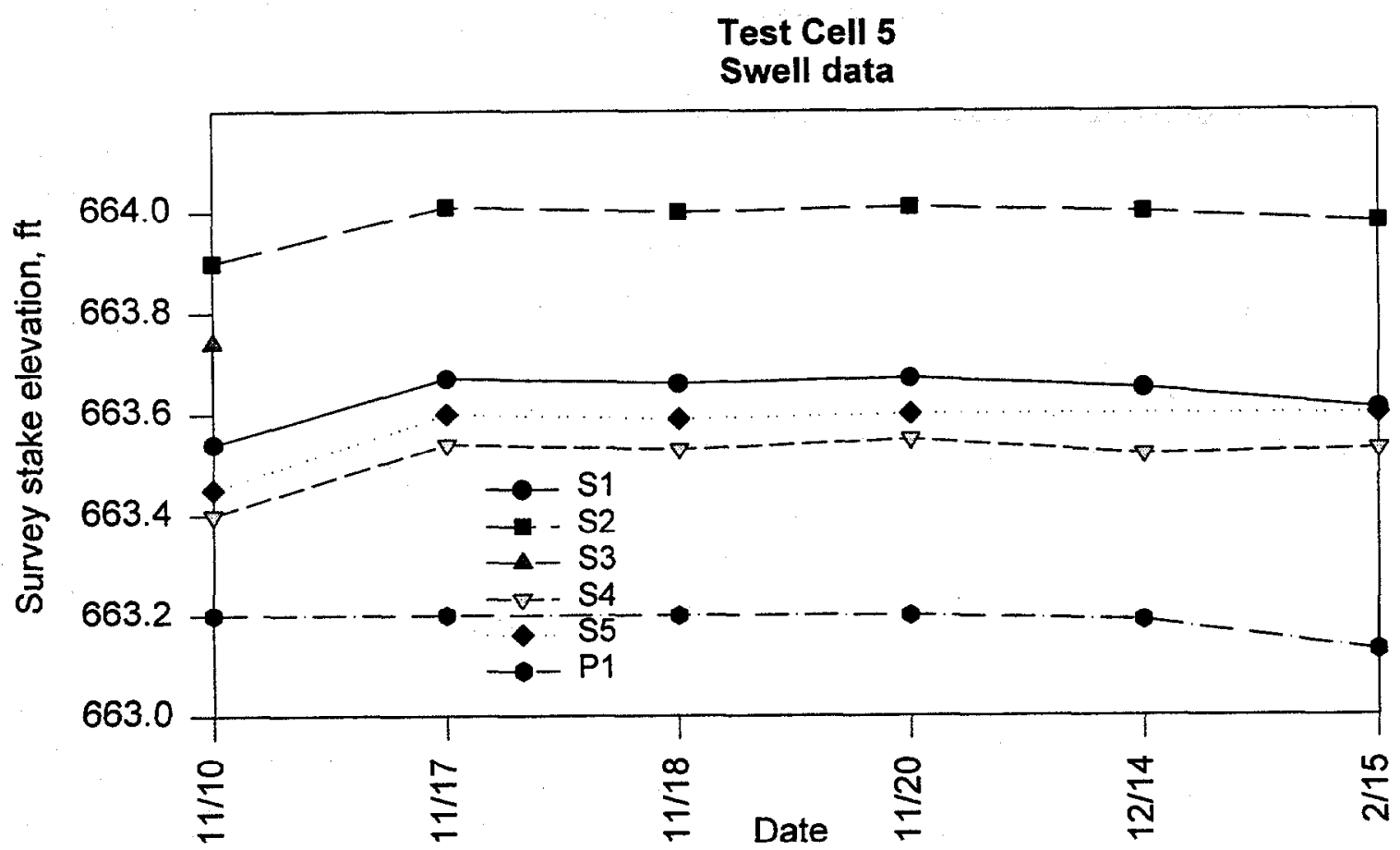

Fig. C.29. Test cell 5 - post-treatment soil swell data.

Test Cell 5

Post-Test

Water pH vs. time

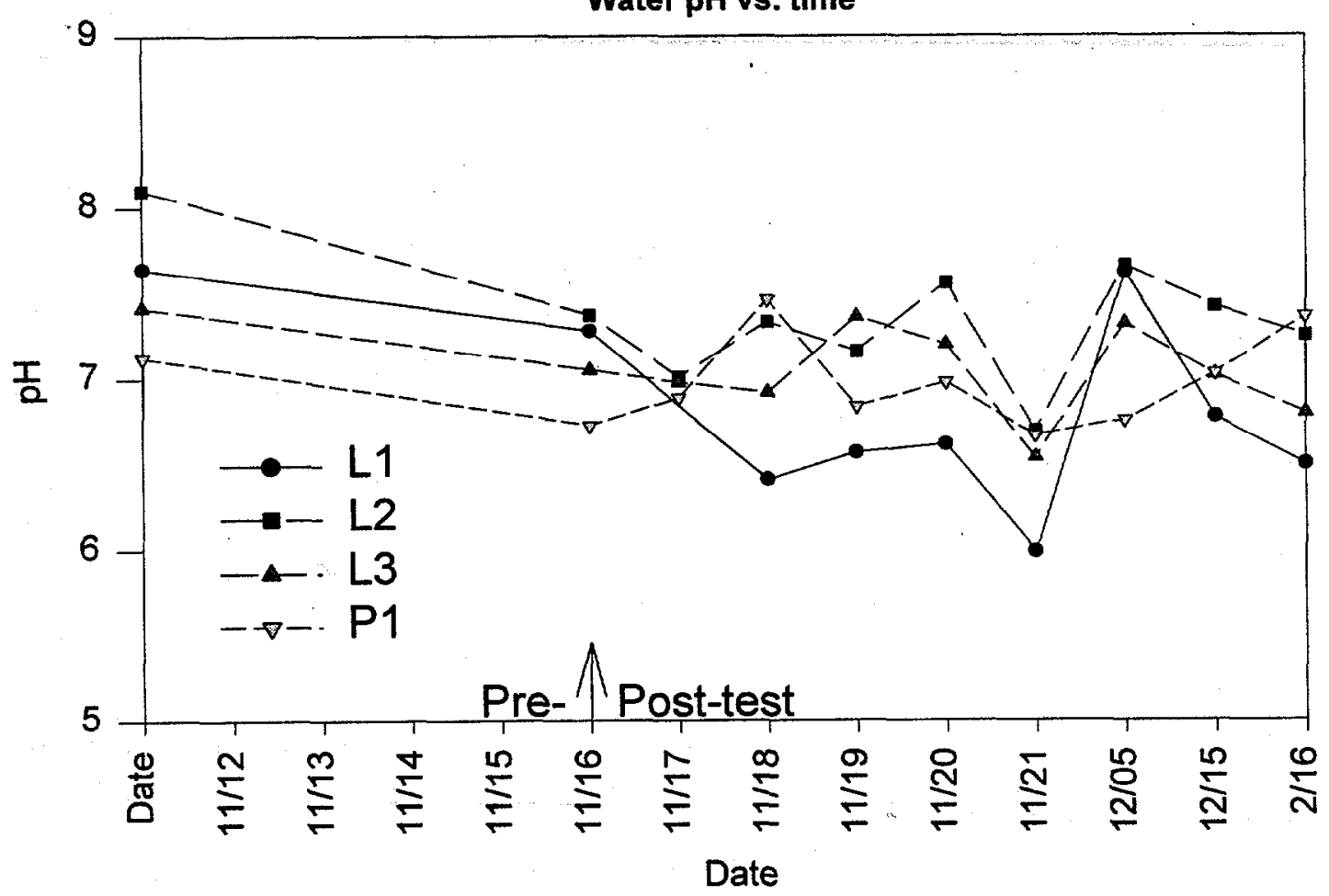

T5PHSD

Fig. C.30. Test cell 5 - post-treatment water pH. 


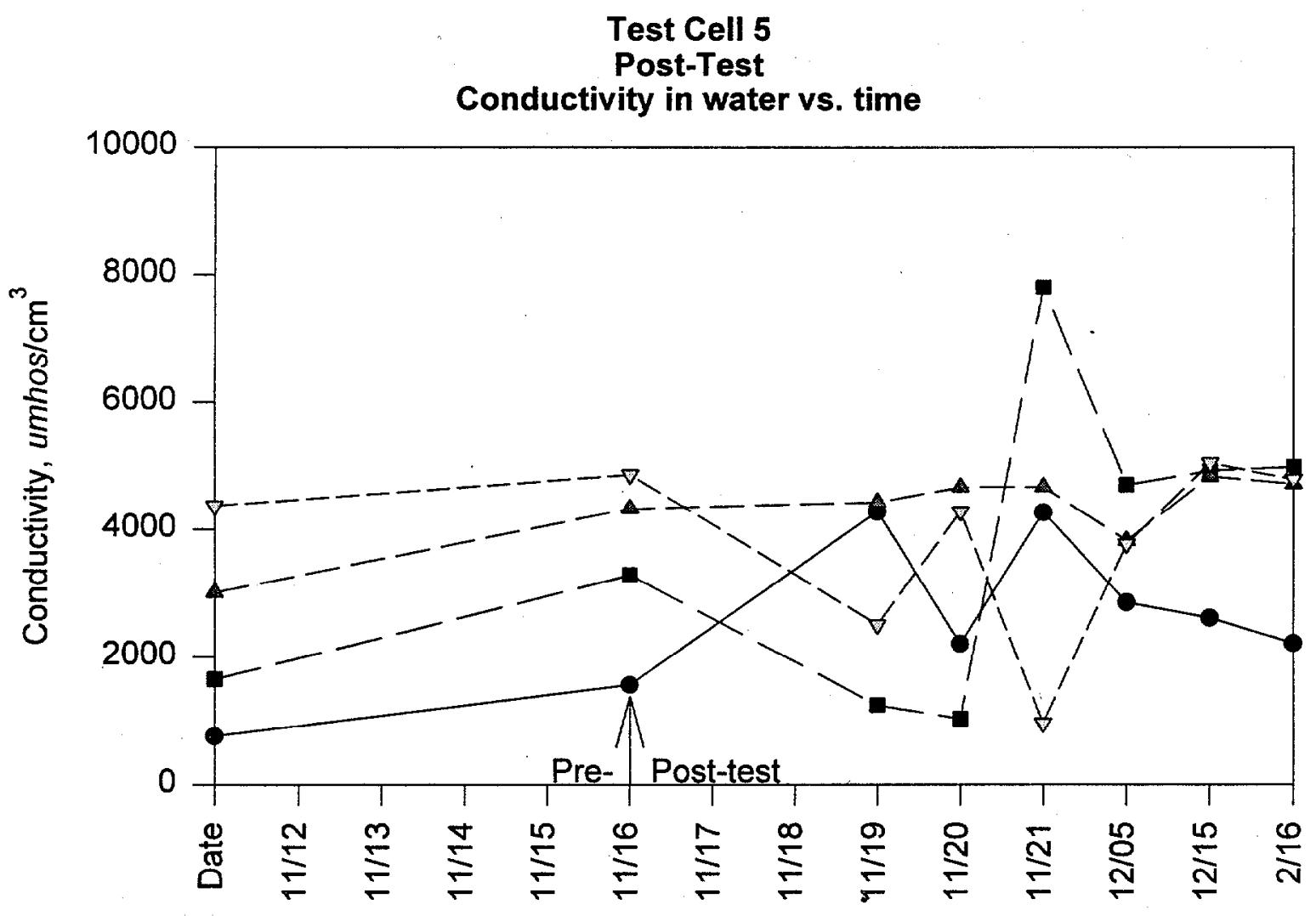

Fig. C.31. Test ce11 5 - post-treatment water conductivity levels.

Test Cell 5

Post-Test

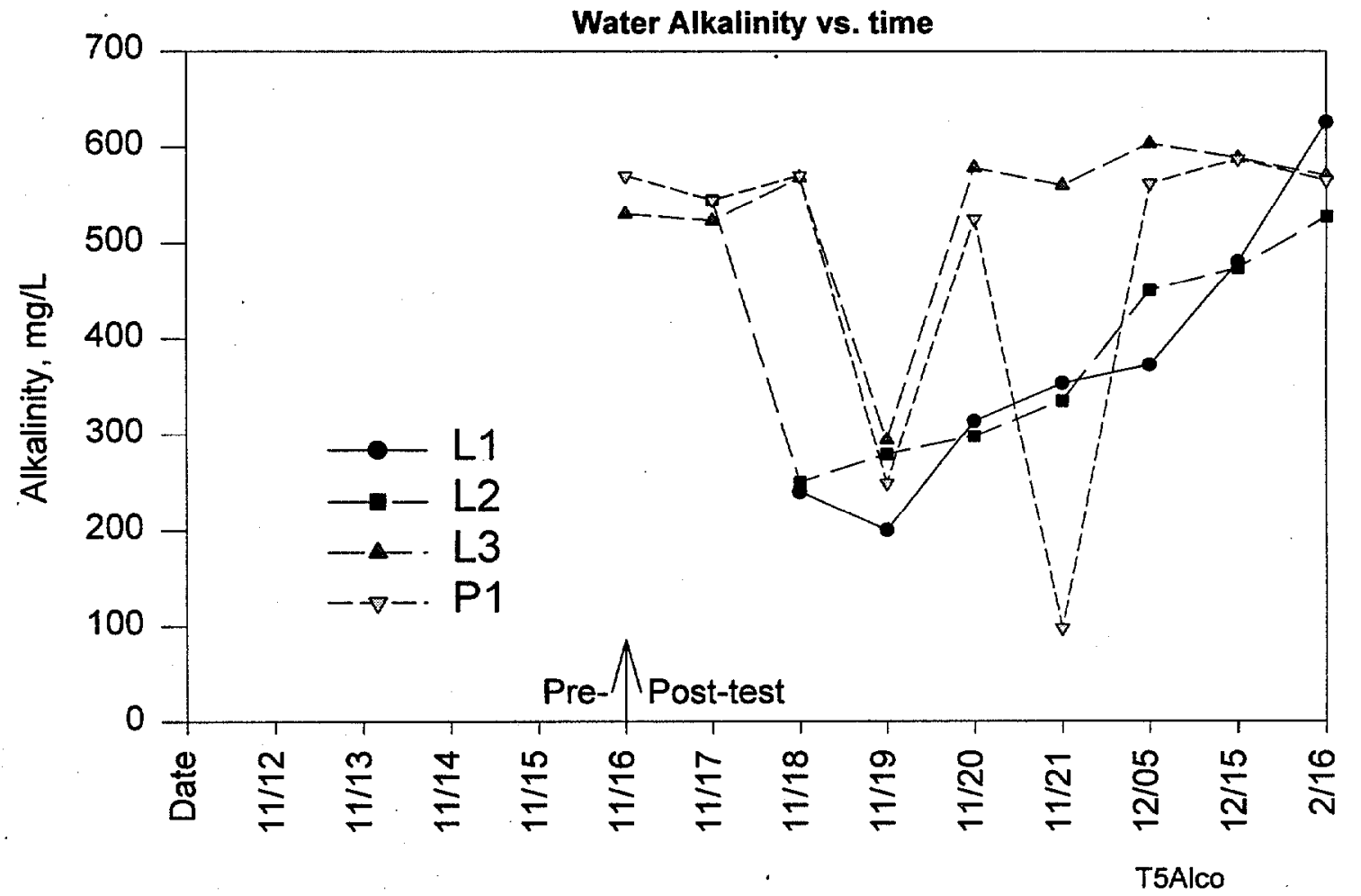

Fig. C.32. Test ce11 5 - post-treatment water alkalinity levels. 
Test Cell 6

Swell data

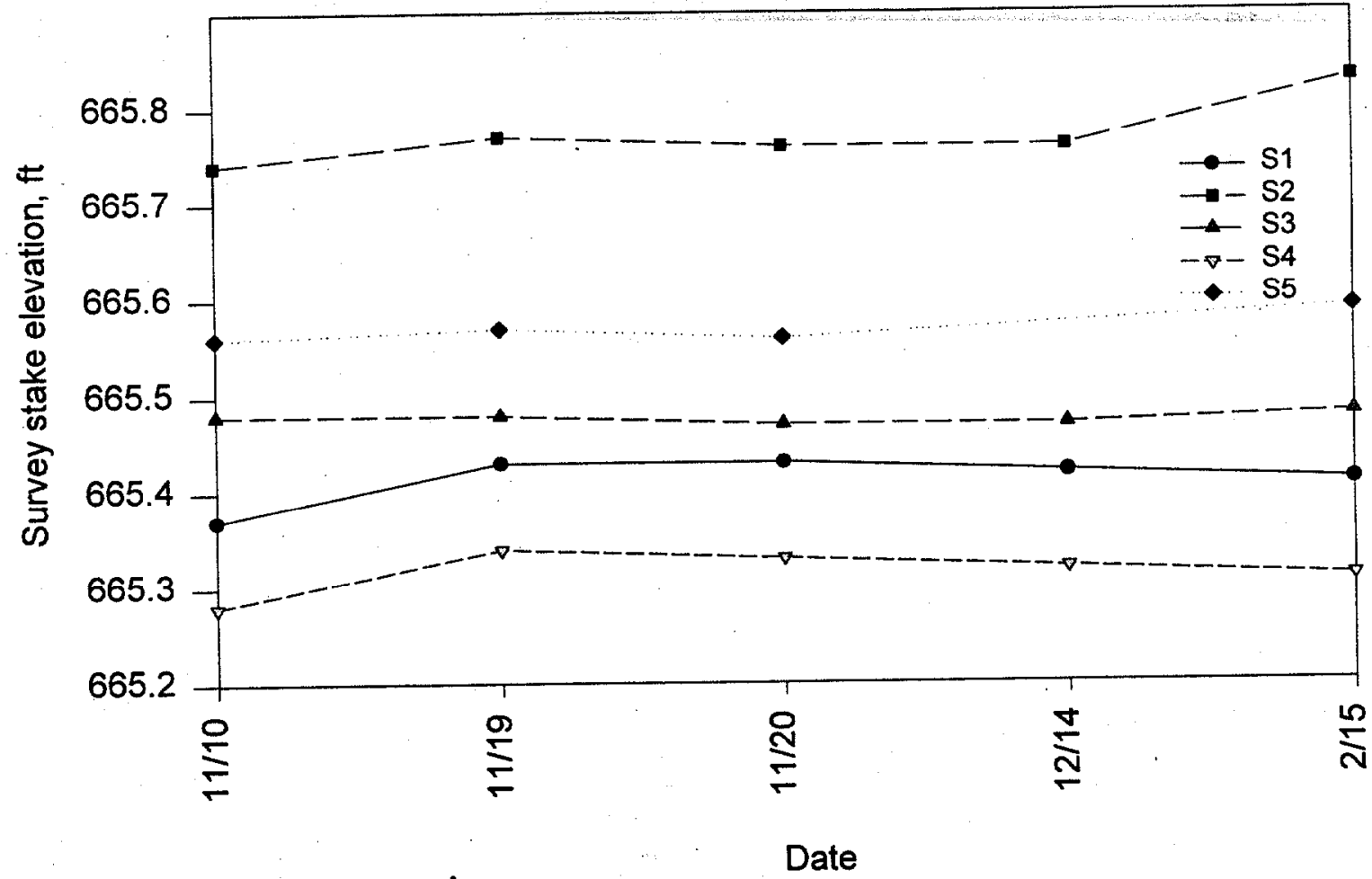

Fig. C.33. Test cell 6 - post-treatment soil swell data.

Test Cell 6

Post-Test

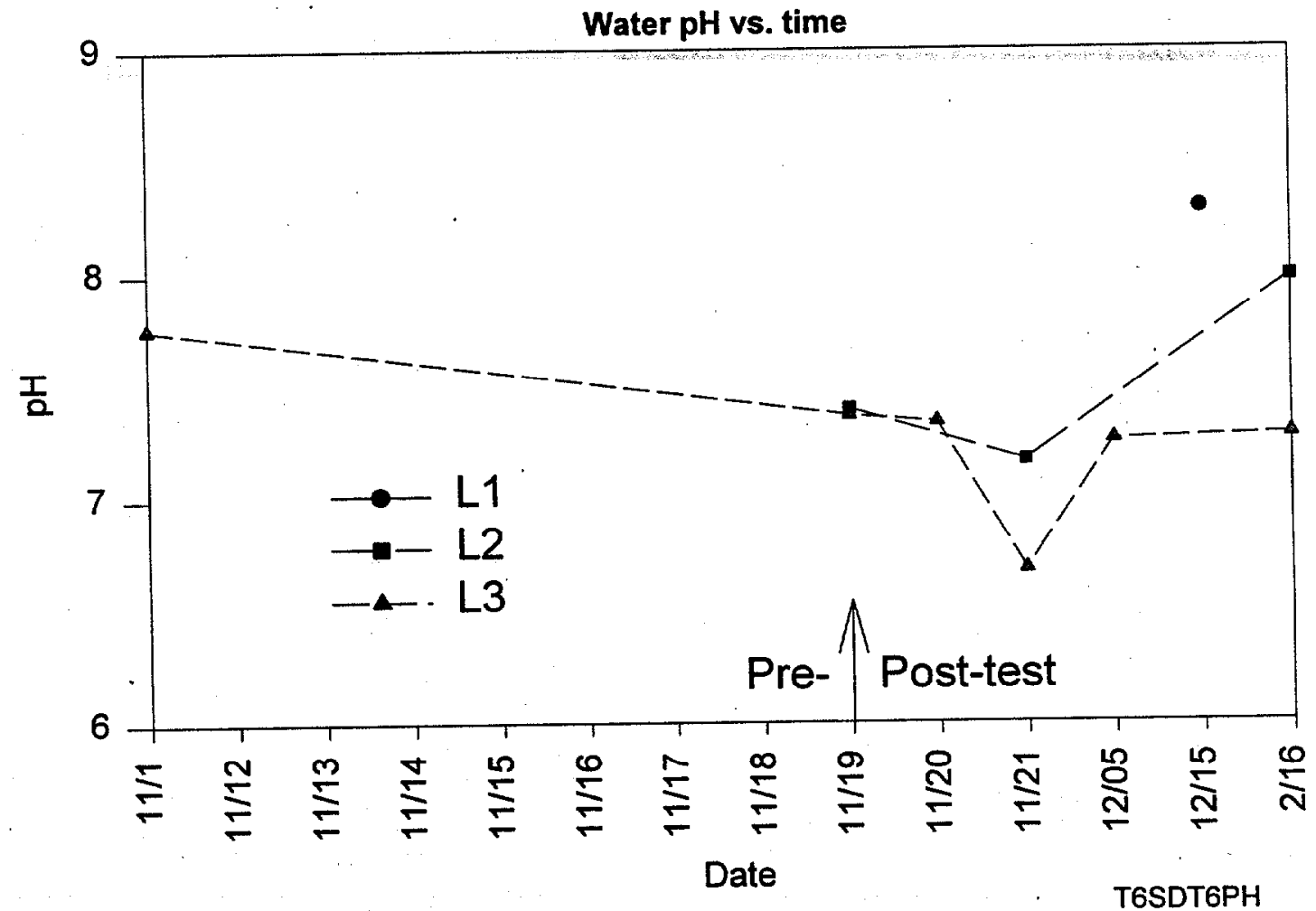

Fig. C.34. Test cell 6 - post-treatment water $\mathrm{pH}$ levels. 


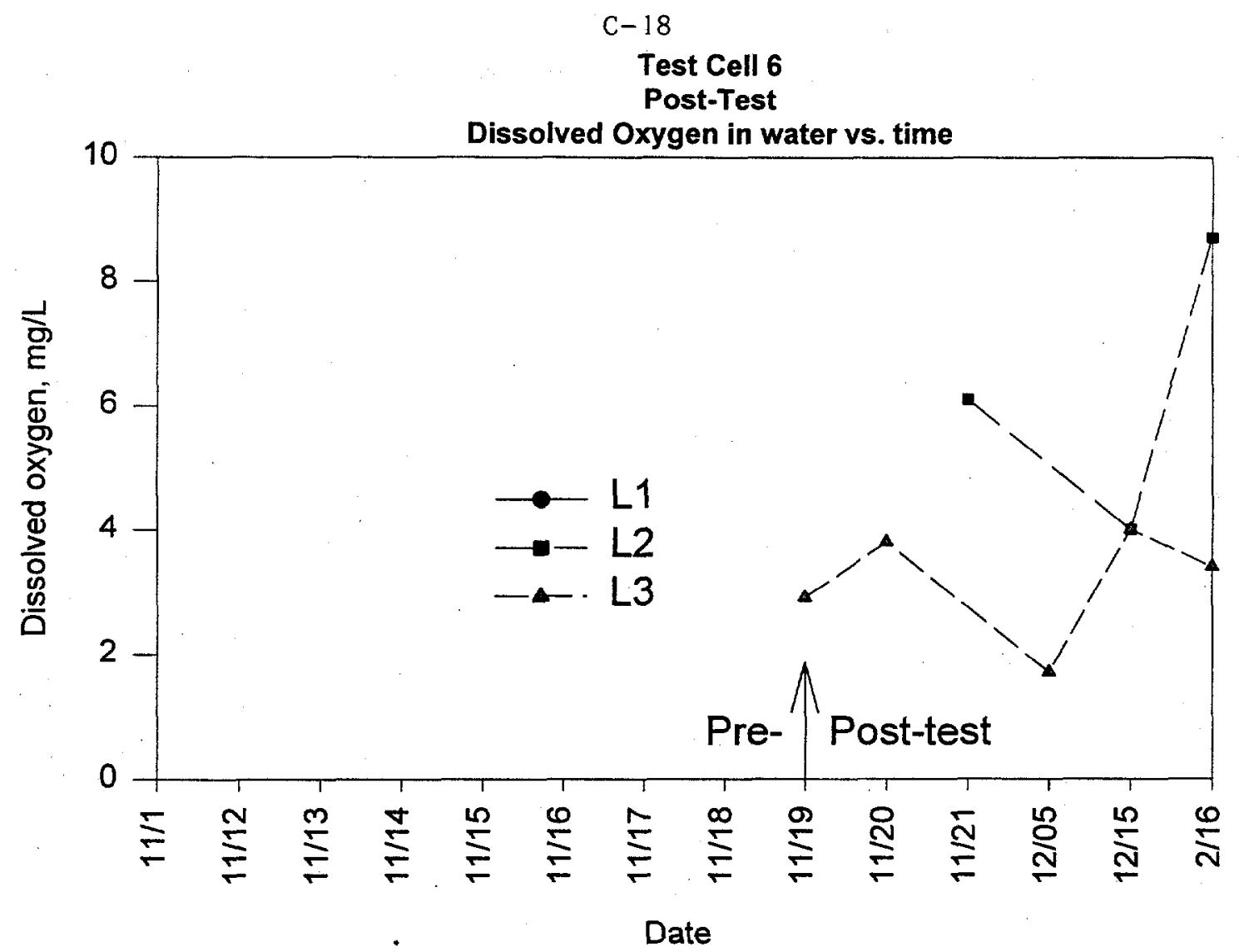

Fig. C.35. Test ce11 6 - post-treatment water Do levels.

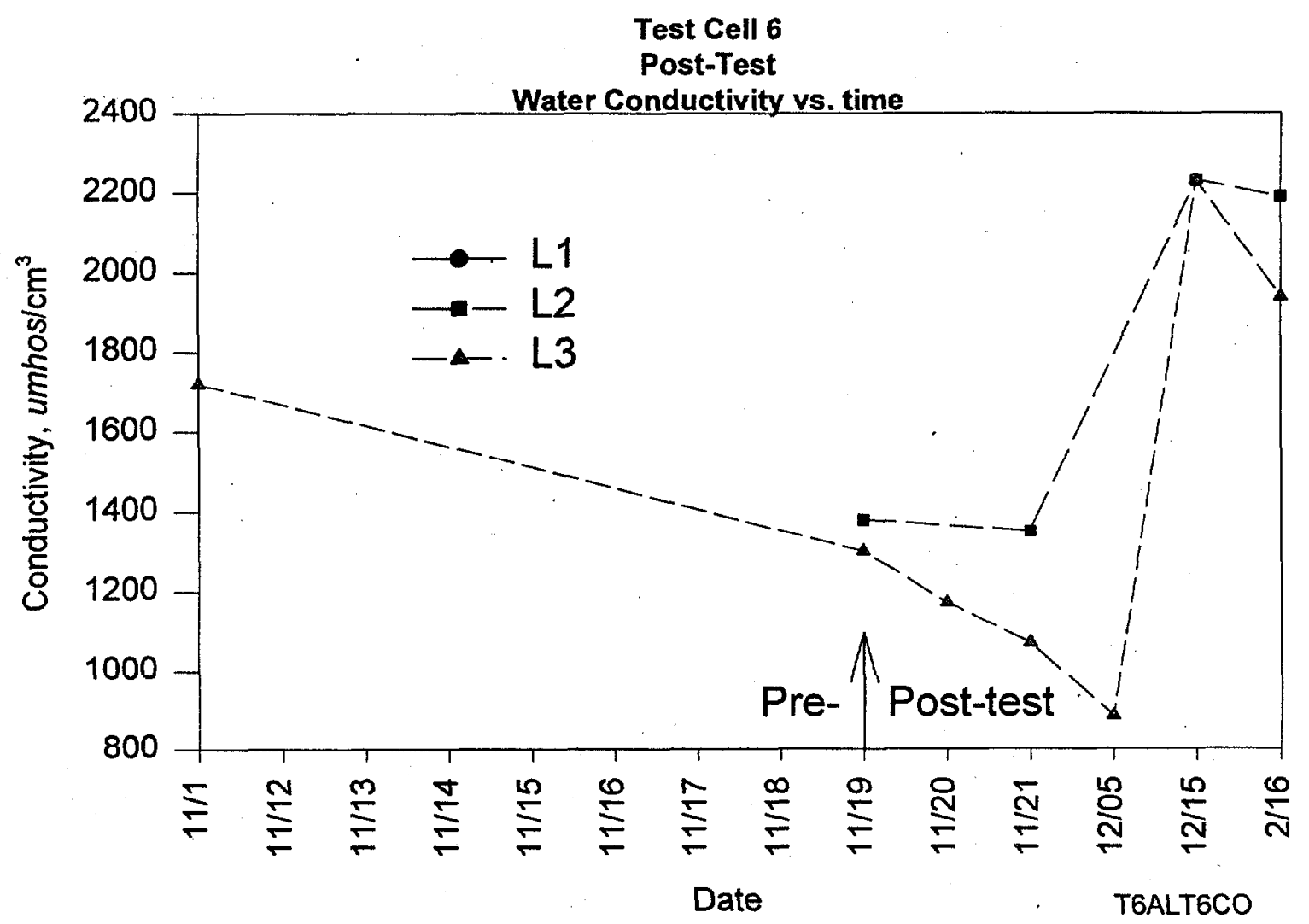

Fig. C.36. Test cell 6 - post-treatment water conductivity levels. 


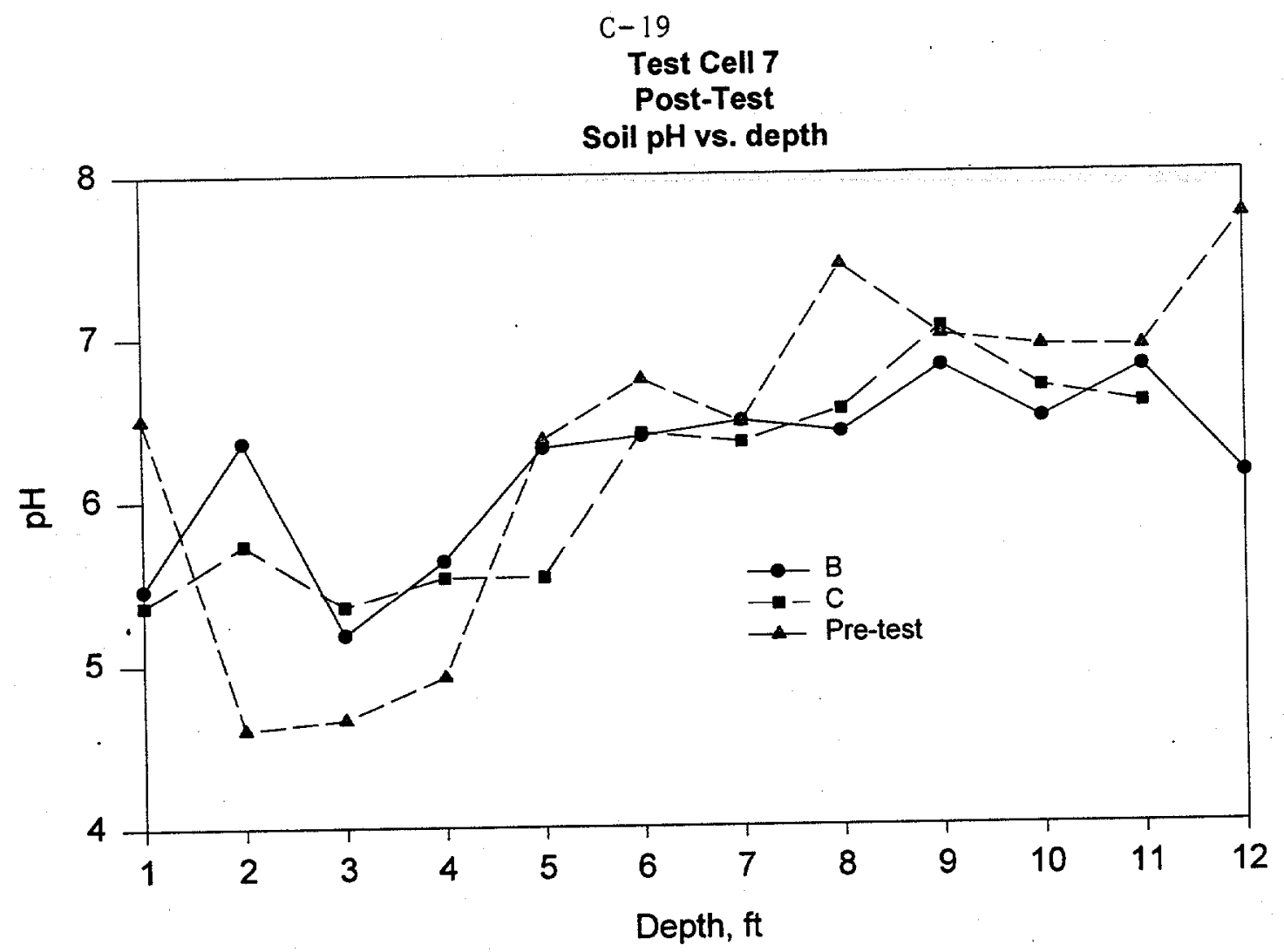

Fig. C.37. Test cell 7 - post-treatment soil $\mathrm{pH}$.

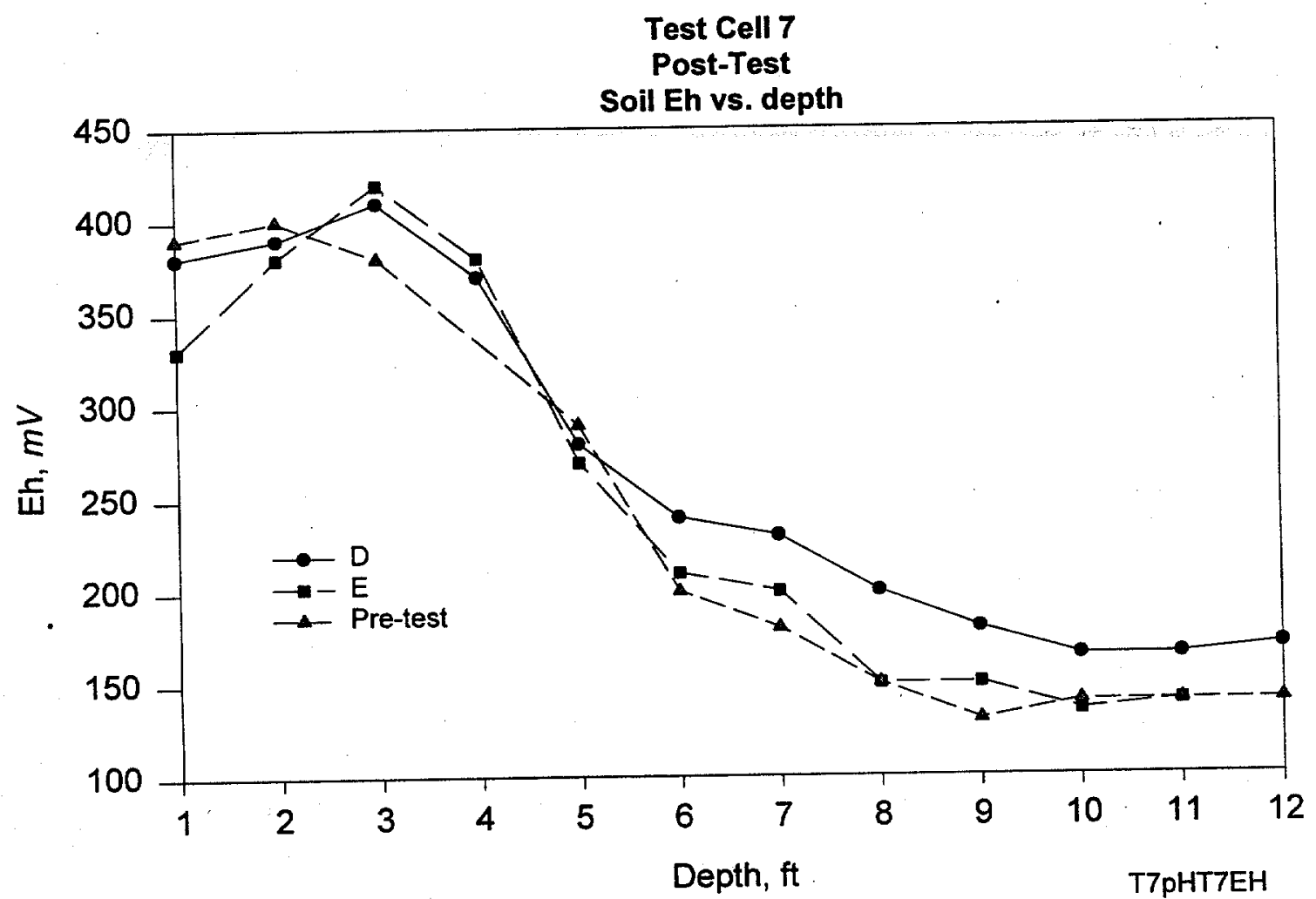

Fig. C.38. Test cell 7 - post-treatment soil Eh levels. 


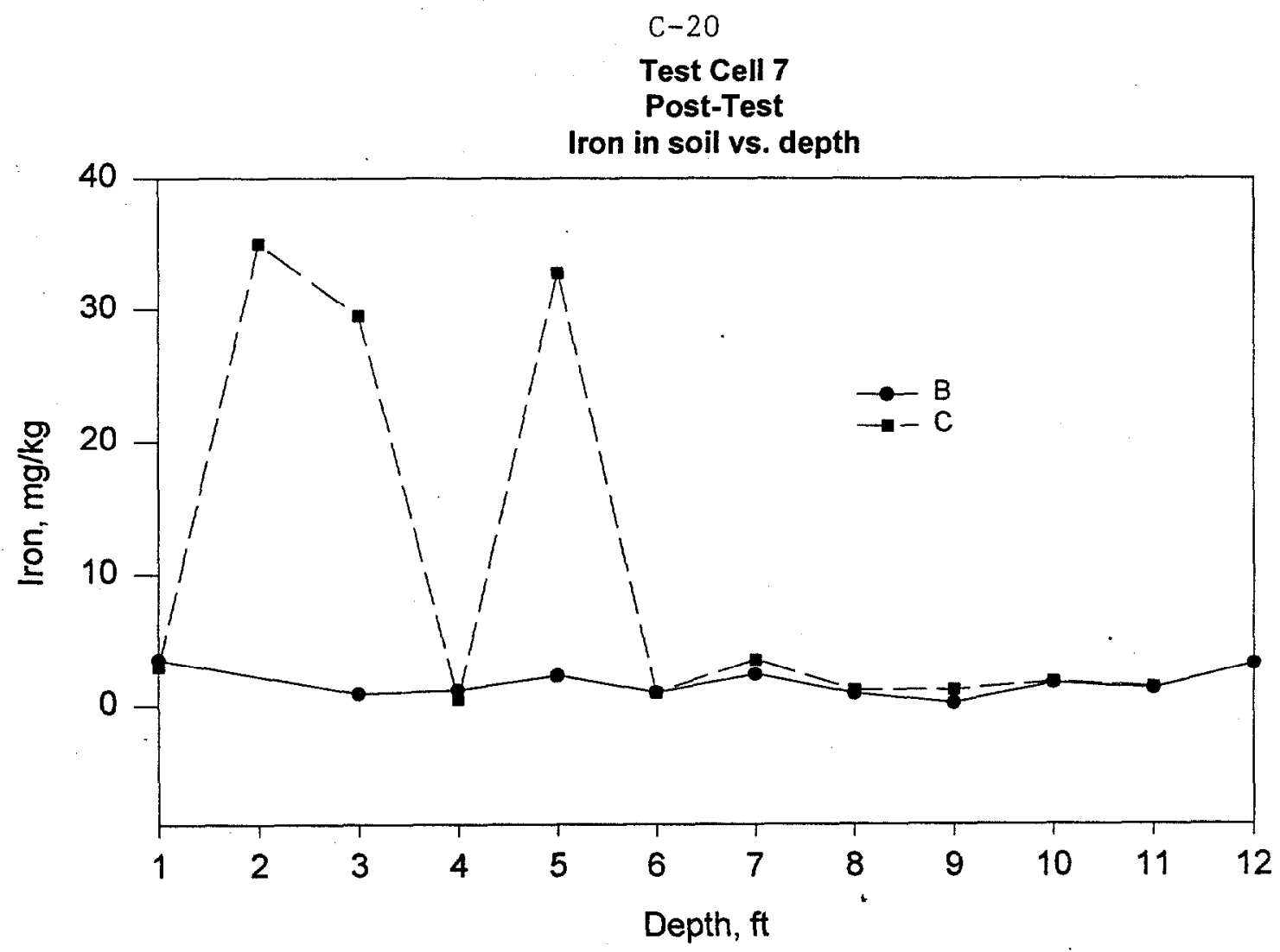

Fig. C.39. Test cell 7 - post-treatment soil iron levels.

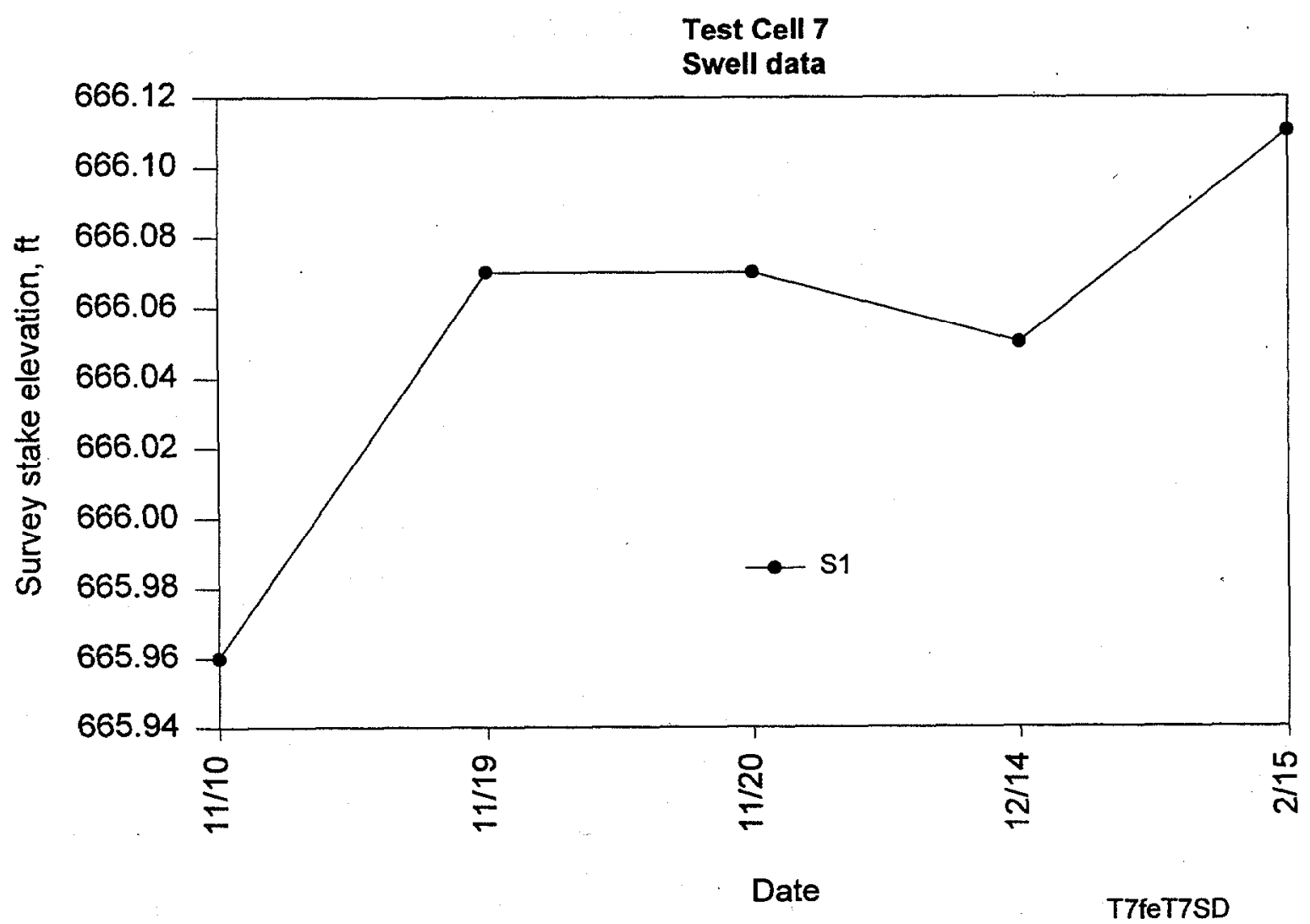

Fig. C.40. Test cell 7 - post-treatment swell data. 


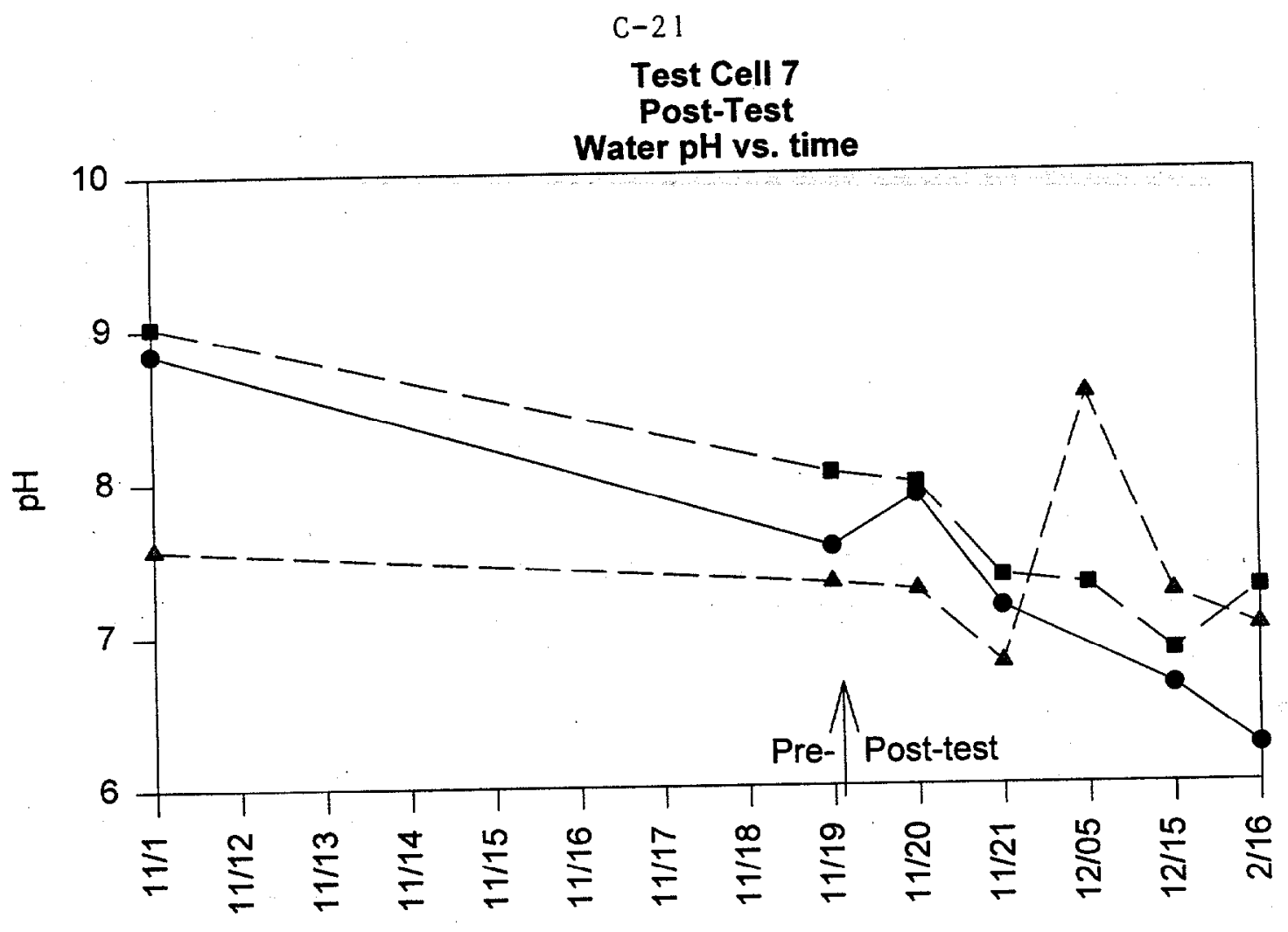

Fig. C.41. Test cell 7 - post-treatment water $\mathrm{pH}$.

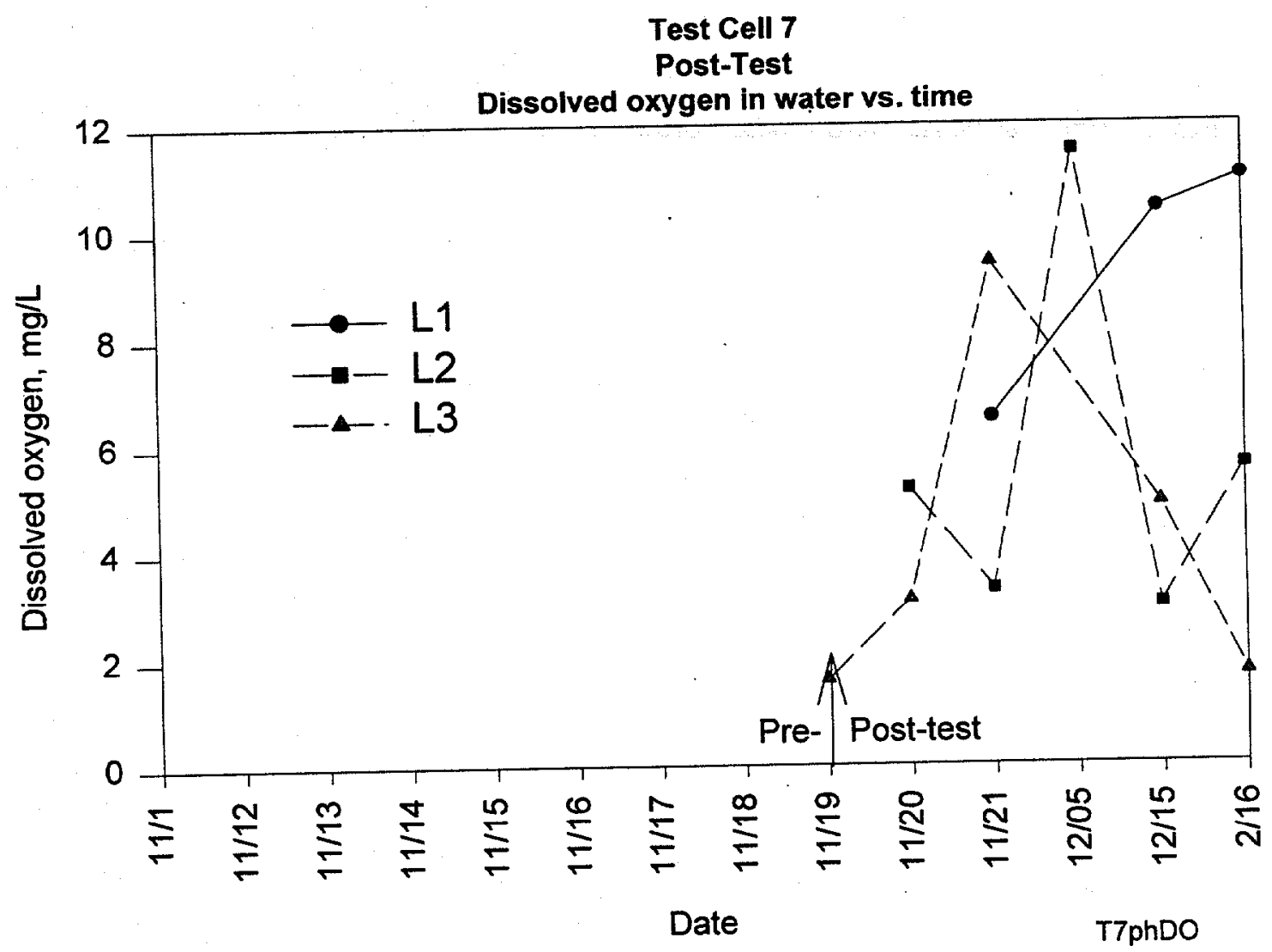

Fig. C.42. Test cel1 7 - post-treatment water Do levels. 


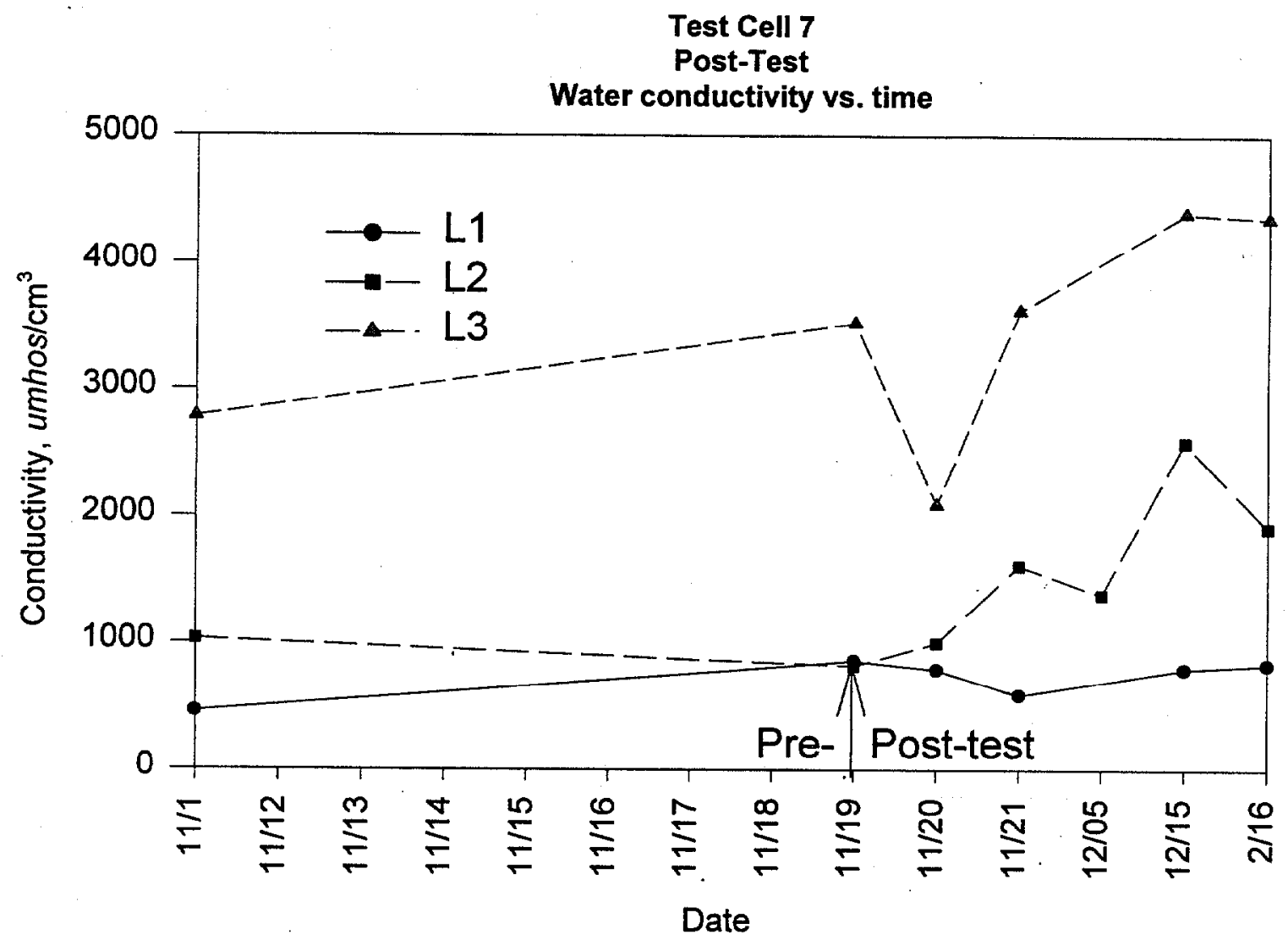

T7AI

Fig. C.43. Test cell 7 - post-treatment water conductivity levels. 


\section{INTERNAL DISTRIBUTION}

1.

2. J. H. Cushman

3. T. O. Early

4. D. E. Fowler

5 D. W. Greene

6. B. $\mathrm{Gu}$

7. S. G. Hildebrand

8. G. K. Jacobs

9. P. Kanciruk

10. N. E. Korte

11. C. A. Little

12. J. M. Loar

13-14. K. S. Lowe

15. R. C. Mann
16. T. E. Myrick

17. D. A. Pickering

18. D. E. Reichle

19. C. Rightmire

20. R. M. Schlosser

21. D. S. Shriner

22-26. R. L. Siegrist

27. O. R. West

28. Central Research Library

29-31. ESD Library

32-33. Laboratory Records Dept

34. Labortatory Records, ORNL-RC

35. ORNL Patent Section

\section{EXTERNAL DISTRIBUTION}

36. M. Broido, Director, Environmental Sciences Division, ER-74, Department of Energy, 19901 Germantown Road, Germantown MD 20874

37. S. Chamberlain, Subsurface Contaminant Focus Area Program Manager, Department of Energy, EM-53, 19901 Germantown Road, Gemantown, MD 20874

38. E. G. Cumesty, ORNL Site Manager, Department of Energy, Oak Ridge National Laboratory, P. O. Box 2008, Oak Ridge, TN 37831-6269

39. D. Davenport, 4725 Sheboygan \#136, Madison, WI 53705

40. H. H. Hopkins, American Petroleum Institute, Health and Environmental Sciences Department, 1220 L Street, NW, Washington, D.C. 20005

41. T. C. Houk, Bechtel Jacobs LLC, Technology Applications, Portsmouth Gaseous Diffusion Plant, Highway 23 South, Building 3012, Piketon, OH 45661

42. M. C. MacCracken, Director, Office of the U. S. Global Change Research Program, Code YS-1, 300 E Street, SW, Washington, DC 20546

43. J. Moore, Technical Program Officer, Department of Energy, Oak Ridge Operations, 3 Main Street, Oak Ridge, TN 37830 
44. E. Philips, Subsurface Contaminant Focus Area DNAPL Product Line Manager, Department of Energy, Oak Ridge Operations, 3 Main Street, Oak Ridge, TN 37830

45. D. R. Smuin, 4221 Purdy Mesa Rd. Whitewater, CO 81527-9642

46. J. S. Walker, Office of Science and Technology, Department of Energy, EM-53, 12800 Middlebrook Road, Gemantown, MD 20874

47. J. Wright, Subsurface Contaminant Focus Area Lead Office Manager, Department of Energy, Savannah River Operations, Building 703A, Rm B202, Highway 125, Aiken, SC 29802

48. Office of Assistant Manger for Energy Research and Development, U. S. Department of Energy Oak Ridge Operations, P. O. Box 2001, Oak Ridge, TN 37831-8600

49-50. Office of Scientific and Technical Information, P. O. Box 62, Oak Ridge, TN 37831 